\title{
Contribuições ao estudo de variáveis dependentes limitadas contínuas e categóricas
}

\author{
Jorge Luis Bazán \\ Universidade de São Paulo \\ Instituto de Ciências Matemáticas e de Computação \\ Departamento de Matemática Aplicada e Estatística
}


Universidade de São Paulo

Instituto de Ciências Matemáticas e de Computação

\title{
Contribuições ao estudo de variáveis dependentes limitadas contínuas e categóricas
}

\author{
JORGE LUIS BAZÁN
}

Tese apresentado ao Instituto de Ciências Matemáticas e de Computação da Universidade de São Paulo, para obtenção do Título de LivreDocente junto ao Departamento de Matemática Aplicada e Estatística.

$$
\begin{gathered}
\text { USP - São Carlos/SP } \\
\text { Julho/2016 }
\end{gathered}
$$




\section{Resumo}

Este texto apresenta e analisa um conjunto de artigos referentes aos trabalhos desenvolvidos sob orientação do autor deste documento. Os artigos são relacionados ao projeto de desenvolvimento de novas distribuições para variáveis com resposta limitada incluindo resposta discreta e contínua assim como a modelagem deste tipo de variáveis como função de covariáveis considerando modelos de regressão e de variáveis latentes. Todo trabalho a ser apresentado é contextualizado dentro de três áreas das respostas limitadas: modelos de regressão para resposta limitada contínua, modelos de regressão para resposta limitada categórica e modelos de regressão limitada latente (modelos de teoría da resposta ao ítem). São descritos os desenvolvimentos propostos assim como os estudos de simulação e aplicações que ilustram a relevância das propostas nas áreas correspondentes. Além disso, são apresentados os trabalhos que estão em andamento, mas que já foram submetidos e estão em fase de revisão. Contudo, o texto sintetiza as principais contribuições do autor para a área de modelagem e analise de regressão de variáveis dependentes limitadas contínuas e categóricas realizadas atuando como orientador de mestrado, doutorado e pós doutorado assim como no relacionamento com outros pesquisadores associados no últimos cinco anos.

Palavras-chave: Modelagem, analise de regressão, inferência, resposta limitada, dados categorizados, estimação bayesiana, teoría da resposta ao ítem, 


\section{Abstract}

This text presents and analyzes a number of papers relating to works developed under the guidance of the author of this document. The papers are related to the project of development of new distributions to variables with limited response including discrete and continuous response as well as the modeling of such variables as function of covariates considering regression and latent variables models. Every paper to be presented is contextualized within three areas of the limited response: regression models for continuous limited response, regression models for categorical limited response and latent limited regression models (models of item response theory). The proposed developments are described as well as simulation studies and applications that illustrate the relevance the proposals in the corresponding areas. Moreover, are presented works that are in progress, but already they were submitted and are under review phase. However, the text summarizes the main contributions of the author to the area of modeling and analysis of regression performed acting as advisor of scientific research work, master's, doctoral and post-doctoral as well as the relationship with other associated researchers the past five years.

Keywords: Modelling, regression analysis, inference, limited response, categorical data, bayesian estimation, item response theory. 


\section{Sumário}

1 Introdução $\quad 3$

1.1 Modelos de regressão para resposta limitada contínua . . . . . . . . . . . . 4

1.2 Modelos de regressão para resposta limitada categórica . . . . . . . . . . . 7

1.3 Modelos de regressão para resposta limitada categórica e preditor latente (modelos Teoria da Resposta ao Item) . . . . . . . . . . . . . . . 10

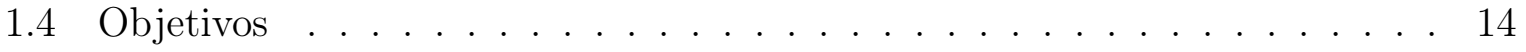

\section{Análise sistematiza dos trabalhos $\quad 15$}

2.1 Modelos de regressão para resposta limitada contínua . . . . . . . . . . . 16

2.2 Modelos de regressão para resposta limitada categórica . . . . . . . . . . . 18

2.3 Modelos de regressão para resposta limitada categórica e preditor latente: (Modelos de resposta ao ítem) . . . . . . . . . . . . . . . . . . 19

2.4 Trabalhos em andamento . . . . . . . . . . . . . . . . . 20

2.4.1 Modelos de regressão para resposta limitada contínua . . . . . . . . 20

2.4.2 Modelos de regressão para resposta limitada categórica . . . . . . . 22

2.4.3 Modelos de regressão para resposta limitada categórica e preditor latente (modelos Teoria da Resposta ao Item) . . . . . . . . . . 23 
2.5 Considerações finais . . . . . . . . . . . . . . . . . . 24

3 Conclusão $\quad 26$

$\begin{array}{ll}\text { Appendices } & 35\end{array}$

Apêndice A . . . . . . . . . . . . . . . . . . . . 37

Apêndice B . . . . . . . . . . . . . . . . . . . . 64

Apêndice C . . . . . . . . . . . . . . . . 76

Apêndice D . . . . . . . . . . . . . . . . . . . . . . . 97

Apêndice E . . . . . . . . . . . . . . . . . . . . . . . . . . . . . . . 114

Apêndice F . . . . . . . . . . . . . . . . . . . . . . . . . . . . . . . . . 124

Apêndice G . . . . . . . . . . . . . . . . . . . . . . . . . . . . . . . 148

Apêndice $\mathrm{H} \ldots \ldots \ldots \ldots$. . . . . . . . . . . . . . . . . . . 171

Apêndice I . . . . . . . . . . . . . . . . . . . . . . . . . . . . 202

Apêndice J . . . . . . . . . . . . . . . . . . . . . . . 225

Apêndice K . . . . . . . . . . . . . . . . . . . . . . . 236

Apêndice L . . . . . . . . . . . . . . . . . . . . . . . . . 260 


\section{Capítulo 1}

\section{Introdução}

Em diversas situações práticas nos deparamos com o problema de analisar variáveis que assumem valores em um intervalo limitado que, sem perda de generalidade, podem ser transformados para o intervalo unitário [0,1], como porcentagens, proporções, taxas ou frações. Por exemplo, a porcentagem de renda gasta com alimentação, o índice de desigualdade, os índices de qualidade de vida ou a proporção de votos obtidos por um partido político por município em uma eleição, mas também o caso de resposta binária $\{0,1\}$ e o intervalo unitário aberto $(0,1)$. Quando tentamos modelar uma distribuição em que a variável resposta é assumida no intervalo aberto ou fechado, considerando covariáveis explicativas, estamos frente a um modelo de regressão para resposta limitada contínua. Quando focamos nas respostas tomando somente os valores zero e uns, estamos frente a uma variável binária e então o correspondente modelo é o de regressão binária. As respostas binárias seguem um processo Bernoulli, assum-se a distribuição de uma variável correspondente a soma destes processos resulta em uma distribuição categórica. Este grupo de modelos faze parte dos modelos de regressão com resposta limitada categórica. Finalmente se temos um caso de respostas binárias multivariadas e assumimos como covariáveis ou fatores explicativos variáveis não observáveis ou latentes teremos uma regressão binária multivariada latente ou uma regressão limitada latente mais conhecida como modelos de teoria da resposta ao item. Um grupo importante de minhas pesqui- 
sas desenvolvidas nos últimos cinco anos fica classificada nessas três áreas ou classes de modelos que descrevemos a seguir em maiores detalhes.

\subsection{Modelos de regressão para resposta limitada contí- nua}

Especificamente, no caso do intervalo $(0,1)$. o principal modelo desenvolvido foi o modelo de regressão Beta o qual descrevemos a seguir.

Considere que $y=\left(y_{1}, y_{2}, \ldots, y_{n}\right)^{\prime}$ denota um vetor $n \times 1$ de $n$ variáveis aleatórias independentes. Também seja $x_{i}=\left(x_{i 1}, \ldots, x_{i n}\right)^{\prime}$ um vetor $k \times 1$ de covariáveis, na qual $x_{i 1}$ pode ser 1 , o que corresponde a um intercepto, $X$ denota a matriz desenho $n \times k$ com filas $x_{i}^{\prime}$, emque $(\mathrm{k}<\mathrm{n})$ são assumidas conhecidas e $\boldsymbol{\beta}=\left(\beta_{1}, \ldots, \beta_{k}\right)^{\prime}$ é um vetor $k \times 1$ de coeficientes de regressão. Suponha que $y_{i}$ segue uma distribuição Beta com média $\mu_{i}$ e parâmetro de precisão desconhecido $\phi$. O modelo de regressão Beta é então definido por

$$
y_{i} \mid \mu_{i}, \phi \sim \operatorname{Beta}\left(\mu_{i} \phi, \phi\left(1-\mu_{i}\right)\right)
$$

$\mathrm{e}$

$$
g\left(\mu_{i}\right)=x_{i}^{T} \boldsymbol{\beta}=\eta_{i}
$$

A função $g(\cdot)$ é chamada de função de ligação, e é estritamente monótona e duplamente diferenciável em $(0,1)$. Exemplos de funções de ligação são o $\operatorname{logito:} g(\mu)=\log \left\{\frac{\mu}{1-\mu}\right\}$, a função probito: $g(\mu)=\Phi^{-1}(\mu)$, em que $\Phi(\cdot)$ é a função de distribuição acumulada de uma variável aleatória Normal padrão, ou ainda a ligação complemento log-log: $g(\mu)=$ $-\log \{-\log \mu\}$, entre outras. Especificamente no caso da função de ligação logito, temos para o i-ésimo individuo, $\mu_{i}=\exp \left(x_{i}^{T} \boldsymbol{\beta}\right) /\left[1+\exp \left(x_{i}^{T} \boldsymbol{\beta}\right)\right]$ emque $x^{T}$ é o vetor de covariáveis.

Para $\phi$ conhecido, a função de verossimilhança é dada por 


$$
\begin{aligned}
& L(\boldsymbol{\beta}, \phi)=[\Gamma(\phi)]^{n} \prod_{i=1}^{n}\left[\Gamma\left(\frac{\exp \left(x_{i}^{T} \boldsymbol{\beta}\right)}{1+\exp \left(x_{i}^{T} \boldsymbol{\beta}\right)} \phi\right)\right]^{-1} \prod_{i=1}^{n}\left[\Gamma\left(\phi\left(1-\frac{\exp \left(x_{i}^{T} \boldsymbol{\beta}\right)}{1+\exp \left(x_{i}^{T} \boldsymbol{\beta}\right)}\right)\right)\right]^{-1} \\
& \times \prod_{i=1}^{n} y_{i}^{\frac{\exp \left(x_{i}^{T} \beta\right)}{1+\exp \left(x_{i}^{T} \beta\right)}} \phi-1 \\
& \prod_{i=1}^{n}\left(1-y_{i}\right)^{\phi\left(1-\frac{\exp \left(x_{i}^{T} \beta\right)}{1+\exp \left(x_{i}^{T} \beta\right)}\right)-1} \cdot
\end{aligned}
$$

Na abordagem clássica, métodos de otimização são propostos para encontrar os estimadores de máxima verossimilhança, ver por exemplo o trabalho de Ferrari e CribariNeto (2004). Na abordagem Bayesiana, os parâmetros são assumidos variáveis aleatórias e não mais constantes desconhecidas. Com isso, a incerteza presente no modelo Beta é $\underset{\sim}{\theta}=(\boldsymbol{\beta}, \phi)$ e é representada por meio de uma distribuição de probabilidade $P(\boldsymbol{\beta}, \phi)$ (a priori sobre os possíveis valores dos parâmetros $\boldsymbol{\beta}$ e $\phi$ desconhecidos). Para isso utiliza-se o teorema de Bayes, para encontrar a distribuição a posteriori desses parâmetros, ver por exemplo Buckley (2003).

Atualmente a regressão Beta é um modelo bastante consolidado (Gupta e Nadarajah, 2004). A literatura sobre este modelo é extensa, entre as quais citamos os trabalhos de Paolino (2001), Ferrari e Cribari-Neto (2004), Smithson e Verkuilen (2006) e Cribari-Neto e Zeileis (2010), que utilizam o método de máxima verossimilhança para a estimação dos parâmetros e, sob uma abordagem bayesiana, os trabalhos de Buckley (2003), Branscum et al. (2007) e Figueroa-Zúñiga et al. (2013). As extensões incluem o uso de funções de ligação alternativas, a inclusão de covariáveis no parâmetro de dispersão e efeitos aleatórios em ambos componentes.

Um modelo de regressão alternativo ao modelo Beta foi proposto por Song e Tan (2000) e Song et al. (2004) (sob uma abordagem clássica) e Qiu et al. (2008) (sob uma abordagem bayesiana) para modelar a variável resposta por meio da distribuição Simplex introduzida por Barndorff-Nielsen e Jorgensen (1991). Analogamente ao modelo de regressão Beta, o modelo de regressão Simplex também acomoda variáveis respostas com variância não constantes, assim como extensões para o caso misto.

Alternativamente, na minha primeira contribuição na área foi o trabalho Bayes 
et al. (2012) (ver Apêndice A) na qual foi proposta uma distribuição denominada Beta retangular (com três parâmetros), que além de possuir a mesma flexibilidade da distribuição Beta usual, pode apresentar comportamento uniforme, assimetria à direita, assimetria à esquerda, e formato de "U". Além disto, dispõe de um terceiro parâmetro que funciona como regulador das caudas, fazendo com que as caudas sejam mais leves ou mais pesadas, acomodando valores que seriam considerados como "aberrantes" na distribuição Beta usual. Na abordagem apresentada em Bayes et al. (2012), modela-se tanto a média quanto o parâmetro de precisão (modelo heterocedástico).

Trabalhos mais recentes considerando o modelo Simplex como alternativo para a resposta limitada, ver por exemplo López (2013) ou estendendo o modelo simplex e beta rectangular, ver por exemplo Galvis et al. (2014), podem também ser citados. Porém, trabalhos incluindo a possibilidade do uso de misturas têm sido pouco explorados o qual motivou o desenvolvimento do trabalho da Paz et al. (2015) (ver apêndice G) em conjunto com minha orientada de doutorado.

Nos modelos de regressão supracitados é considerada a relação entre uma ou mais covariáveis e a média condicional de uma variável resposta dadas as covariáveis. No entanto, em algumas aplicações há o interesse especialmente na modelagem de extremos, cujo foco é nos níveis ou quantis de uma variável resposta, veja por exemplo Gilchrist (2000). Assim, modelos de regressão quantílica para proporções podem ser úteis. Além disso, tais modelos fornecem uma imagem mais completa da distribuição condicional da variável resposta levando em conta as possíveis diferenças nas covariáveis. Considere por exemplo a modelagem quantílica de um índice de nível socioeconômico ou índice de nível de um teste de desempenho escolar, ou seja, estamos interessados em identificar as covariáveis que são significativas para o primeiro ou para o terceiro quartil.

No entanto, a distribuição Beta não é útil para a modelagem quantílica devido a sua distribuição acumulada não ter uma forma fechada. Uma distribuição que pode ser usada no contexto de modelos de regressão quantílica é a distribuição Kumaraswamy (Kumaraswamy, 1980; Jones, 2009), a qual é uma família de distribuições de probabilidade 
contínuas definida no intervalo $(0,1)$, semelhante à distribuição Beta, mas muito mais simples devido à forma fechada tanto da sua função densidade de probabilidade quanto da sua função distribuição acumulada. Foi essa a motivação para a proposta em Bayes et al. (2016) (ver apêndice B).

Adicionalmente, alguns pesquisadores como Kotz e van Dorp (2004) apresentam outras distribuições para variáveis contínuas no intervalo $(0,1)$. Este é o caso da distribuição SB de Johnson (Rennolls e Wang, 2005) a qual não foi explorada o suficiente, e também não foi generalizada para incluir outras distribuições simétricas além da distribuição Normal na modelagem da mediana. Assim, em Lemonte e Bazán (2016) (ver apêndice C) desenvolvemos uma classe mais geral que inclui a SB Johnson como caso particular. Novas propostas de modelos considerando novas distribuições com parameterizações alternativas para a mediana são necessárias, o que motiva o trabalho proposto em da Paz et al. (2016) (ver apêndice H).

\subsection{Modelos de regressão para resposta limitada cate- górica}

Inicialmente, apresentamos os modelos de regressão binária. Considere que $y=$ $\left(y_{1}, y_{2}, \ldots, y_{n}\right)^{\prime}$ denota um vetor $n \times 1$ de $n$ variáveis aleatórias independentes. Também seja $x_{i}=\left(x_{i 1}, \ldots, x_{i n}\right)^{\prime}$ um vetor $k \times 1$ de covariáveis, na qual $x_{i 1}$ pode ser 1 , o que corresponde a um intercepto, $X$ denota a matriz desenho $n \times k$ com filas $x_{i}^{\prime}$, em que $(\mathrm{k}<\mathrm{n})$ são assumidas conhecidas e e $\boldsymbol{\beta}=\left(\beta_{1}, \ldots, \beta_{k}\right)^{\prime}$ e um vetor $k \times 1$ de coeficientes de regressão. Suponha que $y_{i}=1 \mathrm{com}$ probabilidade $p_{i}$ e $y_{i}=0$ com probabilidade $1-p_{i}$. Na modelagem tradicional para dados binários, é usualmente assumido que

$$
y_{i} \sim \operatorname{Bernoulli}\left(p_{i}\right)
$$

e

$$
p_{i}=F\left(\eta_{i}\right)=F\left(x_{i}^{\prime} \beta\right) .
$$


na qual $F($.$) denota a função de distribuição acumulada (fda), F^{-1}$ é tipicamente chamada de função de ligação e $\eta_{i}=x_{i}^{\prime} \beta$ é o $i$-ésimo preditor linear.

Quando $F$ é a fda de uma distribuição simétrica, a ligação resultante é simétrica. Neste caso a curva de resposta para $p_{i}$ tem uma forma simétrica em torno de $p_{i}=0.5$. Exemplos são obtidos quando $F$ é a fda de uma das distribuições elípticas como por exemplo, a Normal padrão, Logística ou Cauchy.

A correspondente função de verossimilhança é dada por

$$
L(\beta, \theta \mid y, X)=\prod_{i=1}^{n}\left[F\left(\eta_{i}\right)\right]^{y_{i}}\left[1-F\left(\eta_{i}\right)\right]^{1-y_{i}}
$$

Na modelagem de dados de resposta binária, categorizados como sucesso (1) ou falha (0), tem sido aplicado largamente o uso da regressão logística, o que traz a vantagem da facilidade da interpretação dos resultados. A função de ligação utilizada na regressão logística é o logito, a qual é uma função de ligação simétrica. Outras funções de ligação simétricas comumente conhecidas são o probito e o cauchit, que proveem das funções de distribuição acumuladas (fda) das distribuições Normal padrão e Cauchy padrão. Maiores detalhes sobre a regressão binária podem ser encontrados em Collett (2003).

Entretanto, Czado e Santner (1992) pesquisaram os efeitos da falta de especificação da função de ligação e chegaram à conclusão de que supor o logito o no ajuste quando a verdadeira função de ligação dos dados é outra leva a encontrar viés nas estimações dos parâmetros e nas probabilidades preditivas. Além disso, mostraram que os efeitos são mais prejudiciais se a verdadeira função de ligação apresenta alta assimetria do que se apresenta alta curtose. As funções de ligação assimétricas mais conhecidas são o log-log e o complemento log-log, que proveem das distribuições Valor extremo (ou Gumbel) e Valor mínimo (ou Gumbel reversa), respectivamente. Porem, por essa característica fixa, essas funções de ligação não fornecem flexibilidade na assimetria. Chen et al. (1999) também sinalizaram que uma função de ligação assimétrica é a mais adequada quando existe muita 
diferença na quantidade de 1's e 0's na variável resposta.

Na necessidade de funções de ligação que possam melhorar a modelagem das respostas binárias, vários autores apresentaram novas propostas. Por exemplo ArandaOrdaz (1981), Guerrero e Johnson (1982) e Morgan (1983) consideraram famílias de um parâmetro; Prentice (1976) e Stukel (1988) introduziram famílias de dois parâmetros. O trabalho de Chen et al. (1999) apresentou uma abordagem de variáveis latentes. Nagler (1994), Gupta e Gupta (2008), Kim et al. (2008) e Wang e Dey (2010) introduziram um parâmetro de forma associado com a assimetria.

A estimação de modelos de regressão binária comumente desenvolvida sob abordagem clássica é apresentada em detalhe em Agresti (2007). Também Dey et al. (2000) apresentam uma revisão sobre a estimação bayesiana para estes modelos.

Bazán et al. (2014a) (apêndice D) e Bazán et al. (2016b) (apêndice I) apresentam os modelos de regressão binária com funções de ligação potência e potência reversa e estes se baseiam na ideia de introduzir um parâmetro adicional de penalização ou bonificação associado com as probabilidades de sucesso. Estes modelos admitem a possibilidade de desbalanceamento de zeros e uns, além de assimetria na função de ligação.

Adicionalmente, notemos que o processo de Bernoulli é um dos processos aleatórios mais importantes na Estatística. No caso comum, dada a probabilidade de sucesso, o resultado de um ensaio não tem qualquer influência sobre o resultado de outro ensaio. Infelizmente, muitas aplicações do mundo real com dados com super ou sub dispersão, esta suposição de independência é violada e a variável Binomial derivada do processo de soma de variáveis Bernoulli ( $Y=\sum_{i=1}^{m} x_{i} \sim \operatorname{Binomial}(m, \theta)$ ) não será útil, o que limita suas aplicações na análise de dados. Para lidar com este tipo de dados de contagem com dispersão têm sido propostos novos modelos estatísticos, ver por exemplo Bahadur (1961) e Kupper e Haseman (1978). No trabalho de Borges et al. (2014) (apêndice E) estudamos uma distribuição para este tipo de dados. Posteriormente, no trabalho Rodrigues et al. (2016) (apêndice J) é mostrada a estimação Bayesiana de um modelo restrito e aplicações 
para este tipo de dados.

\subsection{Modelos de regressão para resposta limitada cate- górica e preditor latente (modelos Teoria da Res- posta ao Item)}

Um modelo probabilístico unidimensional de teoria da resposta ao item tenta explicar a resposta de $n$ indivíduos que respondem a um conjunto de $k$ itens considerando uma variável aleatória unidimensional $\theta$, associada com o traço latente e a um conjunto de parâmetros de itens.

Considere uma sequencia de variáveis aleatórias binárias ou dicotômicas $\left\{Y_{i j}\right.$ :

$1 \leq i \leq n ; 1 \leq j \leq k\}$ associadas com as respostas aos itens. Aqui $Y_{i j}=1$ se o indivíduo $i$ responde corretamente ao item $j$ e $Y_{i j}=0$ em caso contrario. Neste caso, um modelo de resposta ao item, dicotômico e unidimensional, de três parâmetros assume que

$$
y_{i j} \sim \operatorname{Bernoulli}\left(p_{i j}\right)
$$

$\mathrm{e}$

$$
p_{i j}=P\left[Y_{i j}=1 \mid \theta_{i}, a_{j}, b_{j}, c_{j}\right]=c_{j}+\left(1-c_{j}\right) F\left(m_{i j}\right) .
$$

Em que $p_{i j}$ é a probabilidade de que o indíviduo $i$ responda corretamente o íten j. $\quad m_{i j}=a_{j}\left(\theta_{i}-b_{j}\right)$ é um preditor linear latente. Os parâmetros $\beta_{j}=\left(a_{j}, b_{j}, c_{j}\right)$ são denominados parâmetros de ítem, em que em que $c_{j}$ é um parâmetro de adivinhação, $a_{j}$ é o parâmetro de discriminação e $b_{j}$ o parâmetro de dificuldade. $\Theta_{i}$ é a variável latente de interesse associada com o traço latente do indivíduo $i$ e assumida unidimensional. Além disso, $0 \leq c_{j} \leq 1$, valores negativos de $a_{j}$ não são esperadas e $b_{j}$ e $\theta_{i}$ tomam valores reais.

A função $F($.$) é tipicamente conhecida com a função de respostas ao item ou$ curva característica do item e satisfaz a propriedade de monotonicidade latente (função 
estritamente não decrescente de $\Theta_{i}$ ). A função $F($.$) tipicamente é a mesma para todo i$ e $j$ e as mais usadas são as distribuições acumuladas das distribuições Normal e Logística.

Assim podemos considerar que temos uma regressao binária multivariada onde $\theta_{i}$ é uma covaríavel latente. $j, F^{-1}($.$) é a correspondente função de ligação como discutido$ na seção 1.2. Então modelos de teoría da resposta ao ítem podem ser considerados como modelos de regressão latente limitada. Para maiores detalhes ver De Boeck et al. (2011).

Os Modelos TRI satisfazem tipicamente a propriedade de independência condicional, isto é, para um indivíduo $i$, a resposta $Y_{i j}$ correspondente ao item $j=1, \ldots, I$ são condicionalmente independente dado os valores das variáveis latentes $\Theta_{i}, i=1, \ldots, n$. Além disso, também é considerada independência entre as respostas de diferentes indivíduos. Sob as suposições anteriores, a distribuição conjunta de $\boldsymbol{Y}=\left(\boldsymbol{Y}_{1}^{\prime}, \ldots, \boldsymbol{Y}_{n}^{\prime}\right)^{\prime}$ com $\boldsymbol{Y}_{i}=\left(Y_{i 1}, \ldots, Y_{i I}\right)^{\prime}$ dado o vetor de variáveis latentes $\boldsymbol{\Theta}=\left(\theta_{1}, \ldots, \theta_{n}\right)^{\prime}$ e o vetor de parâmetros de ítem $\beta=\left(\beta_{1}, \ldots, \beta_{I}\right)^{\prime}$ pode ser escrita como

$$
p(\boldsymbol{Y}=\boldsymbol{y} \mid \boldsymbol{\Theta}=\boldsymbol{\theta}, \boldsymbol{\beta})=\prod_{i=i}^{n} \prod_{j=1}^{I} F\left(m_{i j}\right)^{y_{i j}}\left(1-F\left(m_{i j}\right)\right)^{1-y_{i j}}
$$

O modelo logístico de três parâmetros, denominado comumente como modelo TRI $3 L$, é dado por

$$
p_{i j}=P\left[Y_{i j}=1 \mid \theta_{i}, a_{j}, b_{j}, c_{j}\right]=c_{j}+\left(1-c_{j}\right) \frac{\exp \left(a_{j}\left(\theta_{i}-b_{j}\right)\right)}{1+\exp \left(a_{j}\left(\theta_{i}-b_{j}\right)\right)} .
$$

Casos particulares são obtidos quando $c_{j}=0$ e $\left(a_{j}=1\right.$ e $\left.c_{j}=0\right)$ e são conhecidos respectivamente como modelos de dois parâmetros (modelo TRI 2L) e modelo de um parámetro (modelo TRI 1L). Neste último caso, este modelo também é chamado de modelo de Rasch embora seja derivado de outra forma.

Modelos de resposta ao item $3 L$ envolvem um total de $n+3 I$ parâmetros desconhecidos sendo como consequência super parametrizado. De outra maneira, para um 
número fixo de itens, parâmetros de itens são conhecidos como parâmetros estruturais e as variáveis latentes são conhecidas como parâmetros incidentais porque eles incrementam quando o tamanho da amostra $n$ incrementa, e porque o analise está focalizado de maneira geral nos parâmetros do item. O modelo é também não identificável, desde que é preservado baixo uma classe especial de transformações dos parâmetros (veja Albert, 1992) e consequentemente as estimativas de máxima verossimilhança podem não ser únicas. Uma maneira de resolver tais dificuldades é impor restrições nos parâmetros dos itens, por exemplo como considerado no trabalho de Bock and Aitkin (1981). Uma outra forma é obtida ao especificar uma distribuição para a variáveis latentes. Lord e Novik (1968, Chap. 16) consideram

$$
\theta_{i} \stackrel{i i d}{\sim} N\left(\mu, \sigma^{2}\right), i=1, \ldots, n
$$

Esta suposição estabelece que a variável latente são "bem comportadas"e que são amostras aleatórias desta distribuição. (Albert, 1992). Como em Tsutakawa (1984), consideramos $\mu=0$ e $\sigma^{2}=1$.

Os problemas de estimação podem ser agrupados em três categorias: estimação freqüentista (ou clássica), estimação Bayesiana sem MCMC e estimação Bayesiana com MCMC.

Na estimação clássica é considerada principalmente a aproximação de verossimilhança. Usando esta metodologia, várias aproximações foram propostas tais como a verossimilhança conjunta, verossimilhança marginal e verossimilhança condicional (Andrade et al., 2000, Baker, 1992). Mas, as estimativas de máxima verossimilhança para os parâmetros estruturais não são consistentemente estimados na presença de parâmetros incidentais (Neyman e Scott, 1948). A aproximação mais usada é a verossimilhança marginal por médio de um algoritmo pseudo-EM com quadraturas gaussianas para aproximar as integrais da etapa E do algoritmo (Book e Aitkin, 1981). Este procedimento de estimação está implementado em software, por exemplo no programa BILOG (Mislevy e Bock, 1990), o qual usa uma restrição "heurística"do modelo (Du Toit, 2003). A estimação dos pa- 
râmetros de habilidade é executada numa segunda etapa com os parâmetros de itens substituídos pelas estimativas previamente obtidas. Limitações desta metodologia são discutidas em Patz e Junker (1999) e Sahu (2002). Para estimar $\theta_{i}$ no caso de escores extremos (valor de escore 0 e de escore $n$ ), Froelich (2000) apresenta limitações nas condições de regularidade que justificam a teoria assintótica para a inferência dos parâmetros destes modelos.

No caso da estimação Bayesiana sem MCMC, a estimação Bayesiana marginal é usada com as estimativas a posteriori do máximo e do valor esperado para as variáveis latente considerando modelos hierárquicos ou não (veja-se Baker, 1992; Kim et al. 1994). Uma característica das aproximações clássicas e Bayesiana sem MCMC é que estas estão baseadas tipicamente na função de ligação logito. Uma maior revisão em detalhe da aproximação clássica e Bayesiana sem MCMC pode ser encontrada em Baker (1992) e Andrade et al. (2000) e para os casos com aproximações Bayesianas usando MCMC em Patz e Junker (1999).

Como veremos nos trabalhos que serão apresentados no próximo capítulo, ver Apêndices nós questionaremos os modelos tradicionais em várias sentidos. Por exemplo podemos assumir ligações diferentes do modelo logito e probito para $F($.$) assim como$ uma distribuição alternativa para $\theta_{i}$ diferente de la distribuição norma e poderemos questionar a suposição de independência condicional quando temos um conjunto de itens que responde a um texto comum chamado de testlet. Isso é apresentado em Bazán et al. (2014b) (Apêndice F ). De modo semelhante ligações assimétricas e efeito de testlet é abordado no trabalho Flores et al. (2016) (Apêndice L). Finalmente quanto estejamos frente a uma situação atípica de limite de tempo para as respostas aos itens, a suposição de unidimensionalidade da variável latente será questionada e então um modelo alternativo considerando outras variáveis latentes será considerado nesta situação de aceleração tentando explicar a conduta dos examinados como apresentado no trabalho Bazán et al. (2016a) (Apêndice L). 


\subsection{Objetivos}

O objetivo general do presente projeto é estudar diferentes propostas de distribuições para a inferência e analise de regressão de respostas limitadas. Os objetivos específicos são: a) Estudar diferentes propostas de distribuições alternativas à distribuição Beta, propor novas distribuições e considerar modelos de regressão mais flexíveis, especialmente sob uma perspectiva Bayesiana levando em consideração aspectos de inferência e modelagem como parte do desenvolvimento de modelos de regressão para respostas contínuas limitadas. b) Desenvolver modelos de regressão binária alternativos ao modelo tradicional de regressão Logística, o qual resulta inadequado quando existe um desbalanceamento de zeros e uns, assim como desenvolver distribuições compostas baseadas na soma de processos de bernoulli ou de respostas binárias quando a independência entre os ensaios não é assumida, o qual permite modelar super e sub dispersão contribuindo desta forma na proposta de modelos de regressão categórica limitada. Finalmente, c) estudar propostas de novos modelos de teoria da resposta ao item como parte de modelos de regressão latente limitada que relaxem os supostos comumente considerados assim como possam ser usados em situações mais gerais de aplicação de testes ou provas como são o fenómeno de assimetria, testlet e aceleração.

Este trabalho está organizado da seguinte forma. No capítulo 2 são apresentadas minhas principais seis contribuições dos últimos cinco anos para modelos de regressão de resposta limitada, específicamente para modelos de regressão de resposta limitada contínua, categórica e modelos de regressão limitada latente (modelos de Teoria da Resposta ao Item), desenvolvidas em conjunto com meus co-autores, alunos de doutorado assim como de pos-doutorado. São incluídos também seis estudos em andamento nas três áreas ou classes de modelos considerados. No capítulo 3, apresentamos as conclusões de nossa revisão sistemática do capítulo 2. Finalmente nos apêndices são apresentados cada uma das contribuições analisadas neste texto. 


\section{Capítulo 2}

\section{Análise sistematiza dos trabalhos}

Este capítulo apresenta de maneira sistemática um conjunto de seis trabalhos em formato de artigo que apresentam propostas de novos desenvolvimentos em análise de regressão para resposta limitada. Isto inclui a proposta de novas distribuições de probabilidade ou o uso de distribuições existentes para novas situações de modelagem. Todos os trabalhos foram desenvolvidos pelo candidato em conjunto com seus co-autores, alunos de pós doutorado, alunos de doutorado e mestrado. Esses trabalhos correspondem as três grandes temáticas deste texto. A primeira temática se refere a proposta de modelos de regressão para resposta limitada e inclui três trabalhos com proposta de novas distribuições assim como novas modelagens com distribuições já existentes. A segunda temática inclui trabalhos voltados a proposta de modelos de regressão categórica e inclui um trabalho com um novo modelo de regressão binária e um outro com um modelo de soma de processos Bernoulli. Por último, o terceiro grupo inclui um trabalho voltados ao desenvolvimento de modelos de regressão latente. Especificamente para o caso de modelos de Teoria da resposta ao Item considerando a proposta de uma nova distribuição para as funções de ligação e traços latentes assim como novas modelagens. Adicionalmente é apresentado uma seção com seis trabalhos em andamento em cada uma das classes ou áreas citadas acima. Finalmente são dadas algumas considerações finais da análise sistemática dos trabalhos apresentados. 


\subsection{Modelos de regressão para resposta limitada con- tínua}

Nosso interesse na área teve início com o desenvolvimento do trabalho Bayes et al. (2012). Neste trabalho, apresentado no Anexo A, foi proposto um novo modelo de regressão para proporções considerando a distribuição Beta rectangular proposto por Hahn (2008). Este novo modelo inclui como casos particulares o modelo de regressão Beta introduzida por Ferrari e Cribari-Neto (2004) e o modelo de regressão Beta com dispersão variável introduzida por Smithson e Verkuilen (2006). Em Branscum et al. (2007), uma abordagem son uma abordagem de inferência Bayesiana foi adotado utilizando o método de Monte Carlo via Cadeias de Markov (MCMC). Foram desenvolvidos estudos de simulação para avaliar a influência de valores extremos ou "outliers". Assim, foram considerados dados contaminados em quatro padrões de perturbação para gerar valores extremos. O intuito foi confirmar que o modelo de regressão Beta retangular é um novo modelo robusto alternativo para a modelagem de dados de proporções e, que o modelo de regressão Beta usual apresenta sensibilidade para a estimativa dos coeficientes de regressão. Isto foi confirmado usando as distribuições a posteriori dos parâmetros e os critérios de comparação de modelo propostos no artigo. Duas aplicações foram apresentados para ilustrar a robustez do modelo Beta retangular. Este modelo teve um interessante impacto e foi estendido recentemente por Wang e Luo (2016).

O trabalho anterior é uma extensão do modelo de distribuição Beta mas não é uma distribuição alternativa. Alem disso, modela a relação entre uma ou mais covariáveis, e a média condicional da variável resposta com base na distribuição Beta ou em uma mistura de distribuição Beta como a distribuição Uniforme (ver Bayes et al., 2012). Contudo, quando estamos interessados em saber como as covariáveis impactam em diferentes níveis da variável resposta, sendo os modelos de regressão quantílica desempenham um papel importante neste contexto. Uma distribuição diferente no contexto de regressão é a distribuição de Kumaraswamy (Jones, 2009). Assim, no trabalho em Bayes et al. (2014) 
e que foi recentemente aceito pelo Journal Statistics and Its Interface (Bayes et al., 2016) nos propomos o uso desta distribuição para modelos de regressão quantílica e modelos de regressão quantílica mista o qual é apresentado no Apêndice B.

Neste trabalho, foi proposto um novo modelo de regressão misto quantil paramétrico para variáveis de resposta limitadas considerando a distribuição introduzida por Kumaraswamy (1980). Foi adotada uma abordagem Bayesiana para a inferência dos parâmetros envolvedos usando o método MCMC. Também foram discutidos critérios de comparação de modelos. Os métodos de inferência propostos podem ser facilmente implementados e utilizados para a modelagem de este tipo de dados. Os resultados dos estudos de simulação desenvolvidos mostraram um bom desempenho dos métodos de inferência propostos. Além disso, resultados de análises de dados usando modelos de regressão com efeitos fixos e mistos foram propostos. Especificamente, foi mostrado que o modelo paramétrico quantil é um ferramenta de modelagem alternativa e complementar para variáveis de resposta limitada, tais como o índice de pobreza municipal no Brasil, que está ligado ao coeficiente de desigualdade de Gini e ao índice de desenvolvimento humano (IDH).

Um outro caminho para a modelagem de proporções é a proposta de novas distribuições no intervalo unitário. Assim, levando em consideração a distribuição pionera SB de Johnson (Johnson, 1949) desenvolvemos um trabalho mais geral que inclui este modelo como caso particular (ver Lemonte e Bazán, 2016). Neste trabalho, recentemente publicado é mostrado no Apêndice C, propomos uma classe ampla de distribuições com suporte limitado na base da família de distribuições simétricas (Fang e Anderson, 1990) em que possui como caso particular a distribuição SB de Johnson, que é uma transformação da distribuição Normal. A nova classe de distribuições fornece uma ampla fonte de distribuições alternativas para a análise de dados univariante delimitados. O trabalho fornece uma descrição completa das propriedades matemáticas desta nova família. Também, é discutido brevemente o processo de estimação dos parâmetros do modelo considerando o método de máxima verossimilhança e de mínimos quadrados. Além disso, foi proposta um novo modelo de regressão baseado nesta classe de distribuições, o qual é 
útil para situações em que a resposta é restrita ao intervalo unitário e a estrutura de regressão envolve covariáveis e parâmetros desconhecidos. O modelo de regressão proposto permite modelar os parâmetros de interesse de um modo semelhante a regressão Beta, isto é modelar os efeitos na locação e na dispersão. Foram definidos dois resíduos para o modelo de regressão proposto para avaliar as suposições do modelo, bem como para detectar observações extremas. Também discutirnos alguns métodos de influência, tais como a influência local e alavancagem generalizada. Finalmente, para mostrar a utilidade do novo modelo de regressão proposto, uma aplicação para dados reais correspondentes a proporção de votos em branco na eleição presidencial geral do Perú em 2006 sendo explicada pelo Índice de Desenvolvimento Humano (IDH) em cada distrito eleitoral. Estes dados foram previamente considerado em Bayes et al. (2012).

\subsection{Modelos de regressão para resposta limitada cate- górica}

Como dito na Seção 1.2, uma vez que muitos autores têm enfatizado a necessidade de funções de ligações assimétricas para ajustar modelos de regressão categórica, especificamente no caso binário, nós apreentamos a seguir duas contribuições nesta área.

No trabalho Bazán et al. (2014a), apresentado no Apéndice D, propomos duas novas funções de ligação para modelos de regressão binária. Estas funções de ligação chamadas no trabalho probito potência e probito potência reversa devido à relação entre elas, incluem a ligação probito como um caso especial. Estas são consideradas como ligações probito assimetrizadas pois introduzem um parâmetro associado com a assimetria da curva de resposta e o modelo de regressão probito é um caso especial dos modelos considerados neste trabalho. Foi desenvolvido uma abordagem de inferência Bayesiana usando o método MCMC o qual pode ser facilmente implementado e utilizado para a modelagem de dados. Os resultados de um estudo de simulação desenvolvidos mostraram 
um bom desempenho dos métodos de inferência propostos assim como mostraram que o uso de mal especificação do modelo verdadeiro considerando o modelo probito pode levar a viés nos coeficientes de regressão estimados e a uma sub estimação de seus verdadeiros valores. Considerando dados reais os resultados encontrados sugerem que as funções de ligação propostas no trabalho foram mais apropriados do que outras funções de ligação utilizados na literatura.

Num segundo trabalho Borges et al. (2014), apresentado no Apêndice E, desenvolvemos distribuições mais flexíveis para a soma de respostas binárias não independentes. Neste trabalho, apresentamos o estudo das propriedades matemáticas da família de distribuições Binomial-COM-Poisson introduzida por Shmueli et al. (2005). Discutimos algumas propriedades adicionais e uma aproximação assintótica desta distribuição pela distribuição COM-Poisson. Além disso, três conjuntos de dados mostraram a relevância da distribuição proposta para a soma de conjuntos de respostas binárias não necessariamente independentes.

\subsection{Modelos de regressão para resposta limitada cate- górica e preditor latente: (Modelos de resposta ao ítem)}

O principal trabalho desenvolvido na área de modelos de Teoría de resposta ao Item é Bazán et al. (2014b) mostrado no Apêndice F. Neste trabalho introduzimos novas aplicações do modelo de Teoria da Resposta ao Item probito assimétrico proposto por Bazán et al. (2006) considerando também uma distribuição skew Normal flexível para as variáveis latentes e estendendo esse modelo para incluir um efeito aleatório adicional para a modelagem dependência entre itens dentro de um mesmo testlet (pacote de itens com um estímulo comum como acontece com os ítens baseados num texto comum nas 
provas de leitura). Uma estrutura hierárquica Bayesiana foi apresentada por méio de uma abordagem introduzindo dois tipo de variáveis latentes auxiliares. Isso pode ser facilmente implementado em pacotes como WinBUGS ou SAS considerando algoritmos MCMC. Foram considerados vários critérios de comparação de modelos Bayesianos como DIC, EAIC e EBIC. Além disso, utilizamos a soma de quadrados dos resíduos latentes como medida de discrepância global para a comparação de modelos. Duas aplicações ilustram a metodologia: um conjunto de dados relacionados a um teste de matemática e um outro relacionado com a compreensão da leitura, ambos aplicados a estudantes peruanos. Os resultados indicam um melhor desempenho dos modelos mais flexíveis propostos neste trabalho em comparação com os modelos tradicionais de teoria da resposta ao item que não levam em consideração a assimetria na função de ligação e nas variáveis latentes consideradas.

\subsection{Trabalhos em andamento}

Nesta seção apresentamos um conjunto de trabalhos, classificados como em andamento. Os artigos incluídos nos apêndices G a L, são oriundos de trabalhos já concluídos que foram submetidos e se encontram em fase de revisão. No entanto, além destas pesquisas, há mais quatro trabalhos de pesquisa que estão em desenvolvimento dentro das áreas consideradas. Novamente vamos classificá-los nas mesmas áreas apresentadas nas seções anteriores antes de sua análise sistematizada nesta Seção.

\subsubsection{Modelos de regressão para resposta limitada contínua}

Como temos dito anteriormente, quando analisamos variáveis que tomam valores no intervalo $(0,1)$, tais como taxas ou proporções que são muito comuns na política e em dados sociais como por exemplo no Índice de Desenvolvimento Humano. Por vezes, este tipo de dados não podem ser adequadamente modelado utilizando uma única distribuição. 
Neste caso, podemos usar uma mistura de distribuições, a qual é uma poderosa e flexível ferramenta probabilística. Assim o trabalho desenvolvido em conjunto com minha orientada de doutorado, o qual se encontra em fase de revisão en um journal internacional, da Paz et al. (2015), é apresentado no Apêndice G com o intuito de resolver este tipo de problema. No trabalho é proposto um modelo de mistura de distribuições Simplex para modelar dados proporcionais. No processo de inferência é proposto uma abordagem completamente Bayesiana considerando o método de Saltos reversíveis MCMC. A utilidade da abordagem proposta é confirmada pelo uso de dados simulados considerando a mistura em vários cenários diferentes. Também, por méio de uma aplicação da aos dados de Índice de Desenvolvimento Humano municipal no Brasil referente às cidades da região Nordeste e o estado São Paulo.

Um segundo trabalho, também com minha orientada, da Paz et al. (2016), é apresentado no Apêndice H. Apresentamos uma nova distribuição para a modelagem de respostas limitadas. Especificamente, neste trabalho é estudada uma distribuição de dois parâmetros para o domínio limitado. Esta distribuição, chamada de distribuição L-Logística, proporciona grande flexibilidade e tem a distribuição Uniforme como caso particular. Além disso, este modelo tem uma função de distribuição explícita que facilita a geração de valores aleatórios seguindo esta distribuição. Foram estudadas várias propriedades da distribuição incluindo a assimetria e a curtose da distribuição propostas. Para a estimação consideramos a inferência Bayesiana, assumindo distribuições a priori não informativas e informativas para os parâmetros do modelo. Como parte dos estudos de simulação, desenvolvemos uma análise de sensibilidade das prioris propostas, além de um estudo de recuperação de parâmetros os quais mostraram a robustez do método de estimação proposto e a eficiência do algoritmo adoptado. Além disso, introduzimos o modelo de regressão considerando que a variável resposta segue a distribuição L-logística. Neste trabalho realizamos aplicações para estudar a Pobreza e Desigualdade no Brasil, comparando resultados usando a distribuição proposta e a regressão Beta. Os resultados obtidos mostraram que, quando os dados apresentam potenciais valores extremos, o mo- 
delo de regressão L-Logística fornece um melhor ajuste para estes dados em comparação com o modelo de regressão Beta.

\subsubsection{Modelos de regressão para resposta limitada categórica}

O primeiro trabalho em andamento na área de modelos de regressão para resposta categórica, Bazán et al. (2016b) apresentado no Apêndice I, dando continuidade ao trabalho em Bazán et al. (2014a), propomos uma nova distribuição para a modelagem de respostas binárias. Como já foi comentado, ligações tradicionais simétricas como logito e probito são geralmente considerados como padrão em regressão binária. No entanto, na presença de desequilíbrio de uns e zeros, estas ligações podem ser inadequados, inflexíveis para ajustar a assimetria na curva de resposta e susceptível de conduzir a má especificação, isto é o fato de considerar um modelo como certo quando de fato o modelo é errado. Este é o caso da cobertura de algum tipo de seguro, onde se verifica que a probabilidade de uma dada resposta variável binária se aproxima de zero a taxas diferentes do que se aproxima de um. Além disso, quando as ligações tradicionais são considerados, não existe um parâmetro relacionado com a assimetria de distribuição escolhida e independente do preditor linear que seja facilmente interpretável. Em ordem para superar tais problemas, uma proposta para a construção de um conjunto de novas ligações assimétricas foi desenvolvida neste trabalho, onde algumas de suas propriedades foram discutidas. Assim, as ligações potência e as suas correspondentes versões de potência reversa foram apresentados. Segundo esta proposta desenvolvemos uma abordagem Bayesiana utilizando o método MCMC para os diferentes modelos apresentados. A metodologia é ilustrada em uma amostra de pessoas que fazem um seguro automóvel, selecionados aleatoriamente por gênero. Os resultados sugerem que as funções de ligação propostas são mais adequados em comparação com as funções de ligação alternativas utilizadas na literatura.

Em um segundo trabalho, apresentado no Apêndice J, Rodrigues et al. (2016), também dando continuidade a um trabalho nosso propondo uma distribuição para a soma 
de variáveis binárias não necessáriamente independentes, previamente desenvolvido em Borges et al. (2014), propomos uma versão Bayesiana restrita da distribuição Binomial Conway-Maxwell introduzida por Shmueli et al. (2005), que também é a distribuição Binomial correlacionada discutida em Kupper e Haseman (1978) e Bahadur (1961), se e somente se algumas restrições são impostas nos parâmetros. Neste trabalho desenvolvemos duas aplicações com base em um conjunto de dados reais ilustrando a utilidade da distribuição de probabilidade proposta, especialmente para o caso de de número de respostas corretas em testes de comprensão leitora em estrutura testlet onde os ítens não podem ser assumidos independentes.

\subsubsection{Modelos de regressão para resposta limitada categórica e preditor latente (modelos Teoria da Resposta ao Item)}

Há dois trabalhos submetidos em fase de revisão voltados para área de analises de regressão latente, especificamente na área de Teoria da resposta ao item.

No primeiro trabalho, Bazán et al. (2016a), aprensentado no Apêndice K, é abordado o problema de aceleração em testes ou provas de desempenho. Aceleração (speededness em inglés) refere-se à situação em que o limite de tempo num teste padronizado não permite a um número substancial de examinandos poder responder todos os itens do teste. Assim, as estimativas usando modelos tradicionais de resposta ao item Logísticos de tres parâmetros (3L) mostrados na Seção 1.3, conduz às estimativas contaminadas dos parâmetros do modelo. Neste trabalho propomos um modelo Bayesiano simples para estimar ambos os tipos de parâmetros: variáveis latentes pessoais e de item para dados com evidência de aceleração. O modelo está fortemente relacionado com o de Goegebeur et al. (2008) mas diferente deste, a estrutura de dependência nos parâmetros pessoais não é assumida inicialmente na formulação do modelo. Nós conduzimos um estudo de caso para analisar dados de fluência em palavras sem sentido em estudantes peruanos. Os dados apresentam alta evidência de aceleração e quando se comparam os resultados do modelo 
3L e o modelo proposto, encontramos que dificuldade e discriminação são super estimados no modelo 3L. Adicionalmente são obtidas medidas semelhantes das habilidades dos examinandos em ambos modelos e os novos parâmetros pessoais: tolerância e propensão frente a aceleração são obtidos considerando-se o modelo proposto. Finalmente, foram futuros estudos sugeridos.

Um pressuposto fundamental na teoria de resposta ao item (TRI) é a independência condicional entre respostas ao item, mas em muitas situações esta hipótese não é válida, como é o caso da compreensão da leitura em que um conjunto de itens está relacionada com uma passagem de leitura (testlet). Um modelo Logístico Testlet (LT) foi proposta para ultrapassar estes problemas por Bradlow et al. (1999). Por outro lado, os modelos da TRI, consideram curvas Características do Item (CCI) simétricas pode levar a algumas inconsistências psicométricas, como apontado por Samejima (2000), que propôs o modelo de Expoente Positivo Logístico (LPE) para superar estes problemas. Essas inconsistências também pode ser observada quando CCI simétricas são usadas para analisar estruturas testlet. Ambos tipos de problema foi abordados em nosso trabalho em Bazán et al. (2014b). porém no trabalho, Flores et al. (2016), apresentado no Apêndice L propomos o modelo Logístico Testlet de Expoente positiva (LPET), que inclui ambos os modelos LT e LPE como versões particulares. Estudos de simulação mostraram que quando um conjunto de respostas estão na estrutura testlet e ainda está presente assimetria nas ICCs, os parâmetros do modelo são melhor estimados usando o correspondente modelo LPET. Uma aplicação com um verdadeiro conjunto de dados de um teste de compreensão de leitura mostra que a abordagem é muito promissor e flexível para lidar com ambas as formas de teste baseada em testlet e assimetria de alguma ICC.

\subsection{Considerações finais}

Os artigos apresentados nesta Seção envolvem o desenvolvimento de novos modelos envolvendo as áreas de regressão para resposta limitada, resposta categórica e re- 
gressão latente específicamente em teoria da resposta ao item. Em todos os casos, junto com a proposta de novas distribuições ou reparametrizações de distribuições previamente apresentadas na literatura, o objetivo foi modelar o efeito de covariáveis nas variáveis de resposta, sejam estas covariáveis observáveis ou latentes. Para os modelos propostos, estudos das propriedades das distribuições consideradas foram analisados e discutidos. Também, como parte destes desenvolvimentos foram propostos métodos de estimação com ênfases na inferência Bayesiana (10 dos 12 trabalhos apresentados). Assim, a implementação computacional foi desenvolvida e então estudos de simulação para avaliar a recuperação dos parâmetros e alguns casos para avaliar a sensibilidade das prioris consideradas foram desenvolvidos. Adicionalmente critérios de comparação de modelos foram propostos e discutidos.

Por fim, em todos os artigos foram apresentadas aplicações relevantes na área de pesquisa de índices sociais, análise político e educação, os quais apresentam características nos dados que fogem do caso comum em outras áreas, o que motivou em certa forma o desenvolvimento dos modelos propostos nestes trabalhos.

Adicionalmente, boa parte do conhecimento produzido por estes trabalhos pode ser empregado em outras áreas incluindo tanto os modelos propostos, quanto as ferramentas computacionais e os resultados principais obtidos nas aplicações.

Os trabalhos que estão em andamento também estão dentro deste escopo da proposta de modelos de regressão para resposta limitada, categórica e latente. 


\section{Capítulo 3}

\section{Conclusão}

A análise de regressão é uma sub área da Probabilidade e Estatística que utiliza a relação entre duas ou mais variáveis de modo a prever os valores de uma variável resposta em função da(s) outra(s) variável(is) chamadas covariável(is). Estes tiposs de modelos são amplamente usados nas áreas da economia, finanças, ciências sociais, psicologia, ciências biológicas, entre outras. Os modelos mais divulgados são aqueles em que assume-se que a variável resposta segue uma distribuição Normal e são chamados de modelos de regressão linear Normal. Outros modelos denominados de modelos lineares generalizados assumem que a variável resposta pertence à família de distribuições exponencial. A literatura em ambos casos é extensa, porém, quando a variável resposta se encontra limitada, isto é, seu domínio é limitado, a literatura é menor e poucos modelos são disponíveis.

Quando a variável resposta limitada é contínua o modelo padrão, é o de regressão Beta. Neste texto apresentamos cinco trabalhos neste área nas quais propomos distribuições alternativas ao modelo Beta como a distribuição Beta retangular, Kumaraswamy, Simplex, L-Logistic e SB-Johnson simétricas. As novas metodologias consideram distribuições previamente formuladas na literatura considerando novas reparametrizaçõe para seu uso em analise de regressão. Também foram propostas novas distribuições contínuas 
limitadas e consideradas a modelagem dos quantis da variável resposta diferente do que acontece no modelo Beta em que é modelada a media da distribuição. Isto resulta mais apropriado na presença de dados extremos. Em todos os casos mostramos como estimar estes modelos, assim como desenvolvemos estudos de simulação convenientes e aplicações relevantes especialmente na área de ciências sociais.

Quando temos o caso em que a variável resposta limitada é categórica, especificamente binária ou dicotômica, o modelo padrão é o modelo de regressão binária (binomial). Neste caso é comum usar a proposta de regressão binária considerando ligações tradicionais como as obtidas considerando a distribuição acumulada das distribuições Logística, Normal, Cauchy (ligações simétricas), Gumbel e Gumbel reversa (ligações assimétricas), porém como mostrado em dois trabalhos nesta área, o uso deste tipo de ligações pode levar a viés nas estimativas dos parâmetros de interesse se os modelo não está adequadamente especificado. Assim, nos trabalhos apresentados propomos modelos mais abrangentes que incluem como casos particulares as ligações tradicionais. Também estudos de simulação e aplicações em dados reais foram apresentados. Estes estudos mostraram as vantages das metodologias propostas frente aos modelos tradicionais. Também, estudamos uma nova distribuição para a soma de distribuições Bernoulli quando estas não são independentes chamada de Binomial-Com. Neste caso, a nova distribuição proposta inclui a distribuição Binomial como caso particular. Em dois trabalhos foram estudadas as propriedades desta distribuição assim como os métodos de estimação de seus parâmetros. Também, foram mostradas as vantages da metodologia proposta em aplicações a dados reais.

Por fim, apresentamos também as contribuições para o caso de regressão com resposta categórica limitada, especificamente binária e multivariada, em que o preditor ou covariável é considerado latente ou não observável. Estes tipos de modelos são conhecidos na literatura como modelos de teoria da resposta ao item. Nessa área apresentamos três trabalhos que relaxam os pressupostos que são assumidos nos modelos tradicionais: 
a) respostas independentes aos itens condicional na variável latente pessoal, b) variável latente assumida que segue uma distribuição Normal, c) ligação logística entre a variável latente pessoal e os parâmetros de item e d) uni dimensionalidade da variável latente pessoal. Em nossas propostas consideramos o uso da distribuição Skew-normal para a variável latente pessoal e, tanto esta distribuição como a distribuição Potencia Normal para as funções de ligação. Também, apresentamos modelos alternativos para a situação em que a suposição de independência entre as respostas aos itens é questionada quando temos uma estrutura de testlet (pacotes de questões para um texto comum) como acontece nos testes de compreensão de leitura. Além disso, foram propostos um trabalho considerando variáveis latentes adicionais que expliquem a situação de aceleração de um teste ou prova quando o limite de tempo influencia nas respostas dos indivíduos.

Assim, produzimos uma ampla variedade de modelos alternativos para a regressão de variáveis de resposta limitada, questionando os supostos dos modelos tradicionais e generalizando estes para situações mais realistas. Os métodos de estimação apresentados são eficientes e relativamente fáceis de implementar. Nos estudos de simulações mostraram as vantages das metodologias propostas e confirmam a eficiência dos métodos computacionais desenvolvidos. Também, apresentamos vários exemplos ilustrativos com dados reais na área educacional e de ciências sociais que mostraram as vantagens das metodologias propostas frente aos modelos tradicionais facilitando sua divulgação o seu uso nas diferentes áreas de aplicação. Por tanto neste texto nossas contribuições ao estudo de variáveis dependentes limitadas contínuas e categórica contribuindo assim com a literatura na área de Estatística. 


\section{Referências Bibliográficas}

Agresti, A. (2007). An introduction to categorical data analysis. Wiley series in probability and statistics. Wiley-Interscience, Hoboken (N.J.).

Aranda-Ordaz, F. J. (1981). On two families of transformations to additivity for binary response data. Biometrika, 68(2), 357-363.

Bahadur, R. R. (1961). A representation of the joint distribution of responses to n dichotomous items.

Barndorff-Nielsen, O. e Jorgensen, B. (1991). Some parametric models on the simplex. Journal of Multivariate Analysis, 39(1), 106 - 116.

Bayes, C. L., Bazán, J. L., e García, C. (2012). A New Robust Regression Model for Proportions. Bayesian Analysis, 7(4), 841-866.

Bayes, C. L., de Castro, M., e Bazán, J. L. (2014). A quantile parametric regression model for bounded response variables with an application in the analysis of attitudes scale. Technical Report 258, Programa Interinstitucional de Pós-Graduaçåo em Estatística UFSCar-USP, Såo Carlos, SP. Brazil.

Bayes, C. L., de Castro, M., e Bazán, J. L. (in press 2016). A quantile parametric mixed regression model for bounded response variables. Statistics and Its Interface.

Bazán, J. L., Branco, M. D., e Bolfarine, H. (2006). A skew item response model. Bayesian Anal., 1(4), 861-892. 
Bazán, J. L., Romeo, J. S., e Rodrigues, J. (2014a). Bayesian skew-probit regression for binary response data. Brazilian Journal of Probability and Statistics, 28(4), 467-482.

Bazán, J. L., Branco, M. D., e Bolfarine, H. (2014b). Extensions of the skew-normal ogive item response model. Brazilian Journal of Probability and Statistics, 28(1), 1-23.

Bazán, J. L., Valdivieso, L., e Branco, M. D. (2016a). Measurement of the nonsense word fluency: Bayesian approach to a item response model with speededness. Submmitted to Biometric Brazilian Journal.

Bazán, J. L., Torres-Avilés, F., Suzuki, A. K., e Louzada, F. (2016b). Power and reversal power links for binary regressions: An application for policyholders of motor insurance. Submmitted to Applied Stochastic Models in Business and Industry.

Borges, P., Rodrigues, J., Balakrishnan, N., e Bazán, J. (2014). A com-poisson type generalization of the binomial distribution and its properties and applications. Statistics E Probability Letters, 87, 158 - 166.

Bradlow, E. T., Wainer, H., e Wang, X. (1999). A bayesian random effects model for testlets. Psychometrika, 64(2), 153-168.

Branscum, A. J., Johnson, W. O., e Thurmond, M. C. (2007). Bayesian beta regression: Applications to household expenditure data and genetic distance between foot-andmouth disease viruses. Australian $\&$ New Zealand Journal of Statistics, 49(3), 287-301.

Buckley, J. (2003). Estimation of models with beta-distributed dependent variables: A replication and extension of paolino's study. Political Analysis, 11(2), 204-205.

Chen, M.-H., Dey, D. K., e Shao, Q.-M. (1999). A new skewed link model for dichotomous quantal response data. Journal of the American Statistical Association, 94(448), 11721186 .

Collett, D. (2003). Modelling Binary Data. Texts in Statistical Science. Chapman \& Hall, London, New York. 
Cribari-Neto, F. e Zeileis, A. (2010). Beta regression in R. Journal of Statistical Software, $34(2), 1-24$.

Czado, C. e Santner, T. J. (1992). The effect of link misspecification on binary regression inference. Journal of Statistical Planning and Inference, 33(2), 213-231.

da Paz, R. F., Bazán, J. L., e Milan, L. A. (2015). Bayesian estimation for mixture of simplex distribution with unknown number of components: Hdi analysis in brazil. Technical Report 261, Programa Interinstitucional de Pós-Graduaçåo em Estatística UFSCar-USP, Såo Carlos, SP. Brazil.

da Paz, R. F., Bazán, J. L., e Balakrishnan, N. L. (2016). L-logistic distribution: Properties, inference and an application to study poverty and inequality in brazil. Technical Report 262, Programa Interinstitucional de Pós-Graduaçåo em Estatística UFSCarUSP, Såo Carlos, SP. Brazil.

De Boeck, P., Bakker, M., Zwitser, R., Nivard, M., Hofman, A., Tuerlinckx, F., e Partchev, I. (2011). The estimation of item response models with the lmer function from the lme4 package in r. Journal of Statistical Software, 39(1), 1-28.

Dey, D. K., Gosh, S. K., e Mallick, B. K. (2000). Generalized linear models: a Bayesian perspective. Marcel Dekker Inc, New York.

Fang, K. T. e Anderson, T. W. (1990). Statistical Inference in Elliptical Contoured and Related Distributions. Allerton Press, New York, NY.

Ferrari, S. e Cribari-Neto, F. (2004). Beta regression for modelling rates and proportions. Journal of Applied Statistics, 31(7), 799-815.

Figueroa-Zúñiga, J. I., Arellano-Valle, R. B., e Ferrari, S. L. P. (2013). Mixed beta regression: A bayesian perspective. Computational Statistics \& Data Analysis, 61, $137-147$. 
Flores, S., Azevedo, C. N., e Bazán, J. L. (2016). A skew testlet irt model under a bayesian approach. Submmitted to Brazilian Journal of Probability and Statistics.

Galvis, D. M., Bandyopadhyay, D., e Lachos, V. H. (2014). Augmented mixed beta regression models for periodontal proportion data. Statistics in Medicine, 33(21), 37593771 .

Gilchrist, W. (2000). Statistical Modelling with Quantile Functions. CRC Press, Abingdon.

Goegebeur, Y., De Boeck, P., Wollack, J. A., e Cohen, A. S. (2008). A speeded item response model with gradual process change. Psychometrika, 73(1), 65-87.

Guerrero, V. M. e Johnson, R. A. (1982). Use of the box-cox transformation with binary response models. Biometrika, 69(2), 309-314.

Gupta, A. e Nadarajah, S. (2004). Handbook of Beta Distribution and Its Applications. Taylor \& Francis, Philadelphia.

Gupta, R. D. e Gupta, R. C. (2008). Analyzing skewed data by power normal model. TEST, 17(1), 197-210.

Hahn, E. D. (2008). Mixture densities for project management activity times: A robust approach to pert. European Journal of Operational Research, 188(2), 450 - 459.

Johnson, N. L. (1949). Systems of frequency curves generated by methods of translation. Biometrika, 36(1/2), 149-176.

Jones, M. C. (2009). Kumaraswamy's distribution: A beta-type distribution with some tractability advantages. Statistical Methodology, 6, 70-81.

Kim, S., Chen, M.-H., e Dey, D. K. (2008). Flexible generalized t-link models for binary response data. Biometrika, 95(1), 93-106. 
Kotz, S. e van Dorp, J. R. (2004). Beyond Beta: Other Continuous Families of Distributions with Bounded Support and Applications. World Scientific Publishing, Singapore.

Kumaraswamy, P. (1980). A generalized probability density function for double-bounded random processes. Journal of Hydrology, 46(1-2), 79-88.

Kupper, L. L. e Haseman, J. K. (1978). The use of a correlated binomial model for the analysis of certain toxicological experiments. Biometrics, 34(1), 69-76.

Lemonte, A. J. e Bazán, J. L. (2016). New class of johnson sb distributions and its associated regression model for rates and proportions. Biometrical Journal, 58(4), $727-746$.

López, F. O. (2013). A bayesian approach to parameter estimation in simplex regression model: A comparison with beta regression. Revista Colombiana de Estatística, 36(1), $1-21$.

Morgan, B. J. T. (1983). Observations on quantitative analysis. Biometrics, 39, 879-886.

Nagler, J. (1994). Scobit: An alternative estimator to logit and probit. American Journal of Political Science, 38(1), 230-255.

Paolino, P. (2001). Maximum Likelihood Estimation of Models with Beta-Distributed Dependent Variables. Political Analysis, 9(4), 325-346.

Prentice, R. L. (1976). A generalization of the probit and logit methods for dose response curves. Biometrics, 32(4), 761-768.

Qiu, Z., Song, P. X.-K., e Tan, M. (2008). Simplex mixed-effects models for longitudinal proportional data. Scandinavian Journal of Statistics, 35(4), 577-596.

Rennolls, K. e Wang, M. (2005). A new parameterization of johnson's sb distribution with application to fitting forest tree diameter data. Canadian Journal of Forest Research, 35(3), $575-579$. 
Rodrigues, J., Bazán, J. L., Suzuki, A. K., e Balakrishnan, N. L. (2016). The bayesian restricted conway-maxwell-binomial model to control dispersion in count data. Submmitted to Statistics and Probability Letters.

Samejima, F. (2000). Logistic positive exponent family of models: Virtue of asymmetric item characteristic curves. Psychometrika, 65(3), 319-335.

Shmueli, G., Minka, T. P., Kadane, J. B., Borle, S., e Boatwright, P. (2005). A useful distribution for fitting discrete data: revival of the conway-maxwell-poisson distribution. Journal of the Royal Statistical Society: Series C (Applied Statistics), 54(1), 127-142.

Smithson, M. e Verkuilen, J. (2006). A better lemon squeezer Maximum-likelihood regression with beta-distributed dependent variables. Psychological Methods, 11(1), 54-71.

Song, P. X.-K. e Tan, M. (2000). A marginal models for longitudinal continuous proportional data. Biometrics, 56(2), 496-502.

Song, P. X.-K., Qiu, Z., e Tan, M. (2004). Modelling heterogeneous dispersion in marginal models for longitudinal proportional data. Biometrical Journal, 46(5), 540-553.

Stukel, T. A. (1988). Generalized logistic models. Journal of the American Statistical Association, 83, 426-431.

Wang, J. e Luo, S. (2016). Augmented beta rectangular regression models: A bayesian perspective. Biometrical Journal, 58(1), 206-221.

Wang, X. e Dey, D. K. (2010). Generalized extreme value regression for binary response data: An application to b2b electronic payments system adoption. The Annals of Applied Statistics, 4(4), 2000-2023. 
Appendices 


\section{Apêndice A}

Bayes, C. L., Bazán, J. L., e García, C. (2012). A New Robust Regression Model for Proportions. Bayesian Analysis, 7(4), 841-866. DOI: 10.1214/12-BA728. 
Bayesian Analysis (2012)

7, Number 2, pp. 771-796

\title{
A New Robust Regression Model for Proportions
}

\author{
Cristian L. Bayes*, Jorge L. Bazán ${ }^{\dagger}$ and Catalina García
}

\begin{abstract}
A new regression model for proportions is presented by considering the Beta rectangular distribution proposed by Hahn (2008). This new model includes the Beta regression model introduced by Ferrari and Cribari-Neto (2004) and the variable dispersion Beta regression model introduced by Smithson and Verkuilen (2006) as particular cases. Like Branscum, Johnson, and Thurmond (2007), a Bayesian inference approach is adopted using Markov Chain Monte Carlo (MCMC) algorithms. Simulation studies on the influence of outliers by considering contaminated data under four perturbation patterns to generate outliers were carried out and confirm that the Beta rectangular regression model seems to be a new robust alternative for modeling proportion data and that the Beta regression model shows sensitivity to the estimation of regression coefficients, to the posterior distribution of all parameters and to the model comparison criteria considered. Furthermore, two applications are presented to illustrate the robustness of the Beta rectangular model.
\end{abstract}

Keywords: Proportions, Beta regression, Bayesian estimation, link function, MCMC

\section{Introduction}

The Beta regression model was introduced by Ferrari and Cribari-Neto (2004) and it is adequate for situations where the variable of interest is continuous, restricted to the interval $(0,1)$ - such as percentages, proportions and fractions or rates (Kieschnick and McCullough, 2003) - and related to other variables through a regression structure.

Examples of these situations can be fluctuations in variables whose support is the standard unit interval, such as income concentration; unemployment rate; proportion of households subscribing to a cable TV service; proportion of household television viewing of various programming streams; proportion of votes for an incumbent president running for re-election, proportion of poor single mothers with children migrating from one state to another, etc.

In the Beta regression model, the regression parameters are interpretable in terms of the mean response, and in many aspects are similar to Generalized Linear Models (GLM). Estimation can be performed by maximum likelihood (Ferrari and CribariNeto 2004) or by Bayesian inference (Branscum et al. 2007). The Beta regression model

\footnotetext{
*Departamento de Ciencias, Pontificia Universidad Católica del Perú, Lima, Perú, cbayes@pucp.edu.pe

†Departamento de Ciencias, Pontificia Universidad Católica del Perú, Lima, Perú, jlbazan@pucp.edu.pe

¥Departamento de Métodos Cuantitativos, Universidad de Granada, España, cbgarcia@ugr.es
}

(C) 2012 International Society for Bayesian Analysis

ba0001 
is sufficiently documented by several publications such as Espinheira et al. (2008a,b); Ferrari et al. (2011); Cribari-Neto and Zeileis (2010) and several applications as, for example, Kelly et al. (2007) and Wallis et al. (2009).

However, the model proposed by Ferrari and Cribari-Neto (2004) does not model the dispersion but treats it solely as a nuisance parameter. As indicated by Smithson and Verkuilen (2006) this is a major oversight, as the ability to model dispersion can prove very useful. In addition, seemingly independently of Ferrari and Cribari-Neto (2004), Kieschnick and McCullough (2003) compared the performance of a Beta regression model for proportions, applied in economics and finance research, with several alternatives and conclude that it is often the best option.

Paolino (2001), by considering maximum likelihood, and Buckley (2002), by considering a Bayesian approach, use a Beta regression model which considers covariates between the mean and the dispersion parameters. This model, extensively presented in Smithson and Verkuilen (2006), is termed the variable dispersion Beta regression in Simas et al. (2010); Ferrari et al. (2011). In this case, the parameter that accounts for the precision of the data is not assumed to be constant across observations, as is the case with the Beta regression model, but is allowed to vary.

The Beta distribution can be considered flexible since the probability density function (pdf) can take different shapes by considering different values of its parameters. However, as was noted by Hahn (2008) and García et al. (2011), the Beta distribution neither considers tail-area events nor greater flexibility in the variance specification. We consider that this fact could limit its applications for modeling proportions. More discussion can be found in Kotz and van Dorp (2004).

It is important to consider diagnostic tools when estimating Beta regressions. The classical perspective of Ferrari and Cribari-Neto (2004) provided some guidelines for diagnostic analysis, including the use of two different residuals. Espinheira et al. (2008a) proposed two new Beta regression residuals and Espinheira et al. (2008b) proposed measures of influence analysis. By considering these measures, these authors, particularly Espinheira et al. (2008b), showed the influence of an observation in applications of the Beta regression model. However, no study has been carried out to show that the Beta regression model is not influenced by the estimation of regression parameters when there are outlying observations in the response variable. Thus, there is no robustness study of the Beta regression model from a Bayesian perspective by introducing perturbations in some observations to obtain artificial outliers and evaluating the impact of these perturbations on regression coefficients and on the measure of global fit. Following Pinheiro et al. (2001) and Barnett and Lewis (1995), we refer to an outlier as an observation (or set of observations) that appears to be inconsistent with the rest of the data.

In order to obtain some additional flexibility, we provide a regression model that permits varying amounts of dispersion and greater likelihood of more extreme tailarea events by considering the Beta rectangular distribution proposed by Hahn (2008). This new model includes the Beta regression model and the variable dispersion Beta regression model as particular cases. In addition, following a robust statistical modeling approach (Pinheiro et al. 2001) we will show that Beta rectangular regression is more 
robust than the Beta regression model.

The Beta rectangular distribution is just a mixture of a Beta distribution with a Uniform distribution and thus is a finite Beta mixture model as given by Bouguila et al. (2006). It is well-known that mixture distributions are more robust to outliers (comparatively large or influential values) since by including an extra distributional component in the model, the variability is better accounted for and the estimation of the "true" mean parameter is less affected, as indicated by Markatou (2000). As expected, we show that the Beta rectangular regression is a simple model and can be more "robust" compared to the usual Beta regression by considering simulation studies. In addition, we show an efficient way of simulating a posterior distribution.

The paper is organized as follows. In Section 2, we review the Beta rectangular distribution and a new parametrization is introduced. In Section 3, the Beta rectangular regression model is proposed, which can fit the mean and dispersion of the model. In the fourth section, a Bayesian inference approach is adopted using a Markov Chain Monte Carlo (MCMC) algorithm. Model comparison criteria for model selection such as Deviance Information Criterion (DIC), Expected Akaike Information Criterion (EAIC) and Expected Bayesian Information Criterion (EBIC) are also shown. In Section 5, two simulation studies are carried out to show that the new model is more robust than the Beta regression model in the presence of artificial outliers obtained by perturbing observations in the data by considering a sensitivity study on (a) the estimation of regression coefficients, (b) the posterior distribution of all parameters and (c) model comparison criteria. Section 6 presents two applications which are developed to show the utility of the Beta rectangular regression model. The conclusions are presented in Section 7 .

\section{Beta rectangular distribution}

\subsection{Beta distribution}

As the Beta distribution is well-known, we will directly review the reparametrization proposed by Ferrari and Cribari-Neto (2004). Then, a random variable $Y$ follows a Beta distribution if its probability density function (pdf) is given by:

$$
b(y \mid \mu, \phi)=\frac{\Gamma(\phi)}{\Gamma(\mu \phi) \Gamma((1-\mu) \phi)} y^{\mu \phi-1}(1-y)^{(1-\mu) \phi-1}, \quad 0<y<1
$$

where $0<\mu<1$ and $\phi>0$. We consider the notation $Y \sim \operatorname{Beta}(\mu, \phi)$. The mean and variance are expressed by:

$$
E(y \mid \mu, \phi)=\mu \quad \text { and } \quad \operatorname{Var}(y \mid \mu, \phi)=\frac{V(\mu)}{1+\phi}
$$

where $V(\mu)=\mu(1-\mu), \mu$ is the mean and $\phi$ can be interpreted as a precision parameter. 
As indicated by Morris (1982) with this parametrization, the Beta distribution is a univariate exponential family but is not a natural exponential family. In addition, by considering that the quadratic variance function above matches that of the binomial, there is a failure to characterize the family within all exponential families.

\subsection{Beta Rectangular distribution}

The Beta distribution can initially be considered as flexible since the pdf can have different shapes by considering different values of $\mu$ and $\phi$. However, as was noted by Hahn (2008) and García et al. (2011), the Beta distribution neither considers tail-area events nor greater flexibility in the variance specification. We consider that this fact could limit its application for modeling proportions. In order to get some additional flexibility, we provide a regression model which permits varying amounts of dispersion and greater likelihood of more extreme tail-area events by considering the Beta rectangular distribution proposed by Hahn (2008) whose pdf is given by:

$$
f(y \mid \mu, \phi, \theta)=\theta+(1-\theta) b(y \mid \mu, \phi),
$$

where $0 \leq \theta \leq 1$ is a mixture parameter. Clearly the Uniform distribution is recovered when $\theta=1$ and the Beta distribution is recovered when $\theta=0$. In Figure 1 we show several probability density and cumulative distribution functions of the Beta rectangular distribution for different values of $\mu, \phi$ and $\theta$.

We consider the notation $Y \sim B R(\mu, \phi, \theta)$. Note that the Beta rectangular distribution is a mixture of two Beta variables, a Beta $(1 / 2,2)$, or the Uniform distribution, and a $\operatorname{Beta}(\mu, \phi)$. The mean and variance of this distribution are given by:

$$
\begin{aligned}
E(y \mid \mu, \phi, \theta) & =\frac{\theta}{2}+(1-\theta) \mu \\
\operatorname{Var}(y \mid \mu, \phi, \theta) & =\frac{V(\mu)}{1+\phi}(1-\theta)(1+\theta(1+\phi))+\frac{\theta}{12}(4-3 \theta) .
\end{aligned}
$$

Note that when $\theta=0$ the expressions given in (4) coincide with the expressions of the mean and variance of the Beta distribution. In a similar way when $\theta=1$, these expressions coincide with the mean and variance of the Uniform distribution. In this case there is not a unique mode, which is of no particular difficulty since the mode is not a quantity of interest. When $0<\theta<1$ the mode is:

$$
m=\frac{\mu \phi-1}{\phi-2}
$$

which clearly is the same as that of the underlying Beta distribution. 

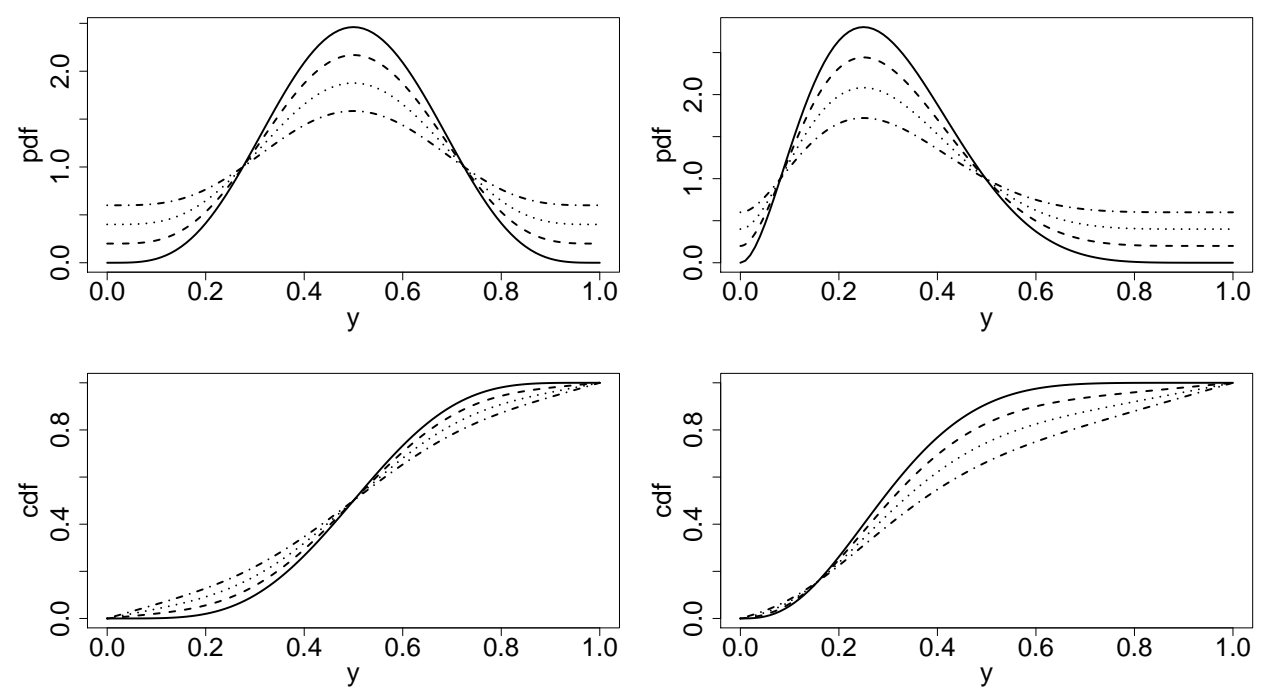

Figure 1: Examples of Beta rectangular pdf and cdf for $\mu=0.5$ and $\phi=10$ (left panels) and $\mu=0.3$ and $\phi=10$ (right panels) with different values of the mixture parameter $\theta$ : $\theta=0$ (solid line), $\theta=0.2$ (dashed line), $\theta=0.4$ (dotted line) and $\theta=0.6$ (dot dashed line).

\subsection{A reparameterization of Beta Rectangular distribution}

For a regression analysis, the mean of the response is typically modeled (Ferrari and Cribari-Neto 2004). However, the mean of the Beta rectangular distribution (4) is a function of the mixture parameter $\theta$ and $\mu$. If we take $E(Y)=\frac{\theta}{2}+(1-\theta) \mu=\gamma$, we obtain that the parametric space of $\theta$ is restricted for the value of $\gamma$ in the following way:

$$
0<\theta<1-|2 \gamma-1|
$$

In order to obtain a more appropriate regression structure for the mean of the Beta rectangular distribution, we take

$$
\gamma=\frac{\theta}{2}+(1-\theta) \mu \quad \text { and } \quad \alpha=\frac{\theta}{1-(1-\theta)|2 \mu-1|}
$$

as a new parametrization. In this case, the parametric space of $\gamma$ and $\alpha$ is the rectangle given by $\{0 \leq \gamma \leq 1,0 \leq \alpha \leq 1\}$. 
Under this parametrization the pdf of the Beta rectangular distribution is given by:

$$
\begin{aligned}
g(y \mid \gamma, \phi, \alpha)= & \alpha(1-|2 \gamma-1|)+(1-\alpha(1-|2 \gamma-1|)) \\
& \times b\left(y \mid \frac{\gamma-0.5 \alpha(1-|2 \gamma-1|)}{1-\alpha(1-|2 \gamma-1|)}, \phi\right) .
\end{aligned}
$$

We consider the following notation: $Y \sim B R r(\gamma, \phi, \alpha)$ with mean parameter $\gamma$. In addition, by considering Figure 2, which depicts the pdf (expression 7) of a BRr distribution for different values of $\gamma, \phi$ and $\alpha$, we note that $\alpha$ is a shape parameter which is associated with the thickness of the tails of the distribution and $\phi$ is a parameter that seems to control the precision of the distribution; for larger values of $\phi$ we observe less dispersion. When $\alpha=0$ the Beta distribution is recovered.
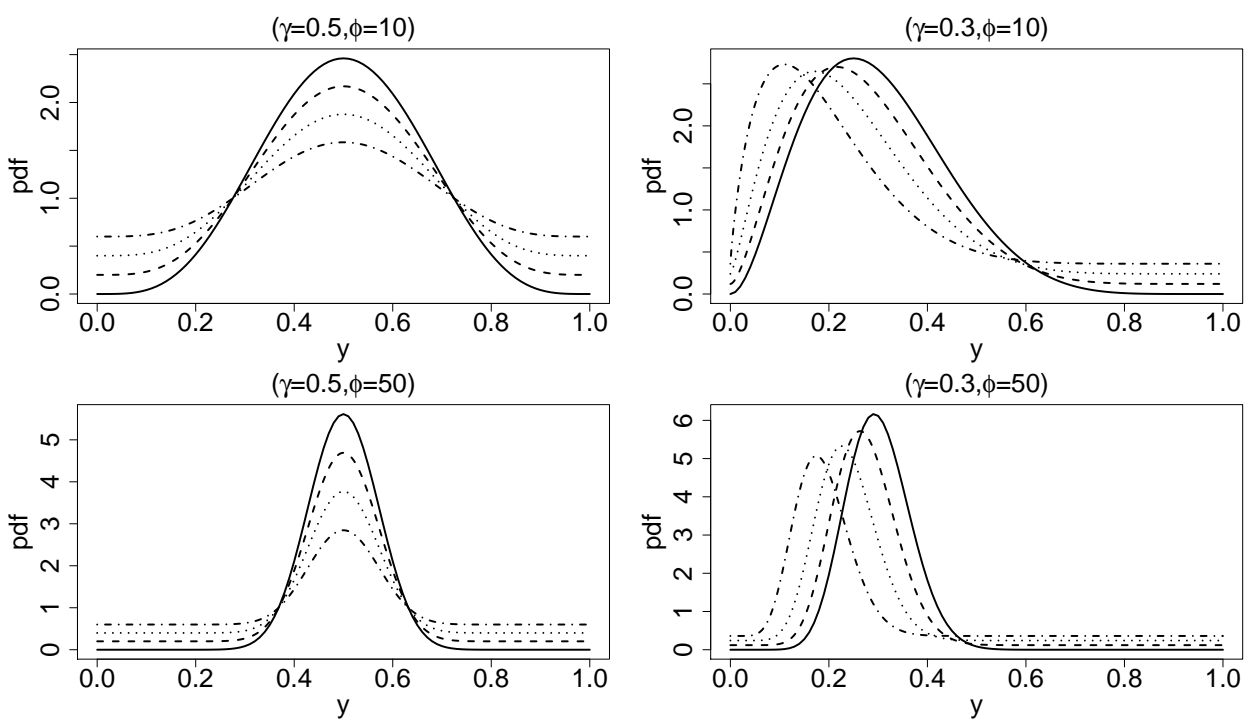

Figure 2: Examples of Beta rectangular pdf under reparametrization (6) for different values of $\gamma, \phi$ and $\alpha: \alpha=0$ (solid line), $\alpha=0.2$ (dashed line), $\alpha=0.4$ (dotted line) and $\alpha=0.6$ (dot dashed line).

\section{Beta Rectangular Regression}

Let $\mathbf{Y}=\left(Y_{1}, \ldots, Y_{n}\right)^{T}$ be a vector of observed responses that takes values in $(0,1)$. The Beta rectangular regression model is given by:

$$
\begin{aligned}
Y_{i} & \sim \operatorname{BRr}\left(\gamma_{i}, \phi_{i}, \alpha\right) \\
F_{1}^{-1}\left(\gamma_{i}\right) & =\mathbf{x}_{i}^{T} \beta \\
F_{2}^{-1}\left(\phi_{i}\right) & =-\mathbf{w}_{i}^{T} \delta
\end{aligned}
$$


where $\beta=\left(\beta_{1}, \ldots, \beta_{k}\right)$ and $\delta=\left(\delta_{1}, \ldots, \delta_{l}\right)$ are vectors of regression parameters, $\mathbf{x}_{i}=$ $\left(x_{i 1}, \ldots, x_{i k}\right)$ and $\mathbf{w}_{i}=\left(w_{i 1}, \ldots, w_{i l}\right)$ are vectors of $k$ and $l$ covariates (possibly overlapping or even identical) and $F_{1}^{-1}(\cdot)$ and $F_{2}^{-1}(\cdot)$ are strictly monotone and double differentiable functions on $(0,1)$ to $\mathbf{R}$ in the first case and $\mathbf{R}^{+}$to $\mathbf{R}$ in the second.

In general $F_{1}(\cdot)$ can be any cumulative distribution function corresponding to a continuous distribution where the inverse function is called the link function relating the mean parameter $\gamma_{i}$ with covariates $\mathbf{x}_{i}$. Some examples of link functions for $F_{1}^{-1}(\cdot)$ are logit, probit and complementary log-log, but other links can be explored. $F_{2}^{-1}(\cdot)$ also is a link function relating the precision parameter $\phi_{i}$ with covariates $\mathbf{w}_{i}$. In addition, as the parameters $\phi_{i}$ must be strictly positive, the log link that can be used for $F_{2}^{-1}(\cdot)$ is $\log \left(\phi_{i}\right)=-\mathbf{w}_{i}^{T} \delta$ where we use the negative sign, as indicated by Smithson and Verkuilen (2006), to make the interpretation of the coefficients $\delta$ easier. Because $\phi_{i}$ is a precision parameter, a positive-signed $\delta_{j}$ indicates smaller variance, which is potentially confusing. It seems more natural to model dispersion rather than precision, and the negative sign enables us to do so.

The likelihood function for the model proposed can be written, alternatively, considering the parameterization given in (3) or the parameterization in (7) as:

$$
L(\eta \mid \mathbf{Y})=\prod_{i=1}^{n} f\left(y_{i} \mid \mu_{i}, \phi_{i}, \theta_{i}\right)=\prod_{i=1}^{n} g\left(y_{i} \mid \gamma_{i}, \phi_{i}, \alpha\right)
$$

where $\eta=(\beta, \delta, \alpha), \gamma_{i}$ and $\phi_{i}$ are defined in (8) with $\theta_{i}=\alpha\left(1-2\left|\gamma_{i}-1 / 2\right|\right)$ and $\mu_{i}=\frac{\gamma_{i}-\theta_{i} / 2}{1-\theta_{i}}$.

Note that in (8) when $\alpha=0$ and $\phi_{i}$ is constant, we obtain the Beta regression model proposed by Ferrari and Cribari-Neto (2004) which is not an exponential family and so is not a GLM. Note also that, if solely $\alpha=0$ then we obtain the variable dispersion Beta regression model introduced by Paolino (2001), Smithson and Verkuilen (2006) and recently by Simas et al. (2010). When other values of $\alpha$ are considered, the proposed regression model achieves greater flexibility.

\section{Bayesian inference}

The maximum likelihood estimators of the parameters of the model given in (8) can be obtained in a similar way to Ferrari and Cribari-Neto (2004). However, in some empirical situations, the sample size may be small and in such cases Bayesian inference seems to be more suitable if previous information about the parameters is available, see Congdon (2003) and Gelman et al. (2003). In this section we propose a Bayesian approach.

With independent data, the likelihood function for the Beta rectangular regression 
model is given by (9) so the posterior distribution is defined as:

$$
p(\eta \mid \mathbf{Y}) \propto L(\eta \mid \mathbf{Y}) p(\eta)
$$

To complete the Bayesian specification of the model, we assume a prior distribution for all the unknown quantities $\eta=(\beta, \delta, \alpha)$. We assume that the elements of the parameter vector are independent and the following condition is verified:

$$
p(\eta)=p(\beta) p(\delta) p(\alpha) .
$$

We can consider the usual priors to coefficients of regression to the mean and dispersion given by $\beta \sim N_{k}(\mathbf{a}, \mathbf{B})$ and $\delta \sim N_{l}(\mathbf{c}, \mathbf{D})$. In addition, we can consider a noninformative uniform prior $\alpha \sim \operatorname{Uniform}(0,1)$. So we have that the posterior distribution is given by

$$
\begin{aligned}
p(\eta \mid \mathbf{Y}) & \propto \prod_{i=1}^{n} \alpha\left(1-\left|2 F_{1}\left(\mathbf{x}_{i}^{T} \beta\right)-1\right|\right)+\left(1-\alpha\left(1-\left|2 F_{1}\left(\mathbf{x}_{i}^{T} \beta\right)-1\right|\right)\right) \\
& \times b\left(y \mid \frac{F_{1}\left(\mathbf{x}_{i}^{T} \beta\right)-0.5 \alpha\left(1-\left|2 F_{1}\left(\mathbf{x}_{i}^{T} \beta\right)-1\right|\right)}{1-\alpha\left(1-\left|2 F_{1}\left(x_{i}^{T} \beta\right)-1\right|\right)}, F_{2}\left(\mathbf{w}_{i}^{T} \delta\right)\right) \\
& \times \quad \phi_{k}(\beta \mid \mathbf{a}, \mathbf{B}) \times \phi_{l}(\delta \mid \mathbf{c}, \mathbf{D}) \times 1
\end{aligned}
$$

where $\phi_{k}($.$) and \phi_{l}($.$) denote the density function of a multivariate normal distribution$ of order $k$ and $l$ respectively.

In the particular case when we have the mean-regression model without modeling the dispersion parameter, the prior distributions considered for $\eta=(\beta, \phi, \alpha)$ are

$$
p(\eta)=p(\beta) p(\phi) p(\alpha)
$$

where $\phi \sim \operatorname{Gamma}(c, c)$ as in Branscum et al. (2007). In preliminary explorations, we have observed that the inference on the coefficients of regression to the mean which are the main focus of interest are similar under different choices of hyperparameter $c=0.1,0.01,0.001$.

The normalizing constant of the posterior distribution of the parameters in (11) cannot be obtained analytically. So, a possible approximation is obtained though MCMC to draw samples from the posterior density. A simple way is to implement a Metropolis sampling in OpenBUGS software (Lunn, Spiegelhalter, Thomas, and Best 2009). In addition, it is possible to implement a Metropolis-within Gibbs and slice sampling in WinBUGS software (Lunn, Thomas, Best, and Spiegelhalter 2000) which can be more stable. For this, we use an augmented version considering the usual mixture model representation similar to the procedure proposed by Bouguila et al. (2006) introducing latent variables for the mixture parameter, see for example the BUGS code in the appendix. 
For all estimations in Sections 5 and 6, we simulate a large number of iterations, discarding the first $50 \%$ of them as a burn-in period. To avoid correlation problems, we considered a spacing of size or thin equal to 10. Efficiency as measured by Effective Sample Sizes above 0.9 was obtained. In addition, convergence criteria given by Geweke (1992) as implemented in CODA (Plummer et al. 2006) were achieved.

\subsection{Model Comparison Criteria}

There are several methodologies for comparing competing models for a given dataset. We consider three approaches to Bayesian model selection: the Deviance Information Criterion (DIC, Spiegelhalter et al. 2002), the Expected Akaike Information Criterion (EAIC) and the Expected Bayesian Information Criterion (EBIC), which were proposed by Brooks (2002) and used for example in Bolfarine and Bazán (2010). These model criteria are simple to compute as the relevant quantities can be calculated directly from the MCMC output.

In order to obtain this, the following criteria are considered:

$$
E[D(\eta)], \quad D(E[\eta]) \text { and } \rho_{D}=E[D(\eta)]-D(E[\eta])
$$

which represent the posterior mean of the deviance; deviance of posterior mean, which is obtained by considering the mean values of the posteriori of the parameters in the deviance of the model; and the effective number of parameters as given in Spiegelhalter et al. (2002).

These quantities can be estimated by using the MCMC output, considering the value of

$$
\bar{D}=\frac{1}{B} \sum_{b=1}^{B} D\left(\eta^{b}\right), \quad \widehat{D}=D\left(\frac{1}{B} \sum_{b=1}^{B} \eta^{b}\right) \text { and } \widehat{\rho_{D}}=\bar{D}-\widehat{D}
$$

respectively, where $B$ represents the number of iterations, and $D\left(\eta^{b}\right)=-2 \log L\left(\eta^{b} \mid \mathbf{Y}\right)$ is the value of the deviance in the iteration $b$.

The criteria EAIC, EBIC and DIC can be estimated using MCMC output by considering

$$
\widehat{E A I C}=\bar{D}+2 p, \widehat{E B I C}=\bar{D}+p \log (n) \text { and } \widehat{D I C}=\bar{D}+\widehat{\rho_{D}}=2 \bar{D}-\widehat{D}
$$

respectively, where $p$ is the number of parameters in the model and $n$ is the total number of observations.

Smaller values of $\bar{D}$, DIC, EBIC and EAIC imply better model fit. 


\section{Robustness Study}

In this section, we compare the sensitivity of the Beta and Beta rectangular regression models in the presence of outliers by considering two simulation studies, one without covariates and the other considering covariates.

\subsection{Simulation Study 1}

In this subsection, an extensive simulation study is carried out to evaluate the relative performance of the procedure for estimating the Beta and Beta rectangular models without covariates for Beta data by considering (a) two values of $\phi=\{10,30\}$, (b) three sample sizes $n=\{50,100,200\}$ and (c) percent of cases in outliers $r=\{2 \%, 5 \%, 8 \%\}$.

First, a dataset with sample size $n$ was simulated from the Beta distribution with parameters $\mu=0.2$ and parameter of dispersion $\phi$. Next, a sample of size $r \times n / 100$ was taken without replacement from $n$. Later, these cases were replaced by values generated from the Uniform distribution $(q, 1)$, where $q$ corresponds to the 0.999 quantile of the simulated Beta distribution - that is, outliers in the right tail of the distribution by considering values generated from another distribution. This data can be considered contaminated Beta data.

The combination of values of $\phi, n$ and $r$ produce $2 \times 3 \times 3=18$ scenarios of contaminated simulated Beta data (see Table 1). For each scenario, 100 replications of contaminated Beta data were generated. For example, for scenario 2 (with $\phi=10, n=100$ and $r=2 \%) 100$ simulations of a sample of size 100 of a $\operatorname{Beta}(\mu \times \phi=2,(1-\mu) \times \phi=8)$ were initially simulated. Later, 2 of the 100 cases selected without replacement were replaced by values of a Uniform $(q, 1)$ where $q=0.999,2,8$.

For each dataset generated, we fit the Beta rectangular and the Beta model, by considering the estimation procedure described in section (4). We burned-in 10,000 of the 20,000 values of the chain. The effective sample is 10,000. An efficiency of over 0.9 was obtained by using the above Effective Sample Sizes.

Bias and MSE were obtained for each model by considering the replications in each scenario. The percentage of cases in which the Beta rectangular model was selected in relation to Beta was obtained. This was defined in terms of the percent of time that the Beta rectangular model achieved a lower DIC. The results are shown in Table 1. From the simulation study, we found that for any scenario with outliers, there was an improvement in the accuracy (bias and MSE decrease) for the estimation of the model's parameters when using a Beta rectangular rather than the Beta model for a contaminated dataset. We confirm the Beta rectangular model rather than the Beta model as the best choice in a high percentage of cases by considering the DIC. This became more evident as sample size increased and the percentage of outliers is incremented. 
Table 1: Comparison of Bias, MSE and percentage of selection of the model Beta Rectangular versus Beta considering DIC for different scenarios of contaminated Beta data (two values of $\phi$, three $\%$ of outliers and three sample sizes) by considering 100 dataset replications in each scenario.

\begin{tabular}{ccccccccc}
\hline & \multicolumn{3}{c}{ Scenarios } & \multicolumn{4}{c}{ Beta } & \multicolumn{2}{c}{ Beta Rectangular } & DIC $\%$ \\
& $\phi$ & \% of outliers & $\mathrm{n}$ & Bias & MSE & Bias & MSE & \\
\hline 1 & 10 & 2 & 50 & 0.0253 & 0.0010 & 0.0234 & 0.0008 & 0.66 \\
2 & 10 & 2 & 100 & 0.0242 & 0.0007 & 0.0186 & 0.0005 & 0.81 \\
3 & 10 & 2 & 200 & 0.0246 & 0.0007 & 0.0157 & 0.0003 & 0.93 \\
4 & 10 & 5 & 50 & 0.0655 & 0.0047 & 0.0434 & 0.0022 & 0.9 \\
5 & 10 & 5 & 100 & 0.0512 & 0.0028 & 0.0325 & 0.0012 & 0.95 \\
6 & 10 & 5 & 200 & 0.0520 & 0.0028 & 0.0318 & 0.0011 & 1 \\
7 & 10 & 8 & 50 & 0.0812 & 0.0070 & 0.0540 & 0.0032 & 0.94 \\
8 & 10 & 8 & 100 & 0.0805 & 0.0067 & 0.0492 & 0.0026 & 1 \\
9 & 10 & 8 & 200 & 0.0797 & 0.0065 & 0.0468 & 0.0023 & 1 \\
10 & 30 & 2 & 50 & 0.0204 & 0.0006 & 0.0179 & 0.0004 & 0.85 \\
11 & 30 & 2 & 100 & 0.0224 & 0.0006 & 0.0159 & 0.0003 & 0.97 \\
12 & 30 & 2 & 200 & 0.0186 & 0.0004 & 0.0118 & 0.0002 & 0.99 \\
13 & 30 & 5 & 50 & 0.0547 & 0.0034 & 0.0353 & 0.0014 & 0.99 \\
14 & 30 & 5 & 100 & 0.0444 & 0.0021 & 0.0291 & 0.0009 & 0.99 \\
15 & 30 & 5 & 200 & 0.0439 & 0.0020 & 0.0257 & 0.0007 & 1 \\
16 & 30 & 8 & 50 & 0.0678 & 0.0050 & 0.0434 & 0.0020 & 0.96 \\
17 & 30 & 8 & 100 & 0.0689 & 0.0049 & 0.0421 & 0.0018 & 1 \\
18 & 30 & 8 & 200 & 0.0671 & 0.0046 & 0.0399 & 0.0016 & 1 \\
\hline
\end{tabular}

\subsection{Simulation Study 2: Sensitivity Study}

In this subsection, we conduct a second specific study to compare the sensitivity in the presence of outliers in the Beta and Beta rectangular models, taking covariates into account when a Beta regression dataset is considered. In order to conduct this study, a dataset was first taken from a Beta regression model with parameters $\beta_{0}=0.5, \beta_{1}=1$, $\phi=30$ and a logit link to consider the model regression structure. It was generated from $y_{i} \sim \operatorname{Beta}\left(\mu_{i}, \phi\right)$ and $\operatorname{logit}\left(\mu_{i}\right)=\beta_{0}+\beta_{1} x_{i}$ and $i=1, . ., n$, where $\mathbf{x}=\left(x_{1}, \ldots, x_{n}\right)^{T}$ was generated from a Uniform distribution on $(-3,3)$ and $n=200$. The data was an uncontaminated Beta dataset.

In Table 2, we present the posterior mean and 95\% Bayesian confidence interval for the parameters of the model for both Beta and Beta Rectangular models. We note that the Beta and Beta Rectangular fits for the regression parameters were identical for this uncontaminated Beta dataset, but as expected the DIC, EAIC and EBIC for the Beta model $(-532.0,-529.0,-519.1)$ are better than that corresponding to the Beta Rectangular model $(-530.4,-525.4,-512.2)$. 
Table 2: Posterior mean and 95\% Bayesian credible interval for the parameters for the second simulated dataset.

\begin{tabular}{ccccccc}
\hline Model & & Beta & \multicolumn{3}{c}{ Beta Rectangular } \\
\hline Parameter & Mean & $2.5 \%$ & $97.5 \%$ & Mean & $2.5 \%$ & $97.5 \%$ \\
\hline$\beta_{0}$ & 0.54 & 0.47 & 0.61 & 0.53 & 0.47 & 0.60 \\
$\beta_{1}$ & 0.98 & 0.93 & 1.03 & 0.98 & 0.92 & 1.03 \\
$\phi$ & 27.34 & 22.13 & 32.97 & 27.58 & 22.67 & 33.86 \\
$\alpha$ & & & & 0.02 & 0.00 & 0.07 \\
\hline
\end{tabular}

Next, for this uncontaminated Beta dataset we defined four contamination strategies by considering outlier patterns described in the next subsection.

\section{Contaminated data under four perturbation patterns to generate outliers}

To evaluate the influence of outlying observations on estimates of regression parameters, we consider contamination of $2 \%$ of the observations for the simulated dataset, that is to say, we replaced these data points $y_{i}^{*}$ by their contaminated values $y_{i}^{*}(\Delta)=y_{i}^{*} \pm \Delta$. We consider four perturbation patterns:

(i) A decrease of $\Delta$ units of the response values to higher values of $x$,

(ii) An increase of $\Delta$ units of the response values to lower values of $x$,

(iii) A decrease and increase of $\Delta$ units of the response values for higher and lower values of $x$, respectively

(iv) A decrease of $\Delta$ units of the response values for central values of $x$.

See Figure 3. For perturbation patterns $(i),(i i)$ and $(i i i) \Delta$ varies from 0 to 0.8 with increments of 0.05 (17 cases) and for perturbation pattern $(\mathrm{iv}) \Delta$ varies from 0 to 0.5 with increments of 0.05 (11 cases).

For each type of contaminated dataset, we studied three aspects in making a comparison between Beta and Beta Rectangular models: (a) sensitivity in the estimation of the regression coefficients; (b) sensitivity on the posterior distribution of all parameters by considering a measure of global influence and (c) effects on model comparison criteria.

\section{(a) Sensitivity on the estimation of regression coefficients}

For each perturbation pattern and each value of $\Delta$ we re-estimate the Beta and Beta Rectangular models. To re-estimate the models, we burned-in 10,000 of the 20,000 values of the chain considering thin equal to 10 . Thus, we have a total of 1,000 samples upon which the posterior inference is based on. Figures 4 and 5 show the posterior mean and the $95 \%$-credible interval for the regression parameters, $\beta_{0}$ and $\beta_{1}$ respectively, in 
(i)

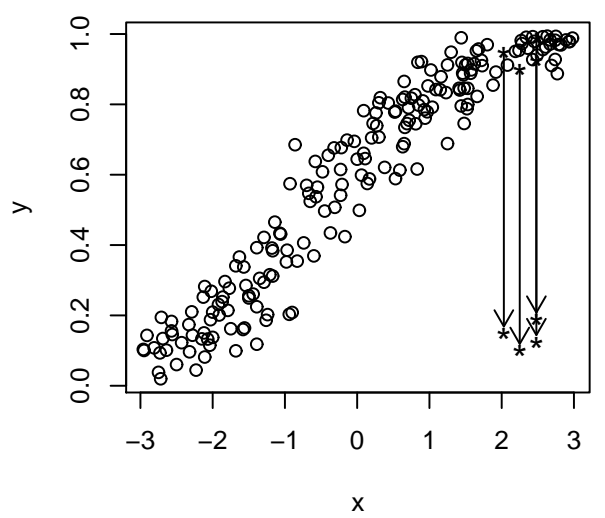

(iii)

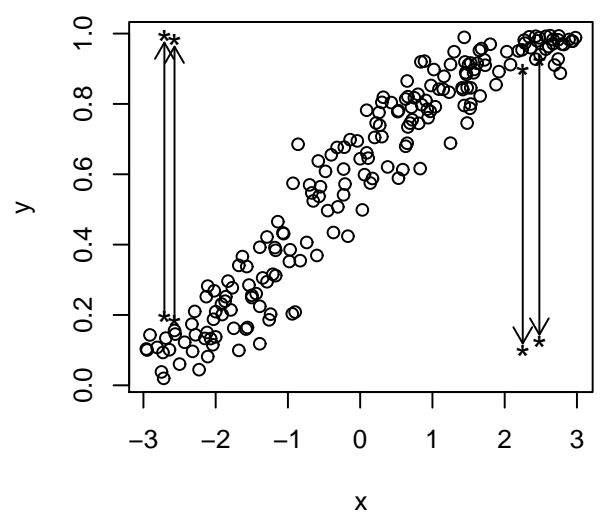

(ii)

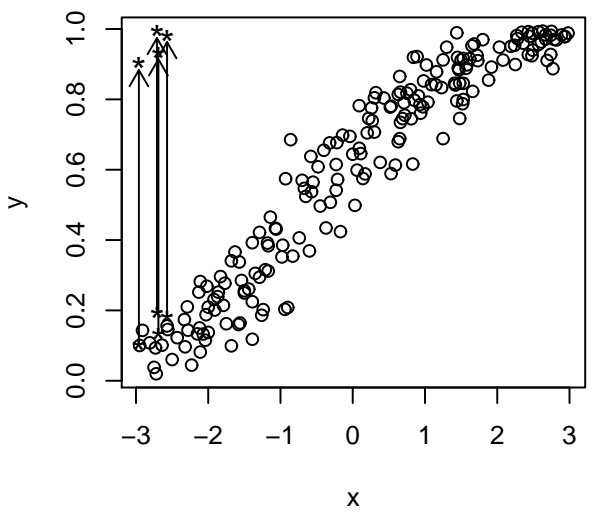

(iv)

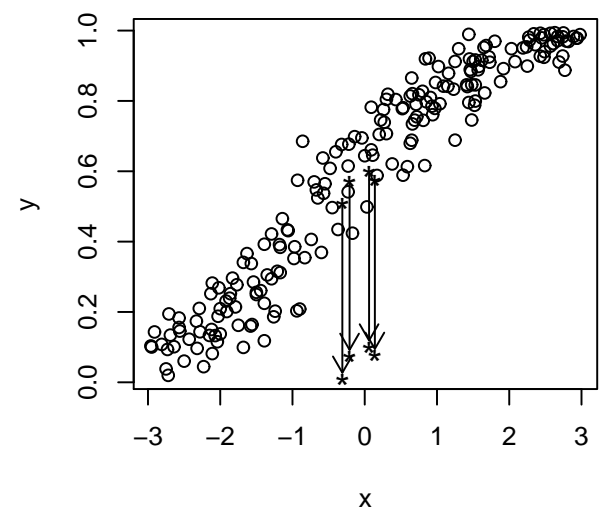

Figure 3: Generation of contaminated datasets under four different outlier patterns in the uncontaminated Beta dataset: $(i)$ decrease $\Delta$ units of the response values to higher values of $x,($ ii) increase $\Delta$ units of the response values to lower values of $x$, (iii) decrease and increase $\Delta$ units of the response values for higher and lower values of $x$ and $(i v)$ decrease $\Delta$ units of the response values for central values of $x$.

each perturbation pattern and each case for the Beta and Beta Rectangular models. The posterior mean is depicted by a dashed line and $95 \%$-credible interval by a solid line for both coefficients.

We find that the Beta Rectangular regression models are less sensitive to variations in $\Delta$ than the Beta regression models. The variations in $\Delta$ have a considerable impact 
for the Beta model on both the posterior mean and the credible interval for all the outlier patterns considered in this study. Note also that the size of the interval increases as $|\Delta|$ increases in particular for $\beta_{0}$.
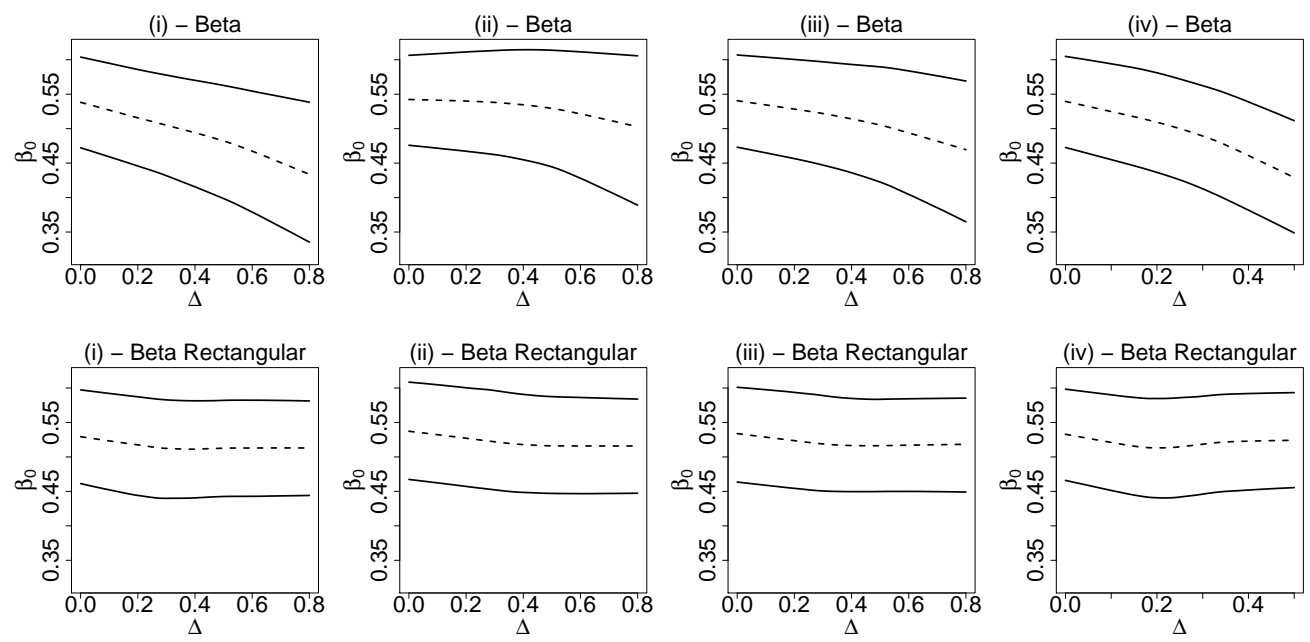

Figure 4: Posterior mean (dashed line) and 95\%-credible interval (solid line) for $\beta_{0}$ under Beta and Beta Rectangular regression models for different values of perturbation $\Delta$ under four different outlier patterns in the contaminated Beta dataset.
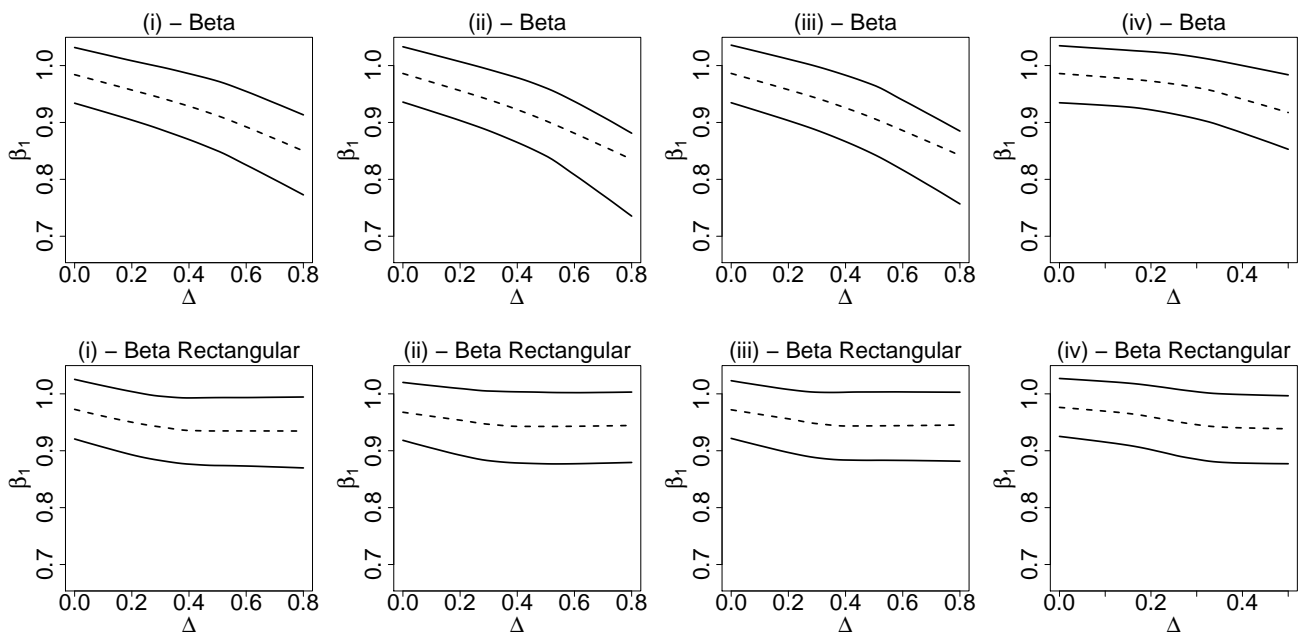

Figure 5: Posterior mean (dashed line) and 95\%-credible interval (solid line) for $\beta_{1}$ under Beta and Beta Rectangular regression models for different values of perturbation $\Delta$ under four different outlier patterns in the contaminated Beta dataset. 


\section{(b) Sensitivity on the posterior distribution of all parameters}

Now we evaluate the influence of the outlier perturbations for each $\Delta$ by considering a divergence measure between the posterior distribution with the uncontaminated data $p(\eta \mid \mathbf{Y})$ and the posterior distribution with the contaminated dataset $p(\eta \mid \mathbf{Y}(\Delta))$ for Beta and Beta Rectangular models, where $\mathbf{Y}(\Delta)$ represents the contaminated dataset. As a measure of divergence, we consider the Kullback-Leibler divergence measure $K L(\Delta)$

$$
K L(\Delta)=\int \log \left(\frac{p(\eta \mid \mathbf{Y})}{p(\eta \mid \mathbf{Y}(\Delta))}\right) p(\eta \mid \mathbf{Y}) d \eta
$$

In order to estimate $K L(\Delta)$ we consider a Monte Carlo estimate of these divergences by using the MCMC output following the ideas of Peng and Dey (1995). In this case the KL estimate is given by:

$$
\widehat{K L}(\Delta)=\log \frac{\left\{\prod_{b=1}^{B} 1 / \vartheta\left(\eta^{b}\right)\right\}^{1 / B}}{\left\{B^{-1} \sum_{b=1}^{B} \vartheta\left(\eta^{b}\right)\right\}^{-1}}
$$

where $\vartheta\left(\eta^{b}\right)=f\left(y_{i}+\Delta \mid \eta^{s}\right) / f\left(y_{i} \mid \eta^{s}\right),\left\{\eta^{b}\right\}_{b=1}^{B}$ are MCMC samples from the posterior distribution $p(\eta \mid \mathbf{Y})$ and $B$ is the sample size of the MCMC procedure.

$K L(\Delta)$ can be considered a measure of influence. We estimate these measures for each Beta and Beta Rectangular model. We expected that the robust model where there were outliers would yield a lower estimated value of $K L(\Delta)$.

Figure 6 shows the $\widehat{K L}(\Delta)$ for both models with Beta shown as a solid line and Beta Rectangular shown as a dashed line under the four outlier patterns described above and for each $\Delta$. We note that the $\widehat{K L}(\Delta)$ for the Beta regression model is an increasing function of $\Delta$ while for the Beta Rectangular regression model, it is more stable. That is to say, the influence of the outlying observations is unbounded for the Beta model, but clearly bounded for the Beta Rectangular model. That can be considered evidence that the Beta Rectangular model performs better compared with the Beta model.

In particular for closer contamination $(\Delta<0.2)$, all models display the same influence curve. This occurs because the contaminated observation is not distant enough from the typical data to be considered as an outlying observation. Therefore, all models have the same efficiency for close contamination cases.

\section{(c) Sensitivity on model comparison criteria}

In Figure 7 we study the behavior of the DIC under the presence of outlying observations. As in Figure 6 using KL, for closer contamination $(\Delta<0.25)$, the DIC favors the Beta regression model. Again, the reason is that the contaminated observation is not considered to be an outlying observation. Also the DIC, as has been shown in Figures 4, 5 and 6 , has the same efficiency for close contamination cases. However for greater contamination $\Delta>0.25$, the DIC favors the Beta Rectangular regression model, indicating the model's robustness where there are outlying observations. 
(i)

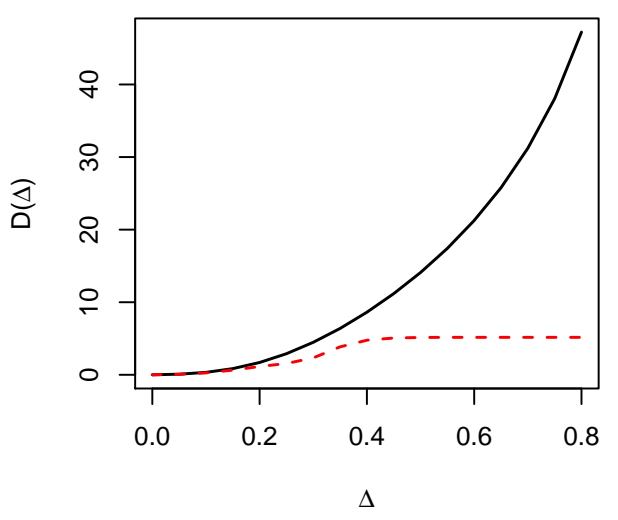

(iii)

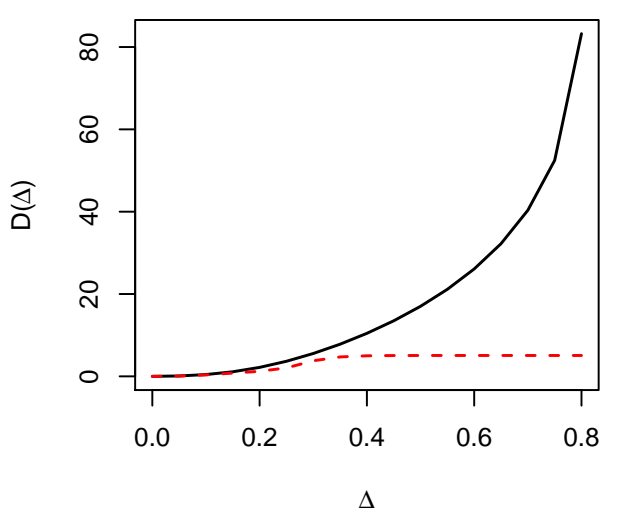

(ii)

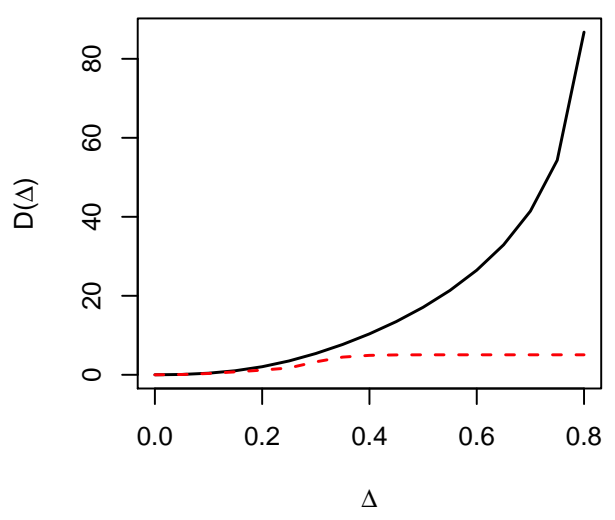

(iv)

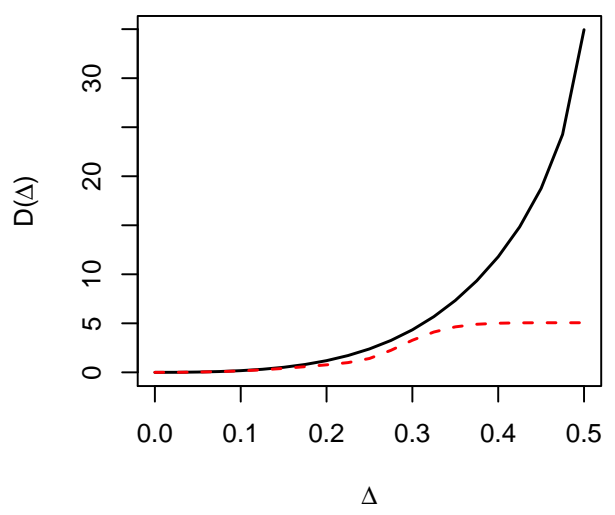

Figure 6: Kullback-Leibler divergence measure between $p(\eta \mid \mathbf{Y})$ and $p(\eta \mid \mathbf{Y}(\Delta))$ under Beta (solid line) and Beta Rectangular (dashed line) regression models for different values of perturbation $\Delta$ under four different outlier patterns in the contaminated Beta dataset.

\section{Applications}

\subsection{Application 1}

In this section, we consider the Bayesian analysis of the Australian Institute of Sport (AIS) Dataset included in the library sn for $\mathrm{R}$ (available for download at http:// azzalini.stat.unipd.it/SN/index.html). We consider only the data of 37 rowing 
(i)

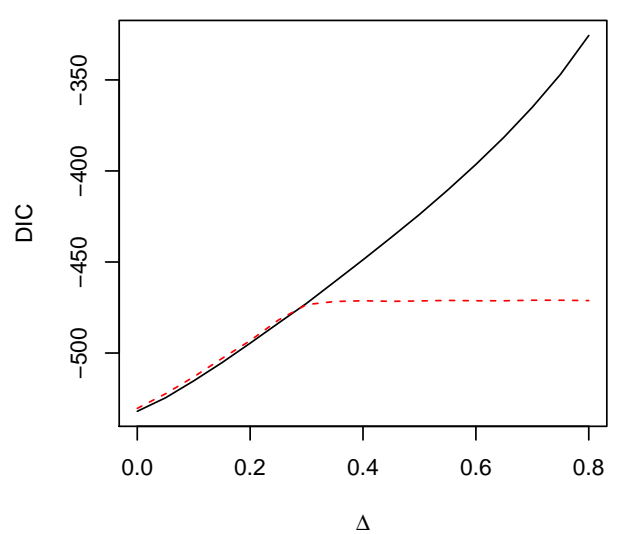

(iii)

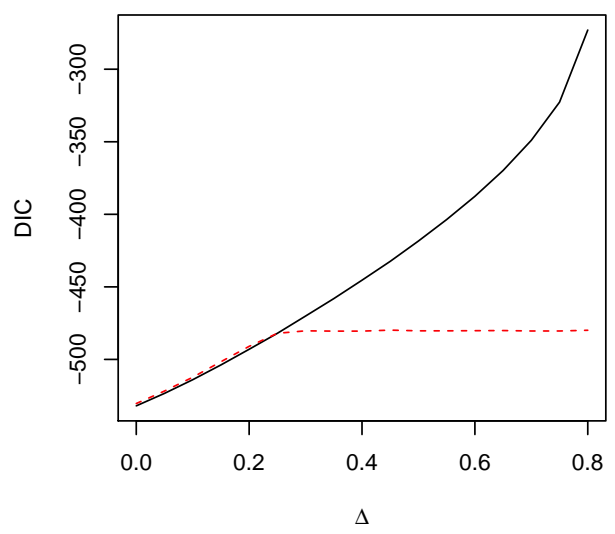

(ii)

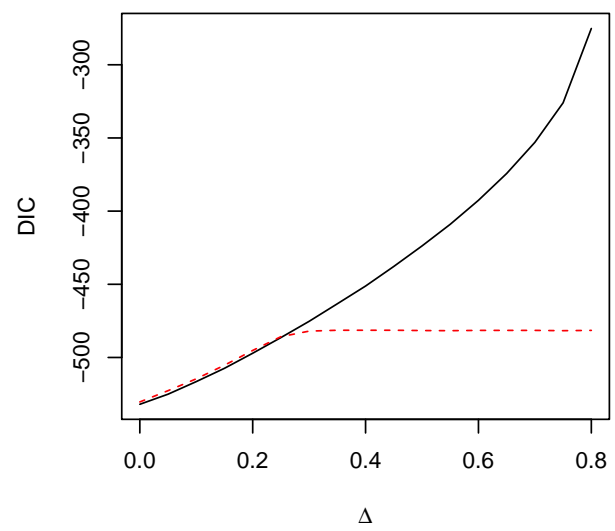

(iv)

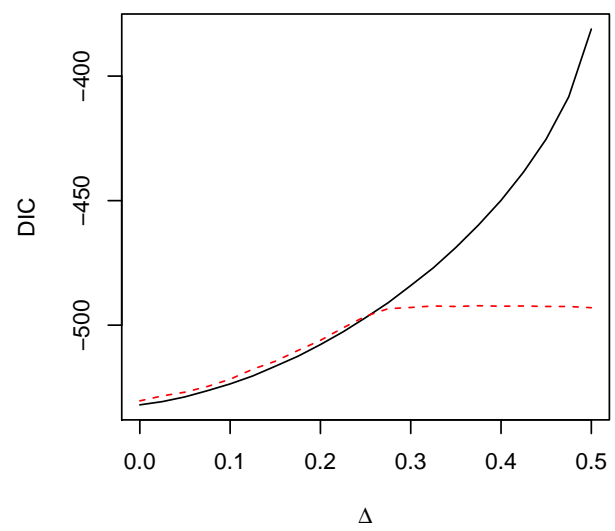

Figure 7: Deviance Information Criterion under Beta (solid line) and Beta Rectangular (dashed line) regression models for different values of perturbation $\Delta$ under four different outlier patterns in the contaminated Beta dataset.

athletes in the AIS dataset. We are interested in the prediction of the body fat percentage $(B f a t)$ of each athlete by considering their lean body mass $(\mathrm{lbm})$.

We define the Beta Rectangular regression model relating $B f a t_{i}$ and $l b m_{i}$ as follows:

$$
B f a t_{i} \sim \operatorname{BRr}\left(\gamma_{i}, \phi, \alpha\right), \operatorname{logit}\left(\gamma_{i}\right)=\beta_{0}+\beta_{1} l b m_{i}, \quad i=1,2 \ldots, n .
$$

We fitted two models: a Beta Rectangular regression as defined in (12) and a Beta Regression (when $\alpha=0$ ) considering all observations. To fit these models, we burned- 
all observations

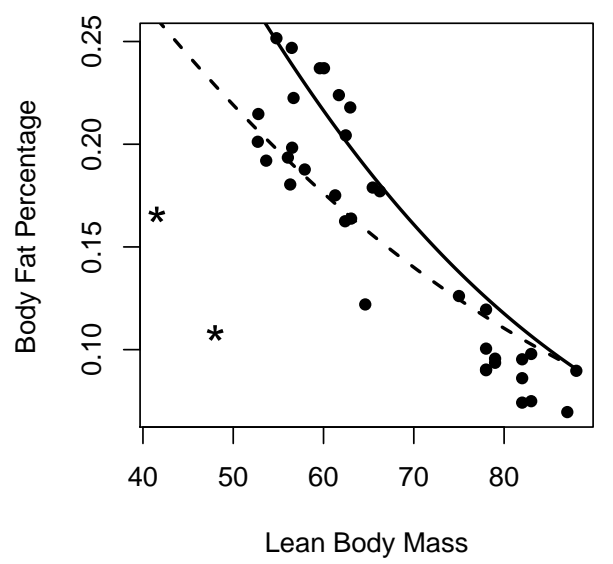

without outliers

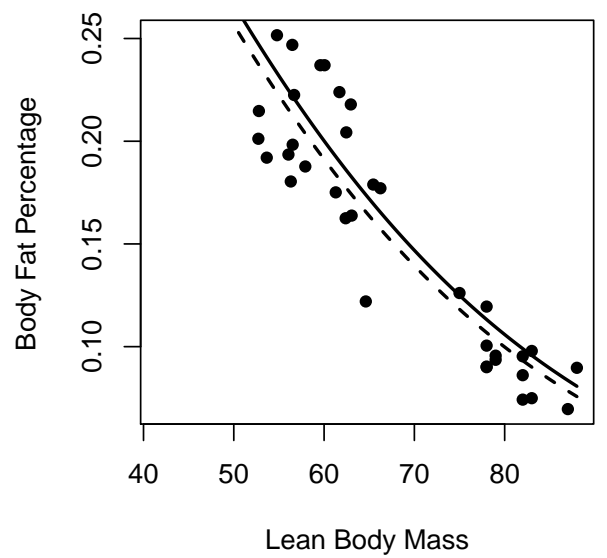

Figure 8: Scatter plot of the AIS dataset with fitted regression lines for the mean of $B$ fat under the Beta distribution (dashed line) and Beta rectangular distribution (solid line) using all observations (left panel) and without outliers (right panel).

in 50,000 of the 100,000 values of a chain considering thin equal to 10 (the runtime for Beta Rectangular regression model is 206.28 seconds and the runtime for Beta regression model is 39.96 seconds on an Intel Core i- 5 processor with $2.30 \mathrm{GHz}$ and 4.00GB RAM). Thus, we have a total of 5,000 samples upon which the posterior inference is based. To carry out a model comparison, we computed DIC, EAIC and EBIC for each model. These criteria and the estimates of the parameters of the models are shown in Table 3. After considering various criteria, the Beta Rectangular regression model yielded the best fit.

As suggested by the Associate Editor, we identified two outlier observations marked as * (see left panel in Figure 8) and then refitted both models after removing these two outliers. The results are shown in Table 3. As expected from Simulation Study 2, the estimates of the parameters are similar but the model comparison criteria correctly choose the Beta regression as the better model. This suggests that there is not much difference between the models in estimating the mean regression model when there are no outliers. However, outlying observations may have a considerable impact on estimates in the Beta regression model. Since this behavior was not observed under the Beta Rectangular regression model, it might be safer to use it rather than the Beta model. 
Table 3: Posterior mean and a 95\%-credible interval for the parameters under the Beta and Beta rectangular regression models for the AIS dataset using all observations and without outliers.

\begin{tabular}{ccrrrrrr}
\hline & & & Beta & \multicolumn{3}{c}{ Beta Rectangular } \\
\hline Observations & Parameter & mean & $2.5 \%$ & $97.5 \%$ & mean & $2.5 \%$ & \multicolumn{1}{c}{$97.5 \%$} \\
\hline \multirow{3}{*}{ All } & $\beta_{0}$ & 0.089 & -0.447 & 0.611 & 0.900 & 0.436 & 1.310 \\
& $\beta_{1}$ & -0.027 & -0.035 & -0.019 & -0.037 & -0.043 & -0.029 \\
& $\phi$ & 86.879 & 50.980 & 132.900 & 203.143 & 106.098 & 316.800 \\
& $\alpha$ & & & & 0.188 & 0.043 & 0.405 \\
& DIC & & -136.13 & & & -145.51 & \\
& EAIC & & -133.24 & & & -141.55 & \\
& EBIC & & -128.41 & & & -135.11 & \\
\hline \multirow{3}{*}{ outliers } & $\beta_{0}$ & 0.830 & 0.412 & 1.244 & 0.859 & 0.443 & 1.264 \\
& $\beta_{1}$ & -0.038 & -0.044 & -0.031 & -0.037 & -0.044 & -0.031 \\
& $\phi$ & 204.435 & 118.985 & 314.800 & 203.628 & 118.098 & 317.703 \\
& $\alpha$ & & & & 0.072 & 0.002 & 0.235 \\
& DIC & & -160.41 & & & -158.61 & -153.81 \\
& EAIC & & -157.51 & & & -147.59 & \\
\hline
\end{tabular}

\subsection{Application 2}

As a second application, we study the influence of the Human Development Index (HDI) of an electoral district on the proportion of blank votes in the 2006 Peruvian general election. We obtained the voting data from www.onpe.gob.pe, which provided data on past elections, and the HDI data from www.pnud.org.pe.

For these datasets, we consider the following general model:

$$
y_{i} \sim \operatorname{BRr}\left(\gamma_{i}, \phi, \alpha\right), \operatorname{logit}\left(\gamma_{i}\right)=\beta_{0}+\beta_{1} H D I_{i}, \log \left(\phi_{i}\right)=\delta_{0}+\delta_{1} H D I_{i}, i=1,2 \ldots, n
$$

where $y_{i}$ is the proportion of blank votes and $H D I_{i}$ is the Human Development Index of electoral district $i$. Peru has $n=194$ electoral districts. We fitted four models: (1) a Beta rectangular regression with variable dispersion as defined in (13); (2) a Beta regression with variable dispersion $(\alpha=0)$; $(3)$ a Beta rectangular regression $\left(\delta_{1}=0\right.$ and $\left.\phi=\exp \left(\delta_{0}\right)\right)$ and (4) a Beta regression $\left(\alpha=0, \delta_{1}=0\right.$ and $\left.\phi=\exp \left(\delta_{0}\right)\right)$. To fit these models, we burned-in 50,000 of the 100,000 values of a chain considering thin equal to 10 . Thus, we have a total of 5,000 samples upon which the posterior inference is based.

Table 4 compares the four models using the model selection criteria presented in section 4.1. The runtimes for each model are also included. We note that the models that assume a Beta Rectangular distribution improved over the corresponding Beta models, in particular the Beta Rectangular model without variable dispersion gave the best fit. Posterior mean and a 95\%-credible interval for the parameters under both 
models without variable dispersion are shown in Table 5 .

Table 4: Model comparison measures for the 2006 Peruvian electoral dataset.

\begin{tabular}{lrccc}
\hline Model & Runtime* & DIC & EAIC & EBIC \\
\hline Beta & 195.11 & -675.56 & -672.61 & -662.81 \\
Beta Rectangular & 1070.27 & -695.71 & -691.51 & -678.44 \\
Beta with variable dispersion & 248.03 & -674.28 & -670.27 & -657.20 \\
Beta Rectangular with variable dispersion & 1046.02 & -693.81 & -688.58 & -672.24 \\
\hline
\end{tabular}

$\left(^{*}\right)$ Runtime in seconds for 100000 iterations in an Intel Core i-5 processor with 2.30

$\mathrm{GHz}$ and 4.00GB RAM

Table 5: Posterior mean and a 95\% -credible interval for the parameters under Beta and Beta Rectangular regression models for the 2006 Peruvian electoral dataset.

\begin{tabular}{ccccrrr}
\hline & \multicolumn{3}{c}{ Beta } & \multicolumn{3}{c}{ Beta Rectangular } \\
\hline Parameter & \multicolumn{1}{c}{ mean } & $2.5 \%$ & $97.5 \%$ & \multicolumn{1}{c}{ mean } & $2.5 \%$ & \multicolumn{1}{c}{$97.5 \%$} \\
\hline$\beta_{0}$ & 2.0472 & 1.6020 & 2.5060 & 2.2603 & 1.8640 & 2.6590 \\
$\beta_{1}$ & -6.2869 & -7.1110 & -5.4730 & -6.6042 & -7.3310 & -5.8820 \\
$\phi$ & 80.6561 & 65.7890 & 97.9302 & 107.9722 & 86.0595 & 134.0000 \\
$\alpha$ & & & & 0.0553 & 0.0119 & 0.1255 \\
\hline
\end{tabular}

\section{Final Comments}

In this paper, we proposed a new regression model for responses measured in the unit interval. The main advantage of this model is its flexibility for working with data where there are outlying observations. Indeed, the Beta Rectangular regression includes the Beta regression model proposed by Ferrari and Cribari-Neto (2004) and the variable dispersion Beta regression model introduced by Smithson and Verkuilen (2006) as particular cases. However, other models can be formulated by considering other values of the mixture parameter between Beta and Uniform distributions.

The Beta Rectangular regression model is easily formulated as the generalization of the Beta regression model. Furthermore, the implementations of the Bayesian approach can easily be obtained in WinBUGS or PROC MCMC of SAS.

Simulation studies on the influence of outliers confirm that the Beta rectangular regression model seems to be a new robust alternative for modeling proportion data and that the Beta regression model offers sensitivity in the estimation of regression coefficients, sensitivity on the posterior distribution of all parameters by considering the Kullback-Liebler divergence as a measure of global influence, and effects on model comparison criteria (DIC) when data is contaminated under the four outlier patterns studied. In addition, the two applications presented here show the potential use of the 
Beta Rectangular regression model for practitioners.

We note that WinBUGS may not be that efficient for a large data set, but it does make Bayesian inference with Beta Rectangular regression models easily accessible for applied researchers and its generic structure allows for a lot of flexibility in model specification. From the perspective of a practitioner, we expect that the WinBUGS code can help to popularize the model. Additional studies including the use of new Bayesian algorithms (see for example Gamerman and Lopes 2006) are needed to study how to improve the performance of the MCMC procedure for the Beta Rectangular regression model when the number of observations is extremely large. Also, a general Metropolis-Hastings algorithm could run much faster in a programming language, for example using $\mathrm{C}++$ with R (Eubank and Kupresanin 2012). As pointed out by an anonymous referee, a possible extension of this work may improve the performance of the Beta Rectangular regression model when the number of observations is extremely large.

Additionally, we suggest future work should explore new choices of prior distributions for $\phi$ and $\alpha$ and their corresponding sensitivity studies for these choices, given that some sensitivity is observed for these parameters. For example we suggest to study the sensitivity of the choice of the hyperparameter $c$ for the prior distribution $\phi \sim$ Gamma $(c, c)$ as in Ghosh et al. (2009). By contrast, sensitivity was not observed in the estimates of the coefficients of regression parameters, which were the main focus of our analysis in this paper.

Also, diagnostic tools in Beta rectangular regression can be considered in future work, for instance in using the Kullback-Liebler divergence as a diagnostic measure for each observation as in Peng and Dey (1995) and Cho et al. (2009), and local influence and residual analysis as proposed by Ferrari et al. (2011) could be formulated from a Bayesian perspective.

\section{Appendix}

The WinBUGS code for a Beta Rectangular regression model with logit link for the mean parameter, a log link for the precision parameter and a single continuous covariate is presented below. For example, in the electoral dataset, $x$ denotes HDI and $y$ denotes the proportion of blank votes of an electoral district. The hyperparameters in the priors for all the parameters need to be specified by the user.

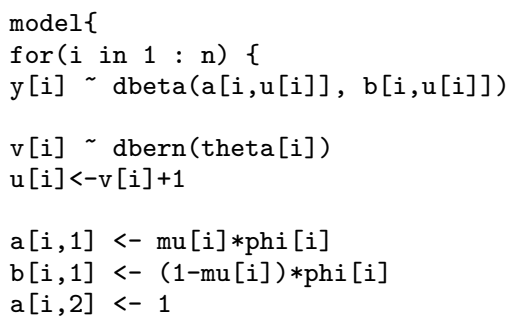




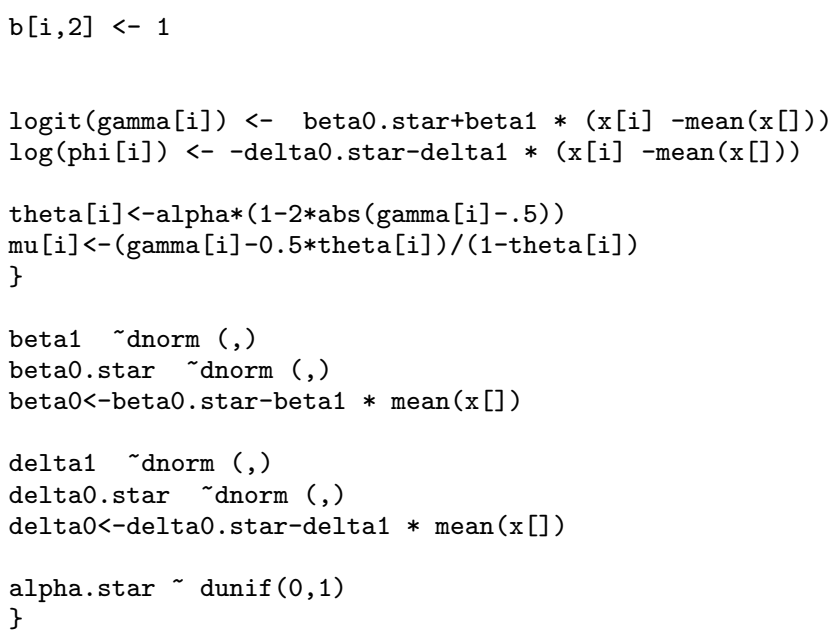

\section{References}

Barnett, V. and Lewis, T. (1995). Outliers in statistical data. Wiley. 772

Bolfarine, H. and Bazán, J. L. (2010). "Bayesian Estimation of the Logistic Positive Exponent IRT Model." Journal of Educational and Behavioral Statistics, 35: 693713. 779

Bouguila, N., Djemel, Z., and Monga, E. (2006). "Practical Bayesian estimation of a finite beta mixture through Gibbs sampling and its applications." Statistical Computing, 16: 215-225. 773,778

Branscum, A. J., Johnson, W. O., and Thurmond, M. C. (2007). "Bayesian Beta regression; application to household data and genetic distance between foot-and-mouth disease viruses." Australian \& New Zealand Journal of Statistics, 49(3): 287-301. 771,778

Brooks, S. P. (2002). "Discussion on the paper by Spiegelhalter, D. J., Best, N. G., Carlin, B. P., and van der Linde, A." Journal of the Royal Statistical Society, Series B, 64: 616-618. 779

Buckley, J. (2002). "Estimation of models with beta-distributed dependent variables: A replication and extension of Paolino (2001)." Political Analysis, 11: 1-12. 772

Cho, H., Ibrahim, J. G., Sinha, D., and Zhu, H. (2009). "Bayesian Case Influence Diagnostics for Survival Models." Biometrics, 65: 116-124. 791

Congdon, P. (2003). Applied Bayesian Modelling. John Wiley \& Sons. 777

Cribari-Neto, F. and Zeileis, A. (2010). "Beta Regression in R." Journal of Statistical Software, 34(2): 1-24.

URL http://www.jstatsoft.org/v34/i02/ 772 
Espinheira, P., Ferrari, S., and Cribari-Neto, F. (2008a). "Influence diagnostics in beta regression." Computational Statistics \& Data Analysis, 52(9): 4417-4431. 772

- (2008b). "On Beta Regression Residuals." Journal of Applied Statistics, 35(4): 407-419. 772

Eubank, R. L. and Kupresanin, A. (2012). Statistical Computing in $C++$ and $R$. Chapman \& Hall/CRC. 791

Ferrari, S. and Cribari-Neto, F. (2004). "Beta regression for modelling rates and proportions." Journal of Applied Statistics, 31: 799-815. 771, 772, 773, 775, 777, 790

Ferrari, S., Espinheira, P. L., and Cribari, F. (2011). "Diagnostic Tools in Beta Regression with Varying Dispersion." Statistica Neerlandica, 65: 337-351. 772, 791

Gamerman, D. and Lopes, H. F. (2006). Markov Chain Monte Carlo: Stochastic Simulation for Bayesian Inference. Chapman \& Hall/CRC. 791

García, C., García, J., and van Dorp, J. R. (2011). "Modeling heavy-tailed, skewed and peaked uncertainty phenomena with bounded support." Statistical Methods and Applications, 20(4): 463-486. 772, 774

Gelman, A., Carlin, J., Stern, H., and Rubin, D. (2003). Bayesian Data Analysis. Chapman and Hall. 777

Geweke, J. (1992). "Evaluating the Accuracy of Sampling-Based Approaches to the Calculation of Posterior Moments." In Bernardo, J. M., Berger, J., Dawid, A. P., and Smith, A. F. M. (eds.), Bayesian Statistics 4, 169-193. Oxford: Oxford University Press. 779

Ghosh, P., Bayes, C. L., and Lachos, V. H. (2009). "A Robust Bayesian Approach to Null Intercept Measurement Error Model with Application to Dental Data." Computational Statistics and Data Analysis, 53: 1066-1079. 791

Hahn, E. D. (2008). "Mixture densities for project management activity times: A robust approach to PERT." European Journal of Operational Research, 188: 450-459. 771, 772,774

Kelly, G., Garabed, R., Branscum, A., Perez, A., and Thurmond, M. (2007). "Prediction model for sequence variation in the glycoprotein gene of infectious hematopoietic necrosis virus in California, USA.” Diseases of Aquatic Organisms, 78: 97-104. 772

Kieschnick, R. and McCullough, B. D. (2003). "Regression analysis of variates observed on $(0,1)$ : percentages, proportions, and fractions." Statistical Modeling, 3: 193-213. 772

Kotz, S. and van Dorp, J. R. (2004). Beyond Beta: other continuous families of distributions with bounded support and applications. World Scientific Press, Singapore. 772 
Lunn, D., Spiegelhalter, D., Thomas, A., and Best, N. (2009). "The BUGS project: Evolution, critique and future directions (with discussion)." Statistics in Medicine, 3049-3082. 778

Lunn, D., Thomas, A., Best, N., and Spiegelhalter, D. (2000). "WinBUGS - a Bayesian modelling framework: concepts, structure, and extensibility." Statistics and Computing, 10: 325-337. 778

Markatou, M. (2000). "Mixture Models, Robustness, and the Weighted Likelihood Methodology." Biometrics, 56: 483-486. 773

Morris, C. N. (1982). "Natural exponential families with quadratic variance functions." The Annals of Statistics, 10: 65-80. 774

Paolino, P. (2001). "Maximum likelihood estimation of models with beta-distributed dependent variables." Political Analysis, 9: 325-346. 772, 777

Peng, F. and Dey, D. K. (1995). "Bayesian analysis of outlier problems using divergence measures." The Canadian Journal of Statistics, 23: 199-213. 785, 791

Pinheiro, J. C., Liu, C., and Wu, Y. N. (2001). "Efficient Algorithms for Robust estimation in Linear Mixed-Effects Models Using the Multivariate $t$ Distribution." Journal of Computational and Graphical Statistics, 10: 249-276. 772

Plummer, M., Best, N., Cowles, K., and Vines, K. (2006). "CODA: Convergence Diagnosis and Output Analysis for MCMC." R News, 6(1): 7-11. 779

Simas, A. B., Barreto-Souza, W., and Rocha, A. V. (2010). "Improved estimators for a general class of beta regression models." Computational Statistics and Data Analysis, 54(2): 348-366. 772, 777

Smithson, M. and Verkuilen, J. (2006). "A Better Lemon Squeezer? MaximumLikelihood Regression With Beta-Distributed Dependent Variables." Psychological Methods, 11(1): 54-71. 771, 772, 777, 790

Spiegelhalter, D. J., Best, N., Carlin, B., and Van der Linde, A. (2002). "Bayesian measures of model complexity and fit (with discussion)." Journal of the Royal Statistical Society, Series B, 64: 583-640. 779

Wallis, E., Mac Nally, R., and Lake, S. (2009). "Do tributaries affect loads and fluxes of particulate organic matter, inorganic sediment and wood? Patterns in an upland river basin in south-eastern Australia." Hydrobiologia, 636: 307-317. 772

\section{Acknowledgments}

The authors are grateful to the Editor-in-Chief, an anonymous Referee and an Associate Editor, whose comments have led to an improved version of our manuscript. We would like to thank the Andalusian Regional Governments Ministry of Innovation, Science and Enterprise as sponsor of the Scholarship Program of Academic Mobility AUIP. This work was funded by the Dirección 
de Gestión de la Investigación at PUCP through grants DGI-2011-0222, DGI-2011-0173 and DGI-2010-0072. 


\section{Apêndice B}

Bayes, C. L., de Castro, M., e Bazán, J. L. (in press 2016). A quantile parametric mixed regression model for bounded response variables. Statistics and Its Interface. 


\title{
A quantile parametric mixed regression model for bounded response variables
}

\author{
Cristian L. Bayes*, Jorge L. BazÁn, and Mário de Castro
}

Bounded response variables are common in many applications where the responses are percentages, proportions, or rates. New regression models have been proposed recently to model the relationship among one or more covariates and the conditional mean of a response variable based on the beta distribution or a mixture of beta distributions. However, when we are interested in knowing how covariates impact different levels of the response variable, quantile regression models play an important role. A new quantile parametric mixed regression model for bounded response variables is presented by considering the distribution introduced by [27]. A Bayesian approach is adopted for inference using Markov Chain Monte Carlo (MCMC) methods. Model comparison criteria are also discussed. The inferential methods can be easily programmed and then easily used for data modeling. Results from a simulation study are reported showing the good performance of the proposed inferential methods. Furthermore, results from data analyses using regression models with fixed and mixed effects are given. Specifically, we show that the quantile parametric model proposed here is an alternative and complementary modeling tool for bounded response variables such as the poverty index in Brazilian municipalities, which is linked to the Gini coefficient and the human development index.

KEYWORDS AND PHRASES: proportions, Kumaraswamy distribution, HDI, Bayesian inference, MCMC methods, Mixed models, RStan.

the score achieved in a test, the fraction of "good" cholesterol (HDL/total cholesterol), the proportion of sand in the soil, and the fraction of a surface covered by vegetation.

In the beta regression model, the regression parameters are interpretable in terms of the mean response, and in many aspects are similar to generalized linear models. Estimation can be performed by maximum likelihood [11] or Bayesian methods [3]. The beta regression model is sufficiently documented in several publications such as [8], [9], [12], and [6] and in several applications like in [22] and [37]. In addition, the beta rectangular model proposed by [1] is more robust to outliers (comparatively large or influential values of the response variable) than the beta regression model. This new model, based on a mixture of a beta distribution and a uniform distribution, includes the beta regression and the variable dispersion beta regression model [12] as particular cases.

Linear mixed models have been used to analyze repeated measures data or clustered data. The popularity of these models can be explained by the flexibility to model the within-subject correlation by handling both balanced and unbalanced data. However, such models are not adequate when the response variable is restricted to the unit interval. For these situations, [36] and [13] proposed a beta mixed regression model considering random effects in both the mean and the dispersion parameters. While the first authors employed a maximum likelihood methodology, the last ones opted for a Bayesian approach. Using a logit transformation of the Student- $t$ distribution, [43] developed a robust mixedeffect models for longitudinal response variables in the unit interval.

In the cited literature, the authors concentrated on the relationship between one or more covariates and the conditional mean of a response variable given the covariates and random effects. However, in many applications the quantiles of the response variable are of central interest. Quantile regression, introduced by [24], has attracted the attention of many researchers in recent years, as can be seen in the works by [42], [7], and [28], to name just a few.

Quantile regression is particularly useful when the rate of change in the conditional quantile, expressed by the regression coefficients, depends on the quantile. The main advantage is its flexibility for modeling data with heterogeneous conditional distributions. Data of this type occurs in many fields, including Econometrics, Survival Analysis,

\footnotetext{
${ }^{*}$ Corresponding author.
}

amples of dependent response variables in these els include the percentage of time devoted to an activity during a certain period of time, the fraction of spent on food, the unemployment rate, the poverty rate,

Regression models for response variables in the unit intions or rates have been introduced recently in the literat Among them the beta regression model introduced by [23] and [11], the beta-rectangular regression model proposed by [1], and the beta mixed regression model proposed by [13]. 

quantiles of the response variable given the covariates and random effects. Quantile mixed regression models also provide a more complete picture of the conditional distribution of the response variable given the covariates and random effects. Consider, for example, a model for the quantiles of a socioeconomic level or the achievement in an educational test. The interest might rest on the upper quantiles.

From a Bayesian perspective, [41] proposed to assume an asymmetric Laplace distribution (ALD) in a parametric quantile regression model for an unbounded response variable. [26] provided an useful stochastic representation for the ALD that facilitates the implementation of a Gibbs sampling scheme for this model. This approach has been extended to a random intercept regression model by [16] and to a mixed regression model by [17]. Our proposal is similar to the one in [17], but for a response variable in the unit interval, which can be easily extended to any bounded response variables on the interval $\left(c_{1}, c_{2}\right)$, with $c_{1}<c_{2}$.

Since the cumulative distribution function (cdf) of the beta distribution does not have a closed form, quantile regression models built upon this distribution pose some difficulties. In contrast, the Kumaraswamy distribution [27, 21] is a continuous probability distribution defined on the $(0,1)$ interval that is similar to the beta distribution, but with the advantage of having a simple closed form for both the probability density function (pdf) and the cdf. In order to formulate a quantile mixed regression models, we consider a convenient reparameterization of the Kumaraswamy distribution in terms of a precision parameter and the $q$-th quantile $\kappa=\kappa(q) \in(0,1)$, which is a location parameter.

The main goal of this paper is to propose a parametric quantile mixed regression model for proportions assuming that the response variable follows a Kumaraswamy distribution. The proposed model can be easily extended to any bounded response variable.

The paper is organized as follows. In Section 2 we present a short account of the Kumaraswamy distribution and a convenient parameterization that is introduced in order to formulate our general mixed quantile regression model. In Sections 3 and 4 we formulate and develop a Bayesian approach for the proposed regression model including model comparison criteria. In Section 5 we present results from simulation studies. Two real data sets are analysed in Section 6 using our proposed models. Final comments are presented in Section 7 .

\section{THE KUMARASWAMY DISTRIBUTION}

A random variable $Y$ follows the Kumaraswamy distribution if its pdf is given by

(1) $f(y \mid \alpha, \beta)=\alpha \beta y^{\alpha-1}\left(1-y^{\alpha}\right)^{\beta-1}, \quad 0<y<1, \alpha, \beta>0$.

2 C. L. Bayes, J. L. Bazán, and M. de Castro
The cdf has closed expression and is given by $F(y \mid \alpha, \beta)=$ $1-\left(1-y^{\alpha}\right)^{\beta}$. The mean and variance of this distribution are

$$
\begin{aligned}
& E(Y \mid \alpha, \beta)=\beta B\left(1+\frac{1}{\alpha}, \beta\right) \text { and } \\
& \operatorname{Var}(Y \mid \alpha, \beta)=\beta B\left(1+\frac{2}{\alpha}, \beta\right)-\beta^{2} B^{2}\left(1+\frac{1}{\alpha}, \beta\right)
\end{aligned}
$$

where $B(\cdot, \cdot)$ denotes the beta function.

As pointed out by [30], the expressions for $E(Y)$ and $\operatorname{Var}(Y)$ make a mean-variance based reparameterization unfeasible. However, we can find a simple expression for the quantile function, given by $\kappa(q)=F^{-1}(q)=\{1-(1-$ $\left.q)^{1 / \beta}\right\}^{1 / \alpha}$, for $0<q<1$. In particular, the median is given by $\kappa(0.5)=\left(1-0.5^{1 / \beta}\right)^{1 / \alpha}$.

In order to propose a quantile regression analysis, we consider a reparameterization of the Kumaraswamy distribution in terms of the $q$-th quantile $\kappa(q)$ and the precision parameter $\varphi=\varphi(q)$ following the ideas presented in [30]. Thus, to obtain a more appropriate regression structure for the Kumaraswamy distribution, we take

(3) $\kappa=\left\{1-(1-q)^{1 / \beta}\right\}^{1 / \alpha}$ and $\varphi=-\log \left(1-(1-q)^{1 / \beta}\right)$

as a new parameterization. In this case, $q$ is assumed to be known and the parameter space of $(\kappa, \varphi)^{T}$ is given by $(0,1) \times(0, \infty)$.

Under this parameterization, the pdf and the cdf of the Kumaraswamy distribution turn out to be

$$
\begin{aligned}
f(y \mid \kappa, \varphi)= & -\frac{\log (1-q) \varphi}{\log \left(1-e^{-\varphi}\right) \log (\kappa)} y^{-\frac{\varphi}{\log (\kappa)}-1} \\
& \times\left\{1-y^{-\frac{\varphi}{\log (\kappa)}}\right\}^{\frac{\log (1-q)}{\log \left(1-e^{-\varphi}\right)}-1}
\end{aligned}
$$

and

$$
F(y \mid \kappa, \varphi)=1-\left\{1-y^{-\frac{\varphi}{\log (\kappa)}}\right\}^{\frac{\log (1-q)}{\log \left(1-e^{-\varphi}\right)}} .
$$

We consider the notation $Y \sim \mathrm{K}(\kappa, \varphi, q)$ with the quantile parameter $\kappa \in(0,1)$ as a location parameter, $\varphi>0$ as a precision parameter, and the probability $q$ is assumed to be fixed according to the quantile of interest.

Figure 1 depicts the pdf of the reparameterized version of the Kumaraswamy distribution in (4) for different values of $\kappa$ and $\varphi$. We pick the first decile, the median, and the last decile. When $\kappa$ is fixed, we note that $\varphi$ is a parameter that controls the precision of the distribution. For larger values of $\varphi$ we observe less dispersion. On the other hand, when $\varphi$ is fixed we note that $\kappa$ acts as a parameter that controls the location of the distribution. For instance, for larger values of $\varphi$ the mode tends to move to the right. In general, since $\kappa$ is the $q$-th quantile of $Y$, we interpret it as a location parameter in the range of values of the variable being modeled. 

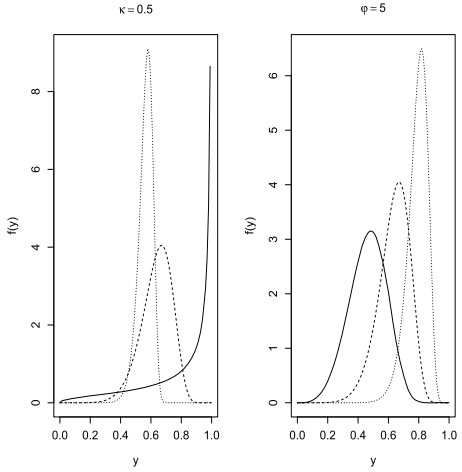

(a) 0.1-quantile

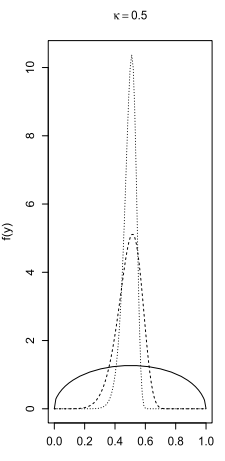

(b) 0.5-quantile

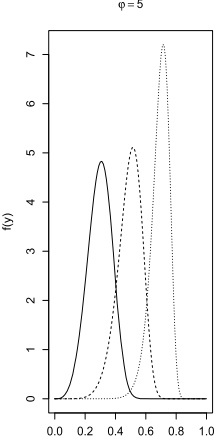

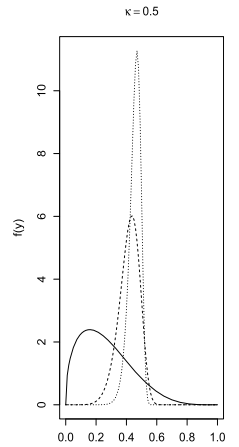

y

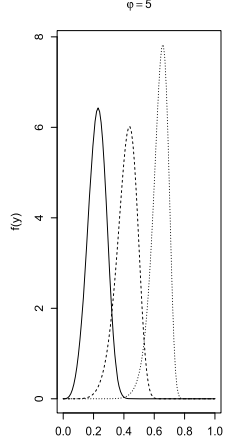

(c) 0.9-quantile

Figure 1. Kumaraswamy pdf for different values of $\kappa$ and $\varphi$. Left panel: $\kappa=0.5$ and different values of $\varphi: 1$ (solid line), 5 (dashed line), and 10 (dotted line). Right panel: $\varphi=5$ and different values of $\kappa: 0.3$ (solid line), 0.5 (dashed line), and 0.7 (dotted line).

\section{THE KURAMASWAMY QUANTILE DISPERSION MIXED REGRESSION MODEL}

As indicated by [40], we introduce random effects for each sample unit (individual or cluster) to incorporate a correlation between the repeated measurements within the unit sample. In this situation, there are two sources of variation in the data: the between-unit variation and the within-unit variation

Let $\boldsymbol{Y}_{i}=\left(y_{i 1}, \ldots, y_{i n_{i}}\right)^{T}$ be a vector of responses for the sample unit $i$, where each component $y_{i j}$ takes values in the $(0,1)$ interval. The Kuramaswamy quantile dispersion mixed regression model is given by

(5)

$$
\begin{gathered}
y_{i j} \stackrel{\text { indep. }}{\sim} \mathrm{K}\left(\kappa_{i j}, \varphi_{i j}, q\right), \\
g_{1}\left(\kappa_{i j}\right)=\boldsymbol{x}_{i j}^{T} \boldsymbol{\beta}+\boldsymbol{z}_{i j}^{T} \boldsymbol{b}_{i}, \text { and } g_{2}\left(\varphi_{i j}\right)=-\boldsymbol{w}_{i j}^{T} \boldsymbol{\delta}-\boldsymbol{h}_{i j}^{T} \boldsymbol{d}_{i},
\end{gathered}
$$

for $j=1, \ldots, n_{i}$ and $i=1, \ldots, n$, where $\boldsymbol{\beta}=$ $\left(\beta_{1}, \ldots, \beta_{k}\right)^{T}$ and $\delta=\left(\delta_{1}, \ldots, \delta_{l}\right)^{T}$ are vectors of regression coefficients (fixed effects) associated with the location and the precision parameters, respectively, $\boldsymbol{b}_{i}=$ $\left(b_{i 1}, \ldots, b_{i p}\right)^{T}$ and $\boldsymbol{d}_{i}=\left(d_{i 1}, \ldots, d_{i r}\right)^{T}$ are the random effects of the location and precision parameters, respectively, $\boldsymbol{x}_{i j}=\left(x_{i j 1}, \ldots, x_{i j k}\right)^{T}, \boldsymbol{w}_{i j}=\left(w_{i j 1}, \ldots, w_{i j l}\right)^{T}$, $\boldsymbol{z}_{i j}=\left(z_{i j 1}, \ldots, z_{i j p}\right)^{T}$, and $\boldsymbol{w}_{i j}=\left(h_{i j 1}, \ldots, h_{i j r}\right)^{T}$ are covariate vectors (possibly overlapping or even identical) and $q \in(0,1)$ is the fixed probability associated to the quantile of interest.

We assume that the random effects $\boldsymbol{b}_{1}, \ldots, \boldsymbol{b}_{n}$ and $\boldsymbol{d}_{1}, \ldots, \boldsymbol{d}_{n}$ are all independent and normally distributed, i.e., $\boldsymbol{b}_{i} \sim N_{p}\left(\mathbf{0}, \boldsymbol{\Sigma}_{b}\right)$ and $\boldsymbol{d}_{i} \sim N_{r}\left(\mathbf{0}, \boldsymbol{\Sigma}_{d}\right)$, for $i=1, \ldots, n$, being $\boldsymbol{\Sigma}_{b}$ and $\boldsymbol{\Sigma}_{d}$ positive definite matrices.
In general, the link function $g_{1}(\cdot)$ relating the quantile $\kappa_{i j}$ with the covariates and random effects can be the inverse of any cdf corresponding to a continuous distribution. Some examples are the logit, probit, and complementary log-log functions. In this paper we adopt the logit link, but other link functions might be explored. Similarly, $g_{2}(\cdot)$ is a link function relating the precision parameter $\varphi_{i j}$ with the covariates and random effects. Since the $\varphi_{i j}$ must be strictly positive, we will use the log link. We take the negative sign, similar to [32], to ease the interpretation of the coefficients. Since $\varphi$ is a precision parameter, a positive-signed $\delta_{i j}$ indicates smaller variability, which can be confusing. It seems more natural to model the dispersion rather than the precision, and the negative sign enables us to do so.

Under the parameterization in (4), the augmented likelihood function can be written as

$$
\begin{aligned}
& \text { (6) } \begin{aligned}
& L(\boldsymbol{\theta}, \boldsymbol{b}, \boldsymbol{d} \mid \boldsymbol{Y})= \\
&= \prod_{i=1}^{n} \prod_{j=1}^{n_{i}} f\left(y_{i j} \mid \kappa_{i j}, \varphi_{i j}\right) \phi_{p}\left(\boldsymbol{b}_{i} \mid \mathbf{0}, \boldsymbol{\Sigma}_{b}\right) \phi_{r}\left(\boldsymbol{d}_{i} \mid \mathbf{0}, \boldsymbol{\Sigma}_{d}\right) \\
&= \prod_{i=1}^{n} \prod_{j=1}^{n_{i}} \frac{-\log (1-q) \varphi_{i j}}{\log \left(1-e^{-\varphi_{i j}}\right) \log \left(\kappa_{i j}\right)} y_{i j}^{-\frac{\varphi_{i j}}{\log \left(\kappa_{i j}\right)}-1} \\
& \times\left\{1-y_{i j} \frac{\varphi_{i j}}{\log \left(\kappa_{i j}\right)}\right. \\
& \frac{\log (1-q)}{\log \left(1-e^{-\varphi_{i j}}\right)}-1 \\
& \times \phi_{p}\left(\boldsymbol{b}_{i} \mid \mathbf{0}, \boldsymbol{\Sigma}_{b}\right) \phi_{r}\left(\boldsymbol{d}_{i} \mid \mathbf{0}, \boldsymbol{\Sigma}_{d}\right),
\end{aligned}
\end{aligned}
$$

where $\boldsymbol{\theta}$ encapsulates $\boldsymbol{\beta}, \boldsymbol{\delta}, \boldsymbol{\Sigma}_{b}, \boldsymbol{\Sigma}_{d}, \boldsymbol{b}=\left(\boldsymbol{b}_{1}^{T}, \ldots, \boldsymbol{b}_{n}^{T}\right)^{T}, \boldsymbol{d}=$ $\left(\boldsymbol{d}_{1}^{T}, \ldots, \boldsymbol{d}_{n}^{T}\right)^{T}, \kappa_{i j}=1 /\left\{1+\exp \left(-\boldsymbol{x}_{i j}^{T} \boldsymbol{\beta}-\boldsymbol{z}_{i j}^{T} \boldsymbol{b}_{i}\right)\right\}, \varphi_{i j}=$ $\exp \left(-\boldsymbol{w}_{i j}^{T} \boldsymbol{\delta}-\boldsymbol{h}_{i j}^{T} \boldsymbol{d}_{i}\right)$, and $\phi_{s}(\cdot \mid \boldsymbol{m}, \boldsymbol{S})$ denotes the pdf of the $s$-variate normal distribution with mean vector $\boldsymbol{m}$ and covariance matrix $\boldsymbol{S}$. 


\section{BAYESIAN INFERENCE}

With independent observations, the likelihood function for the Kumaraswamy quantile mixed regression model is obtained from (5) and (6). In this way, the augmented posterior distribution of $\boldsymbol{\theta}, \boldsymbol{b}$, and $\boldsymbol{d}$, denoted by $p(\boldsymbol{\theta}, \boldsymbol{b}, \boldsymbol{d} \mid \boldsymbol{Y})$, is

$$
p(\boldsymbol{\theta}, \boldsymbol{b}, \boldsymbol{d} \mid \boldsymbol{Y}) \propto L(\boldsymbol{\theta}, \boldsymbol{b}, \boldsymbol{d} \mid \boldsymbol{Y}) p(\boldsymbol{\theta}),
$$

where $p(\boldsymbol{\theta})$ stands for the prior distribution of $\boldsymbol{\theta}$. To complete the Bayesian specification of the model, we set the prior as

$$
p(\boldsymbol{\theta})=p(\boldsymbol{\beta}) p(\boldsymbol{\delta}) p\left(\boldsymbol{\Sigma}_{b}\right) p\left(\boldsymbol{\Sigma}_{d}\right)
$$

We propose the multivariate normal distributions as the prior distribution for the fixed effects, i.e., $\boldsymbol{\beta} \sim N_{k}(\mathbf{0}, \boldsymbol{A})$ and $\boldsymbol{\delta} \sim N_{l}(\mathbf{0}, \boldsymbol{C})$. For the covariance matrices of the random effects, we adopt inverse Wishart distributions, i.e., $\boldsymbol{\Sigma}_{b} \sim I W_{p}\left(\psi_{b}, \boldsymbol{\Psi}_{b}\right)$ and $\boldsymbol{\Sigma}_{d} \sim I W_{r}\left(\psi_{d}, \boldsymbol{\Psi}_{d}\right)$, where $\boldsymbol{A}, \boldsymbol{C}$, $\psi_{b}, \boldsymbol{\Psi}_{b}, \psi_{d}$, and $\boldsymbol{\Psi}_{b}$ are specified hyperparameters.

After combining the likelihood function in (6) with the prior distribution in (8), we get the posterior distribution

$$
\begin{aligned}
p(\boldsymbol{\theta}, \boldsymbol{b}, \boldsymbol{d} \mid \boldsymbol{Y})= & \prod_{i=1}^{n} \prod_{j=1}^{n_{i}} \frac{-\log (1-q) \varphi_{i j}}{\log \left(1-e^{-\varphi_{i j}}\right) \log \left(\kappa_{i j}\right)} y_{i j}^{-\frac{\varphi_{i j}}{\log \left(\kappa_{i j}\right)}-1} \\
& \times\left\{1-y_{i j}^{-\frac{\varphi_{i j}}{\log \left(\kappa_{i j}\right)}}\right\}^{\frac{\log (1-q)}{\log \left(1-e^{-\varphi_{i j}}\right)}-1} \\
& \times \phi_{p}\left(\boldsymbol{b}_{i} \mid \mathbf{0}, \boldsymbol{\Sigma}_{b}\right) \phi_{r}\left(\boldsymbol{d}_{i} \mid \mathbf{0}, \boldsymbol{\Sigma}_{d}\right) \\
& \times \phi_{k}\left(\boldsymbol{\beta} \mid \mathbf{0}, \boldsymbol{\Sigma}_{b}\right) \phi_{l}\left(\boldsymbol{\delta} \mid \mathbf{0}, \boldsymbol{\Sigma}_{d}\right) \\
& \times g\left(\boldsymbol{\Sigma}_{b} \mid \psi_{b}, \mathbf{\Psi}_{b}\right) g\left(\boldsymbol{\Sigma}_{d} \mid \psi_{d}, \mathbf{\Psi}_{d}\right),
\end{aligned}
$$

where $g(\cdot \mid \psi, \Psi)$ denotes the pdf of the inverse Wishart distribution. In the particular case of the fixed effects regression model with a constant precision parameter $\varphi$ in Sections 5.2 and 6.1, the prior distribution for $\left(\boldsymbol{\beta}^{T}, \varphi\right)^{T}$ will be $p(\boldsymbol{\beta}, \varphi)=p(\boldsymbol{\beta}) p(\varphi)$, where $\log (\varphi) \sim N\left(0, \sigma_{1}^{2}\right)$, with $\sigma_{1}^{2}$ being sufficiently large to ensure vague prior knowledge.

The posterior distribution in (9) is intractable. Hence, a possible approximation is obtained through MCMC methods to draw samples from the posterior density. A simple way is to trust in the capabilities of the WinBUGS software [29] or the RStan package [35] in R [34] (see in Appendix A an example of RStan code). For the particular case of a location-regression model without modeling the precision parameter, the MCMC computations in Section 5.2 were implemented using the FORTRAN language.

\subsection{Model comparison criteria}

There are several criteria for comparing different models fitted to a given data set and for selecting the one that best fits the data. First, we mention the deviance information criterion $(D I C)$ proposed by [33]. The $D I C$ is built upon the deviance $\mathcal{D}(\boldsymbol{\vartheta})=-2 \ell(\boldsymbol{\vartheta} \mid \boldsymbol{Y})$, with $\boldsymbol{\vartheta}=$
$\left(\boldsymbol{\theta}^{T}, \boldsymbol{b}^{T}, \boldsymbol{d}^{T}\right)^{T}$ and $\ell(\boldsymbol{\vartheta} \mid \boldsymbol{Y})$ denoting the logarithm of the likelihood function in (6). From $G$ samples $\boldsymbol{\vartheta}_{1}, \ldots, \boldsymbol{\vartheta}_{G}$ generated by the Gibbs sampler, the $D I C$ is computed as $D I C=\mathcal{D}(\overline{\boldsymbol{\vartheta}})+2 p_{D}$, where $p_{D}=\overline{\mathcal{D}}(\boldsymbol{\vartheta})-\mathcal{D}(\overline{\boldsymbol{\vartheta}})$ is termed the effective number of parameters, with $\overline{\mathcal{D}}(\boldsymbol{\vartheta})=$ $\sum_{g=1}^{G} \mathcal{D}\left(\boldsymbol{\vartheta}_{g}\right) / G$ and $\overline{\boldsymbol{\vartheta}}=\sum_{g=1}^{G} \boldsymbol{\vartheta}_{g} / G$. We also consider the expected Akaike's information criteria $(E A I C)$ and its Bayesian version $(E B I C)$, all of them detailed for example in [15]. These criteria are defined as $E A I C=\mathcal{D}(\overline{\boldsymbol{\vartheta}})+2 p^{*}$ and $E B I C=\mathcal{D}(\overline{\boldsymbol{\vartheta}})+p^{*} \log (n)$, respectively, where $p^{*}$ is the number of parameters in the model and $n$ is the sample size. Additionally, we used the criterion proposed by [39], named Wanatabe's information criterion (WAIC). Wanatabe's proposal can be viewed as an approximation to cross-validation [15] and the only difference with respect to $E A I C$ and $E B I C$ is the computation of the complexity penalty $p_{W A I C}$. In this work, we adopt the variance version due to its stability properties. Hence, in this case, $W A I C=$ $\mathcal{D}(\overline{\boldsymbol{\vartheta}})+2 p_{W A I C}$, with $p_{W A I C}=\sum_{i=1}^{n} \operatorname{Var}\left(\log \left(p\left(y_{i} \mid \boldsymbol{\vartheta}\right)\right)\right)$ computed from the output of the Gibbs sampler. Given a set of candidate models, the model yielding the smallest value of these criteria is the one that best fits the data.

\section{SIMULATIONS}

Based on the methodology described in Sections 3 and 4, simulation studies were carried out and two real data sets were analyzed. For all situations, we simulate a large number of samples, discarding the first of them as a burn-in period. To avoid correlation problems, we consider a spacing of size equal to five or more. The convergence of the chains was monitored by the Geweke's statistic [18] and graphical inspection of the chains. The highest posterior density (HPD) intervals were computed following the steps described in $[5$, Section 7.3.1].

\subsection{Prior sensitivity analysis}

In this section, we conduct a sensitivity analysis of the prior specification for the precision parameter $(\varphi)$. We consider a procedure similar to the one developed by [13] for the mixed beta regression model. First, a single data set is generated from a Kumaraswamy mixed regression model given by $y_{i j} \mid \boldsymbol{b}_{i}, \varphi, \boldsymbol{\beta} \stackrel{\text { indep. }}{\sim} \mathrm{K}\left(\kappa_{i j}, \varphi, 0.5\right)$, with $\operatorname{logit}\left(\kappa_{i j}\right)=$ $\left(\beta_{1}+b_{i 1}\right)+\left(\beta_{2}+b_{i 2}\right) x_{i j 2}+\beta_{3} x_{i j 3}$, for $j=1, \ldots, 5$ and $i=1, \ldots, 200$, where $\boldsymbol{\beta}=\left(\beta_{1}, \beta_{2}, \beta_{3}\right)^{T}$. The covariates were generated from a uniform distribution in the unit interval and $\boldsymbol{b}_{i}=\left(b_{i 1}, b_{i 2}\right)^{T} \sim N_{2}\left(\mathbf{0}, \boldsymbol{\Sigma}_{b}\right)$. The parameters were set at $\varphi=50, \boldsymbol{\beta}=(-2,1,2)^{T}$, and $\boldsymbol{\Sigma}_{b}$ has elements $\operatorname{Var}\left(b_{i 1}\right)=1$, $\operatorname{Var}\left(b_{i 2}\right)=0.2$, and $\operatorname{Cov}\left(b_{i 1}, b_{i 2}\right)=-0.3$.

Next, we use the generated data set to perform a sensitivity analysis under different prior specifications for the precision parameter. Specifically, we consider three priors previously used in the literature: (i) $\varphi \sim I G(0.01,0.01)$ (Ma), (ii) $\log (\varphi) \sim N(0,25)(\mathrm{Mb})$, and (iii) $\log (\varphi) \sim N\left(0,10^{4}\right)(\mathrm{Mc})$.
57 58 59 60 61 62 63 64 65 66 


Table 1. Section 5.1. Model comparison criteria for models
fitted to a synthetic data set with different prior specifications
for the precision parameter under a Kumaraswamy mixed
quantile regression model
\begin{tabular}{cccccc}
\hline Model & Prior for $\varphi$ & $D I C$ & $E A I C$ & $E B I C$ & $W A I C$ \\
\hline $\mathrm{Ma}$ & $\varphi \sim I G(0.01,0.01)$ & -2680.2 & -2669.1 & -1326.7 & -2789.8 \\
$\mathrm{Mb}$ & $\log (\varphi) \sim N(0,25)$ & -2684.6 & -2669.9 & -1326.5 & -2795.3 \\
$\mathrm{Mc}$ & $\log (\varphi) \sim N\left(0,10^{4}\right)$ & -2684.2 & -2668.9 & -1326.5 & -2792.7
\end{tabular}

The prior distributions for the remaining parameters were specified as $\boldsymbol{\beta} \sim N_{3}\left(\mathbf{0}, 10^{4} \boldsymbol{I}_{3}\right)$ and $\boldsymbol{\Sigma}_{b} \sim I W_{2}\left(5,20 \boldsymbol{I}_{2}\right)$. Then, we use the MCMC methods outlined in Section 4 to draw samples from the posterior distribution. We discarded the first 10,000 of 20,000 iterations and a thinning equal to 10 resulted in 2000 samples upon which the posterior inference is based on.

Table 1 reports the values of DIC,EAIC,EBIC, and $W A I C$ for the fitted models with different prior distributions for $\varphi$. We observe that the models $\mathrm{Mb}$ and Mc outperform model Ma. Hence, the vaguer prior $\log (\varphi) \sim N\left(0,10^{4}\right)$ is adopted in the models with constant precision (Sections 5.2 and 6.1).

\subsection{Parameter recovery}

We conduct a brief simulation study to assess the performance of our Bayesian approach in estimating the parameters of the model given in (5). In this study we consider a location regression model without random effects and we assume a constant precision parameter $\varphi$. We choose three quantiles levels; namely, a lower quantile $(q=0.1)$, the me- dian $(q=0.5)$, and a higher quantile $(q=0.9)$, that is,

$y_{i} \stackrel{\text { indep. }}{\sim} \mathrm{K}\left(\kappa_{i}, \varphi, q\right), \quad \kappa_{i}=\frac{1}{1+\exp \left(-\beta_{1}-\beta_{2} x_{i 2}-\beta_{3} x_{i 3}\right)}$,

$i=1, \ldots, n, q=0.1,0.5,0.9$.

To generate the data, we first draw $n$ independent $x_{i k} \sim$ $N(0,1)$ covariates with $k=2,3$ and $x_{i 1}=1$ corresponding to the intercept. These values remain fixed throughout the 500 repetitions of the simulations and the three sample sizes: small $(n=40)$, intermediate $(n=100)$, and relatively big $(n=300)$. Therefore, the simulation study comprises nine scenarios.

The prior distributions were specified as $\boldsymbol{\beta} \sim$ $N_{3}\left(\mathbf{0}, 10^{4} \boldsymbol{I}_{3}\right)$ and $\log (\varphi) \sim N\left(0,10^{4}\right)$, with $\boldsymbol{I}_{3}$ denoting the $3 \times 3$ unity matrix. For each replication, after discarding the first 1000 iterations of the Gibbs sampler, we used 10,000 iterations with thinning equal to 5 , leading to 2000 samples for each parameter.

Some posterior results together with the true parameters are summarized in Table 2. We observe that, for all the considered scenarios, our method performs well. In particular, the bias is negligible, even when the sample size is as small as $n=40$, and the coverage probability of the $95 \%$ HPD intervals differs from the nominal value by at most $2.8 \%$. Since the datasets were generated from several scenarios covering different quantile values including extremes, this study indicates that the Bayesian estimator yields good results irrespective of the scenario. Furthermore, as expected, for a given quantile, the average of the posterior standard deviations (SD) and the root mean squared errors of the posterior means (RMSE) are close and decrease when the sample size increases.

Table 2. Section 5.2. Posterior results from 500 replications (Par: parameter to be estimated, True: true value of the parameter, Est: average of the posterior means, SD: average of the posterior standard deviations, RMSE: root mean squared error of the posterior means and CP: coverage probability of the $95 \%$ HPD interval)

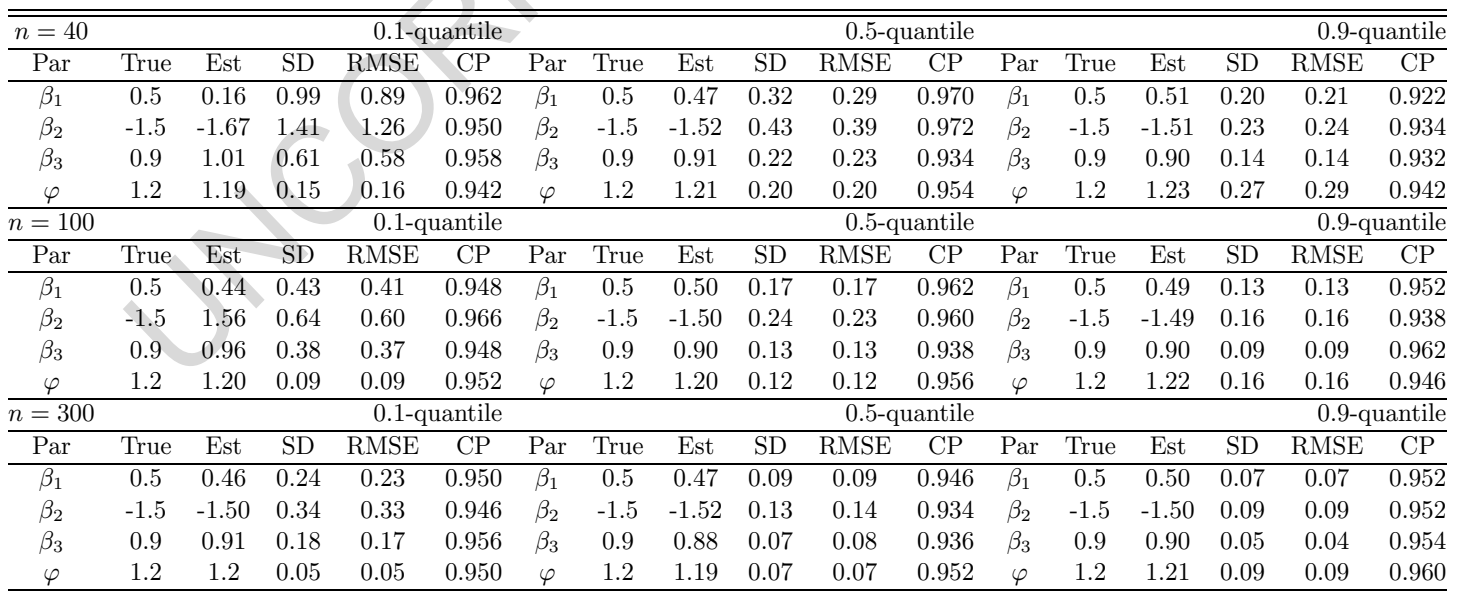

A quantile parametric mixed regression model for bounded response variables 5

57 58

59

60 


\section{REAL DATA ANALYSIS}

3

\subsection{Location quantile regression model}

In this section we analyze a real data set using quantile regression models without random effects and a fixed precision parameter $\varphi$. [10] studied the attitudes toward Statistics of 146 Elementary School teachers of primary education taking into account some characteristics of them such as whether they have a specialty or not, named here as specialty (covariate $x_{2}$ with Sciences as a baseline, and categories Social Sciences, SS, and Elementary School without specialty, ES), the country where the teachers live (covari-

Table 3. Section 6.1. Posterior summaries for the fitted models (Mean: mean and SD: standard deviation)

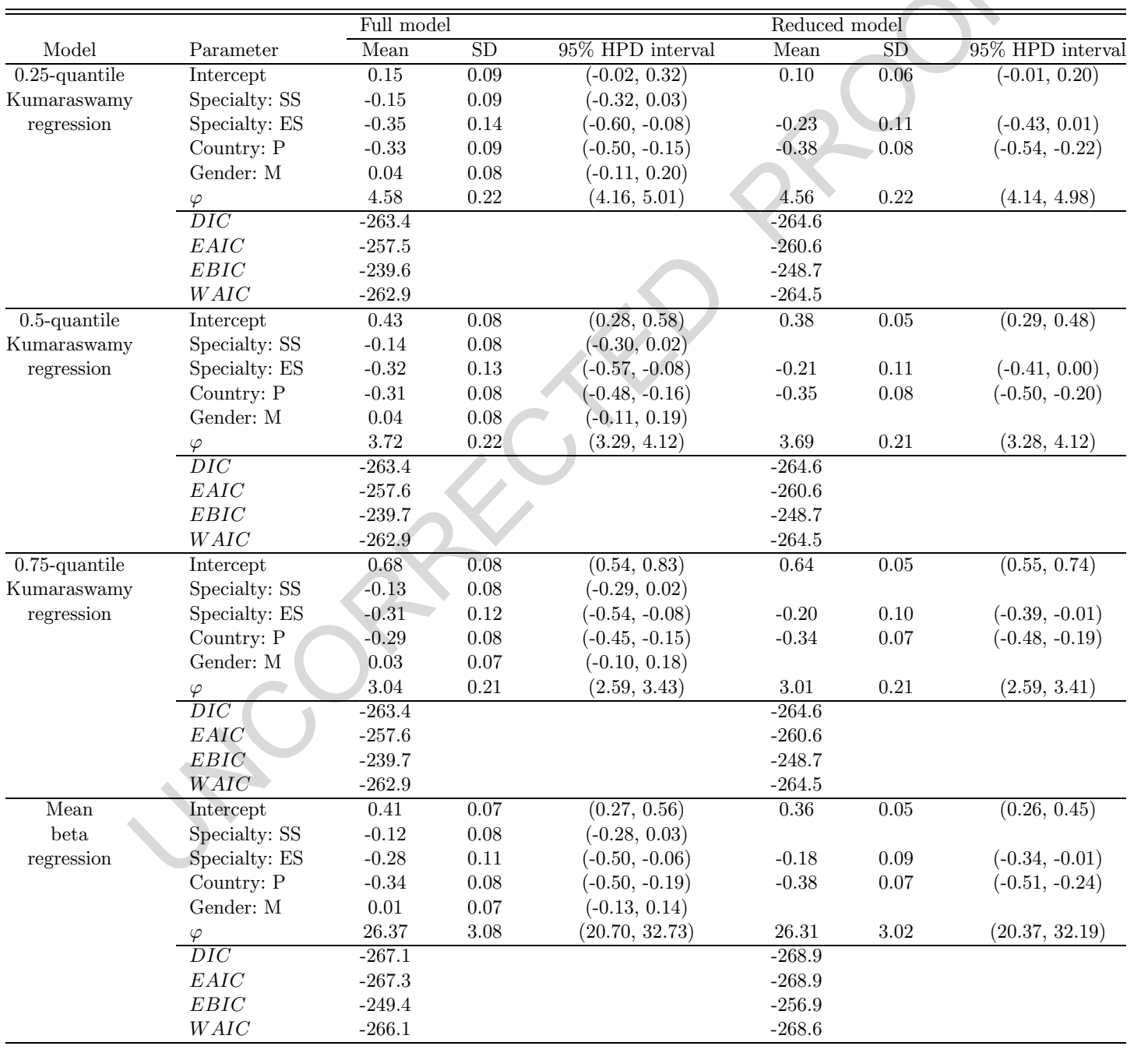

ate $x_{3}$ with categories Spain as baseline and Perú, P), and gender (covariate $x_{4}$ with categories female as baseline and male, M), whereas $x_{1}=1$ in order to accommodate the intercept. The scale of attitudes consists of 25 items from a five-point Likert scale ranging from "strongly disagree" (level 1) to "strongly agree" (level 5). The responses of a subject are added together to form a score $S$ with values in the set $\{5,6, \ldots, 125\}$. For this data set, the score ranges from 48 to 102 , with mean and standard deviation equal to 77.9 and 11.0, respectively. In our application, we take the transformed score $Y$, given by $Y=(S-25) /(125-25)$, as the response variable, ranging from 0.23 to 0.77 , with mean

57 58 50 61

6 C. L. Bayes, J. L. Bazán, and M. de Castro 
and standard deviation equal to 0.53 and 0.11 , respectively.

We have interest in capturing the effect of covariates on different levels of attitude assuming a common effect in the dispersion, that is, we have interest in a quantile regression model for the attitude toward Statistics. Thus, the Kumaraswamy location quantile regression model was considered. We fit the model to assess the effect of the covariates on three levels of attitude, i.e., lower (0.25-quantile), middle (0.5-quantile), and upper (0.75-quantile). The fitted model is specified as $y_{i} \stackrel{\text { indep. }}{\sim} \mathrm{K}\left(\kappa_{i}, \varphi, q\right)$, for $q=0.25,0.5,0.75$, with

$$
\begin{aligned}
\operatorname{logit}\left(\kappa_{i}\right)= & \beta_{1}+\beta_{2} I\left(x_{2 i}=\mathrm{SS}\right)+\beta_{3} I\left(x_{2 i}=\mathrm{ES}\right)+ \\
& \beta_{4} I\left(x_{3 i}=\mathrm{P}\right)+\beta_{5} I\left(x_{4 i}=\mathrm{M}\right),
\end{aligned}
$$

for $i=1, \ldots, 146$, where $I(x=\mathrm{A})=1$, if $x=\mathrm{A}$; 0 , otherwise. As in Section 5.2, we set the prior distributions as $\boldsymbol{\beta} \sim N_{5}\left(0,10^{4} \boldsymbol{I}_{5}\right)$ and $\log (\varphi) \sim N\left(0,10^{4}\right)$. For comparison, we include also the usual beta regression model. In this case we adapted the BUGS code provided by [3]. We ran the Gibbs sampler under the same conditions, discarding the first 10,000 iterations and performing 25,000 additional iterations with thinning equal to 5 , leading to 5000 samples for each parameter. The convergence analysis of the MCMC chains provide strong indication of chain convergence in all fitted models. We fitted also the location-precision model linking the precision parameter $\varphi$ to the covariates. However, according to the information criteria in Section 4.1 (not shown), the location model is preferred.

Table 3 collects posterior summaries of the full (with all covariates) and the reduced models (without non-significant coefficients, i.e., regression coefficients such that the $95 \%$ HPD intervals include 0). Since the three quantile models represent different parameterizations of the same model, the differences in the information criteria are due only to roundoff errors. Taking into account the information criteria in Table 3, we select for simplicity the reduced models as our working models. The results indicate that the effect of the covariates is similar at the three levels of attitude, differing only in the estimate of the intercept. Note also that the median regression and the beta regression models have similar estimates of the coefficients. This is not surprising because mean and median are comparable measures of location. However, note that the estimate of the correspondent dispersion parameter in the median regression model takes lower values in comparison to the corresponding dispersion parameters in the mean regression model.

Considering the results of the four models, we conclude that Elementary School teachers without specialty and Peruvian teachers present significant lower attitudes toward Statistics in comparison with the baseline categories (Sciences/Social Sciences teachers and Spanish teachers, respectively). The results are in accordance with the findings in [10].

Not surprisingly, the posterior means in Tables 3 have the same sign. We observe that the larger the quantile, the

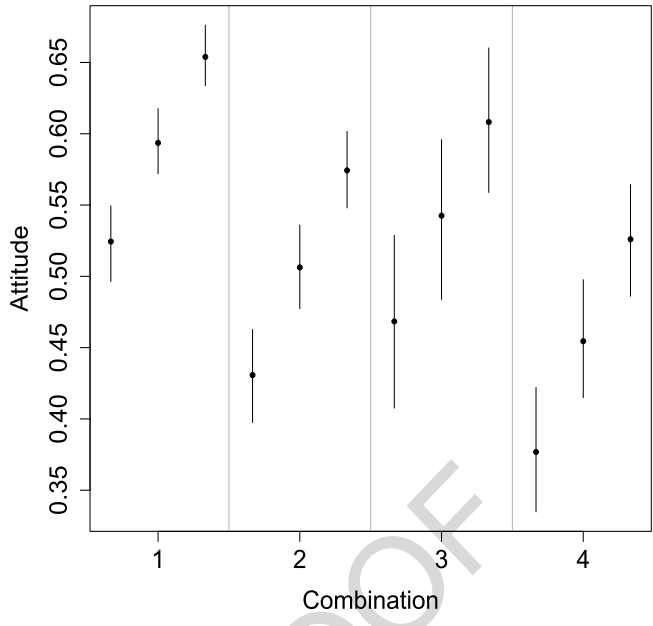

Figure 2. Section 6.1. Posterior means and 95\% HPD intervals for the 0.25-, 0.5-, and 0.75-quantiles of attitude, from left to right. 1: Spanish teachers of Sciences/Social

Sciences, 2: Elementary School Spanish teachers without specialty, 3: Peruvian teachers of Sciences/Social Sciences, and 4: Elementary School Peruvian teachers without specialty.

smaller the estimate of the shape parameter $\varphi$, indicating less precision and higher kurtosis for the quantile of attitude. We also note that the estimates for the 0.5-quantile model and the beta regression model are similar. The effect of specialty slightly changes from non-significant to significant, indicating that our model can reveal that the role of a covariate is not necessarily important at different levels (quantiles) of the response variable.

From (5) we obtain $\kappa=\operatorname{logit}\left(\boldsymbol{x}^{T} \boldsymbol{\beta}\right)$. For a given $q$, using the output of the Gibbs sampler we get samples of the $q$ quantile. Figure 2 shows posterior summaries for the 0.25 , 0.5 , and 0.75 quantiles of attitude. This figure synthesizes the effects of the covariates on the quantiles. There are four different combinations of the levels of specialty and country. Note that for Spanish teachers, comparing the teachers of Sciences/Social Sciences and Elementary School teachers without specialty, the three 95\% HPD intervals of attitude do not overlap. Note also the high variability in the attitude for Peruvian teachers. As pointed out by [10], this can be explained, at least partially, since in Spain there is a greater effort in Statistics teachers' formation, curriculum organization, and didactics.

According to Table 3 , the beta model yields a better fit to the data. However, since we are interested in the quantiles, the Kuramaswamy model was taken as our working model. Moreover, we are aware of the possible quantile crossing issue as pointed out by [2]. In this example this problem was not observed. 
Table 4. Section 6.2. Model comparison criteria for the fitted models

\begin{tabular}{|c|c|c|c|c|c|c|c|c|}
\hline$\overline{\overline{\text { Model }}}$ & $p^{*}$ & $p_{D}$ & $p_{W A I C}$ & $\overline{\overline{\mathcal{D}}(\boldsymbol{\vartheta})(D \text { bar })}$ & $\overline{D I C}$ & $\overline{E E A I C}$ & 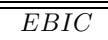 & $\overline{\overline{W A I C}}$ \\
\hline M1 & 4 & 4.0 & 5.7 & -18050.9 & -18042.9 & -18042.9 & -18016.4 & -18041.1 \\
\hline M2 & 6 & 6.0 & 7.8 & -18429.9 & -18418.0 & -18417.9 & -18378.2 & -18416.1 \\
\hline M3 & 32 & 32.1 & 34.3 & -19608.9 & -19544.8 & -19544.9 & -19332.9 & -19541.7 \\
\hline M4 & 62 & 61.7 & 62.0 & -20026.6 & -19903.1 & -19902.6 & -19491.9 & -19899.3 \\
\hline
\end{tabular}

\subsection{Mixed quantile dispersion regression model}

In this section we analyze data collected from a nationwide household survey in Brazil, the so-called PNAD (National Household Survey) [19], carried out in 2013. The data comprises 5563 municipalities in Brazil (two of them were excluded because they present missing values). The response variable is a poverty index defined as the proportion of people with per capita income equal to or less than $\mathrm{R} \$ 140.00$ (Brazilian currency) per month (ranging from 0.002 to 0.786 , with mean and standard deviation equal to 0.232 and 0.179 , respectively). As covariates in (5), we take the Gini coefficient $\left(x_{2}=w_{2}\right.$ : Gini) representing the income distribution inequality (ranging from 0.28 to 0.80 , with mean and standard deviation equal to 0.49 and 0.07 , respectively) and the municipal human development index (MHDI) proposed by the United Nations Development Programme (UNDP) $\left(x_{3}=w_{3}\right.$ : MHDI) (ranging from 0.42 to 0.86 , with mean and standard deviation equal to 0.66 and 0.07 , respectively). The MHDI is built on per capita income, education, and life expectancy at birth. Our interest lies in the relationship between the poverty index and the inequality and human development indexes. Since in Brazil the municipalities are grouped in 27 states, the following models for the median of the poverty index were formulated (in increasing order of complexity):

M1: quantile model

$$
\begin{gathered}
y_{i} \stackrel{\text { indep. }}{\sim} \mathrm{K}\left(\kappa_{i}, \varphi_{i}, 0.5\right), \\
\operatorname{logit}\left(\kappa_{i}\right)=\boldsymbol{x}_{i}^{T} \boldsymbol{\beta}, \quad \log \left(\varphi_{i}\right)=-\delta_{1} .
\end{gathered}
$$

M2: quantile and dispersion model

$$
\begin{gathered}
y_{i} \stackrel{\text { indep }}{\sim} \mathrm{K}\left(\kappa_{i}, \varphi_{i}, 0.5\right), \\
\operatorname{logit}\left(\kappa_{i}\right)=\boldsymbol{x}_{i}^{T} \boldsymbol{\beta}, \quad \log \left(\varphi_{i}\right)=-\boldsymbol{w}_{i}^{T} \boldsymbol{\delta},
\end{gathered}
$$

for $i=1, \ldots, 27$ states.

M3: random intercept quantile model

$$
\begin{gathered}
y_{i j} \stackrel{\text { indep. }}{\sim} \mathrm{K}\left(\kappa_{i j}, \varphi_{i j}, 0.5\right), \\
\operatorname{logit}\left(\kappa_{i j}\right)=\boldsymbol{x}_{i j}^{T} \boldsymbol{\beta}+b_{i}, \quad b_{i} \sim N\left(0, \sigma_{b}^{2}\right), \quad \log \left(\varphi_{i}\right)=-\delta_{1} .
\end{gathered}
$$

M4: random intercepts quantile and dispersion model

$$
y_{i j} \stackrel{\text { indep. }}{\sim} \mathrm{K}\left(\kappa_{i j}, \varphi_{i j}, 0.5\right),
$$

$$
\begin{aligned}
\operatorname{logit}\left(\kappa_{i j}\right)=\boldsymbol{x}_{i j}^{T} \boldsymbol{\beta}+b_{i}, & b_{i} \sim N\left(0, \sigma_{b}^{2}\right), \\
\log \left(\varphi_{i j}\right)=-\boldsymbol{w}_{i j}^{T} \boldsymbol{\delta}-d_{i}, & d_{i} \sim N\left(0, \sigma_{d}^{2}\right),
\end{aligned}
$$

for $j=1, \ldots, n_{i}$ municipalities and $i=1, \ldots, 27$ states, with the number of municipalities ranging from 1 to 853 (median $=143$, mean $=206$ ).

M1 and M2 correspond to regression models where the covariates have an effect on the median $(q=0.5)$ and on both the median and the dispersion parameter, respectively. On the other side, M3 and M4 are obtained from M1 and M2 by introducing random effects in the intercept in order to capture within-state dependence.

We adopt the prior specifications $\boldsymbol{\beta} \sim N_{3}\left(\mathbf{0}, 10^{4} \boldsymbol{I}_{3}\right)$, $\delta_{1} \sim N\left(0,10^{4}\right)(\mathrm{M} 1$ and $\mathrm{M} 3)$, and $\boldsymbol{\delta} \sim N_{3}\left(\mathbf{0}, 10^{4} \boldsymbol{I}_{3}\right)(\mathrm{M} 2$ and M4) for the regression coefficients. Furthermore, $\sigma_{b}^{2} \sim$ $\operatorname{Inv}-\operatorname{Gamma}(0.01,0.01)$ and $\sigma_{d}^{2} \sim \operatorname{Inv}-\operatorname{Gamma}(0.01,0.01)$. We use the RStan package in R taking 20,000 iterations and four chains. By default, only the second half of the chains was used leading to a MCMC sample size of 40,000. The convergence analysis of the chains (not shown) provides strong indication of convergence for all fitted models.

Model comparison criteria are displayed in Table 4. Notice that there is a good agreement between the number of parameters and the effective number of parameters. We see that mixed models are preferable to models without random effects. Overall, model M4 is the one that yields the best fit to the data set. Posterior summaries for this model are shown in Table 5. In what follows, all the discussions pertain to the results from model M4.

Notice that for both components of the model (quantile and dispersion parameter), the Gini coefficient (Gini) has a positive effect while the human development index (MHDI) has a negative effect. Since both Gini and MHDI are centered and are in the same scale, we can say that MHDI has a greater impact on the location and dispersion of the poverty index than Gini. Moreover, we see that the effect of the state, measured by the variance of random intercept, is lower when compared to the effect of the selected covariates.

Looking a little bit closer at the predictions of the random intercept of the quantile component $(b)$ in Table 5 , we can split the states in three clusters of states, as follows: (i) cluster 1 , with negative predictions, is formed by Santa Catarina, Rio Grande do Sul, São Paulo, Mato Grosso do Sul, Paraná, Goiás, Rio de Janeiro, Rondônia, and Mato Grosso states, (ii) cluster 3 , with positive predictions, is formed by Pará, Amazonas, Alagoas, Piauí, Roraima, Bahia, Pernambuco, Paraíba, Sergipe, Tocantins, Rio Grande do Norte, 


\begin{tabular}{|c|c|c|c|c|c|c|c|}
\hline & & \multicolumn{3}{|c|}{ "Quantile $(\boldsymbol{\beta})$} & \multicolumn{3}{|c|}{ 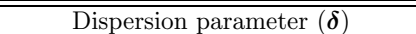 } \\
\hline & & Mean & SD & $95 \% \mathrm{CI}$ & Mean & SD & $95 \% \mathrm{CI}$ \\
\hline \multicolumn{2}{|r|}{ Coefficients: Intercept } & -1.45 & 0.05 & $(-1.55,-1.34)$ & -2.00 & 0.05 & $(-2.10,-1.91)$ \\
\hline \multicolumn{2}{|r|}{ Gini } & 3.86 & 0.09 & $(3.68,4.04)$ & 0.62 & 0.18 & $(0.27,0.96)$ \\
\hline \multicolumn{2}{|r|}{ MHDI } & -11.18 & 0.13 & $(-11.43,-10.94)$ & -2.25 & 0.24 & $(-2.72,-1.77)$ \\
\hline \multicolumn{2}{|r|}{$\sigma^{2}$} & 0.07 & 0.02 & $(0.04,0.13)$ & 0.05 & 0.02 & $(0.03,0.09)$ \\
\hline \multirow{28}{*}{$\begin{array}{c}\text { Random } \\
\text { intercepts } \\
(b \text { and } d)\end{array}$} & States & & & & & & \\
\hline & Santa Catarina & -0.46 & 0.06 & $(-0.58,-0.34)$ & 0.30 & 0.07 & $(0.18,0.43)$ \\
\hline & Rio Grande do Sul & -0.39 & 0.06 & $(-0.51,-0.28)$ & 0.31 & 0.06 & $(0.20,0.43)$ \\
\hline & São Paulo & -0.38 & 0.06 & $(-0.49,-0.26)$ & 0.28 & 0.06 & $(0.17,0.39)$ \\
\hline & Mato Grosso do Sul & -0.31 & 0.06 & $(-0.44,-0.18)$ & -0.04 & 0.09 & $(-0.21,0.13)$ \\
\hline & Paraná & -0.29 & 0.06 & $(-0.40,-0.18)$ & 0.13 & 0.06 & $(0.01,0.25)$ \\
\hline & Goiás & -0.26 & 0.06 & $(-0.38,-0.14)$ & 0.18 & 0.06 & $(0.06,0.31)$ \\
\hline & Rio de Janeiro & -0.20 & 0.06 & $(-0.31,-0.08)$ & -0.37 & 0.09 & $(-0.54,-0.20)$ \\
\hline & Rondônia & -0.19 & 0.06 & $(-0.31,-0.06)$ & -0.19 & 0.10 & $(-0.37,0.01)$ \\
\hline & Mato Grosso & -0.14 & 0.06 & $(-0.26,-0.02)$ & 0.06 & 0.07 & $(-0.08,0.21)$ \\
\hline & Distrito Federal & -0.08 & 0.22 & $(-0.50,0.35)$ & -0.03 & 0.22 & $(-0.47,0.41)$ \\
\hline & Acre & -0.07 & 0.08 & $(-0.23,0.09)$ & 0.06 & 0.13 & $(-0.18,0.32)$ \\
\hline & Minas Gerais & -0.07 & 0.06 & $(-0.18,0.04)$ & 0.24 & 0.05 & $(0.13,0.34)$ \\
\hline & Espírito Santo & -0.01 & 0.06 & $(-0.13,0.10)$ & -0.27 & 0.09 & $(-0.45,-0.09)$ \\
\hline & Pará & 0.01 & 0.06 & $(-0.11,0.13)$ & 0.20 & 0.07 & $(0.06,0.35)$ \\
\hline & Amazonas & 0.05 & 0.07 & $(-0.09,0.20)$ & 0.33 & 0.09 & $(0.16,0.51)$ \\
\hline & Alagoas & 0.07 & 0.06 & $(-0.04,0.19)$ & -0.14 & 0.08 & $(-0.30,0.02)$ \\
\hline & Piauí & 0.13 & 0.06 & $(0.02,0.24)$ & -0.05 & 0.06 & $(-0.18,0.07)$ \\
\hline & Roraima & 0.20 & 0.09 & $(0.02,0.37)$ & 0.06 & 0.16 & $(-0.23,0.38)$ \\
\hline & Bahia & 0.15 & 0.05 & $(0.04,0.25)$ & -0.13 & 0.06 & $(-0.24,-0.02)$ \\
\hline & Pernambuco & 0.17 & 0.06 & $(0.06,0.28)$ & -0.05 & 0.07 & $(-0.18,0.09)$ \\
\hline & Paraíba & 0.18 & 0.06 & $(0.07,0.29)$ & -0.11 & 0.06 & $(-0.23,0.01)$ \\
\hline & Sergipe & 0.20 & 0.06 & $(0.09,0.32)$ & -0.27 & 0.09 & $(-0.44,-0.08)$ \\
\hline & Tocantins & 0.24 & 0.06 & $(0.13,0.35)$ & -0.08 & 0.07 & $(-0.22,0.06)$ \\
\hline & Rio Grande do Norte & 0.25 & 0.06 & $(0.14,0.36)$ & -0.17 & 0.07 & $(-0.31,-0.04)$ \\
\hline & Amapá & 0.33 & 0.08 & $(0.17,0.49)$ & -0.04 & 0.15 & $(-0.32,0.26)$ \\
\hline & Maranhão & 0.29 & 0.06 & $(0.18,0.40)$ & 0.02 & 0.06 & $(-0.11,0.14)$ \\
\hline & Ceará & 0.55 & 0.06 & $(0.44,0.66)$ & -0.25 & 0.07 & $(-0.38,-0.12)$ \\
\hline
\end{tabular}

Amapá, Maranhão, and Ceará states (all of them located at model is built on the distribution introduced by [27]. A repathe north part of the country), and (iii) cluster 2, with pre- rameterization of this distribution in terms of a given quandictions around 0, is formed by Distrito Federal, Acre, Minas tile and the precision parameter enables us to link any quanGerais, and Espírito Santo states. In other words, cluster 1 is tile of the distribution to covariates. Inference is based on a formed by states with low levels of poverty, whereas cluster Bayesian approach with proper (and vague) prior distribu3 is composed by states with high levels of poverty. Taking tions.

into account the states in clusters 1 and 3 and the literature Since the posterior distribution is not amenable to anon gross domestic product studies [see, for example, 20], we alytical treatment, we rely on Markov Chain Monte Carlo can say that our approach clearly identifies the behaviour methods. Results from a simulation study shows that even of the states with respect to their positions in the poverty in case of extreme quantiles (0.25 and 0.75), our Bayesian index ranking. proposal yields estimators with a good performance. Fur-

With respect to the predictions of the random intercept of thermore, two real data sets are analyzed using the proposed the dispersion parameter component, there is no a clear-cut methodologies. Besides the study in Section 5.1, we ran the pattern.

Gibbs sampler with different values of the hyperparameters in (8). The differences in the results are not important when compared with our conclusions in Sections 5 and 6.

We envision future works exploring different link func-

\section{FINAL COMMENTS}

In this paper a new quantile parametric mixed regres- tions in (5), possibly asymmetric ones. Bayesian diagnostic sion model for bounded response variables is proposed. Our tools [31] are also of interest. Models for zero-inflated and 
one-inflated data sets [14] and with a spatial component [4] would extend the present paper, as well as extensions to censored data [38] with a bounded response variable. Another point of interest for future research is a Bayesian solution to deal with the quantile crossing problem.

Finally, the model and inferential methods can be easily implemented using standard software, as can be seen in Appendix A, and then used for data modeling.

\section{ACKNOWLEDGMENTS}

We would like to thank a Co-Editor and two reviewers whose comments lead to an improved presentation of our paper. This work was partially funded by the Dirección de Gestión de la Investigación at PUCP, Perú, through the grants DGI-2014-0017/0070 and DGI-2014-0077/0065. The third author acknowledges partial support from $\mathrm{CNPq}$, Brazil.

\section{APPENDIX A. RSTAN CODE}

The code for the M4 model in Table 4 is given below. We adopted the logit link for the quantile parameter and the log link for the precision parameter. The hyperparameters in the prior distributions for all the parameters need to be specified by the user, as well as the probability $q$ corresponding to the quantile of interest.

data \{

int $\langle$ lower $=0\rangle \mathrm{n} ; / /$ number of observations

int<lower $=0>\mathrm{M} ; / /$ number of subjects

real $\langle$ lower $=0$, upper $=1>\mathrm{y}[\mathrm{n}] ; / /$ response variable

real $\mathrm{x} 1[\mathrm{n}]$; // covariate

real $\mathrm{x} 2[\mathrm{n}] ; / / /$ covariate

int $\langle$ lower $=0\rangle \mathrm{id}[\mathrm{n}] ; / /$ id variable

real<lower $=0$, upper $=1>\mathrm{q} ; / /$ quantile

parameters \{

real delta0;

real delta1;

real delta2;

real beta0;

real beta1;

real beta2;

real $<$ lower $=0\rangle$ sigma $2 \mathrm{~b}$

real $<$ lower $=0>$ sigma $2 \mathrm{~d}$;

real bib [M];

real bid $[M]$;

transformed parameters \{

real<lower $=0\rangle$ sigmab;

real<lower $=0>$ sigmad;

sigmab <- sqrt (sigma2b);

sigmad <- sqrt (sigma2d).

\}

model \{

real kappa[n];

real phi[n];

real $a[n]$;

real $b[n]$;

for $(j$ in $1: M)\{$

bib $[j] \sim \operatorname{normal}(0$, sigmab);

bid $[j] \sim \operatorname{normal}(0$, sigmad);

10 C. L. Bayes, J. L. Bazán, and M. de Castro beta0 normal $(0,100)$;

beta1 normal $(0,100)$

beta2 normal $(0,100)$;

delta0 normal $(0,100)$;

delta1 normal $(0,100)$;

delta2 normal $(0,100)$;

sigma2b inv_gamma $(0.01,0.01)$;

sigma2d inv_gamma $(0.01,0.01)$

for ( $\mathrm{i}$ in $1: \mathrm{n})\{$

phi[i] <- exp(-delta0 - delta1 *x1[i] - delta2 *x2[i]

$-\operatorname{bid}[i d[i]])$;

$b[i]<-\log (1-q) / \log (1-\exp (-p h i[i]))$;

kappa[i]<- inv_logit(beta0 + beta1*x1[i] + beta2 $* x 2[i]$

+ bib[id[i]]);

a[i] <- -phi[i] / log (kappa[i]):

increment_log_prob $(\log (a[i])+\log (b[i])$

$+(a[i]-1) * \log (y[i])+$

$(b[i]-1) * \log 1 \mathrm{~m}($ pow $(y[i], a[i])))$;

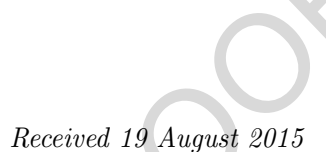

\section{REFERENCES}

[1] Bayes, C. L., Bazán, J. L. and García, C. (2012). A new robust regression model for proportions. Bayesian Analysis 7 771-796. MR3000016

[2] Bondell, H. D., Reich, B. J. and Wang, H. (2010). Noncrossing quantile regression curve estimation. Biometrika 97 825-838. MR2746154

[3] Branscum, A. J., Johnson, W. O. and Thurmond, M. C. (2007). Bayesian beta regression: Application to household data and genetic distance between foot-and-mouth disease viruses. Australian \&s New Zealand Journal of Statistics 49 287-301. MR2405396

[4] Cepeda-Cuervo, E. and Núñez-Antón, V. (2013). Spatial double generalized beta regression models. Extensions and application to study quality of education in Colombia. Journal of Educational and Behavioral Statistics 38 604-628.

[5] Chen, M. H., Shao, Q. M. and Ibrahim, J. G. (2000). Monte Carlo Methods in Bayesian Computation. Springer, New York. MR1742311

[6] Cribari-Neto, F. and Zeileis, A. (2010). Beta regression in R. Journal of Statistical Software 34 1-24.

[7] Dehbi, H. M., Cortina-Borja, M. and Geraci, M. (2016). Aranda-Ordaz quantile regression for student performance assessment. Journal of Applied Statistics 43 58-71. MR3437024

[8] Espinheira, P., Ferrari, S. L. P. and Cribari-Neto, F. (2008). Influence diagnostics in beta regression. Computational Statistics E) Data Analysis 52 4417-4431. MR2432471

[9] Espinheira, P., Ferrari, S. L. P. and Cribari-Neto, F. (2008). On beta regression residuals. Journal of Applied Statistics 35 407-419. MR2420486

[10] Estrada, A., BazÁn, J. L. and Aparicio, A. (2010). Un estudio comparativo de las actitudes hacia la estadística en profesores españoles y peruanos (in Spanish). Unión - Revista Iberoamericana de Educación Matemática $\mathbf{2 4}$ 45-56.

[11] Ferrari, S. L. P. and Cribari-Neto, F. (2004). Beta regression for modelling rates and proportions. Journal of Applied Statistics 31 799-815. MR2095753

[12] Ferrari, S. L. P., Espinheira, P. L. and Cribari, F. (2011). Diagnostic tools in beta regression with varying dispersion. Statistica Neerlandica 65 337-351. MR2857878

[13] Figueroa-Zuñiga, J. I., Arellano-Valle, R. B. and FerRARI, S. L. P. (2013). Mixed beta regression: A Bayesian per-
57

59

65

68 
spective. Computational Statistics and Data Analysis 61 137-147. MR3063006

[14] Galvis, D. M., Bandyopadhyay, D. and Lachos, V. H. (2014). Augmented mixed beta regression models for periodontal proportion data. Statistics in Medicine 33 3759-3771. MR3260658

[15] Gelman, A., Hwang, J. and Vehtari, A. (2014). Understanding predictive information criteria for Bayesian models. Statistics and Computing 24 997-1016. MR3253850

[16] Geraci, M. and BottaI, M. (2007). Quantile regression for longitudinal data using asymmetric Laplace distribution. Biostatistics 8 140-154.

[17] Geraci, M. and Bottai, M. (2014). Linear quantile mixed models. Statistics and Computing 24 461-479. MR3192268

[18] Geweke, J. (1992). Evaluating the accuracy of sampling-based approaches to the calculation of posterior moments. In Proceedings of the Fourth Valencia International Meeting, Peñiscola, 1991 (J. M. Bernardo, J. O. Berger, A. P. Dawid and A. F. M. Sмith, eds.) 169-193. Oxford, New York. MR1380276

[19] IBGE-Brazil (2014). Pesquisa Nacional por Amostra de Domicílios, PNAD: Síntese de indicadores (in Portuguese). http://www.ibge.gov.br. Fundação Instituto Brasileiro de Geografia e Estatística, Departamento de Emprego e Rendimento, Brazil.

[20] IBGE-BraziL (2014). Regional Accounts 2012. http://www. ibge.gov.br/english/estatistica/economia/contasregionais/2012/ default.shtm. November 2014, retrieved November 24, 2014

[21] Jones, M. C. (2009). Kumaraswamy's distribution: A betatype distribution with some tractability advantages. Statistical Methodology 6 70-81. MR2655540

[22] Kelly, G. O., Garabed, R., Branscum, A., Perez, A. and Thurmond, M. (2007). Prediction model for sequence variation in the glycoprotein gene of infectious hematopoietic necrosis virus in California, USA. Diseases of Aquatic Organisms 78 97104.

[23] Kieschnick, R. and McCullough, B. D. (2003). Regression analysis of variates observed on $(0,1)$ : Percentages, proportions and fractions. Statistical Modelling 3 193-213. MR2005473

[24] Koenker, R. and Bassett, G. (1978). Regression quantiles. Econometrica 46 33-50. MR0474644

[25] Koenker, R. and Hallock, K. F. (2001). Quantile regression: An introduction. Journal of Economic Perspectives 15 143-156.

[26] Kozumi, H. and Kobayashi, G. (2011). Gibbs sampling methods for Bayesian quantile regression. Journal of Statistical Computation and Simulation 81 1565-1578. MR2851270

[27] Kumaraswamy, P. (1980). A generalized probability density function for double-bounded random process. Journal of Hidrology 46 79-88.

[28] Lachos, V. H., Chen, M. H., Abanto-Valle, C. A. and Azevedo, C. L. N. (2015). Quantile regression for censored mixed-effects models with applications to HIV studies. Statistics and Its Interface 8 203-215. MR3322167

[29] Lunn, D. J., Thomas, A., Best, N. and Spiegelhalter, D. (2000). WinBUGS - a Bayesian modelling framework: Concepts, structure, and extensibility. Statistics and Computing 10 325337.

[30] Mitnik, P. A. and BaEk, S. (2013). The Kumaraswamy distribution: Median-dispersion re-parameterizations for regression modeling and simulation-based estimation. Statistical Papers $54177-$ 192. MR3016961

[31] Peng, F. and Dey, D. K. (1995). Bayesian analysis of outlier problems using divergence measures. Canadian Journal of Statistics 23 199-213.
[32] Smithson, M. and Verkuilen, J. (2006). A better lemon squeezer? Maximum-likelihood regression with beta-distributed dependent variables. Psychological Methods 11 54-71.

[33] Spiegelhalter, D. J., Best, N. G., Carlin, B. P. and van de Linde, A. (2002). Bayesian measures of model complexity and fit. Journal of the Royal Statistical Society. Series B 64 583-639. MR1979380

[34] R Core Team (2015). R: A Language and Environment for Statistical Computing R Foundation for Statistical Computing, Vienna, Austria.

[35] Stan Development Team (2014). RStan: The R interface to Stan, version 2.5.0.

[36] Verkuilen, J. and Smithson, M. (2012). Mixed and mixture regression models for continuous bounded responses using the beta distribution. Journal of Educational and Behavioral Statistics $\mathbf{3 7}$ 82-113.

[37] Wallis, E., Mac Nally, R. and Lake, S. (2009). Do tributaries affect loads and fluxes of particulate organic matter, inorganic sediment and wood? Patterns in an upland river basin in southeastern Australia. Hydrobiologia 636 307-317.

[38] Wang, H., Zhоu, J., and LI, Y. (2013). Variable selection for censored quantile regression. Statistica Sinica 23 145-167. MR3076162

[39] Watanabe, S. (2010). Asymptotic equivalence of Bayes cross validation and widely applicable information criterion in singular learning theory. Journal of Machine Learning Research 11 35713594. MR2756194

[40] Wu, L. (2009). Mixed Effects Models for Complex Data. Chapman and Hall/CRC. MR2598844

[41] Yu, K. and Moyeed, R. A. (2001). Bayesian quantile regression. Statistics and Probability Letters 54 437-447. MR1861390

[42] Yu, K. M., Chen, C. W. S., Reed, C. and Dunson, D. B. (2013). Bayesian variable selection in quantile regression. Statistics and Its Interface 6 261-274. MR3066690

[43] Zhang, P., Qiu, Z., Fu, Y. and Song, P. X. K. (2009). Robust transformation mixed-effects models for longitudinal continuous proportional data. The Canadian Journal of Statistics 37 266281. MR2531831

Cristian L. Bayes

Departamento de Ciencias

Pontificia Universidad Católica del Perú

Lima

Perú

E-mail address: cbayes@pucp.edu.pe

Jorge L. Bazán

Instituto de Ciências Matemáticas e de Computação

Universidade de São Paulo

São Carlos, SP

Brazil

E-mail address: jlbazan@icmc.usp.br

Mário de Castro

Instituto de Ciências Matemáticas e de Computação

Universidade de São Paulo

São Carlos, SP

Brazil

E-mail address: mcastro@icmc.usp.br

57 


\section{Apêndice C}

Lemonte, A. J., Bazán, J. L. (2016). New class of Johnson SB distributions and its associated regression model for rates and proportions. Biometrical Journal, 58(4), 727746. DOI: 10.1002/bimj.201500030. License Number: 3907231075144. 


\title{
New class of Johnson $S_{B}$ distributions and its associated regression model for rates and proportions
}

\author{
Artur J. Lemonte*,1 and Jorge L. Bazán ${ }^{2}$ \\ 1 Departamento de Estatística, CCEN, Universidade Federal de Pernambuco, Recife/PE, Brazil \\ 2 Departamento de Matemática Aplicada e Estatística, Universidade de São Paulo, São Carlos/SP, \\ Brazil
}

Received 8 February 2015; revised 21 August 2015; accepted 9 October 2015

\begin{abstract}
By starting from the Johnson $S_{B}$ distribution pioneered by Johnson (1949), we propose a broad class of distributions with bounded support on the basis of the symmetric family of distributions. The new class of distributions provides a rich source of alternative distributions for analyzing univariate bounded data. A comprehensive account of the mathematical properties of the new family is provided. We briefly discuss estimation of the model parameters of the new class of distributions based on two estimation methods. Additionally, a new regression model is introduced by considering the distribution proposed in this article, which is useful for situations where the response is restricted to the standard unit interval and the regression structure involves regressors and unknown parameters. The regression model allows to model both location and dispersion effects. We define two residuals for the proposed regression model to assess departures from model assumptions as well as to detect outlying observations, and discuss some influence methods such as the local influence and generalized leverage. Finally, an application to real data is presented to show the usefulness of the new regression model.
\end{abstract}

Keywords: Johnson $S_{B}$ distribution; Proportions; Rates; Regression model; Symmetric distributions.

Additional supporting information including source code to reproduce the results may be found in the online version of this article at the publisher's web-site

\section{Introduction}

Norman L. Johnson has developed in 1949 a system of transformations of the normal distribution that received substantial popularity in the second half of the 20th century. The Johnson system contains the $S_{B}$ class of distributions, which has a bounded support. This distribution is constructed as follows. Let $X$ be a standard normal random variable, that is

$$
X \sim \mathrm{N}(0,1)
$$

where its probability density function (pdf) is $\phi(x)=(2 \pi)^{-1 / 2} \mathrm{e}^{-x^{2} / 2}$, for $x \in \mathbb{R}$. Consider the transformation $Y=t^{-1}((X-\gamma) / \delta)$ or $X=\gamma+\delta t(Y)$, for some suitable function $t(\cdot)$, and parameters $\gamma \in \mathbb{R}$ and $\delta>0$. The transformation of $Y$ given by $\gamma+\delta t(Y)$ has the classical standard normal distribution. The pdf of $Y$ is given by $f(y ; \gamma, \delta)=\delta \phi(\gamma+\delta t(y))|\mathrm{d} t(y) / \mathrm{d} y|$, where $|A|$ is the modulus

\footnotetext{
*Corresponding author: e-mail: arturlemonte@gmail.com
} 
(absolute value) of $A$. The choice of $t(\cdot)$ determines the support of the distribution. In this paper, we are interested in distributions with bounded support. From Johnson (1949), by considering

$$
t(y)=\log \left(\frac{y}{1-y}\right)
$$

we obtain the Johnson $S_{B}$ distribution with bounded support, whose pdf takes the form

$$
f(y ; \gamma, \delta)=\frac{\delta \phi(\gamma+\delta t(y))}{y(1-y)}, \quad y \in(0,1)
$$

where $t(y)$ is given in (2). The cumulative distribution function (cdf) of the Johnson $S_{B}$ variable $Y$ is given by $F(y ; \gamma, \delta)=\Phi(\gamma+\delta t(y))$, for $y \in(0,1)$, where $\Phi(\cdot)$ denotes the standard normal cdf. The Johnson $S_{B}$ distribution has been applied in several fields like meteorology, medicine, biology, forestry, and other sciences. Also, due to its flexibility it may serve as an important alternative to the beta distribution in modeling input distributions for stochastic simulations (DeBrota et al., 1989). The reader is referred to Johnson (1949) and Kotz and van Dorp (2004) for more details about the Johnson $S_{B}$ distribution.

In this paper, a Johnson $S_{B}$ distribution is generated, with the assumption given in (1) being relaxed by the following:

$$
X \sim \mathrm{S}(0,1 ; g),
$$

where $X \sim \mathrm{S}(0,1 ; g)$ means that the random variable $X$ follows the standardized form of the symmetric family of distributions for some function $g$. The symmetrical family of distributions (also known as elliptically contoured univariate distributions) allows an extension of the normal distribution for statistical modeling of real data involving distributions with heavier and lighter tails than the ones of the normal distribution. This class of distributions is appearing with increasing frequency in the statistical literature to model several types of data containing more outlying observations than can be expected based on a normal distribution. The main motivation for the supposition in (4) is based on the search for distributions with bounded support with greater or lesser kurtosis than that of the Johnson $S_{B}$ distribution, thus achieving a Johnson $S_{B}$ distribution that is more platykurtic or leptokurtic, among many other interesting properties.

We say that the random variable $W$ follows a symmetric distribution if its pdf is given by $h(w)=$ $h(w ; \mu, \sigma)=\sigma^{-1} g\left((w-\mu)^{2} / \sigma^{2}\right), w \in \mathbb{R}$, where $\mu \in \mathbb{R}$ is a location parameter, and $\sigma>0$ is a scale parameter. The function $g: \mathbb{R} \rightarrow[0, \infty)$ is such that $\int_{0}^{\infty} g(u) \mathrm{d} u<\infty$ and $\int_{0}^{\infty} u^{-1 / 2} g(u) \mathrm{d} u=1$ to guarantee that $h(\cdot ; \mu, \sigma)$ is a density function. We then write $W \sim \mathrm{S}\left(\mu, \sigma^{2} ; g\right)$. The function $g(\cdot)$, which is independent of $w, \mu$, and $\sigma$, is typically known as density generator. The characteristic function $\psi(t)=\mathrm{E}\left(\mathrm{e}^{\mathrm{i} t W}\right)$ is given by $\psi(t)=\exp (\mathrm{i} t \mu) \varphi\left(t^{2} \sigma^{2}\right), t \in \mathbb{R}$ and $\mathrm{i}=\sqrt{-1}$, for some function $\varphi(\cdot)$, with $\varphi(v) \in \mathbb{R}$, for $v>0$. Provided that they exist, $\mathrm{E}(W)=\mu$ and $\operatorname{var}(W)=k \sigma^{2}$, where $k>0$ is a constant given by $k=-2 \varphi^{\prime}(0)$, where $\varphi^{\prime}(0)=\mathrm{d} \varphi(v) /\left.\mathrm{d} v\right|_{v=0}$. The pdf of $X=(W-\mu) / \sigma$ is $h(x)=$ $h(x ; 0,1)=g\left(x^{2}\right), x \in \mathbb{R}$, which does not involve the parameters $\mu$ and $\sigma$, that is $X \sim \mathrm{S}(0,1 ; g)$ or $X \sim \mathrm{S}(g)$. It is the standardized form of the symmetric distributions. Some distributions that belong to the symmetric family of distributions are provided in the Online Supplementary Material. The reader is referred to Fang and Anderson (1990) for discussions about symmetric distributions. It is worth emphasizing that these distributions will provide a rich source of alternative distributions for analyzing univariate bounded data.

Practitioners oftentimes need to model data that are restricted to the interval $(0,1)$ (e.g. unemployment rate or income concentration measures) that are related to other variables through a regression structure. For example, the fraction of household income spent on food is influenced by variables such as family size, family total income, and so on. It is noteworthy that different regression models for modeling data that are restricted to the interval $(0,1)$ have been proposed. For instance, see Paolino (2001), Kieschnick and McCullough (2003), Vasconcellos and Cribari-Neto (2005), and Melo et al. 
(2009), among others. A class of regression models for modeling data that are restricted to the interval $(0,1)$ that is in many aspects similar to that of generalized linear models was proposed by Ferrari and Cribari-Neto (2004). They called their model the beta regression model, once the model is based on the assumption that the response is beta-distributed. After the work of Ferrari and Cribari-Neto (2004), several research papers have been considered in the literature regarding the beta regression model. Also, it has been quite used in practice mainly because of the very well-developed betareg package (Cribari-Neto and Zeileis, 2010), which can be used to perform inference in beta regression models.

On the basis of the Johnson $S_{B}$ distribution generated, we propose a new regression model for data that are restricted to the interval $(0,1)$ that is in several aspects, like the beta regression model, similar to the generalized linear models. In this new regression model, the median response is related to a linear predictor through a link function and the linear predictor involves covariates and unknown regression parameters, thus allowing for parameter interpretation in terms of the response in the original scale and also allowing the investigator to choose a link function. The regression parameters are interpretable in terms of the median of $Y$ (the variable of interest) and the model easily accommodates asymmetries and bimodality, unlike the beta regression model where regression parameters are interpretable in terms of the mean of $Y$ and the model does not allow bimodality. Here, it is worth emphasizing that if the conditional distribution of the variable of interest is not symmetric (i.e., skewed), then the median as a measure of location may be a much more appropriate quantity than the mean. Additionally, the median is a robust measure of central tendency, while the mean is not. Hence, the proposed regression model is naturally more robust to outlying observations than the beta regression model. The proposed regression model is also indexed by a dispersion parameter, which is not assumed to be constant across observations but it is allowed to vary, leading to the variable dispersion regression model.

It is nowadays a well spread practice, after modeling, to check the model assumptions and conduct diagnostic studies in order to detect possible influential observations that may distort the results of the analysis. To do so, one can make use of the local influence approach where one investigates the model sensitivity under small perturbations (Cook, 1986). Many applications of the local influence method may be found in the statistical literature for various models and under different perturbation schemes. For instance, Vasconcellos and Fernandez (2009), Lemonte and Patriota (2011), Rocha and Simas (2011), and Zevallos et al. (2012), among many others. In this paper, we also propose a similar methodology to detect influential subjects in the new regression model for rates and proportions. In particular, we obtain explicit formulas for Cook (1986)'s normal curvature measure under five perturbation schemes. Additionally, we follow Rocha and Simas (2011) and propose two residuals for the new class of regression models for rates and proportions to study discrepancies between the model and data, as well as presence of outlying observations. The proposed residuals are simple enough to be used in practical applications.

We shall provide a real data application in which it is showed the usefulness of the proposed regression model in practice; that is we consider the proportion of blank votes in the 2006 Peruvian general election of an electoral district as a function of the Human Development Index. As we will see later, these data indicate some evidence of heteroskedasticity and hence the proposed regression model can be used for modeling them in a natural manner. In particular, we verify through residual analysis and diagnostic tools that our regression model can be an interesting alternative to the welldeveloped beta regression model to fit these data, mainly due to the robustness with respect to outlying observations that the proposed regression model can assume.

The article is outlined as follows. In Section 2, we introduce the class of distributions with bounded support on the basis of the symmetric family of distributions, and provide some of its properties. Two estimation methods are briefly discussed in Section 3 for the class of distributions proposed in Section 2. A regression model for rates and proportions that allows to model both location and dispersion effects is introduced in Section 4; the normal curvatures of local influence are derived under various perturbation schemes and two residuals to assess departures from the underlying distribution as well as to detect outlying observations are considered. Section 5 contains an application of the proposed regression model. The paper ends up with some concluding remarks in Section 6. 


\section{New class of distributions and some of its properties}

In this section, we present the class of distributions with bounded support on the basis of the symmetric family of distributions; that is we generate a Johnson $S_{B}$ distribution with the assumption given by (1) being relaxed by the following: $X \sim \mathrm{S}(0,1 ; g)$. We will call the new class as the generalized Johnson $S_{B}$ ("GJS" for short) distribution. Hereafter, if $Y$ follows the GJS distribution, then the notation used is $Y \sim \operatorname{GJS}(\gamma, \delta ; g)$.

The following results will provide the pdf and cdf of the GJS distribution. (All proofs of the propositions presented in this section are given in the Online Supplementary Material.)

Proposition 2.1. Let $Y \sim \operatorname{GJS}(\gamma, \delta ; g)$. Then, the $p d f$ of $Y$ is

$$
f(y ; \gamma, \delta)=\frac{\delta g\left((\gamma+\delta t(y))^{2}\right)}{y(1-y)}, \quad y \in(0,1),
$$

where $t(y)=\log (y /(1-y)), \delta>0$ and $\gamma \in \mathbb{R}$.

Proposition 2.2. Let $Y \sim \operatorname{GJS}(\gamma, \delta ; g)$. Then, the $c d f$ of $Y$ is

$$
F(y ; \gamma, \delta)=\int_{-\infty}^{\gamma+\delta t(y)} g\left(u^{2}\right) \mathrm{d} u, \quad y \in(0,1)
$$

where $t(y)=\log (y /(1-y)), \delta>0$ and $\gamma \in \mathbb{R}$.

In the Online Supplementary Material, we provide explicit expressions for some GJS pdf's obtained from the generalized Student- $t$, type I logistic, generalized logistic, generalized Kotz, double exponential, and extended power distributions. The GJS distribution obtained from the normal distribution corresponds to the Johnson $S_{B}$ distribution. We also provide plots for some GJS pdf's in the Online Supplementary Material. It is evident from those figures that the GJS distribution is quite flexible and it can be an interesting alternative to the other distributions with bounded support for analyzing univariate bounded data in many areas.

Next, we discuss some properties of the GJS distribution. We have the following propositions.

Proposition 2.3. The moments of the GJS distribution exist even if the symmetric distribution that has generated it does not possess moments.

Proposition 2.4. The n-th moment of the GJS distribution is given by

$$
\mu_{n}^{\prime}=\int_{\mathbb{R}} \omega(u)^{n} g\left(u^{2}\right) \mathrm{d} u,
$$

where $\omega(u)=\omega(u ; \gamma, \delta)=\mathrm{e}^{(u-\gamma) / \delta} /\left[1+\mathrm{e}^{(u-\gamma) / \delta}\right]$.

Unfortunately, there is no closed-form expression for the moments of the GJS distribution and hence the integral in (5) has to be computed numerically in software like R, MATLAB, Ox, MAPLE, etc.

Proposition 2.5. The quantile function of $Y \sim \operatorname{GJS}(\gamma, \delta ; g)$ is given by

$$
y_{u}=\left[1+\exp \left(-\frac{x_{u}-\gamma}{\delta}\right)\right]^{-1}, \quad u \in(0,1)
$$

where $x_{u}$ is the $u$-th quantile of $X \sim \mathrm{S}(0,1 ; g)$.

The quantile function in Proposition 2.5 facilitates quantile-based statistical modeling (Gilchrist, 2001). From Proposition 2.5, it follows that the median, $\xi$ say, of $Y \sim \operatorname{GJS}(\gamma, \delta ; g)$ is given by 
$\xi=\left(1+\mathrm{e}^{\gamma / \delta}\right)^{-1}$. Proposition 2.5 also facilitates trivial random variate generation; that is if $X \sim$ $\mathrm{S}(0,1 ; g)$, then

$$
Y=\left[1+\exp \left(-\frac{X-\gamma}{\delta}\right)\right]^{-1}
$$

has the $\operatorname{GJS}(\gamma, \delta ; g)$ distribution.

Proposition 2.6. Let $Y \sim \operatorname{GJS}(\gamma, \delta$; g). If $\gamma=0$, then:

(i) The median of $Y$ is $\xi=1 / 2$.

(ii) The mean of $Y$ is $\mu_{1}^{\prime}=1 / 2$.

(iii) The GJS pdf is symmetric on $(0,1)$ about $\mu_{1}^{\prime}=\xi=1 / 2$.

Proposition 2.7. Let $Y \sim \operatorname{GJS}(\gamma, \delta ; g)$. Then $1-Y \sim \mathrm{GJS}(-\gamma, \delta ; g)$.

Proposition 2.7 means that the GJS distribution possesses the mirror-image symmetry, like the beta distribution. In other words, it means that the reflected GJS distribution is also a member of the GJS family. In this case, the median of $1-Y, M_{1}$ say, is simply given by $M_{1}=\left(1+\mathrm{e}^{-\gamma / \delta}\right)^{-1}=1-\xi$, where $\xi$ is the median of $Y$. It follows from the fact (as mentioned above) that the pdf of $1-Y$ is the reflection of the pdf of $Y$.

Finally, it should be mentioned that by using a simple scale transformation $Z=(b-a) Y+a$, we obtain the GJS distribution with support $(a, b)$. The GJS pdf in this case is given by

$$
f(z ; a, b, \gamma, \delta)=\frac{\delta(b-a)}{(z-a)(b-z)} g\left(\left(\gamma+\delta \log \left(\frac{z-a}{b-z}\right)\right)^{2}\right),
$$

where $a<z<b, \gamma \in \mathbb{R}$ and $\delta>0$.

\section{Estimation of GJS parameters}

In the following, we briefly discuss two estimation methods that may be used to estimate the model parameters of the GJS distribution, namely: the maximum likelihood (ML) method, and the least squares (LS) method. Obviously other methods can also be considered, however, we take into account these two approaches since they were, among others, previously applied to estimate the model parameters of the Jonhson $S_{B}$ distribution (i.e., the GJS distribution obtained from the normal density generator). For simplicity, we restrict our attention to the GJS distribution with support $(0,1)$.

Firstly, the ML method is taken into account to estimate the GJS parameters. Let $y_{1}, \ldots, y_{n}$ be a sample of size $n$ obtained from $Y \sim \operatorname{GJS}(\gamma, \delta ; g)$. Let $\boldsymbol{\theta}=(\gamma, \delta)^{\top}$ be the parameter vector of interest. The log-likelihood function for $\boldsymbol{\theta}$ based on a given sample, apart from a unimportant constant, is given by

$$
\ell(\boldsymbol{\theta})=n \log (\delta)+\sum_{i=1}^{n} \log \left[g\left(\left(\gamma+\delta \log \left(\frac{y_{i}}{1-y_{i}}\right)\right)^{2}\right)\right] .
$$

The ML estimates of the unknown parameters are obtained by maximizing the log-likelihood function $\ell(\boldsymbol{\theta})$ with respect to $\boldsymbol{\theta}$. Let $y_{i}^{\star}=y_{i}^{\star}\left(y_{i} ; \gamma, \delta\right)=\gamma+\delta \log \left(y_{i} /\left(1-y_{i}\right)\right)$, for $i=1, \ldots, n$. Assuming $g(\cdot)$ continuous and differentiable, the likelihood equations are

$$
\frac{\partial \ell(\boldsymbol{\theta})}{\partial \gamma}=2 \sum_{i=1}^{n} y_{i}^{\star} W_{g}\left(y_{i}^{\star 2}\right), \quad \frac{\partial \ell(\boldsymbol{\theta})}{\partial \delta}=\frac{n}{\delta}+\frac{2}{\delta} \sum_{i=1}^{n} y_{i}^{\star}\left(y_{i}^{\star}-\gamma\right) W_{g}\left(y_{i}^{\star 2}\right),
$$


Table 1 The function $W_{g}(u)$ for some distributions.

\begin{tabular}{lcccc}
\hline Normal & Student- $t$ & Type I logistic & Double exponential & Power exponential \\
\hline$-\frac{1}{2}$ & $-\frac{v+1}{2(v+u)}$ & $-\frac{1-\mathrm{e}^{-u}}{1+\mathrm{e}^{-u}}$ & $-\frac{1}{2 \sqrt{u}}$ & $-\frac{u^{-\frac{k}{1+k}}}{2(1+k)}$ \\
\hline
\end{tabular}

where $W_{g}(u)=\mathrm{d} \log (g(u)) / \mathrm{d} u=g^{\prime}(u) / g(u)$ and $g^{\prime}(u)=\mathrm{d} g(u) / \mathrm{d} u$. Table 1 lists $W_{g}(u)$ for some distributions. Note that as $v \rightarrow \infty$, the function $W_{g}(u)$ for the Student- $t$ model tends to $-1 / 2$ (i.e., the value of $W_{g}(u)$ for the normal model, as expected).

The ML estimator $\widehat{\boldsymbol{\theta}}=(\widehat{\gamma}, \widehat{\delta})^{\top}$ of $\boldsymbol{\theta}=(\gamma, \delta)^{\top}$ can be obtained by solving simultaneously the likelihood equations: $\partial \ell(\boldsymbol{\theta}) /\left.\partial \gamma\right|_{\theta=\widehat{\theta}}=0$ and $\partial \ell(\boldsymbol{\theta}) /\left.\partial \delta\right|_{\theta=\widehat{\theta}}=0$. There is no closed-form expression for the ML estimator $\widehat{\boldsymbol{\theta}}$ and its computation has to be performed numerically using a nonlinear optimization algorithm. The Newton-Raphson iterative technique could be applied to solve the likelihood equations and obtain $\widehat{\boldsymbol{\theta}}$ numerically. It is noteworthy that $W_{g}(\cdot)$ may have additional unknown quantities (for instance, the degrees of freedom $v$ in the Student- $t$ distribution and the shape parameter $k$ in the power exponential distribution). These extra quantities are considered as known or fixed. On the other hand, one can use model selection procedures to choose the more appropriate values of such unknown quantities in practice.

Next, the LS method is considered to estimate the GJS distribution parameters. Let $y_{(1)} \leq y_{(2)} \leq$ $\cdots \leq y_{(n)}$ denote the order statistics based on a sample of size $n$ obtained from $Y \sim \operatorname{GJS}(\gamma, \delta ; g)$ with cdf given by $F(\cdot)=F(\cdot ; \gamma, \delta)$; see Proposition 2.2. The transformed random variable $R_{(i)}=$ $F\left(Y_{(i)}\right)$ has the distribution of the $i$-th order statistic in a random sample of size $n$ from the uniform distribution on the unit interval $(0,1)$. Since $R_{(i)}$ has mean $\rho_{(i)}=i /(n+1), R_{(i)}$ can be expressed as $R_{(i)}=\rho_{(i)}+\varepsilon_{(i)}$ so that the $\varepsilon_{(i)}$ 's are translated uniform order statistics with mean zero, and covariance $\vartheta_{(i j)}=\operatorname{Cov}\left(\varepsilon_{(i)}, \varepsilon_{(j)}\right)=\rho_{(i)}\left(1-\rho_{(j)}\right) /(n+2)$, for $1 \leq i \leq j \leq n$ (Kendall and Stuart, 1979). Let $\boldsymbol{R}=$ $\left(R_{(1)}, \ldots, R_{(n)}\right)^{\top}, \boldsymbol{\rho}=\left(\rho_{(1)}, \ldots, \rho_{(n)}\right)^{\top}$, and $\boldsymbol{\varepsilon}=\left(\varepsilon_{(1)}, \ldots, \varepsilon_{(n)}\right)^{\top}$, so that $\boldsymbol{\varepsilon}=\boldsymbol{R}-\boldsymbol{\rho}$. Since the first and second moments of the translated uniform order statistics are known and easily computed, we can exploit this fact to develop a single procedure to estimate $\boldsymbol{\theta}=(\gamma, \delta)^{\top}$. Specifically, the distance between $\boldsymbol{R}$ and $\boldsymbol{\rho}$ is minimized as a function of $\boldsymbol{\theta}$ with respect to a metric defined by a quadratic form in the $n$-dimensional Euclidean space. Let $W$ be a $n \times n$ matrix associated to this quadratic form. Then, an estimate $\overline{\boldsymbol{\theta}}=(\bar{\gamma}, \bar{\delta})^{\top}$ of $\boldsymbol{\theta}=(\gamma, \delta)^{\top}$ can be obtained by solving the following LS estimation problem:

$$
S(\overline{\boldsymbol{\theta}} \mid W)=\min _{\gamma, \delta} S(\boldsymbol{\theta} \mid W),
$$

where $S(\boldsymbol{\theta} \mid W)=\boldsymbol{\varepsilon}^{\top} W \boldsymbol{\varepsilon}$. If $W=I_{n}$ (the identity matrix of order $n$ ), which assumes that the errors $\varepsilon_{(i)}$ 's are independent and identically distributed with equal variances, we obtain the (nonlinear) ordinary LS estimator for the GJS parameters. We obtain the (nonlinear) weighted LS (WLS) estimator for the model parameters of the GJS distribution when $W \neq I_{n}$. The WLS estimators are of interest since the errors $\varepsilon_{(i)}$ 's are neither independent nor homoscedastic. A possible choice is $W=V^{-1}$, where $V$ is the variance-covariance matrix of $\boldsymbol{\varepsilon}$, which can be easily obtained from $\vartheta_{(i j)}$. However, we consider the diagonal weight matrix defined by

$$
W=\operatorname{diag}\left\{\frac{1}{\operatorname{Var}\left(\varepsilon_{(i)}\right)}\right\},
$$

where $\operatorname{diag}\left\{a_{i}\right\}$ stands for a diagonal matrix with typical element $a_{i}(i=1, \ldots, n)$, and obtain the diagonally WLS (DWLS) estimator for the GJS parameters. The variance of $\varepsilon_{(i)}$ is given by $\rho_{(i)}\left(1-\rho_{(i)}\right) /(n+2)$, for $i=1, \ldots, n$. Our choice for $W$ in (8) as the weight matrix is based on the 
empirical comparison/analysis of Swain et al. (1988), who have pointed out that the DWLS estimators are found to be superior to the WLS estimators for the Johnson $S_{B}$ distribution parameters. Hence, on the basis of Swain et al. (1988), we believe that the use of $W$ as in (8) can also be a good choice for estimating the model parameters of the GJS distribution. Therefore, the DWLS estimator for the GJS distribution parameters are obtained by minimizing (7) with respect to $\boldsymbol{\theta}=(\gamma, \delta)^{\top}$ considering the weight matrix as in (8). Finally, it is important to point out that, unlike the ML method, the above estimation procedure may be straightforwardly extended to include estimation of the lower and upper bounds parameters $a$ and $b$ of the GJS distribution in (6), by adding the constraints $a \leq y_{(1)}$ and $b \geq y_{(n)}$ to the optimization procedure minimizing (7).

\section{Regression model}

The GJS pdf (indexed by $\gamma$ and $\delta$ ) is given in Proposition 2.1, whereas the moments are provided in Proposition 2.4. Regression models are typically constructed to model the mean of a distribution (generally associated with a precision (or dispersion) parameter). However, the lack of a simple expression for the mean of the GJS distribution hinders the construction of a regression model for the GJS distribution. On the other hand, the median of the GJS distribution has a very simple form (see Section 2). Therefore, in order to obtain a regression structure for the median of the GJS distribution along with a dispersion parameter, we shall work with a different parameterization of the GJS pdf.

The median of the GJS distribution is given by $\xi=\left(1+\mathrm{e}^{\gamma / \delta}\right)^{-1}$. Hence, we can express

$$
\gamma=\delta \log \left(\frac{1-\xi}{\xi}\right)=-\delta t(\xi),
$$

where $t(\cdot)$ is defined in (2). In this case, substituting the above expression in the GJS pdf given in Proposition 2.1, we obtain a reparameterization for the GJS pdf. (Note that similar reparameterizations for the GJS pdf based on quantiles other than the median are obviously possible.) Thus, the GJS pdf is given by

$$
f(y ; \xi, \delta)=\frac{\delta g\left(\{\delta[t(y)-t(\xi)]\}^{2}\right)}{y(1-y)}, \quad y \in(0,1)
$$

where $0<\xi<1$ and $\delta>0$. We note that the pdf in (9) can display quite different shapes depending on the values of the two parameters $\xi$ and $\delta$. In particular, it can be symmetric (when $\xi=1 / 2$ ) or asymmetric (when $\xi \neq 1 / 2$ ), bimodal, among many other shapes. Additionally, we note that the dispersion of the distribution, for fixed $\xi$, decreases as $\delta$ increases; that is the parameter $\delta$ can be regarded as a dispersion parameter. In the Online Supplementary Material, we prove that the parameter $\delta$ is indeed a dispersion parameter.

Let $Y_{1}, \ldots, Y_{n}$ be $n$ independent random variables, where each $Y_{i}, i=1, \ldots, n$, follows the pdf in (9) with median $\xi_{i}$ and unknown dispersion parameter $\delta_{i}$; that is $Y_{i} \sim \mathrm{GJS}\left(\xi_{i}, \delta_{i} ; g\right)$. Suppose the median and dispersion parameters of $Y_{i}$ satisfy the following functional relations:

$$
d_{1}\left(\xi_{i}\right)=\eta_{1 i}=\boldsymbol{x}_{i}^{\top} \boldsymbol{\beta}, \quad d_{2}\left(\delta_{i}\right)=\eta_{2 i}=\boldsymbol{s}_{i}^{\top} \boldsymbol{\tau},
$$

where $\boldsymbol{\beta}=\left(\beta_{1}, \ldots, \beta_{p}\right)^{\top}$ and $\boldsymbol{\tau}=\left(\tau_{1}, \ldots, \tau_{q}\right)^{\top}$ are vectors of unknown regression coefficients that are assumed to be functionally independent, $\boldsymbol{\beta} \in \mathbb{R}^{p}$ and $\boldsymbol{\tau} \in \mathbb{R}^{q}$ with $p+q<n, \eta_{1 i}$ and $\eta_{2 i}$ are the linear predictors, and $\boldsymbol{x}_{i}^{\top}=\left(x_{i 1}, \ldots, x_{i n}\right)$ and $\boldsymbol{s}_{i}^{\top}=\left(s_{i 1}, \ldots, s_{i n}\right)$ are observations on $p$ and $q$ known covariates (or independent variables or regressors). We assume that the median link function $d_{1}:(0,1) \rightarrow \mathbb{R}$ as well as the dispersion link function $d_{2}:(0, \infty) \rightarrow \mathbb{R}$ are strictly monotonic and twice differentiable. Moreover, we assume that the matrices $X=\left(\boldsymbol{x}_{1}, \ldots, \boldsymbol{x}_{n}\right)^{\top}$ and $S=\left(\boldsymbol{s}_{1}, \ldots, \boldsymbol{s}_{n}\right)^{\top}$ have rank $p$ and $q$, 
respectively. The dispersion covariates in $S$ are commonly, but not necessary, a subset of the median covariates in $X$. It is worth emphasizing that the proposed regression model allows us to jointly model the median and dispersion parameters.

There are several possible choices for the link functions $d_{1}(\cdot)$ and $d_{2}(\cdot)$. For instance, some useful link functions for the median are: $\operatorname{logit} d_{1}(\xi)=\log (\xi /(1-\xi))$; probit $d_{1}(\xi)=\Phi^{-1}(\xi)$, where $\Phi^{-1}(\cdot)$ is the standard normal quantile function; complementary $\log -\log d_{1}(\xi)=\log [-\log (1-\xi)]$; $\log -\log$ $d_{1}(\xi)=-\log [-\log (\xi)]$; and Cauchy $d_{1}(\xi)=\tan [\pi(\xi-0.5)]$. Some possible choices for the dispersion link function are: $\operatorname{logarithmic} d_{2}(\delta)=\log (\delta)$; square root $d_{2}(\delta)=\sqrt{\delta}$; identity $d_{2}(\delta)=\delta$ (with special attention on the positivity of the estimates); among others. Discussions of link functions can be found in McCullagh and Nelder (1989); see also Atkinson (1985).

\subsection{Estimation}

Since $\boldsymbol{\beta}$ and $\boldsymbol{\tau}$ represent the effects of the explanatory variables on the median response and dispersion parameter, respectively, we are interested in simultaneously estimating these parameters. The loglikelihood function for this class of regression models, except from a unimportant constant term, has the form

$$
\ell(\boldsymbol{\beta}, \boldsymbol{\tau})=\sum_{i=1}^{n} \ell_{i}\left(\xi_{i}, \delta_{i}\right),
$$

where $\ell_{i}\left(\xi_{i}, \delta_{i}\right)=\log \left(\delta_{i}\right)+\log \left[g\left(\left\{\delta_{i}\left[t\left(y_{i}\right)-t\left(\xi_{i}\right)\right]\right\}^{2}\right)\right]$, with $\xi_{i}=d_{1}^{-1}\left(\eta_{1 i}\right)$ and $\delta_{i}=d_{2}^{-1}\left(\eta_{2 i}\right)$, which are functions of $\boldsymbol{\beta}$ and $\boldsymbol{\tau}$, respectively. The score function (see the Online Supplementary Material) is given by the $(p+q)$-vector $\boldsymbol{U}(\boldsymbol{\beta}, \boldsymbol{\tau})=\left(\boldsymbol{U}_{\boldsymbol{\beta}}(\boldsymbol{\beta}, \boldsymbol{\tau})^{\top}, \boldsymbol{U}_{\boldsymbol{\tau}}(\boldsymbol{\beta}, \boldsymbol{\tau})^{\top}\right)^{\top}$, with

$$
\boldsymbol{U}_{\beta}(\boldsymbol{\beta}, \boldsymbol{\tau})=X^{\top} \Lambda W T_{1} \xi^{*}, \quad \boldsymbol{U}_{\tau}(\boldsymbol{\beta}, \boldsymbol{\tau})=S^{\top} T_{2} \boldsymbol{\delta}^{*}
$$

where $\quad T_{1}=\operatorname{diag}\left\{1 / \dot{d}_{1}\left(\xi_{i}\right)\right\}, \quad T_{2}=\operatorname{diag}\left\{1 / \dot{d}_{2}\left(\delta_{i}\right)\right\}, \quad W=\operatorname{diag}\left\{w_{i} W_{g}\left(w_{i}^{2}\right)\right\}, \quad \Lambda=\operatorname{diag}\left\{\delta_{i}\right\}, \quad \xi^{*}=$ $\left(\xi_{1}^{*}, \ldots, \xi_{n}^{*}\right)^{\top}, \quad \delta^{*}=\left(\delta_{1}^{*}, \ldots, \delta_{n}^{*}\right)^{\top}, \quad \xi_{i}^{*}=-2 /\left[\xi_{i}\left(1-\xi_{i}\right)\right], \quad \delta_{i}^{*}=\delta_{i}^{-1}+2 \delta_{i}^{-1} w_{i}^{2} W_{g}\left(w_{i}^{2}\right), \quad$ and $w_{i}=$ $\delta_{i}\left[t\left(y_{i}\right)-t\left(\xi_{i}\right)\right]$. Here, $\dot{d}_{j}(z)=\mathrm{d} d_{j}(z) / \mathrm{d} z$ for $j=1,2$. The ML estimators $\widehat{\boldsymbol{\beta}}$ and $\widehat{\boldsymbol{\tau}}$ of $\boldsymbol{\beta}$ and $\boldsymbol{\tau}$, respectively, can be obtained by solving simultaneously the nonlinear system of equations $\boldsymbol{U}_{\boldsymbol{\beta}}(\widehat{\boldsymbol{\beta}}, \widehat{\boldsymbol{\tau}})=\mathbf{0}_{p}$ and $\boldsymbol{U}_{\boldsymbol{\tau}}(\widehat{\boldsymbol{\beta}}, \widehat{\boldsymbol{\tau}})=\mathbf{0}_{q}$, which do not have closed-form, and $\mathbf{0}_{k}$ denotes a $k$-dimensional vector of zeros. Hence, they need to be obtained through a numerical maximization of the log-likelihood function using nonlinear optimization algorithms. The optimization algorithms require the specification of initial values to be used in the iterative scheme. Our suggestion is to use as an initial point estimate for $\boldsymbol{\beta}$ the ordinary least squares estimate of this parameter vector obtained from a linear regression of the transformed responses $d_{1}\left(y_{1}\right), \ldots, d_{1}\left(y_{n}\right)$ on $X$, that is $\left(X^{\top} X\right)^{-1} X^{\top} \boldsymbol{z}$, where $\boldsymbol{z}=\left(d_{1}\left(y_{1}\right), \ldots, d_{1}\left(y_{n}\right)\right)^{\top}$. We also need an initial guess for the parameter vector $\boldsymbol{\tau}$. Unfortunately, this is a more complicated problem to deal with and we do not have a general suggestion in this case. However, when the dispersion link function is taken as the logarithm, we suggest as an initial point estimate for $\boldsymbol{\tau}$ a $q$-dimensional vector of zeros $\left(\mathbf{0}_{q}\right)$; that is the optimization algorithm will start with the GJS regression model when the dispersion parameter does not vary across the observations. (These initial guesses worked very well in the real data application; see Section 5.)

Let $K(\boldsymbol{\beta}, \boldsymbol{\tau})$ be the expected Fisher information matrix for $(\boldsymbol{\beta}, \boldsymbol{\tau})$. When $n$ is large and under some mild regularity conditions, we have that

$$
\left(\begin{array}{l}
\widehat{\boldsymbol{\beta}} \\
\widehat{\boldsymbol{\tau}}
\end{array}\right) \stackrel{a}{\sim} \mathcal{N}_{p+q}\left(\left(\begin{array}{l}
\boldsymbol{\beta} \\
\boldsymbol{\tau}
\end{array}\right), K(\boldsymbol{\beta}, \boldsymbol{\tau})^{-1}\right),
$$


where " $\stackrel{a}{\sim}$ " means approximately distributed. Unfortunately, there is no closed-form expression for the matrix $K(\boldsymbol{\beta}, \boldsymbol{\tau})$. However, the asymptotic behavior remains valid if $K(\boldsymbol{\beta}, \boldsymbol{\tau})$ is approximated by $-J_{n}(\widehat{\boldsymbol{\beta}}, \widehat{\boldsymbol{\tau}})$, where $-J_{n}(\widehat{\boldsymbol{\beta}}, \widehat{\boldsymbol{\tau}})$ is the $(p+q) \times(p+q)$ observed information matrix evaluated at $(\widehat{\boldsymbol{\beta}}, \widehat{\boldsymbol{\tau}})$. It is useful to obtain an expression for $J_{n}(\boldsymbol{\beta}, \boldsymbol{\tau})$, which can be used to obtain asymptotic standard errors for the ML estimates. In the Online Supplementary Material, it is shown that the matrix $J_{n}(\boldsymbol{\beta}, \boldsymbol{\tau})$ is given by

$$
J_{n}(\boldsymbol{\beta}, \boldsymbol{\tau})=\frac{\partial^{2} \ell(\boldsymbol{\beta}, \boldsymbol{\tau})}{\partial\left(\boldsymbol{\beta}^{\top}, \boldsymbol{\tau}^{\top}\right)^{\top} \partial\left(\boldsymbol{\beta}^{\top}, \boldsymbol{\tau}^{\top}\right)}=\left[\begin{array}{cc}
J_{\beta \beta} & J_{\beta \tau} \\
J_{\boldsymbol{\beta} \tau}^{\top} & J_{\tau \tau}
\end{array}\right],
$$

whose elements are $J_{\beta \beta}=X^{\top} W_{1} T_{1} X, J_{\beta \tau}=X^{\top} W_{2} T_{1} T_{2} S$ and $J_{\tau \tau}=S^{\top} W_{3} T_{2} S$, where $W_{1}=$ $\operatorname{diag}\left\{w_{i}^{(1)}\right\}, W_{2}=\operatorname{diag}\left\{w_{i}^{(2)}\right\}$ and $W_{3}=\operatorname{diag}\left\{w_{i}^{(3)}\right\}$, with

$$
\begin{aligned}
w_{i}^{(1)}= & \frac{2 \delta_{i}^{2} \dot{d}_{1}\left(\xi_{i}\right)^{-1}}{\left[\xi_{i}\left(1-\xi_{i}\right)\right]^{2}}\left[\left(1-2 \xi_{i}\right) \delta_{i}^{-1} w_{i} W_{g}\left(w_{i}^{2}\right)+W_{g}\left(w_{i}^{2}\right)+2 w_{i}^{2} W_{g}^{\prime}\left(w_{i}^{2}\right)\right]+ \\
& +\frac{2 \delta_{i} w_{i} W_{g}\left(w_{i}^{2}\right)}{\xi_{i}\left(1-\xi_{i}\right)} \frac{\ddot{d}_{1}\left(\xi_{i}\right)}{\dot{d}_{1}\left(\xi_{i}\right)^{2}}, \\
w_{i}^{(2)}= & -\frac{4}{\xi_{i}\left(1-\xi_{i}\right)}\left[w_{i} W_{g}\left(w_{i}^{2}\right)+w_{i}^{3} W_{g}^{\prime}\left(w_{i}^{2}\right)\right], \\
w_{i}^{(3)}= & \dot{d}_{2}\left(\delta_{i}\right)^{-1}\left[-\frac{1}{\delta_{i}^{2}}+\frac{2 w_{i}^{2} W_{g}\left(w_{i}^{2}\right)}{\delta_{i}^{2}}+\frac{4 w_{i}^{4} W_{g}^{\prime}\left(w_{i}^{2}\right)}{\delta_{i}^{2}}\right]+ \\
& -\left[\frac{1}{\delta_{i}}+\frac{2 w_{i}^{2} W_{g}\left(w_{i}^{2}\right)}{\delta_{i}}\right] \frac{\ddot{d}_{2}\left(\delta_{i}\right)}{\dot{d}_{2}\left(\delta_{i}\right)^{2}},
\end{aligned}
$$

where $\ddot{d}_{j}(z)=\mathrm{d} \dot{d}_{j}(z) / \mathrm{d} z, W_{g}^{\prime}(u)=\mathrm{d} W_{g}(u) / \mathrm{d} u=g^{\prime \prime}(u) / g(u)-\left[g^{\prime}(u) / g(u)\right]^{2}$, and $g^{\prime \prime}(u)=\mathrm{d} g^{\prime}(u) / \mathrm{d} u$. Let $P$ be the $2 n \times(p+q)$ dimensional matrix

$$
P=\left[\begin{array}{cc}
X & 0_{n, q} \\
0_{n, p} & S
\end{array}\right]
$$

where $0_{l, c}$ denotes a $l \times c$ matrix of zeros. Also, let $M$ be the $2 n \times 2 n$ dimensional matrix

$$
M=\left[\begin{array}{cc}
M_{\beta \beta} & M_{\beta \tau} \\
M_{\beta \tau} & M_{\tau \tau}
\end{array}\right],
$$

where $M_{\beta \beta}=W_{1} T_{1}, M_{\beta \tau}=W_{2} T_{1} T_{2}$ and $M_{\tau \tau}=W_{3} T_{2}$. Thus, we can express $J_{n}(\boldsymbol{\beta}, \boldsymbol{\tau})=P^{\top} M P$.

The above asymptotic normal distribution can be used to construct approximate confidence intervals and confidence regions for the parameters. Let $\beta_{r}(r=1, \ldots, p)$ and $\tau_{R}(R=1, \ldots, q)$ be the $r$-th and $R$-th component of $\beta$ and $\boldsymbol{\tau}$, respectively. For $0<\alpha<1 / 2$, we have the asymptotic confidence intervals $\widehat{\beta}_{r} \pm z_{1-\alpha / 2} \operatorname{se}\left(\widehat{\beta}_{r}\right)$ and $\widehat{\tau}_{R} \pm z_{1-\alpha / 2} \operatorname{se}\left(\widehat{\tau}_{R}\right)$ for $\beta_{r}$ and $\tau_{R}$, respectively, both with asymptotic coverage of $100(1-\alpha) \%$. Here, $\operatorname{se}(\cdot)$ is the square root of the diagonal element of $-J_{n}(\widehat{\boldsymbol{\beta}}, \widehat{\boldsymbol{\tau}})^{-1}$ corresponding to 
each parameter (i.e., the standard error), and $z_{1-\alpha / 2}$ denotes the quantile $(1-\alpha / 2)$ of the standard normal distribution.

\subsection{Local influence}

In the following, the local influence method under five perturbation schemes is carried out in order to assess the sensitivity of the ML estimates of the parameters of the proposed regression model. We consider the Cook (1986)'s approach and obtain the matrix $\Delta$ under five different perturbation schemes, namely: case-weights perturbation, response perturbation, median covariate perturbation, dispersion covariate perturbation, and simultaneous explanatory variable perturbation. Technical details are provided in the Online Supplementary Material. The matrix $\Delta$, which is given by $\Delta=\left[\begin{array}{ll}\Delta_{\beta}^{\top} & \Delta_{\tau}^{\top}\end{array}\right]^{\top}$, can be expressed in the forms (the quantities evaluated at $\widehat{\boldsymbol{\theta}}=\left(\widehat{\boldsymbol{\beta}}^{\top}, \widehat{\boldsymbol{\tau}}^{\top}\right)^{\top}$ are written with a circumflex):

Case-weights perturbation We have that $\Delta_{\beta}=X^{\top} \widehat{\Lambda} \widehat{W} \widehat{T}_{1} \widehat{D}_{\xi}$ and $\Delta_{\tau}=S^{\top} \widehat{T}_{2} \widehat{D}_{\delta}$, where $D_{\xi}=\operatorname{diag}\left\{\xi_{i}^{*}\right\}$ and $D_{\delta}=\operatorname{diag}\left\{\delta_{i}^{*}\right\}$.

Response perturbation We obtain $\Delta_{\beta}=\sigma_{y} X^{\top} \widehat{W}_{\beta} \widehat{T}_{1} \widehat{D}_{\xi} D_{y}$ and $\Delta_{\tau}=\sigma_{y} S^{\top} \widehat{W}_{\tau} \widehat{T}_{2} D_{y}$, where $W_{\beta}=$ $\operatorname{diag}\left\{\delta_{i}^{2} W_{g}\left(w_{i}^{2}\right)+2 \delta_{i}^{2} w_{i}^{2} W_{g}^{\prime}\left(w_{i}^{2}\right)\right\}, \quad W_{\tau}=4 \operatorname{diag}\left\{w_{i} W_{g}\left(w_{i}^{2}\right)+w_{i}^{3} W_{g}^{\prime}\left(w_{i}^{2}\right)\right\} \quad$ and $\quad D_{\boldsymbol{y}}=\operatorname{diag}\left\{y_{i}^{-1}(1-\right.$ $\left.\left.y_{i}\right)^{-1}\right\}$.

Median covariate perturbation It follows that $\Delta_{\beta}=\sigma_{x} \widehat{\beta}_{j} X^{\top} \widehat{W}_{1} \widehat{T}_{1}+\sigma_{x} c_{\beta}^{j} \widehat{\xi}^{* \top} \widehat{\Lambda} \widehat{W} \widehat{T}_{1}$ and $\Delta_{\tau}=$ $\sigma_{x} \widehat{\beta}_{j} S^{\top} \widehat{W}_{2} \widehat{T}_{1} \widehat{T}_{2}$, where $c_{\beta}^{j}$ denotes a $p \times 1$ vector with one at the $j$-th position and zero elsewhere, and $\widehat{\beta}_{j}($ for $j=1, \ldots, p)$ denotes the $j$-th element of $\widehat{\boldsymbol{\beta}}=\left(\widehat{\beta}_{1}, \ldots, \widehat{\beta}_{p}\right)^{\top}$.

Dispersion covariate perturbation We obtain $\Delta_{\beta}=\sigma_{s} \widehat{\tau}_{k} X^{\top} \widehat{W}_{2} \widehat{T}_{1} \widehat{T}_{2}$ and $\Delta_{\tau}=\sigma_{s} \widehat{\tau}_{k} S^{\top} \widehat{W}_{3} \widehat{T}_{2}+$ $\sigma_{s} \boldsymbol{c}_{\tau}^{k} \widehat{\boldsymbol{\delta}}^{* \top} \widehat{T}_{2}$, where $\boldsymbol{c}_{\tau}^{k}$ denotes a $q \times 1$ vector with one at the $k$-th position and zero elsewhere, and $\widehat{\tau}_{k}$ (for $k=1, \ldots, q$ ) denotes the $k$-th element of $\widehat{\boldsymbol{\tau}}=\left(\widehat{\tau}_{1}, \ldots, \widehat{\tau}_{q}\right)^{\top}$.

Simultaneous (median and dispersion) explanatory variable perturbation It then follows that $\Delta_{\beta}=\sigma_{x} \widehat{\beta}_{j} X^{\top} \widehat{W}_{1} \widehat{T}_{1}+\sigma_{x} \boldsymbol{c}_{\beta}^{j} \widehat{\xi}^{* \top} \widehat{\Lambda} \widehat{W} \widehat{T}_{1}+\sigma_{s} \widehat{\tau}_{k} X^{\top} \widehat{W}_{2} \widehat{T}_{1} \widehat{T}_{2}$ and $\Delta_{\tau}=\sigma_{s} \widehat{\tau}_{k} S^{\top} \widehat{W}_{3} \widehat{T}_{2}+\sigma_{s} \boldsymbol{c}_{\tau}^{k} \widehat{\boldsymbol{\delta}}^{* \top} \widehat{T}_{2}+$ $\sigma_{x} \widehat{\beta}_{j} S^{\top} \widehat{W}_{2} \widehat{T}_{1} \widehat{T}_{2}$, and all quantities in $\Delta_{\beta}$ and $\Delta_{\tau}$ were defined before.

\subsection{Residual analysis}

Next, we introduce two residuals for the class of regression models proposed in this section. The residuals are defined in order to study discrepancies between the model and data, as well as presence of outlying observations. The first residual we would like to introduce is

$$
r_{i}^{d}=\operatorname{sign}\left(y_{i}-\widehat{\xi}_{i}\right)\left\{2\left[\ell_{i}\left(\widetilde{\xi}_{i}, \widehat{\delta}_{i}\right)-\ell_{i}\left(\widehat{\xi}_{i}, \widehat{\delta}_{i}\right)\right]\right\}^{1 / 2}, \quad i=1, \ldots, n
$$

where $\widehat{\xi}_{i}=d_{1}^{-1}\left(\boldsymbol{x}_{i}^{\top} \widehat{\boldsymbol{\beta}}\right)$ and $\widehat{\delta}_{i}=d_{2}^{-1}\left(\boldsymbol{s}_{i}^{\top} \widehat{\boldsymbol{\tau}}\right)$ are the ML estimates of $\xi_{i}$ and $\delta_{i}$, respectively. Also, $\widetilde{\xi}_{i}$ is the value of $\xi_{i}$ that solves $\partial \ell_{i}\left(\xi_{i}, \delta_{i}\right) / \partial \xi_{i}=0$; that is $\widetilde{\xi}_{i}$ is the ML estimate of $\xi_{i}$ in the saturated model. It can be shown that $\widetilde{\xi}_{i}=y_{i}$. Note that (10) measures the discrepancy of a fit as twice the difference between the maximum log-likelihood achievable (saturated model) and that achieved by the model under investigation. We shall call $r_{i}^{d}$ as $i$-th "deviance residual," once the idea for defining it comes from the generalized linear models (McCullagh and Nelder, 1989). Second, we follow Rocha and Simas (2011) and define the modified deviance residual, which is given by

$$
r_{i}^{m d}=\frac{r_{i}^{d}}{\sqrt{1-h_{i i}}}, \quad i=1, \ldots, n,
$$


where $h_{i i}=h_{i i}(\widehat{\boldsymbol{\beta}}, \widehat{\boldsymbol{\tau}})$ is the $i$-th diagonal value of the generalized leverage matrix (evaluated at $\widehat{\boldsymbol{\beta}}$ and $\widehat{\tau})$

$$
H=\dot{L}\left[-J_{n}(\boldsymbol{\beta}, \boldsymbol{\tau})\right]^{-1} \ddot{L},
$$

where

$$
\dot{L}=\left[\begin{array}{ll}
T_{1} X & 0_{n, q}
\end{array}\right], \quad \ddot{L}=\left[\begin{array}{c}
X^{\top} W_{\beta} T_{1} D_{\xi} D_{y} \\
S^{\top} W_{\tau} T_{2} D_{y}
\end{array}\right] .
$$

It is worth emphasizing that the generalized leverage matrix $H$ (evaluated at $\widehat{\boldsymbol{\beta}}$ and $\widehat{\boldsymbol{\tau}}$ ) can be used to identify those observations that are leverage points; see Wei et al. (1998). The main idea behind the concept of leverage is that of evaluating the influence of $y_{i}$ on its own predicted value. So, index plots of $h_{i i}$ may reveal those observations with high influence on their own predicted values.

Under a well-specified model, one expects the residuals $r_{i}^{d}$ and $r_{i}^{m d}$ to be concentrated around zero. Since the distribution of these residuals are not known, it is usual to adding envelopes as suggested by Atkinson $(1985, \S 4.2)$ into the normal probability plots for $r_{i}^{d}$ and $r_{i}^{m d}$. The main idea is to enhance the usual half-normal plot by adding a simulated envelope that can be used to decide whether the observed residuals are consistent with the fitted model. In order to put some light about the empirical distribution of $r_{i}^{d}$ and $r_{i}^{m d}$, we conduct some Monte Carlo simulation experiments; see the Online Supplementary Material. From the Monte Carlo experiments we have that the distributions of the residuals $r_{i}^{d}$ and $r_{i}^{m d}$ proposed here are well approximated by the standard normal distribution.

\subsection{Special model}

Finally, an important special model of the above regression model, which commonly arises in practice, corresponds to the case when the dispersion parameter does not vary across the observations, that is when this parameter is constant: $Y_{i} \sim \operatorname{GJS}\left(\xi_{i}, \delta ; g\right)$ for $i=1, \ldots, n$. Hence the regression structure is only on the median. In this case, we have that

$$
d_{1}\left(\xi_{i}\right)=\eta_{1 i}=\boldsymbol{x}_{i}^{\top} \boldsymbol{\beta},
$$

and it is assumed that the dispersion parameter $\delta>0$ is unknown and it is the same for all observations. The score vector becomes $\boldsymbol{U}(\boldsymbol{\beta}, \delta)=\left(\boldsymbol{U}_{\boldsymbol{\beta}}(\boldsymbol{\beta}, \delta)^{\top}, U_{\delta}(\boldsymbol{\beta}, \delta)\right)^{\top}$ with

$$
\boldsymbol{U}_{\boldsymbol{\beta}}(\boldsymbol{\beta}, \delta)=\delta X^{\top} W T_{1} \boldsymbol{\xi}^{*}, \quad U_{\delta}(\boldsymbol{\beta}, \delta)=\frac{n}{\delta}+\frac{2}{\delta} \sum_{i=1}^{n} w_{i}^{2} W_{g}\left(w_{i}^{2}\right),
$$

where $w_{i}$ is the same as above just by replacing $\delta_{i}$ with $\delta$. The matrices $P$ and $M$ become, respectively,

$$
P=\left[\begin{array}{cc}
X & \mathbf{0}_{n, 1} \\
0_{n, p} & \mathbf{1}_{n}
\end{array}\right], \quad M=\left[\begin{array}{cc}
M_{\beta \beta} & M_{\beta \delta} \\
M_{\beta \delta} & M_{\delta \delta}
\end{array}\right],
$$

where $\mathbf{1}_{n}$ denotes the $n$-vector of ones, $M_{\beta \beta}=W_{1} T_{1}, M_{\beta \delta}=W_{2} T_{1}$, and $M_{\delta \delta}=W_{3}$. Here,

$$
w_{i}^{(3)}=-\frac{1}{\delta^{2}}+\frac{2 w_{i}^{2} W_{g}\left(w_{i}^{2}\right)}{\delta^{2}}+\frac{4 w_{i}^{4} W_{g}^{\prime}\left(w_{i}^{2}\right)}{\delta^{2}},
$$


whereas $w_{i}^{(1)}$ and $w_{i}^{(2)}$ are the same as above just by replacing $\delta_{i}$ with $\delta$. It thus follows that $J_{n}(\boldsymbol{\beta}, \delta)=P^{\top} M P$. Regarding the local influence approach, for the case-weights perturbation, we have that $\Delta_{\beta}=\widehat{\delta} X^{\top} \widehat{W} \widehat{T}_{1} \widehat{D}_{\xi}$ and $\Delta_{\delta}=\left(\widehat{c}_{1 i}, \ldots, \widehat{c}_{1 n}\right)^{\top}$, where $c_{1 i}=\delta^{-1}+2 \delta^{-1} w_{i}^{2} W_{g}\left(w_{i}^{2}\right)$. For the response perturbation, it follows that $\Delta_{\beta}=\sigma_{y} X^{\top} \widehat{W}_{\beta} \widehat{T}_{1} \widehat{D}_{\xi} D_{y}$ and $\Delta_{\delta}=\sigma_{y}\left(\widehat{c}_{2 i}, \ldots, \widehat{c}_{2 n}\right)^{\top}$, where $c_{2 i}=4\left[w_{i} W_{g}\left(w_{i}^{2}\right)+w_{i}^{3} W_{g}^{\prime}\left(w_{i}^{2}\right)\right] y_{i}^{-1}\left(1-y_{i}\right)^{-1}$. Finally, for the median covariate perturbation, we have $\Delta_{\beta}=\sigma_{y} X^{\top} \widehat{W}_{\beta} \widehat{T}_{1} \widehat{D}_{\xi} D_{y}$ and $\Delta_{\delta}=\sigma_{y}\left(\widehat{c}_{2 i}, \ldots, \widehat{c}_{2 n}\right)^{\top}$, where $c_{3 i}=w_{i}^{(2)} \dot{d}_{1}\left(\xi_{i}\right)^{-1}$. The residuals hold just by replacing $\delta_{i}$ with $\delta$ in $r_{i}^{d}$ and $r_{i}^{m d}$.

\section{Real data application}

This section uses a real dataset to show the usefulness of the GJS regression model in practice. All the computations were carried out using the 0x program (Doornik, 2009), which is freely distributed for academic purposes and available at http://www.doornik.com, and all the graphics were obtained using the $\mathrm{R}$ program (R Development Core Team, 2012). Estimation was performed using the quasiNewton optimization algorithm known as Broyden-Fletcher-Goldfarb-Shanno (BFGS) with analytic first derivatives through the subroutine maxBFGS. Source code to reproduce the results is available as Supporting Information.

We are interested in modelling the proportion of blank votes $(Y)$ in the 2006 Peruvian general election of an electoral district as a function of the Human Development Index (HDI). The data were previously considered in Bayes et al. (2012). We have 194 electoral districts and the data are presented in Fig. 1.

Notice that the data indicate some evidence of heteroscedasticity and hence we assume that $Y_{i} \sim$ $\operatorname{GJS}\left(\xi_{i}, \delta_{i} ; g\right)$, with

$$
d_{1}\left(\xi_{i}\right)=\log \left(\frac{\xi_{i}}{1-\xi_{i}}\right)=\beta_{1}+\beta_{2} \mathrm{HDI}_{i}, \quad d_{2}\left(\delta_{i}\right)=\log \left(\delta_{i}\right)=\tau_{1}+\tau_{2} \mathrm{HDI}_{i},
$$

where $i=1, \ldots, 194$. We shall assume GJS distributions with density generators of the normal and Student- $t$ distributions; that is we have the GJS-normal and GJS-Student- $t$ regression models. The degrees of freedom for the GJS-Student- $t$ model was fixed at $v=4$.

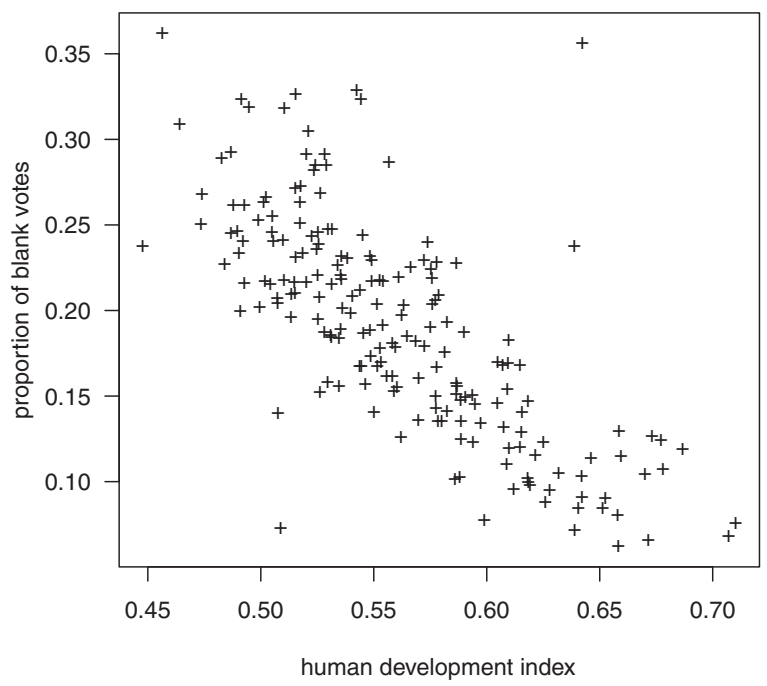

Figure 1 HDI on proportion of blank votes. 
Table 2 Parameter estimates.

\begin{tabular}{lrcc}
\hline Parameter & Estimate & SE & $p$-value \\
\hline GJS-normal regression model & & & \\
$\beta_{1}$ & 2.1220 & 0.2295 & $<0.01$ \\
$\beta_{2}$ & -6.4690 & 0.4151 & $<0.01$ \\
$\tau_{1}$ & 2.3635 & 0.5202 & $<0.01$ \\
$\tau_{2}$ & -1.9936 & 0.9227 & 0.015 \\
GJS-Student- $t$ regression model & & & $<0.01$ \\
$\beta_{1}$ & 2.3057 & 0.2086 & $<0.01$ \\
$\beta_{2}$ & -6.8079 & 0.3780 & $<0.01$ \\
$\tau_{1}$ & 2.7508 & 0.7007 & 0.041 \\
$\tau_{2}$ & -2.1572 & 1.2421 & \\
\hline
\end{tabular}

Table 3 AIC, BIC and HQIC for the fitted models.

\begin{tabular}{lcc}
\hline & \multicolumn{2}{c}{ Model } \\
\cline { 2 - 3 } Criterion & GJS-normal & GJS-Student- $t$ \\
\hline AIC & 79.53 & 57.95 \\
BIC & 99.14 & 77.56 \\
HQIC & 87.47 & 65.89 \\
\hline
\end{tabular}

Table 2 lists the ML estimates, asymptotic standard errors (SE), and $p$-values for the GJS-normal and GJS-Student- $t$ regression models. The figures in Table 2 show that the HDI is statistically significant at the, for instance, $10 \%$ nominal level for both regression models. It is interesting to note that the SEs for the median estimates of the GJS-Student- $t$ model are smaller than the SEs for the median estimates of the GJS-normal model, whereas the contrary happens for the dispersion estimates. To compare the regression models, we consider selection criteria on the candidate models (see Table 3). According to the AIC (Akaike Information Criterion), BIC (Bayesian Information Criterion), and HQIC (HannanQuinn Information Criterion) criteria, the GJS-Student- $t$ regression model outperforms the GJSnormal regression model and therefore should be preferred.

From Table 2, we have a negative relationship between the median response (proportion of blank votes) and the HDI. Additionally, the dispersion decreases with the HDI. That is we observe high proportion of blank votes in electoral districts with low HDI, which can be interpreted as distrust of the political party system, and this behavior decreases in electoral districts with high HDI. This finding is not new in political analysis (see, e.g. Kitschelt et al., 2010). A blank vote (also known as a protest vote) is a vote cast in an election that can be interpreted as a vote to demonstrate the dissatisfaction with the choice of candidates or refusal of the current political system.

In order to detect possible departures from model assumptions as well as outlying observations, we present in Figs. 2 and 3 the deviance $\left(r_{i}^{d}\right)$ and modified deviance $\left(r_{i}^{m d}\right)$ residuals (and the corresponding normal probability plot with generated envelopes) for the GJS-normal and GJS-Student- $t$ regression models, respectively. Figures 2 and 3 indicate a large negative residual (case \#20) and a large positive residual (case \#147) for both regression models. Also, these figures reveal that the GJS-normal regression model seems to be inappropriate to model these data, since there is an observation outside the 

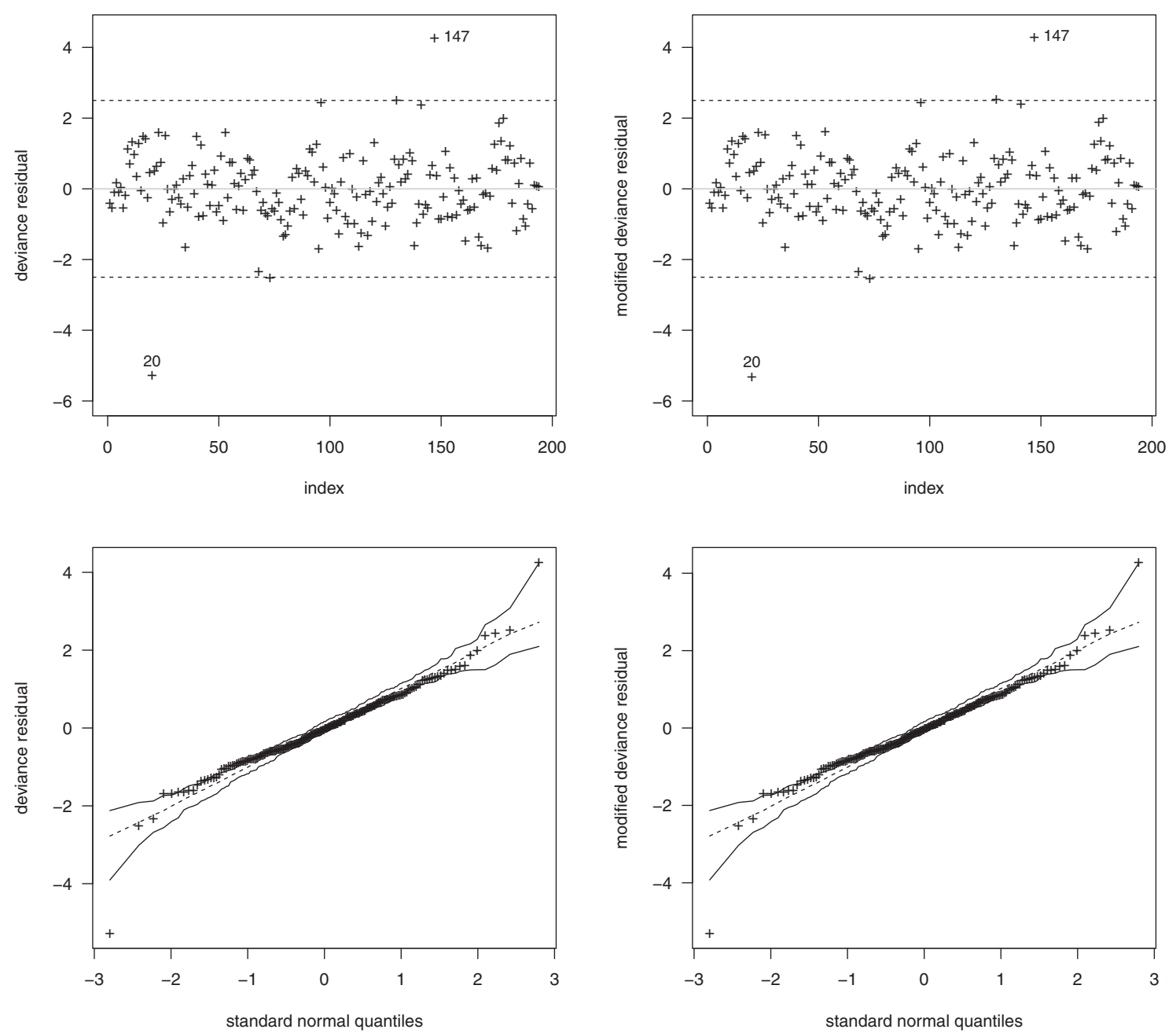

Figure 2 Deviance and modified deviance residuals for the GJS-normal model.

envelope. On the other hand, the GJS-Student- $t$ regression model seems to be appropriate to model these data, since there are no observations falling outside the envelope; that is the generated envelope for the GJS-Student- $t$ model does not present any unusual feature. As can be observed, Figs. 2 and 3 highlight strongly the observations \#20 and \#147. The case \#20 corresponds to a district that has $\mathrm{HDI}=0.5088$ and the proportion of blank votes was approximately $7.31 \%$. The observation \#147 corresponds to a district that has HDI $=0.6423$ and the proportion of blank votes was approximately $35.6 \%$.

Figures 4 and 5 show the index plots of $\left|\boldsymbol{d}_{\max }\right|$ (see the Online Supplementary Material for details) for $(\widehat{\boldsymbol{\beta}}, \widehat{\boldsymbol{\tau}}), \widehat{\boldsymbol{\beta}}$, and $\widehat{\boldsymbol{\tau}}$ under the perturbation scheme indicated for the GJS-normal and GJS-Student- $t$ regression models, respectively. From Fig. 4, notice that the observations \#20 and \#147 appear as the most influential for the GJS-normal regression model, whereas Fig. 5 does not reveal any observation as influential for the GJS-Student- $t$ regression model. The impact of these two observations (cases \#20 and \#147) on the parameter estimates of the GJS-normal and GJS-Student- $t$ regression models is considered in the Online Supplementary Material, which confirms that the GJS-Student- $t$ regression model is suitable to model these real data. We also compare the proposed regression model with the 

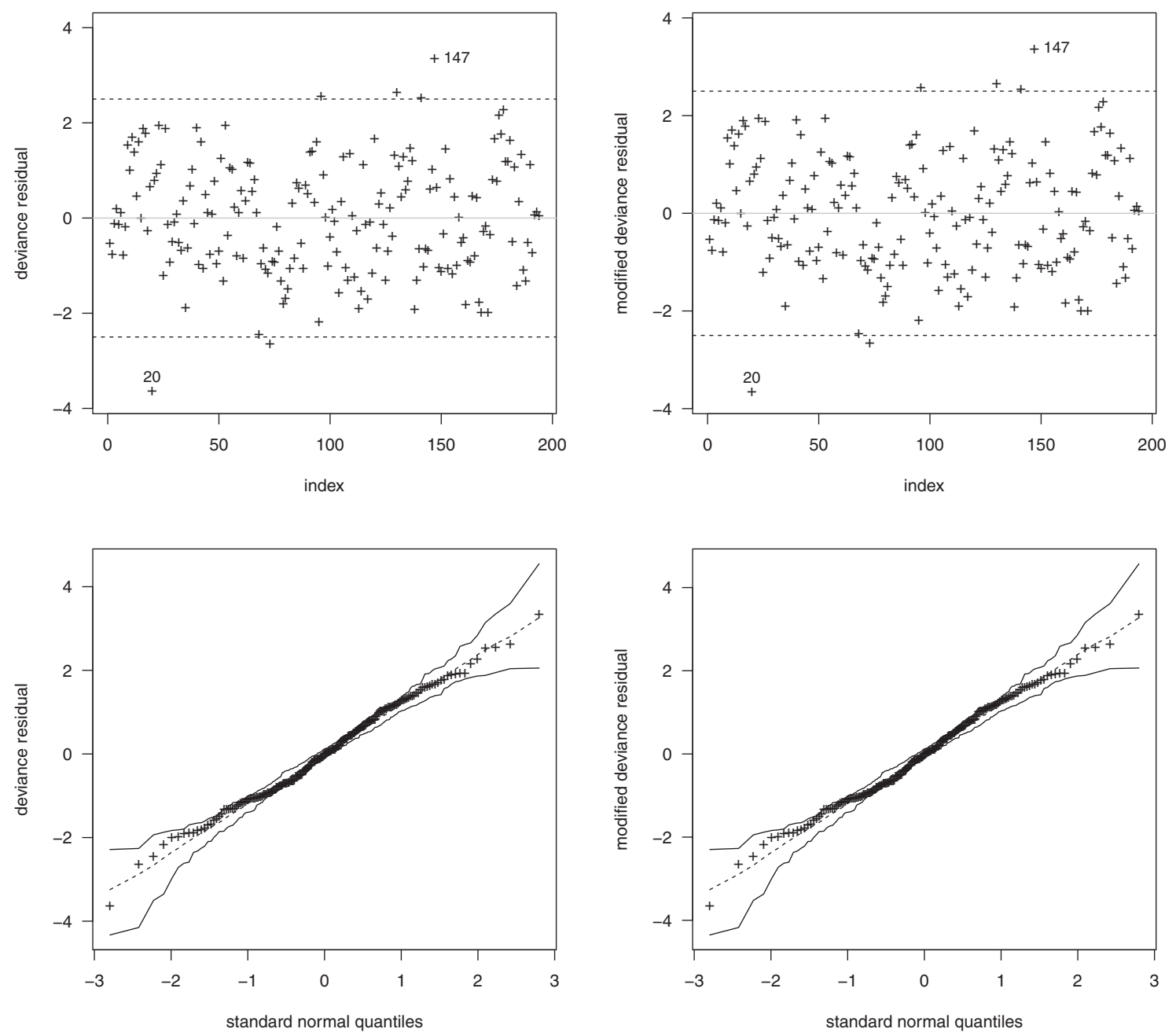

Figure 3 Deviance and modified deviance residuals for the GJS-Student- $t$ model.

beta regression model in the Online Supplementary Material, which reveals that our regression model is more robust to outlying observations than the beta regression model to fit these data. So, robustness to outlying observations may be a great advantage of the proposed regression model in relation to the beta regression model.

Finally, generalized leverage for the GJS-normal and GJS-Student- $t$ regression models are presented in Fig. 6, which reveals that no observation has high influence on its own predicted value for both regression models.

\section{Closing remarks}

The beta distribution is very flexible to model data restricted to any finite interval since it can take a great variety of forms depending on the values of the index parameters. This flexibility encourages its empirical use in a wide range of applications. Another distribution with bounded support was proposed by Kumaraswamy (1980), who argued that the beta distribution does not faithfully fit hydrological 

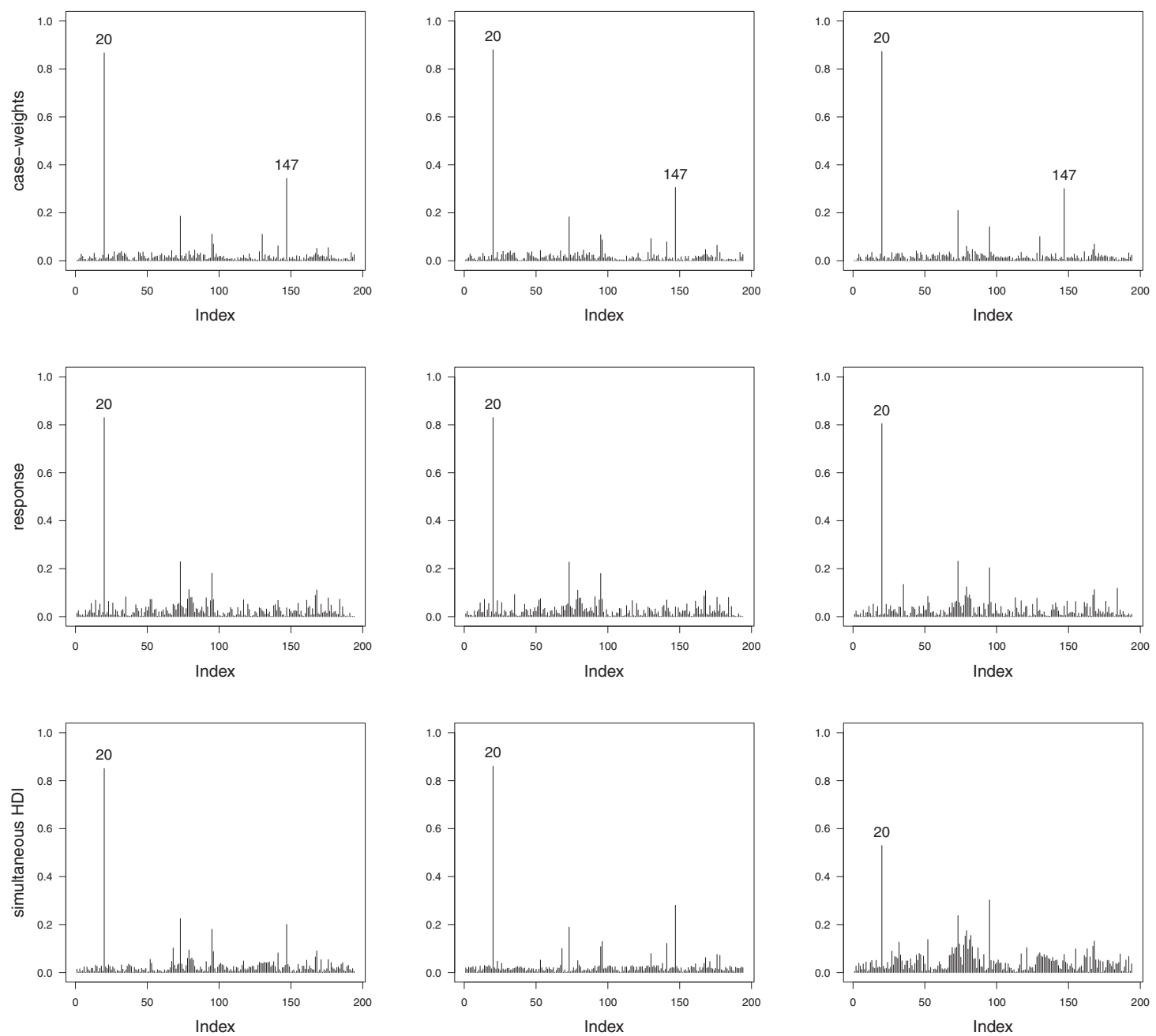

Figure 4 Index plots of $\left|\boldsymbol{d}_{\max }\right|$ for $(\widehat{\boldsymbol{\beta}}, \widehat{\boldsymbol{\tau}}), \widehat{\boldsymbol{\beta}}$ and $\widehat{\boldsymbol{\tau}}$; GJS-normal model.

random variables such as daily rainfall, daily stream flow, etc. This distribution is also known as "minimax" distribution and generalized beta distribution of the first kind (or, beta type I). Like the beta and Kumaraswamy distributions, the Johnson $S_{B}$ distribution can also be used to model ratios, proportions, etc., or variates constrained by extremes. A close look at the existing literature shows that it has found application in a variety of fields including ambient air pollution (Mage, 1980), rainfall distribution (Kottegoda, 1987), forestry (Zhang et al., 2003), among others.

In this paper, we have proposed a generalization of the Johnson $S_{B}$ distribution on the basis of the symmetric family of distributions. The new class of distributions with bounded domain (in particular in $(0,1)$ ), the so-called generalized Johnson $S_{B}$ (GJS) distribution, has many interesting properties and provides a rich source of alternative distributions for analysing bounded data; that is the proposed class of distributions may be a viable alternative to the beta and Kumaraswamy distributions. An interesting feature of the GJS distribution is that, besides the bimodality, we can generate distributions with bounded support that are more platykurtic or leptokurtic than the Johnson $S_{B}$ distribution, which may be useful to model univariate bounded data containing outlying observations. Still more 

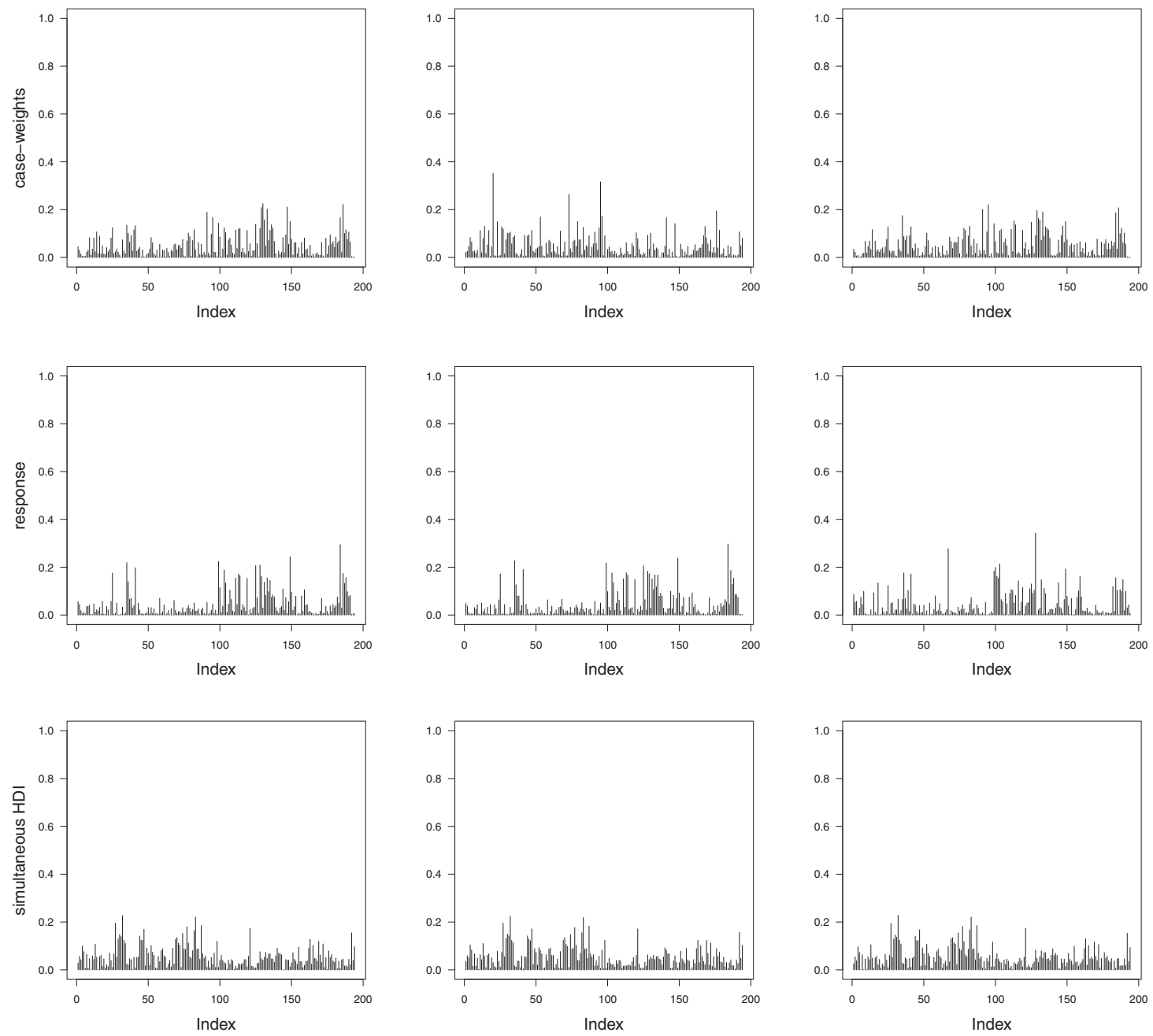

Figure 5 Index plots of $\left|\boldsymbol{d}_{\max }\right|$ for $(\widehat{\boldsymbol{\beta}}, \widehat{\boldsymbol{\tau}}), \widehat{\boldsymbol{\beta}}$ and $\widehat{\boldsymbol{\tau}}$; GJS-Student- $t$ model $(v=4)$.

interesting is that the GJS distribution has finite moments even if the symmetric distribution that generated it does not possess moments. For example, let $Y$ be a random variable that follows the GJS distribution obtained from the Cauchy density generator. The pdf of $Y$ can be obtained from Online Supplementary Material (Corollary 1) and its moments from Proposition 2.4. The moments are

$$
\mu_{n}^{\prime}=\frac{1}{\pi} \int_{\mathbb{R}}\left(\frac{\mathrm{e}^{(u-\gamma) / \delta}}{1+\mathrm{e}^{(u-\gamma) / \delta}}\right)^{n}\left(1+u^{2}\right)^{-1} \mathrm{~d} u
$$

Table 4 lists the four moments as well as the variance of $Y$ obtained from expression (11) for some values of $\gamma$ and $\delta$.

A variety of estimation methods has been developed for estimating the model parameters of the Johnson $S_{B}$ distribution, including the method of matching moments, the method of matching percentiles, the maximum likelihood (ML) method, the weight least squares (WLS) method, and the Bayesian method. The method of matching moments is known to lead to highly variable parameter estimates for small datasets (Slifker and Shapiro, 1980), while the estimates obtained by the method 

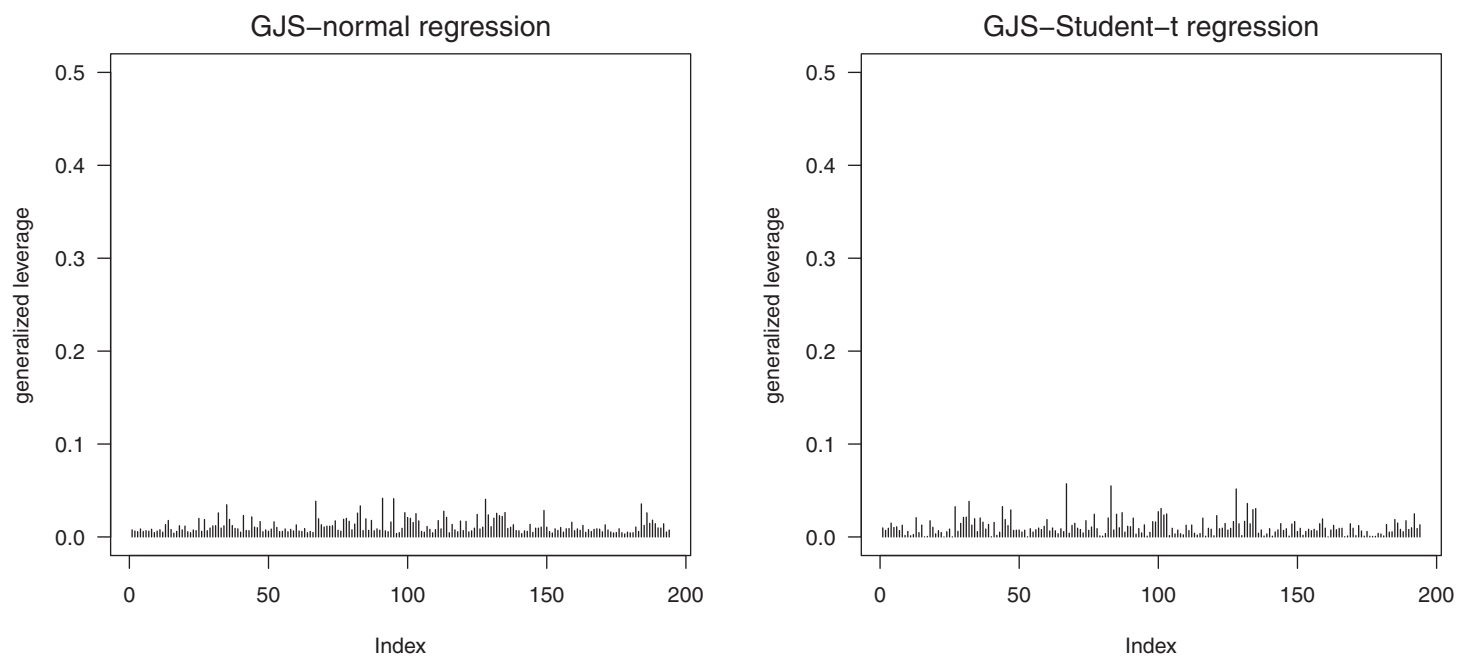

Figure 6 Generalized leverage.

Table 4 Moments of $Y$.

\begin{tabular}{lccc}
\hline$n$ & $\gamma=-0.1, \delta=1$ & $\gamma=0, \delta=1$ & $\gamma=0.1, \delta=1$ \\
\hline 1 & 0.51580 & 0.50000 & 0.48420 \\
2 & 0.35794 & 0.34193 & 0.32634 \\
3 & 0.27691 & 0.26289 & 0.24950 \\
4 & 0.22915 & 0.21720 & 0.20594 \\
Variance & 0.09189 & 0.09193 & 0.09189 \\
\hline
\end{tabular}

of matching percentiles depend on the choice of percentile points (Chou et al., 1999). It implies that these methods are not interesting to estimate the Johnson $S_{B}$ distribution parameters and hence it makes us feel that these methods may not work to estimate the GJS distribution parameters. Section 3 deals with estimation of the GJS parameters, where we consider the ML and WLS methods. The (threshold) parameters associated with the bounded support of the GJS distribution violate the standard regularity conditions that ensure the asymptotical properties of the ML estimators and hence we have restricted to the GJS distribution with support $(0,1)$ to consider the ML method. (It is worth emphasizing that the difficulty of applying the ML method to Johnson $S_{B}$ distribution has been long recognized by Johnson (1949).) On the other hand, the WLS method does not suffer from this particular limitation of the ML method. A frequently used method for estimating the threshold parameters of bounded distributions is the Bayesian method, which allows the incorporation of expert opinion into the estimation procedure via the use of a joint prior density function on the distribution parameters. This method has been successfully applied for estimating the Johnson $S_{B}$ distribution parameters by Tsionas (2001). It is evident that the Bayesian method can also be applied to estimate the model parameters of the GJS distribution. Although the review of the literature suggests that the WLS and Bayesian methods are promising estimating methods for the Johnson $S_{B}$ distribution, it is not clear about these methods for estimating the GJS distribution parameters. This is a very interesting open problem regarding the GJS distribution. However, this kind of study is beyond the scope of this article and hence could be considered in another research paper. Finally, future researches regarding mixture of GJS distributions to obtain more flexibility can also be considered. 
We also proposed a new regression model for responses measured in the unit interval. We use a parameterization in which a function of the median of the response is given by a linear predictor that is defined by regression parameters and explanatory variables. The proposed parameterization allows for a dispersion parameter, which also has a systematic component. An advantage of the proposed GJS regression model in relation to the beta regression model is its flexibility for working with data where there are outlying observations; that is the new class of regression models may serve as a good alternative to the beta regression model in analyzing data restricted to the interval $(0,1)$ in the presence of outlying observations. The parameter estimation of the new regression model is approached by ML and the observed information matrix is derived. We discuss diagnostic techniques in the proposed regression model. Diagnostic methods have been an important tool in regression analysis to detect anomalies with the fitted model, such as departures from the error assumptions, presence of outliers, and presence of influential observations. In particular, appropriate matrices for assessing local influence on the parameter estimates under different perturbation schemes are obtained, which are quite simple, compact, and can be easily implemented into any mathematical or statistical/econometric programming environment with numerical linear algebra facilities. Finally, an application using a real dataset was presented and discussed.

We would like to point out that some studies regarding the proposed regression model can be considered in future researches. A very interesting issue is to expand the GJS regression model for situations where the data contain zeros or ones; that is one may propose a general class of zero-or-one inflated GJS regression models. In this case, the class of zero-or-one inflated GJS regression assumes that the response variable has a mixed continuous-discrete distribution with probability mass at zero or one. The GJS distribution can be used to describe the continuous component of the model, since its density has a wide range of different shapes depending on the values of the two parameters that index the distribution. This model may be an alternative to the class of zero-or-one inflated beta regression models (see, for instance, Ospina and Ferrari, 2012). Additionally, an extension of GJS regression models that allow for explanatory variables to be measured with error may be developed; see, for example, Carrasco et al. (2014). Future work should explore other estimation methods for the GJS regression model as, for instance, the Bayesian approach. Finally, but not less important, one may develop a R package (similar to the betareg) to perform inference in GJS regression models. We plan to develop a R package (i.e., the GJSreg) for modeling GJS-distributed dependent variables as brief as possible.

Acknowledgments The authors would like to thank the Editor, Associate Editor, and an anonymous referee for the valuable comments that have improved considerably the first version of the manuscript. Artur Lemonte gratefully acknowledges financial support from CNPq (Brazil) and FACEPE (Pernambuco, Brazil).

\section{Conflict of interest}

The authors have declared no conflict of interest.

\section{References}

Atkinson, A. C. (1985). Plots, Transformation and Regression: An Introduction to Graphical Methods of Diagnostic Regression Analysis. Oxford University Press, New York, NY.

Bayes, C., Bazán, J. L., García, C. (2012). A new robust regression model for proportions. Bayesian Analysis 7 , 771-796.

Carrasco, J. M. F., Ferrari, S. L. P., Arellano-Valle, R. B. (2014). Errors-in-variables beta regression models. Journal of Applied Statistics 41, 1530-1547.

Chou, Y. M., Polansky, A. M., Mason, R. L. (1999). An algorithm for fitting Johnson transformations to nonnormal data. Journal of Quality Technology 31, 354-350. 
Cook, R. D. (1986). Assessment of local influence (with discussion). Journal of the Royal Statistical Society B $\mathbf{4 8 ,}$ $133-169$.

Cribari-Neto, F., Zeileis, A. (2010). Beta regression in R. Journal of Statistical Software 34, 1-24.

DeBrota, D. J., Roberts, S. D., Dittus, R. S., Wilson, J. R. (1989). Visual interactive fitting of bounded Johnson distributions. Simulation 52, 199-205.

Doornik, J. A. (2009). An Object-Oriented Matrix Language-Ox 6. Timberlake Consultants Press, London, UK.

Fang, K. T., Anderson, T. W. (1990). Statistical Inference in Elliptical Contoured and Related Distributions. Allerton Press, New York, NY.

Ferrari, S. L. P., Cribari-Neto, F. (2004). Beta regression for modeling rates and proportions. Journal of Applied Statistics 31, 799-815.

Gilchrist, W. G. (2001). Statistical Modelling with Quantile Functions. Chapman and Hall/CRC, Boca Raton, LA.

Johnson, N. L. (1949). Systems of frequency curves generated by the methods of translation. Biometrika 36, 149-176.

Kendall, M. G., Stuart, A. (1979). The Advanced Theory of Statistics. Macmillan, New York, NY.

Kieschnick, R., McCullough, B. D. (2003). Regression analysis of variates observed on $(0,1)$ : percentages, proportions and fractions. Statistical Modelling 3, 193-213.

Kitschelt, H., Hawkins, K. A., Luna, J. P., Rosas, G., Zechmeister, E. J. (2010). Latin American Party Systems. Cambridge University Press, Cambridge, UK.

Kottegoda, N. T. (1987). Fitting Johnson $S_{B}$ curve by the method of maximum likelihood to annual maximum daily rainfalls. Water Resources Research 23, 728-732.

Kotz, S., van Dorp, J. R., (2004). Beyond Beta: Other Continuous Families of Distributions with Bounded Support and Applications. World Scientific Press, Singapore.

Kumaraswamy, P. (1980). Generalized probability density-function for double-bounded random-processes. Journal of Hydrology 46, 79-88.

Lemonte, A. J., Patriota, A. G. (2011). Influence diagnostics in Birnbaum-Saunders nonlinear regression models. Journal of Applied Statistics 38, 871-884.

Mage, D. T. (1980). An explicit solution for $S_{B}$ parameters using four percentile points. Technometrics 22, $247-251$.

McCullagh, P., Nelder, J. (1989). Generalized Linear Models. 2nd ed. Chapman \& Hall, London, UK.

Melo, T. F. N., Vasconcellos, K. L. P., Lemonte, A. J. (2009). Some restriction tests in a new class of regression models for proportions. Computational Statistics and Data Analysis 53, 3972-3979.

Ospina. R., Ferrari, S. L. P. (2012). A general class of zero-or-one inflated beta regression models. Computational Statistics and Data Analysis 56, 1609-1623.

Paolino, P. (2001). Maximum likelihood estimation of models with beta-distributed dependent variables. Political Analysis 9, 325-346.

R Development Core Team (2012). R: A Language and Environment for Statistical Computing. R Foundation for Statistical Computing. Vienna, Austria.

Rocha, A. V., Simas, A. B. (2011). Influence diagnostics in a general class of beta regression models. Test 20, 95-119.

Slifker, J. F., Shapiro, S. S. (1980). The Johnson system: selection and parameter estimation. Technometrics 22 , 239-246.

Swain, J. J., Venkatraman, S., Wilson, J. R. (1988). Least-squares estimation of distribution functions in Johnson's translation system. Journal of Statistical Computation and Simulation 29, 271-297.

Tsionas, E. G. (2001). Likelihood and posterior shapes in Johnson's $S_{B}$ system. Sankhya B 63, 3-9.

Vasconcellos, K. L. P., Cribari-Neto, F. (2005). Improved maximum likelihood estimation in a new class of beta regression models. Brazilian Journal of Probability and Statistics 19, 13-31.

Vasconcellos, K. L. P., Fernandez, L. M. Z. (2009). Influence analysis with homogeneous linear restrictions. Computational Statistics and Data Analysis 53, 3787-3794.

Wei, B. C., Hu, Y. Q., Fung, W. K. (1998). Generalized leverage and its applications. Scandinavian Journal of Statistics 25, 25-37.

Zevallos, M., Santos, B., Hotta, L. K. (2012). A note on influence diagnostics in AR(1) time series models. Journal of Statistical Planning and Inference 142, 2999-3007.

Zhang, L., Packard, P. C., Liu, C. (2003). A comparison of estimation methods for fitting Weibull and Johnson's $S_{B}$ distributions to mixed spruce-fir stands in northeastern North America. Canadian Journal of Forest Research 33, 1340-1347. 


\section{Apêndice D}

Bazán, J. L., Romeo, J. S., e Rodrigues, J. (2014a). Bayesian skew-probit regression for binary response data. Brazilian Journal of Probability and Statistics, 28(4), 467-482. DOI: 10.1214/13-BJPS218. 


\title{
Bayesian skew-probit regression for binary response data
}

\author{
Jorge L. Bazán ${ }^{a}$, José S. Romeo ${ }^{\mathrm{b}}$ and Josemar Rodrigues ${ }^{\mathrm{a}}$ \\ ${ }^{\mathrm{a}}$ Universidade de São Paulo \\ ${ }^{\mathrm{b}}$ Universidad de Santiago de Chile
}

\begin{abstract}
Since many authors have emphasized the need of asymmetric link functions to fit binary regression models, we propose in this work two new skew-probit link functions for the binary response variables. These link functions will be named power probit and reciprocal power probit due to the relation between them including the probit link as a special case. Also, the probit regressions are special cases of the models considered in this work. A Bayesian inference approach using MCMC is developed for real data suggesting that the link functions proposed here are more appropriate than other link functions used in the literature. In addition, simulation study show that the use of probit model will lead to biased estimate of the regression coefficient.
\end{abstract}

\section{Introduction}

Binary regression is an important special case of the generalized linear models for which Bayesian inference has been developed in the literature (see, Dey, Ghosh and Mallick, 1999). For example, the Probit model (PM) is a generalized linear model obtained by considering $\mathbf{Y}=\left(Y_{1}, Y_{2}, \ldots, Y_{n}\right)^{\prime}$ a $n \times 1$ vector of $n$ independent dichotomous random variables with probability $p_{i}=P\left[Y_{i}=1\right]$, and $\mathbf{x}_{i}=\left(x_{i 1}, \ldots, x_{i k}\right)^{\prime}$ a $k \times 1$ vector of covariates, where $x_{i 1}$ may equals 1 , corresponding to an intercept, $i=1, \ldots, n$. Also, $\mathbf{X}$ denotes the $n \times k$ design matrix with rows $\mathbf{x}_{i}^{\prime}$, and $\boldsymbol{\beta}=\left(\beta_{1}, \ldots, \beta_{k}\right)^{\prime}$ is a $k \times 1$ vector of regression coefficients. For this model, the probability of binary response variable is given by

$$
p_{i}=E\left(Y_{i} \mid \mathbf{x}_{i}\right)=\Phi\left(\eta_{i}\right)=\Phi\left(\mathbf{x}_{i}^{\prime} \boldsymbol{\beta}\right), \quad i=1, \ldots, n,
$$

where $\Phi(\cdot)$ denotes a cumulative distribution function (c.d.f.) of the standard normal distribution. The inverse of the function $\Phi$, namely $\Phi^{-1}$, is called link function and $\boldsymbol{\eta}_{i}=\mathbf{x}_{i}^{\prime} \boldsymbol{\beta}$, the linear predictor. The graphic considering $p_{i}$ as a function of $\eta_{i}$ is called response curve or probability of success and has a symmetric form centered in 0.5. Other symmetric link functions are obtained when $\Phi$ is replaced by the c.d.f. of a distribution in the class of the elliptical distributions, such as, the logistic, Student- $t$, double exponential and Cauchy distributions (Albert and Chib, 1993). However, as Chen, Dey and Shao (1999) have been argued, when

Key words and phrases. Skew-probit links, binary regression, Bayesian estimation, power normal distribution, reciprocal power normal distribution.

Received April 2012; accepted January 2013. 
the probability of a given binary response variable approaches 0 at different rates than it approaches 1 , symmetric link functions may be not useful to fit binary data and asymmetric link functions must be considered. Many asymmetric link functions, including the logit or probit link as special case, have been considered by Prentice (1976) (available in the Stata software), Guerrero and Johnson (1982), Stukel (1988), Czado and Santner (1992), Czado (1994), Chen, Dey and Shao (1999, 2001), Bazán, Branco and Bolfarine (2006), Bazán, Bolfarine and Branco (2010) and recently Wang and Dey (2010).

Moreover, some textbooks (see, e.g., Collet, 2003) have reported that an asymmetric link function may be more appropriate than a symmetric one for some specific situations.

In this paper, we propose two new asymmetric links. In both cases, the probit link function is a particular case of them. The skew link functions proposed here introduce a parameter that controls the rate of increase (or decrease) of the probability of success (failure) of the binary response variables. One is based on the c.d.f. of the power-normal (PN) distribution given by Gupta and Gupta (2008), Kundu and Gupta (2013) and the other is based on the c.d.f. of named reciprocal power-normal (RPN) distribution introduced here. In this context, the probability of success is obtained from a c.d.f. evaluated at the linear predictor. An asymmetry parameter associated with these c.d.f.'s is also introduced independently of the linear predictor and a latent linear structure will be not necessary for this link approach. The most important aspect of the modeling in this setting is the potential improvement to model fit that is gained by using this particular class of asymmetric link functions since that some data simply cannot be modeled appropriately with symmetric link functions as showed in this paper.

This work is organized as follows. In Section 2, the PN and RPN distributions are presented. In Section 3, two new skew-probit models for binary responses variables are formulated. In Section 4, a Bayesian estimation approach is developed using a selection models criteria and MCMC output. In Section 5, applications are showed, one by considering simulated data and other considering real data. Finally, a discussion and extensions of the link functions proposed in this paper are considered in Section 6.

\section{A power normal and reciprocal power normal distributions}

The probability density function (p.d.f.) of the PN distribution introduced by Gupta and Gupta (2008) is given by

$$
g_{1}(r)=\frac{\lambda}{\sigma}\left[\Phi\left(\frac{r-\mu}{\sigma}\right)\right]^{\lambda-1} \phi\left(\frac{r-\mu}{\sigma}\right)
$$

where $\phi(\cdot)$ and $\Phi(\cdot)$ denote, respectively, the density and cumulative distribution functions of the standard normal distribution. 
The notation considered is $R \sim \operatorname{PN}(\theta)$ with $\theta=\left(\mu, \sigma^{2}, \lambda\right)$, where $\mu \in \mathbb{R}$ is a location parameter, $\sigma^{2}>0$ is a scale parameter and $\lambda>0$ is a shape parameter.

If $\lambda=1$, the density of $R$ in (2.1) reduces to the density of the $N\left(\mu, \sigma^{2}\right)$. The special case $\mu=0$ and $\sigma^{2}=1$ is called the standard $P N$ distribution which will be denoted by $S \sim \operatorname{PN}(\lambda)$ and its corresponding p.d.f. and c.d.f. are given by

$$
f_{1}(s)=\lambda[\Phi(s)]^{\lambda-1} \phi(s), \quad F_{1}(s)=[\Phi(s)]^{\lambda},
$$

respectively. Some properties of these distributions are presented in the Appendix.

A new random variable can be obtained by the following c.d.f. or p.d.f.

$$
F_{2}(s)=1-[\Phi(-s)]^{\lambda}, \quad f_{2}(s)=\lambda[\Phi(-s)]^{\lambda-1} \phi(s) .
$$

In this case we write $S \sim \operatorname{RPN}(\lambda)$, to denote the standard reciprocal $P N$ distribution. The name is justified since $F_{2}(y)=1-F_{1}(-y)$ and, so, the standard PN and the standard RPN distributions are distinct, although, closely related since one is the reflection of the other. That is also justified since that if $X \sim \operatorname{PN}\left(\mu, \sigma^{2}, \lambda\right)$ then $-X \sim \operatorname{RPN}\left(\mu, \sigma^{2}, \lambda\right)$. Also, note that $F_{1}(-y) \neq 1-F_{1}(y)$ or $F_{2}(-y) \neq 1-F_{2}(y)$ and then $F_{1}$ and $F_{2}$ are not symmetric.

A location-scale version of the RPN distribution with parameter $\theta=\left(\mu, \sigma^{2}, \lambda\right)$ is given by

$$
g_{2}(r)=\frac{\lambda}{\sigma}\left[\Phi\left(-\left(\frac{r-\mu}{\sigma}\right)\right)\right]^{\lambda-1} \phi\left(\frac{r-\mu}{\sigma}\right) .
$$

If $\lambda=1$, the density of $R$ in (2.4) reduces to the density of the $N\left(\mu, \sigma^{2}\right)$.

As suggested by Gupta and Gupta (2008), the PN density is an unimodal density which is skewed to the right if $\lambda>1$ and to the left if $0<\lambda<1$. On the other hand, by considering the reciprocal formulation the RPN density is also unimodal density which is skewed to the left if $\lambda>1$ and to the right if $0<\lambda<1$. Thus, the density in (2.2) and (2.3) are weighted normal densities with the weight function $w_{1}(s)=\lambda[\Phi(s)]^{\lambda-1}$ and $w_{2}(s)=\lambda[\Phi(-s)]^{\lambda-1}$, respectively, given by

$$
f_{i}(s)=\frac{w_{i}(s) \phi(s)}{E\left[w_{i}(S)\right]}, \quad i=1,2 .
$$

Figure 1 displays probability density fuctions for various values of $\lambda$ in both cases.

\section{The skew-probit link models}

Two new models for binary data, called here as Skew-Probit models (SPM), can be obtained by replacing $\Phi(\cdot)$ in (1.1) by the standard PN c.d.f. or the standard RPN, that is, for both cases we have:

$$
p_{i}=E\left(Y_{i} \mid \mathbf{x}_{i}\right)=F_{\lambda}\left(\eta_{i}\right)=F_{\lambda}\left(\mathbf{x}_{i}^{\prime} \boldsymbol{\beta}\right),
$$



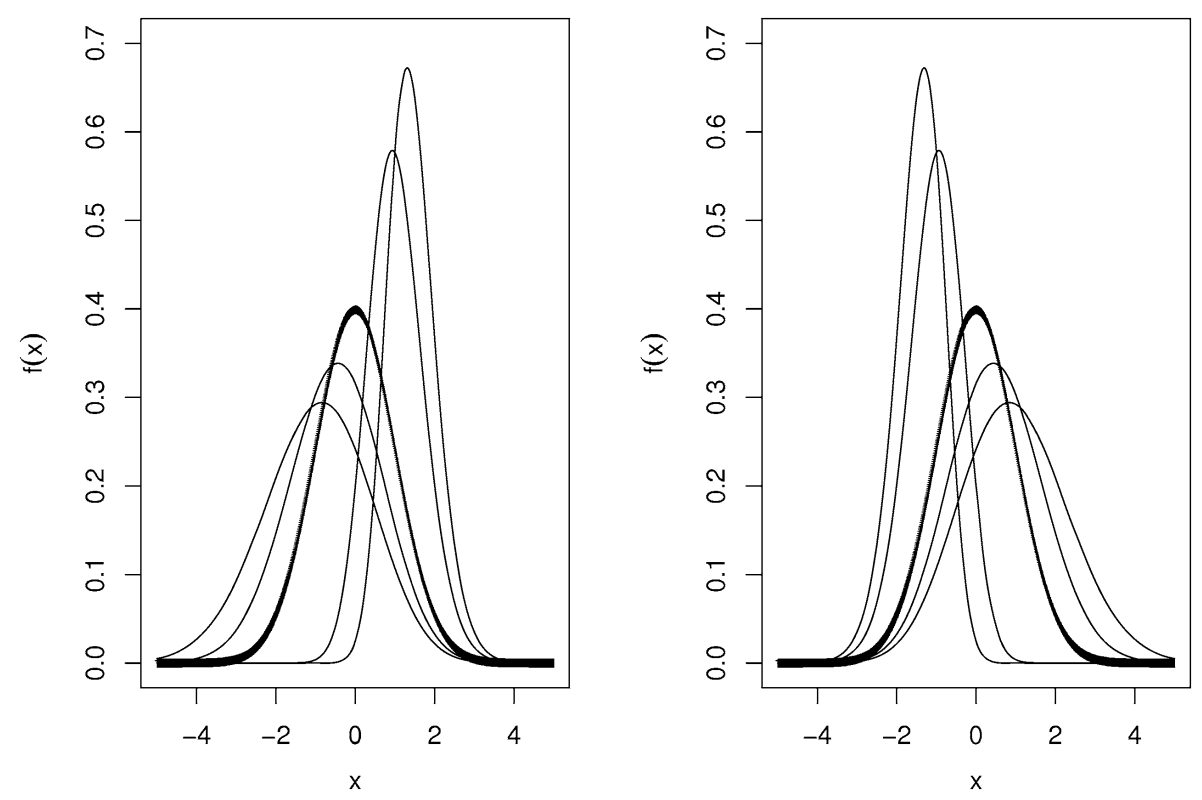

Figure 1 Probability density functions: Power Normal (left) for $\lambda=\{0.4,0.6,1,4,8\}$ and Reciprocal Power Normal (right) for $\lambda=\{8,4,1,0.6,0.4\}$ with curves showed from left to right in both figures.

where $F_{\lambda}$ denotes the c.d.f. $F_{1}(\cdot)$ (or $\left.F_{2}(\cdot)\right)$ in (2.2) (or (2.3)).

The formulations in (2.2) and (2.3) imply that the two new models, named, Power Probit (PP) and Reciprocal Power Probit (RPP) models have the usual probit model in (1.1) as particular case and nested in the class of SPM.

Figure 2 depicts different probability curves for the PP and RPP models by using different values for $\lambda$ and $\eta$. For $\lambda=1$, the PP and the RPP models correspond to the curve of the probit model. For $\lambda<1$ ( or $\lambda>1$ ), the PP curve is generally above (below) to the probit curve for a range of $\eta$ values. Also, for each value of $\lambda$, RPP curve is a reflection of the probit curve and thus for $\lambda<1$ (or $\lambda>1$ ) the corresponding curve is generally below (above) the corresponding curve for the probit model.

The likelihood function corresponding for the SPM model indexed by $\lambda$ is given by

$$
L(\boldsymbol{\beta}, \lambda \mid \mathbf{y}, \mathbf{x})=\prod_{i=1}^{n}\left[F_{\lambda}\left(\eta_{i}\right)\right]^{y_{i}}\left[1-F_{\lambda}\left(\eta_{i}\right)\right]^{1-y_{i}} .
$$

Note that in the SP models the parameters $\beta$ and $\lambda$ have quite different meaning. On one hand, $\lambda$ is a structural parameter associated with the choice of the link function. On the other hand, traditional $\beta$ parameters are a vector of structural parameters inherent to the observed data and not depending on model choice (for a discussion, see, e.g., Taylor and Siqueira, 1996). So, two scenarios can be considered. The first scenario is one in which the traditional $\beta$ parameters and $\lambda$ 

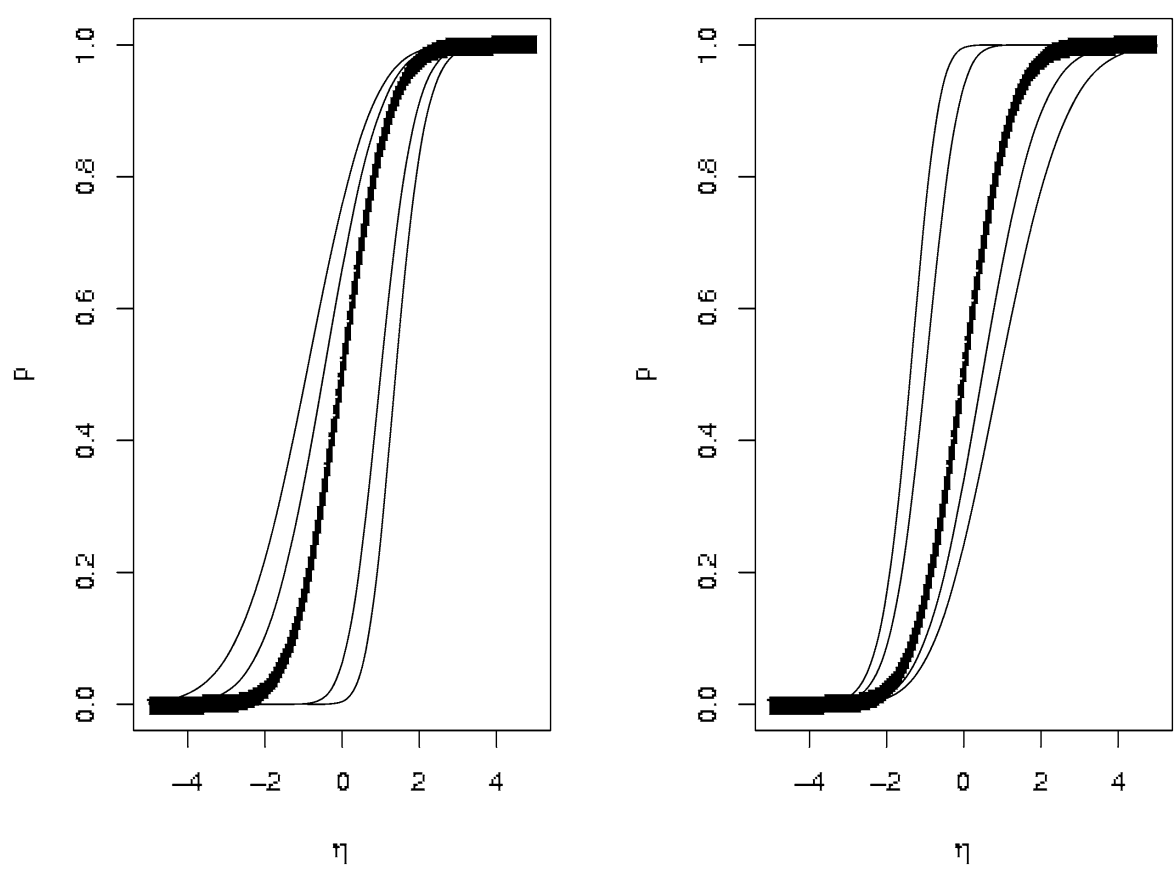

Figure 2 Response curves: Power Probit (left) for $\lambda=\{0.4,0.6,1,4,8\}$ and Reciprocal Power Probit (right) for $\lambda=\{8,4,1,0.6,0.4\}$ with different values of the linear predictor $\eta_{i}$ and curves showed from left to right in both figures.

are jointly estimated; in the second scenario only the traditional parameters $\beta$ are allowed to vary and $\lambda$ is fixed at its "true" value $\lambda_{0}$. As in Taylor and Siqueira (1996), we shall refer to these two scenarios as the unconditional and conditional on $\lambda$, respectively. Inference under the conditional scenario for $\lambda$ is easier to be implemented, because it corresponds to a particular PM model with a fixed value for the parameter $\lambda$. In this paper, we are interested in the unconditional approach for $\lambda$ from the Bayesian paradigm.

\section{Bayesian estimation}

In order to simplify the Bayesian computation, we introduce the $\delta$-transformation $\delta=\ln (\lambda)$ in the SPM model. Under this parametrization or the parameter $\lambda$ in the context of a Bayesian analysis, it is necessary to specify a prior distributions for $\boldsymbol{\beta}$ and $\lambda$ or $\boldsymbol{\beta}$ and $\delta$. It is usual to assume independent priors as

$$
\pi(\boldsymbol{\beta}, \delta)=\pi_{1}(\boldsymbol{\beta}) \pi_{2}(\delta) .
$$

Thus, for $\boldsymbol{\beta}$, we can use the typical priors considered with the probit model (see, e.g., Zellner and Rossi, 1984), including a normal prior $\left(\beta_{j} \sim N\left(\mu_{\beta_{j}}, \sigma_{\beta_{j}}^{2}\right)\right.$ ) where in the common situation where little prior information is available about 
this parameters, one can chose $\sigma_{\beta_{j}}^{2}$ to be a large value. Since $\delta \in \mathfrak{R}$, we can adopt a normal prior for $\delta$, that is, $\delta \sim N\left(\mu_{\delta}, \sigma_{\delta}^{2}\right)$.

Considering the likelihood function in (3.2) and a general prior specification given in (4.1), the Bayesian estimation can be implemented via MetropolisHasting providing a simple and efficient sampling from the marginal posterior distributions. Another possibility by considering an augmented likelihood version as the presented in Bolfarine and Bazan (2010) can be obtained using Gibbs Sampling. We do not implement this procedure due to it is slow to converge given the auxiliary latent variables introduced. Besides, it is required to generate values of the PN and RPN distributions which are not implemented directly in SAS software.

In this case, the prior hierarchical structure using the $\delta$-parametrization is as follows:

$$
\begin{aligned}
Y_{i} \mid \beta, \lambda & \sim \operatorname{Ber}\left(F_{\delta}\left(\eta_{i}\right)\right), \\
\boldsymbol{\beta} & \sim \pi_{1}(\boldsymbol{\beta})
\end{aligned}
$$

and

$$
\delta \sim \pi_{2}(\delta)
$$

This hierarchical structure can be easily implemented in the WinBugs or SAS software. Further, when $\delta=0(\lambda=0)$, the hierarchical structure of the likelihood of the $P M$ model follows by eliminating the third line in the above model.

It is crucial to mention that selection model is an essential part of any statistical analysis, thus for comparison among alternative models for binary regression, different selection procedures have been proposed in the literature in the MCMC scenary. The main selection procedures used here are the Deviance Information Criterion (DIC) proposed by Spiegelhalter et al. (2002), the Expected Information Criteria (Akaike (EAIC) and the Schwarz and Bayesian (EBIC)) which can seen in Carlin and Louis (2000) and Brooks (2002). These criteria are based on the Posterior Mean of the Deviance, $E[D(\beta, \lambda)]$, which is a measure of fit that can be approximated via the MCMC output by

$$
\text { Dbar }=\frac{1}{G} \sum_{g=1}^{G} D\left(\boldsymbol{\beta}^{(g)}, \lambda^{(g)}\right),
$$

where the index $(g)$ represent the $g$ th realization of a total of $G$ realizations, and

$$
D(\boldsymbol{\beta}, \lambda)=-2 \ln (p(\mathbf{y} \mid \boldsymbol{\beta}, \lambda))=-2 \sum_{i=1}^{n} \ln P\left(Y_{i}=y_{i} \mid \boldsymbol{\beta}, \lambda\right),
$$

is the Bayesian deviance.

EAIC, EBIC and DIC can be estimated using MCMC output by considering

$$
\begin{aligned}
& \widehat{E A I C}=\text { Dbar }+2 p, \\
& \widehat{E B I C}=\text { Dbar }+p \log N
\end{aligned}
$$


and

$$
\widehat{D I C}=D b a r+\widehat{\rho_{D}}=2 \text { Dbar }- \text { Dhat }
$$

respectively, where $p$ is the number of parameters in the model, $N$ is the total number of observations and $\rho_{D}$, namely the effective number of parameters, is given by

$$
\rho_{D}=E[D(\boldsymbol{\beta}, \lambda)]-D[E(\boldsymbol{\beta}), E(\lambda)],
$$

where $D[E(\boldsymbol{\beta}), E(\boldsymbol{\lambda})]$ is the deviance of posterior mean. It is obtained by considering the mean of the values generated from the posterior distribution as

$$
\text { Dhat }=D\left(\frac{1}{G} \sum_{g=1}^{G} \boldsymbol{\beta}^{(g)}, \frac{1}{G} \sum_{i=1}^{G} \lambda^{(g)}\right) .
$$

Given two alternative models, the model that fits better to a data set is the one with the smallest value of the Posterior Mean of the Deviance, DIC, EBIC and EAIC.

Additionally, checking through examination of individual observations can be obtained by considering posterior mean of the standardized residual $\frac{\left(y_{i}-E\left(Y_{i}\right)\right)}{\sqrt{v\left(Y_{i}\right)}}$. Also, another measures of global fit by considering posterior mean of unstandardized residuals $e_{i}=y_{i}-E\left(Y_{i}\right)$ can be defined as the sum of squared residuals (SSR) and sum of absolute residuals $(S A R)$, that is, $S S R=\sum_{i=1}^{n} e_{i}^{2}$ and $S A R=\sum_{i=1}^{n}\left|e_{i}\right|$.

In the following section, we illustrate the Bayesian approaches developed in this work under the SPM model by considering two simulation studies: one for the parameter recovery and other for compare model selection criteria. In addition, for a well-known data set from the literature, we improve the fitting in the Binary Regression Model, by using a Skew-Probit Link function, when compared with other links functions in the literature. All the models considered here were implemented using proc mcmc of SAS 9.2 software (SAS Institute Inc., 2009). A code is showed in Appendix B.

\section{Applications}

\subsection{Simulated data}

A simulation study is carried out to evaluate the relative performance of the estimation procedure in terms of parameter recovery and the PP model by considering: (a) three sample sizes $n=\{50,100,200\}$ and (b) the use of posterior mean or posterior median as measure of summary for $\lambda$.

For this purpose, a dataset was simulated following a similar procedures as in Chen, Dey and Shao (1999), that is, by considering the value of $\lambda$ fixed following the strategy: We independently generate $x_{i} \sim N(1,3), i=1,2, \ldots, n$. Then using 
Table 1 Study on parameter recovery of the power probit model with skewed to the left $(\lambda=0.25)$ under three different sizes of the sample with 100 generated datasets

\begin{tabular}{|c|c|c|c|c|c|c|c|}
\hline \multirow[b]{2}{*}{ Parameter } & \multirow[b]{2}{*}{ Estimator } & \multicolumn{3}{|c|}{ Skew probit model } & \multicolumn{3}{|c|}{ Probit model } \\
\hline & & $n=50$ & $n=100$ & $n=200$ & $n=50$ & $n=100$ & $n=200$ \\
\hline \multirow[t]{4}{*}{ beta } & mean & 1.190 & 1.117 & 1.094 & 0.585 & 0.536 & 0.522 \\
\hline & se & 0.036 & 0.025 & 0.020 & 0.016 & 0.009 & 0.007 \\
\hline & bias of mean beta & 0.190 & 0.117 & 0.094 & -0.415 & -0.464 & -0.478 \\
\hline & mse of mean beta & 0.162 & 0.077 & 0.050 & 0.199 & 0.224 & 0.233 \\
\hline \multirow[t]{8}{*}{ lambda } & mean & 0.272 & 0.255 & 0.246 & - & - & - \\
\hline & se & 0.006 & 0.006 & 0.005 & - & - & - \\
\hline & median & 0.247 & 0.240 & 0.239 & - & - & - \\
\hline & se & 0.006 & 0.006 & 0.005 & - & - & - \\
\hline & bias of mean lambda & 0.022 & 0.005 & -0.004 & - & - & - \\
\hline & bias of median lambda & -0.003 & -0.010 & -0.011 & - & - & - \\
\hline & mse of mean lambda & 0.0041 & 0.0035 & 0.0028 & - & - & - \\
\hline & mse of median lambda & 0.0036 & 0.0037 & 0.0031 & - & - & - \\
\hline \multirow[t]{2}{*}{ DIC } & mean & 25.974 & 50.676 & 99.598 & 38.590 & 76.951 & 152.293 \\
\hline & se & 0.658 & 0.930 & 1.317 & 0.685 & 1.010 & 1.534 \\
\hline \multirow[t]{2}{*}{ EAIC } & mean & 28.712 & 53.217 & 101.956 & 39.632 & 77.971 & 153.299 \\
\hline & se & 0.635 & 0.908 & 1.299 & 0.684 & 1.010 & 1.534 \\
\hline \multirow[t]{2}{*}{ EBIC } & mean & 32.536 & 58.427 & 108.553 & 41.544 & 80.576 & 156.598 \\
\hline & se & 0.635 & 0.908 & 1.299 & 0.684 & 1.010 & 1.534 \\
\hline
\end{tabular}

the same set of $x_{i}$ values, we independently generate 100 datasets, so that for each one, $n$ independent Bernoulli response variables $y_{i}$ are obtained for the PP model with one covariate $x_{i}$ and the true value of $\beta=1$ and $\lambda=0.25$, with no intercept.

For each generated data set, we fit the corresponding true model. For each simulated sample, we use the estimation procedure described in Section 4. We burned 4000 in the 100,000 values of chain and thin of 50. The effective sample is 2000. Efficiency by using the Effective Sample Sizes above of 0.9 were obtained. The results are presented in Table 1.

From the simulation study, we found in the PP model as expected there is an improvement in the accuracy (bias and MSE decrease) of the estimation of $\beta$ and $\lambda$ parameters as sample size increases. In addition we found that the best summary measures for $\lambda$ is the posterior median.

In addition, in Table 1, we present a comparative study of the skew-probit model ("true model") with the probit model ("false model") by using model selection criteria presented in Section 4. Our main goal is to compare the above mentioned model selection criteria to find the suitable one. For this purpose, we examine the relative performance of these procedure to select the best underlying model. The data of size 50,100 and 200 are the same considered above. For each one of the 100 generated data set in each case, we fit the corresponding true model (skew probit) and the alternative model (probit). 
Table 1 also presents the mean and standard errors of the different selection criteria for the simulated samples. In all cases DIC, EAIC and EBIC show evidence in favor of the skew probit as best model for the data set generated, confirming an adequate performance of these model comparison criteria. The skew probit model is correctly selected considering all selection criteria in (100\%) of the times. This results show that the use of an incorrect specification of the true model by considering probit model will lead to biased coefficients and specific underestimation of the regression coefficient is observed.

In addition the results of bias and MSE for PP and P models show the performance of the skew-probit model as the sample size increases, as well as the relative performance of it respect to the standard probit model. Only in the skew probit model the estimated values are very close of the real values. However, considering a additional studies suggested by a referee, since the parameter space associated with the $\delta=\ln (\lambda)$ parameter is the whole real line, when values above of $\delta=3$ (approx. $\lambda=20$ ) or below $\delta=-3$ (approx. $\lambda=0.05$ ) are considered, a biased estimator is obtained for this parameter but the bias decreases when the sample size increases.

\subsection{Real data}

We illustrate the Bayesian approaches developed in this paper by using a popular dataset from the literature for the asymmetrical link function in the binary regression. We improve the fitting in Binary Regression Model, by using a Skew-Probit Link function, when compared with other links functions in the literature. All the models considered were implemented using proc mcmc of SAS 9.2 software (SAS Institute Inc., 2009). The code is shown in Appendix B.

Milicer and Szczotka (1966) analyzed the occurrence of menarche as a function of age in a sample of 3918 Warsaw girls. The data are from a study conducted on pre-teen and teenage girls in Warsaw. The subjects were classified into 25 age categories. The number of girls in each group (sample size: $n$ ) and the number that reached menarche at the time of the study were recorded $(y)$. The age for a group corresponds to the midpoint for the age interval $(x)$. The datasets are showed in Table 3 and they are available in Finney (1971) and Stukel (1988).

In order to illustrate the usefulness of the links functions proposed in this work with the Warsaw girl dataset, we performed some comparisons between the skew probit link functions and some link functions from the literature, namely logit, generalized logit (or scobit), power logit, cloglog, loglog and gev (Wang and Dey, 2010).

In all cases, an effective sample size of 2000 was considered discarding the 4000 initial iterations and considering thin of 50. The time of execution and thin values were also evaluated for model comparison. In addition, many procedures based on the BOA and CODA packages were used to evaluate the convergence of the chain. Running Mean Plots for each chain, for all the links functions considered, provide strong indication of the convergence in all cases. 
Table 2 Performance of the selection criteria for different models with the Warsaw data

\begin{tabular}{lllllllll}
\hline Models & Dbar & Dmean & $p_{D}$ & $p$ & DIC & EAIC & EBIC & time (sec) \\
\hline L & 112.78 & 110.76 & 2.02 & 2 & 114.81 & 116.78 & 129.33 & 6.43 \\
P & 108.96 & 106.94 & 2.02 & 2 & 110.98 & 112.96 & 125.51 & 8.00 \\
CLL & 204.82 & 202.88 & 1.94 & 2 & 206.76 & 208.82 & 221.37 & 6.28 \\
LL & 120.66 & 118.69 & 1.96 & 2 & 122.62 & 124.66 & 137.20 & 6.37 \\
PL & 106.10 & 103.26 & 2.83 & 3 & 108.93 & 112.10 & 130.92 & 9.03 \\
RPL & 109.85 & 106.96 & 2.89 & 3 & 112.74 & 115.85 & 134.67 & 8.81 \\
PP & 102.29 & 100.75 & 1.54 & 3 & 103.83 & 108.29 & 127.11 & 8.53 \\
RPP & 100.99 & 99.22 & 1.77 & 3 & 102.75 & 106.99 & 125.81 & 8.12 \\
GEV & 101.49 & 98.52 & 2.97 & 3 & 104.46 & 107.49 & 126.31 & 12.76 \\
\hline
\end{tabular}

Note: L: logit, P: probit, CLL: Cloglog, LL: $\log \log$, PL: power logit, RPL: reciprocal power logit, PP: power probit, RPP: reciprocal power probit, GEV: generalized extreme value link.
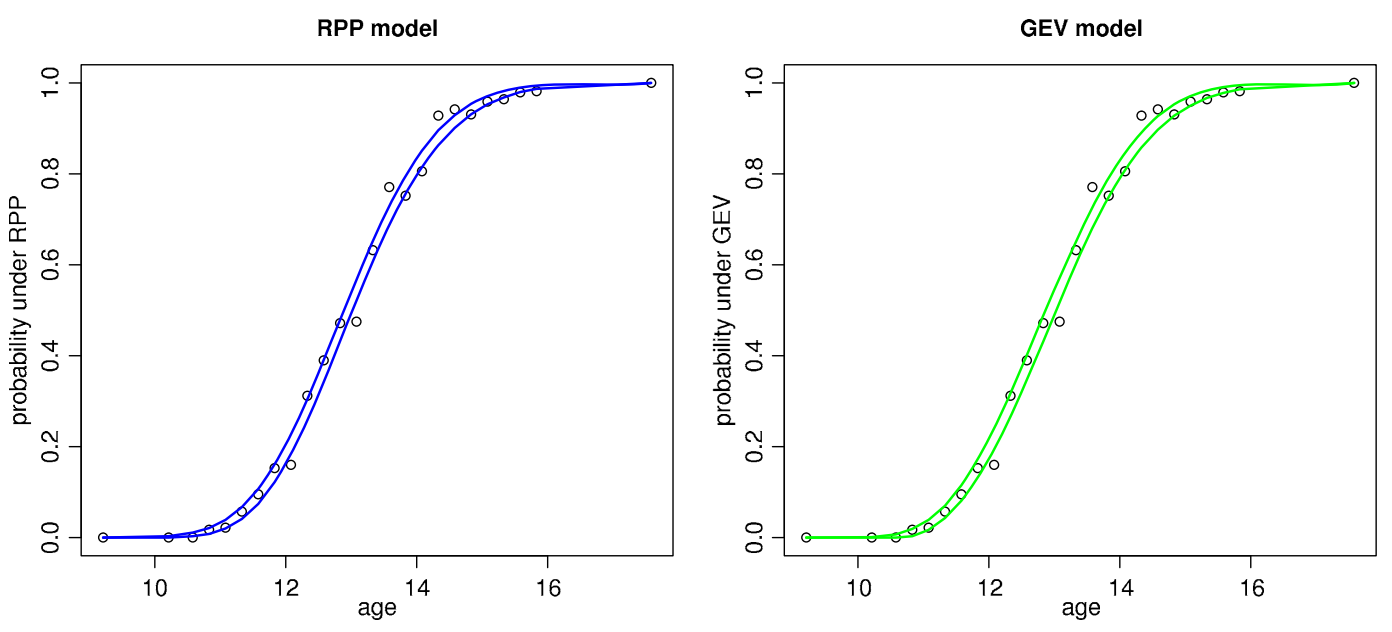

Figure $395 \%$ Credible Interval for proportions under RPP and GEV links.

By considering small values of the three selection procedures in Table 2, GEV, PP and RPP are the better models for fit Warsaw data. Figure 3 shows an 95\% credible interval for proportions to dataset analyzed under RPP and GEV link functions which present maybe a similar performance in the prediction, but by considering all criteria, RPP model is the best model with small convergence time among them. Also, by considering residuals for the 25 age categories we found that standardized residuals in RPP model varying between -1.404 (age $=13.08)$ and 1.458 (age $=14.33$ ) and in the GEV model varying between -1.407 (age $=$ 13.08) and $1.567($ age $=14.33)$ with $S S R=184.079$ and $S A R=47.0715$ for RPN model and $S S R=192.879$ and $S A R=44.152$ for GEV model confirming that the RPN model is the best model for this data. Posterior Values estimated of the number that reached menarche at the time of the study $\hat{y}_{i}=E\left(y_{i}\right)=n \hat{p}_{i}$ by con- 
Table 3 Number that reached menarche $(\hat{y})$ and probability $\hat{p}$ estimated in 2869 Warsaw girls under the RPN model

\begin{tabular}{|c|c|c|c|c|c|c|c|c|c|c|c|c|c|c|c|}
\hline Obs. & $y$ & $n$ & $x$ & $\hat{p}$ & $\hat{E(y)}$ & $v \hat{(y)}$ & st. res. & Obs. & $y$ & $n$ & $x$ & $\hat{p}$ & $\hat{E(y)}$ & $v(y)$ & st. res. \\
\hline 1 & 0 & 376 & 9.21 & 0.000 & 0.005 & 0.005 & -0.069 & 14 & 67 & 106 & 13.33 & 0.630 & 66.809 & 24.701 & 0.038 \\
\hline 2 & 0 & 200 & 10.21 & 0.001 & 0.293 & 0.293 & -0.542 & 15 & 81 & 105 & 13.58 & 0.708 & 74.350 & 21.703 & 1.427 \\
\hline 3 & 0 & 93 & 10.58 & 0.006 & 0.565 & 0.562 & -0.754 & 16 & 88 & 117 & 13.83 & 0.776 & 90.815 & 20.325 & -0.624 \\
\hline 4 & 2 & 120 & 10.83 & 0.014 & 1.670 & 1.646 & 0.257 & 17 & 79 & 98 & 14.08 & 0.833 & 81.676 & 13.605 & -0.725 \\
\hline 5 & 2 & 90 & 11.08 & 0.029 & 2.574 & 2.501 & -0.363 & 18 & 90 & 97 & 14.33 & 0.880 & 85.328 & 10.267 & 1.458 \\
\hline 6 & 5 & 88 & 11.33 & 0.053 & 4.677 & 4.429 & 0.153 & 19 & 113 & 120 & 14.58 & 0.916 & 109.878 & 9.268 & 1.025 \\
\hline 7 & 10 & 105 & 11.58 & 0.090 & 9.461 & 8.609 & 0.184 & 20 & 95 & 102 & 14.83 & 0.943 & 96.148 & 5.516 & -0.489 \\
\hline 8 & 17 & 111 & 11.83 & 0.141 & 15.638 & 13.435 & 0.372 & 21 & 117 & 122 & 15.08 & 0.962 & 117.380 & 4.445 & -0.180 \\
\hline 9 & 16 & 100 & 12.08 & 0.205 & 20.531 & 16.316 & -1.122 & 22 & 107 & 111 & 15.33 & 0.976 & 108.308 & 2.627 & -0.807 \\
\hline 10 & 29 & 93 & 12.33 & 0.282 & 26.185 & 18.812 & 0.649 & 23 & 92 & 94 & 15.58 & 0.985 & 92.583 & 1.396 & -0.493 \\
\hline 11 & 39 & 100 & 12.58 & 0.366 & 36.639 & 23.215 & 0.490 & 24 & 112 & 114 & 15.83 & 0.991 & 112.963 & 1.028 & -0.950 \\
\hline 12 & 51 & 108 & 12.83 & 0.456 & 49.214 & 26.788 & 0.345 & 25 & 1049 & 1049 & 17.58 & 1.000 & 1048.877 & 0.123 & 0.351 \\
\hline 13 & 47 & 99 & 13.08 & 0.545 & 53.957 & 24.549 & -1.404 & & & & & & & & \\
\hline
\end{tabular}

Table 4 Posterior summaries of the parameters of the RPP model under the Warsaw data

\begin{tabular}{lrcrrr}
\hline Parameters & \multicolumn{1}{c}{ mean } & sd & \multicolumn{1}{c}{$P_{2.5}$} & median & $P_{97.5}$ \\
\hline$\alpha$ & -18.753 & 2.099 & -20.386 & -19.085 & -17.376 \\
$\beta$ & 1.591 & 0.200 & 1.462 & 1.625 & 1.747 \\
$\delta$ & -1.582 & 0.340 & -1.851 & -1.668 & -1.393 \\
$\lambda$ & 0.220 & 0.091 & 0.157 & 0.189 & 0.248 \\
\hline
\end{tabular}

sidering the RPN model is showed in Table 3. In addition the posterior estimates of variability associated $v\left(\hat{y}_{i}\right)=n_{i} \hat{p}_{i}\left(1-\hat{p}_{i}\right)$ and standardized residual are also included. As expected, between the ages of 12.58 and 13.83 (when $p_{i}$ is around 0.5 ) the maximum variance is obtained. Also for each age value note that all standardized residuals are between -1.404 and 1.458 indicating that the fit is adequate.

Since the Figure 3, the observed proportions, which are bounded between zero and one, have a lazy S-shape (a sigmoidal function) when plotted against age. The change in the observed proportions for a given change in age is much smaller when the proportion is near 0 or 1 than when the proportion is near $1 / 2$. This phenomenon is captured by the RPN model.

Finally, Table 4 shows the posterior summaries of RPP model for the data. Note that the shape parameter $\lambda$ can be considered as different from zero, since the $95 \%$ credibility interval does not include it. Also, note that the values $\hat{\alpha}=-18.753$ and $\hat{\beta}=1.591$ can be interpreted similarly as the values obtained in the probit model $(-21.182$ and 1.63 , resp.). Since $\hat{\lambda}=0.22$, in the RPP model can estimate the estimated probabilities through $\hat{p}=1-\Phi(-(-18.753+1.591 x))^{0.22}$. 


\section{Extensions and discussion}

This paper was introduced by new asymmetrical link functions for the binary response variables by considering the cumulative distribution of the power-normal distribution (Gupta and Gupta, 2008) and the reciprocal power normal link function. These two skew-probit link functions have as particular cases the probit link function. In these models, we introduce a parameter for the asymmetry of the response curves. This parameter is associated with the selected distribution and is independent of the linear predictor. Also, it defines a class of skew link functions that can control the rate of increasing (or decreasing) of the probability of success (failure) of the binary responses variables.

An attractive aspect of the model is that can be easily implemented via MCMC by using the software WinBugs or proc MCMC in SAS with common proper but non informative priors.

A second version of the likelihood function by considering a latent linear structure for the model similar to Albert and Chib (1995) can be formulated and studied.

The simulation study was carried out to evaluate the relative performance of the procedure of estimation in terms of parameter recovery. Also, the selection model criteria for the comparison of symmetrical and asymmetrical models as the Deviance Information Criterion (DIC) described in Spiegelhalter et al. (2002), the Expected Akaike Information Criterion (EAIC) and the Expected Bayesian Information (Schwarz) Criterion (EBIC) proposed in Brooks (2002) were considered. For study of parameter recovery we found in the PP model, estimated values of the parameters of the model were very close of the real value and acceptable accuracy in the estimation of these parameters. In addition, by considering the skew probit as "true model", this model was correctly selected considering all selection criteria in $(100 \%)$ of the times.

In addition, by using a known dataset from the literature, we improve the fitting in Binary Regression Model, by using a Skew-Probit Link function, when compared with other links functions in the literature.

In our paper, we focus on Bayesian estimation and given the obtained results from the simulation study we believe that these new links can be considered in analyzing binary response data. In addition, we found some difficulties in the implementation of ML estimation and then comparison with Bayesian estimation was not considered. Specifically, we found that estimates of an equivalent model (Power Logistic) are not close with the corresponding estimates obtained in Stata (StataCorp, 2009). Thus, bias correction methods for the estimates of these models and Probit model in ML estimation, (e.g., Firth, 1993 and Cordeiro and McCullagh, 1991, which are compared in Maiti and Pradhan, 2008), should be considered

in order to show a convenient comparison. An interesting algorithm proposed by Devidas and George (1999) can be explored in order to implement ML estimation of PP and RPP model but additional simulation studies should be considered. 
However, note that the bias observed in the estimation of the regression coefficients under the probit model reflects the fact that this model is not the true model.

Extensions of the methods developed in this paper for dichotomous responses variables to ordinal response one (Albert and Chib, 1993 and Johnson and Albert, 1999) are possible if we model in terms of cumulative probabilities. So, the conditional probability of a response in the category $c$ is obtained as the difference among two conditional accumulative probabilities:

$$
P\left(Y_{i}=c \mid \mathbf{x}_{i}\right)=F_{\lambda}\left(\eta_{i, c}\right)-F_{\lambda}\left(\eta_{i, c-1}\right),
$$

where $\eta_{i, c}=\gamma_{c}-\mathbf{x}_{i}^{\prime} \boldsymbol{\beta}$, and $\gamma_{c} \geq \gamma_{c-1}$.

By considering $G(\cdot)=\Phi(\cdot)$ the c.d.f. of the standard normal distribution $F_{1}(\cdot)$ is named Power Normal distribution (Gupta and Gupta, 2008) and $F_{2}(\cdot)$ is a new distribution in the literature and was named here as Reciprocal Power Normal distribution. Both distributions are particular cases of the named Beta-Normal distribution (Eugene, Lee and Famoye, 2002) and can be generalized to another exponentiated models as showed by Achcar et al. (2013).

Also, one possible unification of the models proposed in this work can be obtained from the Kumaraswamy distribution (Cordeiro and de Castro, 2011) which will be our future research.

Applications in many areas, where the symmetric links functions are not justified, can be obtained with the proposed models. It includes binomial models, epidemiological studies, longitudinal data analysis, meta-analysis, measurement error models, calibration model and mixture models in survival analysis and item response models. Also expert prior elicitation as suggests by Bedrick et al. (1996) can be explored with the models proposed in this work. Also, extensions for binary regression mixed models as seen in Longford (1994) are direct.

\section{Appendix A: Properties of the standard power-normal distribution}

Considering $Z \sim \mathrm{PN}(\lambda)$, the following properties are readily established (see Gupta and Gupta, 2008 and Kundu and Gupta, 2013): The mean and variance of $Z$ are given, respectively, by

$$
E[Z]=\frac{(\lambda)(\lambda-1)}{2 \pi} L(\lambda-2,1 / \sqrt{2}) \quad \text { and } \quad \operatorname{Var}[Z]=E\left[Z^{2}\right]-E[Z]^{2},
$$

where

$$
E\left[Z^{2}\right]=1+\frac{(\lambda)(\lambda-1)(\lambda-2)}{4 \pi \sqrt{3}} L(\lambda-3,1 / \sqrt{3})
$$

with

$$
L(n, \lambda)=\int_{-\infty}^{-\infty}[\Phi(\lambda z)]^{n} \phi(z) d z
$$


In addition, the skewness is give by

$$
\gamma=\frac{E\left(Z^{3}\right)-3 E\left(Z^{2}\right) E(Z)+2(E(Z))^{3}}{(\operatorname{Var}(Z))^{3 / 2}} .
$$

The moments also can be obtained by numerical integration by considering

$$
\begin{aligned}
E\left[Z^{k}\right] & =\lambda \int_{-\infty}^{-\infty} z^{k}[\Phi(z)]^{n} \phi(z) d z=\lambda \int_{0}^{1}\left[\Phi^{-1}(u)\right]^{k} u^{\lambda-1} d u \\
& \approx \lambda \sum_{j=1}^{M}\left[\Phi^{-1}\left(u_{j}\right)\right]^{k} u_{j}^{\lambda-1}
\end{aligned}
$$

for $M \rightarrow \infty$ and $u_{j} \sim \operatorname{Uniform}(0,1)$.

Since that $-Z \sim \operatorname{RPN}(\lambda)$, analogous expressions for moments, mean, variance and skewness for the RPN distribution can be easily derived.

\section{Appendix B: Program}

The SAS program, by considering the proc mcmc, used to implement the regression link model proposed in this work is described as follows:

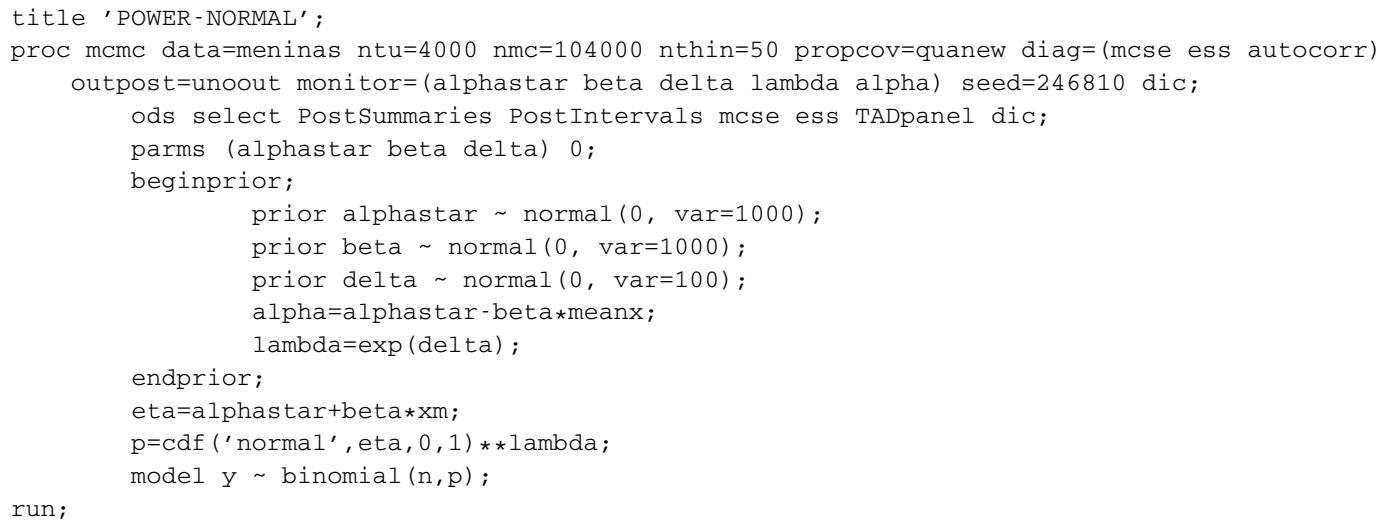

\section{Acknowledgments}

The authors acknowledges the partial financial support from FAPESP and DGIPUCP for this first author. The second author was partially supported by Grants from FONDECYT 11080007.

\section{References}

Achcar, J., Coelho-Barros, E. A. and Cordeiro, G. M. (2013). Beta generalized distributions and related exponentiated models: A Bayesian approach. Brazilian Journal of Probability and Statistics 27, 1-19. MR2991775 
Albert, J. H. and Chib, S. (1993). Bayesian analysis of binary and polytomous response data. Journal of the American Statistical Association 88, 669-679. MR1224394

Albert, J. H. and Chib, S. (1995). Bayesian residual analysis for binary response regression models. Biometrika 82, 747-759. MR1380812

Bazán, J. L., Bolfarine, H. and Branco, M. D. (2010). A framework for skew-probit links in Binary regression. Communications in Statistics-Theory and Methods 39, 678-697. MR2745312

Bazán, J. L., Branco, M. D. and Bolfarine, H. (2006). A skew item response model. Bayesian Analysis 1, 861-892. MR2282209

Bedrick, E. J., Christensen, R. and Johnson, W. (1996). A new perspective on priors for generalized linear models. Journal of the American Statistical Association 91, 1450-1460. MR1439085

Bolfarine, H. and Bazán, J. L. (2010). Bayesian estimation of the logistic positive exponent IRT model. Journal of Educational and Behavioral Statistics 35, 693-713.

Brooks, S. P. (2002). Discussion on "Bayesian measures of model complexity and fit" by D. J. Spiegelhalter, N. G. Best, B. P. Carlin and A. van der Linde. Journal of the Royal Statistical Society, Ser. B 64, 616-618.

Carlin, B. P. and Louis, T. A. (2000). Bayes and Empirical Bayes Methods for Data Analysis, 2nd ed. Boca Raton, FL: Chapman \& Hall. MR1427749

Chen, M. H., Dey, D. K. and Shao, Q.-M. (1999). A new skewed link model for dichotomous quantal response data. Journal of the American Statistical Association 94, 1172-1186. MR1731481

Chen, M. H., Dey, D. K. and Shao, Q.-M. (2001). Bayesian analysis of binary data using skewed logit models. Calcutta Statistical Association Bulletin 51, 201-202. MR1892782

Collet, D. (2003). Modelling Binary Data, 2nd ed. Boca Raton, FL: Chapman \& Hall/CRC. MR1999899

Cordeiro, G. and de Castro, M. (2011). A new family of generalized distributions. Journal of Statistical Computation and Simulation 81, 883-898. MR2806932

Cordeiro, G. M. and McCullagh P. (1991). Bias reduction in generalized linear models. Journal of the Royal Statistical Society, Ser. B 53, 629-643. MR1125720

Czado, C. (1994). Bayesian inference of binary regression models with parametric link. Journal of Statistical Planning and Inference 41, 121-140. MR1292151

Czado, C. and Santner, T. J. (1992). The effect of link misspecification on binary regression inference. Journal of Statistical Planning and Inference 33, 213-231. MR1190622

Devidas, M. and George, E. O. (1999). Monotonic algorithms for maximum likelihood estimation in generalized linear models. Sankhyā, Ser. B 61, 382-396. MR1745742

Dey, D. K., Ghosh, S. K. and Mallick, B. K. (1999). Generalized Linear Models: A Bayesian Perspective. New York: Marcel Dekker. MR1893779

Eugene, N., Lee, C. and Famoye, F. (2002). Beta Normal distribution and its applications. Communication and Statistics-Theory and Methods 31, 497-512. MR1902307

Finney, D. J. (1971). Probit Analysis. London: Cambridge Univ. Press. MR0347013

Firth D. (1993). Bias reduction of maximum likelihood estimates. Biometrika 80, 27-38. MR1225212

Guerrero, V. M. and Johnson, R. A. (1982). Use of the Box-Cox transformation with binary response models. Biometrika 69, 309-314. MR0671968

Gupta, R. D. and Gupta, R. C. (2008). Analyzing skewed data by power normal model. Test 17, 197-210. MR2393359

Johnson, V. and Albert, J. (1999). Ordinal Data Modeling. New York: Springer-Verlag. MR1683018

Kundu, D. and Gupta, R. D. (2013). Power-normal distribution. Statistics 47, 110-125. MR3023018

Longford, N. T. (1994). Logistic regression with random coefficients. Computational Statistics Data Analysis 17, 1-15.

Maiti, T. and Pradhan, V. (2008). A comparative study of the bias corrected estimates in logistic regression. Statistical Methods in Medical Research 17, 621-634. MR2654668 
Milicer, H. and Szczotka, F. (1966). Age at menarche in Warsaw girls in 1965. Human Biology 38, 199-203.

Prentice, R. L. (1976). A Generalization of the probit and logit methods for dose-response curves. Biometrika 32, 761-768.

SAS Institute Inc. (2009). SAS/STAT® 9.2 User's Guide, 2nd ed. Cary, NC: SAS Institute Inc.

Spiegelhalter, D. J., Best, N. G., Carlin, B. P. and van der Linde, A. (2002). Bayesian measures of model complexity and fit. Journal of the Royal Statistical Society, Ser. B 64, 583-639. MR1979380

StataCorp (2009). Stata: Release 11. Statistical Software. College Station, TX: StataCorp LP.

Stukel, T. (1988). Generalized logistic models. Journal of the American Statistical Association 83, 426-431. MR0971368

Taylor, J. and Siqueira, A. (1996). The cost of adding parameters to a model. Journal of the Royal Statistical Society 58, 593-607. MR1394369

Wang, X. and Dey, D. (2010). Generalized extreme value regression for binary response data: An application to B2B electronic payments system adoption. The Annals of Applied Statistics 4, 2000-2023. MR2829944

Zellner, A. and Rossi, P. E. (1984). Bayesian analysis of dichotomous quantal response models. Journal of Econometrics 25, 365-393. MR0752447

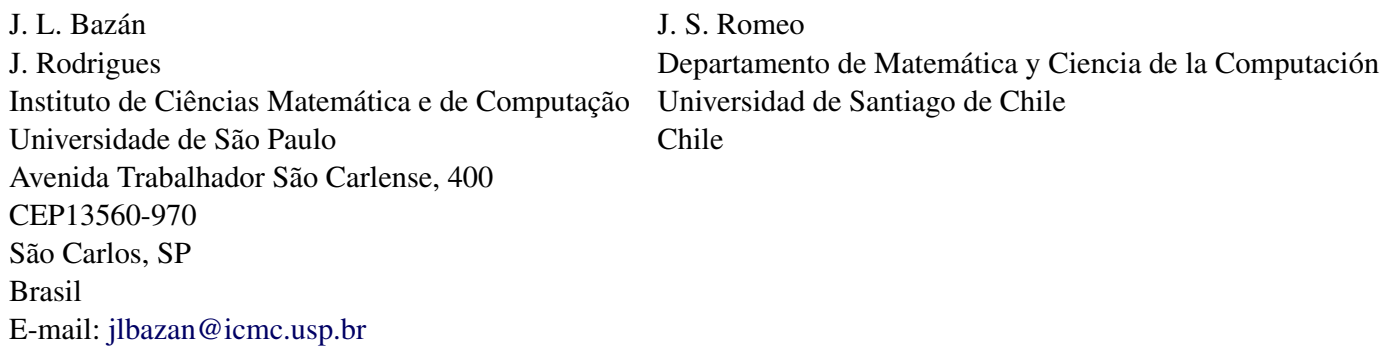

J. S. Romeo

Departamento de Matemática y Ciencia de la Computación Universidad de Santiago de Chile

Chile 


\section{Apêndice E}

Borges, P., Rodrigues, J., Balakrishnan, N., e Bazán, J. (2014). A com-poisson type generalization of the binomial distribution and its properties and applications. Statistics Ef Probability Letters, 87, 158 - 166. DOI: 3907230593595. License Number: 


\title{
A COM-Poisson type generalization of the binomial distribution and its properties and applications
}

\author{
Patrick Borges ${ }^{\mathrm{a}, *}$, Josemar Rodrigues ${ }^{\mathrm{b}}$, Narayanaswamy Balakrishnan ${ }^{\mathrm{c}, \mathrm{d}}$, \\ Jorge Bazán ${ }^{\mathrm{b}}$

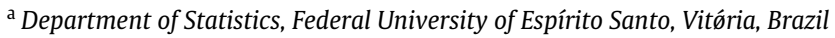 \\ ${ }^{\mathrm{b}}$ Department of Mathematics and Statistics, University of São Paulo, São Paulo, Brazil \\ ${ }^{\mathrm{c}}$ Department of Mathematics and Statistics, McMaster University, Hamilton, Ontario, Canada \\ ${ }^{\mathrm{d}}$ Department of Statistics, King Abdulaziz University, Jeddah, Saudi Arabia
}

\section{A R T I C L E I N F O}

\section{Article history:}

Received 20 January 2014

Accepted 20 January 2014

Available online 29 January 2014

Keywords:

COM-Poisson-binomial distribution

Dependent Bernoulli variables

Correlation coefficient

Exponential family

Weighted Poisson distributions

\begin{abstract}
A B S T R A C T
Shmueli et al. (2005) introduced the COM-Poisson-binomial distribution, but they did not study the mathematical properties of this family of distributions. In this paper, we discuss some properties and an asymptotic approximation of it by the COM-Poisson distribution. Moreover, three datasets are also considered.
\end{abstract}

(c) 2014 Elsevier B.V. All rights reserved.

\section{Introduction}

Usually the binomial and Poisson distributions are used to analyze discrete data. However, it seems wise to consider flexible alternative models to take into account the overdispersion or underdispersion (see Hinde and Demetrio (1998)). For this reason, the binomial and Poisson distributions have been generalized in several ways to handle the problem of dispersion inherent in the analysis of discrete data that may arise in the presence of aggregation of the individuals. For instance:

(i) in plant selection study, the association among two plants arises when they compete for the quantity of nutrients;

(ii) in biological study (see Yakovlev and Tsodikov (1996) and Borges et al. (2012)), it is usually assumed that cells in a tissue are independent. However, the biological independence assumption may not be true when the dynamics of the cell population of a normal tissue is considered. It is therefore desirable to construct new models with strong biological interpretation of the dependence incorporated in the carcinogenesis process.

The binomial distribution has been generalized in various ways. Rudolfer (1990), Madsen (1993) and Luceño and Ceballos (1995) have summarized most of these generalizations. Among these extensions, there are the multiplicative and additive generalized binomial distributions which were derived by Altham (1978). The probability mass function (pmf) of the multiplicative binomial distribution is a multiplication of its pmf by a factor. It makes the variance greater or less than the

\footnotetext{
* Correspondence to: Departamento de Estatística, Universidade Federal do Espírito Santo - UFES. Av. Fernando Ferrari 514, Goiabeiras, CEP 29075-910, Vitǿria ES, Brazil.

E-mail addresses: patrick@cce.ufes.br, patrickborges@yahoo.com.br (P. Borges).
} 
corresponding binomial variance depending on the values of the factor. On the other hand, the additive binomial distribution is a mixture of three conventional binomial models. Altham (1978) developed the correlated binomial model by correcting the binomial model via the method of Bahadur (1961) to encompass dependent Bernoulli variables. A three-parameter binomial distribution was derived by Paul $(1985,1987)$, which is a generalization of the binomial, beta-binomial and the correlated binomial distribution proposed by Kupper and Haseman (1978). Ng (1989) developed the modified binomial distributions. In this approach, the binomial distribution is changed and the resulting distribution becomes more spread out (indicating positive correlation among the Bernoulli variables), or more peaked (indicating negative correlation among the Bernoulli variables) than the binomial distribution. A four-parameter binomial distribution was derived by Fu and Sproule (1995). This new distribution assumes values between $\alpha$ and $\beta$ for $\alpha<\beta$, rather than the usual values 0 or 1 . Lindsey (1995) and Luceño and Ceballos (1995) proposed a generalized binomial distribution which is discussed in detail in Diniz et al. (2010). Chang and Zelterman (2002) generalized the binomial distribution by considering Bernoulli variables with probability of success depending on the previous one. Tsai et al. (2003) presented a model that studies the overall error rate when testing multiple hypotheses. This model involves the distribution of the sum of dependent Bernoulli trials, and it is approximated by means of a beta-binomial structure. Instead of using the beta-binomial model, Gupta and Tao (2010) derived the exact distribution of the sum of dependent Bernoulli variables and not identically distributed. Another extension of the binomial distribution is the COM-Poisson-binomial distribution (CMPB, for short) introduced in Shmueli et al. (2005), but they did not study the mathematical properties of this family; they are studied in detail in this paper. A recent application of CMPB distribution can be found in Kadane and Naeshagen (2013).

The CMPB distribution arises as the conditional distribution of a COM-Poisson variable (Conway and Maxwell, 1962) given a sum of two COM-Poisson variables with the same dispersion parameter. It generalizes the binomial distribution and can be interpreted as the sum of dependent Bernoulli variables with a specific joint distribution (see Remark 1). The dispersion parameter governs the correlation among the Bernoulli variables, with the overdispersion and underdispersion being relative to the binomial distribution. The CMPB distribution is appealing from a theoretical point of view since it belongs to the exponential and weighted Poisson families (Castillo and Pérez-Casany, 1998, 2005), and the sufficient statistic is defined by the mean and the log-geometric mean of the data. We refer to Barndorff-Nielsen (1978) for a general theory of exponential families.

The rest of this paper is organized as follows. In Section 2, we present the CMPB distribution along with its mathematical properties. Section 3 describes the maximum likelihood method for estimating the parameters. In Section 4, we apply the CMPB distribution to three real datasets and show that this model provides an excellent fit to these datasets. Finally, some concluding remarks are made in Section 5.

\section{The CMPB distribution and its properties}

The probability mass function (pmf) of the CMPB distribution (Shmueli et al., 2005) is given by

$$
\mathbb{P}[X=x \mid m, p, v]=\frac{\left(\begin{array}{c}
m \\
x
\end{array}\right)^{v} p^{x}(1-p)^{m-x}}{\sum_{k=0}^{m}\left(\begin{array}{c}
m \\
k
\end{array}\right)^{v} p^{k}(1-p)^{m-k}}, \quad x=0,1, \ldots, m,
$$

for $m \in \mathbb{Z}^{+}$(set of known non-negative integers), $p \in(0,1)$ and $v \in \Re$. For $v=1$, we have the usual binomial distribution. The values of $v>1$ correspond to underdispersion (the mean is greater than the variance) while values of $v<1$ represent overdispersion (the variance exceeds the mean) with respect to the binomial distribution. For $v \rightarrow \infty$, the pmf is concentrated at the point $m p$ and for $v \rightarrow-\infty$ it is concentrated at 0 or $m$. Fig. 2.1 presents the pmf of the CMPB distribution for $m=6$ and different choices of $p$ and $v$.

Remark 1. The CMPB distribution can be interpreted as a sum of equicorrelated Bernoulli variables $Z_{i}(i=1, \ldots, m)$ with joint distribution (see Shmueli et al. (2005))

$$
\mathbb{P}\left[Z_{1}=z_{1}, \ldots, Z_{m}=z_{m}\right]=\frac{\left(\begin{array}{c}
m \\
x
\end{array}\right)^{v-1} p^{x}(1-p)^{m-x}}{\sum_{z_{1}=0}^{1} \ldots \sum_{z_{m}=0}^{1}\left(\begin{array}{c}
m \\
x
\end{array}\right)^{v-1} p^{x}(1-p)^{m-x}}, \quad \boldsymbol{z}=\left(z_{1}, \ldots, z_{m}\right) \in\{0,1\}^{m},
$$

where $x=\sum_{i=1}^{m} z_{i}$. The measure of linear association between Bernoulli variables, i.e., the correlation between $Z_{i}$ and $Z_{j}$, say $\rho=\operatorname{Corr}\left(Z_{i}, Z_{j}\right)$, is given by

$$
\rho=\frac{\mathbb{E}\left[Z_{i} Z_{j}\right]-\mathbb{E}\left[Z_{i}\right] \mathbb{E}\left[Z_{j}\right]}{\sqrt{\mathbb{V}\left[Z_{i}\right] \mathbb{V}\left[Z_{j}\right]}}=\frac{p(1-p)\left(1-4^{\nu-1}\right)}{\left(p+(1-p) 2^{v-1}\right)\left(1-p\left(1-2^{v-1}\right)\right)}, \quad i \neq j, i, j=1, \ldots, m,
$$



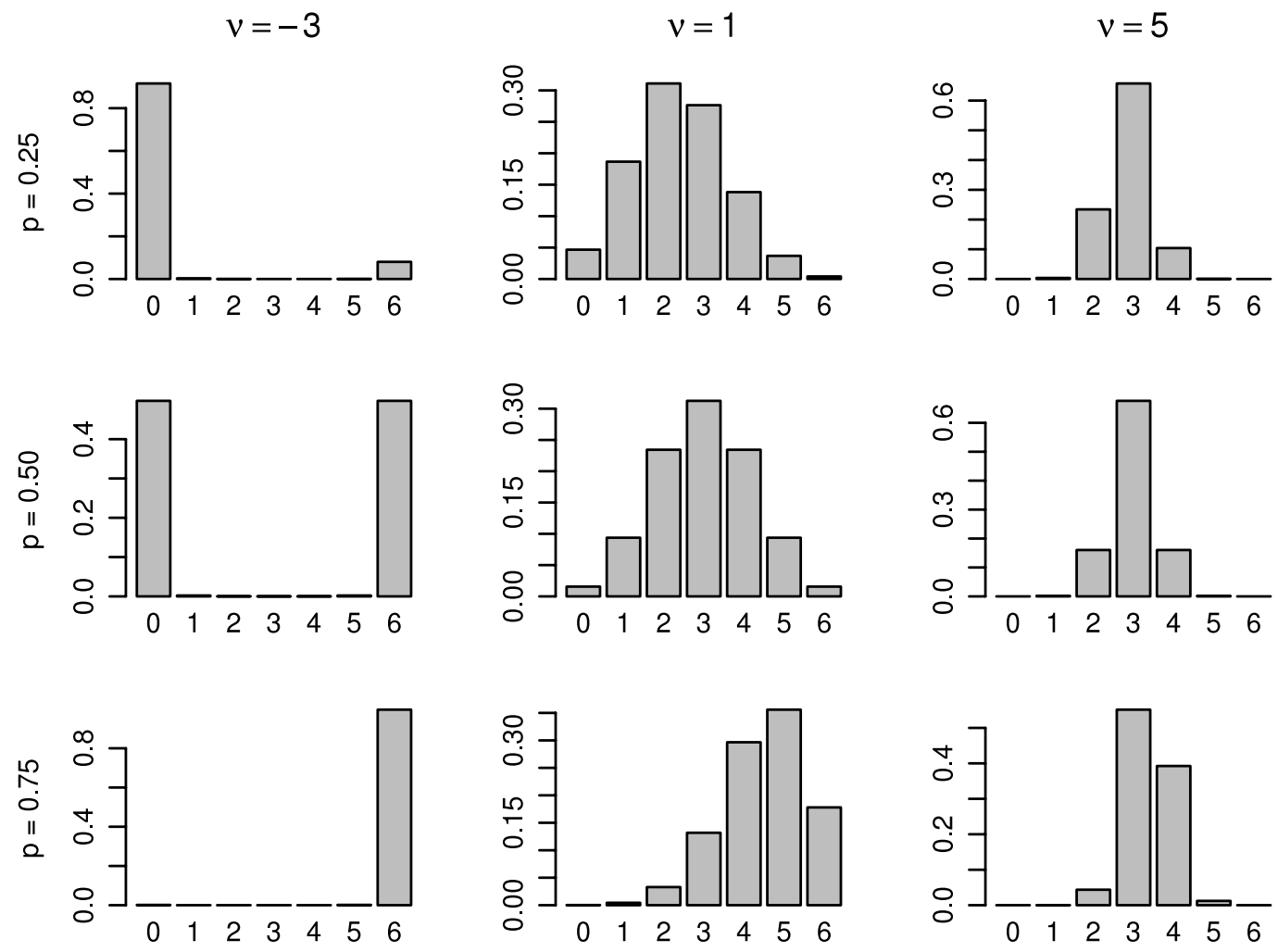

Fig. 2.1. COM-Poisson-binomial for $m=6$ and various choices of $p$ and $v$.

where

$$
\begin{aligned}
& \mathbb{E}\left[Z_{i} Z_{j}\right]=\sum_{Z_{i}=0}^{1} \sum_{z_{j}=0}^{1} z_{i} z_{j} \mathbb{P}\left[Z_{i}=z_{i}, Z_{j}=z_{j}\right]=\mathbb{P}\left[Z_{i}=1, Z_{j}=1\right]=\mathbb{K} p^{2}, \\
& \mathbb{E}\left[Z_{i}\right]=\mathbb{P}\left[Z_{i}=1\right]=\mathbb{K}\left(2^{\nu-1} p(1-p)+p^{2}\right), \\
& \mathbb{V}\left[Z_{i}\right]=\mathbb{K}^{2}\left(2^{v-1} p(1-p)+p^{2}\right)\left((1-p)^{2}+2^{v-1} p(1-p)\right), \\
& \mathbb{K}=\frac{1}{p^{2}+(1-p)^{2}+2^{v} p(1-p)} .
\end{aligned}
$$

Thus, for $v>1$, the $Z$ 's are negatively correlated and for $v<1$ the $Z$ 's are positively correlated.

The next theorem shows that the COM-Poisson distribution (Conway and Maxwell, 1962) is an approximation to the CMPB distribution when $m$ becomes large.

Theorem 1. Let $X$ be a CMPB variable with parameters $m, v$ and $p$, and let

$$
\lambda=m^{v} p,
$$

for $v \geq 0$. Then,

$$
\lim _{m \rightarrow \infty} \mathbb{P}[X=x \mid m, p, v]=\frac{\lambda^{x}}{(x !)^{v}} \frac{1}{\sum_{j=0}^{\infty} \frac{\lambda^{j}}{(j !)^{v}}}, \quad x=0,1, \ldots,
$$

which is the pmf of the COM-Poisson distribution.

The proof of Theorem 1 is given in the Appendix.

The result in (9) is a generalization of the binomial approximation to the Poisson distribution where the dispersion parameter $v$ in (8) indicates the influence of the overdispersion or underdispersion on the approximation by the COM-Poisson distribution. This is an interesting result, not mentioned by Shmueli et al. (2005), and is one of the main contributions of this paper. 
In order to obtain a COM-Poisson type structure for the pmf of the CMPB distribution, we divide the numerator and denominator of $(1)$ by a factor $(1-p)^{m}(m !)^{v}$, and then consider the following parametrization:

$$
\theta=\frac{p}{1-p}
$$

Under the parametrization in (10), the pmf of the CMPB distribution, denoted by $X \sim \operatorname{CMPB}(m, \theta$, $v)$, is given by

$$
\mathbb{P}[X=x \mid m, \theta, v]=\frac{1}{Z(\theta, v)} \frac{\theta^{x}}{[x !(m-x) !]^{v}}, \quad x=0,1, \ldots, m,
$$

where $Z(\theta, v)=\sum_{j=0}^{m} \frac{\theta^{j}}{[j !(m-j) !]^{\nu}}$. Also, the pmf in (11) can be rewritten as

$$
\mathbb{P}[X=x \mid m, \theta, v]=\frac{\exp (x \log (\theta)-v \log (x !(m-x) !))}{Z(\theta, v)} .
$$

It follows from (12) that the CMPB distribution belongs to the full exponential family on $\mathbb{Z}^{+}$, where $T(X)=(X, \log (X !(m-$ $X) !)$ ) is the sufficient statistic and $(\log \theta, v) \in \mathbb{R}^{2}$ is the corresponding natural parameters (see Barndorff-Nielsen (1978)). For a set of $n$ independent and identically distributed variables $\boldsymbol{X}=\left(X_{1}, \ldots, X_{n}\right)$, the sufficient statistic based on $\boldsymbol{X}$ is $T(\boldsymbol{X})=\left(\sum_{i=1}^{n} X_{i}, \sum_{i=1}^{n} \log \left(X_{i} !\left(m-X_{i}\right) !\right)\right)$. Also, the CMPB distribution belongs to the family of weighted Poisson distributions (Castillo and Pérez-Casany, 1998, 2005; Kokonendji et al., 2008) defined as follows:

$$
\mathbb{P}[X=x \mid \theta, v]=\frac{w(x ; v) p^{*}(x ; \theta)}{\mathbb{E}_{\theta}[w(X ; v)]},
$$

where $w(\cdot ; \nu)$ is a non-negative weight function with parameter $v, p^{*}(\cdot ; \theta)$ is the pmf of a Poisson distribution with parameter $\theta$, and $\mathbb{E}_{\theta}[\cdot]$ indicates that the expectation is taken with respect to the Poisson distribution with parameter $\theta$. Therefore, if we take the weight function as

$$
w(x ; v)= \begin{cases}\frac{[x !(m-x) !]^{1-v}}{(m-x) !}, & \text { if } x \leq m \\ 0, & \text { if } x>m\end{cases}
$$

the CMPB distribution in (11) can be expressed as the weighted Poisson distribution in (13). So, some interesting characterizations of the overdispersion and underdispersion for the CMBP distributions can be derived from the weighted Poisson distributions.

Kokonendji et al. (2008) and Rodrigues et al. (2009) have shown that the probability generating function (pgf) of the weighted Poisson variable is given by

$$
\begin{aligned}
\mathbb{A}_{X}(s) & =\mathbb{E}\left[s^{X}\right]=\sum_{x=0}^{\infty} s^{x} \frac{w(x ; v) p^{*}(x ; \theta)}{\mathbb{E}_{\theta}[w(X ; v)]} \\
& =\exp (-\theta(1-s)) \frac{\mathbb{E}_{\theta s}[w(X ; v)]}{\mathbb{E}_{\theta}[w(X ; v)]}, \quad \text { for } 0 \leq s \leq 1 .
\end{aligned}
$$

From (14), the pgf of the CMPB distribution is given by

$$
\begin{aligned}
\mathbb{A}_{X}(s) & =\exp (-\theta(1-s)) \frac{\mathbb{E}_{\theta s}\left[\frac{[X !(m-X) !]^{1-\nu}}{(m-X) !}\right]}{\mathbb{E}_{\theta}\left[\frac{[X !(m-X) !]^{1-\nu}}{(m-X) !}\right]} \\
& =\frac{Z(\theta s, v)}{Z(\theta, v)}, \quad \text { for } \quad 0 \leq s \leq 1 .
\end{aligned}
$$

\subsection{Moments}

Some of the most important features of a distribution can be studied through moments (e.g., tendency, dispersion, skewness and kurtosis). For $X \sim \operatorname{CMPBr}(m, \theta, v)$, the moments can be obtained as

$$
\mathbb{E}\left[X^{r}\right]=\frac{1}{Z(\theta, v)} \sum_{x=0}^{m} x^{r} \frac{\theta^{x}}{[x !(m-x) !]^{v}}, \quad \text { for } r \in \Re .
$$

Hence, the mean and variance of the CMPB distribution are given by

$$
\begin{aligned}
\mathbb{E}[X] & =\frac{1}{Z(\theta, v)} \sum_{x=0}^{m} x \frac{\theta^{x}}{[x !(m-x) !]^{v}} \\
& =\theta \frac{d \log (Z(\theta, v))}{d \theta}
\end{aligned}
$$


and

$$
\begin{aligned}
\mathbb{V}[X] & =\frac{1}{Z(\theta, v)} \sum_{x=0}^{m} x^{2} \frac{\theta^{x}}{[x !(m-x) !]^{v}}-\left(\frac{1}{Z(\theta, v)} \sum_{x=0}^{m} x \frac{\theta^{x}}{[x !(m-x) !]^{v}}\right)^{2} \\
& =\theta \frac{d \mathbb{E}[X]}{d \theta},
\end{aligned}
$$

respectively.

The moment generating function (mgf) of $X$, say $\mathbb{M}_{X}(t)$, is immediately derived from (13) as

$$
\begin{aligned}
\mathbb{M}_{X}(s) & =\mathbb{E}\left[e^{t X}\right]=\mathbb{A}_{X}\left(e^{t}\right) \\
& =\frac{Z\left(\theta e^{t}, v\right)}{Z(\theta, v)} .
\end{aligned}
$$

Remark 2. If we use Remark 1, we obtain the following expressions for the mean and variance of the CMPB distribution

$$
\mathbb{E}[X]=\frac{m \theta\left(\theta+2^{v-1}\right)}{1+2^{v} \theta+\theta^{2}} \quad \text { and } \quad \mathbb{V}[X]=\frac{m \theta\left(2^{1+v}\left(1+\theta^{2}\right)+4^{v} \theta(2-m)+4 m \theta\right)}{4\left(1+2^{v} \theta+\theta^{2}\right)^{2}} .
$$

Remark 3. We notice that the CMPB distribution in (11) is a special case of the generalized power series distribution introduced by Patil (1964), as follows:

$$
P[X=x ; \lambda, \theta]=\frac{a(x ; \lambda) \theta^{x}}{A(\lambda ; \theta)}, \quad x=0,1,2, \ldots,
$$

where $A(\lambda ; \theta)=\sum_{j=0}^{\infty} a(j ; \lambda) \theta^{j}$.

In our case, $\lambda=v$ and

$$
a(x ; v)= \begin{cases}\frac{1}{[x !(m-x) !]^{v}}, & \text { if } x \leq m \\ 0, & \text { if } x>m .\end{cases}
$$

\section{Maximum likelihood estimation of the parameters}

Let $\mathbf{X}=\left(X_{1}, \ldots, X_{n}\right)^{\top}$ be a random sample size of $n$ with observed values $\mathbf{X}=\left(x_{1}, \ldots, x_{n}\right)^{\top}$ from a CMPB distribution with parameters $\theta$ and $v$. Let us define

$$
t_{1}=\frac{1}{n} \sum_{i=1}^{n} x_{i} \quad \text { and } \quad t_{2}=\frac{1}{n} \sum_{i=1}^{n} \log \left(x_{i} !\left(m-x_{i}\right) !\right) .
$$

Note that $t_{1}$ and $t_{2}$ are, respectively, the sample mean and the log-geometric mean.

The log-likelihood function for the CMPB model based on the observed sample $\mathbf{x}$ is

$$
\ell(\theta, v ; \mathbf{x})=n\left(\log (\theta) t_{1}-v t_{2}-\log (Z(\theta, v))\right) .
$$

The likelihood equations may be written as

$$
\left\{\begin{array}{l}
\theta \frac{d}{d \theta} \log (Z(\theta, v))=\mathbb{E}[X]=t_{1} \\
-\frac{d}{d v} \log (Z(\theta, v))=\mathbb{E}[\log (x !(m-x) !)]=t_{2} .
\end{array}\right.
$$

As mentioned in Section 2, the CMPB distribution is a member of the full exponential family on $\mathbb{Z}^{+}$, and $T(X)=$ $(X, \log (X !(m-X) !))$ is the corresponding sufficient statistic. Since $S=T\left(\mathbb{Z}^{+}\right)$, the sample space induced by the statistic $T(X)$, is not included in an affine subspace of $\mathbb{R}^{2}, \bar{T}=\left(T_{1}, T_{2}\right)$ is a minimal sufficient statistic for the CMPB distribution (see Barndorff-Nielsen (1978)). Let $\mathcal{T}$ be the interior of the convex hull of $S$. As the CMPB is a regular exponential distribution, it is well-known that there is a one-to-one transformation from $\mathbb{R}^{2}$ to $\mathcal{T}$ expressed in terms of $\tau(\alpha, v)=\mathbb{E}_{(\alpha, v)}(T)=$ $\left(\tau_{1}(\alpha, v), \tau_{2}(\alpha, v)\right)^{\top}$ (see Barndorff-Nielsen (1978)). So, if $\left(t_{1}, t_{2}\right)$ belongs to $\mathcal{T}$, the maximum likelihood estimates (MLEs) of the parameters $\theta$ and $v$ are unique solution of the system of equations in (24). Since these equations cannot be solved analytically, an iterative method such as the Newton-Raphson method can be used (see Gelman et al. (1995), pages 
272-273). In each iteration, the expectations, variances and covariances of $X$ ! and $\log (X !(m-X) !)$ are computed by plugging the estimates of $\theta$ and $v$ obtained from the previous iterations in the expression

$$
\mathbb{E}[h(X)]=\sum_{x=0}^{m} h(x) \frac{1}{Z(\theta, v)} \frac{\theta^{x}}{[x !(m-x) !]^{v}} .
$$

The MLEs of the parameters can also be obtained by direct maximization of the log-likelihood function in (23) by using the SAS (PROC NLMIXED) or MaxBFGS routine of the Ox program (Doornik, 2013) or optim routine of the R package (R Development Core Team, 2013).

\section{Fitting the COM-Poisson-binomial distribution}

To illustrate the usefulness and flexibility of the CMPB distribution, we consider here three real datasets. In the first example, the dataset consists of the number of male children in families taken from the hospital records in the nineteenth century Saxony (Sokal and Rohlf, 1994), in the second example the secondary association of chromosomes in Brassika (Skellam, 1948), and in the third example the number of combined occurrences of the articles "the", "a" and "an" in samples of words from Macaulay "Essay on Milton", taken from the Oxford edition of Macaulay (1923) literary essays (Bailey, 1990). Furthermore, the binomial and beta-binomial (BB) distributions were also fitted to these datasets by using the maximum likelihood method. The $\mathrm{pmf}$ of the $\mathrm{BB}$ distribution is given by

$$
\mathbb{P}[X=x \mid m, \alpha, \beta]=\left(\begin{array}{c}
m \\
x
\end{array}\right) \frac{B(x+\alpha, n-x+\beta)}{B(\alpha, \beta)}, \quad x=0,1, \ldots, m,
$$

where $\alpha>0, \beta>0$ and $B(\cdot, \cdot)$ denotes the beta function.

Example 1. The data in this example refer to the number of male children among the first 12 children of family size 13 in 6115 families taken from the hospital records in the nineteenth century Saxony (Sokal and Rohlf (1994), Lindsey (1995), p. 59). The thirteenth child is ignored to assuage the effect of families non-randomly stopping when a desired gender is reached. Thus, $m=12$ is the family size and $X$ is the number of male children. The expected frequencies, maximized kernel of the log-likelihood and estimates of the parameters under the binomial, BB and CMPB distributions are given in Table 4.1. The chi-square goodness-of-fit, the likelihood ratio $(2 \Lambda)$ and the kernel of the log-likelihood values are shown in Table 4.1 describing how well the CMPB and BB fit the data.

The kernel of the log-likelihood is obtained as follows: let $P_{x}=\mathbb{P}[X=x]$ and $O_{x}=$ observed frequency of $X=x$. Then, the kernel of the $\log$-likelihood of any model is given by $\sum_{x=0}^{m} O_{x} \log \left(P_{x}\right)=\sum_{x=0}^{m} O_{x} \log \left(\frac{n \hat{P}_{x}}{n}\right)=\sum_{x=0}^{m} O_{x} \log E_{x}-n \log (n)$, where $n=\sum_{x=0}^{m} O_{x}$ (total frequency) and $E_{x}$ is the expected frequency of $X=x$. Thus, it follows immediately that the kernel of the $\log$-likelihood is $\sum_{x=0}^{m} O_{x} \log \left(O_{x}\right)-n \log (n)$.

The $\mathrm{BB}$ and the $\mathrm{CMPB}$ distributions give almost identical fits to the data (the CMPB distribution gives slightly better fit than the BB distribution). The likelihood ratio chi-square values of the BB and CMPB distributions are $-2(-12485.67+$ $12492.87)=82.60$ and $-2(-12485.67+12492.35)=83.64$, respectively. These values show that both the BB and CMPB models give significant improvements over the binomial distribution (the best fit is evident especially among the tails).

Example 2. The data in this example refer to 337 observations on the secondary association of chromosomes in Brassika; $m=3$ is the number of chromosomes and $X$ is the number of pairs of bivalents showing association. Skellam fitted the BB distribution showing a remarkable improvement fit over the binomial distribution. We fit the CMPB distribution to these data and obtained a similar fit. The observed frequencies, the expected frequencies, the kernel of the log-likelihood and the estimates of the parameters are presented in Table 4.2.

Looking at the expected frequencies and the maximized kernel, we see that both the BB and CMPB models give significant improvements over the binomial model.

Example 3. In studies to characterize an author's style, samples of $n$ words are taken and the number of function words in each sample is counted. The data in this example refer to the number of combined occurrences of the articles "the", "a" and "an" in samples of 5 words from Macaulay "Essay on Milton", taken from the Oxford edition of Macaulay (1923) literary essays (Bailey, 1990). Non-overlapping samples were drawn from opening words of two randomly chosen lines from each of 50 pages of printed text. Thus, $m=5$ is the number of words and $X$ is the number of combined occurrences of the articles "the", "a" and "an". The observed frequencies, the expected frequencies, the kernel of the log-likelihood and the estimates of the parameters are presented in Table 4.3 .

The estimated dispersion parameter of CMPB model is $\hat{v}=2.4619$ indicating that the CMPB model could be the best fitted-model since the binomial and BB models are not equipped with the underdispersion level. Thus, looking at the expected frequencies and the maximized kernel, we see that the CMPB model gives significant improvements over the binomial and BB models. 


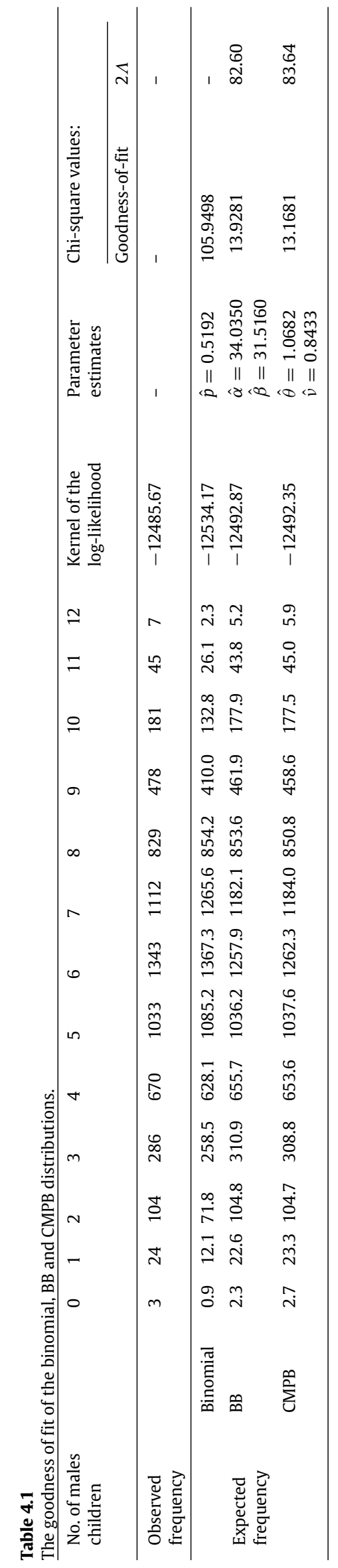


Table 4.2

The goodness of fit of the binomial, BB and CMPB distributions for Skellam's Brassika data.

\begin{tabular}{lllll}
\hline \multirow{2}{*}{ No. of associations } & Observed frequency & \multicolumn{3}{l}{ Expected frequency } \\
\cline { 3 - 5 } & & Binomial & BB & CMPB \\
\hline 0 & 32 & 24.86 & 33.43 & 33.99 \\
1 & 103 & 103.25 & 97.56 & 97.02 \\
2 & 122 & 142.94 & 128.53 & 127.98 \\
3 & 80 & 65.96 & 77.47 & 78.00 \\
\hline Kernel of the log-likelihood & -436.44 & -440.38 & -436.82 & -436.84 \\
\hline Parameter estimates & - & $\hat{p}=0.5806$ & $\hat{\alpha}=6.5375$ & $\hat{\theta}=1.3190$ \\
& & & $\hat{\beta}=4.7213$ & $\hat{v}=0.7026$ \\
\hline Chi-square values: & - & & & 0.78 \\
Goodness-of-fit $2 \Lambda$ & - & 8.10 & - & 7.12 \\
\end{tabular}

Table 4.3

The goodness of fit of the binomial, BB and CMPB distributions.

\begin{tabular}{|c|c|c|c|c|}
\hline \multirow[t]{2}{*}{ No. of associations } & \multirow[t]{2}{*}{ Observed frequency } & \multicolumn{3}{|c|}{ Expected frequency } \\
\hline & & Binomial & $\mathrm{BB}$ & CMPB \\
\hline 0 & 45 & 52.18 & 52.18 & 44.91 \\
\hline 1 & 49 & 36.25 & 36.25 & 49.30 \\
\hline 2 & 06 & 10.07 & 10.07 & 5.67 \\
\hline$>2$ & 00 & 1.50 & 1.50 & 0.12 \\
\hline Kernel of the log-likelihood & -87.77 & -92.77 & -92.77 & -87.90 \\
\hline Parameter estimates & - & $\hat{p}=0.1220$ & $\begin{array}{l}\hat{\alpha}=83635.54 \\
\hat{\beta}=601903.71\end{array}$ & $\begin{array}{l}\hat{\theta}=0.0209 \\
\hat{v}=2.4619\end{array}$ \\
\hline \multicolumn{5}{|l|}{ Chi-square values: } \\
\hline Goodness-of-fit & - & 8.62 & 8.62 & 0.14 \\
\hline $2 \Lambda$ & - & - & 10.0 & 0.26 \\
\hline
\end{tabular}

\section{Concluding remarks}

We study and discuss here the mathematical properties of the CMPB distribution proposed by Shmueli et al. (2005) as a two-parameter extension of the binomial distribution. The main advantage of this model is its flexibility to handle overdispersion or underdispersion commonly encountered in count datasets. The CMPB distribution is appealing from a theoretical point of view since it belongs to the exponential family as well as to the weighted Poisson distributions family. Various statistical and probabilistic properties were derived such as moments, probability and moment generating functions. It is shown how the dispersion parameter affects the approximation of the CMPB distribution by the COM-Poisson distribution as $m$ becomes large. Applications of the CMPB distribution through the maximum likelihood estimation to real datasets show that the CMPB distribution can yield a better fit than some well-known models. Since the CMPB distribution belongs to exponential family, it will also be possible to develop a subjective or objective Bayesian analysis for this model. Work in this direction is currently under progress and we hope to report these findings in a future paper.

\section{Acknowledgment}

The authors are thankful to the referees for their useful comments which improved the paper.

\section{Appendix. Proof of Theorem 1}

$$
\begin{aligned}
\lim _{m \rightarrow \infty} \mathbb{P}[X=x \mid m, p, v] & =\lim _{m \rightarrow \infty} \frac{\left(\begin{array}{c}
m \\
x
\end{array}\right)^{v}\left(\frac{\lambda}{m^{v}}\right)^{x}\left(1-\frac{\lambda}{m^{v}}\right)^{m-x}}{\sum_{j=0}^{m}\left(\begin{array}{c}
m \\
j
\end{array}\right)^{v}\left(\frac{\lambda}{m^{v}}\right)^{j}\left(1-\frac{\lambda}{m^{v}}\right)^{m-j}} \\
& =\lim _{m \rightarrow \infty} \frac{\frac{\lambda^{x}[(m-x+1) \ldots m]^{v}}{(x !)^{v}\left(m^{v}-\lambda\right)^{x}}}{\sum_{j=0}^{m} \frac{\lambda^{k}[(m-j+1) \ldots m]^{v}}{(j !)^{v}\left(m^{v}-\lambda\right)^{j}}} \\
& =\frac{\lambda^{x}}{(x !)^{v}} \frac{1}{\sum_{j=0}^{\infty} \frac{\lambda^{j}}{(j !)^{v}}}, \quad x=0,1, \ldots
\end{aligned}
$$




\section{References}

Altham, P.M.E., 1978. Two generalizations of the binomial distribution. J. Roy. Statist. Soc. Ser. C 27, $162-167$.

Bahadur, R.R., 1961. A representation of the joint distribution of responses to $n$ dichotomous items. In: Studies in Item Analysis and Prediction. Solomon, California.

Bailey, B.J.R., 1990. A model for function word counts. Appl. Stat. 39, 107-114

Barndorff-Nielsen, O., 1978. Information and Exponential Families in Statistical Theory. Wiley, Chichester, UK.

Borges, P., Rodrigues, J., Balakrishnan, N., 2012. Correlated destructive generalized power series cure rate models and associated inference with an application to a cutaneous melanoma data. Comput. Statist. Data Anal. 56, 1703-1713.

Castillo, J., Pérez-Casany, M., 1998. Weighted Poisson distributions for overdispersion and underdispersion situations. Ann. Inst. Statist. Math. 50, $567-585$.

Castillo, J., Pérez-Casany, M., 2005. Overdispersed and underdispersed Poisson generalizations. J. Statist. Plann. Inference 134, $486-500$.

Chang, Y., Zelterman, D., 2002. Sums of dependent Bernoulli random variables and disease clustering. Statist. Probab. Lett. 57, 363-373.

Conway, R.W., Maxwell, W.L., 1962. A queuing model with state dependent service rates. J. Ind. Eng. 12, $132-136$.

Diniz, C.A.R., Tutia, M.H., Leite, J.G., 2010. Bayesian analysis of a correlated binomial model. J. Probab. Stat. $24,68-77$.

Doornik, J., 2013. Ox 5: Object-Oriented Matrix Programming Language, fifth ed. Timberlake Consultants, London.

Fu, J., Sproule, R., 1995. A generalization of the binomial distribution. Comm. Statist. Theory Methods 24, $2645-2658$.

Gelman, A., Carlin, J.B., Stern, H.S., Rubin, D.B., 1995. Bayesian Data Analysis. Chapman and Hall, New York.

Gupta, R.C., Tao, H., 2010. A generalized correlated binomial distribution with application in multiple testing problems. Metrika 71, 59-77.

Hinde, J., Demetrio, C.G.B., 1998. Overdispersion: models and estimation. Comput. Statist. Data Anal. 27, 151-170.

Kadane, J.B., Naeshagen, F., 2013. The number of killings in rural Norway, 1300-1569. Ann. Appl. Stat. 7, 846-859.

Kokonendji, C., Mizere, D., Balakrishnan, N., 2008. Connections of the Poisson weight function to overdispersion and underdispersion. J. Statist. Plann. Inference 138, 1287-1296.

Kupper, L.L., Haseman, J.K., 1978. The use of a correlated binomial model for the analysis of certain toxicological experiments. Biometrics 34, 69-76.

Lindsey, J.K., 1995. Modelling Frequency and Count Data. Oxford University Press, Oxford, UK.

Luceño, A., Ceballos, F., 1995. Describing extra-binomial variation with partially correlated models. Comm. Statist. Theory Methods 24, $1637-1653$.

Macaulay, L., 1923. Literary Essays Contributed to the Edinburgh Review. Oxford University Press, London.

Madsen, R.W., 1993. Generalized binomial distributions. Comm. Statist. Theory Methods 22, 3065-3086.

$\mathrm{Ng}, \mathrm{T} .-\mathrm{H} ., 1989$. A new class of modified binomial distributions with applications to certain toxicological experiments. Comm. Statist. Theory Methods 18 , 3477-3492.

Patil, G.P., 1964. Estimation for the generalized power series distribution with two parameters and its application to binomial distribution. In: Rao, C.R. (Ed.), Contributions to Statistics. Statistical Publishing Society, Calcutta, pp. 335-344. Pergamon, Oxford.

Paul, S.R., 1985. A three-parameter generalization of the binomial distribution. Comm. Statist. Theory Methods 14, 1497-1506.

Paul, S.R., 1987. On the beta-correlated binomial (bcb) distribution-a three-parameter generalization of the binomial distribution. Comm. Statist. Theory Methods 16, 1473-1478.

R Development Core Team, 2013. R: A Language and Environment for Statistical Computing. R Foundation for Statistical Computing, Vienna, Austria.

Rodrigues, J., de Castro, M., Cancho, V., Balakrishnan, N., 2009. COM-Poisson cure rate survival models and an application to a cutaneous melanoma data. J. Statist. Plann. Inference 139, 3605-3611.

Rudolfer, S.M., 1990. A Markov chain model of extrabinomial variation. Biometrika 7, 255-264.

Shmueli, G., Minka, T.P., Kadane, J.B., Borle, S., Boatwright, P., 2005. A useful distribution for fitting discrete data: revival of the Conway-Maxwell-Poisson distribution. J. Roy. Statist. Soc. Ser. C 54, 127-142.

Skellam, J.G., 1948. A probability distribution derived from the binomial distribution by regarding the probability of sucess as variable between the sets of trials. J. Roy. Statist. Soc. Ser. B 10, 257-261.

Sokal, R.R., Rohlf, F.J., 1994. Biometry: The Principles and Practices of Statistics in Biological Research. W.H. Freeman \& Co., New York.

Tsai, C., Hsueh, H., Chen, J.J., 2003. Estimation of false discovery rates in multiple testing: application to genemicroarray data. Biometrics 59, $1071-1081$.

Yakovlev, A., Tsodikov, A., 1996. Stochastic Models of Tumor Latency and their Biostatistical Applications. World Scientific Publishers, Singapore. 


\section{Apêndice F}

Bazán, J. L., Branco, M. D., e Bolfarine, H. (2014b). Extensions of the skew-normal ogive item response model. Brazilian Journal of Probability and Statistics, 28(1), 1-23. DOI: 10.1214/12-BJPS191. 


\title{
Extensions of the skew-normal ogive item response model
}

\author{
Jorge Luis Bazán ${ }^{\mathrm{a}}$, Márcia D. Branco ${ }^{\mathrm{b}}$ and Heleno Bolfarine ${ }^{\mathrm{b}}$ \\ ${ }^{a}$ Pontificia Universidad Católica del Perú \\ ${ }^{\mathrm{b}}$ Universidade de São Paulo
}

\begin{abstract}
We introduce new applications of the skew-probit IRT model by considering a flexible skew-normal distribution for the latent variables and by extending this model to include an additional random effect for modeling dependence between items within the same testlet. A Bayesian hierarchical structure is presented using a double data augmentation approach. This can be easily implemented in WinBUGS or SAS by considering MCMC algorithms. Several Bayesian model selection criteria, such as DIC, EAIC and EBIC, have been considered; in addition, we use posterior sum of squares of the latent residuals as a global discrepancy measure to model comparison. Two applications illustrate the methodology, one data set related to a mathematical test and another related to reading comprehension, both applied to Peruvian students. Results indicate better performance of the more flexible models proposed in this paper.
\end{abstract}

\section{Introduction}

Typically, Item Response Theory (IRT) for multivariate dichotomous responses resulting from $n$ individuals evaluated in a test with $k$ items considers a unidimensional latent variable $\theta$ associated with individual abilities. Moreover, statistical models for IRT consider a set of parameters associated with the items under consideration that are related with the probability that the $i$ th examinee is able to answer the $j$ th item correctly.

Usually a symmetric Item Characteristic Curve (ICC) is considered for IRT models. The supposition of symmetry for the ICC implies that, the probability to answer correctly an item approaches zero with the same rate as it approaches one. Therefore, individuals with high or low abilities are discriminated in a similar fashion. However, when the interest of the test is more directed to discriminate among individuals with high abilities and not as much to discriminate among those with low abilities (or vice-versa) an asymmetric ICC can be more appropriate.

Samejima $(1997,2000)$ exhibits inconsistencies of symmetric ICCs under some philosophical principles. For example, when the goal is to detect student's brightness it is reasonable to consider two principles: (1) more credit (reward) should be given to a person who is successful with difficult items, and (2) a person who fails

Key words and phrases. Bayesian estimation, item response models, latent variables, skewnormal ogive model, skew-normal distribution, skew-probit link, testlet.

Received June 2011; accepted March 2012. 
in an easy item should be penalized more. Since an asymmetric ICC deals better with these two principles, Samejima proposed a family of asymmetric ICCs. This family, termed logistic positive exponential, has the logit link as a special case. A new item parameter associated with skewness is introduced with the intention of adjusting the above principle. Estimation of this model together with a new IRT model, namely the reciprocal logistic positive exponential, is presented in Bolfarine and Bazán (2010).

Bazán, Branco and Bolfarine (2006) proposed another skew item response model, namely here the skew-normal ogive model. In this model, a new asymmetric ICC curve is assumed by considering the cumulative distribution function of the standard skew-normal distribution (Azzalini, 1985). Thus, a new skewness item parameter is introduced over normal curves and the symmetric normal ogive model (Albert, 1992) is a particular case. In this paper, we study extensions and additional properties of the skew-normal ogive model (SNO model).

Statistical assumptions in modeling academic achievement and other latent variables associated with human behavior are based on the normality assumption for these variables. Several authors have questioned this assumption (see Samejima, 1997; Micceri, 1989) since it is somewhat restrictive for modeling human behavior. Micceri (1989) presents many examples of situations where the latent variables can be assumed not to be normally distributed. For instance, when the focus is on item calibration, it is important to cover all levels of abilities in the population, in this case it is reasonable to consider a uniform distribution for the abilities.

For some authors, the parametric distributional assumptions for the latent variable is not part of the Item Response modeling and also a nonparametric model can be assumed for the latent variable (see, e.g., Duncan and MacEachern, 2008). However from a Bayesian perspective, which is assumed in this paper, the complete specification of the IRT model is given by the specification of the likelihood function and all prior distributions, in particular the prior distribution for the latent variable $\theta$. It is a common practice to consider the normal distribution as a prior for latent variables (see, e.g., Albert, 1992; Patz and Junker, 1999). However, we find it important to explore the possibility of using flexible distributional assumptions for the latent variables, such as the skew-normal distribution. This flexible assumption can be an alternative between the restrictive normal model and a full nonparametric model. As we will show here the procedure to estimate the parameters using that distribution is a natural extension of the normal assumption for the latent variables.

On the other hand, in reading comprehension tests the design of testlets or item bundles has been adopted recently in educational and psychological tests (see, e.g., Wainer, Bradlow and Wang, 2001). Additionally, new applications are being considered as, for example, in Wainer et al. (2001) and Wang et al. (2010).

Fitting standard item response models to testlet responses ignores the possible dependence between the items within a testlet. As indicated by Wang and Wilson (2005), not considering this dependence tends to overestimate the precision 
of measures obtained from testlets and yields biased estimation for item difficulty and discrimination parameters. Overstatement of precision and biased estimation lead to inaccurate inferences about the parameters (Wainer and Wang, 2000). Thus, Bradlow, Wainer and Wang (1999) extend the ogive normal model to include an additional random effect to model the dependence between items within the same testlet. The variances of the random testlet effects were assumed to be constant across testlets. This model has been successfully used in multiple applications (see Wainer, Bradlow and Wang, 2001). However, to the best of our knowledge we are no ware of studies on the use of asymmetric links to item characteristic curves in the context of tests with testlets.

The paper is organized as follows. In Section 2, we present a review of the skewnormal ogive IRT model and the data augmentation approach. In the third section, we extend the SNO IRT model by considering asymmetrically distributed latent variables. In Section 4, we present the skew-normal ogive testlet model. Section 5 presents two applications to illustrate the good performance of the approach developed here by considering different criteria for model comparison. The paper ends with a discussion in Section 6 and two appendices. In Appendix A.1, we present properties of the skew-normal distribution, and in Appendix A.2, we present the program code to implement the new model proposed.

\section{The skew-normal ogive model}

Let $Y_{i j}$ denotes the dichotomous variable corresponding to the response of the $i$ th individual, $i=1, \ldots, n$, on the $j$ th item, $j=1, \ldots, k . Y_{i j}$ takes the value 1 if the response is correct and 0 , otherwise. The skew-normal ogive IRT model proposed by Bazán, Branco and Bolfarine (2006) follows by considering:

$$
\begin{aligned}
Y_{i j} \mid \theta_{i}, \eta_{j} & \sim \operatorname{Bern}\left(p_{i j}\right), \\
p_{i j} & =F_{d_{j}}\left(m_{i j}\right), \\
m_{i j} & =\alpha_{j}\left(\theta_{i}-\beta_{j}\right)
\end{aligned}
$$

with $\alpha_{j}>0,-\infty<\beta_{j}<\infty,-1<d_{j}<1$, and $-\infty<\theta<\infty$ and $\operatorname{Bern}(\cdot)$ denoting a Bernoulli distribution. The probability $p_{i j}=P\left(Y_{i j}=1 \mid \theta_{i}, \eta_{j}\right)$ is the conditional probability of correct response given the $i$ th ability value $\theta_{i}$ and the $j$ th item parameter $\eta_{j}=\left(\alpha_{j}, \beta_{j}, d_{j}\right)$. Moreover, $F_{d_{j}}(\cdot)$ denotes the cumulative distribution function (c.d.f.) of the standard skew-normal distribution (see Appendix A.1) and $m_{i j}$ is the latent linear component relating $\theta_{i}$ and the item parameter $\eta_{j}$.

Note that $F_{d_{j}}(\cdot)$ is an asymmetric ICC and $F_{d_{j}}^{-1}(\cdot)$ is the BBB skew-probit link (see Bazán, Bolfarine and Branco, 2010). The SNO model satisfies the latent monotonicity property (Holland and Rosenbaum, 1986), that is, it is a monotone increasing function of the unidimensional quantity $\theta_{i}$. Thus, the SNO model is a unidimensional monotone latent variable model (Junker and Ellis, 1997). Moreover, 
it satisfies the latent conditional independence principle or the local independence principle, which considers that for the $i$ th examinee, $\left\{Y_{i j}: j \geq 1\right\}$ are conditionally independent given $\theta_{i}$. It is assumed that responses from different individuals are also independent.

Let $Y_{i}^{T}=\left(Y_{i 1}, \ldots, Y_{i k}\right), \theta^{T}=\left(\theta_{1}, \ldots, \theta_{n}\right)$ and $\eta^{T}=\left(\eta_{j}, \ldots, \eta_{k}\right)$ and suppose that the assumptions mentioned earlier hold. The multivariate joint probability distribution of $Y=\left(Y_{1}^{T}, \ldots, Y_{n}^{T}\right)^{T}$, given the vector of latent variables $\theta^{T}$ and the item parameter vector $\eta^{T}$, can be written as

$$
p(Y \mid \theta, \eta)=\prod_{i=1}^{n} \prod_{j=1}^{k}\left[p_{i j}\right]^{Y_{i j}}\left[1-p_{i j}\right]^{1-Y_{i j}}, \quad i=1, \ldots, n, j=1, \ldots, k .
$$

For $d_{j}=0$ it follows that $p_{i j}=\Phi\left(m_{i j}\right)$, where $\Phi(\cdot)$ is the c.d.f. of the standard normal distribution. The symmetric ogive normal IRT model then follows. Additionally, an approximation for the logistic IRT model is obtained when $\Phi(\cdot / 1.7)$ is considered (see Camilli, 1994).

Figure 1 depicts skew-probit ICCs for different values of the shape parameter $d_{j}$ and fixed item parameters $\alpha_{j}=1$ and $\beta_{j}=0$. Six different ICCs are considered taking $d_{j}=-0.9,-0.7,-0.5,0.5,0.7,0.9$ for comparison with $d_{j}=0$ (the symmetric ICC). For $d_{j}>0$ the ICC presents positive skewness, and for $d_{j}<0$ it

ICCs with negative asimmetry ICCs with positive asimmetry
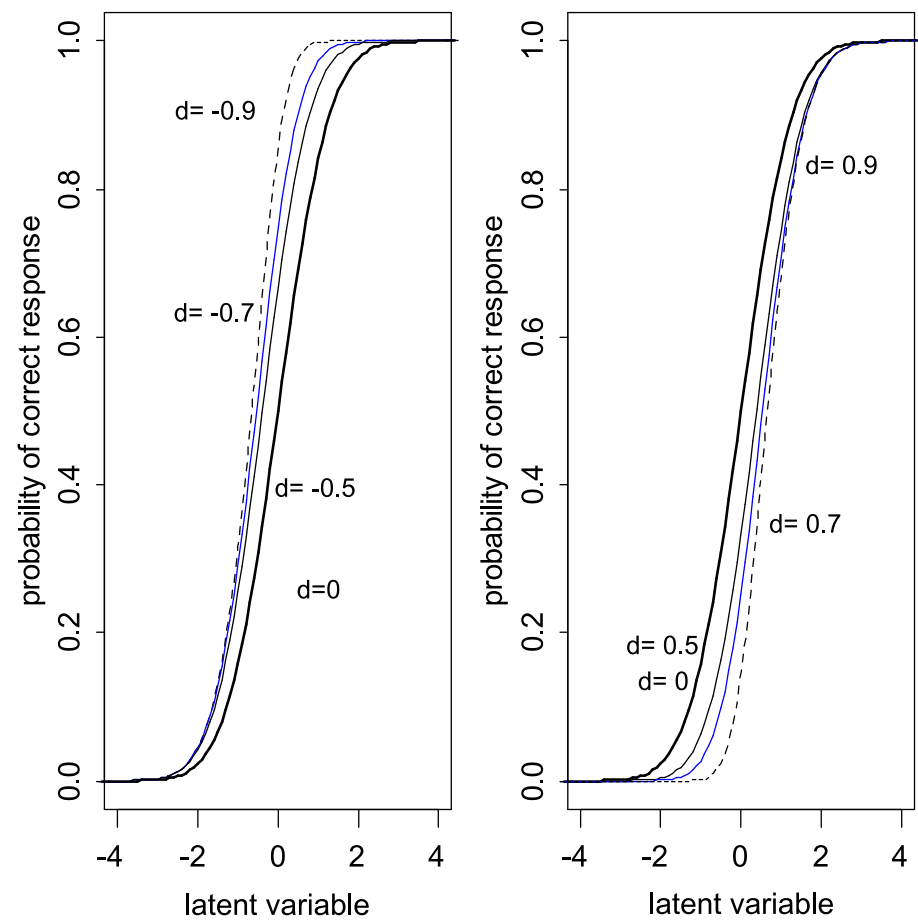

Figure 1 Skew-probit ICCs for $\alpha=1, \beta=0$ and different values of the shape parameter $d$. 
presents negative skewness. As in the positive exponent logistic models considered by Samejima (1997, 2000), the skew-probit ICC also considers a new item parameter to control the asymmetry of the curve; however, now we have an extension for the probit ICC and not for the logistic ICC.

The item shape parameter can be psychometrically interpreted as a penalty (reward) on the probability of correct response. Hence, an item with negative shape parameter penalizes (rewards) students with larger (smaller) levels of the latent variable and an item with positive shape parameter rewards (penalizes) individuals with larger (smaller) levels of the latent variable (see Figure 1). We call the shape parameter $d$ the item penalization parameter.

As in the usual symmetric IRT model, the parameters $\alpha_{j}$ and $\beta_{j}$ are called discrimination (or slope) item parameter and difficulty (or intercept) item parameter, respectively. A steeper item response curve corresponds to an item that highly discriminates students of smaller and greater levels of the latent variable. An item with a small value of $\alpha_{j}$ is a relatively poor discriminator between students for changing values of the latent variable. Moreover, an item of a test with a highly negative value of $\beta_{j}$ corresponds to an easy item in which individuals with smaller averages in the latent variable show relatively low probabilities of correct responses. In contrast, an item with a large value of $\beta_{j}$ is a difficult item since individuals with larger levels of the latent variable show relatively low probabilities of correct responses.

Following different proposals in the literature, we reparameterize the model introduced by considering $a_{j}=\alpha_{j}$ and $b_{j}=-\alpha_{j} \beta_{j}$ such that $m_{i j}=a_{j} \theta_{i}-b_{j}$, with $\eta_{j}=\left(a_{j}, b_{j}\right)$ the item parameter corresponding to the $j$ th item. According to Baker and Kim (2004), this parameterization may result in more stable computations. We use the notation $a=\left(a_{1}, \ldots, a_{k}\right)^{T}$ and $b=\left(b_{1}, \ldots, b_{k}\right)^{T}$.

\subsection{Data augmentation approach}

Denoting $\mathbf{D}_{o b s}=\mathbf{y}$ the observed data, the likelihood function for the SNO can be written as

$$
L\left(\theta, \eta, \mid \mathbf{D}_{o b s}\right)=\prod_{i=1}^{n} \prod_{j=1}^{k}\left[F_{d_{j}}\left(m_{i j}\right)\right]^{y_{i j}}\left[1-F_{d_{j}}\left(m_{i j}\right)\right]^{1-y_{i j}} .
$$

Following Albert (1992), for $n$ examinees responding a test with $k$ items, it is known that the probit link can be rewritten as

$$
Y_{i j}= \begin{cases}1, & Z_{i j}>0 \\ 0, & Z_{i j} \leq 0\end{cases}
$$

where $Z_{i j}=m_{i j}+e_{i j}$ with $e_{i j} \sim N(0,1), i=1, \ldots, n$ and $j=1, \ldots, k$. It follows that

$$
p_{i j}=P\left(Y_{i j}=1 \mid \theta_{i}=u_{i}, \eta_{j}\right)=\Phi\left(m_{i j}\right)
$$


This representation shows a linear structure in the auxiliary latent variable $Z_{i j}$, which produces an equivalent model with a probit link. Further, $e_{i j}$ 's are latent residuals which are independent and identically distributed (see Albert and Chib, 1995) and this fact can be used for model checking.

Similarly, as shown in Bazán, Branco and Bolfarine (2006), it is possible to define a latent linear error structure for the skew-normal ogive model replacing the normality assumption of the error terms by the skew-normality assumption. Following notation from Appendix A.1, when $e_{i j} \sim \mathrm{SN}\left(0,1,-\lambda_{j}\right)$ we have

$$
p_{i j}=P\left(Y_{i j}=1 \mid \theta_{i}, \eta_{j}\right)=F_{d_{j}}\left(m_{i j}\right) .
$$

Note that, the parameter $d_{j}=\frac{\lambda_{j}}{\sqrt{1+\lambda^{2}}}$ is a reparametrization of the shape parameter $\lambda_{j}$. In addition, using the stochastic representation (Henze, 1986) for a skew-normal distribution we can write

$$
e_{i j}=-d_{j} V_{i j}-\left(1-d_{j}^{2}\right)^{1 / 2} W_{i j},
$$

with $W_{i j} \sim N(0,1)$ and $V_{i j} \sim \mathrm{HN}(0,1)$ (the half-normal distribution). It follows that the conditional distribution of the $e_{i j}$ given $V_{i j}=v_{i j}$ is a normal distribution with mean $-d_{j} v_{i j}$ and variance $1-d_{j}^{2}$ (see Appendix A.1).

Simulation of the latent variables $Z_{i j}$ should be considered in two steps. First simulate $V_{i j} \sim \mathrm{HN}(0,1)$ and then, simulate from the conditional distribution $Z_{i j}^{*} \equiv$ $Z_{i j} \mid V_{i j}=v_{i j}$ where $Z_{i j}^{*} \sim N\left(m_{i j} d_{j} v_{i j}, 1-d j\right)$. Additionally, the latent residuals $e_{i j}$ 's (all independent) in the skew probit link can be used also for model checking.

We consider now the complete data likelihood function involving the conditional auxiliary latent variables $\mathbf{Z}^{*}=\left(Z_{1}^{* T}, \ldots, Z_{n}^{* T}\right)^{T}$, with $Z_{i}^{* T}=\left(Z_{i 1}^{*}\right.$, $\left.\ldots, Z_{i k}^{*}\right), i=1, \ldots, n$, and $\mathbf{V}=\left(V_{1}^{T}, \ldots, V_{n}^{T}\right)^{T}$, with $V_{i}^{T}=\left(V_{i 1}, \ldots, V_{i k}\right)$, $i=1, \ldots, n$. The complete-data likelihood function for the SNO IRT model with $\mathbf{D}=\left(\mathbf{Z}^{*}, \mathbf{V}, \mathbf{y}\right)$ is given by

$$
L(\mu, \eta, \lambda \mid D)=\prod_{i=1}^{n} \prod_{j=1}^{k} \phi^{*}\left(Z_{i j}^{*}\right) I\left(Z_{i j}^{*}, Y_{i j}\right) \phi\left(V_{i j}\right) I\left(V_{i j}>0\right),
$$

where $\phi^{*}(\cdot)$ denotes the probability density function of the normal distribution with mean $m_{i j}-d_{j} v_{i j}$, variance $1-d_{j}^{2}$ and $I\left(Z_{i j}^{*}, Y_{i j}\right)=I\left(Z_{i j}^{*}>0\right) I\left(Y_{i j}=1\right)+$ $I\left(Z_{i j}^{*} \leq 0\right) I\left(Y_{i j}=0\right)$. Note that, when $d_{j}=0$ the likelihood function above is the one given in Albert (1992).

\subsection{Prior specification}

We start considering the following general class of independent prior distributions:

$$
\pi(\theta, \eta)=\prod_{i=1}^{n} g_{1}\left(\theta_{i}\right) \prod_{j=1}^{k} g_{2}\left(\eta_{j}\right)
$$


where $g_{1}$ and $g_{2}$ are specified probability density functions for $\theta_{i}$ and $\eta_{j}$, respectively, $i=1, \ldots, n$ and $j=1, \ldots, k$.

Additionally, for simplicity we assume independence between $a_{j}, b_{j}, d_{j}$, so that

$$
g_{2}\left(\eta_{j}\right)=g_{21}\left(a_{j}\right) g_{22}\left(b_{j}\right) g_{23}\left(d_{j}\right) .
$$

For the normal ogive model, Ghosh et al. (2000) and Albert and Ghosh (2000) showed that $g_{21}$ should be proper in order to guarantee a proper posterior distribution, however $g_{22}$ can be improper. We consider proper prior densities of probabilities for all item parameters to avoid possible problems. Following Rupp, Dey and Zumbo (1992) and Sahu (2002), we take a normal with positive values for $g_{21}$ denoted by $N\left(\mu_{a}, \sigma_{a}^{2}\right) I(\cdot, \cdot)$ and $N\left(\mu_{b}, \sigma_{b}^{2}\right)$ for $g_{22}$. For the new item parameters $d_{j}$, we consider a noninformative prior uniform on $[-1,1]$. The prior specification for the parameters associated with the individuals $\theta_{i}$ will be discuss in the next section.

\section{Extending the SNO IRT model by considering asymmetrically distributed latent variables}

In the classical formulation of the IRT models one assumption typically added to the model, although not widely accepted, is that $\theta_{i} \sim N\left(\mu, \sigma^{2}\right)$. This establishes that the latent variables associated with the individuals taking the test are well behaved and that their abilities are a random sample from this distribution. We can specify, for $\mu$ and $\sigma^{2}, \mu=0$ and $\sigma^{2}=1$ (as in Albert, 1992), or specify probability distributions for $\mu$ and $\sigma^{2}$ (as Patz and Junker, 1999) to solve the identifiability problem of the IRT model.

From a Bayesian perspective, the specification of a probability distribution for the latent variables $\theta_{i}$ is the same as the specification of a prior distribution. We propose here an asymmetric class of prior distributions for the $i$ th individual latent variable $\theta_{i}$, given by

$$
\theta_{i} \sim \mathrm{SN}\left(\mu, \sigma^{2}, \gamma\right), \quad i=1, \ldots, n
$$

with $-\infty<\mu<\infty, \sigma^{2}>0,-\infty<\gamma<\infty$.

This skew-normal probability density function (p.d.f.) will be denoted by $g_{1}\left(\theta_{i}\right)$.

Notice that, considering a priori equal asymmetry for all the abilities, does not imply that, a posteriori, equal asymmetry will result. That is, after we observe the results of the tests, the posterior distributions of the asymmetry for the abilities can take different values for each individual.

As before, we prefer to use the alternative parametrization for the shape parameter given by $\omega=\frac{\gamma}{\sqrt{1+\gamma^{2}}}$, which takes values in $[-1,1]$.

Figure 2 depicts the density functions of the latent variables for different values of the shape parameter $\gamma$. The three curves on the right-hand side are examples with positive shape parameter $\gamma$ modeling latent variables concentrated on lower 


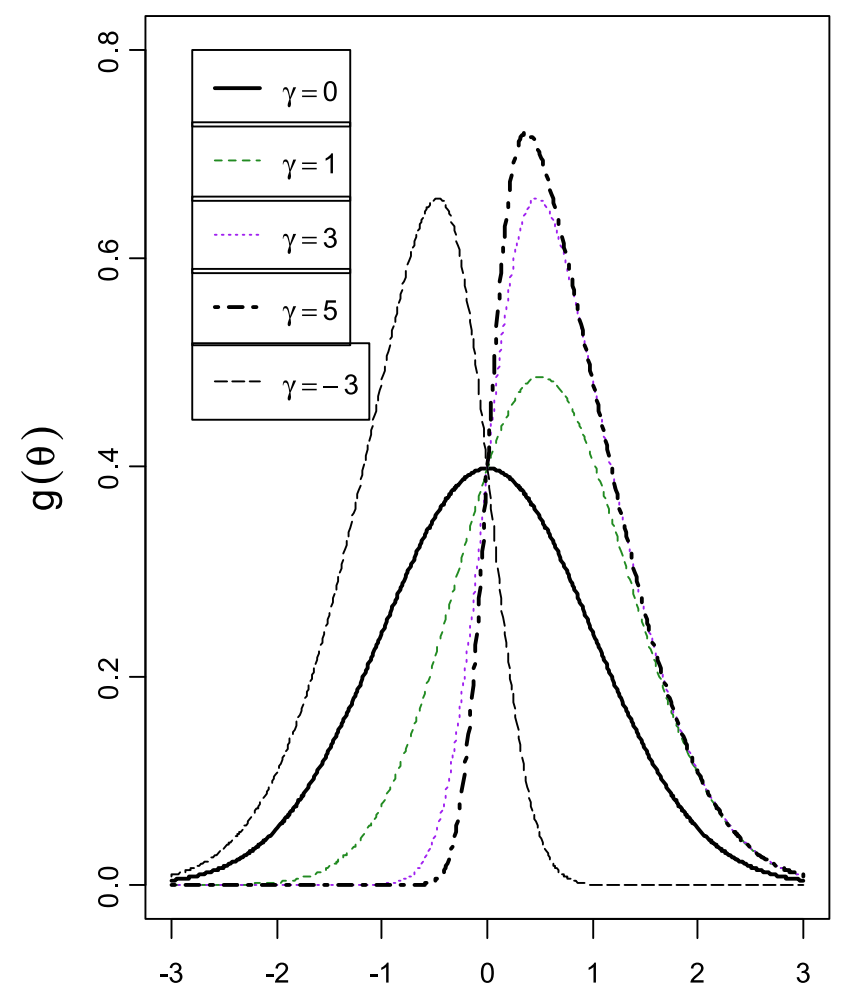

Figure 2 Different skew-normal density functions, with $\mu=0$ and $\sigma^{2}=1$.

values. The three curves on the left side are examples with a negative shape parameter $\gamma$ modeling latent variables concentrated on higher values. As a reference, in all cases the $N(0,1)$ curve is also presented.

The curves shown in Figure 2 are reasonable assumptions for the distribution of the latent variables associated with human behavior in different contexts, as observed in Micceri (1989). Examples of such behavior are anxiety (see Zaider et al., 2001) and depression (see Riddle, Blais and Hess, 2002), where certain skewness is expected considering a non-clinic population. Moreover, as noted in Hashimoto (2002), in educational contexts several predictor variables related to school proficiency can be asymmetrically distributed.

Another situation to motivate the assumption of asymmetry for latent variables is obtained by a selection process where a bias is induced in the sample process which induces skewness in the original distribution as discussed in Arellano-Valle, Branco and Genton (2006).

Hence, the specification in (3.1) is flexible and also accommodates the normal distribution as a special case. Note that, the asymmetry considered here is different from the ICC asymmetry, which is related to a latent error for the definition of threshold to correct response.

The idea of the formulation considered here for the latent variable in (3.1) was originally presented in Arellano-Valle, Branco and Genton (2006). As noted by 
Azevedo, Bolfarine and Andrade (2010) the model is not identifiable. However, differently from their formulation which considers a centered parameterization to overcome this issue, we consider the use of priors distributions for the hyperparameter.

A particular specification for the abilities is to consider the $\operatorname{SN}(0,1, \gamma)$. In this case, the usual normal specification is a particular case $(\gamma=0)$. In that case, the mean and variance are not centered, that is, they are not 0 and 1 , respectively. A centered parametrization can be obtained by considering $\mu=\frac{-0.7978846 \gamma}{\sqrt{\left(1-0.6366198 \gamma^{2}\right)}}$ and $\sigma^{2}=\frac{1}{1-0.6366198 \gamma^{2}}$, then $E\left(\theta_{i}\right)=0$ and $V\left(\theta_{i}\right)=1$. It is equivalent to the use of a centered parametrization (see Azevedo, Bolfarine and Andrade, 2010).

By considering two or just one type of asymmetry on the specification of the ICC curve or on the specification of the distribution of the latent variable, four scenarios are possible:

(a) skew-normal distribution for ICC and skew-normal distribution for abilities, namely Skew-Probit Skew-Normal (SPSN) model;

(b) skew-normal distribution for ICC and normal distribution for abilities, namely Skew-Probit Normal (SPN) model;

(c) normal distribution for ICC and skew-normal distribution for abilities, namely Probit Skew-normal (PSN) model and

(d) normal distribution for ICC and normal distribution for abilities, namely Probit normal $(P N)$ model.

Notice that, (a) and (b) are skew-normal ogive models and (c) and (d) are normal ogive models where (d) is the usual model (Albert, 1992). We call these four scenarios the SN-IRT family (see also Bazán, Bolfarine and Branco, 2004).

An interesting aspect of the models formulated above is the flexibility in detecting items specified according to ICCs with skew-probit links and items specified according to ICCs with probit links. Thus, the SN-IRT family is a very flexible model.

The model in (a) is more general and it involves a total of $n+3+3 k$ unknown parameters. In contrast, the model in (d) is simpler and it involves $n+2 K$ unknown parameters. As a consequence of the introduction of new parameters, these models become overparameterized and then nonidentifiable. In such cases, a potential advantage of the Bayesian analysis over likelihood-based one is that if informative priors are available, as is the case here, proper inferences can be obtained despite of having an overparameterized (Rannala, 2007) model. In addition, as indicated in Poleto et al. (2011), the use of proper prior distributions in the Bayesian framework readily allows us to obtain valid inferences even for nonidentifiable models.

\subsection{Fully Bayesian specification}

Considering the augmented likelihood given in (2.6) and the prior specification discussed before, the fully Bayesian set-up for the most general ogive skew-normal 
IRT model is given by the following hierarchical structure:

$$
\begin{aligned}
Z^{*} \mid v_{i j}, y_{i j}, \theta_{i}, a_{j}, b_{j}, d_{j} & \sim N\left(m_{i j}-d_{j} v_{i j}, 1-d_{j}^{2}\right) I\left(Z_{i j}^{*}, Y_{i j}\right), \\
v_{i j} & \sim \operatorname{HN}(0,1), \\
\theta_{i} & \sim \operatorname{SN}\left(\mu, \sigma^{2}, \omega\right), \\
a_{j} & \sim N\left(\mu_{a}, \sigma_{a}^{2}\right) I(\cdot, \cdot), \quad b_{j} \sim N\left(\mu_{b}, \sigma_{b}^{2}\right), \\
d_{j} & \sim U(-1,1), \\
\mu & \sim N(0,1), \quad 1 / \sigma^{2} \sim \operatorname{Gamma}(0.01,0.01), \\
\omega & \sim U(-1,1) .
\end{aligned}
$$

By considering the hierarchical structure, this formulation can be easily implemented in WinBUGS (Lunn et al., 2000). Alternatively, one can use the MCMC procedure in SAS (SAS Institute Inc., 2009).

Particular cases of this more general SNO model can be derived by eliminating some lines in the hierarchical structure.

\section{Extending the SNO IRT model by considering testlets}

Wainer and Kiely (1987) introduced the testlet terminology and defined that as a group of items related to a single content area, developed as a unit. It contains a fixed number of predetermined paths that an examinee may follow. Examples of testlets include a set of reading items associated with a common passage, a group of social studies items referring to a map, or a collection of mathematics items based on a graph or a table. Thus, items that are part of a testlet are not statistically independent. Item responses within a testlet are not locally independent because they are related through a common stimulus. Therefore, in this case, the usual IRT models can lead to an inaccurate estimation of examinees' and items' parameters, and also overestimate the precision of these parameters (Tuerlinckx and De Boeck, 2001). Bradlow, Wainer and Wang (1999) propose to retain the item as the unit of measurement and add a person-specific random effect parameter, to account for the shared variance among items within a testlet. This parameter is called the testlet effect parameter and is denoted $\gamma_{i l}$.

In order to extend the model by considering the testlets, we consider the hierarchical structural specification of the most general SNO IRT model later in this section. The following modification of the latent linear component presented in (2.3) is considered, that is,

$$
m_{i j}=\alpha_{j}\left(\theta_{i}-\beta_{j}+\gamma_{i l}\right), \quad i=1, \ldots, n, j=1, \ldots, k, l=1, \ldots, t,
$$

where $\gamma_{i l}$ is a person-specific testlet effect or the random effect for person $i$ on testlet $l$. Thus, $\gamma_{i l}$ describes the interaction between persons and items (local item 
dependence) within the testlet independent of the ability and item parameters. The prior specification for these parameters is given by

$$
\gamma_{i l} \sim N\left(0, \sigma_{\gamma_{l}}^{2}\right)
$$

The testlet effects were centered at zero to emphasize their status as deviations from the SNO IRT model and to identify the model and $\sigma_{\gamma_{l}}^{2}$ indicates the amount of the testlet effect for testlet $l$.

\subsection{Fully Bayesian specification}

The hierarchical structure specification of the SNO testlet model is given by

$$
\begin{aligned}
Z^{*} \mid v_{i j}, y_{i j}, \theta_{i}, a_{j}, b_{j}, d_{j} & \sim N\left(m_{i j}-d_{j} v_{i j}, 1-d_{j}^{2}\right) I\left(Z s_{i j}, Y_{i j}\right), \\
v_{i j} & \sim \operatorname{HN}(0,1), \\
\theta_{i} & \sim N(0,1), \\
\gamma_{i l} & \sim N\left(0, \sigma_{\gamma_{l}}^{2}\right), \\
a_{j} & \sim N\left(\mu_{a}, \sigma_{a}^{2}\right), \quad b_{j} \sim N\left(0, \sigma_{b}^{2}\right), \quad d_{j} \sim U(-1,1), \\
1 / \sigma_{\gamma_{k}}^{2} & \sim \chi(s),
\end{aligned}
$$

where $\chi(s)$ corresponds to a chi-square distribution with $s$ degrees of freedom.

This formulation can be easily implemented in WinBUGS or with the MCMC procedure in SAS.

When $\sigma_{\gamma_{l}}^{2}=\sigma_{\gamma}^{2}$ (the same variance for all testlets) the model reduces to the twoparameter testlet model proposed by Bradlow, Wainer and Wang (1999). When $a_{i}=0$ the model reduces to the one-parameter Rasch testlet model proposed by Wang and Wilson (2005). If a skew-normal distribution is considered for the abilities, then corresponding prior must be considered for the hyperparameters.

\section{Applications}

We illustrate the methodology developed in the earlier sections using two data sets from Peruvian students. The first data set shows results from a mathematical test applied in rural schools in Peru. The second data set, is related to reading comprehension test applied to Peruvian students in some cities in the jungle region of Peru. Prior specification, starting values for the MCMC algorithm and convergence diagnostics are discussed. The MCMC procedure is based on the data augmentation approach discussed in Sections 3.1 and 4.1, respectively, and it is implemented using the WinBUGS software. Model comparison between symmetrical and asymmetrical IRT models are developed by using the Deviance Information Criterion (DIC) described in Spiegelhalter et al. (2002), the Expected Akaike Information Criterion (EAIC) and the Expected Bayesian Information Criterion (EBIC). Moreover, the 
sum-of-squared-latent residuals $\left(S S R=\sum_{i=1}^{n} \sum_{j=1}^{k} e_{i j}^{2}\right)$ introduced in Section 2 is also considered.

EAIC and EBIC are criteria proposed in Brooks (2002) and Carlin and Louis (2000) and were used by Bolfarine and Bazán (2010) in the context of TRI. These criteria penalize the posterior expected deviance by using $2 p$ and $p \log n$ as penalties function, respectively, where $p$ is the number of parameters in the model and $n$ is the sample size. On the other hand, DIC penalizes the posterior expected deviance by using $2 \rho_{D}$, where $\rho_{D}$ is a complexity measure associated with the effective number of parameters in a model. This is given by the difference between the posterior mean of the deviance function and the deviance at the posterior estimates of the parameter of interest. In fact, the posterior expected deviance or Dbar can also be considered as a model comparison criterion. For all criteria, the smaller values indicate better fit.

\subsection{Math data set}

We consider an analysis on the response pattern obtained by the application of a Mathematical Test for fourth grade students of rural Peruvian Elementary Schools. Item response vectors are available from the authors upon request and correspond to the response of 974 students to 18 items qualified as binary response (correct and incorrect). The scores have mean equal to 8.27 , median 8 and standard deviation 4.20. The sample skewness and kurtosis indexes are -0.075 and -0.836 , respectively. The test presents a regular reliability index given by Cronbach's alpha equal to 0.83 , and the mean proportion for the items equal to 0.449 . The Mathematical Test is formed with independent items corresponding to different tasks with different definitions. Given the latent ability $\theta_{i}$, it is considered that the correct responses to the items are independent. Furthermore, the autocorrelations within individual responses seem to be low, which provides additional support for the assumption of local independence.

As it has been mentioned, proper priors for $a_{j}$ and $b_{j}$ guarantee that the complete posterior for the model is proper. Further, informative prior distributions placed on $a_{j}$ and $b_{j}$ can be used to reflect the prior belief that the values of the item parameters are not extreme (in the boundary of the parametric space). In the common situations where little prior information is available on the difficulty parameters, we can choose $S_{b}^{2}$ to be large. This choice will have a modest effect on the posterior distribution for non-extreme data, and it will result in a proper posterior distribution in the case of extreme data. Extreme data occurs when students get correct (or incorrect) answers for all items. However, Sahu (2002) states that larger values of the variance led to unstable estimates. We consider here the same priors given in Sahu (2002) and Bazán, Branco and Bolfarine (2006), that is $a_{j} \sim N(1 ; 0.5) I(0 ; \cdot)$ and $b_{j} \sim N(0 ; 2), j=1, \ldots, k$. For the skew models, a uniform prior distribution on $(-1,1)$ is specified for each $d_{j}, j=1, \ldots, k$. Finally, we consider $\theta_{i} \sim \mathrm{SN}\left(\mu, \sigma^{2}, \gamma\right), i=1, \ldots, n$, where it is assumed that $w \sim U(-1,1)$, $1 / \sigma^{2} \sim \operatorname{Gamma}(0.01,0.01)$ and $\mu \sim N(0,1)$. 
Table 1 Comparing models using different criteria for the Math data

\begin{tabular}{lrrrr}
\hline Criterion & \multicolumn{1}{c}{ PN } & \multicolumn{1}{c}{ SPN } & PSN & SPSN \\
\hline Number of parameters & 1010 & 1028 & 1013 & 1049 \\
Deviance of the posterior means & 16,865 & 15,139 & 16,861 & 15,168 \\
Posterior expected deviance & 16,012 & 14,096 & 15,999 & 15,994 \\
$\rho_{D}$ effective number of parameters & 853 & 1042 & 862 & -826 \\
DIC & 17,718 & 16,181 & 17,723 & 14,341 \\
Expected AIC & 18,885 & 17,195 & 18,887 & 17,266 \\
Expected BIC & 26,734 & 25,184 & 26,760 & 25,418 \\
SSR posterior mean & 17,570 & 12,800 & 17,550 & 12,470 \\
\hline
\end{tabular}

The model considering asymmetry for the ICC and the abilities, denoted by SPSN, is the more general one. The Math data set involves 54 item parameters and 974 individual traits for the individuals in the sample. Additionally, in the SPSN model the hyperparameters $\left(\mu, \sigma^{2}, w\right)$ were estimated from the data set. The others models considered are particular cases and have fewer parameters.

Table 1 on page 13 shows the number of parameters in each model.

The MCMC procedure is somewhat slow because of the great number of chains that must be generated. For example, the PSN model takes about 150 seconds to run 1000 iterations on a Intel Core2 Duo E8400 Processor $3.003 \mathrm{GHz}$ with $3.2 \mathrm{~GB}$ RAM. For the SPSN model it takes twice this time, under the SPN model it takes about 1.5 times and under the PN model it takes about three times the PSN times. The time to run the Markov Chains for each model is related to the presence of dependence structures on the latent variables (Chen, Shao and Ibrahim, 2000), with the sample size (Sahu, 2002) and also with the prior specification.

We consider 1 and 0 as initial values for the item parameters $a_{j}$ and $b_{j}$, $j=1, \ldots, k$, respectively. We propose zero as initial values for the skewness parameters $w$ and $d_{j}$ 's because it corresponds to the mean of the uniform distribution on $(-1,1)$. Initial values for the latent variable $\theta_{i}$ and auxiliary latent variables corresponding to the different models (as $V_{i j}$ and $W_{i j}$ ) can be considered as generated from distributions specified in Section 3.1 but we prefer fixing this value in 0.5 to improve the performance and stability of the developed software.

When using MCMC, the sampled values for initial iterations of the chains are discarded because of their dependence on starting states. Also, the presence of autocorrelations between values of the chain is expected when latent variables are introduced (Chen, Shao and Ibrahim, 2000). Therefore, thinning values up to 100 are recommended. For example, Jackman (1992) consider for the PN model, running half million iterations and retaining only every thousandth iteration so as to produce an approximately independent sequence of sampled values from the joint posterior density.

Chen, Shao and Ibrahim (2000) reported the slow convergence of the AlbertChib algorithm. In the mathematics data set, the convergence for the shape pa- 
rameter was found to be slow. Some algorithms to improve the convergence of the Gibbs sampler in the second data augmentation approach are proposed in the literature (see Holmes and Held, 2006). A simpler alternate considered here was to generate a great number of iterations and use large thinning values. Here we considered a total of 204,000 iterations. Starting with a burn-in of 4000 iterations and them using thinning $=100$, a sample of size 2000 is obtained. Several criteria computed using the CODA package in the WinBUGS program were used for the convergence analysis. Results are showed in Table 1.

From Table 1 on page 13, we see that all models in the skew-normal IRT family improve the corresponding symmetric probit model. Moreover, the SPSN and SPN models present the best fit for the data set by considering several criteria. Spiegelhalter et al. (2002) mention the possibility of negative values of the effective number of parameters, as we can see in Table 1 for the SPSN model. Some possible explanations for the negative values are that, the posterior distribution is extremely asymmetric or symmetric and bimodal, where the posterior mean is a poor summary statistics. Negative $\rho_{D}$ can also indicate conflicting information between prior and data. Informative prior elicitation using historical data and model sensitivity to different prior choices will be explored in subsequent studies.

One of the advantages of the proposed model is to be able to extract more information from the items, by considering a new item parameter, and more information from abilities, by considering the hyperparameter in the new specification of the prior distribution for the latent variables. Figure 3 illustrates the behavior of the item parameters estimates and Table 2 on page 15 the behavior of hyperparameters of abilities estimates for the SPSN model.

Given the high skewness observed in the posterior distribution for the shape parameters $d_{j}$, we prefer median to mean as summary measures. Moreover, a $95 \%$ credible interval for the shape parameter $\gamma$ results in negative endpoints and, hence, not containing zero, clearly indicating $\gamma$ to be different from zero, so that the PN model is not adequate for fitting this data set. Thus, while perhaps asymmetry in ICC is not justified and Normal ICC can be sufficient, asymmetry in abilities was found.

A high and positive value for the penalty parameter corresponding to item 14 (see Table 2 and Figure 3) is observed.

Figure 4(a) compares item 14 ICCs under the PN and SPSN models, clearly showing differences among them. Figure 4(b) shows that for low ability levels, the probability of a correct response with the PN model is greater than with the SPSN model and it is the opposite for high ability levels. The positive value of the $d_{14}$ implies that, for low ability levels the probability of a correct response increases faster with the SPSN than with the PN model. For instance, when $-1.5 \leq \theta \leq-0.5$, the change on the probability of a correct response with the SPSN model is 0.28 and with the PN model is 0.23 . The opposite is true, because with high levels of abilities the change in the probability of a correct response increases slower with the PN 


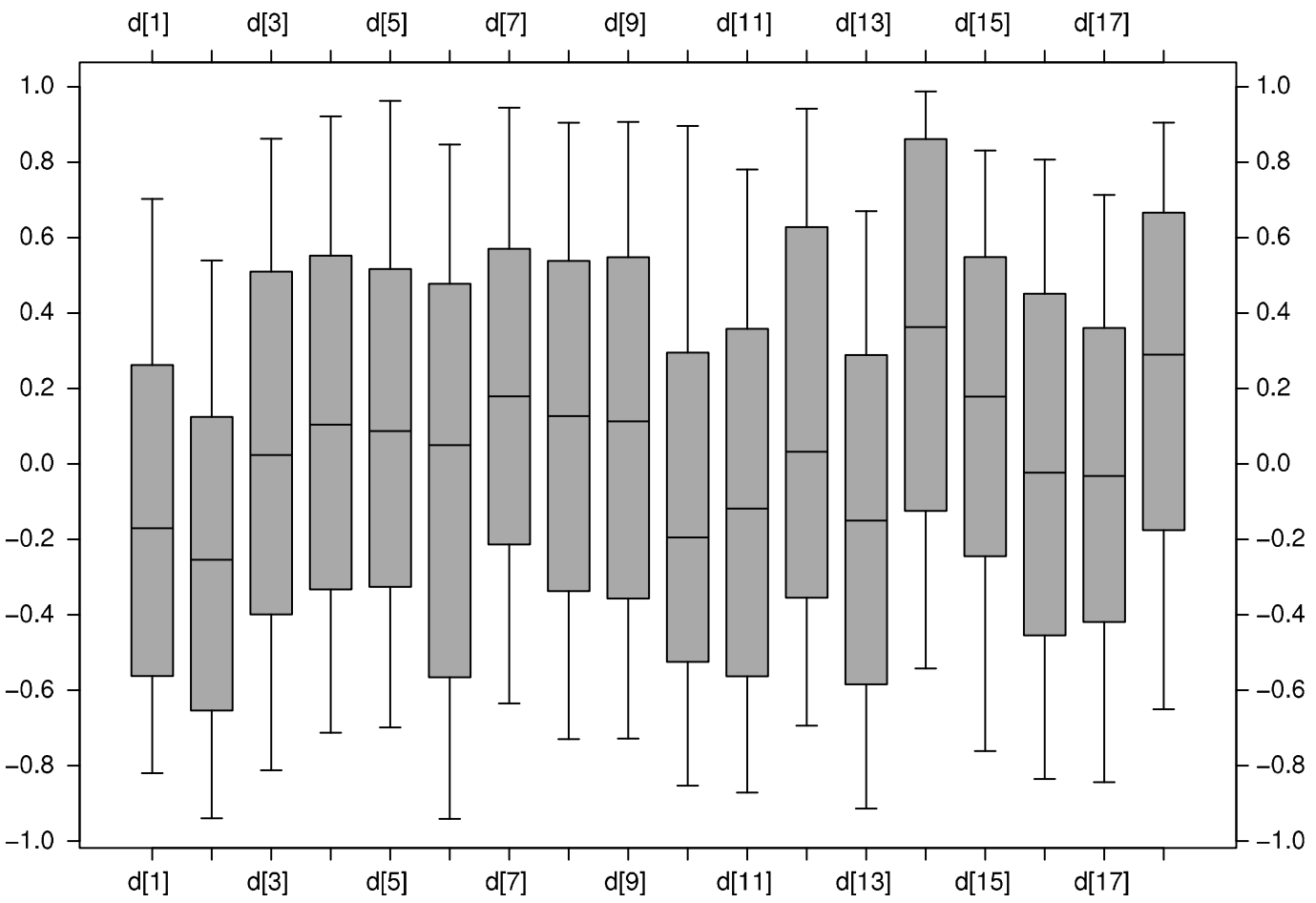

Figure 3 Box-plots for the d parameters for the 18 items of Math test under the SPSN IRT model.

Table 2 Posterior statistics for latent hyperparameters under the SPSN IRT model for the Math data set

\begin{tabular}{lrlrcc}
\hline Parameter & Mean & SD & Median & Percentil 2.5 & Percentil 97.5 \\
\hline$\gamma$ & -6.420 & 2.737 & -5.886 & -13.300 & -2.644 \\
$\mu$ & 0.554 & 0.250 & 0.557 & 0.088 & 1.044 \\
$\sigma^{2}$ & 0.739 & 0.189 & 0.721 & 0.427 & 1.169 \\
$E(\theta)$ & -1.139 & 0.3325 & -1.111 & -1.733 & -0.5968 \\
$V(\theta)$ & 0.3513 & 0.07661 & 0.3438 & 0.2273 & 0.5101 \\
\hline
\end{tabular}

model than with the SPSN model. For instance, when $1.5 \leq \theta \leq 2.0$ the change in the probability of a correct response with the PN model is 0.053 and with the SPSN model is 0.031 . Hence, we note that the PN model overestimates the probability of correct response for lower levels of mathematical ability and underestimates it for higher levels of mathematical ability. Therefore, considering the information provided by the SPSN model, item 14 rewards students with lower levels of mathematical ability and penalizes students with higher levels of mathematical ability.

By considering the estimates of the hyperparameter to the Mathematical ability in Table 2 on page 15, we found that the posterior mean and variance for the mean mathematical ability are -1.144 and 0.354 , respectively, substantially differing 


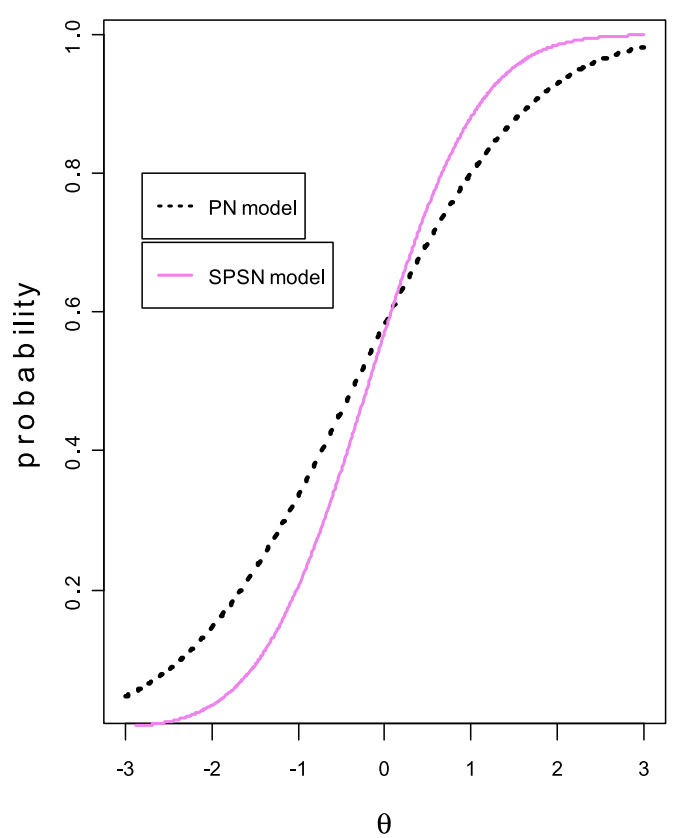

(a)

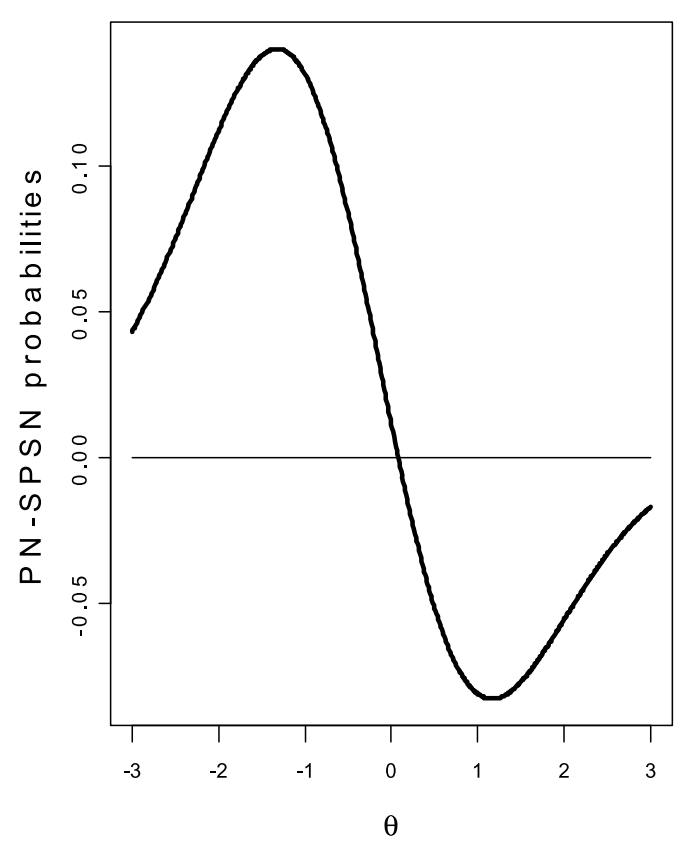

(b)

Figure 4 (a) ICCs for item 14 for the Math data set, under PN and SPSN-IRT models, (b) Differences between the PN and SPSN probabilities estimative.

from the values when considering the PN model which are assumed as 0 and 1, respectively. The values found are more in accordance with the distribution for the scores that presents a proportion mean of $0.4595(-0.0405$ with respect to an ideal proportion mean of 0.5 ) and a standard deviation of 0.2335 .

\subsection{Reading comprehension data set}

We consider an analysis on the response pattern obtained by the application of a Reading Comprehension Test in a group of seventh grade students from Peruvian elementary schools. Item response data are available from authors upon request and correspond to the response of the 297 students to 14 items qualified as binary response (correct and incorrect). The mean score is 10.28, the median 11 and the standard deviation 2.41. The sample skewness and kurtosis indexes are 0.141 and 0.537 , respectively. The test presents a median reliability index given by Cronbach's alpha equal to 0.65 , and the mean proportion for the items equal to 0.734 .

The original Reading Comprehension Test was to read four comprehension passages by 1535 students (see Chincaro, 2010). In our analysis, only items from the three first passages and students from the cities in Peruvian jungle region are considered. Items in testlet corresponds to different task with different definitions. The first testlet have 3 items, the second testlet have 6 items and, finally, the third testlet have 5 items. 
Table 3 Comparing testlet models using different criteria for the Reading Comprehension data

\begin{tabular}{lcccr}
\hline Criteria & PN & SPN & PN testlet & SPN testlet \\
\hline Number of parameters & 325 & 339 & 1513 & 1527 \\
Deviance of the posterior means & 3434.44 & 3166.29 & 3335.6 & 3138.88 \\
Posterior expected deviance & 3236.27 & 2825.55 & 3064.98 & 2852.31 \\
$\rho_{D}$ effective number of parameters & 198.17 & 340.739 & 270.63 & 286.57 \\
DIC & 3632.61 & 3507.03 & 3606.23 & 3425.45 \\
Expected AIC & 4084.44 & 3844.29 & 6361.6 & 6192.88 \\
Expected BIC & 6142.60 & 5991.11 & $15,943.11$ & $15,863.05$ \\
SSR posterior mean & 4172 & 2992 & 4167 & 3044 \\
\hline
\end{tabular}

The priors considered are $u_{i} \sim N(0,1), \gamma_{i l} \sim N\left(0, \sigma_{\gamma_{l}}^{2}\right), a_{j} \sim N(1 ; 0.5) I(0 ; \cdot)$, $b_{j} \sim N(0 ; 2), d_{j} \sim U[-1,1], 1 / \sigma_{\gamma_{k}}^{2} \sim \chi(0.5)$.

In the SNO testlet model, 42 item parameters, 297 individual traits, 891 parameters associated with testlets and 3 hyperparameters corresponding to $\sigma_{\gamma_{1}}^{2}, \sigma_{\gamma_{2}}^{2}$ and $\sigma_{\gamma_{3}}^{2}$ were estimated from the data set. The WinBUGS code is in Appendix A.2. Table 3 on page 17 shows the number of parameters in each model.

We consider 54,000 iterations, starting with a burn-in of the 4000 iterations and them using thinning equal to 25. The MCMC final sample size is 2000. Several criteria, computed using the CODA package in the WinBUGS program, were used for the convergence analysis.

We consider initial values 1,0 and 0 for the item parameters $a_{j}, b_{j}$ and $d_{j}$, respectively. Initial values for the latent variable $\theta_{i}$ and auxiliary latent variables corresponding to the different models could be by generated from the distributions specified in Section 4, however, we prefer to fix this value in 0.5 to improve the performance and stability of the developed software. From Table 3 on page 17, all criteria seem to indicate that SPN fits better than the PN IRT model and hence asymmetrical ICCs are justified. However, we found that only item 9 has a slight asymmetry with the following posterior estimates for the shape parameter: Median $=0.2975$, Percentile $5=-0.1293$ and Percentile $95=0.5662$.

For the testlet models, considering DIC and SSR, we notice that PN and SPN models present improvement. The EAIC and EBIC criteria are discarded because the number of parameters in the models with and without testlet are not comparable and inadequately penalize the deviance of the posterior mean. The SPN testlet model presents better fit for the data set than PN testlet model, by considering the four criteria. However, we found that only item 9 has a significant asymmetry with the following posterior estimates for the shape parameter: Median $=0.3016$, Percentile $5=0.03991$ and Percentile $95=0.5428$ (see Figure 5).

Finally, considering the posterior mean, the estimates for the variance of each testlet effect are 0.2992, 0.3184 and 0.3495. These results indicate a modest effect of testlet dependence for this particular data set. 


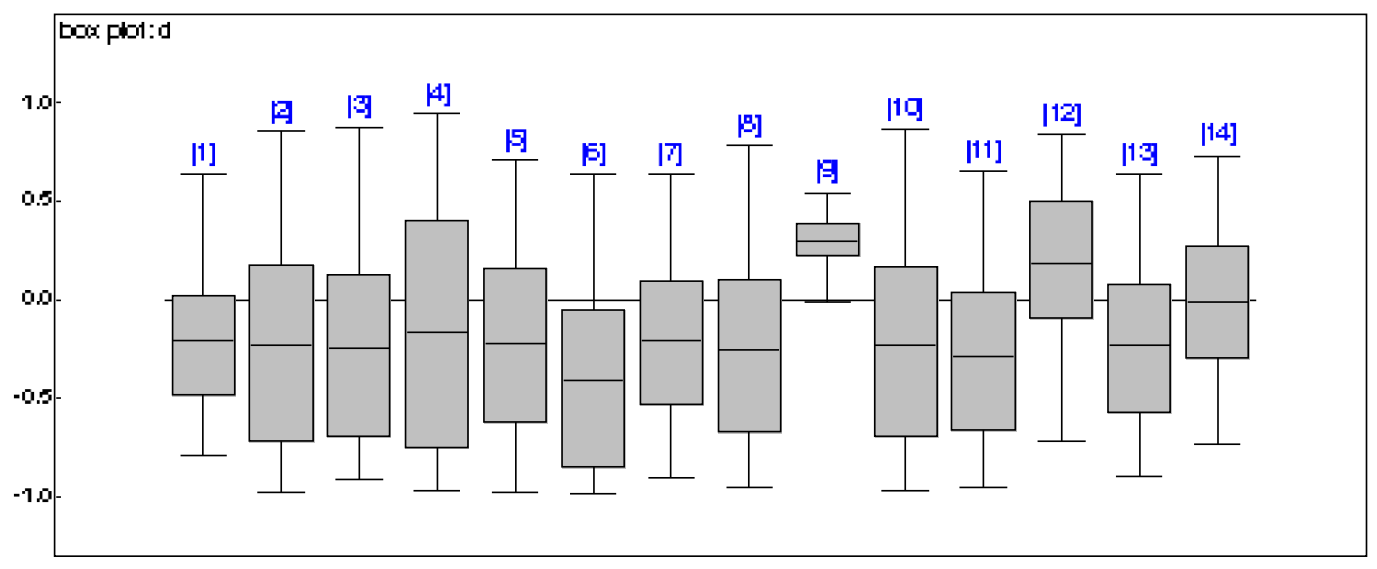

Figure 5 Box-plots for the d parameters of the 14 items of Reading Comprehension test under the skew-probit testlet IRT model.

\section{Concluding remarks}

This article introduces new applications of the skew-normal ogive IRT model proposed by Bazán, Branco and Bolfarine (2006), which extends the work of Albert (1992) for asymmetrical IRT models. Two extensions are considered for this model: the standard skew-normal distribution as prior distribution for the latent variables and the inclusion of an additional random effect for the dependence between items within the same testlet. The full Bayesian specification by considering the hierarchical structure can be easily implemented using MCMC methodology in WinBUGS or SAS.

In addition, several model comparisons procedures are used to compare the symmetrical and asymmetrical IRT models (DIC, EAIC and EBIC). We also introduce latent residuals for the models and global discrepancy measures as the posterior sum of squares of the latent residuals. All these measurements show that the SN-IRT model obtained considering combinations of both types of asymmetry presents better fit than the usual ogive normal IRT model for the observed data.

For the Math data set considered, there is clear indication that the shape parameter for the ability distributions is different from zero, indicating the usefulness of the SN-IRT model in explaining asymmetric abilities. Extensions to more general models such as SN-IRT multidimensional model, hierarchical SN-IRT model, SNIRT multilevel models will be the subject of future work. Other extensions of the skew probit link for ordinal responses, as in Johnson (2003), will also be studied in future developments.

For the Reading Comprehension data set, we showed that the version testlet of the skew-normal model, which combine both the estimation of the penalty parameter as well as the random effects associated with the testlet, improves the model fit. 
It may be interesting to study versions of skew-normal ogive models which consider Rasch type models or guessing parameter with and without testlet effect. Also extensions for Polychotomous and multidimensional Item Response Models can be studied.

\section{Appendix}

\section{A.1 The skew-normal distribution (Azzalini, 1985)}

A random variable $X$ follows a skew-normal distribution with location parameter $\mu$, scale parameter $\sigma^{2}$ and shape parameter $\lambda$, which controls skewness, if the density function of $X$ is given by

$$
f_{\lambda}(x)=\frac{2}{\sigma} \phi\left(\frac{x-\mu}{\sigma}\right) \Phi\left(\lambda\left(\frac{x-\mu}{\sigma}\right)\right) .
$$

$\phi(\cdot)$ and $\Phi(\cdot)$ denote, respectively, the density and distribution function of the standard normal distribution. We use the notation $X \sim \operatorname{SN}\left(\mu, \sigma^{2}, \lambda\right)$. The parameter $\lambda$ is also called skewness parameter, the asymmetry is positive when $\lambda>0$ and negative when $\lambda<0$. If $\lambda=0$, then the skewness vanishes and the density above reduces to the density of the $N\left(\mu, \sigma^{2}\right)$.

An alternative parametrization of the skewness parameter is given by

$$
d=\frac{\lambda}{\left(1+\lambda^{2}\right)^{1 / 2}}
$$

where $d$ is in $[-1,1]$.

The mean and variance are given, respectively, by $E(X)=\mu+\sqrt{\frac{2}{\pi}} \sigma d$ and $V(X)=\left(1-\frac{2}{\pi} d^{2}\right) \sigma^{2}$. The special case with $\mu=0$ and $\sigma^{2}=1$ is called standard skew-normal distribution. Moreover, the random variable $Z=(X-\mu) / \sigma$ is distributed according to the standard skew-normal distribution with density function given by

$$
f_{\lambda}(z)=2 \phi(z) \Phi(\lambda z)
$$

and cumulative distribution function (c.d.f.) give by

$$
F_{\lambda}(z)=\int_{-\infty}^{z} 2 \phi(t) \Phi(\lambda t) d t=2 \Phi_{2}\left((z, 0)^{T} ; 0, \Omega\right) .
$$

Straightforward algebraic manipulations yield the expression on the right (see Bazán, Branco and Bolfarine, 2006) with $\Phi_{2}(\cdot)$ denoting the distribution function of the bivariate standard normal distribution with mean vector $\mathbf{0}=(0,0)^{T}$ and correlation matrix $\Omega=\left(\begin{array}{cc}1 & -d \\ -d & 1\end{array}\right)$ where $d$ is given by (A.1).

Considering the stochastic representation (see Henze, 1986), the conditional distribution $Z \mid V=v$ is normal with mean $d v$ and variance $1-d^{2}$, that is, $Z \mid V=v \sim N\left(d v, 1-d^{2}\right)$. In addition, if $Z \sim \mathrm{SN}\left(\mu, \sigma^{2}, \lambda\right)$ then $Z s=a Z+b \sim$ $\mathrm{SN}\left(a \mu+b, a^{2} \sigma^{2}, \operatorname{sign}(a) \lambda\right)$. 


\section{A.2 Code in WinBUGS for testlet model}

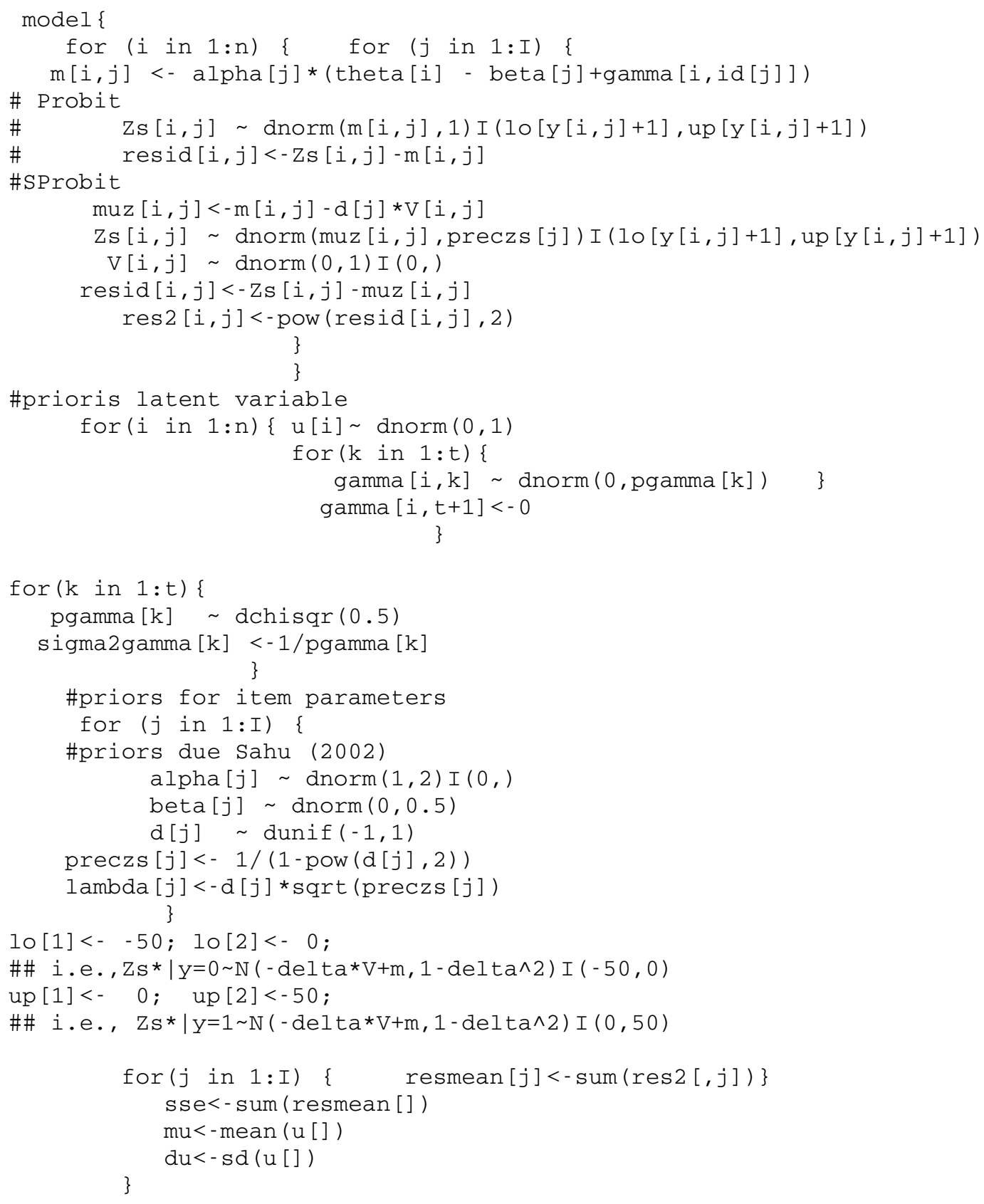

\section{Acknowledgments}

Jorge Luis Bazán was supported by DGI PUCP 2011-0173 and FAPESP 2009/ 50105-8, for which we are duly grateful. This work was completed while the first author was a visiting research fellow at the University of Sao Paulo under supervision of Márcia Branco. 


\section{References}

Albert, J. H. (1992). Bayesian estimation of normal ogive item response curves using Gibbs sampling. Journal of Educational Statistics 17, 251-269.

Albert, J. H. and Chib, S. (1995). Bayesian residual analysis for binary response regression models. Biometrika 82, 747-759. MR1380812

Albert, J. H. and Ghosh, M. (2000). Item response modeling. In Generalized Linear Models: A Bayesian Perspective (D. K. Dey, S. K. Ghosh and B. F. Mallick, eds.) 173-193. New York: Marcel Dekker. MR1893789

Arellano-Valle, R. B., Branco, M. D. and Genton, M. G. (2006). A unified view on skewed distributions arising from selections. The Canadian Journal of Statistics 34, 581-601. MR2347047

Azzalini A. (1985). A class of distributions which includes the normal ones. Scandinavian Journal Statistical 12, 171-178. MR0808153

Azevedo, C. L. N., Bolfarine, H. and Andrade, D. F. (2010). Bayesian inference for a skew-normal IRT model under the centred parameterization. Computational Statistics and Data Analysis $\mathbf{5 5}$, 353-365. MR2736560

Baker, F. B. and Kim, S.-H. (2004). Item Response Theory_Parameter Estimation Techniques, 2nd ed. New York: Marcel Dekker. MR2086862

Bazán, J. L., Branco, D. M. and Bolfarine, H. (2006). A skew item response model. Bayesian Analysis 1, 861-892. MR2282209

Bazán, J. L., Bolfarine, H. and Branco, D. M. (2004). A new family of asymmetric models for item response theory: A Skew-Normal IRT Family. Technical report RT-MAE-2004-17, Dept. Statistics, Univ. São Paulo.

Bazán, J. L., Bolfarine, H. and Branco, D. M. (2010). A framework for skew-probit links in Binary regression. Communications in Statistics-Theory and Methods 39, 678-697. MR2745312

Bolfarine, H. and Bazán, J. L. (2010). Bayesian estimation of the logistic positive exponent IRT model. Journal of Educational Behavioral Statistics 35, 693-713.

Bradlow, E., Wainer, H. and X. Wang (1999). A Bayesian random effect model for testlets. Psychometrika 64, 153-168.

Brooks, S. P. (2002). Discussion on "Bayesian measures of model complexity and fit" by Spiegelhalter, Best, Carlin and van der Linde (2002). Journal of the Royal Statistical Society, Ser. B 64 , 616-618.

Camilli G. (1994). Origin of the scaling constant $d=1.7$ in item response theory. Journal of Educational and Behavioral Statistics 19, 293-295.

Carlin, B. P. and Louis, T. A. (2000). Bayes and Empirical Bayes Methods for Data Analysis, 2nd ed. Boca Raton, FL: Chapman \& Hall.

Chen, M. H., Shao, Q. M. and Ibrahim, J. G. (2000). Monte Carlo Methods in Bayesian Computation. New York: Springer-Verlag. MR1742311

Chincaro, O. (2010). Dichotomous Rasch model with application to education. M.Sc. thesis, Pontificia Universidad Católica del Perú (in Spanish).

Duncan, K. and MacEachern, S. (2008). Nonparametric Bayesian modelling for item response. Statistical Modeling 8, 41-66. MR2750630

Ghosh, M., Ghosh, A., Chen, M.-H. and Agresti, A. (2000). Noninformative priors for one parameter item response models. Journal of Statistical Planning and Inference 88, 99-115. MR1767562

Hashimoto, Y. (2002). Motivation and willingness to communicate as predictors of reported 12 use: The Japanese ESL context. Second Language Studies 20, 29-70.

Holland, P. and Rosenbaum, P. (1986). Conditional association and unidimensionality in monotone latent variable models. The Annals of Statistics 14, 1523-1543. MR0868316

Henze, N. (1986). A probabilistic representation of the "skew-normal" distribution. Scandinavian Journal Statistical 13, 271-275. MR0886466 
Holmes, C. and Held, L. (2006). Bayesian auxiliary variable models for binary and multinomial regression. Bayesian Analysis 1, 145-168. MR2227368

Jackman, S. (2004). Bayesian analysis for political research. Annual Review of Political Science 7, 483-505.

Johnson, T. (2003). On the use of heterogeneous thresholds ordinal regression models to account for individual differences in response style. Psychometrika 68, 563-583. MR2272428

Junker, B. W. and Ellis, J. L. (1997). A characterization of monotone unidimensional latent variable models. The Annals of Statistics 25, 1327-1343. MR1447754

Lunn, D. J., Thomas, A., Best, N. and Spiegelhalter, D. (2000). WinBUGS-A Bayesian modelling framework: Concepts, structure, and extensibility. Statistics and Computing 10, 325-337.

Micceri, T. (1989). The unicorn, the normal curve, and other improbable creatures. Psychological Bulletin 105, 156-166.

Patz, R. J. and Junker, B. W. (1999). A straightforward approach to Markov chain Monte Carlo methods for item response models. Journal of Educational and Behavioral Statistics 24, 146178.

Poleto, F. Z., Paulino, C. D., Molenberghs, G. and Singer, J. M. (2011). Inferential implications of over-parametrization: A case study in incomplete categorical data. International Statistical Review 79, 92-113.

Rannala, B. (2002). Identifiability of parameters in MCMC Bayesian inference of phylogeny. Systematic Biology 51, 754-760.

Riddle, A. S., Blais, M. R. and Hess, U. (2002). A multi-group investigation of the CES-D's measurement structure across adolescents, young adults and middle-aged adults. Scientific Series 2002s-36, Centre Interuniversitaire de recherche eit analysis des organizations, Montreal.

Rupp, A., Dey, D. K. and Zumbo, B. (2004). To Bayes or not to Bayes, from whether to when: Applications of Bayesian methodology to item response modeling. Structural Equations Modeling 11, 424-451. MR2061898

Sahu, S. K. (2002). Bayesian estimation and model choice in item response models. Journal of Statistical Computation and Simulation 72, 217-232. MR1909259

Samejima, F. (1997). Departure from normal assumptions: A promise for future psychometrics with substantive mathematical modeling. Psychometrika 62, 471-493.

Samejima, F. (2000). Logistic positive exponent family of models: Virtue of asymmetric item characteristics curves. Psychometrika 65, 319-335.

SAS Institute Inc. (2009). The MCMC Procedure, SAS/STAT Help Documentation. Cary, NC: SAS Institute Inc.

Spiegelhalter, D. J., Best, N. G., Carlin, B. P. and van der Linde, A. (2002). Bayesian measures of model complexity and fit. Journal of the Royal Statistical Society, Ser. B 64, 583-639. MR1979380

Tuerlinckx, F. and De Boeck, P. (2001). The effects of ignoring item interactions on the estimated discrimination parameters in item response theory. Psychological Methods 6, 181-195.

Wainer H. and Kiely, G. L. (1987). Item clusters and computerized adaptive testing: A case for testlets. Journal of Educational Measurement 24, 185-201.

Wainer, H. and Wang, X. (2000). Using a new statistical model for testlets to score TOEFL. Journal of Educational Measurement 37, 203-220.

Wainer, H., Bradlow, E. T. and Wang, X., eds. (2007). Testlet Response Theory and Its Applications. New York: Cambridge Univ. Press.

Wainer, H., Brown, L. M., Bradlow, E. T., Wang, X., Skorupski, W. P., Boulet, J. and Mislevy, R. J. (2006). An application of testlet response theory in the scoring of a complex certification examination. In Automated Scoring of Complex Tasks in Computer Based Testing (D. M. Williamson, R. J. Mislevy and I. I. Bejar, eds.) Chapter 6, 169-200. Hillsadle, NJ: Lawrence Erlbaum Associates. 
Wang, X., Baldwin, S., Wainer, H., Bradlow, E. T., Reeve, B. B., Smith, A. W., Bellizzi, K. M. and Baumgartner, K. B. (2010). Using testlet response theory to analyze data from a survey of attitude change among breast cancer survivors. Statistics in Medicine 29, 2028-2044. MR2758445

Wang, W.-C. and Wilson, M. (2005). The Rasch testlet model. Applied Psychological Measurement 29, 126-149. MR2113223

Zaider, T. I., Heimberg, R. G., Fresco, D. M., Schneier, F. R. and Liebowitz, M. R. (2003). Evaluation of the Clinical Global Impression Scale among individuals with social anxiety disorder. Psychological Medicine 33, 611-622.

J. L. Bazán

Departamento de Ciencias

Pontificia Universidad Católica del Perú

Av. Universitaria 1801

San Miguel, Lima

Lima 32

Peru

URL: http://argos.pucp.edu.pe/ jlbazan/principal.html

E-mail: jlbazan@ pucp.edu.pe
M. D. Branco

H. Bolfarine

Departamento de Estatística

Universidade de São Paulo

Rua do Matão, 1010 - Cidade Universitária - São Paulo SP - Brasil CEP 05508-090

Brasil

E-mail: mbranco@ime.usp.br hbolfar@ime.usp.br 


\section{Apêndice G}

da Paz, R. F., Bazán, J. L., e Milan, L. A. (2015). Bayesian estimation for mixture of simplex distribution with unknown number of components: Hdi analysis in brazil. Technical

Report 261, Programa Interinstitucional de Pós-Graduaçåo em Estatística UFSCar-USP, Såo Carlos, SP. Brazil. 
PROGRAMA INTERINSTITUCIONAL DE PÓS-GRADUAÇÃO EM ESTATÍSTICA UFSCar-USP

\section{DEs-UFSCar e SME-ICMC-USP}

BAYESIAN ESTIMATION FOR MIXTURE OF SIMPLEX DISTRIBUTION WITH UNKNOWN NUMBER OF COMPONENTS: HDI ANALYSIS IN BRAZIL

Rosineide F. da Paz Jorge Luis Bazán Luis Aparecido Milan

\section{RELATÓRIO TÉCNICO}

\section{TEORIA E MÉTODO - SÉRIE A}

Junho/2015

$$
\text { no } 261
$$


Bayesian Estimation for Mixture of Simplex Distribution with Unknown Number of Components: HDI Analysis in Brazil

\author{
Rosineide F. da Paz ${ }^{1,2,3}$, Jorge Luis Bazán ${ }^{1}$, Luis Aparecido Milan² \\ Universidade de São Paulo, Instituto de Ciências Matemáticas e de Computação, São Carlos-SP, Brazil. ${ }^{1}$ \\ Universidade Federal de São Carlos, Departamento de Estatística, São Carlos-SP, Brazil ${ }^{2}$ \\ E-mail: rfpaz@icmc.usp.br ${ }^{3}$
}

\begin{abstract}
Variable taking value on $(0,1)$, such as rates or proportions, are frequently analysed by researchers, for instance, political and social data as well as Human Development Index. However, sometime this type of data cannot be modelled adequately using a unique distribution. In this case, we can use a mixture of distribution that is a powerful and flexible probabilistic tool. This manuscript deals with a mixture of simplex distribution for model proportional data. A Full Bayesian approach is considered in the inference process with Reversible-jump Markov Chain Monte Carlo method. The usefulness of the proposed approach is confirmed by use of the simulated mixture data from several different scenarios and through an application of the methodology to analyses municipal Human Development Index data of the cities (or towns) of the Northeast region and São Paulo state in Brazil.
\end{abstract}

Key words: Bayesian Analysis, Markov chain Monte Carlo, Mixture model, Simplex distribution, Human development index.

\title{
1 Introduction
}

Variable taking values on $(0,1)$, such as index and proportions, are frequently analysed by researchers, for instance, Impartial Anonymous Culture (Stensholt, 1999) and the Human Development 
Index (HDI) (McDonald \& Ransom, 2008; Cifuentes et al., 2008). Sometimes, the data cannot be modelled adequately using a unique distribution as is the case of the proportion of votes obtained by a political party in Presidential Elections in each cities of an country analysed in (Paz et al., 2015). In addition, in the data of HDI of several regions in Brazil different components can be identified, see index in Fundação Instituto Brasileiro de Geografia e Estatística (2014).

The models with mixture of distributions can be a powerful and flexible probabilistic tool for modelling many kind of the data, see for example McLachlan \& Peel (2004). In financial data we can cite Faria \& Gonalves (2013). In addition, mixture of distributions have been widely analysed for normal data, see for example Tanner \& Wong (1987); Gelfand \& Smith (1990); Diebolt \& Robert (1994); Richardson \& Green (1997). For data in $(0,1)$ there are some works which consider a finite mixture of Beta distributions (Bouguila et al., 2006; Bouguila \& Elguebaly, 2012). However there are in the literature other distributions which take values on $(0,1)$, such as simplex distribution, for instance. The simplex distribution was proposed by Barndorff-Nielsen \& Jorgensen (1991) and recently has been considered as a complementary and alternative regression model to the beta regression model (López, 2013; Song \& Tan, 2000).

This manuscript deals with a new framework for modelling the bounded variables with multimodality as a complementary model to the correspondent beta model. The model proposed considerer a mixture of simplex distribution with the number of components unknown (simplex mixture model). This work is motivated by the municipal HDI data in Brazil. Thus, at present we focus on the identification of the numbers of components and the characteristics of each population identified by the model considering the HDI of the cities of São Paulo state and Northeast region of Brazil. For the inference process a fully Bayesian analysis is assumed where the unknown number of components and the parameters should be regarded as drawn from appropriate prior distribution. For dealing with the problem of estimating the number of components of the mixture model we adopt a reversible-jump Markov chain Monte Carlo (RJMCMC) approach proposed, in the case of mixture of normal distributions, by Green (1995) and Richardson \& Green (1997). The results obtained are promising since 
that the performance of the method is tested by applying it to simulated data sets from mixture of simplex distributions, considering several different scenarios.

In future developments we can consider that the phenomenon can be explained by sociological and economical factors which should be included. In addition the response variable might be associated considering geospatial information as potential covariates.

The remainder of the manuscript is organized as follows: The Section 2 is dedicated to give a description of general mixture model. In Section 3 we present the mixture of simplex distributions. Section 4 addresses the Bayesian Inference approach considering estimation RJMCMC. The Section 5 is dedicate to investigate if our algorithm is able to estimate the mixture parameters and select the number of components considering several scenarios of generated data. In the Section 6 we present an analysis of the municipal HDI data set considered show that are strong evidence for two component of cities we found that some cities in the Northeast region of Brazil show HDI similar to cities of the Paulo state. Finally, some conclusions are drawn in Section 7 .

\section{The general mixture model}

Finite mixture of distributions is a flexible method of modelling. Its more direct role in data analysis and inference is to provide a convenient and flexible family of distributions to estimate or approximate distributions which are not well modelled by any standard parametric family. This type of model is useful in the modelling of data from a heterogeneous population, that is, a population which can be divided in clusters or components. In this sense, the components in the data can be modelled for uni-modal distributions. For more details about modelling and applications of finite mixture models, see for example McLachlan \& Peel (2000).

Consider initially a sequence of $n$ continuous random variables $\boldsymbol{Y}=\left(Y_{1}, \ldots, Y_{n}\right)$ each following a distribution with probability density function (pdf) $f_{i}\left(. \mid \theta_{i}\right)$ for $i=1, \ldots, n$. Now suppose that $f_{i}\left(. \mid \theta_{i}\right)=f_{j}\left(. \mid \theta_{j}\right)$ for some $i$ 's where $j=1, . ., k$ with $1 \leqslant k \leqslant n$. Thus, a random variable $Y \in \boldsymbol{Y}$ is 
said to follow a mixture of distributions with $k$ components and its probability density function (pdf) can be write as

$$
f(y \mid \boldsymbol{\theta}, \boldsymbol{\omega}, k)=\sum_{j=1}^{k} \omega_{j} f_{j}\left(y \mid \boldsymbol{\theta}_{j}\right)
$$

where each $f_{j}\left(y \mid \boldsymbol{\theta}_{j}\right)$ is a pdf called component density of the mixture, indexed by a parameter vector $\boldsymbol{\theta}_{j}$ (here we write $f\left(y \mid \boldsymbol{\theta}_{j}\right)$ without the index $j$ because the component density belong to the same parametric family $), \boldsymbol{\theta}=\left(\theta_{1}, \ldots, \theta_{k}\right)$ is a vector containing all the parameters of the components in the mixture and the components of the vector $\boldsymbol{\omega}=\left(\omega_{1}, \ldots, \omega_{k}\right)$ are called weights of the mixture where $0<\omega_{j}<1$ with $\sum_{j=1}^{k} \omega_{j}=1$. In the equation (1) $k$ is the number of components in the mixture. We call the model defined by the pdf in (1) mixture model, whose distribution is called mixtures of distributions. For a review on exwhoseisting techniques for Bayesian modelling and inference on mixtures of distributions, see for example Marin et al. (2005).

In order to make inference about the parameters of the mixture model, suppose $\boldsymbol{Y}=$ $\left(Y_{1}, \ldots, Y_{n}\right)$ a random sample from the distribution defined by equation (1). The likelihood function related to a sample $\boldsymbol{y}=\left(y_{1}, \ldots, y_{n}\right)$, where each $y_{i}$ is a observation of $Y_{i}$ for $i=1, \ldots, n$, is given by

$$
L(\boldsymbol{\theta}, \boldsymbol{\omega}, k \mid \boldsymbol{y})=\prod_{i=1}^{n} \sum_{j=1}^{k} \omega_{j} f\left(y_{i} \mid \theta_{j}\right) .
$$

A way to simplify the inference process of mixture model is to consider a unobserved random vector $Z_{i}=\left(Z_{i 1}, \ldots, Z_{i k}\right)$ such that $Z_{i j}=1$ if the $i$ th observation is from the $j$ th mixture component and $Z_{i j}=0$ otherwise, $i=1, \ldots, n$. Note that $\sum_{j=1}^{k} Z_{i j}=1$ then we suppose each random vector $Z_{1}, . ., Z_{n}$ is distributed according to the multinomial distribution with parameters 1 and $\boldsymbol{\omega}=\left(\omega_{1}, \ldots, \omega_{k}\right)=$ $\left(P\left(Z_{i 1}=1 \mid \omega, k\right), \ldots, P\left(Z_{i k}=1 \mid \omega, k\right)\right)$, for $i=1, \ldots, n$. Then

$$
P\left(Z_{i j}=1 \mid y_{i}, \theta_{j}, \omega, k\right) \propto P\left(Z_{i j}=1 \mid \boldsymbol{\omega}, k\right) f\left(y_{i} \mid Z_{i j}=1, \theta_{j}, \boldsymbol{\omega}, k\right),
$$

$j=1, \ldots, k, i=1, \ldots, n$. To simplify the notation we consider $\mathbf{Z}=\left(Z_{1}, \ldots, Z_{n}\right)$ an vector $n k$ containing all the unobserved indicator vectors $Z_{i}$. Note that the distribution of each $Y_{i}$ given $Z_{i}$ has pdf given 
by

$$
f\left(y_{i} \mid Z_{i}, \boldsymbol{\theta}, k\right)=\prod_{j=1}^{k}\left[f\left(y_{i} \mid \theta_{j}\right)\right]^{Z_{i j}}
$$

then the joint distribution of $\left(Y_{i}, Z_{i}\right)$ can be written as

$$
f\left(y_{i}, Z_{i} \mid \boldsymbol{\theta}, \boldsymbol{\omega}, k\right)=P\left(Z_{i} \mid \boldsymbol{\omega}, k\right) f\left(y_{i} \mid Z_{i}, \boldsymbol{\theta}, k\right)=\prod_{j=1}^{k}\left[\omega_{j} f\left(y_{i} \mid \theta_{j}\right)\right]^{Z_{i j}}
$$

Note that, the vector $Z_{i}$ have just one component equal to 1 and the others equal to zero then

$$
\prod_{j=1}^{k}\left[\omega_{j} f\left(y_{i} \mid \theta_{j}\right)\right]^{Z_{i j}}=\left\{\begin{array}{cc}
\omega_{1} f\left(y_{i} \mid \theta_{1}\right) & \text { if } Z_{i}=(1,0, \ldots, 0) \\
\omega_{2} f\left(y_{i} \mid \theta_{2}\right) & \text { if } Z_{i}=(0,1, \ldots, 0) \\
\vdots & \vdots \\
\omega_{k} f\left(y_{i} \mid \theta_{k}\right) & \text { if } Z_{i}=(0,0, \ldots, 1)
\end{array}\right.
$$

thus,

$$
f\left(y_{i} \mid \boldsymbol{\theta}, \boldsymbol{\omega}, k\right)=\sum_{Z_{i}} f\left(y_{i}, Z_{i} \mid \boldsymbol{\theta}, \boldsymbol{\omega}, k\right)=\sum_{j=1}^{k} \omega_{j} f\left(y_{i} \mid \theta_{j}\right) .
$$

After the inclusion of the indicator vectors in the model, the augmented data likelihood to $(\boldsymbol{y}, \mathbf{Z})$ can be written as

$$
L(\boldsymbol{\theta}, \boldsymbol{\omega}, k \mid \boldsymbol{y}, \boldsymbol{Z})=\prod_{i=1}^{n} \prod_{j=1}^{k}\left[\omega_{j} f\left(y_{i} \mid \theta_{j}\right)\right]^{Z_{i j}}
$$

Finally, the joint distribution of all variables of the model including the augmented version and the prior specifications is

$$
P(\boldsymbol{y}, \boldsymbol{\theta}, \boldsymbol{Z}, \boldsymbol{\omega}, k)=f(\boldsymbol{y} \mid \boldsymbol{\theta}, \mathbf{Z}, \boldsymbol{\omega}, k) P(\boldsymbol{\theta} \mid \mathbf{Z}, \boldsymbol{\omega}, k) P(\mathbf{Z} \mid \boldsymbol{\omega}, k) P(\boldsymbol{\omega} \mid k) P(k) .
$$

Here, we assume conditional independence such that

$$
P(\boldsymbol{\theta} \mid \mathbf{Z}, \boldsymbol{\omega}, k)=P(\boldsymbol{\theta} \mid \mathbf{Z}, k) \text { and } P(\mathbf{y} \mid \boldsymbol{\theta}, \mathbf{Z}, \boldsymbol{\omega}, k)=P(\mathbf{y} \mid \boldsymbol{\theta}, \mathbf{Z})
$$

to obtain

$$
P(\mathbf{y}, \boldsymbol{\theta}, \mathbf{Z}, \boldsymbol{\omega}, k)=P(\mathbf{y} \mid \boldsymbol{\theta}, \mathbf{Z}) P(\boldsymbol{\theta} \mid \mathbf{Z}, k) P(\mathbf{Z} \mid \boldsymbol{\omega}, k) P(\boldsymbol{\omega} \mid k) P(k),
$$

where $P(\mathbf{Z} \mid \boldsymbol{\omega}, k)=\prod_{i=1}^{n} P\left(Z_{i} \mid \boldsymbol{\omega}, k\right)=\prod_{i=1}^{n}\left(\prod_{j=1}^{k} \omega_{j}^{Z_{i j}}\right)$. 


\section{Simplex Mixture Distribution}

Now consider a sequence of $n$ continuous random variables $\boldsymbol{Y}$ where each $Y \in \boldsymbol{Y}$ assume values in $(0,1)$ and follow the distribution whose pdf is given by (1). Let consider that the component densities, $f_{j}\left(. \mid \theta_{j}\right)$ for $j=1, \ldots, k$, are taken to belong the simplex distribution (Jørgensen, 1997), whose pdf is given by

$$
S\left(y \mid \mu, \sigma^{2}\right)=\left(2 \pi \sigma^{2}(y(1-y))^{3}\right)^{-1 / 2} \exp \left\{-\left(\frac{1}{2 \sigma^{2}}\right)\left(\frac{(y-\mu)^{2}}{y(1-y) \mu^{2}(1-\mu)^{2}}\right)\right\} I_{(0,1)}(y),
$$

where $0<\mu<1$ is the location parameter and $\sigma^{2}>0$ is the dispersion parameter. The mean of simplex distribution is given by $E(Y)=\mu$. Since the components density $f_{j}\left(. \mid \theta_{j}\right)$ are taken to belong to the simplex family, we shall refer the component density in the mixture as simplex component, the model given by (1) as Simplex Mixture (SM) and to rewrite its pdf as

$$
P(y \mid \boldsymbol{\theta}, \boldsymbol{\omega}, k)=\sum_{j=1}^{k} \omega_{j} S\left(y \mid \mu_{j}, \sigma_{j}^{2}\right)
$$

where $\boldsymbol{\theta}=\left(\theta_{1}, \ldots, \theta_{k}\right)$ with each $\theta_{j}=\left(\mu_{j}, \sigma_{j}^{2}\right)$

\section{Inference}

Consider $\mathbf{y}=\left(y_{1}, . ., y_{n}\right)$ a realization of $\mathbf{Y}$ where $y_{i}$ is the observed value of the $Y_{i}$, for $i=1, \ldots, n$, then the likelihood corresponding to a SM model with k-component is given by

$$
L(\boldsymbol{\theta}, \boldsymbol{\omega}, k \mid \mathbf{y})=\prod_{i=1}^{n} \sum_{j=1}^{k} w_{j} S\left(y_{i} \mid \mu_{j}, \sigma_{j}^{2}\right) .
$$

Thus, the augmented data likelihood to $(\mathbf{y}, \mathbf{Z})$ can be written as

$$
L(\boldsymbol{\theta}, \boldsymbol{\omega}, k \mid \mathbf{y}, \mathbf{Z})=\prod_{i=1}^{n} \prod_{j=1}^{k}\left[\omega_{j} S\left(y_{i} \mid \mu_{j}, \sigma_{j}^{2}\right)\right]^{Z_{i j}} .
$$

The representation of a mixture model, presented in this thesis, precludes the use of improper prior. This is because improper prior lead to improper posterior when some the component became empty. We define the prior, which we suppose that are all drawn independently since that is a common assumption taken generally when defining Bayesian models. For the distribution of $P(\boldsymbol{\theta} \mid k)$ consider 
$\phi_{j}=\sigma_{j}^{-2}$, then for the parameters $\theta_{j}=\left(\mu_{j}, \phi_{j}\right)$ given $k$ we assume the following independent prior

$$
\mu_{j} \mid k \sim \operatorname{Uniform}(0,1) \text { and } \phi_{j} \mid k \sim \operatorname{Gamma}(a, b), \quad j=1, \ldots, k,
$$

where the hyperparameters $a$ and $b$ are fixed.

Also, for $P(\boldsymbol{\omega} \mid k)$ since the vector of weights $\boldsymbol{\omega}$ is defined on the simplex $\left\{\boldsymbol{\omega} \in \mathbb{R}^{k}: 0<\right.$ $\left.\omega_{j}<1, j=1, \ldots, k, \sum_{j=1}^{k} \omega_{j}=1\right\}$ we consider a Dirichlet prior distribution for $\boldsymbol{\omega}$ given $k$, that is $\boldsymbol{\omega} \mid k \sim \operatorname{Dirichlet}\left(\nu_{1}, \ldots, \nu_{k}\right)$. Finally, for $P(k)$, that is to the parameter $k$ we adopt a uniform distribution between 1 and $k_{\max }$.

Therefore, the full conditional posterior distributions can be obtained and consequently a Markov chain Monte Carlo method (MCMC) (Ross, 2006, pages, 245 - 271) can be used to sample from the joint probability distribution of the parameters $(\boldsymbol{\theta}, \boldsymbol{\omega}, k)$, given the observed data $\mathbf{y}, \mathbf{Z}$. Then the sample of the joint posterior distribution produced by MCMC is used for Bayesian inference.

The full conditional distributions of the parameters for $j$ th components as given by

$$
\begin{aligned}
& P\left(\phi_{j} \mid \mathbf{y}, \mathbf{Z}, \mu_{j}\right) \quad \propto \quad \phi_{j}^{n_{j} / 2+a-1} \exp \left\{-\phi_{j}\left(\sum_{i \in\left\{i: Z_{i j}=1\right\}} \frac{\left(y_{i}-\mu_{j}\right)^{2}}{2 y_{i}\left(1-y_{i}\right) \mu_{j}^{2}\left(1-\mu_{j}\right)^{2}}+b\right)\right\} \\
& P\left(\mu_{j} \mid \mathbf{y}, \mathbf{Z}, \phi_{j}\right) \propto \exp \left\{-\frac{\phi_{j}}{2 \mu_{j}^{2}\left(1-\mu_{j}\right)^{2}} \sum_{i \in\left\{i: Z_{i j}=1\right\}}\left(\frac{\left(y_{i}-\mu_{j}\right)^{2}}{y_{i}\left(1-y_{i}\right)}\right)\right\},
\end{aligned}
$$

where $n_{j}=\sum_{i=1}^{n} Z_{i j}$ denotes the number of observations drawn from a $j$ th component of the mixture. Note that $\left(\phi_{j} \mid \mathbf{y}, Z, \mu_{j}\right) \sim \operatorname{Gamma}\left(n_{j} / 2+a, \sum_{i \in\left\{i: Z_{i j}=1\right\}} \frac{\left(y_{i}-\mu_{j}\right)^{2}}{2 y_{i}\left(1-y_{i}\right) \mu_{j}^{2}\left(1-\mu_{j}\right)^{2}}+b\right) . \quad$ In addition, the full conditional density of $\boldsymbol{\omega}$ is

$$
P(\boldsymbol{\omega} \mid \mathbf{y}, \mathbf{Z}) \propto \prod_{j=1}^{k} \omega_{j}^{\nu_{j}+n_{j}-1},
$$

that is the pdf of a Dirichlet distribution, that is, $(\boldsymbol{\omega} \mid \mathbf{y}, Z) \sim \operatorname{Dirichlet}\left(\nu_{1}+n_{1}, \ldots, \nu_{k}+n_{k}\right)$.

The parameter $k$ is estimated by use the reversible-jump step, which is described in details in the Subsection 4.1. A step by step description of the whole algorithm specific to simulate this distributions is given in Appendix A.1. 


\subsection{Reversible-jump for the number of component in the mixture}

Reversible-jump MCMC was introduced by Green (1995) as an extension to MCMC in which the dimension or number of components of the model is uncertain and need to be estimated. The move in the RJ step, called split-combine moves, allow to increases or reduces the number of components by one in each step. In each move, the reversible-jump compare two models with different number of simplex components.

The split-combine move form a reversible pair. For these pair, we choosing the proposal distribution $T_{k \rightarrow k^{*}}$ according to informal considerations in order to obtain a reasonable probability of acceptance. The notation $T_{k \rightarrow k^{*}}$ means proposal transition function for the move of model with $k$ simplex component to model with $k^{*}$ simplex component. This move is chosen with probability $p_{k^{*} \mid k}$. Since the parametric space of parameters $(\boldsymbol{\theta}, \boldsymbol{\omega}, k)$ is different from $\left(\boldsymbol{\theta}^{*}, \boldsymbol{\omega}^{*}, k^{*}\right)$, the smaller parameter

space should be increased. We generate a three-dimensional random vector $\mathbf{u}$ from a $g(\mathbf{u})$ to complete the parameters space. Green (1995) show that the balance condition is determined by the acceptance probability to this move given by $\alpha\left(\left(\boldsymbol{\theta}^{*}, \boldsymbol{\omega}^{*}, k^{*}\right) \mid(\boldsymbol{\theta}, \boldsymbol{\omega}, k)\right)=\min \{1, A\}$ where

$$
A=\frac{L\left(\left(\boldsymbol{\theta}^{*}, \boldsymbol{\omega}^{*}, k^{*}\right) \mid \mathbf{y}, Z\right) P\left(\left(\boldsymbol{\theta}^{*}, \boldsymbol{\omega}^{*}\right) \mid k^{*}\right) P\left(k^{*}\right) p_{k \mid k^{*}}}{L((\boldsymbol{\theta}, \boldsymbol{\omega}, k) \mid \mathbf{y}, Z) P((\boldsymbol{\theta}, \boldsymbol{\omega}) \mid k) P(k) p_{k^{*} \mid k} g(\mathbf{u})}|J|
$$

where $J$ is the Jacobian of transformation. The probability of the inverse of move is given by $\alpha\left((\boldsymbol{\theta}, \boldsymbol{\omega}, k) \mid\left(\boldsymbol{\theta}^{*}, \boldsymbol{\omega}^{*}, k^{*}\right)\right)=\min \left\{1, A^{-1}\right\}$.

The choice between split or combine move is made randomly with probability $b_{k}$ and $d_{k}=$ $1-b_{k}$ respectively, depending on $k$. Note that $d_{1}=0$ and $b_{k_{\max }}=0$ with $k_{\max }$ being a constant representing the maximum value allowed for $k$, as seen in the previous subsection. If $2<k<k_{\max }$ we adopt $b_{k}=d_{k}=0.5$.

If the split move is chosen, we select randomly one component $j_{*}$ to break into two new components $\left(j_{1}, j_{2}\right)$ and create a new state with $k^{*}=k+1$ component. In order to specify the new values of parameters for the two components, generate the vector $\mathbf{u}=\left(u_{1}, u_{2}, u_{3}\right)$ from beta distributions, i.e., $u_{1} \sim \operatorname{Beta}(2,2), u_{2} \sim \operatorname{Beta}(1,1)$ and $u_{3} \sim \operatorname{Beta}(2,2)$. Than the new parameters 
are set as

$$
\begin{array}{rlrl}
\omega_{j_{1}} & =\omega_{j_{*}} u_{1}, & \omega_{j_{2}} & =\omega_{j_{*}}\left(1-u_{1}\right), \\
\mu_{j_{1}}=\mu_{j_{*}}-u_{2} u_{1}\left(\mu_{j_{*}}-\mu_{j_{*}}^{2}\right), & \mu_{j_{2}}=\mu_{j_{*}}+u_{2}\left(1-u_{1}\right)\left(\mu_{j_{*}}-\mu_{j_{*}}^{2}\right), \\
\sigma_{j_{1}}^{2}=\sigma_{j_{*}}^{2} u_{3}\left(1-u_{2}^{2}\right) / u_{1}, & \sigma_{j_{2}}^{2}=\sigma_{j_{*}}^{2}\left(1-u_{3}\right)\left(1-u_{2}^{2}\right) /\left(1-u_{1}\right) .
\end{array}
$$

All the observation previously allocated to $j_{*}$ is reallocated doing $z_{i}=j_{1}$ or $z_{i}=j_{2}$ follow the same criteria used on the Gibbs sampling algorithm (2a).

The combine proposal begins by choosing a pair of component $\left(j_{1}, j_{2}\right)$, which the first is chosen randomly, in a uniform way, and the second is chosen by making $j_{2}=j_{1}+1$, the $k$ th component can not chosen in the first place. This two components are merged, reducing $k$ by 1 . The new component is labelled $j_{*}$ and contain all the observation previously allocated to $j_{1}$ and $j_{2}$ doing $z_{i}=j_{*}$. The parameters for the component $j_{*}$ are set as $\omega_{j_{*}}=\omega_{j_{1}}+\omega_{j_{2}}, \mu_{j_{*}}=\frac{\mu_{j_{1}} \omega_{j_{2}}+\mu_{j_{2}} \omega_{j_{1}}}{\omega_{j_{*}}}$ and $\sigma_{j_{*}}^{2}=\frac{\sigma_{j_{2}}^{2}\left(\frac{\omega_{j_{2}}}{\omega_{j_{*}}}\right)}{\left(1-\left(\frac{\mu_{j_{2}}-\mu_{j_{1}}}{\mu_{j_{*}}-\mu_{j_{*}}^{2}}\right)^{2}\right)\left(\frac{\sigma_{j_{2}}^{2} \omega_{j_{2}}}{\sigma_{j_{1}}^{2} \omega_{j_{1}}+\sigma_{j_{2}}^{2} \omega_{j_{2}}}\right)}$. This process is reversible, i.e., if we first split one component in two and then combine the components $j_{1}$ and $j_{2}$ we can recover the previous state. Also we can compute corresponding value of $u_{i}$ 's in the merge move as $u_{1}=\frac{\omega_{j_{1}}}{\omega_{j_{*}}}, u_{2}=\frac{\mu_{j_{2}}-\mu_{j_{1}}}{\mu_{j_{*}}-\mu_{j_{*}}^{2}}$ and $u_{3}=\frac{\omega_{j_{1}} \sigma_{j_{1}}^{2}}{\omega_{j_{1}} \sigma_{j_{1}}^{2}+\omega_{j_{2}} \sigma_{j_{2}}^{2}}$. The acceptance probability for split and combine are $\min \{1, A\}$ and $\min \left\{1, A^{-1}\right\}$ respectively, according to (15), with

$$
\begin{aligned}
A= & \frac{(k+1)\left(\prod_{i \in\left\{i: Z_{i j_{1}}=1\right\}} S\left(y_{i} \mid \mu_{j_{1}} \sigma_{j_{1}}^{2}\right)\right)\left(\prod_{i \in\left\{i: Z_{i j_{2}}=1\right\}} S\left(y_{i} \mid \mu_{j_{2}} \sigma_{j_{2}}^{2}\right)\right)}{\left(\prod_{i \in\left\{i: Z_{i j_{*}}=1\right\}} S\left(y_{i} \mid \mu_{j_{*}} \sigma_{j_{*}}^{2}\right)\right)} \\
& \times \frac{P(k+1)}{P(k)} \frac{\omega_{j_{1}}^{\nu-1+n_{1}} \omega_{j_{2}}^{\nu-1+n_{2}}}{\omega_{j_{*}}^{\nu-1+n_{1}+n_{2}}} \frac{P\left(\sigma_{j_{2}}^{2}\right) P\left(\sigma_{j_{2}}^{2}\right)}{P\left(\sigma_{j_{*}}^{2}\right)} \frac{P\left(\mu_{j_{2}}\right) P\left(\mu_{j_{2}}\right)}{P\left(\mu_{j_{*}}\right)} \\
& \times \frac{d_{k+1}}{b_{k} P_{\text {alloc }} g(\mathbf{u})} \frac{1}{2}\left(\sigma_{j_{1}}^{2}+\sigma_{j_{2}}^{2}\right)\left(\omega_{j_{1}}+\omega_{j_{2}}\right)\left[2\left(\mu_{j_{1}}+\mu_{j_{2}}\right)-\left(\mu_{j_{1}}+\mu_{j_{2}}\right)^{2}\right],
\end{aligned}
$$

where $d_{k+1}$ is the probability of choosing the merge movement between the components $j_{1}$ and $j_{2}$, $b_{k}$ is the probability of choosing the split movement of the component $j_{*}, P_{a l l o c}$ is the probability of a specific allocation defined as the product of conditional posterior probabilities used to allocate the observations, $g(\mathbf{u})$ is the joint distribution of $\mathbf{u}$ given by product of density of beta distributions, $(\mathrm{k}+1)$ is the ratio $\frac{(k+1) !}{k !}$ from the order statistics densities for the parameters $\left(\mu, \sigma^{2}\right)$ and the last term of equation is the Jacobian of the transformations used to complete the dimension. The second term 
in (17) is the rate of the density of the prior distribution.

\section{Analysis of simulated data sets in several scenarios}

This subsection is dedicated to investigate if our algorithm is able to estimate the mixture parameters and select the number of clusters effectively considering several scenarios of generated data. For this purpose, we implemented the algorithm described in Appendix A.1 by using the R program (R Development Core Team, 2015). The analysis was conduced to simulated data set considering six scenarios to simplex mixture models We simulated independent values $Y \sim S M\left(\mu, \sigma^{2}, \boldsymbol{\omega}, k\right)$ with $k \in\{2,3\}$. The parameters of the six models are shown in the first column of Table 1 and are noted as $\mathcal{M}_{1}, \ldots, \mathcal{M}_{6}$. For each model we simulated tree data sets, being the first with size $n=1000$ and the others two with size $n<1000$, as seen in the second column of Table 1 . The value of $k_{\max }$ was fixed in 5 and the hyper-parameters for gamma prior were fixed in $a=2$ and $b=1 / 2$. After discarding the first 100000 iterations, we used 100000 iterations with thinning equal to 10 to the inference process.

The posterior relative frequency of $k$, shown in Table 1 , gives evidence that the reversiblejump estimated correctly the number of components to these simulated data sets. In addition, Tables 2 and 3 shows the estimated values of parameters to the six models. Posterior mean and empirical standard deviation (SD) are shown in this table. We can observe that the SD decrease as $n$ increase and the estimated values of the parameters are always close the true values. Finally, we show the real histogram and estimated density in Figure 1 which confirm the adequate performance of the estimation method to the simulated data sets. 
Table 1: Parameters used to simulate the data sets and the posterior relative frequency for the number of components obtained from the each simulated data set of the size $n$.

\begin{tabular}{|c|c|c|c|c|c|c|c|}
\hline \multirow{2}{*}{\multicolumn{2}{|c|}{ Model }} & \multirow[t]{2}{*}{$\mathrm{n}$} & \multicolumn{5}{|c|}{ Posterior relative frequency } \\
\hline & & & $\mathrm{k}=1$ & $\mathrm{k}=2$ & $\mathrm{k}=3$ & $\mathrm{k}=4$ & $\mathrm{k}=5$ \\
\hline \multirow{3}{*}{$\mathcal{M}_{1}$} & $\mu=(0.34,0.72)$ & 1000 & 0 & 0.9874 & 0.0125 & 0.0001 & 0 \\
\hline & $\left\{\sigma^{2}=(0.8,1.5)\right.$ & 500 & 0 & 0.9804 & 0.0194 & 0.0002 & 0 \\
\hline & $w=(0.5,0.5)$ & 100 & 0.2790 & 0.6866 & 0.0333 & 0.0010 & 0. \\
\hline \multirow{3}{*}{$\mathcal{M}_{2}$} & $\mu=(0.08,0.40)$ & 1000 & 0 & 0.9941 & 0.0059 & 0 & 0 \\
\hline & $\left\{\sigma^{2}=(2,1)\right.$ & 500 & 0 & 0.9852 & 0.0145 & 0.0003 & 0 \\
\hline & $w=(0.65,0.35)$ & 100 & 0.1060 & 0.8532 & 0.0389 & 0.002 & 0.0001 \\
\hline \multirow{3}{*}{$\mathcal{M}_{3}$} & $\mu=(0.23,0.58)$ & 1000 & 0 & 0.9876 & 0.0123 & 0.0001 & 0 \\
\hline & $\sigma^{2}=(1.8,0.8)$ & 500 & 0 & 0.9843 & 0.0154 & 0.0002 & 0.0001 \\
\hline & $w=(0.30,0.70)$ & 100 & 0.1648 & 0.7711 & 0.0591 & 0.005 & 0 \\
\hline \multirow{3}{*}{$\mathcal{M}_{4}\{$} & $\mu=(0.30,0.55,0.80)$ & 1000 & 0.01 & 0.051 & 0.9370 & 0.0024 & 0 \\
\hline & $\sigma^{2}=(0.20,0.10,0.20)$ & 500 & 0.0062 & 0.0523 & 0.9387 & 0.0028 & 0 \\
\hline & $w=(0.20,0.30,0.50)$ & 300 & 0.0199 & 0.3393 & 0.6316 & 0.009 & 0.0003 \\
\hline \multirow{3}{*}{$\mathcal{M}_{5}$} & $\mu=(0.15,0.47,0.75)$ & 1000 & 0.0001 & 0.1140 & 0.8667 & 0.0189 & 0.0003 \\
\hline & $\sigma^{2}=(5.0,0.2,0.8)$ & 500 & 0.0005 & 0.1660 & 0.8157 & 0.0177 & 0.0001 \\
\hline & $w=(0.25,0.45,0.30)$ & 400 & 0.0023 & 0.3831 & 0.5906 & 0.0240 & 0 \\
\hline \multirow{3}{*}{$\mathcal{M}_{6}$} & $\mu=(0.10,0.50,0.90)$ & 1000 & 0.0047 & 0.0208 & 0.9518 & 0.0224 & 0.0003 \\
\hline & $\sigma^{2}=(6.0,0.5,8.0)$ & 500 & 0.0126 & 0.0583 & 0.8984 & 0.0388 & 0.001 \\
\hline & $w=(0.3,0.50,0.20)$ & 400 & 0.0106 & 0.1409 & 0.7929 & 0.0536 & 0.0020 \\
\hline
\end{tabular}


Table 2: Posterior mean of the parameters and empirical standard deviation (SD) for each simulated data set considering six models with $k=\underline{2 \text { described in Table } 1 .}$

\begin{tabular}{|c|c|c|c|c|c|}
\hline Model & $\mathrm{n}$ & & Estimative to $\mu$ & Estimative to $\sigma^{2}$ & Estimative to $\omega$ \\
\hline \multirow{6}{*}{$\mathcal{M}_{1}$} & \multirow{2}{*}{1000} & Mean & $(0.33,0.71)$ & $(0.69,1.57)$ & $(0.46,0.54)$ \\
\hline & & SD's & $(0.005,0.006)$ & $(0.061,0.134)$ & $(0.019,0.016)$ \\
\hline & \multirow{2}{*}{500} & Mean & $(0.33,0.72)$ & $(0.77,1.43)$ & $(0.47,0.53)$ \\
\hline & & SD's & $(0.010,0.011)$ & $(0.1225,0.1990)$ & $(0.031,0.031)$ \\
\hline & \multirow{2}{*}{100} & Mean & $(0.35,0.69)$ & $(0.61,1.83)$ & $(0.41,0.59)$ \\
\hline & & SD's & $(0.041,0.047)$ & $(0.556,0.741)$ & $(0.123,0.123)$ \\
\hline \multirow{6}{*}{$\mathcal{M}_{2}$} & \multirow{2}{*}{1000} & Mean & $(0.082,0.40)$ & $(1.99,0.98)$ & $(0.70,0.3)$ \\
\hline & & SD's & $(0.001,0.006)$ & $(0.1178,0.0915)$ & $(0.015,0.015)$ \\
\hline & \multirow{2}{*}{500} & Mean & $(0.079,0.40)$ & $(2.00,0.89)$ & $(0.68,0.32)$ \\
\hline & & SD's & $(0.002,0.008)$ & $(0.3417,0.1115)$ & $(0.021,0.021)$ \\
\hline & \multirow{2}{*}{100} & Mean & $(0.091,0.40)$ & $(2.96,0.77)$ & $(0.72,0.28)$ \\
\hline & & SD's & $(0.008,0.026)$ & $(0.811,0.661)$ & $(0.058,0.058)$ \\
\hline \multirow{6}{*}{$\mathcal{M}_{3}$} & \multirow{2}{*}{1000} & Mean & $(0.21,0.61)$ & $(1.86,0.91)$ & $(0.29,0.71)$ \\
\hline & & SD's & $(0.009,0.005)$ & $(0.2386,0.0659)$ & $(0.018,0.018)$ \\
\hline & \multirow{2}{*}{500} & Mean & $(0.19,0.60)$ & $(2.03,1.08)$ & $(0.27,0.73)$ \\
\hline & & SD's & $(0.012,0.003)$ & $(0.970,0.1327)$ & $(0.028,0.028)$ \\
\hline & \multirow{2}{*}{100} & Mean & $(0.24,0.58)$ & $(2.00,1.11)$ & $(0.23,0.77)$ \\
\hline & & SD's & $(0.078,0.028)$ & $(2.085,0.706)$ & $(0.111,0.111)$ \\
\hline
\end{tabular}

$M_{1}$

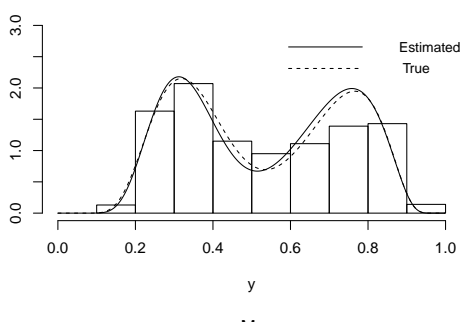

$\mathrm{M}_{4}$

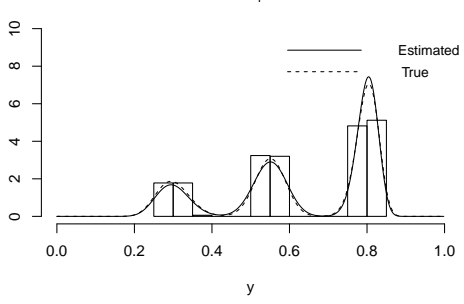

$\mathrm{M}_{2}$

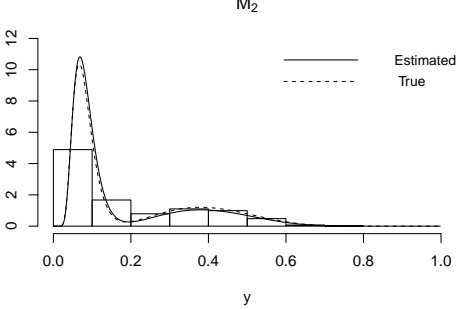

$M^{2}$

$\mathrm{M}_{5}$

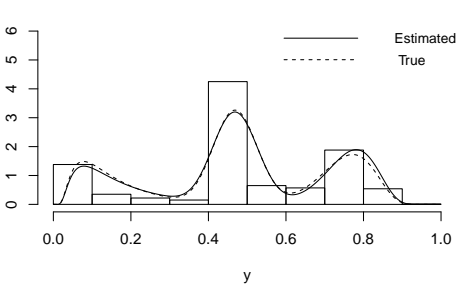

$M_{3}$

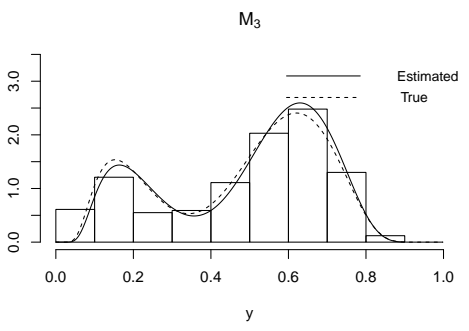

$\mathrm{M}_{6}$

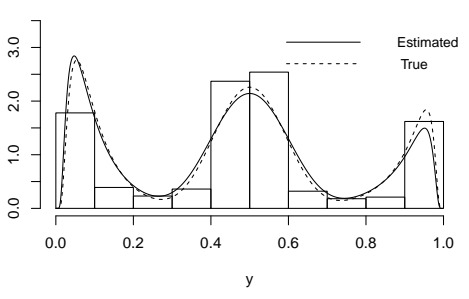

Figure 1: Histograms and estimated density function 
Table 3: Posterior mean of the parameters and empirical standard deviation (SD) for simulated data set considering six models with $\underline{k=3 \text { described in Table } 1 .}$

\begin{tabular}{|c|c|c|c|c|c|}
\hline Model & $\mathrm{n}$ & & Estimative to $\mu$ & Estimative to $\sigma^{2}$ & Estimative to $\omega$ \\
\hline \multirow{6}{*}{$\mathcal{M}_{4}$} & \multirow{2}{*}{1000} & Mean & $(0.30,0.55,0.80)$ & $(0.20,0.12,0.18)$ & $(0.18,0.31,0.51)$ \\
\hline & & SD's & $(0.007,0.004,0.03)$ & $(0.07,0.08,0.05)$ & $(0.01,0.02,0.02)$ \\
\hline & \multirow{2}{*}{500} & Mean & $\left(\begin{array}{lll}0.30 & 0.55 & 0.80\end{array}\right)$ & $(0.23,0.10,0.20)$ & $\left(\begin{array}{lll}0.17 & 0.31 & 0.52\end{array}\right)$ \\
\hline & & SD's & $\left(\begin{array}{lll}0.009 & 0.007 & 0.007\end{array}\right)$ & $(0.10,0.100 .06)$ & $\left(\begin{array}{lll}0.02 & 0.02 & 0.02\end{array}\right)$ \\
\hline & \multirow{2}{*}{300} & Mean & $(0.30,0.55,0.80)$ & $(0.27,0.13,0.22)$ & $(0.17,0.32,0.52)$ \\
\hline & & SD's & $(0.025,0.016,0.014)$ & $(0.32,0.25,0.13)$ & $(0.034,0.042,0.041)$ \\
\hline \multirow{6}{*}{$\mathcal{M}_{5}$} & \multirow{2}{*}{1000} & Mean & $(0.16,0.47,0.76)$ & $(5.25,0.21,0.77)$ & $(0.24,0.45,0.31)$ \\
\hline & & SD's & $(0.01,0.01,0.01)$ & $(0.7,0.1,0.1)$ & $(0.02,0.02,0.02)$ \\
\hline & \multirow{2}{*}{500} & Mean & $(0.14,0.46,0.75)$ & $(3.19,0.26,0.76)$ & $\left(\begin{array}{lll}0.20 & 0.47 & 0.33\end{array}\right)$ \\
\hline & & SD's & $(0.02,0.01,0.01)$ & $(0.65,0.26,0.19)$ & $(0.02,0.03,0.03)$ \\
\hline & \multirow{2}{*}{400} & Mean & $(0.15,0.48,0.76)$ & $(4.41,0.37,0.83)$ & $(0.20,0.45,0.35)$ \\
\hline & & SD's & $(0.031,0.038,0.028)$ & $(2.9,1.8,0.35)$ & $(0.04,0.06,0.07)$ \\
\hline \multirow{6}{*}{$\mathcal{M}_{6}$} & \multirow{2}{*}{1000} & Mean & $(0.10,0.50,0.89)$ & $(7.34,0.58,7.50)$ & $(0.31,0.51,0.18)$ \\
\hline & & SD's & $(0.012,0.009,0.026)$ & $(0.9,0.9,1.9)$ & $(0.02,0.02,0.02)$ \\
\hline & \multirow{2}{*}{500} & Mean & $(0.098,0.49,0.88)$ & $(6.05,0.73,9.25)$ & $(0.31,0.51,0.18)$ \\
\hline & & SD's & $(0.02,0.01,0.06)$ & $(6,3,4)$ & $(0.03,0.04,0.06)$ \\
\hline & \multirow[t]{2}{*}{400} & Mean & $(0.097,0.49,0.87)$ & $(4.843,1.00,10.45)$ & $(0.31,0.49,0.20)$ \\
\hline & & SD's & $(0.02,0.03,0.08)$ & $(1,5,6)$ & $(0.05,0.05,0.06)$ \\
\hline
\end{tabular}

We observed in the simulation process that the convergence speed is improved if initial value of number of component is set as $k^{(0)}=k_{\max }$. The convergence is also affected by the acceptance of MR step in the Gibbs sampling algorithm then a strategy to avoid low rate of acceptance in the MR step is presented in Appendix A.1.

\section{Analysis of municipal HDI data set in Brazil}

The Human Development Index (HDI) is a summary measure of long-term progress in three basic dimensions of human development that takes into account education, income and longevity indexes. The HDI is the geometric mean of normalized indexes for each of the three dimensions of human development. In this work we analyse the municipal HDI data set, that is, the HDI of the cities 
(or towns) of São Paulo state and Northeast region of Brazil. The Northeast was chosen because it is the third largest region of Brazil and the largest in number of states and considered a region with poor distribution of resources, see index in Fundação Instituto Brasileiro de Geografia e Estatística (2014). In this region are the states of Alagoas, Bahia, Ceará, Maranhão, Paraíba, Pernambuco, Piauí, Rio Grande do Norte and Sergipe. There are 1794 cities in the Northeastern region and 645 in São Paulo state leading to a sample of size $n=2439$. The histogram of the data is showed in Figure 2 where we can see the multimodality phenomenon. This phenomenon is already expected because the HDI depend of characteristics that can be similar to some cities or towns.

Table 4: Relative frequency of $k$ to the municipal HDI data set considering alternative SM models.

\begin{tabular}{cccccc}
$k$ & 1 & 2 & 3 & 4 & 5 \\
\hline & 0.073 & 0.923 & 0.005 & 0.0004 & 0 \\
\hline
\end{tabular}

The municipal HDI data set was analysed with the SD model where we set $a=2$ and $b=1 / 2$ in the gamma prior distribution to $\sigma_{j}^{-2}$, for $j=1, \ldots, k$. In order to reduce prior information we set $\nu_{1}=\nu_{2}=\ldots=\nu_{k}=1$ to Dirichlet prior distribution and $k_{\max }=5$ to prior distribution of $k$. Table 4 show the posterior distribution of parameter $k$ with high posterior probability to $k=2$. Then, there are evidence for two components in the data. The mean and empirical SD of the parameter estimate are showed in Table 5 . 


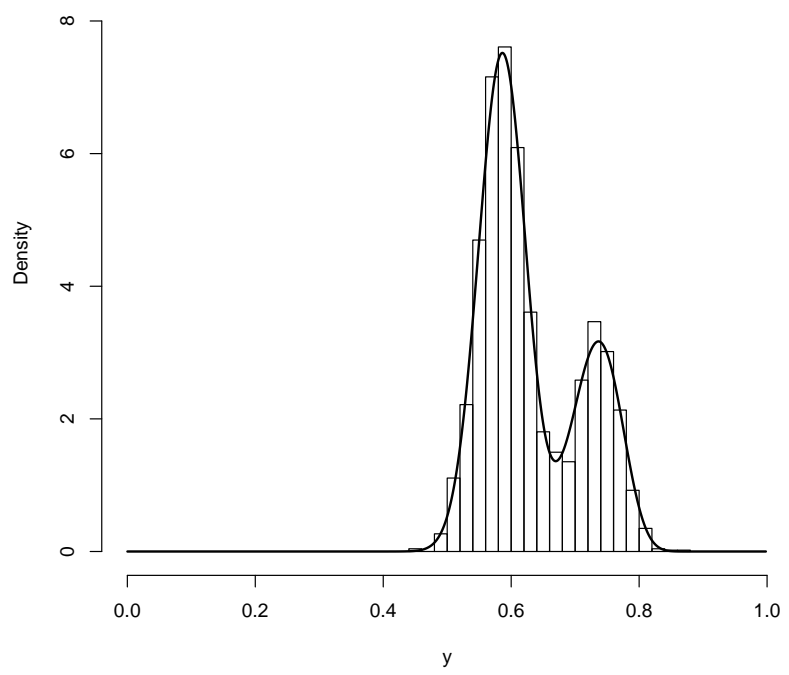

Figure 2: Real histogram and Estimated density function to the HDI data set.

Table 5: Posterior estimates of the parameters and the empirical standard deviation to the municipal HDI data set.

\begin{tabular}{|c|c|c|c|c|c|}
\hline \multicolumn{2}{|c|}{$\hat{\mu}$} & \multicolumn{2}{|c|}{$\hat{\sigma^{2}}$} & \multicolumn{2}{|c|}{$\hat{w}$} \\
\hline means & SD's & means & SD's & means & SD's \\
\hline$(0.59,0.73)$ & $(0.004,0.010)$ & $(0.09,0.21)$ & $(0.03,0.076)$ & $(0.69,0.31)$ & $(0.03,0.031)$ \\
\hline
\end{tabular}

The results of analysis show that there are strong evidence for two component of cities with similar characteristics. The first component have, in mean, smaller municipal HDI than second component. The component with less municipal HDI have larger mixing proportions than second component, as expected. The Figure 3(A) shows in red the cities classified as belonging to the first component. We can observe that there are some cities in the Northeastern region classified in the first component. This cities has better municipal HDI than those which are classified in the second component, shown in (3)(B) cities detached with colour blue. 
(A)

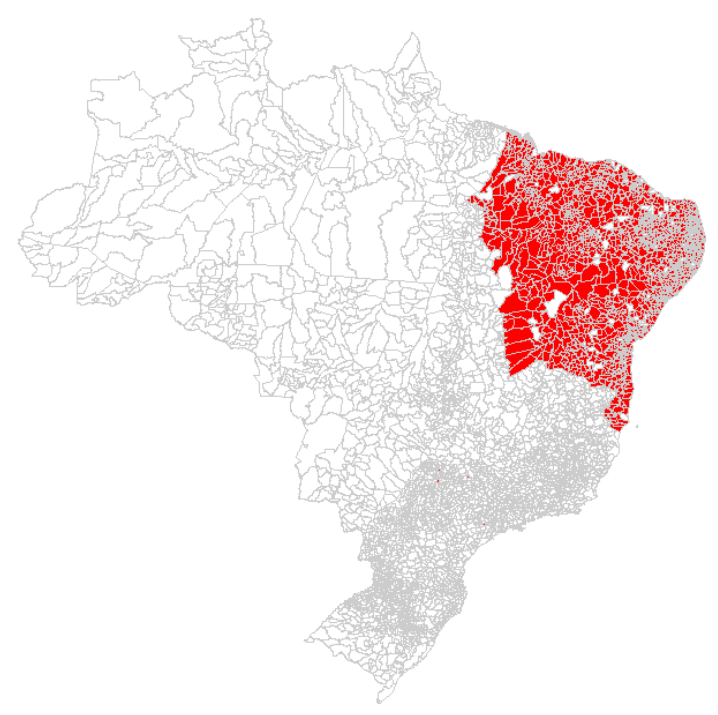

(B)

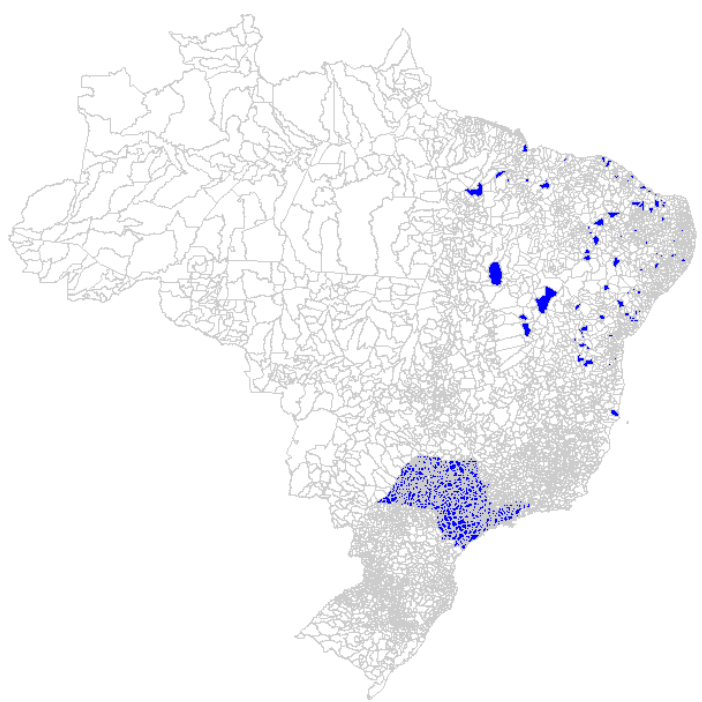

Figure 3: Classification of HDI of cities of the states São Paulo and Northeastern region of Brazil where the cities classified in the first component is in red (A) and cities classified in the second component is in blue (B).

\section{$7 \quad$ Final comments}

The main advantage of mixture of simplex models is its flexibility for working with bounded data with multimodality identified the components or populations in the data. A Full Bayesian approach considering an MCMC with reversible-jump algorithm similar to the methodology proposed by Richardson \& Green (1997) and Green (1995) was developed.

An application to generated data sets from a mixture of simplex distributions with 2 and 3 components were conducted. For these applications, we found that the method provides a good estimate to the number of component as well as the other parameters of the model since the estimated values lie close to the real values of the parameters. In addition, the results from the simulated data sets with different size show that the empirical standard deviation decrease as the size of sample increase, as expected when the method works well. Another application was conduced with real data set and we fond small empirical standard deviations to the sample of the estimates of the parameters 
of the components and mixing proportions, as we can see in Table 5.

The proposed model can be extended to the another problems, for instance, where the random variable $Y$ (response) can be modelled as a function of another variable $x$ (predictor variable). In this case, the mixing proportions can or can not be modelled as functions of a vector of predictor variable, not necessarily having some elements in common with the vector of covariates $x$, a example of the link function that can be used to mixing proportions is presented in McLachlan \& Peel (2004, p. 145). In addition, since we observed that the acceptance of RJ decrease as size of the sample increases, strategy to avoid persistent rejection of proposed moves in a RJ algorithm can be added to improve the Gibbs sampling algorithm, strategy are discussed in Green \& Mira (2001); Al-Awadhi et al. (2004).

\section{References}

Al-Awadhi, F., Hurn, M. \& Jennison, C. (2004). Improving the acceptance rate of reversible jump MCMC proposals. Statistics and Probability Letters, 69(2), 189-198.

Barndorff-Nielsen, O. \& Jorgensen, B. (1991). Some parametric models on the simplex. Journal of Multivariate Analysis, 39(1), 106 - 116.

Bouguila, N. \& Elguebaly, T. (2012). A fully Bayesian model based on reversible jump MCMC and finite beta mixtures for clustering. Expert Syst. Appl., 39(5), 5946-5959.

Bouguila, N., Ziou, D. \& Monga, E. (2006). Practical bayesian estimation of a finite beta mixture through gibbs sampling and its applications. Statistics and Computing, 16(2), 215-225.

Cifuentes, M., Sembajwe, G., Tak, S., Gore, R., Kriebel, D. \& Punnett, L. (2008). The association of major depressive episodes with income inequality and the human development index. Social Science and Medicine, 67(4), $529--539$.

Diebolt, J. \& Robert, C. P. (1994). Estimation of finite mixture distributions through bayesian sampling. Journal of the Royal Statistical Society. Series B, 56(2), 363-375. 
Faria, S. \& Gonalves, F. (2013). Financial data modeling by poisson mixture regression. Journal of Applied Statistics, 40(10), 2150-2162.

Fundação Instituto Brasileiro de Geografia e Estatística, D. d. E. e. R. (2014). Pesquisa nacional por amostra de domicilios, PNAD.: Síntese de indicadores. IBGE.

Gelfand, A. E. \& Smith, A. F. M. (1990). Sampling-based approaches to calculating marginal densities. Journal of the American Statistical Association, 85(410), 398-409.

Green, P. J. (1995). Reversible jump Markov chain Monte Carlo computation and Bayesian model determination. Biometrika, 82, 711-732.

Green, P. J. \& Mira, A. (2001). Delayed rejection in reversible jump Metropolis-Hastings. Biometrika, 88, 1035-1053.

Jørgensen, B. (1997). The Theory of Dispersion Models. Monographs on Statistics and Applied Probability. Taylor \& Francis.

López, F. O. (2013). A bayesian approach to parameter estimation in simplex regression model: A comparison with beta regression. Revista Colombiana de Estatística, 36(1), 1-21.

Marin, J. M., Mengersen, K. \& Robert, C. P. (2005). Bayesian modelling and inference on mixtures of distributions. Elsevier.

McDonald, J. \& Ransom, M. (2008). The generalized beta distribution as a model for the distribution of income: Estimation of related measures of inequality. In Modeling Income Distributions and Lorenz Curves, volume 5 of Economic Studies in Equality, Social Exclusion and Well-Being, pages 147-166. Springer New York.

McLachlan, G. \& Peel, D. (2000). Finite Mixture Models (Wiley Series in Probability and Statistics). Wiley-Interscience, first edition.

McLachlan, G. \& Peel, D. (2004). Finite Mixture Models. Wiley series in probability and statistics: Applied probability and statistics. Wiley. 
Paz, R. F., Brazan, J. L. \& Elher, R. 1. (2015). A Weibull mixture model for the votes of a Brazilian political party. In EBEB: Interdisciplinary Bayesian Statistics, volume 118 of Springer Proceedings in Mathematics and Statistics, pages 229-241. Springer.

R Development Core Team (2015). R: A Language and Environment for Statistical Computing. R Foundation for Statistical Computing, Vienna, Austria. ISBN 3-900051-07-0.

Richardson, S. \& Green, P. J. (1997). On bayesian analysis of mixtures with an unknown number of components. Journal of the Royal Statistical Society, 59(4), 731-792.

Ross, S. M. (2006). Simulation, Fourth Edition. Academic Press, Inc., Orlando, FL, USA.

Song, P. X.-K. \& Tan, M. (2000). A marginal models for longitudinal continuous proportional data. Biometrics, 56(2), 496-502.

Stensholt, E. (1999). Beta distributions in a simplex and impartial anonymous cultures. Mathematical Social Sciences, $\mathbf{3 7}(1), 45-57$.

Tanner, M. A. \& Wong, W. H. (1987). The calculation of posterior distributions by data augmentation. Journal of the American Statistical Association, 82(398), 528-540.

\section{A Appendix}

Let's now summarize the MCMC technique mentioned above by giving a description of the Gibbs sampling algorithm used to sample from the joint probability distribution. The Gibbs sampling algorithm is used combined with Metropolis-Hastings (MR and reversible-jump) algorithm for obtain the sample of the posterior distribution of parameters $(\boldsymbol{\theta}, \boldsymbol{\omega}, k)$ and $Z_{i}$, for $i=1, \ldots, N$. A scheme of the algorithm is shown below. 


\section{A.1 Algorithm}

1. Initialize choosing $k^{(t)}=k^{(0)}, \boldsymbol{\omega}^{(t)}=\boldsymbol{\omega}^{(0)}, \mu_{j}^{(t)}=\mu_{j}^{(0)},\left(\sigma_{j}^{2}\right)^{(t)}=\left(\sigma_{j}^{2}\right)^{(0)}$ and $Z_{i j}^{(t)}=Z_{i j}^{(0)}$, for $i=1, \ldots, n j=1, \ldots, k^{(t)}$.

2. For $t=0,1,2, \ldots$ repeat

(a) For $i=1, \ldots, n$ draw $Z_{i}^{(t+1)} \sim \operatorname{Multinomial}\left(1, \pi_{i 1}^{(t)}, \ldots, \pi_{i k^{(t)}}^{(t)}\right)$, wherein

$$
\pi_{i j}^{(t)}=P\left(Z_{i j}^{(t)}=1 \mid y_{i}, \mu_{j}^{(t)},\left(\sigma_{j}^{2}\right)^{(t)}\right) \propto \omega_{j} S\left(y_{i} \mid \mu_{j}^{(t)},\left(\sigma_{j}^{2}\right)^{(t)}\right)
$$

(b) Generate $\boldsymbol{\omega}^{(t+1)}$ from the distribution given by (14).

(c) For $j=1, \ldots, k^{(t)}$ do

i. Generate $\phi_{j}^{(t+1)}$ from the distribution given by (12) and do $\left(\sigma_{j}^{2}\right)^{(t+1)}=1 / \phi_{j}^{(t+1)}$.

ii. For updating $\mu_{j}$ a Metroplis-hastings step is done, then

- generate $\mu_{j}^{\prime} \sim \operatorname{Beta}\left(\delta^{(t)}, \eta^{(t)}\right)$ where $\left(\delta^{(t)}, \eta^{(t)}\right)$ is computed in A.1.1.

- Compute

$\alpha\left(\mu_{j}^{(t)}, \mu_{j}^{\prime}\right)=\min \left\{1, \frac{P\left(\mu_{j}^{\prime} \mid \mathbf{y}, Z,\left(\sigma_{j}^{2}\right)^{(t+1)}\right)}{P\left(\mu_{j}^{(t)} \mid \mathbf{y}, Z,\left(\sigma_{j}^{2}\right)^{(t+1)}\right)} \frac{B e\left(\mu_{j}^{(t)} \mid \delta^{(t+1)}, \eta^{(t+1)}\right)}{B e\left(\mu_{j}^{\prime} \mid \delta^{(t)}, \eta^{(t)}\right)}\right\}$

where $B e(x \mid$.$) is the density of beta distribution evaluated at x$.

- Generate $u \sim \operatorname{Uniform}(0,1)$

- If $\alpha\left(\mu_{j}^{(t)}, \mu_{j}^{\prime}\right)<u$ then $\mu_{j}^{(t+1)}=\mu_{j}^{\prime}$ else $\mu_{j}^{(t+1)}=\mu_{j}^{(t)}$.

(d) For updating $k^{(t)}$, merge two component of the mixture into one or splinting one into two by using reversible-jump step.

\section{A.1.1 Proposal distribution}

We observed in the simulation process that the convergence of algorithm Gibbs sampling is affected by the acceptance of MR step in (2(c)ii). In order to improve the acceptance rate of $\mu_{j}^{\prime}($ $j=1, \ldots, k^{(t)}$ and $\left.t=0,1,2, \ldots\right)$, in the Metropolis-Hastings step (2(c)ii) of the algorithm, we adopt 
a beta distribution as the proposal distribution where the parameters $\delta^{(t)}$ and $\eta^{(t)}$ are obtained by solving

$$
\left\{\begin{array}{l}
\mu_{j}^{(t)}=\frac{\delta^{(t)}}{\delta^{(t)}+\eta^{(t)}} \\
\psi^{(t)}=\frac{\delta^{(t)} \eta^{(t)}}{\left(\delta^{(t)}+\eta^{(t)}\right)^{2}\left(\delta^{(t)}+\eta^{(t)}+1\right)}
\end{array}\right.
$$

where $\mu_{j}^{(t)}$ and $\psi^{(t)}$ is the mean and variance of beta distribution with parameters $\delta^{(t)}>0$ and $\delta^{(t)}>0$.

Then we have

$$
\left\{\begin{array}{l}
\eta^{(t)}=\delta^{(t)}\left(\frac{1}{\mu_{j}^{(t)}}-1\right) \\
\delta^{(t)}=\left(\mu_{j}^{(t)}\right)^{2}\left(\frac{1-\mu_{j}^{(t)}}{\psi^{(t)}}-\frac{1}{\mu_{j}^{(t)}}\right)
\end{array}\right.
$$

The positivity of $\delta^{(t)}$ and $\delta^{(t)}$ is secured by making $\psi^{(t)}<\mu^{(t)}\left(1-\mu^{(t)}\right)$ leading to $\psi^{(t)}=\mu_{j}^{(t)}\left(1-\mu_{j}^{(t)}\right) \times \tau$, with $0<\tau<1$. 


\section{Apêndice $\mathrm{H}$}

da Paz, R. F., Bazán, J. L., e Balakrishnan, N. L. (2016). L-logistic distribution: Properties, inference and an application to study poverty and inequality in brazil. Technical Report 262, Programa Interinstitucional de Pós-Graduaçåo em Estatística UFSCar-USP, Såo Carlos, SP. Brazil. 


\title{
PROGRAMA INTERINSTITUCIONAL DE PÓS-GRADUAÇÃO EM ESTATÍSTICA UFSCar-USP
}

\section{L-LOGISTIC DISTRIBUTION: PROPERTIES,} INFERENCE AND AN APPLICATION TO STUDY POVERTY AND INEQUALITY IN BRAZIL

\author{
Rosineide F. da Paz \\ Narayanaswamy Balakrishnan \\ Jorge Luis Bazán
}

\section{RELATÓRIO TÉCNICO}

\section{TEORIA E MÉTODO - SÉRIE A}

\author{
Abril/2016
}

$$
\text { no } 262
$$




\title{
L-logistic distribution: Properties, Inference and an Application to Study Poverty and Inequality in Brazil
}

\author{
Rosineide F. da Paz* \& Narayanaswamy Balakrishnan \& Jorge Luis Bazán²
}

April 7, 2016

\begin{abstract}
A two-parameter distribution on a bounded domain is studied in this work. This distribution, called l-logistic distribution, provides great flexibility and has the uniform distribution as a particular case. In addition, it has an explicit distribution function that facilitates easy random number generation. Several properties of the distribution are studied including skewness and kurtosis. Bayesian inference is discussed with non informative and informative prior distributions. Simulation studies considering prior sensitivity analysis and parameter recovery studies show the robustness of the proposed estimation method and the efficiency of the algorithm adopted. In addition, a regression model considering with the response following the l-logistic distribution is introduced. Applications to Study Poverty and Inequality in Brazil are performed showing a comparison of results obtained from the beta and l-logistic distributions. The obtained results show that when the contain potential outliers, the l-logistic model provides a better fit for these data than the beta model.
\end{abstract}

Key words: Bayesian analysis, l-logistic distribution, Regression analysis, Gini index, Beta distribution.

\section{Introduction}

Despite many alternatives and generalizations present in the literature, the beta distribution is still a popular family of continuous distributions with bounded support. Recently, Gómez-Déniz et al. (2014) and Mitnik and Baek (2013) proposed new alternatives to beta distribution. However, there are still continuous distributions with continuous bounded support that need further study. For example, Kotz and van Dorp (2004) discuss such distributions with attractive statistical properties that can be useful in various applied fields. In this work, we discuss a continuous distribution on

\footnotetext{
* Universidade Federal and Universidade de São Paulo, São Carlos-SP, Brazil. E-mail: rfpaz@icmc.usp.br

${ }^{1}$ McMaster University, Department of Mathematics and Statistics, Hamilton, Ontario, Canada.

${ }^{2}$ Universidade de São Paulo, Instituto de Ciências Matemáticas e de Computação, São Carlos-SP, Brazil.
} 
unit interval, which we refer to as l-logistic distribution. We discuss some of its properties concerning the shape of the probability density function (pdf), the cumulative distribution function (cdf), the percentiles, and some re-parameterizations. The generation of random numbers from the l-logistic distribution is also discussed. The moments and some descriptive measures such as mode, skewness, and kurtosis are also presented. The l-logistic distribution was originally proposed by Tadikamalla and Johnson (1982), but a new parameterization is presented here, with an emphasis on regression analysis, based on this model.

We adopt a Bayesian approach using Markov chain Monte Carlo (MCMC) algorithm for our modeling framework. The issues of model fitting is addressed via Gibbs sampling suitable, choice of prior distributions, and model comparison criteria. In this context, we report two studies with simulated data sets to investigate the performance of the proposed estimation method concerning parameter recovery and influence of the prior distributions. Results obtained from the simulation studies display that the proposed estimation works very well.

Finally, we apply the model to social data, in which the proportion of children vulnerable to poverty and the Gini index of the municipalities of the state of Alagoas in Brazil for the 2010 season are modeled. The Gini index is modeled as a function of the percentage of people employed in the manufacturing industry. For the case of the l-logistic distribution, we use the median regression model in the context of quantile regression. Quantile regression (QR) models were introduced by Koenker and Bassett (1978) and can model conditional quantiles as functions of predictors. The median regression model accomplishes the same goal in order to represent the relationship between the median (central location) of the response and a set of covariates. If the data are highly skewed, since the median remains robust is a natural measure of the center, the conditional median modeling is more useful than conditional mean modeling in this context. This fact is seen in our first application.

The rest of the paper is organized as follows. In Section 2, we present the pdf, the cdf, the quantile function, and also describe the generation of the l-logistic distribution. In Section 3, we study some characteristics of the distribution, other parameterizations, some related distributions, the moments, and the skewness and kurtosis of the l-logistic distribution. Section 4 is dedicated to the Bayesian estimation of the model parameters. Some methods for model comparison and diagnosis are also discussed in this section. Section 5 presents the results of a simulation study that examines a prior sensitivity analysis and the estimation of the model parameters. Section 6 discusses an application of the model to a on social data from the state of Alagoas, Brazil (proportion of children vulnerable to poverty and Gini index as function of the percentage of people employed in manufacturing). Finally, some concluding comments are made in Section 7. 


\section{The L-logistic Distribution}

We say that the r.v. $Y$ follows a l-logistic distribution if its probability density function (pdf) is given by

$$
f(y \mid m, b)=\frac{b(1-m)^{b} m^{b} y^{b-1}(1-y)^{b-1}}{\left[(1-m)^{b} y^{b}+m^{b}(1-y)^{b}\right]^{2}}, \quad 0<y<1,0<m<1, \quad b>0 .
$$

The parameters $m$ and $b$ allow l-logistic distribution, denoted by $Y \sim L L(m, b)$, to take on a variety of density shapes (see Figure 1 and 2). Note that when we set $m=0.5$ and $b=1$ in (1), then the pdf of the l-logistic distribution simply becomes the pdf of the standard uniform distribution. $m$ is a location parameter, which simply shifts the graph to the left or right on the horizontal axis. On the other hand, $b$ is a shape parameter that governs the shape of the distribution. The l-logistic density is uni-modal (or "uni-antimodal"), increasing, decreasing, or constant, depending on the values of its parameters. More details on this issue are presented with another parameterization of the l-logistic model in Section 3.
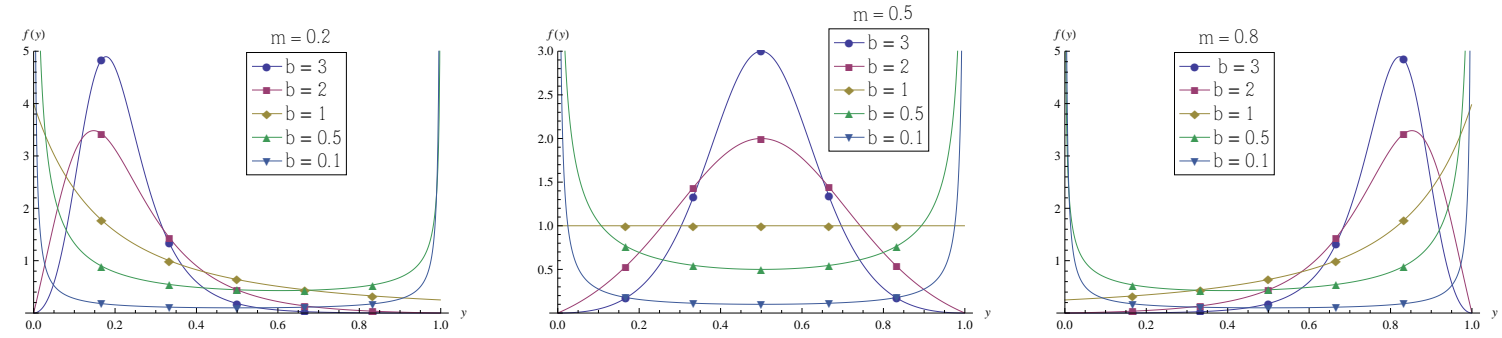

Figure 1: L-logistic probability density function for scale parameter $m=0.2,0.5$ and 0.8 and some values of parameter $b$.
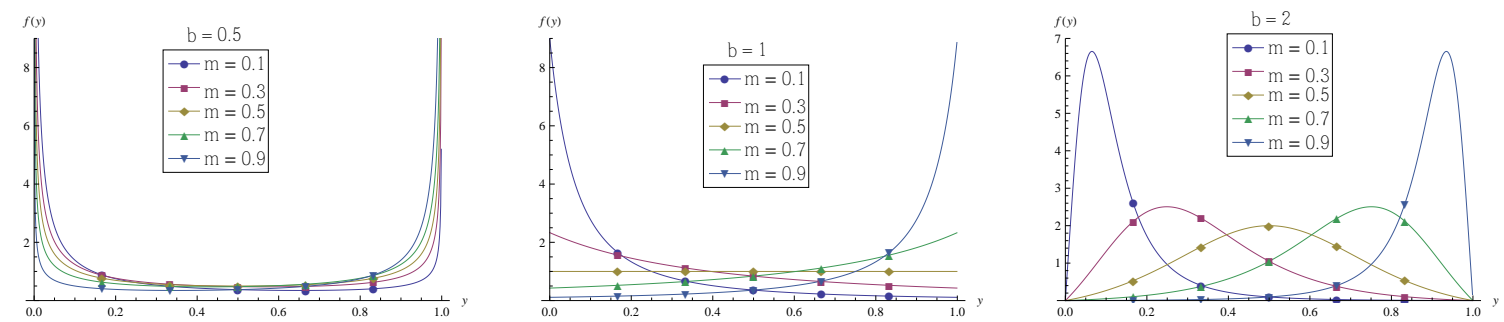

Figure 2: L-logistic probability density function for shape parameter $b=0.5,1$ and 2 and some values of scale parameter $m$.

The cumulative distribution function of the l-logistic distribution is given by

$$
F_{Y}(y \mid m, b)=\left(1+\left(\frac{m(1-y)}{y(1-m)}\right)^{b}\right)^{-1}, 0<y<1 .
$$

which can be readily inverted to yield the quantile function.

$$
Q_{Y}(p)=F_{Y}^{-1}(p)=\frac{m p^{1 / b}}{(1-p)^{1 / b}(1-m)+p^{1 / b} m}, 0 \leq p \leq 1 .
$$


This would readily enable a quantile-based analysis of this model; for example, see Nair et al. (2013) for pertinent details. Note that if $p=(1-p)=0.5$, then $Q(p)=m$, which means that the location parameter $m$ is indeed the $50^{\text {th }}$ percentile or the median of the l-logistic distribution.

Equation (3) facilitates simple random variate generation. If $U \sim \operatorname{Uniform}(0,1)$, then

$$
X=Q(U)=\frac{m U^{1 / b}}{(1-U)^{1 / b}(1-m)+U^{1 / b} m} \sim L L(m, b)
$$

We can also express the inter-quartile range (IQR) as

$$
I Q R=Q(0.75)-Q(0.25)=\frac{m 3^{1 / b}}{(1-m)+3^{1 / b} m}-\frac{m}{3^{1 / b}(1-m)+m} .
$$

The IQR has a breakdown point of $50 \%$, and is often preferred over range. When the distribution is symmetric, half IQR equals the median absolute deviation (MAD), and it is often to detect outliers in data.

\section{Properties of the L-logistic distribution}

This section discuss some properties of the L-logistic distribution such as some related distributions, measures of skewness and kurtosis, mode and the moments. Some pertinent derivations are presented in Appendix A.

\subsection{Related Distributions}

The following property shows the relation between l-logistic distribution and logistic distribution.

Property 3.1. If $Y \sim L L(m, b)$ then $Z=b \log \left(\frac{Y(1-m)}{m(1-Y)}\right)$ has the standard logistic distribution.

Next, we present two alternative parameterizations for the l-logistic distribution.

Property 3.2. If $Y \sim L L(m, b)$, then, with $m=\frac{e^{-\frac{\delta}{b}}}{1+e^{-\frac{\delta}{b}}}(\delta>0)$, the pdf and cdf of the l-logistic distribution become

$$
f(y \mid \delta, b)=\frac{b e^{\delta} y^{b-1}(1-y)^{b-1}}{\left[y^{b} e^{\delta}+(1-y)^{b}\right]^{2}}, \quad 0<y<1,
$$

and

$$
F_{Y}(y \mid \delta, b)=\left(1+e^{-\delta}\left(\frac{1-y}{y}\right)^{b}\right)^{-1}, 0<y<1,
$$

respectively, where $b>0$ and $\delta \in \mathbb{R}$ are both shape parameters.

The parameterization given in (6) and (7) is denoted by $Y \sim L L(\delta, b)$. The pdf of $Y \sim L L(\delta, b)$ was introduced by Tadikamalla and Johnson (1982) and Wang and Rennolls (2005), which extended 
this pdf for any bounded interval by introducing two extra parameters. These authors referred to this distribution as logit-logistic distribution.

Property 3.3. If $Y \sim L L(m, b)$ and $\mu=\frac{1}{1+\left(\frac{m}{1-m}\right)^{b}}$, then the pdf and cdf the alternative parametrization of l-logistic distribution, denoted by $Y \sim L L(\mu, b)$, is given by

$$
f(y \mid \mu, b)=\frac{b \mu(1-\mu) y^{b-1}(1-y)^{b-1}}{\left[y^{b} \mu+(1-y)^{b}(1-\mu)\right]^{2}}, \quad 0<y<1,
$$

and

$$
F_{Y}(y \mid \mu, b)=\left(1+\left(\frac{1-\mu}{\mu}\right)\left(\frac{1-y}{y}\right)^{b}\right)^{-1}, 0<y<1,
$$

with $\mu \in(0,1)$ and $b>0$.

Note that, although the expressions of the alternative parameterization of the l-logistic distribution have simple expresions for the pdf and cdf, they do not have the median as location parameter. An advantage of the parametrization in (1) and (2) is that the parameter $m$ is the median of the distribution and, consequently, the interpretation of this parametrization becomes more easier.

Property 3.4. If $Y \sim L L(\delta, b)$, then $Z^{\prime}=\delta+b \log \left(\frac{Y}{1-Y}\right)$ has the standard logistic distribution. The reciprocal property was first introduced by Tadikamalla and Johnson (1982), based on an equivalent transformation described by Johnson et al. (1994, pg. 34-49) and first investigated by Johnson (1949), for the case of the standard normal distribution. In this case, $Y$ follows the SB-Johnson distribution.

Property 3.5. A more general form of the l-logistic distribution can be given as

$$
f(y \mid m, b, c, d)=\frac{(d-c) b(1-m)^{b} m^{b}(y-c)^{b-1}(d-y)^{b-1}}{\left[(1-m)^{b}(y-c)^{b}+m^{b}(d-y)^{b}\right]^{2}},
$$

$c<y<d$, with $c, d \in \mathbb{R}$. To see justifications of these propiertes, see Appendix A.

\subsection{Mode}

Property 3.6. For $b>1$, the mode of the l-logistic distribution is the solution of the equation

$$
\left(\frac{1-m}{m}\right)^{b}=\left(\frac{1-y_{0}}{y_{0}}\right)^{b} \frac{b+2 y_{0}-1}{b-2 y_{0}+1}
$$

Note that, upon taking $\delta=-b \log \left(\frac{m}{1-m}\right)$, the mode $y_{0}$ can be obtained by solving the equation

$$
\delta=\log \left(\left(\frac{1-y_{0}}{y_{0}}\right)^{b} \frac{b+2 y_{0}-1}{b-2 y_{0}+1}\right) .
$$

In addition, from (11) and (12), if $y_{0}=m=0.5$, then $\delta=0$ for all values of $b$. Thus, we can study the behavior of the mode by studying the function given in (12). For this purpose, we take the derivative 
of the right-hand side of $(12)$ with respect to $y_{0}$ to obtain the equation

$$
\frac{\partial \delta}{\partial y_{0}}=\frac{b\left(b^{2}-1\right)}{\left(y_{0}-1\right) y_{0}\left\{\left(b^{2}-1\right)+4 y_{0}-4 y_{0}^{2}\right\}} .
$$

(11) is negative for $b>1$, the situation where $\delta$ decreases as $y_{0}$ (mode) increases (first derivative test), then the mode lies in $(0,1 / 2)$ if $\delta>0$ (or $m<1 / 2)$ and for $\delta<0$ (or $m>1 / 2$ ) the mode is in $(1 / 2,0)$. If $b<1,(13)$ is positive whenever $\left\{\left(b^{2}-1\right)+4 y_{0}-4 y_{0}^{2}\right\}>0$, that is, whenever $\frac{1-b}{2}<y<\frac{1+b}{2}$, the situation where $\delta$ increases as $y$ increases. Thus, from (12) and (13) the minimum of the pdf lies in $\left(\frac{1-b}{2}, 1 / 2\right)$ for $\delta<0$ or $m>1 / 2$, and in $\left(1 / 2, \frac{1+b}{2}\right)$ for $\delta>0$ or $m<1 / 2$.

\subsection{Skewness and Kurtosis}

First, we have the following symmetric property.

Property 3.7. The l-logistic density is symmetric when $m=0.5$ whatever the value of $b$ is.

For the case when the l-logistic density is asymmetric, the degree of skewness can be quantified by some measures of skewness. Since the l-logistic distribution is related to the logistic distribution, the skewness measure introduced by Arnold and Groeneveld (1995), and denoted by $\gamma_{M}$, seems to be an appropriate skewness measure. The measure $\gamma_{M}$ is based on the mode of distribution and is given by

$$
\gamma_{M}=1-2 F(M)
$$

where $M$ is the mode of the distribution and $F($.$) is the distribution function. The value of \gamma_{M}$ lies in $(-1,1)$, and if $\gamma_{M}$ is near 1 , it indicates extreme right skewness. On the other hand, if $\gamma_{M}$ is near -1 , it indicates extreme left skewness.

We also consider another measure of skewness called octile skewness (denoted here by $\gamma_{p}$ ), first proposed by Hinkley (1975) and discussed further Brys et al. (2003). This skewness measure is given by

$$
\gamma_{p}=\frac{Q(1-p)+Q(p)-2 m}{Q(1-p)-Q(p)}
$$

which is a function of high and low percentiles defined by $p \in(0,0.5)$ with $Q($.$) as in (3). The maximum$ value of $\gamma_{p}$ is 1 , representing extreme right skewness, and the minimum is -1 , representing extreme left skewness. This measure is also zero for any symmetric distribution. However, the function in (15) depends on the value of $p$. We can remove this dependence by integrating over $p$, (see Groeneveld and Meeden, 1984), or to decide which value of $p$ is appropriate for use. In Brys et al. (2003), there is a comparison between several robust skewness measures in which accuracy, robustness, and computational complexity are considered. The most interesting skewness measure of the measures 
investigated is octile skewness. Octile skewness takes $p=0.125$ in (15), that is, it is given by

$$
\gamma_{125}=\frac{Q(0.875)+Q(0.125)-2 m}{Q(0.875)-Q(0.125)} .
$$

For the l-logistic distribution, we mase use of this particular skewness measure instead of removing the dependence over $p$ thorough integration.

Moreover, the kurtosis of the l-logistic distribution can also be derived easily by using the quantiles. The kurtosis measure introduced by Moors (1988) is given by

$$
k_{Q}=\frac{Q(0.875)-Q(0.625)-Q(0.375)+Q(0.125)}{Q(0.75)-Q(0.25)},
$$

with $k_{Q} \in(0, \infty)$.

Figure 3 presents the results of the measures of skewness and kurtosis described here for some values of the location parameter $m$ as a function of the shape parameter $b, b>1$. In this figure, we can see that the two measures of skewness become close as $b$ increases, as intuition suggests. Moors (1988) justified the use of the kurtosis measure in 17 by the interpretation that the two terms in the numerator of (17) are large (small) if relatively little (much) probability mass is concentrated in the neighborhood of $Q(0.75)$ and $Q(0.25)$. This corresponds to large (small) dispersion around (roughly) $E_{Y}[Y] \pm \operatorname{Var}_{Y}[Y]$ where $E_{Y}[Y]$ and $\operatorname{Var}_{Y}[Y]$ are the mean and variance of r.v. $Y$, respectively.
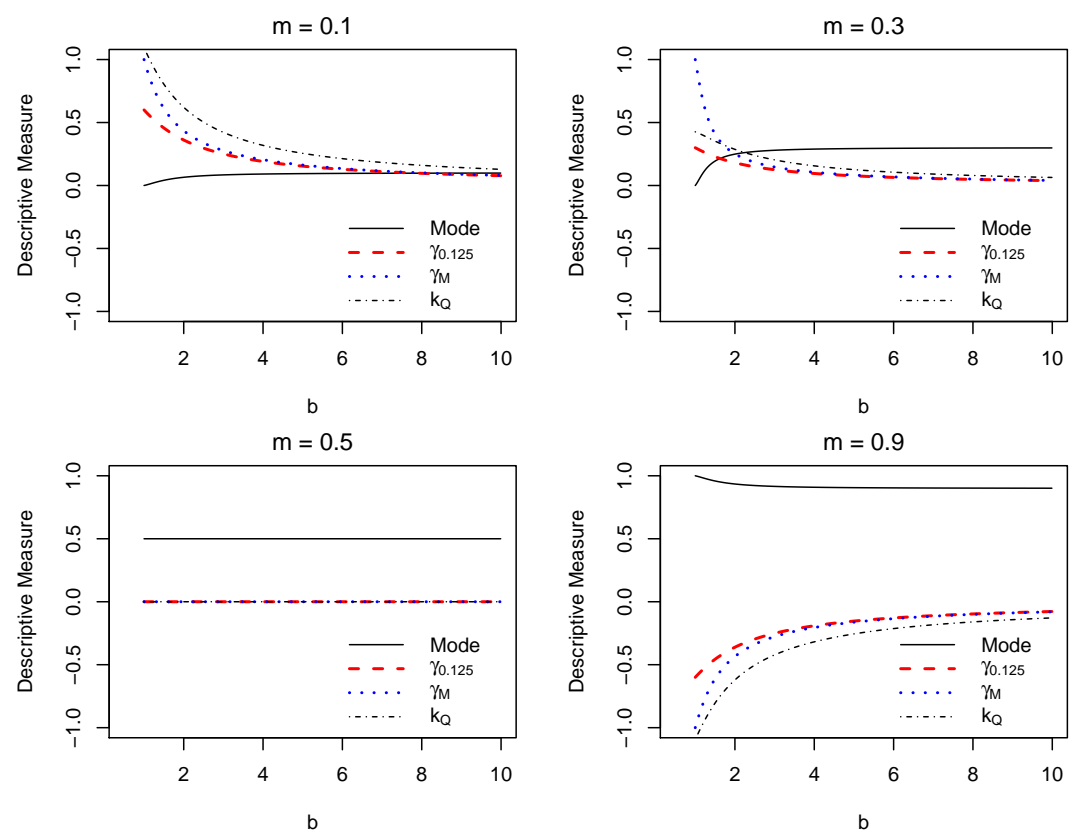

Figure 3: The mode, skewness $\left(\gamma_{M}\right.$ and $\left.\gamma_{0.125}\right)$ and kurtosis $\left(k_{Q}\right)$ of the l-logistic distribution for some values of the parameters.

\subsection{Moments}

The following propositions gives an expression for the moments of the l-logistic distribution. 
Property 3.8. If $Y \sim L L(m, b)$, then the $t$-th moment of $Y$ about zero is given by

$$
E\left[Y^{t}\right]=\int_{0}^{1}\left[1+\left(\frac{1-v}{v}\right)^{1 / b}\left(\frac{1-m}{m}\right)\right]^{-t} d v .
$$

The integral in (18) cannot be expressed in an analytical form. However, we can use numerical integration to evaluate some moments as $E_{Y}(Y), E_{Y}\left(Y^{2}\right)$ and $\operatorname{Var}_{Y}(Y)=E_{Y}\left(Y^{2}\right)-E_{Y}(Y)^{2}$. Table 1 shows some values of the first and second moments and the variance of the l-logistic distribution. In addition, Figure 4 shows the graphs of the mean and the variance as functions of the shape parameter $b$, for some values of the location parameter $m$. For this purpose, the integral in (18) was evaluated by the Gauss quadrature through the 'statmod' R package (Smyth et al., 2015).
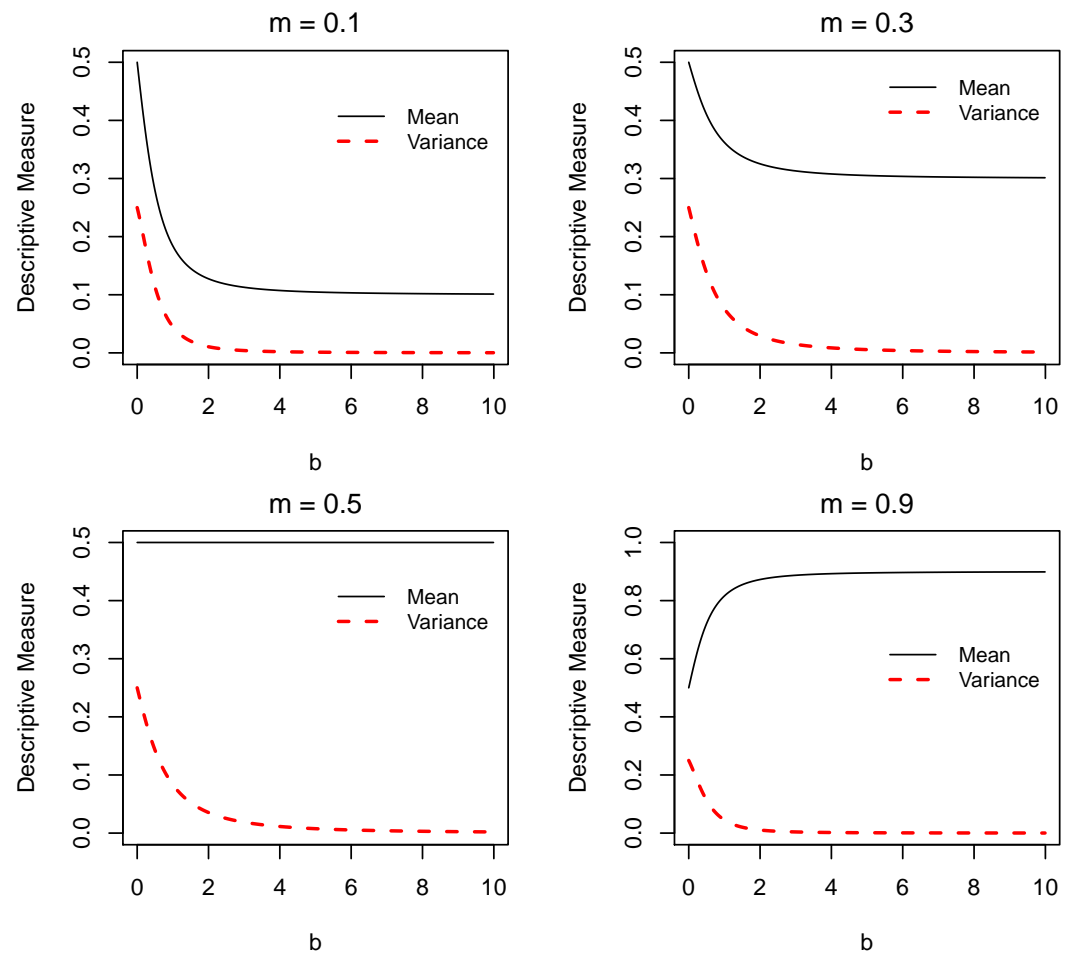

Figure 4: Descriptive measures of the l-logistic distributions for some values of the parameters

Table 1: $E_{Y}[Y], E_{Y}\left[Y^{2}\right]$, and $\operatorname{Var}_{Y}(X)$ of the l-logistic distribution for some values of $b$ and $m$.

\begin{tabular}{c|cccccc}
\hline$m$ & 0.2 & 0.5 & 0.8 & 0.2 & 0.5 & 0.8 \\
$b$ & 1 & 1 & 1 & 3 & 3 & 3 \\
\hline$E_{Y}[Y]$ & 0.283 & 0.5 & 0.717 & 0.216 & 0.5 & 0.784 \\
$E_{Y}\left[Y^{2}\right]$ & 0.145 & 0.333 & 0.579 & 0.056 & 0.269 & 0.625 \\
$\operatorname{Var}_{Y}[Y]$ & 0.065 & 0.083 & 0.065 & 0.010 & 0.019 & 0.01 \\
\hline
\end{tabular}




\section{Bayesian inference}

In this section, we describe the Bayesian approach for the estimation of the parameters of the l-logistic model. If we consider a random sample $\boldsymbol{Y}=\left(Y_{1}, \ldots, Y_{n}\right)$ from the distribution in (2), then the likelihood function is given by

$$
L(\theta \mid \boldsymbol{y})=\prod_{i=1}^{n} \frac{b(1-m)^{b} m^{b} y_{i}^{b-1}\left(1-y_{i}\right)^{b-1}}{\left[(1-m)^{b} y_{i}^{b}+m^{b}\left(1-y_{i}\right)^{b}\right]^{2}} .
$$

\subsection{Prior specification}

To complete the Bayesian specification of the model, since parameters $m$ and $b$ have different behavior, we assume independence between them, and the following structure is then considered:

$$
\pi(m, b)=\pi(m) \pi(b)
$$

where $\pi(m)$ and $\pi(b)$ are the prior densities for $m$ and $b$, respectively.

Assuming that $m \sim$ unifom $(0,1)$, where uniform $(0,1)$ represents the uniform distribution on the unit interval, and prior $\pi(b)$ for the parameter $b$, the joint posterior distribution for $(m, b)$ is given by

$$
\pi(m, b \mid \boldsymbol{y}) \propto \prod_{i=1} \frac{b^{n}(1-m)^{b} m^{b} \pi(b)}{\left[(1-m)^{b} y_{i}^{b}+m^{b}\left(1-y_{i}\right)^{b}\right]^{2}} .
$$

The prior $\pi(b)$ can be, for example, the pdf of the gamma distribution with parameters vector $(\epsilon, \epsilon)$, $\epsilon$ a small value. Some priors for parameter $b$ are compared and discussed in Section 7.

Since the posterior distribution is not available in a form closed, the Markov Chain Monte Carlo (MCMC) approach (Gelman et al., 2013, pp. 259 - 349) is used to estimate the model parameters. Initially, we consider the full conditional posterior distributions for the parameters $(m, b)$ given by

$$
\begin{aligned}
& \pi(m \mid b, \boldsymbol{y})=K_{1}^{-1} \frac{(1-m)^{n b} m^{n b}}{\prod_{i=1}^{n}\left[(1-m)^{b} y_{i}^{b}+m^{b}\left(1-y_{i}\right)^{b}\right]^{2}} \\
& \pi(b \mid m, \boldsymbol{y})=K_{2}^{-1} \prod_{i=1}^{n}\left(\frac{b(1-m)^{b} m^{b} y_{i}^{b-1}\left(1-y_{i}\right)^{b-1}}{\left[(1-m)^{b} y_{i}^{b}+m^{b}\left(1-y_{i}\right)^{b}\right]^{2}}\right) \pi(b)
\end{aligned}
$$

where $K_{1}$ and $K_{2}$ are normalizing constants.

Thus, a hybrid algorithm that combines Metropolis-Hastings and Gibbs sampling was implemented in $\mathrm{R}$ language ( $\mathrm{R}$ Development Core Team, 2015) to obtain a sample from the posterior distribution of model parameters $(m, b)$. These codes are available upon request. The model can also be implemented easily in Bugs or other software such as Jags or R Stan (Lunn et al., 2000; Plummer, 2003; Guo, 2015). 


\subsection{Model comparison criteria}

In order to compare different models, we made use of some model comparison criteria. Specifically, we consider the Expected Akaike information criteria (EAIC), the expected Bayesian information criteria (EBIC), the deviance information criteria (DIC), and the Watanabe-Akaike information criteria (Watanabe, 2010, WAIC). For a review of these criteria, one may refer to Gelman et al. (2013). The EAIC, EBIC and DIC can be estimated as

$$
\begin{aligned}
E A I C & =\bar{D}+2 \times p \\
E B I C & =\bar{D}+10 \times \log n \\
D I C & =\bar{D}+p_{D},
\end{aligned}
$$

where

$$
\begin{gathered}
\bar{D}=G^{-1} \sum_{g=1}^{G}\left(-2 \sum_{i=1}^{n} \log \left(f\left(y_{i} \mid b^{g}, m^{g}\right)\right),\right. \\
\hat{D}=-2 \sum_{i=1}^{n} \log \left(f\left(y_{i} \mid \bar{m}, \bar{b}\right),\right.
\end{gathered}
$$

$p_{D}=\bar{D}-\hat{D}$, and $p$ represents the number of model parameters. Here, the notation $\bar{\theta}$ means the posterior mean of $\theta$ and $\theta^{(g)}$ represents the $g$ th parameters of vector $\theta$ of a sequence of size $G$ generated from the posterior distribution by $M C M C$ method.

WAIC is a Bayesian approach for estimating the expected pointwise log predictive density (elppd) for a new dataset, and is given by

$$
\text { elppd }=\sum_{i=1}^{n} E_{y}[\log (P(\tilde{y}))],
$$

where the expectancy $E_{y}[$.$] and the pdf P($.$) are related to the predictive distribution (pd) induced$ by the posterior distribution $P(m, b \mid \boldsymbol{y})$ and $\tilde{y}$ is a future data. To estimate the elppd, we start by computing the pointwise log predictive density (lppd) as

$$
\begin{aligned}
l p p d & =\sum_{i=1}^{n} \log P\left(y_{i}\right) \\
& =\sum_{i=1}^{n} \log \int f\left(y_{i} \mid m, b\right) d P(m, b \mid \boldsymbol{y}) \\
& \approx \sum_{i=1}^{n} \log \left(G^{-1} \sum_{g=1}^{G} f\left(y_{i} \mid m^{g}, b^{g}\right)\right)=l \hat{p p} d .
\end{aligned}
$$

Thus, we can use a factor of correction for the effective number of parameters to adjust for overfitting. In the literature, there are two factors of correction that can be viewed as approximations to crossvalidation (Gelman et al., 2013, pp. 169-174). The factor of correction used here makes use of the 
variance in each term of the log predictive density and it is used here to obtain the WAIC. This factor is given by

$$
\begin{aligned}
p_{W A I C} & =\sum_{i=1}^{n} \operatorname{Var}_{(m, b) \mid \boldsymbol{y}}\left[\log \left(f\left(y_{i} \mid(m, b)\right)\right]\right. \\
\approx & \sum_{i=1}^{n}\left(\frac{1}{G-1} \sum_{g=1}^{G}\left[\log \left(f\left(y_{i} \mid m^{g}, b^{g}\right)\right)-G^{-1} \sum_{g=1}^{G} \log \left(f\left(y_{i} \mid m^{g}, b^{g}\right)\right)\right]^{2}\right)=\hat{p}_{W A I C_{2}} .
\end{aligned}
$$

Finally, we can compute the WAIC as an approximation to the elppd as

$$
W A I C=l \hat{p p} d-\hat{p}_{W A I C}
$$

\subsection{Posterior predictive checking}

One point that will be of interest is the predictive distribution for a future observation. The density estimation of the posterior predictive distribution is obtained by integrating the unconditional predictive distribution $P(\tilde{y} \mid \mathbf{y})=\int P(\tilde{y} \mid \boldsymbol{\theta}) d P(\boldsymbol{\theta} \mid \boldsymbol{y})$, where $P(\boldsymbol{\theta} \mid \mathbf{y})$ is the density of the posterior distribution of the parameters of the assumed model. In practice, we will be interested in simulating draws from the posterior predictive distribution of unknown observables $\tilde{y}$. Thus, as discussed by Gelman et al. (2013), the predictive distribution can be used to compare the predicted value under the assumed model $y^{r e p}$ with the actual data $y$, where $y^{r e p}$ can be thought as an estimate of $\tilde{y}$, or as an attempt to replicate the observed data based on the parameters. If the model fits well, then this predicted value should be similar to the observed data.

Using MCMC techniques, we could simulate values of the posterior predictive distribution by generating $y^{r e p}$ from the distribution assumed by its model structure with the parameters generated from the posterior distribution. Let us consider $y_{1}, \ldots, y_{n}$ as observations generated independently from the l-logistic distribution. Then, we can generate $y^{r e p}$ from the l-logistic distribution with appropriate parameters, that is,

$$
y_{i}^{r e p,(s)} \sim L L\left(m^{s}, b^{s}\right)
$$

$s=1, \ldots, S$, where $\left(m^{1}, b^{1}\right), \ldots,\left(m^{S}, b^{S}\right)$ is a sample generated from the posterior distribution. After generating $\left(y_{1}^{r e p,(s)}, \ldots, y_{n}^{r e p,(s)}\right)$, we order the sample to achieve $\left(y_{(1)}^{r e p,(s)}, \ldots, y_{(n)}^{r e p,(s)}\right)$, the ordered generated value. We can then compare the distribution of the ordered generated values $y_{(i)}^{r e p,(s)}$ with the ordered observed values $y_{(i)}$. Finally, error bar can be constructed or posterior predictive values can be obtained by making use of the discrepancy measure, allowing for an evaluation of the model fit. Details about the predictive model checking are discussed by Gelman et al. (2013), Ntzoufras (2011), and Berkhof et al. (2000). 


\section{Simulation studies}

This section is devoted two simulation studies, one that examines a prior sensitivity analysis and another investigates the recovery of the parameters of the model by the proposed estimation method. For this purpose, the Bayesian method is applied on simulated data sets from the l-logistic distribution, considering different scenarios. For the estimation of parameters, we generated 20,000 samples from the posterior distribution given in (21), then the first 10,000 samples were discarded and sequences of 10 observations were eliminated, and finally the resulting samples of size 1,000 were used for inference.

\subsection{Prior sensitivity analysis}

Prior sensitivity analysis plays an important role in applied Bayesian analyses. This is especially true for Bayesian models used for new distribution, where the interpretability of the corresponding parameters becomes important. In this section, we consider a simulation study to evaluate the sensitivity of different choices of prior distributions for parameter $b$ since this is different from parameter $m$, which is clearer in its interpretation. Specifically, we assume prior independence between parameter $b$ and $m$, considering a unit uniform distribution for parameter $m$.

The models estimated with different prior distributions were compared by using WAIC, EAIC, EBIC and DIC. We considered five different prior distributions for parameter $b$, considering simulated data sets from the l-logistic distribution for some pairs of parameters $m$ and $b$. The values for the parameters $m$ and $b$ used are as follows: $b \in\{0.5,1,5\}$ and $m \in\{0.2,0.5,0.9\}$, leading to nine pairs of parameters. We simulated samples of size $n=100, y_{1}, \ldots y_{n}$, from the l-logistic distribution considering these pairs of parameters, then nine distinct simulated datasets were considered for the analysis.

Based on the works of Gelman (2006) and Figueroa-Zúñiga et al. (2013), we consider for the parameter $b$ three non-informative and two informative prior distributions. The non-informative prior distributions are the gamma distribution with parameters vector $(0.001,0.001)(b \sim \operatorname{Gamma}(0.001,0.001))$, denoted by prior A, the uniform distribution with parameters vector $(1,100)$ for $U(U \sim$ Uniform $(0,100))$ with $b=U^{2}$, denoted by prior $\mathrm{B}$, and the central Student $\mathrm{t}$ distribution with parameters vector $(10,0,2)(L \sim S t(0,100))$ for $L$ with $\log (b)=L$, denoted by prior C. The prior B is chosen as it is less informative than the usual gamma with parameter vector $(\epsilon, \epsilon)$. For the informative prior distributions, we consider $b \sim \operatorname{Gamma}(2.5,1)$, denoted by prior $\mathrm{D}$, and $b \sim \operatorname{Gamma}(50,1)$, denoted by prior E. Note that prior $\mathrm{E}$ provides incorrect information about parameter $b$, while prior $\mathrm{D}$ provides almost correct information. For all the cases, the prior distribution for parameter $m$ is the uniform distribution with parameters 0 and $1,(m \sim \operatorname{Uniform}(0,1))$.

Table 2 shows the values of WAIC, EAIC, EBIC, and DIC for the fitted models. For all 
the simulated datasets, we found that with prior E the estimated model achieves the worst fit among all models fitted for the same dataset. However, for the models using all other prior distributions, the values of WAIC, EAIC, EBIC, and DIC are quite close, showing no significant difference, giving evidence that the estimated models provide almost the same quality of fit for the analyzed samples. Thus, for these cases, the posterior distribution does not seen to be sensitive with respect to the specification of these prior distributions.

Additionally, we chose two non-informative priors $\mathrm{A}$ and $\mathrm{C}$ and the worst informative prior E. The prior A was chosen for this analysis was it is the simplest among the non-informative priors considered, while prior $\mathrm{C}$ is chosen as it is less informative than A. Table 3 reports the posterior mean and the 95\% HPD interval (obtained by the package of Martin et al. (2011)). We observe that when the prior is $\mathrm{E}$, the posterior mean is not far from the true value of $b$, showing that the data still dominates the prior information for these data. However, for some cases, the HPD interval does not contain the true value of $b$.

Table 2: Statistics for model comparison, prior distributions for parameter $b$ and the true value of the parameters of the l-logistic distribution used to simulate the data sets.

\begin{tabular}{|c|c|c|c|c|c|}
\hline \multirow{2}{*}{$\begin{array}{c}\text { Parameter } \\
\qquad(m, b)\end{array}$} & \multirow[t]{2}{*}{ Prior } & \multicolumn{4}{|c|}{ Criteria } \\
\hline & & WAIC & EAIC & EBIC & DIC \\
\hline \multirow{5}{*}{$(0.2,0.5)$} & $\mathrm{A}, b \sim \operatorname{Gamma}(0.001,0.001)$ & 41.761 & -77.482 & 10.622 & -82.685 \\
\hline & $\mathrm{B}, b=U^{2}, U \sim$ Uniform $(0,100)$ & 41.763 & -77.483 & 10.620 & -82.688 \\
\hline & $\mathrm{C}, \log (b)=L, L \sim S t(10,0,2)$ & 41.782 & -77.516 & 10.587 & -82.754 \\
\hline & $\mathrm{D}, b \sim \operatorname{Gamma}(2.5,1)$ & 41.793 & -77.464 & 10.639 & -82.650 \\
\hline & $\mathrm{E}, b \sim \operatorname{Gamma}(50,1)$ & 35.833 & -64.595 & 23.508 & -56.912 \\
\hline \multirow{5}{*}{$(0.2,1)$} & $\mathrm{A}, b \sim \operatorname{Gamma}(0.001,0.001)$ & 31.945 & -58.058 & 30.045 & -63.480 \\
\hline & $\mathrm{B}, b=U^{2}, U \sim$ Uniform $(0,100)$ & 31.959 & -57.995 & 30.109 & -63.353 \\
\hline & $\mathrm{C}, \log (b)=L, L \sim S t(10,2)$ & 31.971 & -58.066 & 30.038 & -63.496 \\
\hline & $\mathrm{D}, b \sim \operatorname{Gamma}(2.5,1)$ & 31.971 & -58.026 & 30.077 & -63.416 \\
\hline & $\mathrm{E}, b \sim \operatorname{Gamma}(50,1)$ & 26.129 & -45.275 & 42.829 & -37.914 \\
\hline \multirow{5}{*}{$(0.2,5)$} & $\mathrm{A}, b \sim \operatorname{Gamma}(0.001,0.001)$ & 160.483 & -314.935 & -226.831 & -320.145 \\
\hline & $\mathrm{B}, b=U^{2}, U \sim$ Uniform $(0,100)$ & 160.482 & -315.031 & -226.927 & -320.336 \\
\hline & $\mathrm{C}, \log (b)=L, L \sim S t(10,2)$ & 160.493 & -315.006 & -226.903 & -320.288 \\
\hline & $\mathrm{D}, b \sim \operatorname{Gamma}(2.5,1)$ & 160.369 & -314.847 & -226.743 & -319.969 \\
\hline & $\mathrm{E}, b \sim \operatorname{Gamma}(50,1)$ & 156.062 & -305.213 & -217.110 & -300.702 \\
\hline \multirow{5}{*}{$(0.5,0.5)$} & $\mathrm{A}, b \sim G(0.001,0.001)$ & 25.885 & -45.841 & 42.263 & -51.163 \\
\hline & $\mathrm{B}, b=U^{2}, U \sim$ Uniform $(0,100)$ & 25.904 & -45.847 & 42.256 & -51.176 \\
\hline & $\mathrm{C}, \log (b)=L, L \sim S t(10,2)$ & 25.921 & -45.844 & 42.259 & -51.170 \\
\hline & $\mathrm{D}, b \sim \operatorname{Gamma}(2.5,1)$ & 25.915 & -45.862 & 42.242 & -51.205 \\
\hline & $\mathrm{E}, b \sim \operatorname{Gamma}(50,1)$ & 19.934 & -32.760 & 55.344 & -25.001 \\
\hline
\end{tabular}


Table 2 - Continued

\begin{tabular}{|c|c|c|c|c|c|}
\hline \multirow{2}{*}{$\begin{array}{c}\text { Parameter } \\
\qquad(m, b)\end{array}$} & \multirow[t]{2}{*}{ Prior } & \multicolumn{4}{|c|}{ Criteria } \\
\hline & & WAIC & EAIC & EBIC & DIC \\
\hline \multirow{5}{*}{$(0.5,1)$} & $\mathrm{A}, b \sim \operatorname{Gamma}(0.001,0.001)$ & 1.634 & 2.633 & 90.736 & -2.734 \\
\hline & $\mathrm{B}, b=U^{2}, U \sim$ Uniform $(0,100)$ & 1.647 & 2.665 & 90.768 & -2.670 \\
\hline & $\mathrm{C}, \log (b)=L, L \sim S t(10,2)$ & 1.664 & 2.623 & 90.726 & -2.754 \\
\hline & $\mathrm{D}, b \sim \operatorname{Gamma}(2.5,1)$ & 1.658 & 2.628 & 90.732 & -2.744 \\
\hline & $\mathrm{E}, b \sim \operatorname{Gamma}(50,1)$ & -4.103 & 15.133 & 103.236 & 22.266 \\
\hline \multirow{5}{*}{$(0.5,5)$} & $\mathrm{A}, b \sim \operatorname{Gamma}(0.001,0.001)$ & 117.115 & -228.297 & -140.194 & -233.624 \\
\hline & $\mathrm{B}, b=U^{2}, U \sim$ Uniform $(0,100)$ & 117.121 & -228.277 & -140.174 & -233.583 \\
\hline & $\mathrm{C}, \log (b)=L, L \sim S t(10,2)$ & 117.126 & -228.282 & -140.179 & -233.594 \\
\hline & $\mathrm{D}, b \sim \operatorname{Gamma}(2.5,1)$ & 116.994 & -228.085 & -139.982 & -233.199 \\
\hline & $\mathrm{E}, b \sim \operatorname{Gamma}(50,1)$ & 112.630 & -218.350 & -130.247 & -213.730 \\
\hline \multirow{5}{*}{$(0.9,0.5)$} & $\mathrm{A}, b \sim \operatorname{Gamma}(0.001,0.001)$ & 91.031 & -176.006 & -87.903 & -181.160 \\
\hline & $\mathrm{B}, b=U^{2}, U \sim$ Uniform $(0,100)$ & 91.051 & -176.081 & -87.977 & -181.309 \\
\hline & $\mathrm{C}, \log (b)=L, L \sim S t(10,2)$ & 91.069 & -176.135 & -88.031 & -181.418 \\
\hline & $\mathrm{D}, b \sim \operatorname{Gamma}(2.5,1)$ & 91.059 & -176.039 & -87.936 & -181.227 \\
\hline & $\mathrm{E}, b \sim \operatorname{Gamma}(50,1)$ & 84.975 & -162.958 & -74.854 & -155.064 \\
\hline \multirow{5}{*}{$(0.9,1)$} & $\mathrm{A}, b \sim \operatorname{Gamma}(0.001,0.001)$ & 84.183 & -162.356 & -74.253 & -167.553 \\
\hline & $\mathrm{B}, b=U^{2}, U \sim$ Uniform $(0,100)$ & 84.195 & -162.383 & -74.280 & -167.608 \\
\hline & $\mathrm{C}, \log (b)=L, L \sim S t(10,2)$ & 84.240 & -162.419 & -74.316 & -167.680 \\
\hline & $\mathrm{D}, b \sim \operatorname{Gamma}(2.5,1)$ & 84.202 & -162.330 & -74.227 & -167.501 \\
\hline & $\mathrm{E}, b \sim \operatorname{Gamma}(50,1)$ & 78.539 & -150.041 & -61.938 & -142.923 \\
\hline \multirow{5}{*}{$(0.9,5)$} & $\mathrm{A}, b \sim \operatorname{Gamma}(0.001,0.001) 9$ & 218.348 & -430.817 & -342.714 & -436.198 \\
\hline & $\mathrm{B}, b=U^{2}, U \sim$ Uniform $(0,100)$ & 218.364 & -430.837 & -342.734 & -436.239 \\
\hline & $\mathrm{C}, \log (b)=L, L \sim S t(10,2)$ & 218.362 & -430.666 & -342.563 & -435.897 \\
\hline & $\mathrm{D}, b \sim \operatorname{Gamma}(2.5,1)$ & 218.246 & -430.697 & -342.594 & -435.958 \\
\hline & $\mathrm{E}, b \sim \operatorname{Gamma}(50,1)$ & 213.936 & -421.048 & -332.945 & -416.660 \\
\hline
\end{tabular}


Table 3: Posterior mean with 95\% HPD interval, prior distributions for parameter $b$ and true values of the parameters of l-logistic distribution used to simulate the data sets.

\begin{tabular}{|c|c|c|c|c|c|c|}
\hline \multirow{2}{*}{$\begin{array}{l}\text { Real } \\
\text { Value }\end{array}$} & \multicolumn{2}{|c|}{ Prior A } & \multicolumn{2}{|c|}{ Prior $\mathrm{C}$} & \multicolumn{2}{|c|}{ Prior E } \\
\hline & Mean & HPD $(95 \%)$ & Mean & HPD (95\%) & Mean & HPD $(95 \%)$ \\
\hline $\mathrm{m}=0.20$ & 0.24 & $(0.14,0.35)$ & 0.24 & $(0.14,0.35)$ & 0.24 & $(0.16,0.33)$ \\
\hline $\mathrm{b}=0.50$ & 0.58 & $(0.49,0.67)$ & 0.59 & $(0.50,0.68)$ & 0.78 & $(0.68,0.90)$ \\
\hline $\mathrm{m}=0.20$ & 0.21 & $(0.17,0.26)$ & 0.21 & $(0.17,0.26)$ & 0.22 & $(0.18,0.26)$ \\
\hline $\mathrm{b}=1.00$ & 1.15 & $(0.98,1.34)$ & 1.17 & $(0.98,1.35)$ & 1.55 & $(1.34,1.77)$ \\
\hline $\mathrm{m}=0.20$ & 0.20 & $(0.19,0.21)$ & 0.20 & $(0.19,0.21)$ & 0.20 & $(0.19,0.21)$ \\
\hline $\mathrm{b}=5.00$ & 5.77 & $(4.89,6.76)$ & 5.77 & $(4.83,6.77)$ & 7.51 & $(6.49,8.55)$ \\
\hline $\mathrm{m}=0.50$ & 0.54 & $(0.40,0.68)$ & 0.54 & $(0.39,0.68)$ & 0.54 & $(0.43,0.66)$ \\
\hline $\mathrm{b}=0.50$ & 0.58 & $(0.48,0.67)$ & 0.59 & $(0.49,0.68)$ & 0.78 & $(0.67,0.88)$ \\
\hline $\mathrm{m}=0.50$ & 0.52 & $(0.44,0.58)$ & 0.52 & $(0.45,0.59)$ & 0.52 & $(0.47,0.58)$ \\
\hline $\mathrm{b}=1.00$ & 1.16 & $(0.97,1.33)$ & 1.17 & $(0.98,1.36)$ & 1.55 & $(1.33,1.76)$ \\
\hline $\mathrm{m}=0.50$ & 0.50 & $(0.49,0.52)$ & 0.50 & $(0.49,0.52)$ & 0.50 & $(0.49,0.52)$ \\
\hline $\mathrm{b}=5.00$ & 5.78 & $(4.79,6.77)$ & 5.79 & $(4.83,6.68)$ & 7.52 & $(6.51,8.68)$ \\
\hline $\mathrm{m}=0.90$ & 0.90 & $(0.85,0.95)$ & 0.90 & $(0.86,0.95)$ & 0.91 & $(0.87,0.94)$ \\
\hline $\mathrm{b}=0.50$ & 0.58 & $(0.49,0.68)$ & 0.59 & $(0.49,0.69)$ & 0.78 & $(0.68,0.89)$ \\
\hline $\mathrm{m}=0.90$ & 0.90 & $(0.88,0.93)$ & 0.90 & $(0.88,0.93)$ & 0.91 & $(0.89,0.93)$ \\
\hline $\mathrm{b}=1.00$ & 1.15 & $(0.98,1.34)$ & 1.17 & $(0.98,1.36)$ & 1.55 & $(1.34,1.77)$ \\
\hline $\mathrm{m}=0.90$ & 0.90 & $(0.90,0.91)$ & 0.90 & $(0.90,0.91)$ & 0.90 & $(0.90,0.91)$ \\
\hline $\mathrm{b}=5.00$ & 5.78 & $(4.96,6.78)$ & 5.79 & $(4.80,6.72)$ & 7.51 & $(6.60,8.76)$ \\
\hline
\end{tabular}

\subsection{Parameter recovery}

We carried out an evaluation of the point estimation, based on the $\sqrt{M S E}$ and bias, for simulated data sets from the l-logistic distribution. The mean and variance of an estimator $\hat{\theta}$ can be computed by Monte Carlo simulation, and it can be made done using the approximations

$$
\begin{gathered}
E_{\hat{\theta}}[\hat{\theta}] \approx G^{-1} \sum_{g=1}^{G} \hat{\theta}^{g}, \\
\operatorname{Var}_{\hat{\theta}}[\hat{\theta}] \approx G^{-1} \sum_{g=1}^{G}\left(\hat{\theta}^{g}-E_{\hat{\theta}}[\hat{\theta}]\right)^{2},
\end{gathered}
$$

where $\hat{\theta}^{1}, \ldots, \hat{\theta}^{G}$ are obtained from $G$ different simulated samples. Thus, the MSE of $\hat{\theta}$ is the function of $\theta$ defined by

$$
E_{\hat{\theta}}\left[(\hat{\theta}-\theta)^{2}\right]=\operatorname{Var}_{\hat{\theta}}[\hat{\theta}]+\left(E_{\hat{\theta}}[\hat{\theta}]-\theta\right)^{2} \approx G^{-1} \sum_{g=1}^{G}\left(\hat{\theta}^{g}-\theta\right)^{2},
$$


where $E[\hat{\theta}]-\theta$ is the bias of $\hat{\theta}$. Of course, a good estimator should produce mean, standard deviation (square root of variance), and bias close to zero.

For the analysis presented here, we generated samples of size $n=50, n=100$, and $n=500$, the values of the parameters were set as $m \in\{0.2,0.5,0.9\}$ and $b \in\{0.3,0.5,1,2,4\}$. For these data sets, we estimated the parameters of the l-logistic model by using the Bayesian method under the assumption of independent priors for $m$ and $b$ with non-informative prior distributions uniform and gamma for $m$ and $b$, respectively, that is,

$$
m \sim \operatorname{Uniform}(0,1) \quad \text { and } \quad b \sim \operatorname{Gamma}(0.001,0.001)
$$

Gamma distribution is commonly used in the literature for shape parameters (specifically for precision parameters) and, based on the analysis presented in Subsection 5.1, the posterior distribution is not sensitive with respect to the specification of this prior distribution.

Bayes estimator used here is that the mean of the posterior distribution (estimator with respect to squared error loss function).

Table 4 shows the values of the $\sqrt{M S E}$ and bias from the simulated data sets. The estimates for these quantities were obtained by $G=1,000$ Monte Carlo replications. We can see that the $\sqrt{M S E}$ and bias are close to zero even when the the sample size is $n=50$. For these samples, the estimator performs very well as both $\sqrt{M S E}$ and bias are very small, for all the analyzed samples. 
Table 4: Bias and square root of mean square error $(\sqrt{M S E})$ of the Bayesian estimator of the parameters $m$ and $b$.

\begin{tabular}{|c|c|c|c|c|c|c|c|c|}
\hline \multicolumn{3}{|c|}{ Real value } & \multicolumn{2}{|c|}{$\mathrm{m}=0.2$} & \multicolumn{2}{|c|}{$\mathrm{m}=0.5$} & \multicolumn{2}{|c|}{$\mathrm{m}=0.9$} \\
\hline & $\mathrm{n}$ & parameter & Bias & $\sqrt{M S E}$ & Bias & $\sqrt{M S E}$ & Bias & $\sqrt{M S E}$ \\
\hline \multirow{6}{*}{$\mathrm{b}=0.3$} & \multirow{2}{*}{50} & $\mathrm{~m}$ & $-1,5 \mathrm{e}-02$ & $1,5 \mathrm{e}-02$ & $-1,7 \mathrm{e}-01$ & $1,7 \mathrm{e}-01$ & $-2,2 \mathrm{e}-01$ & $2,2 \mathrm{e}-01$ \\
\hline & & $\mathrm{b}$ & $1,9 \mathrm{e}-02$ & $1,9 \mathrm{e}-02$ & $1,9 \mathrm{e}-02$ & $1,9 \mathrm{e}-02$ & $1,8 \mathrm{e}-02$ & $1,8 \mathrm{e}-02$ \\
\hline & \multirow{2}{*}{100} & $\mathrm{~m}$ & $-5,3 e-02$ & $5,3 \mathrm{e}-02$ & $-2,4 \mathrm{e}-01$ & $2,4 \mathrm{e}-01$ & $-2,8 \mathrm{e}-01$ & $2,8 \mathrm{e}-01$ \\
\hline & & $\mathrm{b}$ & $-7,0 \mathrm{e}-03$ & $7,0 \mathrm{e}-03$ & $-7,1 \mathrm{e}-03$ & 7,1e-03 & $-5,6 \mathrm{e}-03$ & $5,6 \mathrm{e}-03$ \\
\hline & \multirow{2}{*}{500} & $\mathrm{~m}$ & $-1,8 \mathrm{e}-02$ & $1,8 \mathrm{e}-02$ & $-9,8 \mathrm{e}-02$ & $9,8 \mathrm{e}-02$ & $-1,0 \mathrm{e}-01$ & $1,0 \mathrm{e}-01$ \\
\hline & & $\mathrm{b}$ & $-1,2 \mathrm{e}-02$ & $1,2 \mathrm{e}-02$ & $-1,1 \mathrm{e}-02$ & $1,1 \mathrm{e}-02$ & $-1,1 \mathrm{e}-02$ & $1,1 \mathrm{e}-02$ \\
\hline \multirow{6}{*}{$\mathrm{b}=0.5$} & \multirow{2}{*}{50} & $\mathrm{~m}$ & $-2,4 \mathrm{e}-02$ & $2,4 \mathrm{e}-02$ & $-1,3 \mathrm{e}-01$ & $1,3 \mathrm{e}-01$ & $-1,3 \mathrm{e}-01$ & $1,3 \mathrm{e}-01$ \\
\hline & & $\mathrm{b}$ & $2,8 \mathrm{e}-02$ & $2,8 \mathrm{e}-02$ & $3,2 \mathrm{e}-02$ & $3,2 \mathrm{e}-02$ & $3,2 \mathrm{e}-02$ & $3,2 \mathrm{e}-02$ \\
\hline & \multirow{2}{*}{100} & $\mathrm{~m}$ & $-4,3 \mathrm{e}-02$ & $4,3 \mathrm{e}-02$ & $-1,7 \mathrm{e}-01$ & $1,7 \mathrm{e}-01$ & $-1,6 \mathrm{e}-01$ & $1,6 \mathrm{e}-01$ \\
\hline & & b & $-8,8 \mathrm{e}-03$ & $8,8 \mathrm{e}-03$ & $-9,5 \mathrm{e}-03$ & $9,5 \mathrm{e}-03$ & $-8,1 \mathrm{e}-03$ & $8,1 \mathrm{e}-03$ \\
\hline & \multirow{2}{*}{500} & $\mathrm{~m}$ & $-1,6 \mathrm{e}-02$ & $1,6 \mathrm{e}-02$ & $-6,1 \mathrm{e}-02$ & $6,1 \mathrm{e}-02$ & $-5,5 \mathrm{e}-02$ & $5,5 \mathrm{e}-02$ \\
\hline & & $\mathrm{b}$ & $-1,9 \mathrm{e}-02$ & $1,9 \mathrm{e}-02$ & $-1,8 \mathrm{e}-02$ & $1,8 \mathrm{e}-02$ & $-1,9 \mathrm{e}-02$ & $1,9 \mathrm{e}-02$ \\
\hline \multirow{6}{*}{$\mathrm{b}=1$} & \multirow{2}{*}{50} & $\mathrm{~m}$ & $-1,9 \mathrm{e}-02$ & $1,9 \mathrm{e}-02$ & $-7,1 \mathrm{e}-02$ & $7,1 \mathrm{e}-02$ & $-6,0 \mathrm{e}-02$ & $6,0 \mathrm{e}-02$ \\
\hline & & $\mathrm{b}$ & $5,7 \mathrm{e}-02$ & $5,7 \mathrm{e}-02$ & $5,6 \mathrm{e}-02$ & $5,6 \mathrm{e}-02$ & $5,2 \mathrm{e}-02$ & $5,2 \mathrm{e}-02$ \\
\hline & \multirow{2}{*}{100} & $\mathrm{~m}$ & $--2,7 \mathrm{e}-02$ & $2,7 \mathrm{e}-02$ & $-9,3 e-02$ & $9,3 \mathrm{e}-02$ & $-7,3 \mathrm{e}-02$ & $7,3 \mathrm{e}-02$ \\
\hline & & $\mathrm{b}$ & $-1,7 \mathrm{e}-02$ & $1,7 \mathrm{e}-02$ & $-1,6 \mathrm{e}-02$ & $1,6 \mathrm{e}-02$ & $-2,2 \mathrm{e}-02$ & $2,2 \mathrm{e}-02$ \\
\hline & \multirow{2}{*}{500} & $\mathrm{~m}$ & $-9,9 \mathrm{e}-03$ & $9,9 \mathrm{e}-03$ & $-3,3 e-02$ & $3,3 \mathrm{e}-02$ & $-2,4 \mathrm{e}-02$ & $2,4 \mathrm{e}-02$ \\
\hline & & $\mathrm{b}$ & $-3,4 \mathrm{e}-02$ & $3,4 \mathrm{e}-02$ & $-3,5 \mathrm{e}-02$ & $3,5 \mathrm{e}-02$ & $-3,5 \mathrm{e}-02$ & $3,5 \mathrm{e}-02$ \\
\hline \multirow{6}{*}{$\mathrm{b}=2$} & \multirow{2}{*}{50} & $\mathrm{~m}$ & $-1,2 \mathrm{e}-02$ & $1,2 \mathrm{e}-02$ & $-3,7 \mathrm{e}-02$ & $3,7 \mathrm{e}-02$ & $-2,7 \mathrm{e}-02$ & $2,7 \mathrm{e}-02$ \\
\hline & & b & $1,2 \mathrm{e}-01$ & $1,2 \mathrm{e}-01$ & $1,2 \mathrm{e}-01$ & $1,2 \mathrm{e}-01$ & 1,3e-01 & $1,3 \mathrm{e}-01$ \\
\hline & \multirow{2}{*}{100} & $\mathrm{~m}$ & $-1,5 \mathrm{e}-02$ & $1,5 \mathrm{e}-02$ & $-4,9 \mathrm{e}-02$ & $4,9 \mathrm{e}-02$ & $-3,3 \mathrm{e}-02$ & $3,3 \mathrm{e}-02$ \\
\hline & & $\mathrm{b}$ & $-3,4 \mathrm{e}-02$ & $3,4 \mathrm{e}-02$ & $-4,3 \mathrm{e}-02$ & $4,3 \mathrm{e}-02$ & $-3,4 \mathrm{e}-02$ & $3,4 \mathrm{e}-02$ \\
\hline & \multirow{2}{*}{500} & $\mathrm{~m}$ & $-6,5 \mathrm{e}-03$ & $6,5 \mathrm{e}-03$ & $-1,7 \mathrm{e}-02$ & $1,7 \mathrm{e}-02$ & $-1,1 \mathrm{e}-02$ & $1,1 \mathrm{e}-02$ \\
\hline & & $\mathrm{b}$ & $-7,2 \mathrm{e}-02$ & $7,2 \mathrm{e}-02$ & $-6,9 \mathrm{e}-02$ & $6,9 \mathrm{e}-02$ & $-7,2 \mathrm{e}-02$ & $7,2 \mathrm{e}-02$ \\
\hline \multirow{6}{*}{$\mathrm{b}=4$} & \multirow{2}{*}{50} & $\mathrm{~m}$ & $-7,2 \mathrm{e}-03$ & $7,2 \mathrm{e}-03$ & $-1,8 \mathrm{e}-02$ & $1,8 \mathrm{e}-02$ & $-1,2 \mathrm{e}-02$ & $1,2 \mathrm{e}-02$ \\
\hline & & $\mathrm{b}$ & $2,6 \mathrm{e}-01$ & $2,6 \mathrm{e}-01$ & $2,4 \mathrm{e}-01$ & $2,4 \mathrm{e}-01$ & $2,6 \mathrm{e}-01$ & $2,6 \mathrm{e}-01$ \\
\hline & \multirow{2}{*}{100} & $\mathrm{~m}$ & $-8,7 \mathrm{e}-03$ & $8,7 \mathrm{e}-03$ & $-2,4 \mathrm{e}-02$ & $2,4 \mathrm{e}-02$ & $-1,6 \mathrm{e}-02$ & $1,6 \mathrm{e}-02$ \\
\hline & & $\mathrm{b}$ & $-7,0 \mathrm{e}-02$ & $7,0 \mathrm{e}-02$ & $-6,9 \mathrm{e}-02$ & $6,9 \mathrm{e}-02$ & $-6,2 \mathrm{e}-02$ & $6,2 \mathrm{e}-02$ \\
\hline & \multirow{2}{*}{500} & $\mathrm{~m}$ & $-2,7 \mathrm{e}-03$ & $2,7 \mathrm{e}-03$ & $-7,6 \mathrm{e}-03$ & $7,6 \mathrm{e}-03$ & $-4,9 \mathrm{e}-03$ & $4,9 \mathrm{e}-03$ \\
\hline & & $\mathrm{b}$ & $-1,6 \mathrm{e}-01$ & $1,6 \mathrm{e}-01$ & $-1,4 \mathrm{e}-01$ & $1,4 \mathrm{e}-01$ & $-1,4 \mathrm{e}-01$ & $1,4 \mathrm{e}-01$ \\
\hline
\end{tabular}

\section{Applications to real data}

In order to illustrate the proposed methodology, we consider data from municipalities of the state of Alagoas in Brazil, collected in 2010. The state of Alagoas is located in the eastern part of the Northeast Region of Brazil and is made up of 102 municipalities. This state is one of the poorest states of Brazil and its HDI (Human Development Index) is the country's worst, based on 
information available in Fundação (2010). Specifically, we are interested in modeling the proportion of children vulnerable to poverty (PPOBC) and the Gini index in the municipalities of Alagoas; see also Fundação (2010). In the case of the Gini index, we model this data as a function of the percentage people employed in the manufacturing industry (EMP) in the municipalities of the Alagoas.

\subsection{Aplication to PPOBC data}

In this subsection, we consider the PPOBC data set, which contains the proportion of children (0-14 years olds) vulnerable to poverty in each municipality of Alagoas. Here, a child is considered vulnerable to poverty if the per capita household income is equal to or less than BRL 255, in 2010. The PPOBC data set comprises 102 observations and is modeled here using the l-logistic model and the beta model that is frequently used to model data when a distribution over some finite interval is needed; see Gupta and Nadarajah (2004). Here, we use the re-parameterized beta distribution discussed by Ferrari and Cribari-Neto (2004) in the context of regression analysis.

The Bayesian methodology was used to estimate the parameters of both models. For the l-logistic distribution with parameters $m$ and $b$, we considered the gamma prior distribution for parameter $b(b \sim \operatorname{Gamma}(0.001,0.001))$ and the uniform prior distribution in the unit interval for parameter $m(m \sim \operatorname{Uniform}(0,1))$. For the beta distribution with parameters $0<\mu<1$ and $\phi>0$, we considered the same prior distributions considered in the l-logistic case, that is, $\phi \sim \operatorname{Gamma}(0.001,0.001)$ and $\mu \sim \operatorname{Uniform}(0,1)$. These priors distributions were chosen based on the discussion in Section 2. In the case of beta distribution, we used the non-informative proper prior distribution commonly used in the literature for the parameters of precision.

Table 5: Estimates and 95\% HPD intervals for the parameters of the l-logistic and beta models and the Bayesian information criteria values for these models

\begin{tabular}{|c|c|c|c|c|c|c|}
\hline \multirow{2}{*}{ Model } & & & \multicolumn{4}{|c|}{ Criteria } \\
\hline & \multicolumn{2}{|c|}{ Parameter } & WAIC & EAIC & $\mathrm{EBIC}$ & DIC \\
\hline \multirow{2}{*}{ L-logistic } & $m$ & $0.86(0.85,0.87)$ & \multirow{2}{*}{155.1322} & \multirow{2}{*}{-304.2996} & \multirow{2}{*}{-299.0496} & \multirow{2}{*}{-306.3422} \\
\hline & $b$ & $4.04(3.42,4.72)$ & & & & \\
\hline \multirow{2}{*}{ Beta } & $\mu$ & $0.85(0.84,0.86)$ & \multirow{2}{*}{150.8993} & \multirow{2}{*}{-295.3312} & \multirow{2}{*}{-290.0813} & \multirow{2}{*}{-297.3437} \\
\hline & $\phi$ & $37.81(27.55,47.83)$ & & & & \\
\hline
\end{tabular}

The final result of the estimation is presented in Table 5. This table also shows the Bayesian information criteria of model comparison in order to evaluate the ability of l-logistic and beta models to fit the data. According to this table, it is clear that the l-logistic model is better for modeling the PPOBC data than the beta model. In addition, Figure 5 shows two graphs with the mean values and error bars with $95 \%$ credibility intervals plotted against the corresponding observed value of the data. 
The errors bars were constructed from 1000 samples (ordered, and of size 102) generated from the l-logistic and beta distributions, respectively for each graph, with the estimated parameters. In the case of the l-logistic model, the bars crossed by the diagonal line $y=x$ indicate that the model is quite suitable for the data. On the other hand, in the case of the beta model, we observe high deviations between the predicted and observed data, mainly in the tail of the distribution. In this case, an observation is flagged as an outlier, since the corresponding posterior interval does not contain these values that are situated between 0 and 0.6. Thus, Figure 5 provides evidence that the beta model is unsuitable for these data. Finally, the estimated and the observed histogram of the PPOBC data are presented in Figure 6.1, which confirms that the l-logistic model provides a better fit for these data than the beta model.
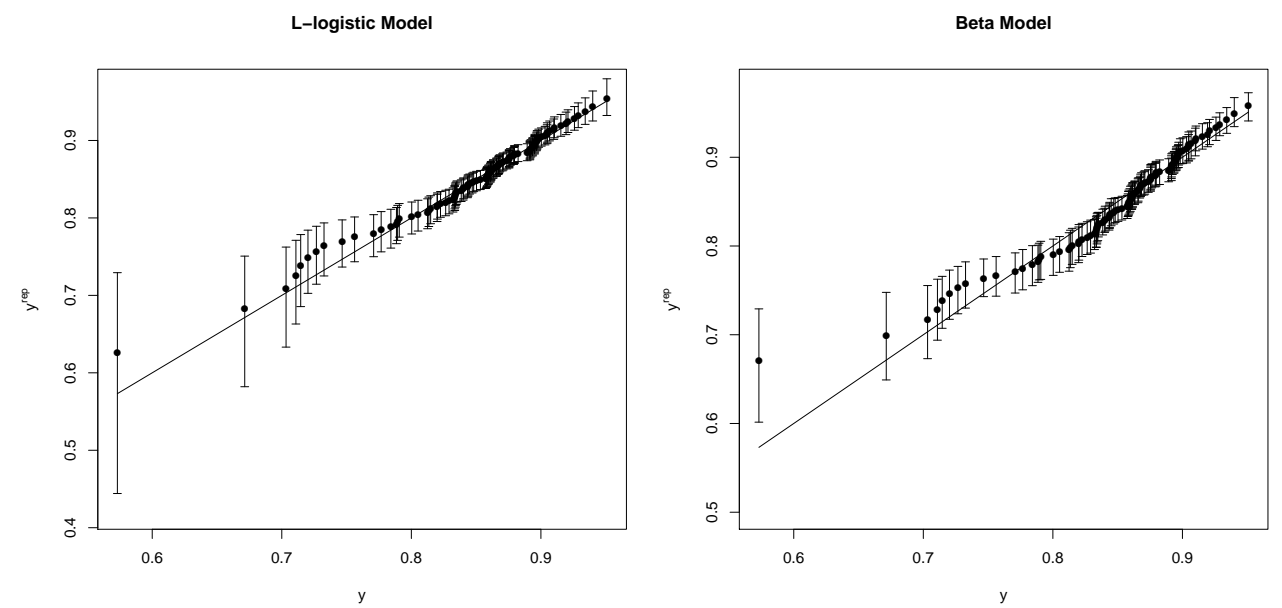

Figure 5: Posterior predictive error bars with 95\% confidence intervals of the generated values $y_{(i)}^{r e p}$ versus ordered observed data $y_{(i)}$ for the PPOBC data, using l-logistic and beta models.

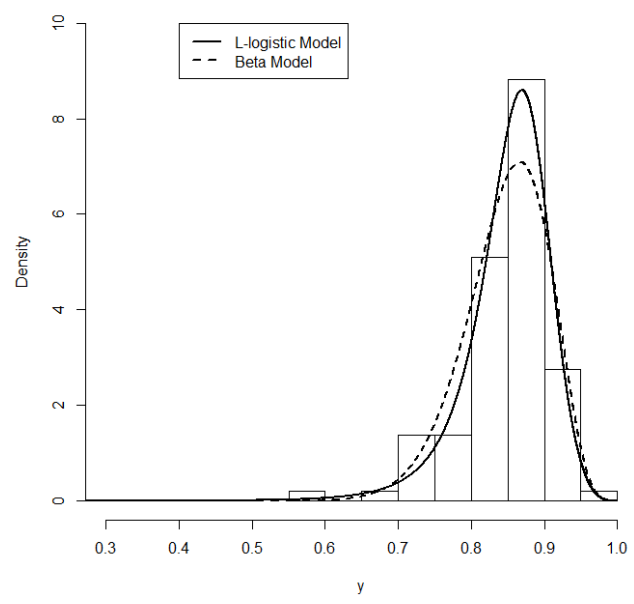

Figure 6: Estimated density of PPOBC data. 


\subsection{Regression Analysis with l-logistic model}

Regression analysis estimates the potential differential effect of a covariate on mean or quantiles in the conditional distribution (Hao and Naiman, 2007). Here, we are interested in studying the conditional (or regression) median as a function of the covariates, when the response variable takes values in a bounded interval. In the analysis with the l-logistic distribution, we assume that conditional on the explanatory variables (covariates), the random variable $Y_{i}, i=1, \ldots, n$, are mutually independent with l-logistic distribution, $Y_{i} \sim L L\left(m_{i}, b_{i}\right)$. Thus, given $\boldsymbol{x}_{1 i}^{T}$ and $\boldsymbol{x}_{2 i}^{T}(q$ and $d$-dimensional vectors, respectively, containing the explanatory variables both with 1 as in the first component), the likelihood of the observed sample $\boldsymbol{y}=\left(y_{1}, . ., y_{n}\right)$ can be written as

$$
L\left(\boldsymbol{\beta}, \boldsymbol{\delta} \mid \boldsymbol{y}, \boldsymbol{X}=\prod_{i=1}^{n} \frac{b_{i}\left(1-m_{i}\right)^{b_{i}} m_{i}^{b_{i}} y_{i}^{b_{i}-1}\left(1-y_{i}\right)^{b_{i}-1}}{\left[\left(1-m_{i}\right)^{b_{i}} y_{i}^{b}+m^{b_{i}}\left(1-y_{i}\right)^{b_{i}}\right]^{2}},\right.
$$

where $\boldsymbol{X}$ is the matrix containing all the explanatory variables, and

$$
\operatorname{logit}\left(m_{i}\right)=\boldsymbol{x}_{1 i}^{T} \boldsymbol{\beta} \quad \text { and } \quad \log \left(b_{i}^{2}\right)=\boldsymbol{x}_{2 i}^{T} \boldsymbol{\delta}
$$

In $(37), \boldsymbol{\beta}=\left(\beta_{0}, \ldots, \beta_{q-1}\right)$ and $\boldsymbol{\delta}=\left(\delta_{0}, \ldots, \delta_{d-1}\right)$ represent, respectively, the $q$ and d-dimensional vectors of unknown regression parameters, $\operatorname{logit}($.$) is the logit function, and \log ($.$) is the natural$ logarithm function.

In addition, we adopt the following proper prior distributions with large range as is frequently considered in the literature:

$$
\begin{aligned}
& \beta_{j} \sim \operatorname{Normal}(0,100), \text { for } j=0, . ., q-1, \\
& \delta_{l} \sim \operatorname{Normal}(0,100), \text { for } l=0, . ., d-1
\end{aligned}
$$

Thus, samples of the joint posterior distribution of $\boldsymbol{\beta}$ and $\boldsymbol{\delta}$ can be obtained by considering the MCMC method to simulate from the posterior distribution, with pdf given by

$$
\pi(\beta, \delta \mid \boldsymbol{y}) \propto L(\boldsymbol{\beta}, \boldsymbol{\delta} \mid \boldsymbol{y}, \boldsymbol{x}) \pi(\boldsymbol{\beta}) \pi(\boldsymbol{\delta})
$$

\subsubsection{Modeling Gini index in Brazil}

In this subsection, we consider the Gini index data of the municipalities of the state of Alagoas in Brazil. The Gini index is used to measure how evenly income is distributed throughout a country. For more details, one may refer to Lambert and Aronson (1993). In Brazil, the Gini index of the municipalities is elaborated by IBGE ( Portuguese, Instituto Brasileiro de Geografia e Estatística); see IBGE (2010). Since Alagoas comprises 102 municipalities, our sample is composed of 102 observations $(n=102)$. The scatterplot of the Gini index data versus EMP data and the histograms of these data are presented in Figure 8. 


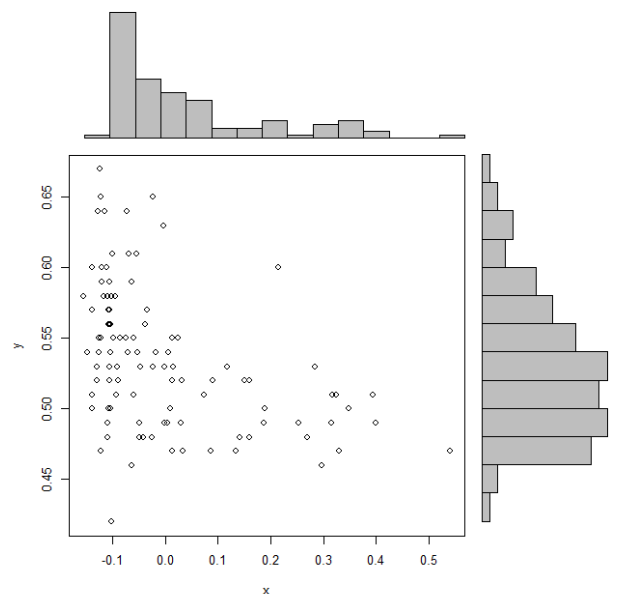

Figure 7: Scatterplot and histograms of the real data.

Considering the l-logistic model, we still consider four models with the following specification, for $i=1, \ldots, n$ :

$$
Y_{i} \sim L L\left(m_{i}, b_{i}\right) \Longrightarrow \begin{cases}M_{0}: & \operatorname{logit}\left(m_{i}\right)=\beta_{0} \text { and } \log \left(b_{i}^{2}\right)=\boldsymbol{\delta} \\ M_{1}: & \operatorname{logit}\left(m_{i}\right)=\beta_{0} \text { and } \log \left(b_{i}^{2}\right)=\boldsymbol{x}_{1 i}^{T} \boldsymbol{\delta} \\ M_{2}: & \operatorname{logit}\left(m_{i}\right)=\boldsymbol{x}_{1 i}^{T} \boldsymbol{\beta} \text { and } \log \left(b_{i}^{2}\right)=\delta_{0} \\ M_{3}: & \operatorname{logit}\left(m_{i}\right)=\boldsymbol{x}_{1 i}^{T} \boldsymbol{\beta} \text { and } \log \left(b_{i}^{2}\right)=\boldsymbol{x}_{2 i}^{T} \boldsymbol{\delta} .\end{cases}
$$

In addition, we consider the models $M_{0}, M_{1}, M_{2}$ and $M_{3}$ for the case where the response follows the re-parameterized beta distribution, that is, for $i=1, . ., n$,:

$$
Y_{i} \sim \operatorname{Beta}\left(\mu_{i}, \phi_{i}\right) \Longrightarrow \begin{cases}M_{0}: & \operatorname{logit}\left(\mu_{i}\right)=\beta_{0} \text { and } \log \left(\phi_{i}^{2}\right)=\boldsymbol{\delta} \\ M_{1}: & \operatorname{logit}\left(\mu_{i}\right)=\beta_{0} \text { and } \log \left(\phi_{i}^{2}\right)=\boldsymbol{x}_{1 i}^{T} \boldsymbol{\delta} \\ M_{2}: & \operatorname{logit}\left(\mu_{i}\right)=\boldsymbol{x}_{1 i}^{T} \boldsymbol{\beta} \text { and } \log \left(b_{i}^{2}\right)=\delta_{0} \\ M_{3}: & \operatorname{logit}\left(\mu_{i}\right)=\boldsymbol{x}_{1 i}^{T} \boldsymbol{\beta} \text { and } \log \left(\phi_{i}^{2}\right)=\boldsymbol{x}_{2 i}^{T} \boldsymbol{\delta},\end{cases}
$$

where $\phi_{i}$ is a parameter of precision.

For both, beta and l-logistic models, the Bayesian approach is considered for the inference process with prior distribution for the unknown regression parameters as given in (6.2). All the algorithms were prepared in $\mathrm{R}$ language and we report the results corresponding to 10, 000 iterations following a burn-in period also of 10,000 iterations. In order to eliminate dependence, we eliminated a sequence of 10 observations every 11 simulations in the sample of size 10,000, resulting in a final sample of 1,000 elements. Finally, the convergence of MCMC chain was assessed by using the separated partial means test of Geweke (1992), which provided evidence for the chains to have converged. 
Table 6 shows the estimated parameters for the l-logistic and beta cases for all the models. This table also shows the 95\% HPD intervals for all the coefficients, where we can see that the amplitude of the intervals are considered small. Additionally, since the HPD intervals for $\beta_{1}$ and $\delta_{1}$ do not contain zero, we can conclude that the EPM covariate is significant to explain the Gini index in both the l-logistic and beta models.

Table 6: Parameter estimates and 95\% HPD intervals for the l-logistic and beta models.

\begin{tabular}{|c|c|c|c|c|c|}
\hline \multirow{2}{*}{ Model } & & \multicolumn{4}{|c|}{ Coefficient } \\
\hline & & $\beta_{0}$ & $\beta_{1}$ & $\delta_{0}$ & $\delta_{1}$ \\
\hline \multirow{4}{*}{ L-logistic } & $M_{3}$ & $0.13(0.090,0.164)$ & $-0.48(-0.620,-0.305)$ & $4.59(4.243,4.920)$ & $3.71(1.170,6.038)$ \\
\hline & $M_{2}$ & $0.13(0.098,0.167)$ & $-0.56(-0.781,-0.347)$ & $4.50(4.144,4.801)$ & - \\
\hline & $M_{1}$ & $0.11(0.050,0.161)$ & - & $4.28(3.985,4.630)$ & $1.42(-1.225,4.316)$ \\
\hline & $M_{0}$ & $0.13(0.078,0.162)$ & - & $4.27(3.956,4.604)$ & - \\
\hline \multirow{4}{*}{ Beta } & $M_{3}$ & $0.13(0.101,0.175)$ & $-0.49(-0.652,-0.339)$ & $9.66(9.109,10.216)$ & $6.88(3.068,10.681)$ \\
\hline & $M_{2}$ & $0.14(0.102,0.176)$ & $-0.56(-0.792,-0.330)$ & $9.47(8.902,9.979)$ & - \\
\hline & $M_{1}$ & $0.12(0.065,0.167)$ & - & $9.14(8.576,9.665)$ & $2.59(-1.897,6.550)$ \\
\hline & $M_{0}$ & $0.14(0.04,0.176)$ & - & $9.10(8.571,9.670)$ & - \\
\hline
\end{tabular}

In addition, in both cases, the models $M_{0}, M_{1}, M_{2}$ and $M_{3}$ were compared by the use of EAIC, EBIC, DIC and WAIC criteria described earlier. Results are presented in Table 7, in which we can see that the model $M_{3}$ is the best for both distributions. Note that values of coefficients $\beta_{0}$ and $\beta_{1}$ are similar for both models and that values of $\delta_{0}$ and $\delta_{1}$ are different. Thus, there is no significant difference between the models for both distributions. Therefore, based on the obtained results, both models explain equally the phenomenon considered here. So, we can choose either of the two distributions in this case.

Table 7: Model comparison criteria for model comparison.

\begin{tabular}{ccccccccccc}
\hline & \multicolumn{4}{c}{ L-logistic model } & & \multicolumn{5}{c}{ Beta model } \\
\cline { 2 - 4 } \cline { 8 - 10 } Sub-model & WAIC & EAIC & EBIC & DIC & & WAIC & EAIC & EBIC & DIC \\
\hline$M_{3}$ & 175.22 & -339.09 & -328.59 & -343.29 & & 175.07 & -338.24 & -327.74 & -342.26 \\
$M_{2}$ & 170.22 & -331.99 & -324.12 & -335.15 & & 169.73 & -330.74 & -322.87 & -333.67 \\
$M_{1}$ & 159.62 & -310.10 & -302.22 & -313.25 & & 160.61 & -312.29 & -304.41 & -315.33 \\
$M_{0}$ & 158.82 & -311.87 & -306.62 & -313.96 & & 159.89 & -313.96 & -308.71 & -316.06 \\
\hline
\end{tabular}

Finally, for the l-logistic and beta models $M_{3}$, we performed a predictive check based on the ordered data $y_{(i)}$ and generated values $y_{(i)}^{r e p}$ of the posterior predictive distribution, as mentioned in Subsection 4.3. Error bars of the $y_{(i)}^{r e p}$ against the correspondent observed data are presented in Figure 8 , in which we can see that the diagonal line $y=x$ crosses the error bars for all observations for both 
distributions. Thus, both models seem to fit the data well in this case. Figure 8 also presents the realized residual versus adjusted values $\left(\hat{y}_{i}, i=1, . ., n\right)$. The realized residual $\left(r_{i}=y_{i}-\hat{y}_{i}\right)$ is based on a posterior draw of the parameters rather than point estimations, for more details, see for example, (Gelman et al., 2013). Based on Figure 8, we can see that the spread of the residuals is quite very similar for the beta and the l-logistic models.
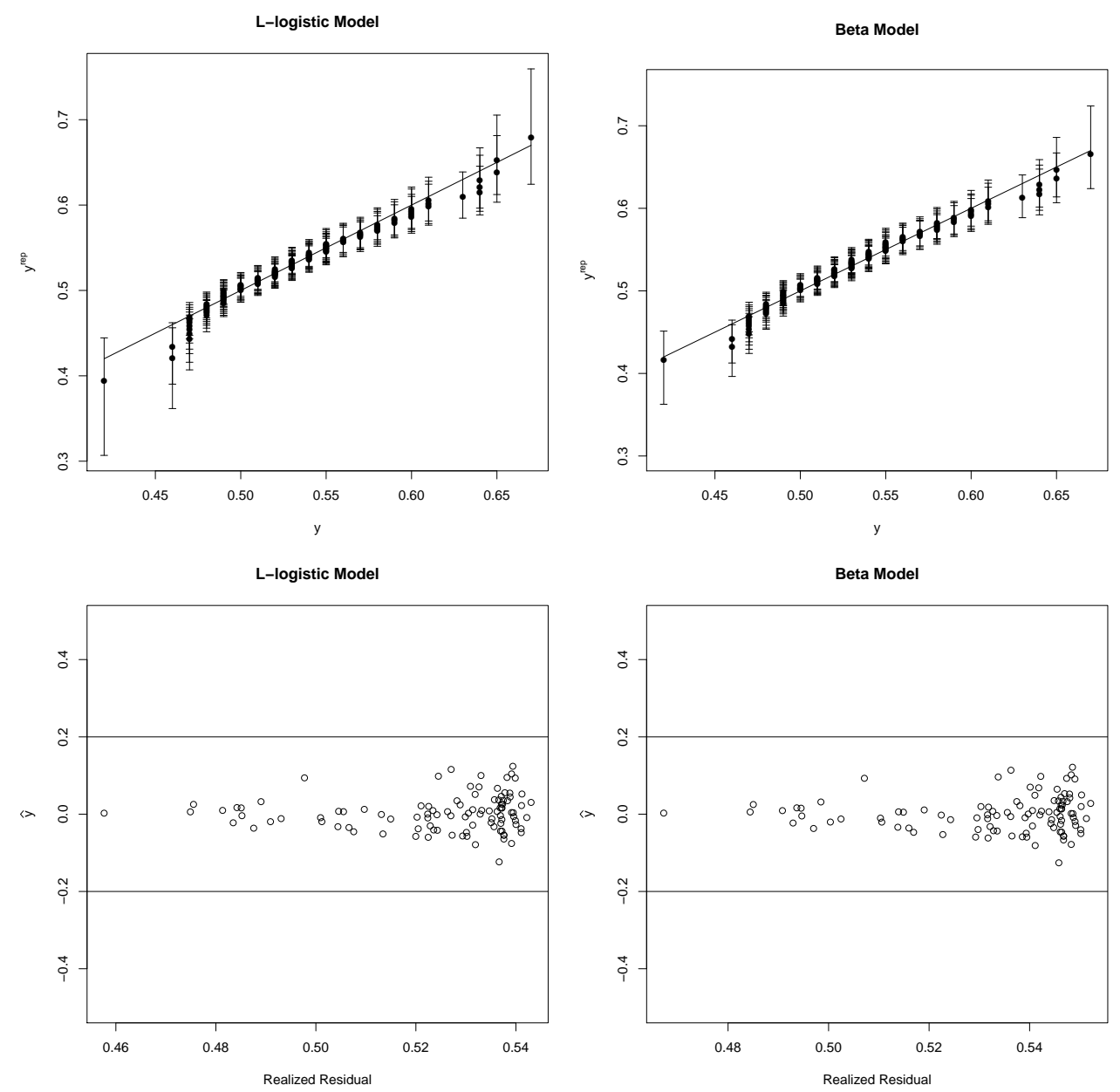

Figure 8: Posterior predictive error bars of generated values $y_{(i)}^{r e p}$ versus ordered observed data $y_{(i)}$ and realized residual versus adjusted values for the model l-logistic $M_{3}$ and beta model $M_{3}$ for the Gini index data.

\section{$7 \quad$ Final remarks}

The l-logistic distribution is a bounded continuous distribution that possesses some properties, as discussed in Section 3. In the Bayesian context, a non-informative prior distribution can be adopted for the location parameter $m$ since it lies in the unit interval, enabling the use of unit uniform distribution as a non-informative prior distribution. Two simulation studies are presented in Section 6 for evaluating the posterior distribution with respect to the specification of the prior distribution 
for the shape parameter $b$ and to evaluate the performance of the Bayesian estimator chosen. In the first study, for the studied cases, we observe that the non-informative prior distributions provide correct information about parameter $b$, based on the results of WAIC, EAIC, EBIC, and DIC. Thus, the posterior distribution is not sensitive with respect to the specification of these prior distributions. Some characteristics of the posterior distribution are also calculated where two non-informative and one informative prior distributions for the parameter $b$ are considered. In this study, we observe that the prior information is dominated by the sample information. In the second study, we evaluate the estimates of the parameters of the l-logistic distribution obtained by using Bayesian method upon considering the prior gamma distribution with parameters vector $(0.001,0.001)$. We observe that the $\sqrt{M S E}$ and bias lie always close to zero even when the sample size is small. Hence, for the samples analyzed, the estimator seems to provide reasonable estimates.

In addition, we introduce the l-logistic distribution in the context of conditional median regression models. Conditional median regression is a special case of quantile regression in which the conditional 0.5th quantile is modeled as a function of covariates. An advantage of this approach is the possibility of modeling other quantiles in order to describe a non-central position of a distribution. So, one may choose a position a specific for his needs

inquiries. For example, poverty studies concern the low-income population and tax-policy studies concern the rich people. Conditional quantile models offer the flexibility to focus on these population segments, whereas conditional mean models do not. Thus, multiple quantiles can be modeled. However, since quantile regression curves are estimated individually, the quantile curves can cross, leading to an invalid distribution for the response. Thus, this problem, referred to as crossing in the literature, needs to be studied carefully. Some authors have proposed methods to deal with this problem, see, for example, Cai and Jiang (2015).

Finally, for the future, we aim to develop techniques for mixed quantile regression for the l-logistic distribution. Moreover, we intend to explore mixtures of L-logistic distributions in a Bayesian framework as well as a multivariate version of this distribution. 


\section{A Appendix}

If $Z=b \log \left(\frac{Y(1-m)}{m(1-Y)}\right)$ and $Y \sim L L(m, b)$, then the pdf of $Z$ can be obtained by using the transformation technique as

$$
\begin{aligned}
& f_{Z}(z)= f_{Y}\left(\left(1+e^{-z / b}\left(\frac{1-m}{m}\right)\right)^{-1}\right)\left|\frac{\partial\left(1+e^{-z / b}\left(\frac{1-m}{m}\right)\right)^{-1}}{\partial z}\right| \\
&= \frac{b(1-m)^{b} m^{b}\left(\frac{1-1}{1+\left(\frac{1-m}{m}\right) e^{-z / b}}\right)^{b-1}\left(\frac{\left(\frac{1-m}{m}\right) e^{-z / b}}{1+\left(\frac{1-m}{m}\right) e^{-z / b}}\right)^{b-1}}{\left[(1-m)^{b}\left(\frac{1}{1+\left(\frac{1-m}{m}\right) e^{-z / b}}\right)^{b}+m^{b}\left(\frac{\left(\frac{1-m}{m}\right) e^{-z / b}}{1+\left(\frac{-m}{m}\right) e^{-z / b}}\right)^{b}\right]^{2}}\left(\frac{\left(\frac{1-m}{m}\right) e^{-z / b}}{b\left[1+\left(\frac{1-m}{m}\right) e^{-z / b}\right]^{2}}\right) \\
&= \frac{(1-m)^{b} m^{b}\left(\left(\frac{1-m}{m}\right) e^{-z / b}\right)^{b-1}}{\left[(1-m)^{b}+m^{b}\left(\frac{1-m}{m}\right)^{b} e^{-z}\right]^{2}}\left(\left(\frac{1-m}{m}\right) e^{-z / b}\right) \\
&= \frac{(1-m)^{b} m^{b}(1-m)^{b-1} e^{-z(b-1) / b}}{m^{b-1}\left[(1-m)^{b}+(1-m)^{b} e^{-z}\right]^{2}}\left(\frac{1-m}{m}\right) e^{-z / b}=\frac{e^{-z}}{\left[1+e^{-z}\right]^{2}} \\
& \Rightarrow f_{Z}(z)=\frac{e^{z}}{\left[1+e^{z}\right]^{2}} I_{\mathbb{R}}(z),
\end{aligned}
$$

that is, $Z$ has the standard logistic distribution.

Using the transformation technique, as in (40), we can achieve the pdf and cdf of the distribution of $Z^{\prime}=\delta+b \log \left(\frac{Y}{1-Y}\right)$ with $Y \sim L L(\delta, b)$ as the pdf and cdf of the standard logistic distribution.

Since $m=\frac{e^{-\frac{\delta}{b}}}{1+e^{-\frac{\delta}{b}}}$ with $\delta>0$, and $Y \sim L L(m, b)$, we can replace the parameter $m=\frac{e^{-\frac{\delta}{b}}}{1+e^{-\frac{\delta}{b}}}$ in (1) and (2) to obtain

$$
\begin{aligned}
f(y \mid \delta, b) & =\frac{b\left(1-\frac{e^{-\frac{\delta}{b}}}{1+e^{-\frac{\delta}{b}}}\right)^{b}\left(\frac{e^{-\frac{\delta}{b}}}{1+e^{-\frac{\delta}{b}}}\right)^{b} y^{b-1}(1-y)^{b-1}}{\left[\left(1-\frac{e^{-\frac{\delta}{b}}}{1+e^{-\frac{\delta}{b}}}\right)^{b} y^{b}+\left(\frac{e^{-\frac{\delta}{b}}}{1+e^{-\frac{\delta}{b}}}\right)^{b}(1-y)^{b}\right]^{2}} \\
& =\frac{b\left(\frac{1}{1+e^{-\frac{\delta}{b}}}\right)^{b}\left(\frac{e^{-\frac{\delta}{b}}}{1+e^{-\frac{\delta}{b}}}\right)^{b} y^{b-1}(1-y)^{b-1}}{\left[\left(\frac{1}{1+e^{-\frac{\delta}{b}}}\right)^{b} y^{b}+\left(\frac{e^{-\frac{\delta}{b}}}{1+e^{-\frac{\delta}{b}}}\right)^{b}(1-y)^{b}\right]^{2}} \\
& =\frac{b e^{-\delta} y^{b-1}(1-y)^{b-1}}{\left[y^{b}+e^{-\delta}(1-y)^{b}\right]^{2}}=\frac{b e^{\delta} y^{b-1}(1-y)^{b-1}}{\left[y^{b} e^{\delta}+(1-y)^{b}\right]^{2}}
\end{aligned}
$$

and

$$
\begin{aligned}
F_{Y}(y \mid \delta, b) & =\left(1+\left(\frac{e^{-\frac{\delta}{b}}\left(1+e^{-\frac{\delta}{b}}(1-y)\right.}{y\left(\frac{1}{1+e^{-\frac{\delta}{b}}}\right)}\right)^{b}\right)^{-1} \\
& =\left(1+\left(\frac{e^{-\frac{\delta}{b}(1-y)}}{y}\right)^{b}\right)^{-1} \\
& =\left(1+e^{-\delta}\left(\frac{1-y}{y}\right)^{b}\right)^{-1}
\end{aligned}
$$

which are the pdf and cdf of the l-logistic distribution with parameters $\delta$ and $b$. 
Assuming $\mu=\frac{1}{1+\left(\frac{m}{1-m}\right)^{b}}$ with $Y \sim L L(m, b)$, as in (42), by replacing parameter $m=$ $\frac{1}{1+\left(\frac{\mu}{1-\mu}\right)^{1 / b}}$ in (1) and (2), we obtain the corresponding pdf and cdf as

$$
f(y \mid \mu, b)=\frac{b \mu(1-\mu) y^{b-1}(1-y)^{b-1}}{\left[y^{b} \mu+(1-y)^{b}(1-\mu)\right]^{2}}, \quad 0<y<1,
$$

and

$$
F_{Y}(y \mid \mu, b)=\left(1+\left(\frac{1-\mu}{\mu}\right)\left(\frac{1-y}{y}\right)^{b}\right)^{-1}, 0<y<1,
$$

with $\mu \in(0,1)$ and $b>0$.

If $Y=X(d-c)+c$ with $c, d \in \mathbb{R}$ and $X \sim L L(m, b)$, then $Y \in(c, d)$. In this case, we can obtain the pdf of $Y$ by transformation technique as

$$
f(y \mid m, b, c, d)=\frac{(d-c) b(1-m)^{b} m^{b}(y-c)^{b-1}(d-y)^{b-1}}{\left[(1-m)^{b}(y-c)^{b}+m^{b}(d-y)^{b}\right]^{2}} .
$$

Thus, $Y$ has the l-logistic distribution with support on $(c, d), c, d \in \mathbb{R}$.

Assuming that $Y \sim L L(m, b)$, then the t-th moment of the random variable $Y$ about zero can be obtained from (1) and (41) as

$$
\begin{aligned}
E\left[Y^{t}\right] & =\int_{0}^{1} y^{t} \frac{b(1-m)^{b} m^{b} y^{b-1}(1-y)^{b-1}}{\left[(1-m)^{b} y^{b}+m^{b}(1-y)^{b}\right]^{2}} d y \\
& =\int_{-\infty}^{\infty}\left(\frac{1}{1+\left(\frac{1-m}{m}\right) e^{-\frac{z}{b}}}\right)^{t} \frac{e^{z}}{\left[1+e^{z}\right]^{2}} d z
\end{aligned}
$$

Let $v=\frac{e^{z}}{1+e^{z}} \Rightarrow z=\log \left(\frac{v}{1-v}\right)$ and $d v=\frac{e^{z}}{\left(1+e^{z}\right)^{2}} d z$. Then, $E\left[Y^{t}\right]=\int_{0}^{1}\left[1+\left(\frac{1-v}{v}\right)^{1 / b}\left(\frac{1-m}{m}\right)\right]^{-t} d v$.

In order to find the mode of the l-logistic distribution, we can obtain the derivative of the $f(y \mid m, b)$, given in (1), relative to $y$ as

$$
\frac{\partial f}{\partial y}=\frac{b((1-m) m)^{b}((1-y) y)^{-2+b}\left\{m^{b}(1-y)^{b}(-1+b+2 y)-(1-m)^{b}(1+b-2 y) y^{b}\right\}}{\left(m^{b}(1-y)^{b}+(1-m)^{b} y^{b}\right)^{3}} .
$$

Thus, $\frac{\partial f}{\partial y}\left(y_{0}\right)=0 \Leftrightarrow\left\{m^{b}(1-y)^{b}(-1+b+2 y)-(1-m)^{b}(1+b-2 y) y^{b}\right\}=0$. Therefore, the mode $y_{0}$ is a solution of the equation

$$
\left(\frac{1-m}{m}\right)^{b}=\left(\frac{1-y_{0}}{y_{0}}\right)^{b} \frac{b+2 y_{0}-1}{b-2 y_{0}+1}
$$

when $b>1$. For $b \leqslant 1$, the curve is convex and does not have mode.

To show that the density of l-logistic distribution is symmetric when $m=0.5$ whatever the value of $b$ is, let $f(y)$ be the pdf of the l-logistic distribution with parameters $b$ and $m=0.5$ :

$$
\begin{aligned}
f(m-y) & =\frac{b(1-m)^{b} m^{b}(m-y)^{b-1}(1-m+y)^{b-1}}{\left[(1-m)^{b}(m-y)^{b}+m^{b}(1-m+y)^{b}\right]^{2}} \\
& =\frac{m^{2 b}}{m^{2 b}} \frac{b(m-y)^{b-1}(m+y)^{b-1}}{\left[(m-y)^{b}+(m+y)^{b}\right]^{2}} \\
& =\frac{b\left(m^{2}-y^{2}\right)^{b-1}}{\left[(m-y)^{b}+(m+y)^{b}\right]^{2}} \\
& =f(m+y) .
\end{aligned}
$$




\section{References}

Arnold, B. C. and R. A. Groeneveld (1995). Measuring skewness with respect to the mode. The American Statistician 49(1), 34-38.

Berkhof, J., I. van Mechelen, and H. Hoijtink (2000). Posterior predictive checks: Principles and discussion. Computational Statistics 15(3), 337-354.

Brys, G., M. Hubert, and A. Struyf (2003). A comparison of some new measures of skewness. In R. Dutter, P. Filzmoser, U. Gather, and P. J. Rousseeuw (Eds.), Developments in Robust Statistics, pp. 98-113. Springer-Verlag.

Cai, Y. and T. Jiang (2015). Estimation of non-crossing quantile regression curves. Australian and New Zealand Journal of Statistics 57(1), 139-162.

Ferrari, S. and F. Cribari-Neto (2004). Beta regression for modelling rates and proportions. Journal of Applied Statistics 31(7), 799-815.

Figueroa-Zúñiga, J. I., R. B. Arellano-Valle, and S. L. P. Ferrari (2013). Mixed beta regression: A Bayesian perspective. Computational Statistics Data Analysis 61(1), 137-147.

Fundação, J. o. P. (2010). Atlas do desenvolvimento humano no brasil. ttp://www.atlasbrasil. org.br/2013/pt/ranking/. [Online: accessed 30-setember-2015].

Gelman, A. (2006). Prior distributions for variance parameters in hierarchical models. Bayesian Analysis 1(3), 515-533.

Gelman, A., J. Carlin, H. Stern, D. Dunson, A. Vehtari, and D. Rubin (2013). Bayesian Data Analysis, Third Edition (3 ed.). Philadelphia: Taylor \& Francis.

Geweke, J. (1992). Evaluating the accuracy of sampling-based approaches to the calculation of posterior moments. In Bayesian Statistics, pp. 169-193. University Press.

Gómez-Déniz, E., M. A. Sordo, and E. Calderín-Ojeda (2014). The log-lindley distribution as an alternative to the beta regression model with applications in insurance. Insurance: Mathematics and Economics 54 (1), 49-57.

Groeneveld, R. A. and G. Meeden (1984). Measuring skewness and kurtosis. Journal of the Royal Statistical Society, Series D (The Statistician) 33(4), 391-399.

Guo, J. (2015). R Interface to Stan, Version 2.8.0.

Gupta, A. and S. Nadarajah (2004). Handbook of Beta Distribution and Its Applications. Philadelphia: Taylor \& Francis. 
Hao, L. and D. Naiman (2007). Quantile Regression. New Jersey: SAGE Publications.

Hinkley, D. V. (1975). On power transformations to symmetry. Biometrika 62(1), 101-111.

IBGE, D. d. P. (2010). Pesquisa nacional por amostra de domicílios, PNAD.: Síntese de indicadores. Fundação Instituto Brasileiro de Geografia e Estatística - IBGE.

Johnson, N., S. Kotz, and N. Balakrishnan (1994). Continuous Univariate Distributions, Volume 1. New York: John Wiley \& Sons.

Johnson, N. L. (1949). Systems of frequency curves generated by methods of translation. Biometrika 36(1/2), 149-176.

Koenker, R. and J. G. Bassett (1978). Regression quantiles. Econometrica, 46(1), 33-50.

Kotz, S. and J. R. van Dorp (2004). Beyond Beta: Other Continuous Families of Distributions with Bounded Support and Applications. Singapore: World Scientific Publishing.

Lambert, P. J. and J. R. Aronson (1993). Inequality decomposition analysis and the gini coefficient revisited. Economic Journal 103(420), 1221-27.

Lunn, D. J., A. Thomas, N. Best, and D. Spiegelhalter (2000, October). Winbugs \&ndash; a Bayesian modelling framework: Concepts, structure, and extensibility. Statistics and Computing 10(4), 325337.

Martin, A. D., K. M. Quinn, and J. H. Park (2011). MCMCpack: Markov chain monte carlo in R. Journal of Statistical Software 42(9), 0-22.

Mitnik, P. A. and S. Baek (2013). The kumaraswamy distribution: median-dispersion reparameterizations for regression modeling and simulation-based estimation. Statistical Papers 54 (1), $177-192$.

Moors, J. J. A. (1988). A quantile alternative for kurtosis. Journal of the Royal Statistical Society 37(1), 25-32. Series B.

Nair, N. U., P. Sankaran, and N. Balakrishnan (2013). Quantile-Based Reliability Analysis. Boston: Birkhäuser Basel.

Ntzoufras, I. (2011). Bayesian Modeling Using WinBUGS. New Jersey: John Wiley \& Sons.

Plummer, M. (2003). JAGS: A program for analysis of Bayesian graphical models using Gibbs sampling. In Proceedings of the 3rd International Workshop on Distributed Statistical Computing.

R Development Core Team (2015). R: A Language and Environment for Statistical Computing. Vienna, Austria: R Foundation for Statistical Computing. 
Smyth, G. K., Y. Hu, P. Dunn, B. Phipson, and Y. Chen (2015). statmod: statistical modeling.

Tadikamalla, P. R. and N. L. Johnson (1982). Systems of frequency curves generated by transformations of logistic variables. Biometrika $69(2), 461-465$.

Wang, M. and K. Rennolls (2005). Three diameter distribution modelling: Introducing the logitlogistic. Canadian Journal of Forest Research 35 (6), 1305-1313.

Watanabe, S. (2010). Asymptotic equivalence of Bayes cross validation and widely applicable information criterion in singular learning theory. Journal of Machine Learning Research 11, 3571-3594. 


\section{Apêndice I}

Bazán, J. L., Torres-Avilés, F., Suzuki, A. K., e Louzada, F. (2016). Power and reversal power links for binary regressions: An application for policyholders of motor insurance. Submmitted to Applied Stochastic Models in Business and Industry. 


\title{
Power and Reversal Power Links for Binary Regressions: An Application for Policyholders of Motor Insurance
}

\author{
J.L. Bazán ${ }^{(1) *} \quad$ F. Torres-Avilés ${ }^{(1,2)} \quad$ A. K. Suzuki ${ }^{(1)}$ \\ F. Louzada ${ }^{(1)}$ \\ ${ }^{(1)}$ Instituto de Ciências Matemáticas e de Computação, Universidade de \\ São Paulo, Brazil \\ ${ }^{(2)}$ Departamento de Matemática y Ciencia de la Computación, Universidad \\ de Santiago de Chile, Chile
}

\begin{abstract}
In binary regression symmetric links such as logit and probit are usually considered as standard. However, in presence of unbalancing of ones and zeros, these links can be inappropriate, inflexible to fit the skewness in the response curve and likely to lead to misspecification. This is the case of covering of some type of insurance, where it is noted that the probability of a given binary response variable approaches zero at different rates than it approaches one. Additionally when usual links are considered, there is not a skewness parameter associated with the distribution chosen and independent of the linear predictor, easily interpreted. In order to overcome such problems, a proposal for the construction of set of new skew links is development in this paper, where some their properties are discussed. In this context, power links and their reversal versions are presented. A Bayesian inference approach using MCMC is developed to the presented models. The methodology is illustrated on a sample of policyholders of motor insurance selected randomly by gender. Results suggest that the proposed link functions are more appropriate than other alternative link functions commonly used in the literature.
\end{abstract}

keywords binary regression, bayesian approach, MCMC, power links, skewed link

\section{Introduction}

Historically, binary models have been widely used by financial and insurance companies as a major tool of vital importance for rating applicants/customers on granting credit to clients and ensuring integrity of financial operations. According to Altman and Saunders (1998), granting of credit facilities and ensuring integrity of financial operations started

\footnotetext{
*Corresponding author: email: jlbazan@icmc.usp.br. Department of Applied Mathematics and Statistics, ICMC-USP C.P. 668 - São Carlos, SP, Brazil - CEP 13560-970.
} 
to be more important in the profitability of companies in the financial sector, becoming one of the main sources of revenue for financial and insurance institutions in general.

In this context, the immediate example is the logit model $(\mathrm{L})$, which is obtained by considering $\boldsymbol{Y}=\left(Y_{1}, Y_{2}, \ldots, Y_{n}\right)^{\prime}$, a $n \times 1$ vector of $n$ independent dichotomous random variables with probability $p_{i}=P\left[Y_{i}=1\right]$, and $\boldsymbol{x}_{i}=\left(x_{i 1}, \ldots, x_{i k}\right)^{\prime}$ a $k \times 1$ vector of covariates, where $x_{i 1}$ may equals 1 , this leads to assume an intercept, $i=1, \ldots, n$. Therefore, $\boldsymbol{X}$ will denote a $n \times k$ design matrix with rows $\boldsymbol{x}_{i}^{\prime}$, and $\boldsymbol{\beta}=\left(\beta_{1}, \ldots, \beta_{k}\right)^{\prime}$ a $k \times 1$ vector of regression coefficients. For this model, the probability of binary response variable will be given by

$$
p_{i}=E\left(Y_{i} \mid \boldsymbol{x}_{i}\right)=L\left(\boldsymbol{\eta}_{i}\right)=L\left(\boldsymbol{x}_{i}^{\prime} \boldsymbol{\beta}\right)=\frac{\exp \left(\boldsymbol{x}_{i}^{\prime} \boldsymbol{\beta}\right)}{1+\exp \left(\boldsymbol{x}_{i}^{\prime} \boldsymbol{\beta}\right)}, \quad i=1, \ldots, n,
$$

where $L($.$) denotes a cumulative distribution function (cdf) of the standard logistic distri-$ bution. The inverse of the function $L$, namely $L^{-1}$, is called link function and $\boldsymbol{\eta}_{i}=\boldsymbol{x}_{i}^{\prime} \boldsymbol{\beta}$, is the corresponding linear predictor. The graphic considering $p_{i}$ as a function of $\eta_{i}$ is called response curve or probability of success, and has a symmetric form centered in 0.5.

Bayesian approach for Binary regression models has been widely developed in the literature since 90's (see, Dey, Ghosh and Mallick, 1999). In finance and insurance, credit scoring (see for example Steenackers and Goovaerts, 1989; Hardle et al, 1996; Finlay, 2008, Kočenda and Vojtek, 2011; Louzada et al, 2012 and Wu 2014, only to mention a few) and fraud detection (see for example Owen, 2007; Bermúdez et al, 2008; Jha et al, 2012; Louzada and Ara, 2012 and Li, 2014, only to mention a few) are some of the applications where logistic regression is considered as standard procedure.

Other known symmetric link functions is obtained when $L$ is replaced by the cdf of the standard normal, $\Phi($.$) , and standard Cauchy distribution, C($.$) , (Albert and Chib, 1993),$ raising the probit, $p_{i}=\Phi\left(\boldsymbol{x}_{i}^{\prime} \boldsymbol{\beta}\right)$, and cauchit, $p_{i}=C\left(\boldsymbol{x}_{i}^{\prime} \boldsymbol{\beta}\right)=0.5+\frac{1}{\pi} \arctan \left(\boldsymbol{x}_{i}^{\prime} \boldsymbol{\beta}\right)$, link functions, respectively. On the other hand, some textbooks (see for example, Collet, 2003) have reported that an asymmetric link function may be more appropriate than a symmetric one for some specific situations. Thus, the loglog, $p_{i}=G u\left(\boldsymbol{x}_{i}^{\prime} \boldsymbol{\beta}\right)=\exp \left\{-\exp \left(-\boldsymbol{x}_{i}^{\prime} \boldsymbol{\beta}\right)\right\}$, and $\operatorname{cog} \log , p_{i}=R G u\left(\boldsymbol{x}_{i}^{\prime} \boldsymbol{\beta}\right)=1-\exp \left\{-\exp \left(\boldsymbol{x}_{i}^{\prime} \boldsymbol{\beta}\right)\right\}$, are other known links, which can be obtained by considering the cdf of the gumbel $G u($.$) , and the called reversed gumbel$ distribution $R G u($.$) , respectively. This name will be justified in next section.$

Several authors have argued, for example, Chen, Dey and Shao (1999), that when the probability of a given binary response variable approaches to 0 at different rates, than it approaches to 1 . It is the case of unbalancing of ones or zeros, symmetric link functions may be not useful to fit binary data and asymmetric link functions must be considered. Unbalancing may occur for data of credit scoring, fraud, attrition, churning and insurance claim. Consequently, many asymmetric link functions has been proposed in the literature. Some examples include Prentice (1976), Guerrero and Johnson (1982), Stukel (1988), Czado and Santner (1992), Czado (1994), Chen et al. (1999) Chen et al (2001), Bazán, Branco and Bolfarine (2006), Bazán, Bolfarine and Branco (2010), Wang and Dey (2010) and Bazán, Romeo and Rodrigues (2014).

In this paper, we propose a general approach for asymmetric link functions in binary regression. We consider the relation between the Gumbel and reversal Gumbel distributions, named here as its reversal property, to extend this to a class of asymmetrical link functions which are different of the classical cloglog and log links, due to the inclusion of an additional parameter which is associated with the asymmetry of the distribution and used in the construction of the link function, which controls the rate of increasing (or 
decreasing) of the probability of success (failure) of the binary response variables.

The link functions introduced here have as particular cases some known links mostly used in the literature, and the asymmetry parameter associated with these cdf's is also introduced independently of the linear predictor and the latent linear structure will be not necessary for this link approach. The most important aspect of the modelling stage under this setting, is the potential improvement to model fit in binary regression that can be obtained considering a particular class of asymmetric link functions when data cannot be modeled appropriately with usual links as showed in this paper.

This work is organized as follows. In Section 2 the reversal property is presented and several distributions satisfying this property are showed with emphases in power and reversal power distributions. In Section 3 the modelling for binary response variables considering a class of asymmetric links functions based in power and reversal power distributions are formulated. In Section 4 a Bayesian estimation approach is developed including a discussion about model comparison criteria obtained from the MCMC output. In Section 5 an illustrative example is presented through a real application by considering real data already analysed in the insurance specialised literatures. Finally, a discussion and extensions of the links functions proposed in this paper are considered in Section 6.

\section{Reversal property and power and reversal power dis- tributions}

In a general framework, consider $F^{-1}$ link functions to binary regression with $F($.$) and$ $f($.$) the correspondent cdf and pdf respectively of a random variable S$. In this section We define the reversal property and introduce the power and reversal power distributions.

Definition 1. Let $S \sim F($.$) (or S \sim f($.$) ), we say that the distribution of S$ satisfy the reversal property if the cdf of $-S$ is a different distribution which can be write as $-S \sim G(.) \equiv 1-F(-$.$) (or g(s) \equiv f(-s)$ ). In this case the distribution of $G($.$) is named$ the reversal distribution of $F($.$) .$

Result 1. Consider $S \sim F($.) (or $S \sim f($.$) ) a random variable (r.v.) following a symmet-$ ric distribution, that is, a pdf $f($.$) is said to be symmetric if and only if there exists a value$ $x_{0}$ such that $f\left(x_{0}-\delta\right)=f\left(x_{0}+\delta\right)$ for all real numbers $\delta$. Then, $F($.$) do not satisfy the$ reversal property. That is, $S$ and $-S$ have the same distribution and $F(s)=1-F(-s)$, $f(s)=f(-s)$. Examples of this are Logistic, Normal and Cauchy distributions.

Result 2. Consider $S \sim \operatorname{Gumbel}(\mu, \beta)$ with pdf given by $f(s ; \mu, \beta)=\frac{1}{\beta} e^{-\left(z+e^{-z}\right)}$, where $z=\frac{s-\mu}{\beta}$. Then, it is easy to see that $S$ satisfy the reversal property and just $-S \sim$ reversed Gumbel $(\mu, \beta)$ with pdf given by $g(s ; \mu, \beta)=\frac{1}{\beta} e^{-\left(z+e^{-z}\right)}$ where $z=\frac{-s-\mu}{\beta}$. In addition, note also that the reversed Gumbel distribution satisfy the reversal property and its reversal distribution is just the Gumbel distribution. In this case the correspondents cdf satisfy $F(s)+G(-s)=1$ and $f(s)=g(-s)$ and $S$ and $-S$ have the the Gumbel and reversed Gumbel distributions, respectively. Thus the latter two distributions are not symmetrical in this sense, but are closely related where they are called mirror images of one another.

Remarks 1. Some examples of distributions considered in binary regression that do not satisfy the reversal property are the scale mixtures of normal distributions which were 
considered by Basu, S. and Mukhopadhyay, S. (2000) and the generalised t considered by Kim, Chen and Dey (2008). On the other hand, examples of distributions considered to propose link functions in binary regression that satisfy the reversal property are the skew normal, skew t, which were used by Chen, Dey and Shao (1999), Bazán et al. (2010), Kim et al. (2004) respectively to propose asymmetric links for binary regression. Therefore, the case treated by Wang, X. and Dey, D. K. (2010), which the use of the generalised extreme value (GEV) distribution, also satisfy the property.

Definition 2. A univariate random variable $S$ is said to follow a power distribution, $S \sim \mathcal{P}\left(\mu, \sigma^{2}, \lambda\right)$, with location, scale and shape parameters given by $-\infty<\mu<\infty$, $\sigma^{2}>0$ and $\lambda>0$ respectively, if the density of such distribution has the form

$$
f_{p}\left(s \mid \mu, \sigma^{2}, \lambda\right)=\frac{\lambda}{\sigma} g\left(\frac{s-\mu}{\sigma}\right)\left[G\left(\frac{s-\mu}{\sigma}\right)\right]^{\lambda-1},
$$

with $G($.$) denoting any absolute continuous cdf with real support and g($.$) a unimodal and$ log concave pdf with support in the line real $\langle-\infty, \infty>$ named the baseline distribution.

If $\lambda=1$, the density of $S$ in (2) reduces to the density of the $g\left(\mu, \sigma^{2}\right)$ baseline distribution. The standard power distribution is obtained from equation (2) with $\mu=0$ and $\sigma^{2}=1$. It is denoted by $Z \sim \mathcal{P}(\lambda)$ with corresponding $p d f$ and cdf given by

$$
f_{p}(z \mid \lambda)=\lambda g(z)[G(z)]^{\lambda-1}
$$

and

$$
F_{p}(z)=[G(z)]^{\lambda}
$$

Result 3. Consider $S$ a r.v. following a standard power distribution with $\operatorname{cdf} F_{p}(s)=$ $G(s)^{\lambda}$, where $G($.$) is the cdf of a baseline distribution and \lambda>0$ is additional parameter. Then $F_{p}($.$) satisfy the reversal property with F_{r p}(s)=1-G(-s)^{\lambda}$ being its corresponding reversal cdf distribution. Similarly, consider $S$ a r.v. with $c d f F_{r p}(s)=1-G(-s)^{\lambda}$, named standard reversal power, where $G($.$) is the cdf of a baseline distribution and \lambda>0$ an additional parameter. Then $F_{r p}($.$) satisfy the reversal property with F_{p}(s)=G(s)^{\lambda}$ being its correspondent reversal cdf distribution.

Remarks 2. Some remarks are as following:

- $F_{p}(-s) \neq 1-F_{p}(s)$ or $F_{r p}(-s) \neq 1-F_{r p}(s)$ and then $F_{p}$ and $F_{r p}$ are not pointsymmetric, for $\lambda \neq 1$.

- $F_{p}( \pm s)+F_{r p}(\mp s)=1$ and thus, both distributions are distinct, though closely related.

- When $\lambda=1$ then $F_{p}(s)=G(s)=F_{r p}(s)$ and thus $G($.$) is a particular case of both$ distributions.

- It is easy to observe that if $S$ follow a $F_{p}($.$) distribution, then -S$ follows a $F_{r p}($. distribution.

Remarks 3. Some examples of distributions power and reversal power are as following: 
- By considering the Result 3 and taking $G()=.L($.$) , the cdf of the standard lo-$ gistic distribution $F_{p}($.$) is named proportional reversed hazard logistic distribution$ (Nadarajah, 2009) and is also known as the Type-I generalized logistic distribution (Johnson, Kotz and Balakrishnan, 1995). Here we named this distribution as Power Logistic (PL). Additionally, $F_{r p}($.$) is named scobit distribution (Nagler, 1994) and$ also is known as the Type-II generalized logistic distribution (Johnson, Kotz and Balakrishnan, 1995) which is named here as reversal power logistic (RPL). Both distributions are particular cases of the named beta-logistic distribution or $\log \mathrm{F}$ distributions (Jones, 2004), or Type-IV generalized logistic distribution (Johnson, Kotz and Balakrishnan, 1995).

- By considering the Result 3 and taking $G()=.\Phi($.$) the cdf of the standard normal$ distribution $F_{p}($.$) is named power normal distribution (PN) (Gupta and Gupta,$ 2008, Kundu and Gupta, 2013). Also $F_{r p}($.$) is a new distribution in the literature$ and can be named reversal power normal distribution (RPN). Both distribution are particular cases of the named beta-normal distribution (Eugene, Lee and Famoye, 2002).

- Other examples of power distributions are the power cloglog (PCL) and Power loglog (PLL) distribution, recently proposed by Abanto, Bazán and Smith (2015). About this, both distribution should be named here as power reversal gumbel and power gumbel distribution since this distributions are the correspondent base distribution based in the distribution of the extreme minimum and extreme maximum respectively. In addition, we propose the correspondent reversal versions of each one, that is: reversal power cloglog (RPCL) and reversal power loglog (RPL). Note that this distributions are not respectively the reversal version one of the other and also power cloglog is not Reversal power loglog and power loglog is not reversal power cloglog.

- In addition two news distributions, the power cauchy distribution (PC) and the reversal power cauchy distribution (RPC) are proposed here by considering the Cauchy distribution as baseline.

\section{On the new class of asymmetric link functions in bi- nary regression}

A new class of models for binary data, can be obtained by considering that the probability of sucess is give by

$$
p_{i}=E\left(y_{i} \mid \boldsymbol{x}_{i}\right)=F_{\lambda}\left(\eta_{i}\right)=F_{\lambda}\left(\boldsymbol{x}_{i}^{\prime} \boldsymbol{\beta}\right),
$$

where $F_{\lambda}$ can be the cdf's of a standard power or a standard reversal power distribution indexed with $\lambda>0$, that is,

$$
F_{p}(y)=G(y)^{\lambda} \quad \text { or } \quad F_{r p}(y)=1-G(-y)^{\lambda}
$$

with $G($.$) denoting any a cdf of baseline distribution with support in the line real. We$ named this new class of links to binary regression models as the positive exponent links. 
Note that the above formulation to new links to binary regression is rather general and then several case can be viewed as particular cases of the new class as is discussed below. Also note that $\lambda$ parameter have quite different meaning that $\boldsymbol{\beta}$ parameters because is a structural parameter associated with the choice of the link function. On the other hand, $\boldsymbol{\beta}$ parameters are a vector of structural parameters inherent to the observed data and not depending on model choice.

In Binary regression, by considering $G()=.\Phi($.$) , the cdf of the standard normal$ distribution $F_{p}^{-1}($.$) is a power probit link and F_{r p}^{-1}($.$) is its reversal power probit and the$ probit link will be a particular case. Both cases of links were proposed by Bazán et al (2014). By considering $G()=.L($.$) the cdf of the standard logistic distribution F_{p}^{-1}($.$) is$ a power logit link and $F_{r p}^{-1}($.$) is its reversal power logit, and the logit link is a particular$ case again. Both are particular cases of the link proposed by Prentice (1976). $F_{p}^{-1}($. is usually named power logit link and $F_{r p}^{-1}($.$) is also named scobit link (Nagler, 1994).$ Table 1 shows the pdf of some positive exponent links in the literature, including someone based on the power distributions and its reversal versions.

[Table 1 about here.]

Figure 1 depicts different response curves for the power and reversal power models by using different values for $\lambda$, for different values of linear predictor $\eta$ considering different baseline distributions as baseline links (logit, probit, loglog, cloglog and cauchit). For $\lambda=1$ the correspondents power and reversal power links corresponds to the baseline link and for $\lambda<1$ ( or $\lambda>1$ ) the curve corresponding to power model is generally above (below) the curve corresponding to the baseline link model within a range of $\eta$ values. Note also that for each value of $\lambda$, reversal power curve is a reflection of the correspondent power curve and thus for $\lambda<1$ (or $\lambda>1$ ) the corresponding curve is generally below (above) the corresponding curve for the baseline curve.

[Figure 1 about here.]

Specifically, by example, consider the different probability curves for the power cauchit and reversal power cauchit in Figure 1(e). For $\lambda=1$, both links correspond to the curve of the cauchit model. For the power cauchit link if $\lambda<1$, the correspondent curve is generally above to the cauchit curve and then your probability of success is greater that the correspondent probability under the cauchit link. Thus, $\lambda$ is a bonus parameter. Conversely, if $\lambda>1$, the power cauchit curve is generally below to the cauchit curve and then your probability of success is less that the correspondent probability under the cauchit link. Thus, $\lambda$ is a penalty parameter. To the reversal power cauchit the interpretation is inverse, that is, when $\lambda<1$ that is a penalty parameter and if $\lambda>1$ then is a bonus parameter.

\section{Bayesian Inference}

For inference we consider a full Bayesian approach. The likelihood function to the binary regression model considering the new class of positive exponent links is given by

$$
L(\boldsymbol{\beta}, \lambda \mid y, X)=\prod_{i=1}^{n}\left[F_{\lambda}\left(\boldsymbol{x}_{i}^{\prime} \boldsymbol{\beta}\right]^{y_{i}}\left[1-F_{\lambda}\left(\boldsymbol{x}_{i}^{\prime} \boldsymbol{\beta}\right)\right]^{1-y_{i}}\right.
$$


In addition, introducing the latent variables

$$
y_{i}=I\left(s_{i}>0\right)=\left\{\begin{array}{ll}
1, & s_{i}>0, \\
0, & s_{i} \leq 0,
\end{array}, \quad i=1, \ldots, n,\right.
$$

we can obtain a alternative and complete-data likelihood function which is given by

$$
L(\boldsymbol{\beta}, \lambda \mid s, y, X)=\prod_{i=1}^{n} f_{\lambda}^{*}\left(s_{i}\right) p\left(y_{i} \mid s_{i}\right),
$$

with $p\left(y_{i} \mid s_{i}\right)=I\left(s_{i}, y_{i}\right)=I\left(s_{i}>0\right) I\left(y_{i}=1\right)+I\left(s_{i} \leq 0\right) I\left(y_{i}=0\right)$ and $f_{\lambda}^{*}$ is the pdf of the distribution corresponding to the reversal distribution of $F_{\lambda}$ considered in (3).

As prior distributions, we are assuming independence such that,

$$
\pi(\boldsymbol{\beta}, \delta)=\pi_{1}(\boldsymbol{\beta}) \pi_{2}(\delta)
$$

whit $\boldsymbol{\beta} \sim \pi_{1}($.$) and \delta \sim \pi_{2}($.$) , where \delta=\log (\lambda)$. For $\pi_{1}($.$) usual priors for regression$ as $\beta_{j} \sim N\left(\mu_{\beta}, \sigma_{\beta}^{2}\right), j=1,2, \ldots, k$ (see Zellner and Rossi, 1984) can be considered with $\mu_{\beta}=0$, and $\sigma_{\beta}^{2}=100$ to assure non information about them. For $\pi_{2}($.$) we tested$ two prior distributions for $\delta$ parameter, the first one was $N(0,1)$, and the second one a Uniform $(-2,2)$ since values out of the range $\left[e^{-2}, e^{2}\right]$ have much less or non probability of occurrence.

\subsection{MCMC scheme}

Considering the likelihood function in (7) and a general prior specification given (8), the Bayesian estimation can be easily implemented via Metropolis-Hasting providing a simple and efficient sampling from the marginal posterior distributions which will be used to inference about the parameters of the model.

Therefore, the hierarchical structure of the binary regression model considering positive exponent links using the $\delta$-parametrization is as follows:

$$
\begin{gathered}
Y_{i} \mid \boldsymbol{\beta}, \delta \sim \operatorname{Bernoulli}\left(F_{\delta}\left(\boldsymbol{x}_{i}^{\prime} \boldsymbol{\beta}\right)\right) \\
\boldsymbol{\beta} \sim \pi_{1}(\boldsymbol{\beta}),
\end{gathered}
$$

and

$$
\delta \sim \pi_{2}(\delta),
$$

Note that when $\delta=0(\lambda=1)$, the hierarchical structure of the likelihood of the baseline model based in the $G($.$) distribution in (6) follows by eliminating the third line$ in the above model.

Further, note that, this hierarchical structure can be easily implemented in several packages as WinBugs, JAGS, Rstan or SAS software. In this paper, all the models considered in the application were implemented using PROC MCMC of SAS 9.3 software (SAS Institute Inc., 2015). In all cases, an effective sample size of 4000 was considered discarding the 5000 initial iterations and considering thin of 50 .

An evaluation of the mean plot, first order autocorrelations of the posterior samples, the effective sample size of each parameter and the standard errors of the posterior mean estimate provide strong indication of the convergence of MCMC output in all cases In addition Geweke, Heidelberger-Welch and Raftery-Lewis Diagnostics as implemented for the PROC MCMC (see more details in SAS Institute Inc., 2015) were calculated, indicates that all tests have been passed and convergence has been reached. Results are omitted to save space. 


\subsection{Model Comparison Criteria}

In this work, we evaluate several measures for model comparison purposes, some traditional other recently proposed, to asses the potential fit. One issue to consider in our comparison analysis is that each of them are deviance-based, easily computed after the MCMC samples were obtained. Thus, we started with the main selection procedures such as the Deviance Information Criterion $(D I C)$ proposed by Spiegelhalter et al. (2002), the Expected Akaike's Information Criteria (Akaike $(E A I C)$ and its Schwarz's Bayesian version $(E B I C)$, all of them considered in Carlin and Louis (2000) and Brooks (2002). As it was mentioned above, these criteria are based on the Posterior Mean of the Deviance, $E[D(\boldsymbol{\beta}, \lambda)]$, and it is a measure of fit that can be approximated using the MCMC output by

$$
\text { Dbar }=\frac{1}{M} \sum_{k=1}^{M} D\left(\boldsymbol{\beta}^{(k)}, \lambda^{(k)}\right),
$$

where the index $(k)$ represents the $k$-th realization of a total of $M$ realizations, and

$$
D(\boldsymbol{\beta}, \lambda)=-2 \ln (p(\boldsymbol{y} \mid \boldsymbol{\beta}, \lambda))=-2 \sum_{i=1}^{n} \ln P\left(Y_{i}=y_{i} \mid \boldsymbol{\beta}, \lambda\right),
$$

is the Bayesian deviance.

Hence, the measures $E A I C, E B I C$ and $D I C$ can be estimated using the MCMC output through $E A I C=D b a r+2 p, E B I C=D b a r+p l o g(N)$ and $D I C=D b a r+\widehat{\rho_{D}}=$ 2 Dbar - Dhat, respectively, where $p$ is the number of parameters in the model, $N$ is the total number of observations and $\rho_{D}$, namely the effective number of parameters, is given by $\rho_{D}=E[D(\boldsymbol{\beta}, \lambda)]-D[E(\boldsymbol{\beta}), E(\lambda)]$ where $D[E(\boldsymbol{\beta}), E(\boldsymbol{\lambda})]$ is the deviance of posterior mean. It is obtained by means of the mean of the values generated from the posterior distribution as

$$
\text { Dhat }=D\left(\frac{1}{G} \sum_{g=1}^{G} \boldsymbol{\beta}^{(g)}, \frac{1}{G} \sum_{i=1}^{G} \lambda^{(g)},\right) .
$$

Additionally, we used other recent proposals to asses the model fit. Among them, two other criteria were the proposals given by Watanabe (2010, 2013), named Watanabe's Information Criterion (denoted by WAIC) and Bayesian Predictive Information criterion (or simply IC), respectively. Wanatabe's proposal can be viewed as an approximation to cross-validation (Gelman et al., 2014) and the only difference is the computation of the parameter of complexity $p_{W A I C}$. In this work, we will use the variance version to approximate this parameter given its stability properties. Hence, in this case,

$$
p_{W A I C}=\sum_{i=1}^{N} \operatorname{Var}\left(\ln \left(p\left(y_{i} \mid \boldsymbol{\beta}, \lambda\right)\right)\right)
$$

Therefore,

$$
W A I C=\text { Dhat }+2 p_{W A I C} .
$$

On the other hand, Ando (2011) proposed a model comparison alternative to obtain a measure which represents the predictive behavior of the model. Evenmore, the author states that this measure will avoid the over-fitting problems that measures such as DIC 
can cause. This measure is simply approximated from the already computed measures by

$$
I C=D b a r+2 p_{D}
$$

Given all the alternative models, the model that fits better to a data set is that one with the smallest value of each of the already computed measures.

\section{An application}

In this section, we will illustrate the performance of our models using the data Full Coverage available in Frees et al. (2014; see Chapter 3). The term Full Coverage is referred to the contract that covers the costs associated to the damage of the insured vehicle produced by any accident or collision, car theft and vandalism, damage caused by storm or flood or any impact made by an inanimate object. The data set consists on a sample with 4000 policyholders of motor insurance selected randomly by gender. The response variable is whether the client bought a full coverage plan (success coded as 1) or not (failure coded as 0). Potential predictors to explain the coverage choice are given by individual characteristics, like SEX $(\mathrm{M}=1, \mathrm{~F}=0)$, DRIVING AREA (Urban=1, Other=0), VEHICLE USE (Particular=1, Other $=0$ ), MARITAL STATUS of the policyholder (Single, Married and Others), AGE, and SENIORITY in the company. It is expected that most of these features can identify a potential client of this plan. More details about the data set can be obtained in the chapter of the book. Our aim is to propose and compare different regression models to predict the probability that a policy holder chooses FULL COVERAGE, considering this set of predictors. The guidelines of our analysis are those exposed by the author, with the difference that we will discuss our results in terms of obtaining the best model fit.

Based on the results from Guillén (2014), the covariate MARITAL STATUS does not seem to influence in the explanation of buying a vehicle full coverage plan, thus we decided to compared two group of models, a set of complete models where the covariate Marital Status was considered and a second set of models, where this variable was dropped out from the analysis. We started the analysis comparing the different links we are exposing in this work, specifically were fit L: logit, P: probit, Ll: $\log \log$, Cll: cloglog, C: cauchit and your correspondent power versions and reversal power versions of the logit, probit and cauchit were considered. To comparison we also consider the SP: skew probit proposed by Bazán, Bolfarine and Branco (2010). Different model comparison criteria discussed in section 3 were obtained to the all models fits in each group of models. The results are presented in the lines of Table 2.

\section{[Table 2 about here.]}

Based on the results from our gold-standard, the Bayesian version of the logit link model, were verified results of Guillén (2014), that is, the covariate MARITAL STATUS does not seem to influence in the explanation of buying a vehicle full coverage plan. Even more, most fitted models reveals a non-influence of the categories of this variable, as can be seen in Figure 2 where are showed 95\% HPD interval that includes the zero point to this effect. Based in this results, we decided not to consider this variable (that could be important in the specialised literature) to make the model choice.

In addition, the different measures of model comparison criteria point out to the power versions of the cauchit link as the best fit, where the reversal power cauchit obtained 
the lowest values at all six criteria. We decided for the reduced version of this models to continue with our analysis, due to the inconsistency that the inclusion of the marital status can produce in the final results.

Parameter estimates for the logit link model and the two best choices: power cauchit and reversal power cauchit to the reduced model are presented in Table 3 .

[Table 3 about here.]

[Figure 2 about here.]

We can also see that the parameter associated with variable AGE continues being negative for all models, reaching a lower value for the reversal power cauchit link, that is, we can argue that while older the policyholder is, the lower are the chances he or she buys a full coverage plan. The parameter for the selected link model for MEN considers a negative and the lowest value for all the models. So, as was expected, men would be less prone to buy full coverage than women. On the other hand, customers driving in an urban area have higher probabilities of buying full coverage compared to those who drive in rural areas, obtaining a higher influence in the reversal version of the power cauchit link. Indeed the SENIORITY in the company has a positive influence.

Its parameter continues with a positive effect across the models, therefore, customers who have been in the company for a longer period of time have a higher probability of buying full coverage than recent or new customers. Finally, variable PRIVATE is also of interest in this class of problems and it is possible to observe that vehicles for private is a factor that is crucial in order to policy holders with private use vehicles are more likely to by a FULL COVERAGE plan than those insurers with a vehicle for commercial use. As is argued by Guillén (2014), this effects are clearly good predictors for buying a Full coverage plan. Even more, our proposal seems to reinforce with higher and lower estimates those covariates included in our model.

On the other hand, since that we are interested in compare the predictive assessment of our link models, we will use standard measures, such as, rate of good classification, sensitivity, specificity and area under the curve using the empirical and bi-normal approximations (see Gonen, 2007). Predictive measures for the logit link model and the two best choices: power cauchit and reversal power cauchit are showed in Table 4.

For each model under analysis a $2 \times 2$ sub table of frequencies between values predicted and observed is showed in Table 4. In columns Predicted and Observed, the code 1 (success) corresponds to the prediction if the client bought a full coverage plan or your corresponding observed value. The code 0 (failure) corresponds to the prediction if the client not bought a full coverage plan or your corresponding observed value. For each sub table the frequencies in the diagonal cells represent the two types of correct prediction: true positives (TP) or correctly identified and true negatives (TN) or correctly rejected. Another cells in the subtable represent the two types of incorrect prediction: false positives (FP) or incorrectly identified and false negatives $(\mathrm{FN})$ or incorrectly rejected. Then the rate of good classification or accuracy is defined how $(T P+T N) /(T P+F P+F N+T N)$, the Sensitivity or the true positive rate is defined as $T P /(T P+F N)$, and the Specificity or true negative rate is defined as $T N /(T N+F P)$

Therefore to each model, rate of good classification measure the proportion of clients that bought or not full coverage plan that are correctly identified as such. Sensitivity measures the proportion of clients that bought a full coverage plan that are correctly 
identified as such and Specificity measure the proportion of clients that not bought a full coverage plan that are correctly identified as such. Finally, as it is mentioned by Guillén (2014), ROC analysis provides a way to select possibly optimal models and to discard suboptimal ones based on classification performance at various threshold levels, a subproduct of this analysis, the area under the curve, was used in this work to identify the best performance. As it is mentioned in the literature, a model with the largest area under the should be preferred to other possible models.

\section{[Table 4 about here.]}

According to our computations (Table 4), it is possible to observe that the best results are exposed by the reversal power cauchit link, considering that it improves the rate of good classification, the sensitivity of the prediction and the area under the curve, when we are interested in predicting those clients who will buy a FULL COVERAGE plan. It is interesting to see the increment in all of the measures while we evaluate their power assuming the different models. Specificity is clearly having an opposite behaviour due to the unbalanced quantities of successes and failures of the sample, $34 \%$ and $66 \%$ respectively, and showing a reduction of its measure while its sensitivity improves.

This effect is common in most of the predictive models working with unbalanced samples: a classification method with a high specificity will have a very low rate of false alarms, caused by classifying normal event (absence of the rare event) as abnormal (rare event) (see Marques de Sá, 2007), that is, when the event in the response variable is rare, the ROC curve will be dominated by minority class and thus insensitive to the change of true positive rate and consequently give high values of specificity, which provides litter information for model diagnosis as is the case of the logit model here.

Finally, by considering the analysis conduced, the reversal power cauchit link model presents the best performance to fit the data Full Coverage, where the probabilities estimated are obtained considering:

$$
\hat{p}_{i}=1-\left(0.5+\frac{1}{\pi} \arctan (-(1.80-3.48 \mathrm{MEN}+4.64 \mathrm{URBAN}+4.35 \mathrm{PRIVATE}-0.20 \mathrm{AGE}+0.48 \mathrm{SENIORITY}))\right)^{0.35}
$$

where particular cases can be obtained substituting the values of covariates.

We consider that this final model assures a good fit and covariates with well-behaved parameters, from a Bayesian point of view, and fulfilled their significative roles in the analysis. Also, to this model all parameters associated with the predictores were significant since that HPD intervals excluding zero indicate a significant covariate effect on the response variable. Even more, their performance in terms of predictive modelling, seems to be better than the other choices.

Specifically, we found that men would be less prone to buying full coverage than women since that the parameter associated with the variable MEN is negative (-3.48) and significant. We can see that the parameter associated with variable AGE is also negative (ấL Š 0.20 ) and significant indicating that the older the policyholder is, the lower are the chances he or she buys full coverage. Likeliwise, Customers driving in an urban area have a higher probability of buying full coverage compared to those who drive in rural areas. This is because the parameter for URBAN is positive (4.64) and significant. Also PRIVATE is positive (4.35) and significant indicating that policyholders who own a private use vehicle have a larger probability of buying FULL COVERAGE than insureds with a vehicle for commercial use. Also, the SENIORITY in the company has a positive influence. Its 
parameter is positive (0.48) and significant. This means that those customers who have been in the company for a longer period of time have a higher probability of buying full coverage than recent or new customers. Marital status of the policyholder, which separates single, married, and other individuals, does not seem to have a clear effect on this case as observed in Figure 2. Finally, we found a penalty parameter (0.35) and significant indicating that the probability of buying full coverage present a penalization factor associated with the predictors.

\section{Final Comments}

In this paper we introduce power and reversal power as new links for binary regression that need asymmetrical links as is the case of unbalanced data. In this links, the $\lambda$ parameter is a shape parameter of the considered cdf $F($.$) which is independent of the interval of$ variation of the linear predictor. In addition, known links of generalised linear models are particular cases. We present two versions of the likelihood function and classical and Bayesian estimation can be implemented by considering them. We introduce a Bayesian approach which can be easily implemented for instance in proc mcmc of SAS, WinBUGS, OpenBUGS or RJAGS.

Moreover, finance and insurance applications whose use logistic regression as default procedure must also be analysed by considering the links introduce in this paper in order to verify which one is the most adequate for fitting data. For instance, in the insurance dataset considered here the best results are obtained by a reversal power cauchit link, leading to improvements on the rate of good classification, sensitivity of the prediction and area under the curve. Particularly, when we are interested in predicting those clients who will buy a Full Coverage plan. Another applications include Big data in the Industry as in Krueger and Montgomery (2014) or consumer heterogeneity as in Pancras and Dey (2011).

Extensions of the methods developed in this paper to mixed ordinal response data, follows by considering this model in terms of cumulative probabilities in such a way that the conditional probability of a response in a category $c$ can be obtained as the difference of two conditional cumulative probabilities:

$$
P\left(Y_{i j}=c \mid \boldsymbol{b}_{i}, \boldsymbol{x}_{i j}, \boldsymbol{z}_{i j}\right)=F_{\lambda}\left(\eta_{i j c}\right)-F_{\lambda}\left(\eta_{i j c-1}\right)
$$

where

$$
\eta_{i j c}=\gamma_{c}-\left[\boldsymbol{x}_{i j}^{\prime} \boldsymbol{\beta}+\boldsymbol{z}_{i j}^{\prime} \boldsymbol{b}_{i}\right]
$$

and we have $c-1$ strictly increasing thresholds $\gamma_{c}$. This yields a random-effects ordinal regression model for multilevel analysis. Also model multivariate binary data based on copulas using the links proposed here can be defined as future researchers. In addition, applications in several areas of interest as binomial models, multilevel models, item response theory, calibration model, dose response, mixture models in survival analysis, should be suggested. Moreover, the use of criteria to elicitation of priors for the probabilities $p_{i}$ can be introduced. Besides, by considering another baseline pdf $g($.$) defined in the$ real line with unique mode, continuous and log concave, another links can be obtained, for example using the links bases in the generalised extreme value function (Way and Dey, 2010). 


\section{Acknowledgments}

The authors would like to thank the Editor, Associate Editor, and an anonymous referee for the valuable comments that have improved considerably the first version of the manuscript. J.L. Bazán and A. K. Suzuki are founded by FAPESP, Brazil, F.TorresAvilés was founded with a Post-doctoral fellowship by Becas Chile and F. Louzada is founded by CNPq and FAPESP.

\section{References}

Altman, E. I. and Saunders, A. Credit risk measurement: Developments over the last 20 years. Journal of Banking and Finance 1998; 21, 1721-1742.

Ando, T. Predictive Bayesian Model Selection. American Journal of Mathematical and Management Sciences 2011; 31 (1-2), 13-38.

Albert, J. H. and Chib, S. Bayesian analysis of binary and polytomous response data. Journal of the American Statistical Association 1993; 88 (422), 669-679.

Basu, S. and Mukhopadhyay, S. Binary response regression with normal scale mixtures links, in Generalized Linear Models: A Bayesian Perspective, eds. D.K. Dey, S.K. Ghosh, and B.K: Mallick, New York: Marcel Dekker; 2000, 231-242.

Bazán, J. L., Branco, M. D. and Bolfarine, H. A skew item response model. Bayesian Analysis 2006; 1, 861-892.

Bazán, J. L., Bolfarine, H. and Branco, M. D. A framework for skew-probit links in Binary regression. Communications in Statistics - Theory and Methods 2010; 39 (4), 678-697.

Bazán, J. L., Romeo, J. S. and Rodrigues, J. Bayesian skew-probit regression for binary response data. Brazilian Journal of Probability and Statistics 2014; 28 (4), 467-482.

Bermúdez, L. I., Pérez, J. M., Ayuso, M., Gómez, E. and Vásquez, F. J. A Bayesian dichotomous model with asymmetric link for fraud in insurance. Insurance: Mathematics and Economics 2008; 42 (2), 779-786.

Brooks, S. P. Discussion on the paper by Spiegelhalter, Best, Carlin, and van der Linde. Journal of the Royal Statistical Society Series B 2002; 64 (3), 616-618.

Carlin, B. P. and Louis, T. A. Bayes and Empirical Bayes Methods for Data Analysis. Chapman and Hall, Boca Raton, FL, 2nd edition 2000.

Chen, M. H., Dey, D. K. and Shao, Q-M. A new skewed link model for dichotomous quantal response data. Journal of the American Statistical Association 1999; 94 (448), 1172-1186.

Chen, M. H., Dey, D. K. and Shao, Q-M. Bayesian analysis of binary data using skewed logit models. Calcutta Statistical Association Bulletin 2001; 51, 201-202.

Collet, D. Modelling Binary Data. Chapman \& Hall/CRC, Second Edition, Boca Raton, USA 2003. 
Czado, C. and Santner, T. J. The effect of link misspecification on binary regression inference. Journal of Statistical Planning and Inference 1992; 33 (2), 213-231.

Czado, C. Bayesian inference of binary regression models with parametric link. Journal of Statistical Planning and Inference 1994; 41 (2), 121-140.

Dey, D. K., Ghosh, S. K. and Mallick, B. K. Generalized linear models: A Bayesian perspective. New York: Marcel Dekker 1999.

Eugene, N., Lee, C. and Famoye, F. Beta Normal distribution and its applications. Communication and Statistics: Theory and Methods 2002; 31 (4), 497-512.

Frees, E., Derrig, R. A. and Meyers, G. Predictive Modeling Applications in Actuarial Science. Cambridge University Press 2014.

Finlay, S. M. Towards Profitability: A Utility Approach to the Credit Scoring Problem. The Journal of the Operational Research Society 2008; 59 (7), 921-931.

Gonen, M. Analyzing Receiver Operating Characteristic Curves Using SAS. SAS Press 2007.

Guerrero, V. M. and Johnson, R. A. Use of the Box-Cox transformation With binary response models. Biometrika 1982; 69 (2), 309-314.

Guillén, M. Regression with Categorical Dependent Variables. In Frees, E.W, Derrig, R., Meyer, G. (Eds) Predictive Modeling Handbook for Actuarial Science. Volume I. Cambridge University Press. 2014, 65-86.

Gelman, A., Hwang, J. and Vehtari, A. Understanding predictive information criteria for Bayesian models, Statistics and Computing 2014; 24, 997-1016.

Gupta, R. D. and Gupta, R. C. Analysing skewed data by power normal model. Test 2008; 17, 197-210.

Hardle, W., Mammen, E. and Muller, M. Testing Parametric versus Semiparametric Modeling in Generalized Linear Models. Journal of the American Statistical Association 1998; 93 (44), 1461-1474.

Jha, S. A., Guillen, M. B. and Westland, J. C. (2012). Employing transaction aggregation strategy to detect credit card fraud. Expert Systems with Applications 2012; 39 (16), 12650-12657.

Johnson, N. L., Kotz, S. and Balakrishnan, N. Continuous Univariate Distributions, Vol. 2. New York: Wiley 1995.

Jones, M. C. Family of Distributions Arising from Distribution of Order Statistics. Test 2004; 13 (1), 1-43.

Kim, H. J. Binary regression with a class of skewed t link models. Communications in Statistics. Theory Methods 2002; 31 (10), 1863-1886.

Kim, S., Chen, M. H. and Dey, D. K. Flexible generalized t-link models for binary response data. Biometrika 2008; 95 (1), 93-106. 
Kočenda, E. and Vojtekb, M. Default Predictors in Retail Credit Scoring: Evidence from Czech Banking Data. Emerging Markets Finance and Trade 2011; 47 (6), 80-98.

Kundu, D. and Gupta, R. D. Power-normal distribution. Statistics 2013; 47 (1), 110-125.

Kruegera, D. C. and Montgomery D. C. Modeling and analyzing semiconductor yield with generalized linear mixed models, Applied Stochastic Models in Business and Industry 2014; 30 (6), 691-707.

$\mathrm{Li}, \mathrm{Z}$. Research on distinguish the accounting information distortion based on the principle components-logistic regression model. International Journal of Security and its Applications 2014; 8, 37-50.

Louzada, F., Ferreira-Silva, P. H. and Diniz, C. A. R. On the impact of disproportional samples in credit scoring models: An application to a Brazilian bank data. Expert Systems with Applications 2012; 39 (9), 8071-8078.

Louzada, F. and Ara, A. Bagging k-dependence probabilistic networks: An alternative powerful fraud detection tool. Expert Systems with Applications 2012; 39 (14), 11583-11592.

Marques de Sá, J. P. Applied Statistics Using SPSS, STATISTICA, MATLAB and R. Springer-Verlag Berlin Heidelberg By Joaquim P 2007.

Nadarajah, S. The skew logistic distribution. AStA Advances in Statistical Analysis 2009; 93, 187-203.

Nagler J. Scobit: an alternative estimator to logit and probit. American Journal Political Science 1994; 38 (1), 230-255.

Owen, A. B. Infinitely imbalanced logistic regression. Journal of Machine Learning Research 2007; 8, 761-773.

Pancras, J. and Dey, D. K. A comparison of generalized multinomial logit and latent class approaches to studying consumer heterogeneity with some extensions of the generalized multinomial logit model. Applied Stochastic Models in Business and Industry 2011; (27), 567-578.

Prentice, R. L. A Generalization of the probit and logit methods for dose-response curves. Biometrika 1976; 32, 761-768.

SAS Institute Inc. SAS/STAT 9.3 14.1 User's Guide, Chapter 73 MCMC Procedure. Cary, NC: SAS Institute Inc. 2015

Spiegelhalter, D. J., Best, N. G., Carlin, B. P. and van der Linde, A. Bayesian measures of model complexity and fit. Journal Royal Statistical Society, Series B 2002; 64 (3), 583-639.

Steenackers, A. and Goovaerts, M. J. A credit scoring model for personal loans. Insurance: Mathematics and Economic 1989; 8, 31-34. 
Stukel, T. Generalized logistic models. Journal of the American Statistical Association 1988; 83 (402), 426-431.

Wang, X., and Dey, D. K. Generalized Extreme Value Regression for Binary Response Data: An Application to B2B Electronic Payments System Adoption. The Annals of Applied Statistics 2010; 4 (4), 2000-2023.

Watanabe, S. Asymtotic equivalence of Bayes crross validation and widely applicable information criterion in singular learning theory, Journal of Machine Learning Research 2010; 14, 867-897.

Watanabe, S. A widely applicable Bayesian information criterion, Journal of Machine Learning Research 2013; 14, 867-897.

Wu, D. D., Olson, D. L. and Luo, C. A Decision Support Approach for Accounts Receivable Risk Management. IEEE Transactions on Systems, Man and Cybernetics Systems 2014; 44 (12), 1624-1632.

Zellner, A. and Rossi, P. E. Bayesian analysis of dichotomous quantal response models. Journal of Econometrics 1984; 25 (3), 365-393. 
Table 1: Some Baseline, power and reversal power distributions and your correspondent links and positive exponent links to binary regression

\begin{tabular}{|c|c|c|c|c|}
\hline Type & Name of distributions & pdf & Name of link & Abbreviature \\
\hline \multirow[t]{4}{*}{ Baseline } & logistic & $L(z)=\frac{1}{1+e^{-z}}$ & $\operatorname{logit}$ & $\mathrm{L}$ \\
\hline & normal & $\Phi(z)=\frac{1}{\sqrt{2 \pi}} \int_{-\infty}^{z} e^{-t^{2} / 2} d t$ & probit & $\mathrm{P}$ \\
\hline & gumbel & $G u(z)=e^{-e^{-z}}$ & $\log \log$ & $\mathrm{Ll}$ \\
\hline & reversal-gumbel & $\operatorname{Rgu}(z)=1-e^{-e^{z}}$. & cloglog & Cll \\
\hline \multirow{4}{*}{ power } & power normal & $\Phi(z)^{\lambda}$ & power probit & PP \\
\hline & power cauchy & $C(z)^{\lambda}$ & power cauchit & $\mathrm{PC}$ \\
\hline & power gumbel & $G u(z)^{\lambda}$ & power loglog & PLl \\
\hline & power reversal-gumbel & $\operatorname{Rgu}(z)^{\lambda}$ & power cloglog & PCll \\
\hline \multirow{2}{*}{$\begin{array}{c}\text { reversal } \\
\text { power }\end{array}$} & type II generalized logistic & $1-L(-z)^{\lambda}$ & reversal power logit & RPL \\
\hline & reversal power reversal-Gumbel & $1-R g u(-z)^{\lambda}$ & reversal power cloglog & RPCll \\
\hline
\end{tabular}

where $z=(x-\mu) / \sigma$. 
Table 2: Model choice criteria for the Full coverage dataset. Comparison among complete model considering Marital Status and a reduced version without this covariate.

\begin{tabular}{|c|c|c|c|c|c|c|c|c|c|c|c|c|}
\hline Link & \multicolumn{6}{|c|}{ Complete Model } & \multicolumn{6}{|c|}{ Reduced Model } \\
\hline Model* & Dbar & DIC & WAIC2 & EAIC & EBIC & $\mathrm{IC}$ & Dbar & DIC & WAIC2 & EAIC & EBIC & $\mathrm{IC}$ \\
\hline $\mathrm{L}$ & 4295.8 & 4303.7 & 4304.6 & 4311.8 & 4324.6 & 4311.6 & 4296.0 & 4302.0 & 4302.6 & 4308.0 & 4317.6 & 4308.0 \\
\hline $\mathrm{P}$ & 4294.0 & 4301.9 & 4302.8 & 4310.0 & 4322.8 & 4309.7 & 4294.0 & 4300.0 & 4300.7 & 4306.0 & 4315.6 & 4306.0 \\
\hline SP & 4149.1 & 4155.8 & 4161.1 & 4167.1 & 4181.5 & 4162.4 & 4161.6 & 4164.5 & 4176.0 & 4175.6 & 4186.8 & 4167.4 \\
\hline $\mathrm{Ll}$ & 4250.8 & 4258.8 & 4260.2 & 4266.8 & 4279.6 & 4266.8 & 4252.1 & 4258.1 & 4259.4 & 4264.1 & 4273.7 & 4264.0 \\
\hline Cll & 4387.8 & 4395.7 & 4397.1 & 4403.8 & 4416.6 & 4403.7 & 4386.2 & 4392.2 & 4393.0 & 4398.2 & 4407.8 & 4398.1 \\
\hline $\mathrm{C}$ & 4341.2 & 4348.9 & 4351.0 & 4357.2 & 4370.1 & 4356.5 & 4343.5 & 4349.2 & 4350.7 & 4355.5 & 4365.1 & 4354.8 \\
\hline PL & 4249.5 & 4258.3 & 4259.2 & 4267.5 & 4281.9 & 4267.0 & 4250.8 & 4257.5 & 4258.5 & 4264.8 & 4276.0 & 4264.3 \\
\hline $\mathrm{PP}$ & 4270.4 & 4273.6 & 4279.8 & 4288.4 & 4302.8 & 4276.7 & 4269.6 & 4271.4 & 4276.7 & 4283.6 & 4294.8 & 4273.3 \\
\hline PLl & 4250.9 & 4258.9 & 4260.4 & 4268.9 & 4283.3 & 4267.0 & 4252.0 & 4258.0 & 4259.4 & 4266.0 & 4277.2 & 4263.9 \\
\hline PCll & 4280.8 & 4286.4 & 4290.0 & 4299.0 & 4313.2 & 4292.1 & 4279.8 & 4283.5 & 4287.0 & 4293.8 & 4305.0 & 4287.1 \\
\hline $\mathrm{PC}$ & 4131.8 & 4140.8 & 4141.2 & 4149.8 & 4164.2 & 4149.9 & 4140.4 & 4147.3 & 4147.8 & 4154.4 & 4165.6 & 4154.3 \\
\hline RPL & 4206.6 & 4215.6 & 4216.8 & 4224.6 & 4239.0 & 4224.6 & 4209.6 & 4216.6 & 4217.8 & 4223.6 & 4234.8 & 4223.5 \\
\hline $\mathrm{RPP}$ & 4273.1 & 4276.0 & 4282.8 & 4291.1 & 4305.5 & 4278.9 & 4273.4 & 4276.1 & 4281.0 & 4287.4 & 4298.7 & 4278.7 \\
\hline $\mathrm{RPC}$ & 3998.2 & 4007.2 & 4007.9 & 4016.2 & 4030.6 & 4016.3 & 4032.1 & 4039.1 & 4040.0 & 4046.1 & 4057.3 & 4045.1 \\
\hline
\end{tabular}

* L: logit, P: probit, SP: skew-probit, Ll: loglog, Cll: cloglog, C: cauchit, PL: power logit, PP: power probit, PLl: power $\log \log$, PCll: power cloglog, PC: power cauchit, RPL: reversal power logit, RPN: reversal power probit, RPC: reversal 
Table 3: Parameter estimates for the logit link model and the two best choices: power cauchit and reversal power cauchit.

\begin{tabular}{|c|c|c|c|c|c|c|c|c|c|}
\hline Link & \multicolumn{3}{|c|}{ logit } & \multicolumn{3}{|c|}{ power cauchit } & \multicolumn{3}{|c|}{ reversal power cauchit } \\
\hline Parameter & Mean & St. Dev. & 95\% HPD & Mean & St. Dev. & $95 \%$ HPD & Mean & St. Dev. & $95 \%$ HPD \\
\hline Intercept & -0.29 & 0.49 & $(-1.31,0.60)$ & 0.92 & 0.45 & $(-0.02,1.74)$ & 1.80 & 2.03 & $(-2.13,5.24)$ \\
\hline MEN & -0.97 & 0.08 & $(-1.14,-0.81)$ & -1.01 & 0.08 & $(-1.18,-0.86)$ & -3.48 & 0.39 & $(-4.23,-2.73)$ \\
\hline URBAN & 1.18 & 0.08 & $(1.03,1.33)$ & 1.26 & 0.08 & $(1.09,1.42)$ & 4.64 & 0.50 & $(3.66,5.59)$ \\
\hline PRIVATE & 1.10 & 0.48 & $(0.24,2.09)$ & 0.97 & 0.42 & $(0.18,1.83)$ & 4.35 & 2.01 & $(0.83,7.97)$ \\
\hline AGE & -0.06 & 0.004 & $(-0.07,-0.05)$ & -0.06 & 0.004 & $(-0.06,-0.05)$ & -0.20 & 0.02 & $(-0.24,-0.16)$ \\
\hline SENIORITY & 0.13 & 0.007 & $(0.12,0.15)$ & 0.14 & 0.008 & $(0.12,0.15)$ & 0.48 & 0.05 & $(0.39,0.58)$ \\
\hline$\lambda$ & & & & 2.30 & 0.14 & $(2.05,2.57)$ & 0.35 & 0.02 & $(0.32,0.38)$ \\
\hline
\end{tabular}


Table 4: Predictive measures for the logit link model and the two best choices: power cauchit and reversal power cauchit.

\begin{tabular}{|c|c|c|c|c|c|c|c|c|}
\hline Link & Predicted & $\mathrm{Ob}$ & ved & $\begin{array}{l}\text { Rate of Good } \\
\text { Classification }\end{array}$ & Sensitivity & Specificity & $\begin{array}{c}\text { Empirical } \\
\text { AUC }\end{array}$ & $\begin{array}{c}\text { Binormal } \\
\text { AUC }\end{array}$ \\
\hline logit & $\begin{array}{l}0 \\
1\end{array}$ & $\begin{array}{c}0 \\
2446 \\
167\end{array}$ & $\begin{array}{c}1 \\
1150 \\
237\end{array}$ & 0.67 & 0.17 & 0.94 & 0.79 & 0.76 \\
\hline $\begin{array}{l}\text { power } \\
\text { cauchit }\end{array}$ & $\begin{array}{l}0 \\
1\end{array}$ & $\begin{array}{c}0 \\
2079 \\
534\end{array}$ & $\begin{array}{c}1 \\
607 \\
780\end{array}$ & 0.71 & 0.56 & 0.80 & 0.79 & 0.78 \\
\hline $\begin{array}{l}\text { reversal } \\
\text { Power } \\
\text { cauchit }\end{array}$ & $\begin{array}{l}0 \\
1\end{array}$ & $\begin{array}{c}0 \\
1966 \\
647\end{array}$ & $\begin{array}{c}1 \\
452 \\
935\end{array}$ & 0.72 & 0.67 & 0.75 & 0.79 & 0.80 \\
\hline
\end{tabular}



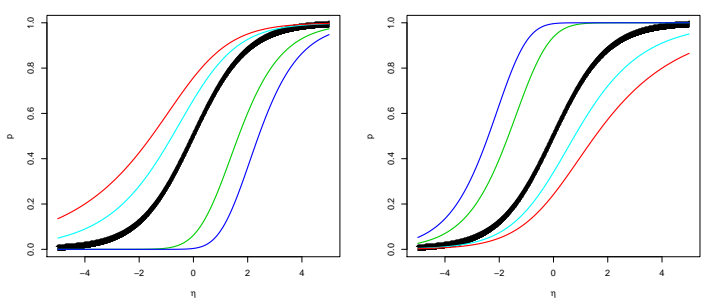

(a)
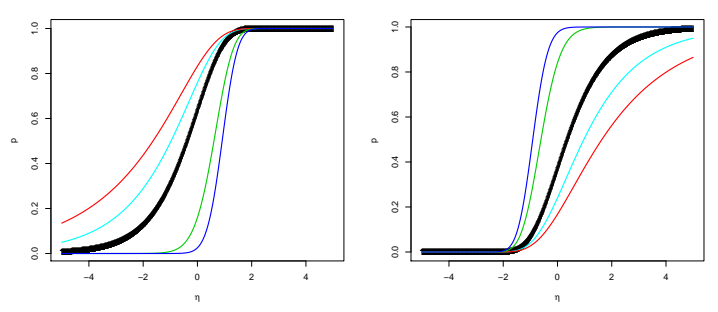

(c)

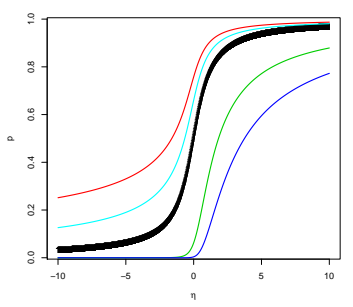

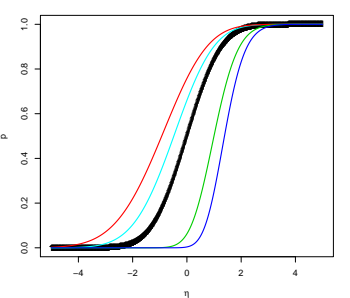

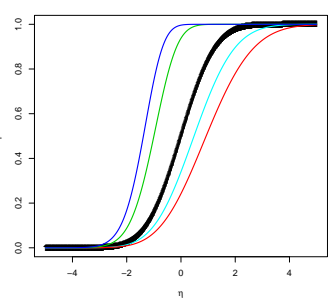

(b)
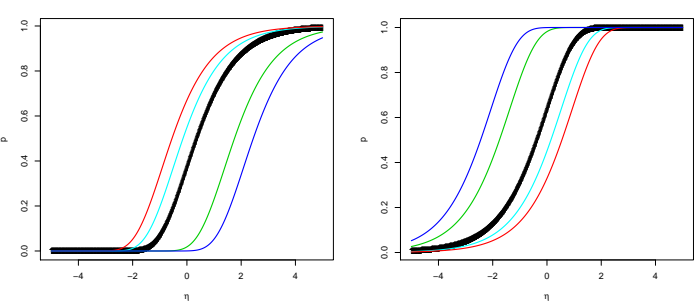

(d)

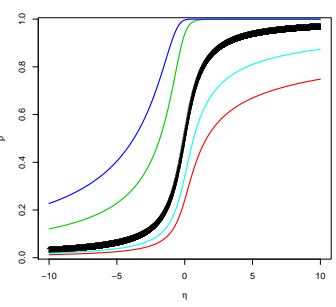

(e)

Figure 1: CDFs comparison for $\lambda=0.4$ (red), 0.6 (grey), 1.0 (black), 4.0 (green), 8.0 (blue): (a) power logit vs reversal power logit; (b) power probit vs reversal power probit; (c) power loglog vs reversal power loglog, (d) power cloglog vs reversal power cloglog, (e) power cauchit vs reversal power cauchit. 

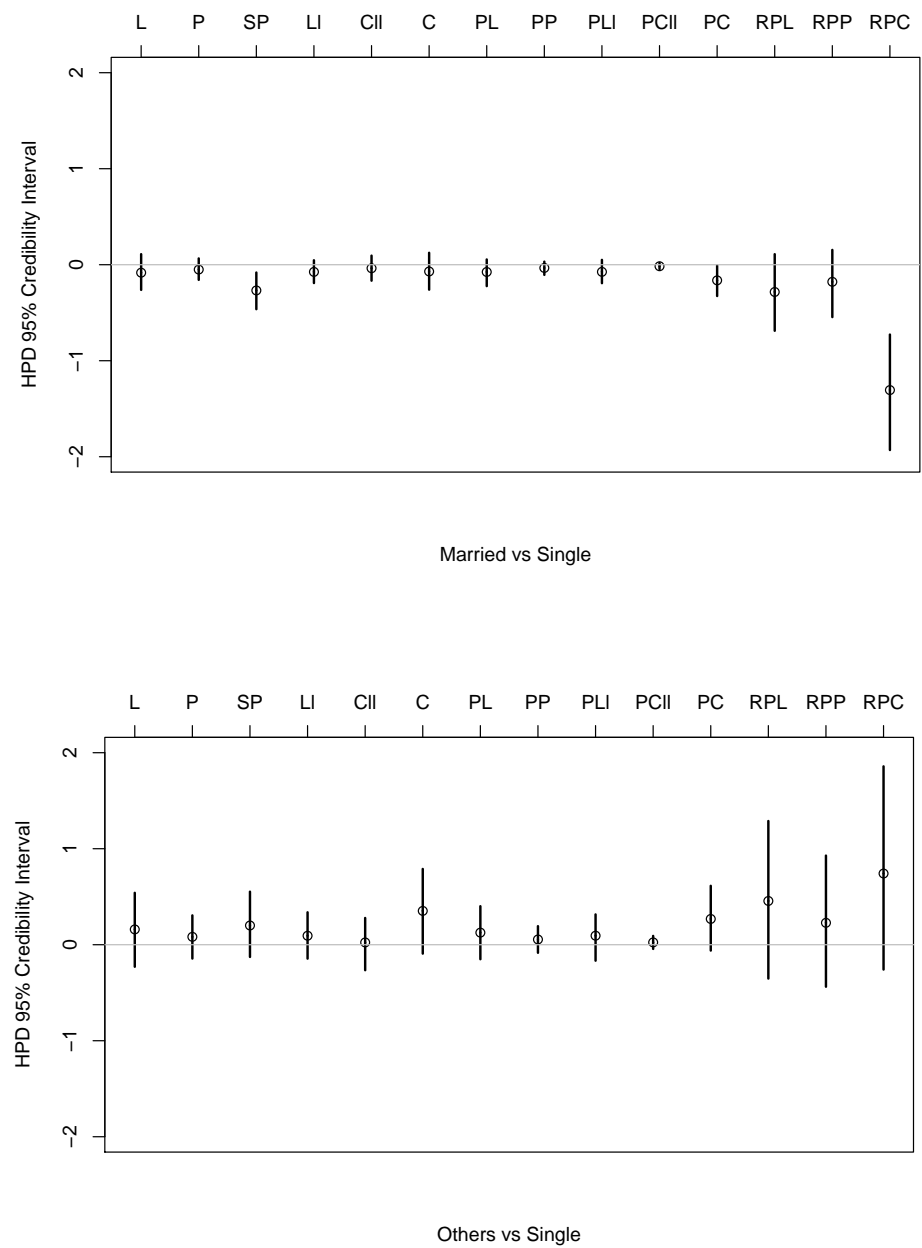

Figure 2: 95\% HPD interval. Upper panel: Married vs Single for the fitted models. Lower panel: Other vs Single for the fitted models. L: logit, P: probit, SP: skew-probit, Ll: loglog, Cll: cloglog, C: cauchit, PL: power logit, PP: power probit, PLl: power loglog, PCll: power cloglog, PC: power cauchit, RPL: reversal power logit, RPP: reversal power probit, RPC: reversal power cauchit. 


\section{Apêndice J}

Rodrigues, J., Bazán, J. L., Suzuki, A. K., e Balakrishnan, N. L. (2016). The bayesian restricted conway-maxwell-binomial model to control dispersion in count data. Submmitted to Statistics and Probability Letters. 


\title{
The Bayesian restricted Conway-Maxwell-Binomial model to control dispersion in count data
}

\author{
Josemar Rodrigues ${ }^{a}$ and Jorge L. Bazán ${ }^{a}$ and Adriano K. Suzuki ${ }^{a}$ and Narayanaswamy \\ Balakrishnan $^{b}$ \\ ${ }^{a}$ Department of Mathematics and Statistics, Universidade de São Paulo, São Paulo, Brazil \\ ${ }^{b}$ Department of Mathematics and Statistics, McMaster University, Hamilton, Ontario, Canada
}

\begin{abstract}
This paper deals with a Bayesian restricted version of the Conway-Maxwell-Binomial (CMB) distribution introduced by Shmueli et al. (2005) which is also the Correlated Binomial distribution (CB) discussed in Kupper and Haseman (1978) and Bahadur (1961) if and only if some restrictions are imposed on the parameters. Two illustrative examples based on a real data are used to illustrate the usefulness of the proposed probability distribution.
\end{abstract}

Keywords: binomial distributions; dispersion; correlated binomial distributions; Bayesian inference; MCMC methods

\section{Introduction}

The Bernoulli process is one of the most important random processes in probability theory. Essentially, this process is a finite or infinite sequence of generic $Z_{i}$ binary random variables, and it is a discrete-time stochastic process taking the values zero (failure) and one (success) with the following assumption from the Bayesian point of view: The binary random variables $Z_{i}, i=1,2, \ldots$, are conditionally independent given the random quantity $\theta \in(0,1)$, where $\theta$ is the probability of success. Given $\theta$, the outcome of one trial has no influence over the outcome of another trial and the quantity $\theta$ works as a "labeling parameter". Given $\theta$, the information provided by a finite Bernoulli process, $Z_{i}, i=1, \ldots, m$, with respect to this unknown parameter, is summarized by the binary sufficient random variable $Y=\sum_{i=1}^{m} Z_{i}$. Unfortunately, in many real-world applications with overdispersed or underdispersed data, this assumption is violated and in such situations the Bernoulli process or the binomial variable will be not useful for modeling purposes (see, for example, Kupper and Haseman (1978) and Yu and Zelterman (2002)). As in Kupper and Haseman (1978), the lack of mutual independence means that there is some relationship among the $m$ Bernoulli variables; there may be first-order (pairwise) correlation, second-order correlation, or higher-order correlation. Consequently, different assumptions regarding these correlations lead to different generalizations of the basic binomial model as discussed in several works. However, for the sake of tractability and convenience, it is usually assumed that all correlations among the $m$ Bernoulli variables higher than order two are zero and the pairwise correlation is the same for all pairs. A distribution based on these assumptions for the sum of Bernoulli variables results in the so-called correlated binomial distribution (CB) discussed in Kupper and Haseman (1978) and Bahadur (1961) whose probability mass function is given by

$$
P[Y=y \mid m, \theta, \rho]=\left(\begin{array}{c}
m \\
y
\end{array}\right) \theta^{y}(1-\theta)^{m-y} f(y ; m, \theta, \rho)
$$


where $f(y ; m, \theta, \rho)$ is a correction factor for the lack of mutual independence among $Z_{i}^{\prime} s$ and is given by

$$
f(y ; m, \theta, \rho)=1+\frac{\rho}{2 \theta(1-\theta)}\left[(y-m \theta)^{2}+y(2 \theta-1)-m \theta^{2}\right] .
$$

Bahadur (1961) showed that the probability mass function in (1) is a valid probability distribution if and only if

$$
a(\theta, m)=-\frac{2}{m(m-1)} \min \left(\frac{\theta}{1-\theta}, \frac{1-\theta}{\theta}\right) \leq \rho \leq \frac{2 \theta(1-\theta)}{(m-1) \theta(1-\theta)+\frac{1}{4}-\gamma_{0}}=b(\theta, m),
$$

and $\gamma_{0}=\min _{y}\left\{\left[y-(m-1) \theta-\frac{1}{2}\right]^{2}\right\}$. This restriction has to be imposed necessarily on (1) for the probability to be non-negative and it is known as "Bahadur's restrictions". The main purpose of the present work is to show from the Bayesian viewpoint that this restriction is a powerful mechanism to control the dispersion in count data and to show how the correlation $\rho$ goes to zero by increasing values of $m$. The correlation $\rho$ plays an important role in this restriction as well. An extension of the binomial model, through the addition of a new dispersion parameter, is the Conway-Maxwell Binomial distribution (CMB, for short) discussed by Shmueli et al. (2005) and Kadane and Naeshagen (2013). More recently, Kadane (2015) formulated a conjugate Bayesian analysis for the CMB model wherein the correlation coefficient was abandoned as the measure of association. In this paper, we approach the dispersion problem in another viewpoint in which the correlation coefficient becomes crucial to control the dispersion via Bahadur's restrictions.

We show here that the CMB model with Bahadur's restrictions is the CB model, which will be called Restricted-Conway-Maxwell-Binomial distribution (RCMB). The RCMB distribution is more realistic than the CMB distribution because its correlation gets changed by different values of $m$, which could be natural in many applications. Unfortunately, Bahadur's restrictions are strong restrictions over the parametric space and the data and is hard to implement for inferential purposes. For this reason, we adopt a Bayesian paradigm to control the dispersion phenomenon in the data. This Bayesian inference involves relaxing Bahadur's restriction by formulating a prior distribution to control the dispersion for different values of $m$. Under this prior, we could have a positive probability to violate Bahadur's restrictions implying a partial control of the Bayesian procedure to handle the dispersion in the data. On the other hand, it is possible to compute, via Markov chain Monte Carlo (MCMC) techniques, the posterior probability to obtain a control over the dispersion under Bahadur's restrictions.

The rest of this paper is organized as follows: In Section 2 and 3, we describe the CMB and RCMB distributions. In Section 4, we show how the RCMB model can be used and the Bayesian paradigm is presented. An application to a real count dataset is illustrated in Section 5. Finally, we make some concluding remarks in Section 6.

\section{The CMB distributions}

Following Shmueli et al. (2005) and the recent discussion by Kadane and Naeshagen (2013), Borges et al. (2014) showed that the joint probability of the Bernoulli correlated process model can be expressed as

$$
P\left[\mathbf{Z}=\left(z_{1}, \ldots, z_{m}\right) \mid m, \pi, \nu\right]=\frac{\left(\begin{array}{c}
m \\
y
\end{array}\right)^{\nu-1}}{C_{\mathbf{Z}}(m, \pi, \nu)} \prod_{j=1}^{m} \pi^{z_{j}}(1-\pi)^{1-z_{j}}=\frac{\left(\begin{array}{c}
m \\
y
\end{array}\right)^{\nu-1} \pi^{y}(1-\pi)^{m-y}}{C_{\mathbf{Z}}(m, \pi, \nu)}
$$

where $\nu \in \mathbb{R}, \pi \in[0,1], y=\sum_{j=1}^{m} z_{j}$ and $C_{\mathbf{Z}}(m, \pi, \nu)=\sum_{z_{1}=0}^{1} \ldots, \sum_{z_{m}=0}^{1}\left(\begin{array}{c}m \\ y\end{array}\right)^{\nu-1} \pi^{y}(1-\pi)^{m-y}$. It is easy to see that the pmf of $Y=\sum_{j=1}^{m} Z_{j}$ is then given by 


$$
P[Y=y \mid m, \pi, \nu]=\frac{\left(\begin{array}{c}
m \\
y
\end{array}\right)^{\nu}}{D_{y}(m, \pi, \nu)} \prod_{j=1}^{m} \pi^{z_{j}}(1-\pi)^{1-z_{j}}=\frac{\left(\begin{array}{c}
m \\
y
\end{array}\right)^{\nu} \pi^{y}(1-\pi)^{m-y}}{D_{y}(m, \pi, \nu)},
$$

where $D_{y}(m, \pi, \nu)=\sum_{j=0}^{m}\left(\begin{array}{c}m \\ j\end{array}\right)^{\nu} \pi^{j}(1-\pi)^{m-j}$ is the normalizing constant. This probability distribution is called the Conway-Maxwell-Binomial distribution, denoted here by $\operatorname{CMB}(m, \pi, \nu)$ distribution.

\section{Restricted CMB distributions}

By assuming that all correlations higher than order two are zero (Bahadur, 1961), Borges et al. (2014) showed that the probability of success and the correlation between any pair of responses $\left(Z_{i}, Z_{j}\right)$ $(i \neq j, i, j=1, \ldots, m)$ are given by

$$
\begin{gathered}
E\left[Z_{i} \mid \theta\right]=\theta=\theta(\pi, \nu)=\frac{\pi^{2}+\pi(1-\pi) 2^{\nu-1}}{\pi^{2}+(1-\pi)^{2}+2^{\nu} \pi(1-\pi)}, \\
\rho=\operatorname{Corr}\left[Z_{i}, Z_{j} \mid \theta\right]=\rho(\pi, \nu)=\frac{\pi(1-\pi)\left(1-4^{\nu-1}\right)}{\left[\pi+(1-\pi) 2^{\nu-1}\right]\left[1-\pi\left(1-2^{\nu-1}\right)\right]}, i \neq j,
\end{gathered}
$$

respectively.

From (6) and (7), we have the following useful properties:

$$
\begin{aligned}
& \lim _{\nu \rightarrow-\infty} \theta(\pi, \nu)=\frac{\pi^{2}}{\pi^{2}+(1-\pi)^{2}}, \\
& \lim _{\nu \rightarrow \infty} \theta(\pi, \nu)=\frac{1}{2}, \\
& \lim _{\nu \rightarrow \infty} \rho(\pi, \nu)=-1 \text {, for } m=2 \text {, } \\
& \lim _{\nu \rightarrow-\infty} \rho(\pi, \nu)=1 \text {, } \\
& \theta=\frac{1}{2} \quad \leftrightarrow \quad \pi=\frac{1}{2}, \\
& \lim _{\nu \rightarrow 1} \theta(\pi, \nu)=\pi \text {. }
\end{aligned}
$$

The parametrizations in (6)-(7) become essential for obtaining a restricted version of the CMB distribution, denoted here by $\mathrm{RCMB}$ distribution, whose probability mass function (denoted by $\operatorname{RCMB}(m, \pi, \nu)$ ) is given in (5) for $(\pi, \nu) \in A(\theta, \rho, m)$, where

$$
A(\theta, \rho, m)=\{(\pi, \nu): a[\theta(\pi, \nu), m]<\rho(\pi, \nu)<b[\theta(\pi, \nu), m]\} .
$$

The quantities $a(\theta(\pi, \nu), m)$ and $b(\theta(\pi, \nu), m)$ are the lower and upper bounds in (3), respectively.

Theorem 3.1. If all correlations among the $m$ Bernoulli variables $Z_{i}, i=1, \ldots, m$, of higher than order two are zero and pairwise correlation is the same for all pairs, we have $\operatorname{RCMB}(m, \nu, \pi)$ model to be the $\mathrm{CB}(m, \theta, \rho)$ model in (1), where the parameters $\theta$ and $\rho$ are as defined in (6) and (7), respectively. 
Proof: From (4)-(5) and Kupper and Haseman (1978), we have

$$
\begin{aligned}
P[Y=y \mid m, \pi, \nu] & =\frac{\left(\begin{array}{c}
m \\
y
\end{array}\right)^{\nu} \pi^{y}(1-\pi)^{m-y}}{D_{y}(m, \pi, \nu)} \\
& =\left(\begin{array}{c}
m \\
y
\end{array}\right) \mathbb{P}\left(\mathbf{Z}=\left(z_{1}, \ldots, z_{m}\right) \mid m, \pi, \nu\right) \\
& =\left(\begin{array}{c}
m \\
y
\end{array}\right) \mathbb{P}\left(\mathbf{Z}=\left(z_{1}, \ldots, z_{m}\right) \mid m, \theta, \rho\right) \\
& =\left(\begin{array}{c}
m \\
y
\end{array}\right) \theta^{y}(1-\theta)^{m-y} f(y ; m, \theta, \rho),
\end{aligned}
$$

where $(\pi, \nu) \in A(\theta, \rho, m), Y=\sum_{i=1}^{m} Z_{i}$ and $f(y ; m, \theta, \rho)$ is the correction factor in (2).

Remark 1. The above result will be essential to introduce the Bayesian inference in order to solve dispersion problems through the correlation coefficient and also to see how this dispersion can be affected by small or larger values of $m$. The proposed Bayesian inference is an alternative to the conjugate Bayesian analysis under the CMB model formulated in Kadane (2015). It is important to emphasis that the RCMB model proposed here does not follow the following ideas mentioned in Kadane (2015):

- Abandon correlation as a measure of association;

- Abandon exchangeability of the Bernoulli random variables (exchangeability of order two implies identical one - and two-dimensional distributions);

- Model the sum directly, without fully specifying the distribution of the underlying Bernoulli random variables;

- Important to mention that the properties of the CMB distribution discussed before can be extended to RCMB dsitribution.

Note that the RCMB distribution admits negative values for $\nu$ implying more flexibility to handle overdispersion than $0 \leq \nu<1$ for different values of $m$. So, for $\nu<1(\nu>1)$, the random variable $Y$ becomes overdispersed (underdispersed) relative to the binomial distribution, and for large values of $m$ it behaves like a binomial model. Also, it is easy to see that these properties can be extended to the CMB distribution.

\subsection{The RCMB distribution as a $C B$ distribution}

Since the $\operatorname{CMB}(m, \pi, \nu)$ distribution is a $\operatorname{CB}(m, \theta, \rho)$, by now assuming that the parameters $\nu$ and $\pi$ do not violate Bahadur's restrictions in (3), we obtain the Restricted-Conway-Maxwell-Binomial distribution in (5) and (9). In order to evaluate the impact of these restrictions on the RCMB distribution, Figure 1 displays the values of the probability of success, the correlation and the variance of $Y$ for a range of values of $\nu$ for different values of $\pi$. Note that under Bahadur's restrictions, the RCMB distribution is defined only for some values of $\nu$. Also, given $m$ and $\pi$, some values of $\nu$ lead to negative variances of $Y$ or values of $\rho$ which violate Bahadur's restrictions. So, from Figure 1, we conclude that the variances of $Y$ for $\operatorname{CMB}(6,0.3,5)$ and $\operatorname{CMB}(5,1 / 3,2)$ in Borges et al. (2014) and Kadane and Naeshagen (2013), respectively, could be negative. 

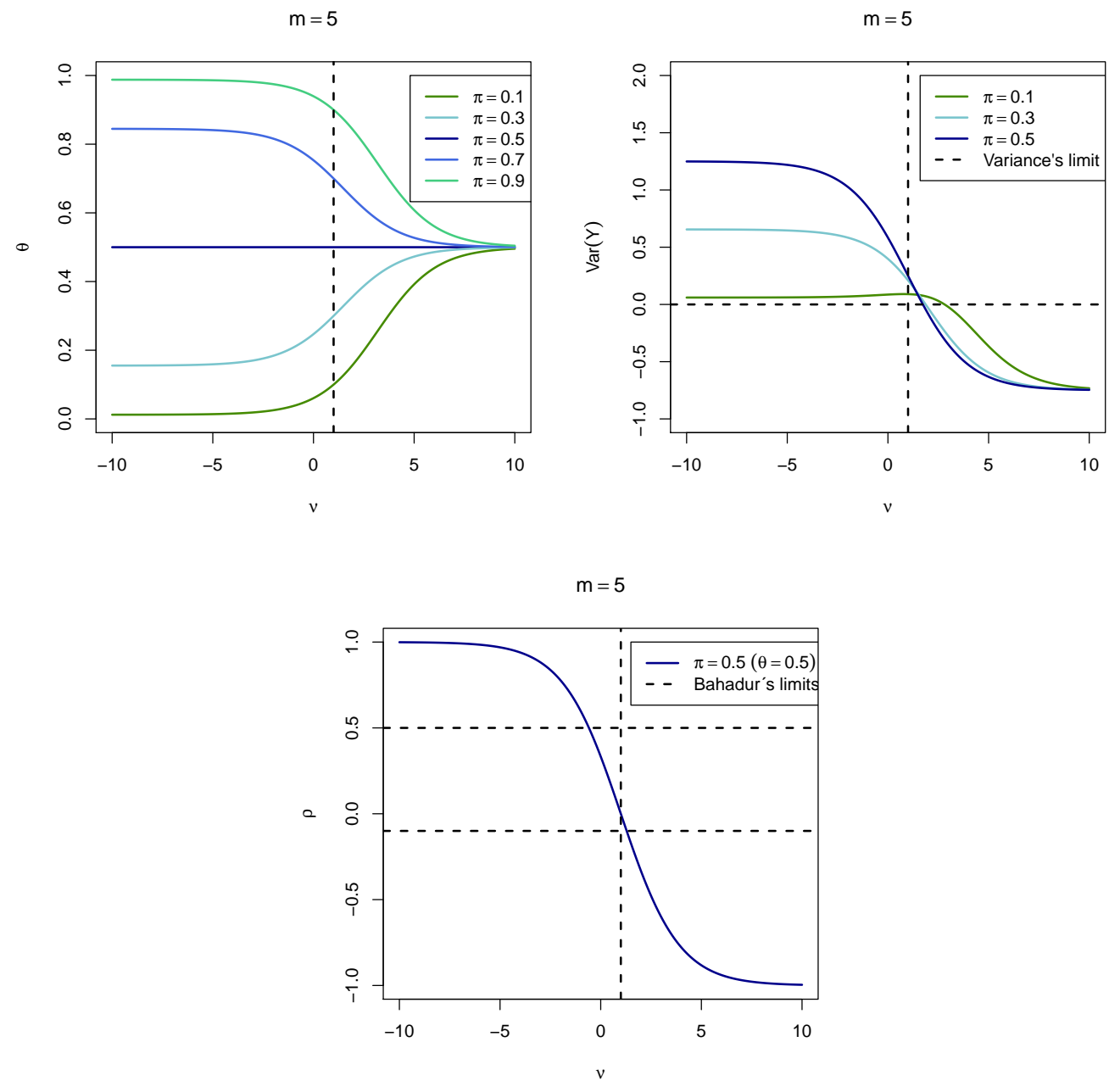

Figure 1: Probability of success $(\theta)$, variance of $\mathrm{Y}(V(Y))$ and correlation $(\rho)$ as a function of $\nu$ for different values of $\pi$ under the $\operatorname{RCMB}(5, \pi, \nu)$ distribution. Note that $\nu=1$ corresponds to the binomial distribution

Table 1 showed by Kupper and Haseman (1978) gives an idea on the ranges of the parameter $\rho$ of the RCMB model and how to use it. These ranges show clearly, via Bahadur's restrictions in (3), the strong influence of large and small values of $m$ and $\theta$ over the parameter $\nu$ (see Table 2). In general, for values of $m>2$, the Bahadur's lower bound is greater than or equal to $-2 / m(m-1)$ and the Bahadur's upper bound is close to $2 / \mathrm{m}$. These bounds are needed to ensure that the resulting probability values are not negative. For small values of $m(m<20)$, large intervals for $\rho$ are expected (negative and positive values); on the other hand, for high values of $m(m \geq 20)$, the interval for $\rho$ goes to 0 implying that the binomial model is actually an adequate model. Also, the upper bound of $\rho$ is not restrictive implying more flexibility to the parameter $\nu<1$, which is desirable since overdispersion is expected in various situations. Also, note that both bounds become closer to zero as $m$ increases. So, in practice, the largest $m$ is associated with the most restrictive set of bounds, and (10) gives a clear insight on how to develop a Bayesian inference with a complete control over the dispersion under the RCMB model. 
Table 1: Ranges of values for $\rho$ based on (10) for different choices of $\theta$ and $m$

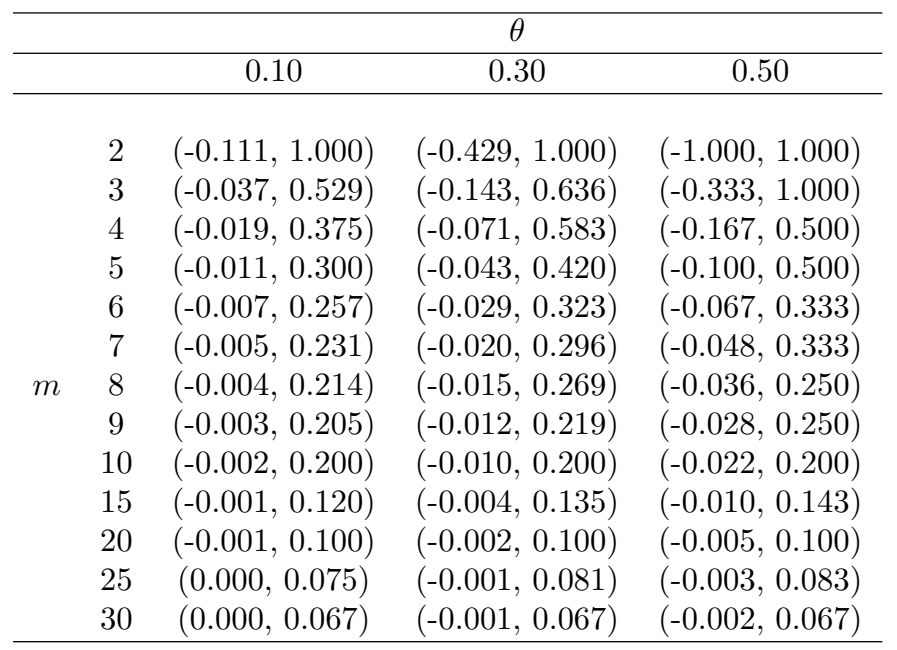

\section{The use of the RCMB model from the Bayesian paradigm}

Based on Theorem 3.1, we emphasise in this section that the CB and RCMB models are equivalent for inferential purposes. That is, the RCMB model is the CB model and some characteristics of it can be used to solve estimation problems and to formulate convenient prior distributions for Bayesian purpose. In this section, we consider one way of using the RCMB distribution and about how to formulate a non-informative prior distribution for $(\pi, \nu)$ involved in this model.

\subsection{The use of the $R C M B$ model through $C B$ Model}

First of all, it is convenient to show how the dispersion could be affected by Bahadur's restrictions. This can be done from Table 2 which is obtained as follows: Given $\pi$ and $m$, range of values for $\nu$ are obtained for different values of $\theta$ and $\rho$ through Bahadur's bounds in (3). These ranges of $\nu$ show clearly the strong influence of large and small values of $m$ and $\pi$ have on them. In general, for $m>2$, the lower bound is greater than or equal to -2.27 and the upper bound is close to 2 . These bounds are needed to ensure that the variances are not negative. For $m<15$, negative values of $\nu$ are expected if the values of $\pi$ are small. For $m \geq 15$, the parameter $\nu$ goes to 1 reducing to the binomial model. 
Table 2: Ranges of values for $\nu$ for different choices of $\pi$ and $m$ in RCMB distribution

\begin{tabular}{|c|c|c|c|c|}
\hline & & \multicolumn{3}{|c|}{$\pi$} \\
\hline & & 0.10 & 0.30 & 0.50 \\
\hline & 2 & $(-52.356,512.598)$ & $(-\infty, \infty)$ & $(-\infty, \infty)$ \\
\hline & 3 & $(-2.270,1.360)$ & $(-1.176,1.579)$ & $(-\infty, 2)$ \\
\hline & 4 & $(-1.375,1.162)$ & $(-0.688,1.264)$ & $(-0.584,1.485)$ \\
\hline & 5 & $(-0.912,1.093)$ & $(-0.584,1.153)$ & $(-0.584,1.289)$ \\
\hline & 6 & $(-0.625,1.061)$ & $(-0.214,1.100)$ & $(0.000,1.192)$ \\
\hline & 7 & $(-0.432,1.043)$ & $(0.046,1.071)$ & $(0.000,1.137)$ \\
\hline \multirow[t]{7}{*}{$m$} & 8 & $(-0.296,1.032)$ & $(0.121,1.053)$ & $(0.263,1.103)$ \\
\hline & 9 & $(-0.197,1.025)$ & $(0.144,1.041)$ & $(0.263,1.080)$ \\
\hline & 10 & $(-0.123,1.020)$ & $(0.320,1.033)$ & $(0.416,1.064)$ \\
\hline & 15 & $(0.035,1.008)$ & $(0.531,1.014)$ & $(0.585,1.027)$ \\
\hline & 20 & $(0.298,1.004)$ & $(0.658,1.007)$ & $(0.711,1.015)$ \\
\hline & 25 & $(0.403,1.003)$ & $(0.722,1.005)$ & $(0.759,1.010)$ \\
\hline & 30 & $(0.498,1.002)$ & $(0.771,1.003)$ & $(0.807,1.007)$ \\
\hline
\end{tabular}

Tables 1 and 2 show the strong influence of $m$ on the parameters $\rho$ and $\nu$. Also, we note that for large values of $m$, we have the binomial case $(\nu=1)$. So, in practice, the largest $m$ is associated with the most restrictive interval for the parameter $\nu$ which gives a clear and simple way for the ability to control the dispersion in count data. Unfortunately, it is hard to make Bayesian inference for the parameters of interest involved in the RCMB model from the Bayesian procedure developed for the parameters $\theta$ and $\rho$ in the $\mathrm{CB}$ model since we do not have an exact transformation from $(\theta, \rho)$ to $(\pi, \nu)$. However, it is possible to develop a Bayesian mechanism with some ability to control the dispersion and to compute numerically the posterior probability to get a total control of the dispersion via Bahadur's bounds. In order to do this, we first formulate an informative prior distribution for the parameters $\pi$ and $\nu$ to control the dispersion in count data from a pessimistic point of view as follows:

- Let $\pi \sim U(0,1)$ with prior mean $E(\pi)=0.5$ and suggesting from (8) to take $\theta=\theta(0.5, \nu)=0.5$.

- Prior distribution for $\nu \mid(\theta=0.5)$ as

$$
\nu \sim U(A(0.5, \rho, m))
$$

where

$$
A(\theta, \rho, m)=\{(\pi, \nu): a[\theta(\pi, \nu), m]<\rho(\pi, \nu)<b[\theta(\pi, \nu), m]\},
$$

$a(\theta(\pi, \nu), m)$ and $b(\theta(\pi, \nu), m)$ being the lower and upper bounds in (3), respectively;

- Non-informative joint prior distribution:

$$
(\pi, \nu) \sim U((0,1) \times A(0.5, \rho, m))
$$

where $\rho=\rho(0.5, \nu)=\frac{1-2^{\nu-1}}{1+2^{\nu-1}}, a(0.5, m)=-\frac{2}{m(m-1)}, b(0.5, m)=\frac{2}{m-4 \gamma_{0}}$ and $\gamma_{0}=\min _{y}\left\{\left[y-\frac{m}{2}\right]^{2}\right\}$. So, we have

$$
A(0.5, \rho, m))=\left\{(0.5, \nu):-\frac{2}{m(m-1)} \leq \frac{1-2^{\nu-1}}{1+2^{\nu-1}} \leq \frac{2}{m-4 \gamma_{0}}\right\}
$$


We note from the last column of Table $1(\theta=0.5)$ that this non-infornative joint prior distribution is the main mechanism to provide partial power to change the correlation scenario towards the independence case as $m$ becomes large. Also, this non-informative joint prior distribution could give a positive posterior probability to violate Bahadur's restrictions implying that the RCMB distribution is not a CB distribution in spite of the fact that the dispersion is still under control by the correlation coefficient. This posterior probability can be computed via MCMC procedure, and let us denote it by $P_{H}$. In this work, the proposed Bayesian inference makes use of the non-informative joint prior distribution to develop inference for the parameters $\pi$ and $\nu$, and the numerical computation of the posterior probability of the complete control of the dispersion via Bahadur's bounds.

\subsection{Bayesian inference}

Let $\mathbf{y}=\left(y_{1}, \ldots, y_{n}\right)^{\top}$ be $n$ observed values from a RCMB distribution with parameters $m, \pi$ and $\nu$ with $m$ known, and

$$
t_{1}=\frac{1}{n} \sum_{i=1}^{n} y_{i} \quad \text { and } \quad t_{2}=\frac{1}{n} \sum_{i=1}^{n} \log \left(\Gamma\left(y_{i}+1\right) \Gamma\left(m-y_{i}+1\right)\right) .
$$

Note that $t_{1}$ and $t_{2}$ are the sample mean and the log-geometric mean, respectively.

The log-likelihood function for the RCMB model based on the observed data $\mathbf{y}$ (Borges et al., 2014) is

$$
\ell(\pi, \nu \mid \mathbf{y}, m)=n\left(\log (\pi /(1-\pi)) t_{1}-\nu t_{2}-\log (S(m, \pi /(1-\pi), \nu))\right) I_{(0,1) \times A(0.5, \rho, m)}(\pi, \nu),
$$

where $\left.S(m, \pi /(1-\pi), \nu)=\sum_{j=0}^{m} \frac{\alpha^{j}}{[\Gamma(y+1) \Gamma(m-y+1)}\right]^{\nu}$ and $I_{A}($.$) the indicator function of the set A$. The posterior distribution is given by

$$
p(\pi, \nu \mid \mathbf{Y}, m) \propto \exp (\ell(\pi, \nu \mid \mathbf{y}, m)) I_{(0,1) \times A(0.5, \rho, m)}(\pi, \nu) .
$$

Since the posterior distribution in (12) has an analytically intractable expression, we can use the MCMC procedure via WinBUGS software (Lunn and Spiegelhalter, 2000) for drawing samples from it.

\section{Illustrative example: Reading Comprehension Test (RCT)}

The RCT has four testlets which consist of four comprehension passages or texts with different items related with the reading of these texts (Wang and Wilson, 2005). The first testlet has 3 items, the second 6 items and the third 5 items. Table 3 shows the data set used in this example based on a sample of Peruvian students (for more details, see Chincaro (2010)). In this data, for each testlet, $Z_{j}, j=1, . ., m$, correspond to binary responses, where $Z_{j}=1$ means correct answer and $m$ is the number of items. In this context, it is obvious that items within a testlet are not independent and that $Y=\sum_{j=1}^{m} Z_{j}$, the number of correct answers, has a correlated binomial model. Standard item response models to testlet responses usually ignore the possible dependence between the items within a testlet overestimating the precision of measures obtained from testlets and so it results in biased estimation of the parameters of the model. In this example, we assume that the correlations between the binary responses in the testlet are constant. So, we resume that the RCMB model could be a good alternative for these data. Under this model, we need to estimate this common correlation, the probability of the correct answers of the items in the testlet and to solve possible overdispersion or underdispersion. Also, the mean and variance of the the discrete variable $Y$ for each testlet will be estimated and compared with those of the binomial model. 
Table 3: Number of students with correct answers in Peruvian Reading Comprehension Test (among $n=1536$ students)

\begin{tabular}{ccccccccc}
\hline \hline Testlet & \multicolumn{7}{c}{ Number of students by Number of correct answers } & Number of items $(m)$ \\
& $y=0$ & $y=1$ & $y=2$ & $y=3$ & $y=4$ & $y=5$ & $y=6$ & \\
\hline \hline 1 & 33 & 139 & 564 & 800 & & & & 3 \\
2 & 17 & 56 & 101 & 154 & 289 & 634 & 285 & 5 \\
3 & 20 & 62 & 217 & 445 & 512 & 280 & & 4 \\
4 & 123 & 526 & 513 & 269 & 105 & & & 5 \\
\hline \hline
\end{tabular}

The Bayesian procedure in (12) was implemented via MCMC by considering 50,000 iteractions, a burn-in period of 10,000 simulated samples to eliminate the effect of initial values in the iterative simulation procedure and two chains. We also consider jumps of size 40, i.e., only 1 draw from every 40, so as to a sample of size of 1,000 to make inference on the parameters of the models. Table 4 presents the posterior mean, standard deviation (sd), higher posterior density interval (HPD), posterior probability that Bahadur's restrictions are not violated $\left(P_{H}=1\right)$, binomial models and the deviance information criterion (DIC) which is defined as $\mathrm{DIC}=\mathrm{Dbar}+\mathrm{pD}$, where Dbar $=E[D(\pi, \nu) \mid \mathbf{y}], \mathrm{pD}=\operatorname{Dbar}-D[E((\pi, \nu) \mid \mathbf{y})]$, and $D(\pi, \nu)=-2 \ell(\pi, \nu \mid \mathbf{y}, m)$. The model with the smallest DIC value is the best fitting model (Spiegelhalter et al., 2002).

Considering the results presented in Table 4, we see that the RCMB model presents better fit than the binomial model in the first three testlets and a similar fit in testlet 4 . This is quite reasonable since the correlation values between the items in the first three testlets are clearly higher than 0 (by considering the HPD interval) while for testlet 4 it is close to 0 . In addition, we find that the estimates of $\theta$, the probability of the correct answers of the items in the testlet, under the RCMB are lower than that of the binomial model. This means that the binomial model overestimates this probability as it ignores the structure of the testlet. We observe that this data presents overdispersion caused by the dependence between the binary items which is ignored by the binomial model. Finally, in this example, Bahadur's restrictions are not violated $\left(P_{H}=1\right)$ showing that the suggested non-informative prior provides a complete control of the dispersion which means that the RCMB model is working as a CB model. Thus, these results demonstrate that the RCMB model is a good alternative for modeling this type of data.

Table 4: Posterior estimates of the parameters in Peruvian Reading Comprehension Test

\begin{tabular}{|c|c|c|c|c|c|c|c|c|c|c|c|c|c|c|c|c|}
\hline \multirow{4}{*}{$\begin{array}{c}\text { par. } \\
\pi\end{array}$} & \multicolumn{8}{|c|}{ Testlet $1(\mathrm{~m}=3)$} & \multicolumn{8}{|c|}{ Testlet $2(\mathrm{~m}=6)$} \\
\hline & \multicolumn{4}{|c|}{$\operatorname{RCMB}\left(P_{H}=1\right)$} & \multicolumn{4}{|c|}{ Binomial } & \multicolumn{4}{|c|}{$\operatorname{RCMB}\left(P_{H}=1\right)$} & & \multicolumn{3}{|c|}{ Binomial } \\
\hline & \multirow{3}{*}{$\begin{array}{c}\text { mean } \\
0.76 \\
0.70\end{array}$} & \multirow{2}{*}{$\begin{array}{c}\mathrm{sd} \\
0.01\end{array}$} & \multirow{2}{*}{$\begin{array}{r}\mathrm{HP} \\
0.74\end{array}$} & \multirow{2}{*}{$\begin{array}{l}\text { Int } \\
0.78\end{array}$} & \multirow[t]{3}{*}{ mean } & \multirow[t]{3}{*}{$\mathrm{sd}$} & \multirow{2}{*}{\multicolumn{2}{|c|}{ HPD Int }} & \multirow{3}{*}{$\begin{array}{l}\text { mean } \\
0.65 \\
0.44\end{array}$} & \multirow{3}{*}{$\begin{array}{c}\mathrm{sd} \\
0.01 \\
0.03\end{array}$} & \multirow{3}{*}{$\begin{array}{l}0.64 \\
0.38\end{array}$} & \multirow{3}{*}{$\begin{array}{c}\text { Int } \\
0.66 \\
0.51\end{array}$} & \multirow{3}{*}{ mean } & \multirow{3}{*}{$\mathrm{sd}$} & \multirow{2}{*}{\multicolumn{2}{|c|}{ HPD Int }} \\
\hline & & & & & & & & & & & & & & & & \\
\hline & & & 0.54 & 0.83 & & & & & & & & & & & & \\
\hline$\theta$ & 0.78 & 0.01 & 0.77 & 0.80 & 0.80 & 0.01 & 0.78 & 0.81 & 0.68 & 0.01 & 0.66 & 0.69 & 0.73 & 0.01 & 0.72 & 0.74 \\
\hline$\rho$ & 0.08 & 0.02 & 0.04 & $\begin{array}{l}0.80 \\
0.12\end{array}$ & & & & & $\begin{array}{l}0.68 \\
0.17\end{array}$ & $\begin{array}{l}0.01 \\
0.01\end{array}$ & $\begin{array}{l}0.66 \\
0.15\end{array}$ & $\begin{array}{l}0.69 \\
0.20\end{array}$ & & & 0.72 & 0.74 \\
\hline$\alpha$ & 3.24 & 0.18 & 2.89 & 3.59 & 3.89 & 0.15 & 3.63 & 4.20 & 1.86 & 0.05 & 1.76 & 1.96 & 2.75 & 0.07 & 2.62 & 2.88 \\
\hline $\begin{array}{c}\text { Dbar } \\
\text { pD } \\
\text { DIC }\end{array}$ & \multicolumn{4}{|c|}{$\begin{array}{c}45547.66 \\
2.04\end{array}$} & \multicolumn{4}{|c|}{$\begin{array}{c}45562.65 \\
1.05\end{array}$} & \multicolumn{4}{|c|}{$\begin{array}{c}47417.38 \\
2.02\end{array}$} & \multicolumn{4}{|c|}{$\begin{array}{c}47628.54 \\
1.06\end{array}$} \\
\hline \multirow{3}{*}{ par. } & \multicolumn{8}{|c|}{ Testlet 3 $(\mathrm{m}=5)$} & & & & Testl & $(\mathrm{m}=4)$ & & & \\
\hline & & CMB & $H=$ & & & Bin & & & & $\mathrm{CMB}$ & $H=$ & & & $\operatorname{Bin}$ & ial & \\
\hline & mean & sd & $\mathrm{HF}$ & Tnt & mean & $\mathrm{sd}$ & $\mathrm{HI}$ & Int & mean & $\mathrm{sd}$ & $\mathrm{HF}$ & Tnt & mean & sd & $\mathrm{HP}$ & Int \\
\hline$\pi$ & 0.66 & 0.01 & 0.64 & 0.67 & & & & & 0.46 & 0.01 & 0.44 & 0.47 & & & & \\
\hline$\nu$ & 0.74 & 0.04 & 0.66 & 0.82 & & & & & 0.88 & 0.04 & 0.80 & 0.97 & & & & \\
\hline$\theta$ & 0.67 & 0.01 & 0.66 & 0.68 & 0.69 & 0.01 & 0.68 & 0.70 & 0.45 & 0.01 & 0.44 & 0.47 & 0.45 & 0.01 & 0.44 & 0.46 \\
\hline$\rho$ & 0.08 & 0.01 & 0.06 & 0.11 & & & & & 0.04 & $\begin{array}{l}0.01 \\
0.02\end{array}$ & 0.01 & 0.07 & & & & \\
\hline$\alpha$ & 1.91 & 0.06 & 1.80 & 2.03 & 2.20 & 0.05 & 2.09 & 2.30 & 0.84 & 0.02 & 0.80 & 0.88 & 0.83 & 0.02 & 0.79 & 0.87 \\
\hline Dbar & & 4705 & .04 & & & 470 & & & & 468 & & & & 468 & & \\
\hline $\begin{array}{l}\mathrm{pD} \\
\mathrm{DIC}\end{array}$ & & $\begin{array}{r}1 . \\
4705\end{array}$ & & & & $\begin{array}{r}0 \\
470\end{array}$ & & & & $\begin{array}{r}2 \\
468\end{array}$ & & & & $\begin{array}{r}0 \\
468\end{array}$ & & \\
\hline
\end{tabular}

\section{Concluding remarks}

Fitting standard models to binomial data which ignore the possible dependence between Bernoulli variables results in the overestimation of the precision of measurements obtained from binomial experi- 
ments leading to inaccurate inference about the parameters. In this work, we have shown that the CMB model is a CB model if and only if some restrictions are imposed on the parameters implying a possible negative dispersion parameter. This model is RCMB and the Bayesian inference is then developed to solve dispersion problems is then developed. One illustrative example from a Reading Comprehension Test administered to seventh grade students from Peruvian elementary schools demonstrates the Bayesian inference proposed here works via Bahadur's restrictions. Also, the proposed procedure is totally different from the conjugate Bayesian procedure in Kadane (2015). However, some care is necessary for formulating various prior distributions. In this paper, we have used a simple non-informative prior with the power to solve dispersion problems leading to reasonable inferences and a simple alternative to the conjugate Bayesian approach formulated in Kadane (2015). We emphasise that the Bahadur's representation of the CMB was very crucial to throw some light with regard to how to take the dependence into account for different values of $m$.

\section{Acknowledgments:}

We thank a referee and the associate editor for some helpful comments and suggestions on an earlier version of this paper.

\section{References}

Shmueli, G.; Minka, T.P.; Kadane, J.B.; Borle, S.; Boatwright, P. A useful distribution for fitting discrete data: revival of the Conway-Maxwell-Poisson distribution. Journal of the Royal Statistical Society, Series C 2005, 54, 127-142.

Kupper, L.L.; Haseman, J.K. The use of a correlated binomial model for the analysis of certain toxicological experiments. Biometrics 1978, 34, 69-76.

Bahadur, R.R. A representation of the joint distribution of responses to $n$ dichotomous items. In Studies in Item Analysis and Prediction (ed. H. Solomon). Stanford Mathematical Studies in the Social Sciences VI, Stanford University Press, Stanford, California 1961, 158-168.

Yu, C.; Zelterman, D. Sums of dependent Bernoulli random variables and disease. Statistics E Probability Letters 2002, 5\%, 363-373.

Williams, D.A. The analysis of binary responses from toxicological experiments involving reproduction and teratogenicity. Biometrics 1975, 31, 949-952.

Kadane, J.B.; Naeshagen, F. The number of killings in rural Norway, 1300-1569. Annals of Applied Statistics 2013, 7, 846-859.

Kadane, J. Sums of possibly associated Bernoulli variables: The Conway-Maxwell-Binomial distribution. Bayesian Analysis 2015, 1-8.

Borges, P.; Rodrigues, J.; Balakrishnan, N.; Bazan, J. A COM-Poisson type generalization of the binomial distribution and its properties and applications. Statistics \& Probability Letters 2014, 87, 158-166.

Altham, P. Two generalizations of the binomial distribution. Applied Statistics 1978, 27, $162-167$.

Spiegelhalter, D.J.; Best, N.G.; Carlin, B.P.; Van Der Linde, A. Bayesian measures of model complexity and fit. Journal of the Royal Statistical Society Series B 2002, 164, 583-639.

Lunn, D.J.; Spiegelhalter, D. WinBUGS - a Bayesian modelling framework: concepts, structure, and extensibility. Statistics and Computing 2000, 10, 325-337.

Chincaro, O. Dichotomous Rasch model with application to Education. Master's Thesis, Pontificia Universidad Católica del Perú (In spanish) 2010.

Wang, W.; Wilson, M. The Rasch testlet model. Applied Psychological Measurement 2005, 29, 126-149. 


\section{Apêndice K}

Bazán, J. L., Valdivieso, L., e Branco, M. D. (2016a). Measurement of the nonsense word fluency: Bayesian approach to a item response model with speededness. Submmitted to Biometric Brazilian Journal. 


\section{MEASUREMENT OF THE NONSENSE WORD FLUENCY: BAYESIAN APPROACH TO A ITEM RESPONSE MODEL WITH SPEEDEDNESS}

- ABSTRACT: Speededness refers to the situation where the time limit on a standardized test does not allow substantial number of examinees to fully consider all items in a Test, thus, estimation using common three parameter logistic $(3 L)$ item response model can leads to contaminated estimates of the parameters of the model. In this work is proposed a simple Bayesian model to estimate both type of parameters: personal and item parameters to data with evidence of Speededness. The model is strongly related with a model proposed by Goegebeur, de Boeck, Wollack and Cohen (2008) but different of this, dependence structure in personal parameters is not assumed initially in the formulation of the model. We conduce a case study to analyze data set of Nonsense Word Fluency in Peruvian students. Data set present high evidence of Speededness and when compared the results of $3 L$ and the proposed model we found that difficulty and discrimination are overestimated under $3 L$, similar measures of the abilities of the examinees are obtained in both models and new personal parameters: tolerance and propensity toward speededness are obtained considering the model proposed. Finally, future studies are suggested.

- KEYWORDS: Item response models; Bayesian estimation; Speededness; Logistic model; Personal latent variables, Nonsense Word Fluency

\section{Introduction}

Bayesian methods have become popular in social sciences, health sciences, education and psychology due to its flexibility in accommodating numerous models for different situations in data analysis. "Bayesian methods have become a viable alternative to traditional maximum likelihood-based estimation techniques and may be the only solution for more complex psychometric data structures." (RUPP et al., 2004) One field in which these data structures commonly arise is Item Response Theory (IRT). 
A unidimensional IRT model is a probabilistic model used to explain the response of $n$ examinees to a set of $k$ items by considering a unidimensional latent variable $\theta$, associated with individual abilities, and a set of item parameters.

Consider a sequence of binary random variables $\left\{Y_{i j}: 1 \leq i \leq n ; 1 \leq j \leq k\right\}$ associated with item responses and assume they are conditionally independent given $\theta_{i}$, the latent variable associated with the ability or trait for examinee $i$. Here $Y_{i j}=1$ if examinee $i$ correctly answers item $j$ and $Y_{i j}=0$ otherwise.

A three parameter item response model assumes that the probability of a correct response is given by

$$
p_{i j}=P\left[Y_{i j}=1 \mid \theta_{i}, a_{j}, b_{j}, c_{j}\right]=c_{j}+\left(1-c_{j}\right) F\left(m_{i j}\right) .
$$

where $c_{j}$ is a guessing parameter for item $j, F$ is a cumulative distribution function (cdf) and $m_{i j}=a_{j}\left(\theta_{i}-b_{j}\right)$ is a latent linear predictor involving the discrimination item parameter $a_{j}$, the difficulty item parameter $b_{j}$ and the latent variable $\theta_{i}$ associated to the examinee's $i$ ability.

Two popular examples for $F$ are the standard normal and the standard logistic distribution functions. For instance, the logistic three parameter item response model, named here as $3 L$ IRT model, is given by

$$
p_{i j}=P\left[Y_{i j}=1 \mid \theta_{i}, a_{j}, b_{j}, c_{j}\right]=c_{j}+\left(1-c_{j}\right) \frac{\exp \left(a_{j}\left(\theta_{i}-b_{j}\right)\right)}{1+\exp \left(a_{j}\left(\theta_{i}-b_{j}\right)\right)} .
$$

For fixed values of the item parameters $a_{j}, b_{j}$ and $c_{j}$, we can draw the probability in (2) as a function of the ability $\theta_{i}$. This is called the item characteristic curve (ICC). Figure 1 shows the ICC for the $3 L$ IRT model to $a_{j}=1.6, b_{j}=0$ and $c_{j}=0.2$.

Note that the item difficulty parameter $b_{j}$ is the inflection point of the ICC curve on the horizontal axis; it shifts the curve from left to right as the item becomes more and more difficult. Also $b_{j}$ is in the same scale of $\theta_{i}$, with $-\infty<b_{j}<\infty$. When $\theta_{i}=b_{j}$ we have that $p_{i j}=\left(1+c_{j}\right) / 2$ and this is the point where the slope is maximum. Higher values of $b_{j}$ indicate that greater skill is required to correctly answer the item.

The item discrimination parameter $a_{j}$ is assumed to be positive, since in our context the ICC curve should be increasing. This parameter is associated with the slope of the curve. Higher values of $a_{j}$ indicate a more marked change in the probability of success for a fixed variation on the ability.

The lower asymptote is given by the guessing parameter $c_{j}$. It is the probability of a correct response for an examinee with infinitely low skill. Theoretically it could range from 0 to 1 , but more realistically it is not more than 0.3 .

Note that the number of parameters involved in the model is $3 k+n$, which makes it to obtain the maximum likelihood estimates. Classical solutions for this problem consider a probability distribution for the latent variables $\theta_{i}$ and use a two 


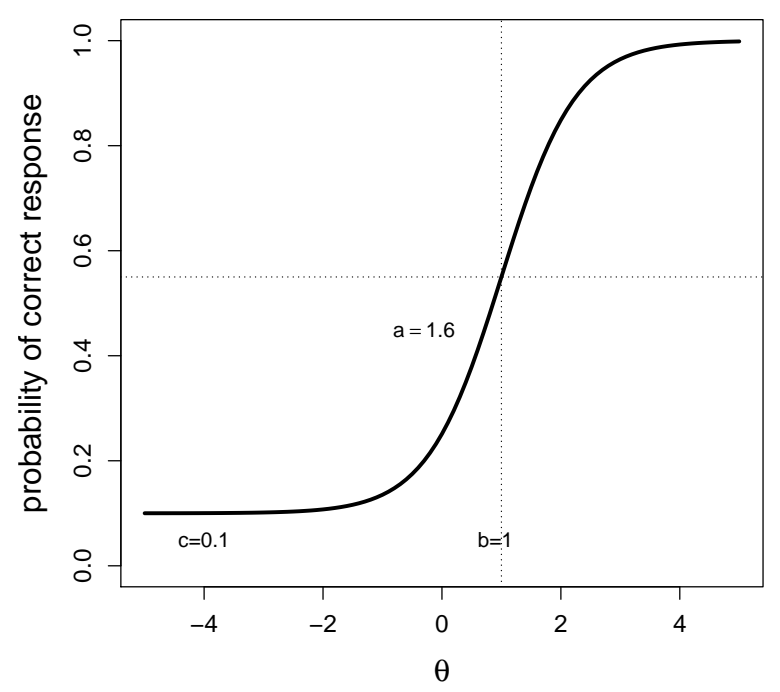

Figure 1 - Item Characteristic Curve for the $3 L$ IRT model with $a=1.6, b=1$ and $c=0.1$. 
step procedure (BAKER AND KIM, 2004). In the first step, the likelihood function is integrated over the latent variable and this marginal likelihood is maximized to obtain estimates for the items parameters. These parameters are then fixed to maximize the original likelihood and obtain the $\theta_{i}$ estimates. Bock and Aitikin (1981) propose an pseudo-EM algorithm to implement the first step. Limitations of this methodology are discussed in Patz and Junker (1999) and Sahu (2002).

In this paper we will focus on Bayesian IRT speededness models. These are IRT models in which examinees have a time limit. In the context of popular unidimensional IRT models the probability that an examinee gives a correct response to an item depends only on the examinee proficiency and the characteristic of the item. In addition, there is an assumption that the examinee has sufficient time to answer all items in the test.

However, "A test is speeded when some portion of the test taking population does not have sufficient time to attempt every item in the test within the allocated time" (BEJAR, 1985, p.1). So, when speedness exists and then the IRT assumptions of sufficient time is violated but even so the speed is modeled by a popular IRT model so the examinees can fail to give correct answers not because of limited proficiency, but because of limited time. In this case new models considering other personal variables joint with the examinee's proficiency and the characteristics of the item should be considered. In this paper we will focus in a Bayesian IRT speededness model, that is, IRT models to data set when examinees have a time limit and consequently evidence of speededness is observed.

In the next section, we discuss the fully Bayesian approach for IRT using MCMC. In section 3, the concept of speededness is presented in details and some approaches to model this latent characteristic are discussed. A simple Bayesian model to estimate both type of parameters: personal and item parameters to data with evidence of speededness is presented in section 4 . The model is strongly related with the speeded item response model with gradual process change proposed by Wollack and Cohen (2005) and Goegebeur, de Boeck, Wollack and Cohen (2008) but different of this, dependence structure is not assumed initially in the formulation of the model. By cause of this, we named this model as alternative $3 L$ speeded. In section 5, we conduce a case study to analyze data set of Nonsense Word Fluency measured in Peruvian student which show high evidence of Speededness comparing the model proposed and the common $3 L$ IRT model. Data set are obtained of the Early Grade Reading Assessment (EGRA) instrument (RTI-FDA, 2008) designed to measure pre-reading skills in peruvian students. Finally, conclusions and future works are presented in section 6.

\section{Bayesian approach in IRT}

As pointed out by Rupp et al. (2004), a fully Bayesian analysis is taken when prior distributions are specified for all unknown quantities. In the classical IRT literature empirical Bayes estimators are, as explained before, used to estimate the latent parameters after obtaining the maximum likelihood item parameter 
estimators. This approach is taken in traditional commercial programs like BILOG or MULTILOG. In this chapter we will restrict our analysis to a fully Bayesian approach using Markov Chain Montecarlo (MCMC) method where, instead of using plug-in estimators and a two step procedure, all parameter will be estimated together using the complete posterior distribution. Maximum Likelihood estimation to some common IRT models proposed in the literature are available for free as a package in $\mathrm{R}$ program (http://cran.r-project.org). See by example ltm package of Rizopoulos (2006), eRm package (MAIR AND HATZINGER, 2007), lme4 package (DE BOECK et al.,2011). On the other hand, only the MCMC package (GELMAN and HILL, 2007) and pscl package allows to implement some common IRT models under bayesian approach.

A seminal paper to this respect is Albert (1992) where a data augmentation procedure was suggested for the two parameters probit model [i.e, with $c_{j}=0$ and a normal cdf in (1)]. Béguin and Glas (2001) generalized this approach for the three parameter probit and a multidimensional model, while Fox and Glas (2001) extended this approach for multilevel IRT models. Further details are given in Fox (2010). In addition, alternative models with asymmetric links have been proposed by Bazán, Branco and Bolfarine (2006) and Bolfarine and Bazán (2010). While the first authors introduced a skew-probit IRT model using the cdf of a skew-normal distribution (AZZALINI, 1985), the last considered a skew version of the logistic model. In both cases a new set of item parameters to control the skewness of the distribution is introduced. The Bayesian inference for these models were performed using a data augmentation approach similar to Albert (1992).

In general, by considering the likelihood function and the correspondent prior specification, a joint posterior distribution for these IRT models can be fitted easily using MCMC, for example using WiNBUGS / OpenBUGS (CURTIS, 2010) or SAS (STONE AND ZHU, 2015). MCMC algorithms can be quite sophisticated, their proper use require careful attention to several aspects of the implementation and demand a heavy computational knowledge (KIM AND BOLT, 2007). This may hinder the large-scale use of this methodology by more applied researchers. The use of the BUGS software (www.mrc-bsu.cam.ac.uk/bugs) offers many advantages, including its relative ease of implementation, velocity and availability as a free software. Moreover, the use of BUGS software to estimate IRT models allows to change existing code in order to fit new variations of the current models, which cannot be fitted in the main classical software packages (IRT PRO, CAI et al., 2011). For more details see Curtis(2010) and Bazán (2012).

\section{Speededness in IRT}

In the usual context of a unidimensional IRT the probability that an examinee gives a correct response to an item depends only on the examinee's proficiency and the characteristic of the item. As a consequence it assumes that the examinee has sufficient time to answer all items in the test, ignoring speededness effects. According to $\mathrm{Lu}$ and Sireci (2007) speededness refers to the situation where the 
time limit does not allow substantial number of examinees to fully consider all items on a standardized test.

When speededness exists in a test not designed to take it into account and the speed is not modeled as examinee's proficiency, the IRT assumptions are violated and the examinees may fail to give correct responses not because of limited proficiency, but because of limited time. Hence, undetected speeded responses allow a time factor to contaminate the ability estimates. Furthermore, since examinees who are running out of time will often either hurry through the latter stages of a test or omit or randomly complete items towards the end of the test, these items tend to appear harder than they do when they are administered under nonspeeded conditions (OSHIMA, 1994).

As indicated by Yamamoto and Everson (1997), traditional methods of assessing test speededness are limited to the analysis of missing response distributions, especially at the end of a test. However, analysis of missing responses is inadequate in evaluating the speededness of multiple choice tests when the test score or raw score is a function of the total number of correct responses. A revision of these methods can be found in Lu and Sireci (2007).

In the past few years, several models that account speededness effects have been developed. Yamamoto and Everson (1997) have proposed a hybrid model which assumes that a two parameter logistic IRT model is appropriate throughout most of the test up to a point at which examinees switch to response randomly. Bolt, Cohen and Wollack (2002) have proposed a two class mixture Rasch model with ordinal constraints. These constraints are designed to distinguish a class with no speededness effects from a class whose responses are affected by speededness. More precisely, for items early in the test, the item difficulty parameters are constrained to be equal in both classes; however, the item difficulty parameters of end-of- test items in the speeded class are constrained to be larger than the respective item difficulty parameters in the nonspeeded class. Using a more general IRT model, Goegebeur et al. (2008) have proposed a speeded item response model with gradual process change. This model was first formulated by Wollack and Cohen (2005) as a model to simulate speededness data and can be regarded as a multidimensional IRT model that extends the three parameter logistic model by considering three personal latent variables to explain the behavior of the examinees in the test under a speeded situation. We refer to this model as a $3 L$ speeded model.

An alternative approach to modeling speededness has been considered by Van der Linden (2007) and Klein Entink, Fox and Van der Linden (2009). They assume a separate model for response time in order to measure speed of working besides an IRT model for measuring accuracy. At a higher level their models postulates a correlation between working speed and accuracy. 


\section{Two 3L speeded IRT model}

\subsection{The $3 L$ speeded IRT model}

The $3 L$ speeded IRT model with gradual process change (GOEGEBEUR et al., 2008) extends the $3 L$ IRT model by taking into account speededness effects. The model is formulated as:

$$
Y_{i j} \mid \boldsymbol{\beta}, \Theta \sim \operatorname{Bernoulli}\left(p_{i j}\right), \quad i=1, \ldots, n, j=1, \ldots, k .
$$

where $\boldsymbol{\beta}$ is a $k \times 3$ matrix containing the vector item parameters: $\boldsymbol{a}=$ $\left[a_{1}, a_{2}, \ldots, a_{k}\right]^{\prime}, \quad \boldsymbol{b}=\left[b_{1}, b_{2}, \ldots, b_{k}\right]^{\prime}$ and $\boldsymbol{c}=\left[c_{1}, c_{2}, \ldots, c_{k}\right]^{\prime}, \boldsymbol{\Theta}$ is a $n \times 3$ matrix containing the vector personal latent variables or pesonal parameters $\boldsymbol{\theta}=\left[\theta_{1}, \theta_{2}, \ldots, \theta_{n}\right]^{\prime}, \boldsymbol{\eta}=\left[\eta_{1}, \eta_{2}, \ldots, \eta_{n}\right]^{\prime}$ and $\boldsymbol{\lambda}=\left[\lambda_{1}, \lambda_{2}, \ldots, \lambda_{n}\right]^{\prime}$ and $\boldsymbol{y}=\left[y_{i j}\right]$ is the data matrix containing the observed dichotomous responses of the $n$ examinees to the $k$ items. Specifically, $Y_{i j}$ are the dichotomous response corresponding to the $i$-th individual to the $j$-th item, $\boldsymbol{\beta}_{\boldsymbol{j}}=\left(a_{j}, b_{j}, c_{j}\right)$ is the vector of item parameters that correspond to item discrimination, item difficulty and item guessing parameters of the item $j$ respectively and $\boldsymbol{\Theta}_{i}=\left(\theta_{i}, \eta_{i}, \lambda_{i}\right)$ the vector of personal parameters corresponding to latent trait, tolerance towards speededness and the propensity to guessing under speededness describing the personal ability of the examinee $i$ in answering the test with $k$ items. In addition, is assumed that $p_{i j}$, the probability of correct answer for examinee $i$ in the item $j$, is given by

$$
p_{i j}=P\left[Y_{i j}=1 \mid \theta_{i}, \eta_{i}, \lambda_{i}, a_{j}, b_{j}, c_{j}\right]=c_{j}+\left(1-c_{j}\right) G\left(m_{i j}\right),
$$

where

$$
\begin{gathered}
G\left(m_{i j}\right)=F\left(m_{i j}\right) P_{j}\left(\eta_{i}, \lambda_{i}\right), \\
P_{j}\left(\eta_{i}, \lambda_{i}\right)=\min \left\{1, r_{j}\left(\eta_{i}, \lambda_{i}\right)\right\},
\end{gathered}
$$

and

$$
r_{j}\left(\eta_{i}, \lambda_{i}\right)=\left[1-\left(\frac{j}{k}-\eta_{i}\right)\right]^{\lambda_{i}}
$$

with $m_{i j}=a_{j}\left(\theta_{i}-b_{j}\right)$, a linear function of $\theta_{i}, i=1, \ldots, n$ and $j=1, \ldots, k$.

Note that in comparison with $3 L$ IRT model, two additional personal parameters associated associated with speededness effects $\left(\eta_{i}\right.$ and $\left.\lambda_{i}\right)$ are introduced in the model. We will call them, respectively, the tolerance towards speededness and the propensity to guessing under speededness. Observe that $\eta_{i} \in[0,1]$ identifies the point $j / k$, expressed as a fraction of the number of items, where examinee $i$ first experiences an effect due to speededness, while $\lambda_{i}>0$ controls the rate of decrease towards a guessing situation.

The rationality behind model (3) is as follows. When examinee $i$ encounters item $j$, the examinee answers according to a $3 L$ IRT model or a random guessing process, with probabilities $P_{j}\left(\eta_{i}, \lambda_{i}\right)$ and $1-P_{j}\left(\eta_{i}, \lambda_{i}\right)$ respectively. Under the 
problem solving process the examinee knows the answer with probability $F\left(m_{i j}\right)$, given by a logistic model; if ignorant, the examinee guesses at random.

Note that $P_{j}\left(\eta_{i}, \lambda_{i}\right)$ in (4) can be regarded as a penalizing factor due to speededness. When speededness is not present in item $j$, i.e., if examinee $i$ has a relatively high tolerance $\eta_{i} \geq \frac{j}{k}$ towards speededness, then $r_{j}\left(\eta_{i}, \lambda_{i}\right)>1$ and $P_{j}\left(\eta_{i}, \lambda_{i}\right)=1$. Consequently $F\left(m_{i j}\right)$ is not decreasing. On the other hand, if examinee $i$ has a relatively low tolerance $\eta_{i}<\frac{j}{k}$ towards speededness, then $r_{j}\left(\eta_{i}, \lambda_{i}\right)<1$ and consequently $P_{j}\left(\eta_{i}, \lambda_{i}\right)<1$ decreases the probability $F\left(m_{i j}\right)$. Moreover this factor can be magnified by having a high propensity $\lambda_{i}$ to guessing under speededness.

The parameter $\eta_{i}$ can be considered as a personal latent variable associated with the tolerance to speededness in contrast with the relative position $j / k$ of the item in the test. This relation is similar to the one between ability and difficulty. Both $\eta_{i}$ and $j / k$ should be on the same scale (between 0 and 1 ), despite the fact that $\eta_{i}$ is a random variable and $j / k$ is fixed.

High values of $\lambda_{i}$ are associated with the increase of the penalization factor $P_{j}\left(\eta_{i}, \lambda_{i}\right)$ and therefore the decrease of the probability of correct response. However, note that the $\eta_{i}$ parameter seems to be more relevant than the $\lambda_{i}$ parameter because it can be interpreted in any scenario, while the second only under a speededness situation. Thus the $\lambda_{i}$ parameter express a propensity to guessing which does not necessarily affect the probability of a correct response.

To complete the formulation Goegebeur et al (2008) considered the personal parameters $\boldsymbol{\Theta}$ with joint distribution function give by:

$$
G(\boldsymbol{\Theta})=G(\boldsymbol{\theta}, \boldsymbol{\eta}, \boldsymbol{\lambda})=C\left(G_{1}(\boldsymbol{\theta}), G_{2}(\boldsymbol{\eta}), G_{3}(\boldsymbol{\lambda})\right)
$$

where $C$ is a Gaussian copula and $G_{1}(),. G_{2}($.$) and G_{3}($.$) are respectively the$ marginal cumulative distribution functions of personal parameters $\theta_{i}, \eta_{i}$, and $\lambda_{i}$.

Thus, combinating (3-5) and (6) we have finally the $3 L$ speeded IRT model proposed by Goegebeur et al (2008).

To estimate the item parameters in the $3 L$ speeded model and recalling that item responses are conditionally independent given $\theta_{i}$ and assuming independence among examinees, Goegebeur et al (2008) use the marginal maximum likelihood methodology by considering the marginal likelihood function

$$
L=\int_{-\infty}^{\infty} \int_{0}^{1} \int_{0}^{\infty} L(\boldsymbol{\beta}, \boldsymbol{\Theta} \mid \boldsymbol{y}) d G\left(\theta_{i}, \eta_{i}, \lambda_{i}\right)
$$

where

$$
L(\boldsymbol{\beta}, \boldsymbol{\Theta} \mid \boldsymbol{y})=\prod_{i=1}^{n} \prod_{j=1}^{k} p_{i j}^{y_{i j}}\left(1-p_{i j}\right)^{1-y_{i j}},
$$

Maximizing $L$ with respect to the item and Gaussian copula parameters initially, and then they used these estimated values for a second stage to obtain the maximum likelihood estimations of the personal parameters. 
The choice of Gaussian copula was justified by the possibility to regard the model as a linear mixed model and then use the NLMIXED SAS procedure in the estimation process.

\subsection{The alternative $3 L$ speeded IRT model}

A disadvantage of the $3 L$ speeded IRT is that a consideration of a dependence structure among the latent personal variables makes difficult not only the multidimensional evaluation of (7) but also involves an increase in the number of parameters. To overcome these issues we propose in this paper an alternative model by starting with (3-5), but assuming that the personal latent variables $\boldsymbol{\theta}, \boldsymbol{\eta}$ and $\boldsymbol{\lambda}$ in (6) to be initially independent, that is:

$$
g(\boldsymbol{\Theta})=g(\boldsymbol{\theta}, \boldsymbol{\eta}, \boldsymbol{\lambda})=g_{1}(\boldsymbol{\theta}) \times g_{2}(\boldsymbol{\eta}) \times g_{3}(\boldsymbol{\lambda})
$$

where $g_{1}(),. g_{2}($.$) and g_{3}($.$) are respectively continuous probability distribution$ functions defined in the correspondent parametric space of each personal latent variable. We will refer to the model (3-5) and (9) as the alternative $3 L$ speeded IRT model.

Note that this formulation is an Bayesian approach, and then in the new model, we stress that in this formulation the natural correlations between the personal latent parameters will be data dependent and will appear in the posterior distribution. This argument is similar to the case of assume independent prior to item parameter where empirical evidence (see Patz and Junker, 1999, among others) suggests the presence of a posterior correlation between item parameters. We will show in section 5 that this formulation is not only convenient but also can be a alternative method of estimation to data with dependence structure in personal parameters.

\subsection{Bayesian estimation of the alternative $3 L$ speeded IRT model}

The alternative $3 L$ speeded IRT model will assume, as usually considered in the literature, independent priors for all the parameters in the model. The following item parameter prior distributions are usually specified in IRT modelling:

$a_{j} \sim \operatorname{LN}(0,0.25)$ or $T N(0,0.5) I(a>0), b_{j} \sim \operatorname{Normal}(0,1)$ and $c_{j} \sim \operatorname{Beta}(5,17)$.

where $L N$ and $T N$ denote the log-normal and truncated normal distributions, respectively. The $L N(0,0.25)$ (Patz and Junker, 1999) and $T N(0,0.5) I(a>0)$ (BAZÁN et al., 2006) are non-negative distributions with mean-standard deviation pair $(1.13,0.60)$ and $(1.11,0.61)$, respectively. On the other hand, the Beta $(5,17)$ distribution (FU, et al., 2009) has a mean-standard deviation pair $(0.23,0.09)$. The 
distribution for $b$ is justified using a similar argument given to choose the normal for $\theta$. See, for instance, Albert and Ghosh (2000) and Sinharay, et al., (2006). However, sometimes, instead of the usual parameterization we can opted for the parametrization $m_{i j}=a_{j} \theta_{i}-b_{j}^{*}$ where the item difficulty parameter is easily recovery using $b_{j}=b_{j}^{*} / a_{j}$. In this case a prior specification to $b_{j}^{*}$ similar that $b_{j}$ is adopted. This is a common practice in Bayesian Inference (see for example Sahu (2002)).

To complete the specification of personal parameters we will set the following priors:

$$
g_{1}(.): \theta_{i} \sim N(0,1), g_{2}(.): \eta_{i} \sim \operatorname{Beta}(\alpha, \beta) \quad \text { and } \quad g_{3}(.): \lambda_{i} \sim L N\left(\mu_{\lambda}, \sigma_{\lambda}^{2}\right) .
$$

As frequently considered in the literature (RUPP, et al., 2004), we take $g_{1}($.$) :$ $\theta_{i} \sim N(0,1), i=1, \ldots, n$. This assumption establishes that it is believed that the latent variables are well behaved and abilities conform a random sample from this distribution. This additionally establishes a metric for the abilities estimates.

Specifications for hyperparameters of $g_{2}($.$) : \operatorname{Beta}(\alpha, \beta)$ can be made by considering information about the point where an examinee is more likely to experience a speededness situation. This can be obtained from judges or experts by asking them about the mean $\left(\mu_{\eta}\right)$ and standard deviation $\left(\sigma_{\eta}\right)$ of $\eta_{i}$. For example, a choice can be $\left(\mu_{\eta}=0.67, \sigma_{\eta}=0.18\right)$ which correspond to a $\operatorname{Beta}(4,2)$ distribution, which means a moderate tolerance towards speededness. Other possibilities could be a $\operatorname{Beta}(2,9)$ or a $\operatorname{Beta}(9,2)$ distribution with, respectively, $\left(\mu_{\eta}=0.18, \sigma_{\eta}=0.01\right)$ and $\left(\mu_{\eta}=0.8, \sigma_{\eta}=0.01\right)$. In the former case the tolerance towards speededness is low while in the second case high. Situations where no information is given can be modeled with a $\operatorname{Beta}(1,1)$ distribution, or equivalently, a uniform distribution on the interval $(0,1)$.

For the $\lambda$ personal parameter of propensity, Goegebeur et al., (2008) considered $g_{3}():. L N\left(\mu_{\lambda}, \sigma_{\lambda}\right)$ with $\mu_{\lambda}=-3.604$ and $\sigma_{\lambda}=2.771$. After simulating 1000 samples from this distribution we found a maximum value of 17140.48 and a minimum of $2.497 \times 10^{-8}$. This scale is too broad for any meaningful interpretation of the distances between the values, so in order to shrink the scale, we set the hyperparameters $\mu_{\lambda}=0$ and $\sigma_{\lambda}=1$, which yields a mean of 1.65 and standard deviation of 2.16 .

Since the posterior density in the likelihood function defined (8) and the priors in (10) and (11) can not be fully obtained in closed form we will use a Markov chain Monte Carlo (MCMC) approach to simulate parameter values and obtain parameter estimates. Further, note that, this hierarchical structure can be easily implemented in several packages as OpenBugs, WinBugs, JAGS, Rstan or SAS software. In this paper the models were fit using WinBUGS and the codes are available under requirement. 


\section{A case study with evidence of speededness: the NWF data set}

The Nonsense Word Fluency (NWF) data comes from a pilot study to adapt the Snapshot of School Management Effectiveness (SSME) and Early Grade Reading Assessment (EGRA) instruments to the Peruvian reality (RTI-FDA, 2008). The EGRA instrument includes a battery of test that are designed for the initial years in primary school and provides a quick information regarding school management and pre-reading skills. The NWF data was obtained after evaluating 512 eight years old students who were able to correctly read each of the 50 nonsense words in the NWF test within a time limit of 60 seconds. Figure 2 shows a subset of this test.

$\begin{array}{cccccc}\text { pul } & \text { quibe } & \text { ino } & \text { mise } & \text { jud } & 5 \\ \text { udo } & \text { zel } & \text { bedi } & \text { cur } & \text { miz } & 10 \\ \text { lline } & \text { rite } & \text { duso } & \text { jafi } & \text { fica } & 15 \\ \vdots & \vdots & \vdots & \vdots & \vdots & \vdots \\ \text { quira } & \text { cuto } & \text { dofu } & \text { afo } & \text { duba } & 50\end{array}$

Figure 2 - Subset of the Nonsense Word Fluency data in the EGRA instrument.

Figure 3 presents the percentage of students who were able to correctly read each of the 50 nonsense words. We see that this percentage decreases at the end of the test giving the impression that the last words are the hardest and suggesting the presence of speededness.

In figure 3 we considered non-reached words as incorrectly read. This certainly could introduce a bias that we need to address. An alternative for a more reliable speed measure was proposed by Stafford (1971) and discussed in Lu and Sirecci (2007). Under the assumption that examinees keep no track of time during the test, which seems to be the case in our application, Stafford suggests to use the Speededness Quotation (SQ) index

$$
S Q=\frac{\sum_{i=1}^{n} U_{i}}{\sum_{i=1}^{n} W_{i}+\sum_{i=1}^{n} U_{i}},
$$

where $n$ is the number of examinees, $U_{i}$ is the number of non-reached items by examinee $i$ and $W_{i}$ is the number of the incorrectly answered or omitted items by examinee $i$. Indices closer to 1 give evidence of speededness.

In the EGRA application we obtained a Speededness Quotation index of 0.9081 , that is, data with evidence of speededness which supports the use of the a 


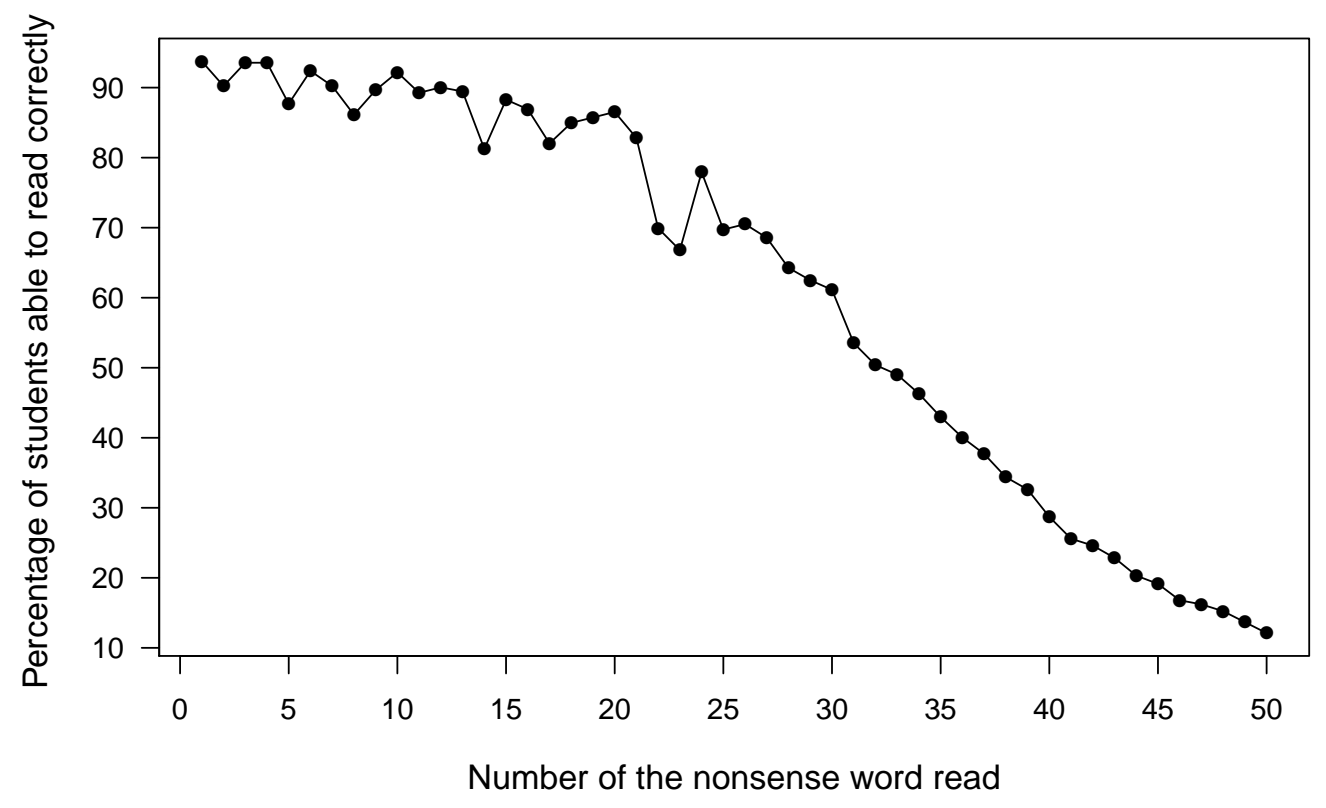

Figure 3 - Percentage of students who are able to correctly read each of the Nonsense Words in the NWF data. 
Table 1 -

Model comparison for the NWF data by considering a $3 L$ and a alternative $3 L$ speeded IRT model

\begin{tabular}{cccc}
\hline Model & $\begin{array}{c}\text { Number of } \\
\text { parameters }\end{array}$ & Dbar & DIC \\
\hline \hline $3 L$ & 662 & 9083 & 9459 \\
\hline alternative 3L speeded & 1686 & 8314 & 8886 \\
\hline
\end{tabular}

Table 2 -

Descriptive statistics and correlations between personal latent variables under the $3 L$ and alternative $3 L$ speeded IRT models with raw score for 512 Peruvian students in the NWF test

\begin{tabular}{|c|c|c|c|c|c|c|c|c|c|c|}
\hline \multirow[t]{2}{*}{ Models } & \multirow{2}{*}{$\begin{array}{l}\text { Personal } \\
\text { variables }\end{array}$} & \multicolumn{4}{|c|}{ Descriptive statistics } & \multicolumn{5}{|c|}{ correlations } \\
\hline & & Mean & Min. & Max. & S.D. & $\theta$ & $\theta^{*}$ & $\eta$ & $\lambda$ & raw scores \\
\hline $3 L$ IRT & $\theta$ & -0.047 & -3.745 & 2.405 & 1.473 & 1.000 & & & & \\
\hline alternative & $\theta^{*}$ & -0.016 & -2.506 & 2.293 & 1.239 & 0.725 & 1.000 & & & \\
\hline $3 L$ speeded & $\eta$ & 0.568 & 0.007 & 0.862 & 0.243 & 0.874 & 0.446 & 1.000 & & \\
\hline IRT & $\lambda$ & 3.328 & 0.229 & 27.550 & 5.116 & -0.727 & -0.136 & -0.712 & 1.000 & \\
\hline Classical & raw score & 30.701 & 0.000 & 50.000 & 12.976 & 0.996 & 0.733 & 0.879 & -0.707 & 1.000 \\
\hline
\end{tabular}

$\theta$ : ability under the $3 L$ model, $\theta^{*}$ : ability under speededness, $\eta$ : tolerance toward speededness,

$\lambda$ : propensity to guessing under speededness and raw scores: number of words correctly read.

alternative $3 L$ speeded IRT model instead of the usual $3 L$ IRT model or the calculate of the classical raw score model to measure NWF.

To evaluate the $3 L$ IRT model and the alternative $3 L$ speeded IRT models with this data we will consider the following prior distributions: $\theta_{i} \sim \operatorname{Normal}(0,1), \eta_{i} \sim$ $\operatorname{Beta}(1,1), \lambda_{i} \sim \operatorname{LN}(0,1), a_{j} \sim T N(1,0.5) I(0),, b s_{j} \sim \operatorname{Normal}(0,2)$ and $c_{j} \sim \operatorname{Beta}(5,17)$, where $b_{i}=b s_{i} / a_{i}$ is the difficulty parameter and $b s_{i}$ is an intercept parameter.

Starting with a burn-in of 5000 iterations and a thinning of 20, a sample of size 2000 was obtained. Several criteria using the CODA package, were computed for the convergence analysis.

Table 3 shows the fit comparison using the Dbar and DIC criteria. As seen, the a alternative $3 L$ speeded model shows a better fit than the $3 L$ model for the NWF data. This confirms the evidence given by the SQ index.

Table 2 summarizes the estimation results for the personal latent variables under the $3 L$ and the alternative $3 L$ speeded IRT models. We have also considered the raw scores to measure Nonsense Word Fluency. Correlations between personal latent variables are also included. 
Figure 4 shows the scatter plot between ability estimations and classical raw scores under the $3 L$ and $3 L$ speeded IRT models. Variables were standardized to facilitate the comparison. Observe from Table 3 and Figure 4 that the abilities under the $3 L$ model and the classical scores are highly and positively correlated $(r=0.996)$, so they could be interchangeable. The relatively high correlation $(r=0.773)$ obtained with the $3 L$ speeded model can be understood by observing that the examinees with low scores (below 19 correct responses) and marked inside the circle of Figure 3 obtained similar measures of abilities under the alternative $3 L$ speeded model.
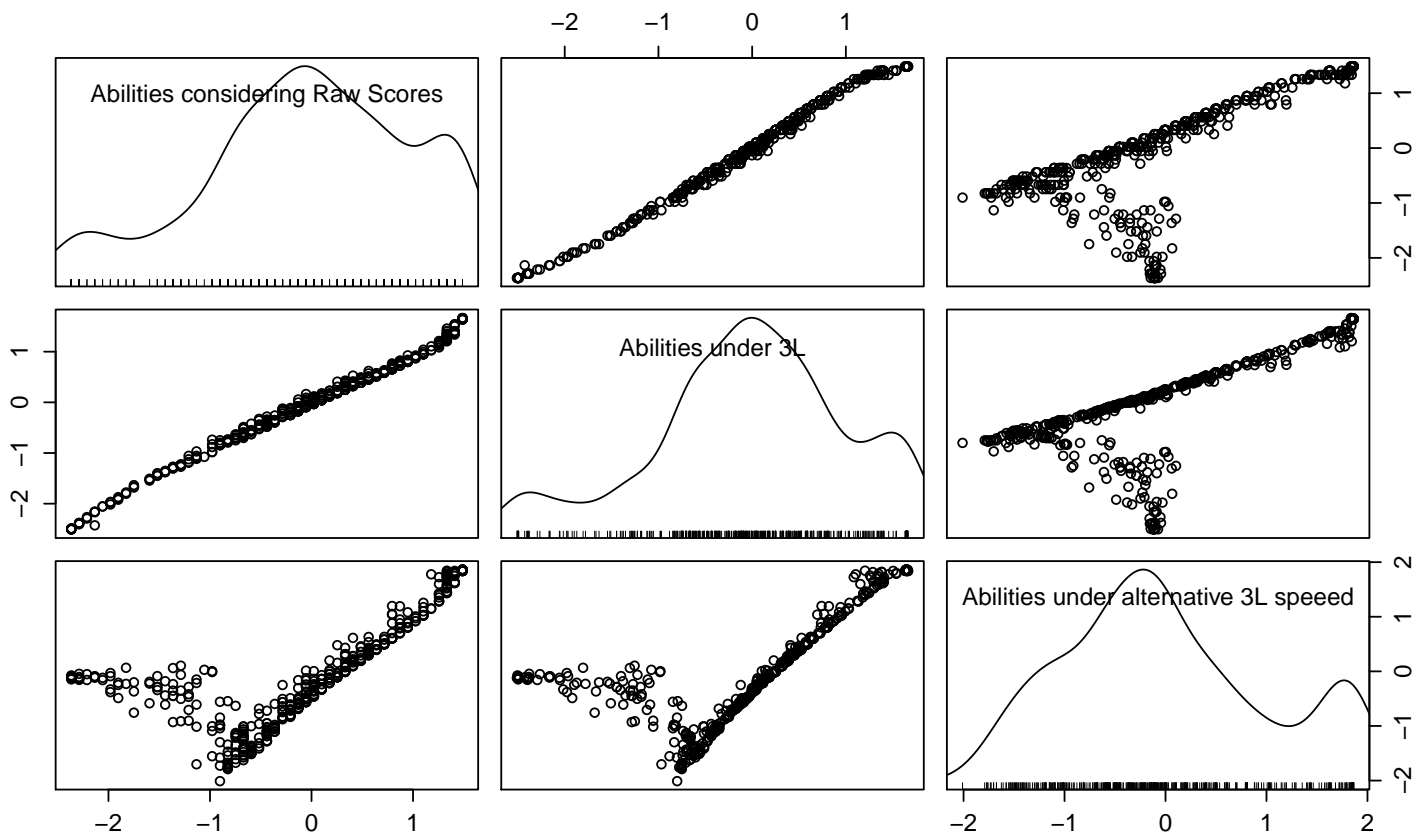

Figure 4 -

Scatter plot for abilities estimates under $3 L$, alternative $3 L$ speeded IRT models and raw scores for Peruvian students in NWF data. Variables were standardized to facilitate the comparison

As expected, Table 3 and Figure 5 show that $\theta$ and $\eta$ are positively correlated $(r=0.446)$, which means that a low tolerance towards speededness is mainly associated with a low ability or NWF measure. On the other hand, the tolerance towards speededness and the propensity to guessing under speededness are highly and negatively correlated $(r=-0.712)$. Moreover, a low negative correlation but significant, is observed between ability and propensity $(r=-0.136)$ indicating 


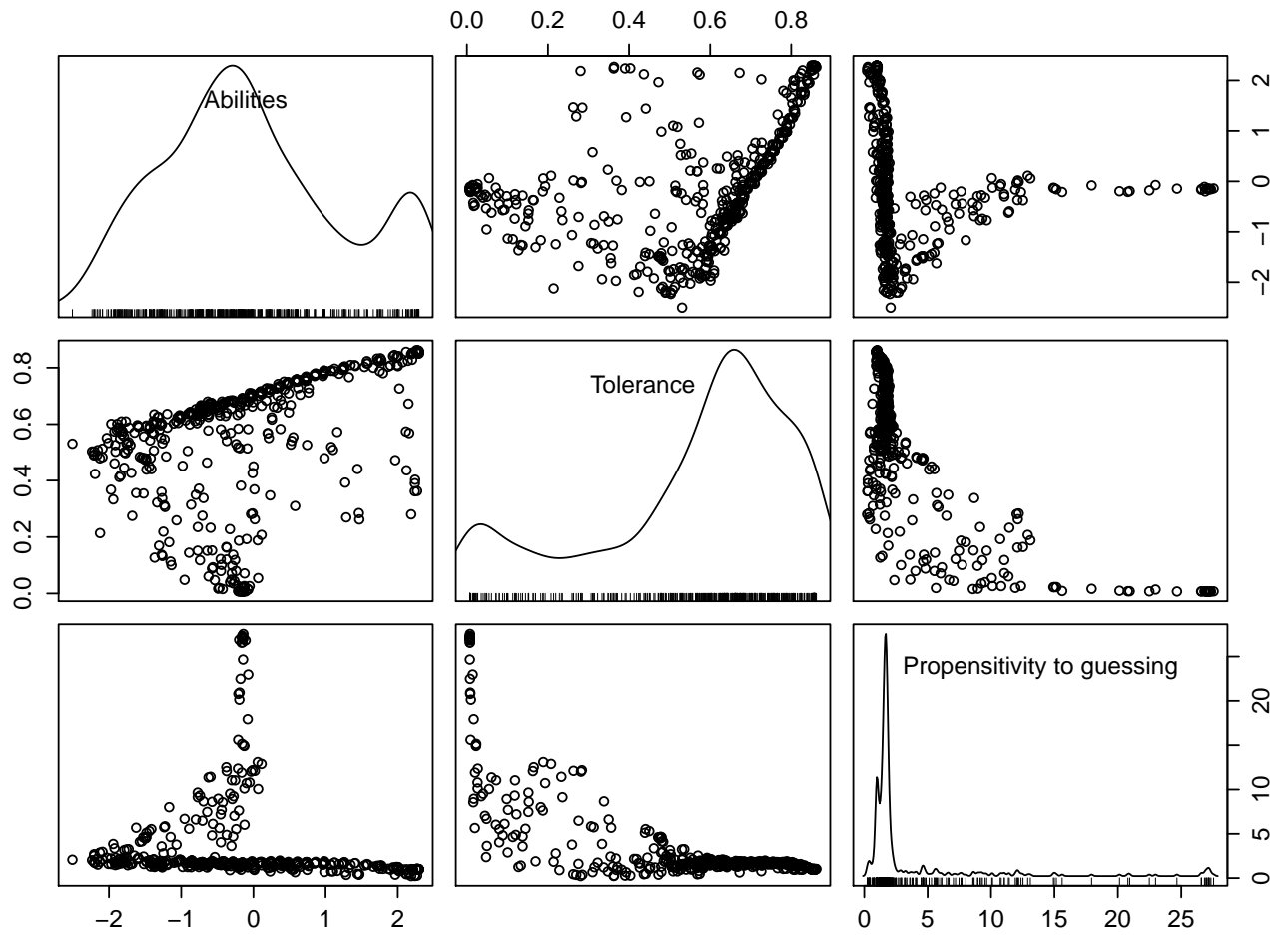

Figure 5 - Scatter plot for the personal latent variables estimates under alternative $3 L$ speeded IRT model for Peruvian students in NWF data. 
Table 3 -

Personal latent variables in some cases of low scoring Peruvian students in the NWF test under alternative 3L speeded model

\begin{tabular}{cccccc}
\hline case & $\theta^{*}$ & $\eta$ & $\lambda$ & $\begin{array}{c}\text { rawe } \\
\text { score }\end{array}$ \\
\hline \hline 234 & -0.201 & 0.187 & 7.630 & 16 & 11111111110111111000000000000000000000000000000000 \\
185 & -0.214 & 0.027 & 12.360 & 4 & 10110100000000000000000000000000000000000000000000 \\
276 & -0.196 & 0.010 & 20.130 & 1 & 01000000000000000000000000000000000000000000000000 \\
195 & -0.208 & 0.008 & 20.790 & 1 & 00010000000000000000000000000000000000000000000000 \\
257 & -0.192 & 0.008 & 20.930 & 1 & 00010000000000000000000000000000000000000000000000 \\
172 & -0.198 & 0.007 & 26.890 & 0 & 00000000000000000000000000000000000000000000000000 \\
\hline
\end{tabular}

that for some examinees high propensity to guess is associated with low ability or NWF measure. The importance of this type of results is that the examinees can be best characterized in relation to personal latent variables which is important in the assessment of Nonsense Word Fluency, an important predictor of Reading Proficiency (see Fien, et al., 2008).

For a better understanding of the personal latent variables inside the circle of Figure 4, we have further studied some characteristics of this group. The results are shown in Table 4 . The group, in general, has a low tolerance towards speededness and, as expected, a high propensity to guessing. Although many of the raw scores and measures of abilities under the $3 L$ model were different, we find similar measures under the $3 L$ speeded model. Note that, this is only true for low scores. Consequently the alternative $3 L$ speeded model assigns similar NWF measures to low scoring examinees and is able to differentiate among examinees in terms of their tolerance and propensity due to a speededness situation.

In Figure 6 we show the discrimination, difficulty and guessing estimates under the $3 L$ and the alternative $3 L$ speeded IRT models. In general these estimates look very similar, but there are remarkable differences in some items due to the speededness phenomenon. For instance, the estimates of the difficulty parameters under the $3 L$ model are larger than under the alternative $3 L$ speeded model. This confirms the statement of Oshima (1994) presented in the introduction that under speed conditions last items tend to appear harder than they are when administered under non speededness conditions. Moreover, we found that several items, especially the first, present high values for the discrimination parameter under a $3 L$ IRT model. Therefore, speededness seems to overestimate the discrimination power of these items. 
(a) discrimination parameter

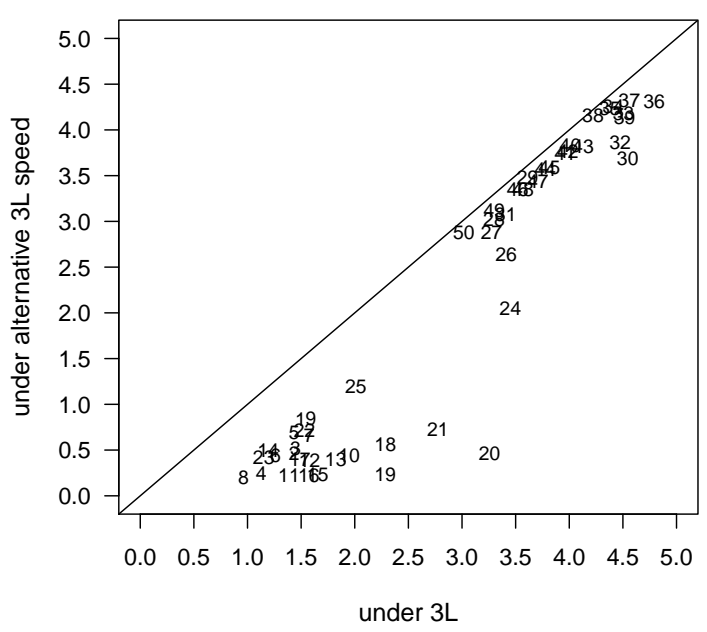

(c) guessing parameter

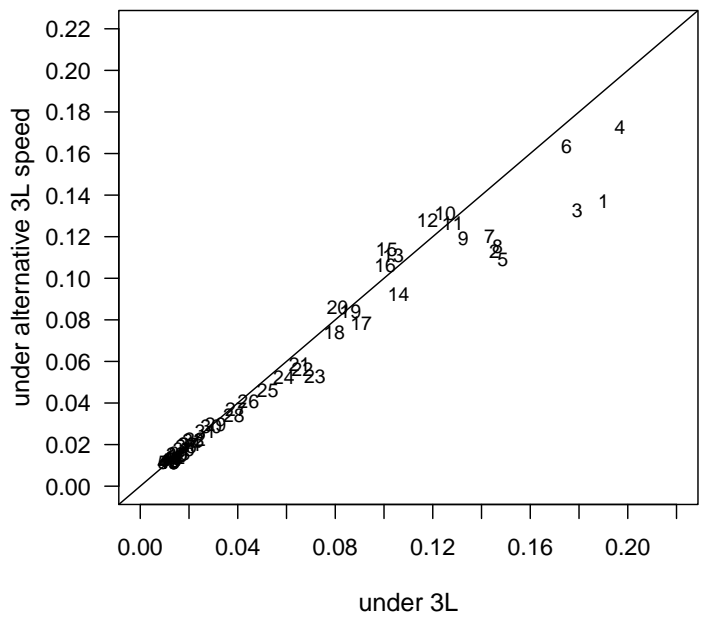

(b) difficulty parameter

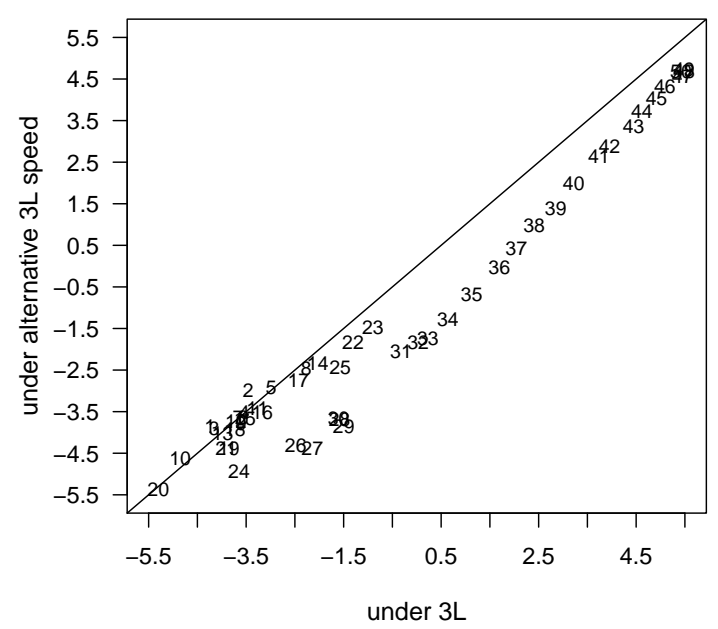

Figure 6 - Item parameter estimates under $3 L$ and alternative $3 L$ speeded IRT models. 


\section{Conclusions}

The speeded item response model of Goegebeur et al., (2008) which incorporates a gradual process change is an interesting model to data with speededness evidence offering a new set of personal latent variables to better understanding the for performance of the examinees in a test. Inspired in the classical approach of this model, we propose an alternative $3 \mathrm{~L}$ speeded IRT model which initially consider an independent structure to the personal parameters under Bayesian approach. Thus, independent priors are assumed not only to personal parameters as to item parameters as is usually considered in the literature. By considering this specification, dependence between the parameters of the model can be obtained considering your correspondent posterior distributions. In IRT models the priors have an additional role to identify the model and not only to give an idea about the uncertainty of the parameters in the model. For example, when we consider the $b$ and $\theta$ parameters with a normal standard distribution, we are also giving a simple scale to these parameters which is easy to interpret.

The model has been easily implemented using a hierarchical formulation in several packages as WinBUGS, OpenBugs, SAS, Rstan or JAGS. Although there is a large number of parameters in the model, our estimators performed reasonably good and they were obtained in a straightforward way. We only observe some bias in the estimation of $\lambda$ parameter and consequently further research is needed to study the sensibility of this parameter to alternative prior specifications. More comprehensive studies are needed to obtain conclusive results. Additionally, we note that the term $P_{j}\left(\eta_{i}, \lambda_{i}\right)$ in the probability of correct response in (6) is an penalized factor under speededness and consequently alternative models can be formulated condering other penalized factor with other rationality.

As a future work, we suggest to explore others models for the EGRA data, such as, the one given by Jansen (1997) or the one proposed by van der Linden (2006) for speeded tests with response times. To go in the last direction we would additionally requiere the subject response times for the items.

In addition a further sensitivity study for the priors and other Item Characteristic Curves, such as the skew ICC given by Bazan et al., (2006), can

be explored also. For more about Bayesian modeling in IRT we suggest to see Fox (2010). 
- RESUMO: Aceleração refere-se à situação em que o limite de tempo num teste padronizado não permite a um número substancial de examinandos poder fazer todos os itens do teste, assim, estimativas usando modelos de resposta ao item logísticos de tres parâmetros (3L) conduz a estimativas contaminadas dos parâmetros do modelo. Neste trabalho foi proposto um modelo bayesiano simples para estimar ambos os tipos de parâmetros: parâmetros: pessoais e parâmetros de item para dados com evidência de aceleração. O modelo está fortemente relacionado com um modelo proposto por Goegebeur, De Boeck, Wollack e Cohen (2008) mas diferente deste, a estrutura de dependência nos parâmetros pessoais não é assumida inicialmente na formulação do modelo. Nós conduzimos um estudo de caso para analisar dados de fluência em palavras sem sentido em estudandes peruanos. Os dados apresentam alta evidência de aceleração e quando se comparam os resultados de $3 L$ e o modelo proposto, encontramos que dificuldade e discriminação são superestimados sob $3 L$, são obtidas medidas semelhantes das habilidades dos examinandos em ambos modelos e novos parâmetros pessoais: tolerância e propensão frente a aceleração são obtidos considerando-se o modelo proposto. Finalmente, futuros estudos são sugeridos.

- PALAVRAS-CHAVE: Modelos de resposta ao item, estimação bayesiana, aceleração, modelo logístico, variáveis latentes pessoais, fluência en palavras sem sentido

\section{References}

ALBERT, J.H. Bayesian estimation of normal ogive item response curves using Gibbs sampling. Journal of Educational Statistics, v. 17, p. 251-269, 1992.

ALBERT, J.H. and GHOSH, M. Item response modeling. In Dey, K. D. , Ghosh, S. K. and Mallick B. K. (Eds). Generalized Linear Models: A Bayesian Perspective. New York: Marcel-Dekker, 2000. p. 173-193.

BAKER, F. B. and KIM, S.-H. (2004). Item Response Theory - Parameter Estimation Techniques. (2nd ed.). New York: Marcel Dekker, Inc, 2004. 528p.

BAZÁN, J. L.; BRANCO, M. and BOLFARINE, H. A Skew Item Response Model Bayesian Analysis, v. 1, p. 861-892. 2006

BAZÁN, J. L. Item Response Theory in WinBUGS using BayesianModeling Software. Software Highlight in ISBA Bolletin, v. 19(1), p. 8-10. 2012.

BÉGUIN, A. A. and GLAS, C.A.W. Estimation of multidimensional IRT models. Psychometrika, v. 66, p. 541-562, 2001.

BEJAR, I., H. (2006). Test speededness under number-right scoring: An analysis of the Test of English as a Foreign Language. (Report No. ETS-RR-85-11), 2006, 57p. Princeton, NJ: Educational Testing Service. (ERIC Document Reproduction Service No. ED 263128).

BOCK, R. D. and AITKIN, M., Marginal maximum likelihood estimation of item parameters: An application of an EM algorithm, Psychometrika. v. 45, p. 433-459. 1981 
BOLT, D. M.; COHEN, A. S. and WOLLACK, J. A. Item parameter estimation under conditions of test speededness: Application of a mixture Rasch model with ordinal constraints. Journal of Educational Measurement, v. 39, p. 331-348. 2002.

BOLFARINE, H. and BAZÁN, J. L. (2010) Bayesian Estimation of the Logistic Positive Exponent IRT model. Journal of Educational Behavioral Statistics, v. 35-6, p. 693-713. 2010.

CAI, L.; DU TOIT, S. H. C. and THISSEN, D. IRTPRO: Flexible, multidimensional, multiple categorical IRT modeling [Computer soft- ware]. Chicago: SSI International. 2011.

CURTIS, M. S. BUGS Code for Item Response Theory. Journal of Statistical Software. v. 36: Snippet 1. p. 1-34. 2010.

DE BOECK, P.; M. BAKKER, R.; ZWITSER, M.; NIVARD, A.; HOFMAN, F.; TUERLINCKX, and I. PARTCHEV. The estimation of item response models with the lmer function from the lme4 package in r. Journal of Statistical Software. v. 39(1), p. 1-28. 2011.

FIEN, H.; BAKER, S.; SMOLKOWSKI, K.; MERCIER, J.; KAME’ENEUI, E. and BECK, C. Using Nonsense Word Fluency to Predict Reading Proficiency in Kindergarten Through Second Grade for English Learners and Native English Speakers. School Psychology Review. v. 37, p. 391-408. 2008.

FOX J.P. Bayesian Item Response Modeling: Theory and Applications. New York: Springer , 2010. 314p.

FOX J.P. and GLAS, C.A.W. Bayesian estimation of a multilevel IRT model using Gibbs sampling. Psychometrika, v. 66, p. 269-286. 2001.

FU, Z-H; TAO, J. and SHI, N-Z. Bayesian estimation in the multidimensional threeparameter logistic model. Journal of Statistical Computation and Simulation, v. 79(6), p. 819-835. 2009.

GELMAN, A. Prior distributions for variance parameters in hierarchical models. Bayesian Analysis. v. 1, p. 515-33. 2006.

GELMAN, A. and HILL, J. Data Analysis Using Regression and Multilevel/Hierarchical Models. Cambridge: Cambridge University Press, 2007. 625p.

GOEGEBEUR, Y.; DE BOECK, P.; WOLLACK, J.A. and COHEN, A.S. (2008). A Speeded Item Response Model with Gradual Process Change, Psychometrika, v. 73, p. 65-87. 2008.

JANSEN, M (1997). The Rasch Model for Speed Test and Some Extensiones With Applications to Incomplete Designs. Journal of Educactional and Behavioral Statistics, v. 22, p. 125-140. 1997.

KIM, J. S. and BOLT, D. M. Markov chain Monte Carlo estimation of item response models. Educational Measurement: Issues and Practice, v. 26, p. 38-51. 2007.

KLEIN, ENTINK, R.H.; FOX, JP and VAN DER LINDEN, W.J. A multivariate multilevel approach to the modeling of accuracy and speed of test takers. Psychometrika, v. 74, 21-48. 2009. 
LU, Y.; SIRECI, S. G. Validity Issues in Test Speededness. Educational Measurement: Issues and Practice, v. 26, p. 29-37. 2007.

MAIR, P. and R. HATZINGER. Extended rasch modeling: The erm package for the application of irt models in r. Journal of Statistical Software, v. 20(1), p. 1-20. 2007.

MARTIN, A. D.; QUINN, K. M. and PARK, J. H. MCMCpack: Markov Chain Monte Carlo in R. Journal of Statistical Software. v. 42(9), p. 1-21. 2011.

OSHIMA, T. C. The effect of speededness on parameter estimation in item response theory. Journal of Educational Measurement, v. 31(3), p. 200-219. 1984.

PATZ, R. J. and JUNKER, B. W. A straightforward approach to Markov Chain Monte Carlo methods for item response models. Journal of Educactional and Behavioral Statistics, v. 24, p. 146-178. 1999.

RIZOPOULOS, D. ltm: An $\mathrm{r}$ package for latent variable modelling and item response theory analyses. Journal of Statistical Software, v. 17(5), p. 1-25. 2006.

RUPP, A.; DEY, D. K. and ZUMBO, B. To Bayes or Not to Bayes, from Whether to When: Applications of Bayesian methodology to item response modeling. Structural Equations Modeling, v. 11, p. 424-45. 2004.

RTI-FDA. Snapshot of School Management Effectiveness.Peru Pilot Study. 2008, 53p,. EDDATA II. RTI. Available in http://pdf .usaid.gov/pdf_docs/Pnadp642. pdf.

SAHUM, S. K. Bayesian Estimation and Model Choice in Item Response Models. Journal of Statistical Computation and Simulation, v. 72, p. 217-232. 2002.

SINHARAY, S.; JOHNSON, M. S.; and STERN, H. S. Posterior predictiv e assessment of item response theory models. Applied Psychological Measurement, v. 30 , p. $298-321.2006$.

SPIEGELHALTER, D. J.; BEST, N. G.; CARLIN, B. P.; and VAN DER LINDE, A. Bayesian Measures of Model Complexity and Fit. Journal of the Royal Statistical Society, Series B, v. 64(4), p. 583-616. 2002.

STAFFORD, R. E. The speed quotient: A new descriptive statistic for tests. Journal of Educational Measurement, v. 8, p. 275-278. 1971.

STONE, C. A. and ZHU, X. Bayesian Analysis of Item Response Theory Models Using SAS. SAS Institute Inc. Cary, NC, USA. 2015, 265p.

SWAMINATHAN, H.; HAMBLETON, R; SIRECI, S. ; XING, D.; and RIVAZI, S. Small Sample Estimation in Dichotomous Item Response Models: Effect of Priors Based on Judgmental Information on the Accuracy of Item Parameter Estimates. Applied Psychological Measurement, v. 27, p. 27-51. 2003.

VAN DER LINDEN, W. J. A Lognormal Model for Response Times on Test Items. Journal of Educactional and Behavioral Statistics, v. 31, p. 181-204. 2006.

Rev. Bras. Biom., São Paulo, v.undef vo, n.undef no, p.undef pages, undef year 
WANG, X., BERGER, J.O. and BURDICK, D.S. Bayesian analysis of dynamic item response models in educational testing. The Annals of Applied Statistics, v. 7, p. 126-153. 2013.

WOLLACK, J. A. and COHEN, A. S. A model for simulating speeded test data. Technical Report. 2005, 29p. University of Wisconsin-Madison, Madison.

YAMAMOTO, K.; EVERSON, H. (1997). Modeling the effects of test length and test time on parameter estimation using the hybrid model. In Rost, J. and Langeheine, R. (Eds.). Applications of latent trait and latent class models in the social sciences. New York: Waxmann, 1997, p. 89-99.

\section{Appendix}

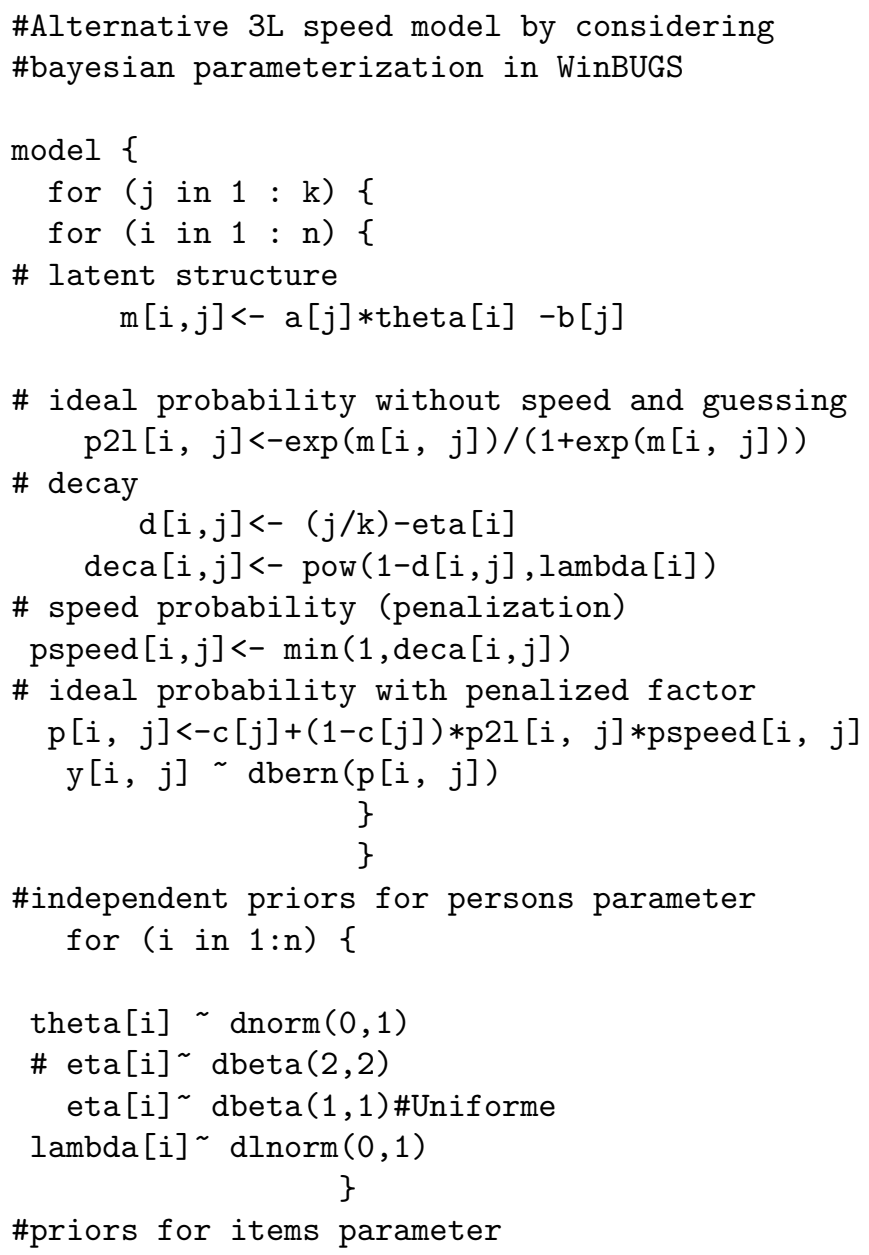




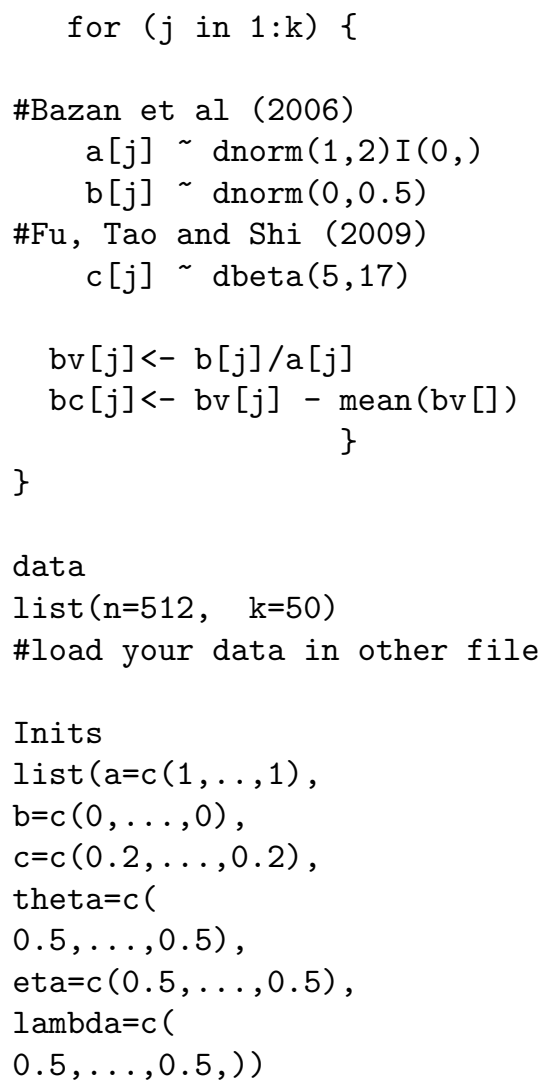

Received in 0x.0x.20xx.

Approved after revised in 0x.0x.20xx. 


\section{Apêndice L}

Flores, S., Azevedo, C. N., e Bazán, J. L. (2016). A skew testlet irt model under a bayesian approach. Submmitted to Brazilian Journal of Probability and Statistics. 


\title{
A Skew Testlet IRT Model under a Bayesian Approach
}

\author{
Sandra Flores ${ }^{1}$, Caio L. N. Azevedo², Jorge Luis Bazán ${ }^{3}$ \\ Universidade de São Paulo, SP, Brazil. ${ }^{1}$ \\ Universidade Estadual de Campinas, Campinas-SP, Brazil. ${ }^{2}$ \\ Universidade de São Paulo, Instituto de Ciências Matemáticas e de Computação, São Carlos-SP, Brazil. ${ }^{3}$ \\ E-mail: jlbazan@icmc.usp.br ${ }^{3}$
}

\begin{abstract}
A critical assumption in Item response theory (IRT) is the conditional independence among item responses, but in many situations this assumption does not hold, like reading comprehension where a set of items is related to a reading passage (testlet). A logistic testlet (LT) model was proposed to overcome these problems by Bradlow et al. (1999). On the other hand, IRT models which consider symmetric item characteristics curves (ICC) can lead to some psychometric inconsistencies, as pointed out by Samejima (2000), which proposed the logistic positive exponent (LPE) IRT model to overcome these problems. These inconsistencies can be also observed when symmetric ICC is used for analyze testlet structures. Inspired by these works, we propose the logistic positive exponent testlet model (LPET), which includes both, the LT and LPE models as a particular versions. Simulation studies show that when a set of responses are in testlet structure and present ICC with asymmetry, parameters of the model are better estimated by using the corresponding LPET model. An application with a real data set from a reading comprehension test showing that the approach is a very promising and flexible way to deal with both the testlet-based test forms and asymmetry in some ICC.
\end{abstract}

Keywords: Item response model, asymmetrical link, Bayesian estimation, logistic positive exponent, testlet-effect. 


\section{Introduction}

Item response theory (IRT) is a standard psychometric approach which comprises sets of models for responses from individuals evaluated in a educational and/or psychological test with a set of items (or another measurement instrument such as psychiatric questionnaires or genetic studies). The IRT models have been extensively used in many fields to analyze the underlying construct that a Test is intended to reflect which is often called the latent variable. As examples, we can cite: educational measurements, clinical variables and gene expression information. IRT models consider such latent characteristics or latent traits, which are related to the individuals (examinees, patients or any other experimental unity), directly in their formulation. Specific examples of latent traits are: the knowledge in some cognitive field, depression level, genetic predisposition in manifesting some disease or concept of democracy in political analysis.

At present, IRT models are very popular and provide a conceptual framework on latent variable modeling originates from psychometrics. Specifically, IRT models to dichotomous responses are based on the idea that the probability of a correct/incorrect response to an item can be modeled by a mathematical function of person and item parameters so called ICC. In many works it is assumed a symmetric ICC as the logistic curve. The person parameter associated with individual is construed considering (usually) a single latent trait or dimension.

It is well know that the IRT models can be quite sensitive to the lacking from the related usual assumptions. Thus, depending on the structure and/or the intrinsic nature of the items and/or persons, different models must be considered in order to take into account these characteristics. Examples of more complex IRT models include: asymmetric behavior of the latent traits distribution, see Azevedo et al. (2011), asymmetric shape of the ICC, see Bazán et al. (2006) or items within a testlet structure, see Wainer and Kiely (1987). In this work we will focus on the models for take into account simultaneously asymmetric shape of the ICC and testlet structure.

The seminal work of Wainer and Kiely (1987) introduced the testlet terminology and defined this as a group of items related to a single content area, developed as a unit. It contains a fixed number of predetermined paths that an individual may follow. Examples of testlets include a set of reading items associated with a common passage, a group of social studies items referring to a map, or a collection of mathematics items based on a graph or a table.

Testlets are an attractive item format for test developers due to their efficiency in both item development and administration. However, the use of testlets poses a challenge to the use of IRT because of the fundamental assumption of conditional or local independence (that is, conditional on the trait of the individual, your response on any particular item is statistically independent from a response to any other item). Item response within a testlets may not be locally independent because they are related through a common stimulus.

In reading comprehension tests, the design of testlets or item bundles have been adopted recently in educational and psychological tests (e.g. Wainer et al. (2007)). Additionally, new applications are being considered, such as in Wang et al. (2010). This is also true in educational assessment systems as PISA study. However this is not take into account in the traditional item response models. Fitting 
standard item response models to analyze result of a testlet ignores a possible dependence among the responses, of the same individual, to the items within the same testlet structure. Therefore, in this case, the using of standard IRT models can lead to inaccurate estimation of individuals and item parameters, and also overestimate the precision (standard errors) of these parameters, see Tuerlinckx and De Boeck (2001). More specifically, as indicated by Wang and Wilson (2005), do not take this dependence into account may lead to overestimate the precision of latent trait obtained from testlets and may yield biased estimates for the difficulty and discrimination item parameters. Furthermore, overestimation of the precision and biased estimation lead to inaccurate inferences about the parameters, see Wainer and Wang (2000).

To overcome this problem, Bradlow et al. (1999) extended the standard ogive normal irt model including additional random effects, besides the latent traits, to model the between-items dependency for items belonging to the same testlet. The variances of the so-called testlet random effects were assumed to be constant across testlets. This model has been successfully used in multiple applications, see Wainer et al. (2007). However, even though this model deals with the absence of local independence in a proper way, it imposes symmetric behavior for both ICC and latent traits distributions. Very often, no one of these assumptions are verified in practice. Particularly, the using of symmetric ICCs may lead to some psychometric inconsistencies as we will discuss below.

On the other hand, the work of Samejima (1997) indicated the need of consider departures from normal (trait) assumptions in developing psychometric theories and methods, indicating that asymmetric item characteristic curves (ICCs) are more appropriate for modeling human item response behavior. In successive papers, see Samejima (1997, 2000), Samejima presented the derivation of a skewed logistic IRT model, named logistic positive exponent (LPE), which considers asymmetric ICCs that can be more appropriate than symmetric ICCs to model IRT data sets. The asymmetric ICCs circumvent some psychometric inconsistencies sometimes observed when symmetric ICCs are used. One feature of symmetric ICCs is that both correct and incorrect responses are considered symmetrically. However, this leads to a logical contradiction in the ordering of individuals in the trait or latent variable under study. The works of Samejima $(1999,2000)$ shows 32 possible response patterns of five dichotomous items that are arranged in the ascending order of the maximum likelihood estimates of the latent trait for the normal ogive model (which can also occurs when the logistic model is considered), highlighting the following contradiction:

- For five response patterns with only one item was answered correctly, individuals are arranged in the order of difficulty of the item that is answered correctly, and

- For five response patterns with four out of five items were answered correctly, individuals are arranged in the order of easiness of the item that is not answered correctly.

As was pointed out by Samejima $(1997,2000)$, this ordering is contradictory. As indicated by Samejima (2000), the contradiction in the rank response patterns does not exist in the LPE model. The LPE model includes the logistic IRT model (L) as a special case, so it is more flexible, by allowing either symmetric (logit) ICCs either asymmetric (skew-logit) ICCs (links) for modelling the probability of correct answer. However, the using of LPE model is based on the assumption of local independence. 
Therefore, it is not suitable to analyze psychometric data sets related to test composed by testlets. Very often, the response process to the items belonging to testlets within a test should be modeled by asymmetric ICCs, as the data set we considered in this paper. However, no one of these two models (testlet and LPE) take into account the lacking of local independence and the asymmetric behavior of the ICC simultaneously.

In order to overcome this problem, we propose a LPE version of the testlet model proposed by Bradlow et al. (1999), named here tesltet LPE (LPET) model, and develop a Bayesian approach for parameter estimation through an MCMC algorithm. Also, we discuss some aspects concerning the interpretation of model parameters as well as the corresponding ICC. Since the LPE model have not been studied in detail in the literature, we also performed a sensitivity analysis to the choice of prior distribution to the new item parameter to the LPE model and verify the quality of parameter recovery of the MCMC algorithm developed to the LPET model analyzing the robustness of the LPE model under testlets structure. Finally, we compare our model with some competing models in a application related to a reading test with a testlet structure.

The paper is organized as follows. In Section 2 we introduce the LPET IRT model. In Section 3, we deal with Bayesian inference of this model. In section 4 , we report the results of two simulation studies. In the first study, we develop a sensitivity analysis to explore three different prior distributions for the penalty parameter in the LPE model. In the second study, we measure the quality of parameter recovery in the LPET model. An application is presented in Section 5 illustrating the usefulness of our model by comparing it with other IRT models to analyze a real data set. For model comparison, we consider the deviance information criterion (DIC) as presented in Spiegelhalter et al. (2002) and other model comparison criteria presented in Bolfarine and Bazán (2010). The paper ends with concluding remarks in Section 6.

\section{Logistic Positive Exponent Model with Testlets}

\subsection{The LPE model}

Let $Y_{i j}$, the answer of individual $i$ to item $j$, be a Bernoulli random variable, with 1 indicating a correct answer and 0 otherwise. Then the LPE model can be written as

$$
\begin{gathered}
Y_{i j} \mid \theta_{i}, a_{j}, b_{j}, d_{j} \sim \operatorname{Bernoulli}\left(p_{i j}\right) \\
p_{i j}=P\left(Y_{i j}=1 \mid \theta_{i}, a_{j}, b_{j}, d_{j}\right)=F_{d_{j}}\left(m_{i j}\right)=\left[\Psi\left(m_{i j}\right)\right]^{d_{j}} \\
m_{i j}=a_{j}\left(\theta_{i}-b_{j}\right), \\
i=1, \ldots, n ; j=1, \ldots, k
\end{gathered}
$$

where $p_{i j}$ is the conditional probability of the event $Y_{i j}=1$ (correct response), $\Psi()=.\exp () /.(1+$ $\exp ()$.$) is the cumulative density function (cdf) of the logistic distribution, m_{i j}$ is a latent linear predictor with $a_{j}$ and $b_{j}$ being parameters associated with the items (called discrimination and difficulty parameters, respectively), and $\theta_{i}$ is the latent variable or latent trait associated with the individual $i$. 
In addition, $d_{j}>0$ is named the penalty parameter. Note that when $d_{j}=1$, the logistic ICC is obtained as a particular case and the ICC is symmetric around $\left(b_{j}=0.5\right)$.

The strength of the LPE model is that it provides asymmetrical curves when $d_{j} \neq 1$. The ICC have a inflection point at $\left(\theta_{0}, \Psi\left(\theta_{0}\right)^{d_{j}}\right)$, where $\theta_{0}=b_{j}+\frac{\log \left(d_{j}\right)}{a_{j}}$.

Figure 1 displays several ICCs with $a_{j}=1, b_{j}=0$ and different values for $d$. As in the usual symmetric IRT model, the parameters $a_{j}$ and $b_{j}$ are called discrimination (or slope) item parameter and difficulty (or intercept) item parameter, respectively. A steeper item response curve corresponds to an item that highly discriminates between a individual with small value and a individual with high value of the latent trait. Thus, the item parameter $a_{j}$ represents the degree to which the item discriminates between individuals in different regions on the latent trait. This parameter characterizes the slope of the ICC where the slope is at its maximum. An item with a small value of $a_{j}$ is a relatively poor discriminator between latent trait of individuals. Moreover, an item of a test with a highly negative value of $b_{j}$ corresponds to an easy item in which individuals with small values of the latent variable show relatively high probabilities of correct responses. In contrast, an item with a large value of $b_{j}$ is a difficult one, since individuals with high levels of the latent trait present low probabilities of correct responses.

In LPE model, for $d=1$, the ICC corresponds to the L model. For $0<d<1$ (or $d>1$ ), the ICC of LPE model is either above (below) with respect to the ICC of the L model. In LPE, the ICC follows the principle of penalizing failure in solving an easy item when $0<d_{j}<1$ (also it is considered that the item is less complex), whereas it follows the opposing principle; that is, greater credit is given for solving a more difficult item when $d_{j}>1$ (also, it is considered that the item is more complex). As indicated in Bolfarine and Bazán (2010), it is expected that the ICC for a less complex task assumes higher probabilities of success than that for a more complex task or level of demands in a task. Then when $0<d_{j}<1$, the penalization of failure in completing an item will be more emphasized than giving a credit to the accomplishment of the task. On the other hand, when $d_{j}>1$ credit to those who have passed the criterion will be more emphasized than penalizing failure in qualifying.

On the other hand, the item shape parameter $d_{j}$ can be psychometrically interpreted as a penalty (reward) on the probability of correct response. Hence, an item with $0<d_{j}<1$ parameter penalizes students with high values of the latent trait and an item with penalty parameter $d_{j}>1$ rewards individuals with small values of the latent trait (see Figure 1). This shape parameter $d_{j}$ is typically called the acceleration parameter, in the sense that this will accelerate the point (value) theta at which the slope or discrimination power of the ICC becomes greatest.

\subsection{Extending the LPE model by considering testlets}

To overcome the problems of using traditional IRT models with testlets, Bradlow et al. (1999) proposed to retain the item as the unit of measurement and add a person-specific random effect parameter, to account for the shared variance among items within a testlet. This quantity is called the testlet effect parameter and is denoted by $\gamma_{i l}$.

In order to extend the LPE model to consider testlets, the following modification of the latent linear component presented in (1) is considered 


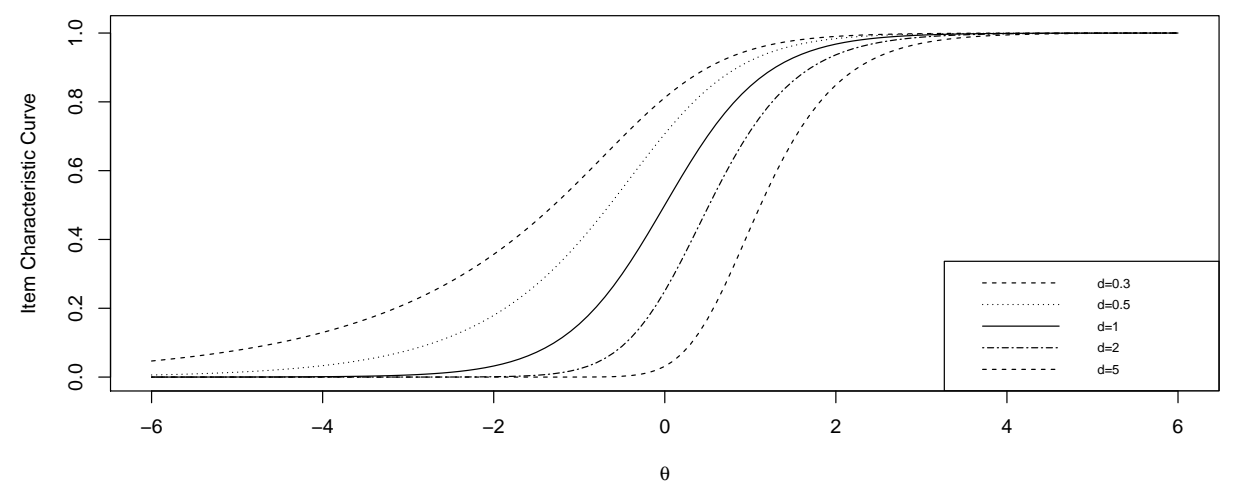

Figure 1: ICC of the LPE model with $a_{j}=1, b_{j}=0$ and $d=0.3,0.5,1,2,5$

$$
m_{i j}=a_{j}\left(\theta_{i}-b_{j}-\gamma_{i l}\right), i=1, \ldots, n, j=1, \ldots, k, l=1, \ldots, t,
$$

where $\gamma_{i l}$ is a person-specific testlet effect or the random effect for person $i$ on testlet $l$ assumed to be normally distributed:

$$
\gamma_{i l} \sim N\left(0, \sigma_{\gamma_{l}}^{2}\right) .
$$

Thus, as indicated in Wang and Wilson (2005) $\gamma_{i l}$ describes the interaction between persons and items (local item dependence) within the testlet and for each testlet is given its own specific variance $\sigma_{\gamma_{l}}^{2}$ which indicates the amount of the testlet effect for testlet $l$.

The LPET model not only handle with the absence of local independence but also circumvents the psychometric inconsistencies related to symmetric ICC. Note that the several nested models can be obtained. Two-parameter testlet model proposed by Bradlow et al. (1999) named here LT model, one-parameter Rasch testlet model proposed by Wang and Wilson (2005), LPE model and the usual two-parameter logistic model named here L model.

\section{$3 \quad$ Bayesian Inference}

The likelihood for the LPET model is given by

$$
L(\boldsymbol{\beta}, \boldsymbol{\theta}, \boldsymbol{\gamma} \mid \boldsymbol{y})=\prod_{i=1}^{n} \prod_{j=1}^{k}\left[F_{d_{j}}\left(m_{i j}\right)\right]^{y_{i j}}\left[1-F_{d_{j}}\left(m_{i j}\right)\right]^{1-y_{i j}},
$$

where $\boldsymbol{\beta}=\left(\boldsymbol{a}^{\prime}, \boldsymbol{b}^{\prime}, \boldsymbol{d}^{\prime}\right)^{\prime}, \boldsymbol{a}=\left(a_{1}, \ldots, a_{k}\right)^{\prime}, \boldsymbol{b}=\left(b_{1}, \ldots, b_{k}\right)^{\prime}, \boldsymbol{d}=\left(d_{1}, \ldots, d_{k}\right)^{\prime}, m_{i j}$ is the latent linear predictor in (3) and $F_{d_{j}}\left(m_{i j}\right)$ is the cdf defined in (1), indexed by $d_{j}$ and evaluated at $m_{i j}$. In addition, $\boldsymbol{\theta}=\left(\theta_{1}, \ldots, \theta_{n}\right)^{\prime}$ and $\boldsymbol{\gamma}=\left(\gamma_{11}, \ldots, \gamma_{i l}, \ldots \gamma_{n t}\right)^{\prime}$.

In this paper, we adopt mainly the fully Bayesian view, i.e., we estimate all parameters simultaneously, instead of using a two step approach (as in the marginal maximum likelihood and marginal 
Bayesian approaches, see Baker et al. (2011)). The reason for this is that several researchers have demonstrated that accurate estimation of the item parameters in small samples can only be accomplished through a fully Bayesian approach, as indicated by Swaminathan et al. (2003). Both marginal maximum likelihood and marginal Bayesian procedures totally rely on large sample theory. However, even for a large number of individuals, accurate results may not be obtained due to the presence of incidental parameters. One uses these approaches typically to separate the estimation of item and person parameters, making the estimation process, sometimes, easier. However, there is no way to jointly evaluate the precision of the estimates (both latent traits and item parameters), see Patz and Junker (1999). This estimation procedure is usually implemented through a pseudo EM type algorithm such that the one given by Bock and Aitkin (1981). On the other hand, such problems do not occur with the fully Bayesian approach, in which, for a large number of individuals, the prior distribution has little effect on the posterior distribution, see Sinharay and Johnson (2003). Also, the literature presents empirical evidence in favour of the fully Bayesian approach compared with marginal methods, see Azevedo et al. (2012).

\subsection{Prior specification}

Prior specification is an important step in Bayesian analysis. It is even more important when one has to analyze data sets with small number of observations and then, the posterior distribution represents more of a compromise between the observed data and previous personal opinion. For data sets with a large number of observations, it has less importance since the data typically dominates the posterior (information) distribution. However, it is still usefull, since the bayesian estimates lie always in the parametric space.

In the IRT literature it is usually assumed that $\theta_{i} \sim N\left(\mu, \sigma^{2}\right)$ for $i=1, \ldots, n$, even though other distributions have been considered, see Azevedo et al. (2011), for example. On the other hand, some prior distributions have been investigated for the item parameters $a_{j}$ and $b_{j}$ Rupp et al. (2004). Empirical evidence, for example that presented by Patz and Junker (1999), indicates the presence of posterior correlation between the item parameters of the same items. However, it is not an easy task to assign a multivariate prior distribution with a suitable covariance structure. Hence, we considered usual prior distributions, mutually independent, for $\boldsymbol{a}, \boldsymbol{b}$ and $\boldsymbol{d}$. That is,

$$
\pi(\theta, \mathbf{a}, \mathbf{b}, \mathbf{d}, \gamma)=\prod_{i}^{n} g\left(\theta_{i}\right) \times \prod_{j}^{k} \pi_{1}\left(a_{j}\right) \pi_{2}\left(b_{j}\right) \pi_{3}\left(d_{j}\right) \times \prod_{l}^{t} \prod_{j}^{k} \pi_{4}\left(\gamma_{i l}\right) .
$$

where $g($.$) is the density of the normal distribution with mean \mu$ and variance $\sigma^{2}$ and $\pi_{1}(),. \pi_{2}(),. \pi_{3}($. are the prior distributions for parameters $a_{j}, b_{j}$ and $d_{j}$, respectively. Although some authors, such as Albert (1992) and Fox and Glas (2001), use improper noninformative priors for the traditional item parameters $a_{j}$ and $b_{j}$ such as $\pi_{1}\left(a_{j}\right) \pi_{2}\left(b_{j}\right)=I\left(a_{j}>0\right)$, we prefer consider proper priors for the discrimination parameters $\left(a_{j}\right)$, since the existence of the joint posterior distribution is not guaranteed when an improper prior is used (see Albert and Ghosh (1999)).

Several informative distributions for $a_{j}$ have been proposed in the literature, for example: a) Bradlow et al. (1999) and Albert (1992) use the $N\left(\mu_{a}, \sigma_{a}^{2}\right)$ distribution with and without hyperparameter 
distributions specified for $\mu_{a}$ and $\sigma_{a}^{2}$, respectively; b) Kim et al. (1994) and Patz and Junker (1999) use the $L N\left(\mu_{a}, \sigma_{a}^{2}\right)$ distribution with and without hyperparameter distributions specified for $\mu_{a}$ and $\sigma_{a}^{2}$, respectively, where $L N($.$) is the log-normal distribution, c) Sahu (2002) use the T N\left(\mu_{a}, \sigma_{a}^{2}\right) I(0, \infty)$ where $T N() I.(0, \infty)$ is the truncated-normal distribution with known values for $\mu_{a}$ and $\sigma_{a}^{2}$, and finally, d) Swaminathan and Gilford (1985) use the $I G(r, s)$, that is, the inverse gamma distribution with (known) hyperparameters $s$ and $r$ such that $E(a)=\frac{1}{(s-1) r}$. We consider in this paper the specifications presented in item b) since $a_{j}>0$ and also to obtain conditional conjugacy for the full conditional distributions.

When independent informative priors are considered for the item parameters, the usual choice for the parameter $b_{j}$ is $N\left(\mu_{b}, \sigma_{b}^{2}\right)$. Usually since little prior information is available about the difficulty parameter, one can choose $\sigma_{b}^{2}$ to be large. As mentioned in Albert and Ghosh (1999) for the logistic IRT model, this choice will have a modest effect on the posterior distribution, and it will result in a proper posterior distribution when extreme data (all items are correctly answered or all items are incorrectly answered by the individuals) are observed. Thus, vague priors can be also admissible for the difficulty parameter.

In this paper, we set the hyperparameters $\left(\mu, \sigma^{2}, \mu_{a}, \sigma_{a}^{2}, \mu_{b}, \sigma_{b}^{2}\right)$ in specific values. However, in more general situations, the prior structure needs to be enlarged so that hyperprior information can also be considered for those parameters Fox (2010).

In contrast with the extensive available literature related to prior choice for the traditional item parameters (in our case, $a_{j}$ and $b_{j}$ ), there is not much work about prior specification for $d_{j}$ parameter. Bolfarine and Bazán (2010) consider exchangeable prior gamma distributions dor $d_{j}$ parameters, that is $d_{j} \stackrel{\text { ind. }}{\sim} \operatorname{gamma}(s, r), j=1, \ldots, k$ where $\operatorname{gamma}(s, r)$ corresponds to a gamma distribution with parameters of shape $s$ and rate $r$ and $E\left(d_{j}\right)=s / r$. In this paper, we explore the using of two other priors. Besides the suggestion of Bolfarine and Bazán (2010), we consider $d_{j} \sim L N\left(\mu_{d}, \sigma_{d}^{2}\right)$ or equivalently $u=\ln \left(d_{j}\right) \sim N\left(\mu_{d}, \sigma_{d}^{2}\right)$ and $d=(1+u) /(1-u)$ with $u \sim U\left(\mathrm{a}_{d}, \mathrm{~b}_{d}\right)$ where $U\left(\mathrm{a}_{d}, \mathrm{~b}_{d}\right)$ corresponds to a uniform distribution between $\mathrm{a}_{d}$ and $\mathrm{b}_{d}$. For all these prior distributions the hyperparameters are fixed in suitable values.

Finally, the testlet-effect parameters are assumed to be normally distributed, and for each testlet is given its own specific variance

$$
\gamma_{i l} \sim N\left(0, \sigma_{\gamma_{l}}^{2}\right) .
$$

The testlet effects can be centered at zero to emphasize their status as deviations from the LPE model and to identify the model. On the other hand $\sigma_{\gamma_{l}}^{2}$ indicates the amount of the testlet effect for testlet $l$. It can be fixed or a prior structure needs to be enlarged so that hyperprior information can also be considered for $\sigma_{\gamma_{l}}^{2}$. For example Bradlow et al. (2002) and Bradlow et al. (1999) consider $\sigma_{\gamma_{l}}^{2} \sim I G(s, r)$ or equivalently precision $v_{\gamma_{l}}=1 / \sigma_{\gamma_{l}}^{2} \sim \operatorname{gamma}(s, r)$ with values of $s=0.25$ and $r=0.5$ which are equivalent to $v_{\gamma_{l}}=1 / \sigma_{\gamma_{l}}^{2} \sim \chi^{2}(0.5)$. 


\subsection{MCMC Bayesian estimation}

Considering the likelihood presented in equation (3) and the general prior specification given in (4), Bayesian estimation or the testlet LPE model can be implemented by using Markov chain Monte Carlo methods, which make simple to implement efficient (approximate) sample from the joint posterior distribution from which marginal posterior distributions can be obtained, since it is not possible to obtain them analytically.

Hierarchically, the model specification is given as follows:

$$
\begin{aligned}
y_{i j} \mid a_{j}, b_{j}, \theta_{j}, d_{j}, \gamma_{i l} & \sim \operatorname{Ber}\left(F_{d_{j}}\left(a_{j}\left(\theta_{i}-b_{j}-\gamma_{i l}\right)\right)\right) \\
\gamma_{i l} & \sim N\left(0, \sigma_{\gamma_{l}}^{2}\right) ; \\
\theta_{i} & \sim N\left(\mu, \sigma^{2}\right), \\
a_{j} & \sim L N\left(\mu_{a}, \sigma_{a}^{2}\right), \\
b_{j} & \sim N\left(\mu_{b}, \sigma_{b}^{2}\right) \\
d_{j} & \sim \pi(d) \\
v_{\gamma_{l}}=1 / \sigma_{\gamma_{l}}^{2} & \sim \operatorname{gamma}(s, r) .
\end{aligned}
$$

Particular models are obtained easily of the hierarchical structure above. For example, to the twoparameter testlet model prior specification to $d_{j}$ is unnecessary. In addition, to the one-parameter Rasch testlet model prior specification to $a_{j}$ is unnecessary too. On the other hand, prior specification to testlet effects when the two-parameter model is assumed also is unnecessary.

For the hyperparameters, usual values found in the literature of the two-parameter model were considered: $\mu=0, \sigma^{2}=1, \mu_{a}=0, \sigma_{a}^{2}=0.25, \mu_{b}=0, \sigma_{b}^{2}=1$. To testlet effect, we consider $s=0.1$ and $r=0.1$ implying that $E\left(v_{\gamma_{l}}\right)=1$ and $V\left(v_{\gamma_{l}}\right)=10$.

in simulation studies we set $s=4$ and $r=2$, implying that is expected a precision of $E\left(v_{\gamma_{l}}\right)=2$ and $V\left(v_{\gamma_{l}}\right) \equiv 1$ and consequently more accurate values can be obtained since that we known the value of the parameter, whereas in the applieation set $s=3$ and $r=1$, implying that $E\left(v_{\gamma_{l}}\right) \equiv 3$ and $V\left(v_{\gamma_{l}}\right)=3$ and consequently more vague values in correspondence with our greatest ignorance about these parameters. In this case more uncertainty is assumed in the prior specification since this is unknown.

Since a sensitivity analysis to explore the three different priors proposed for $d$ in the LPE model will be easily done, hyperparameter values are later presented.

The implementations of the Bayesian approach using the hierarchical structure above can easily be obtained in WinBUGS or PROC MCMC of SAS. However, it is possible the implementation directly in R or Matlab using a procediment similar as the described in Patz and Junker (1999) obtaining complete conditional distributions to the parameters in the model.

Indeed, all computational implementation in the simulation studies and in the application were done through R2Winbugs. In this case, a Rejection Sampling within Gibbs, with target densities logconcave being made automatically (Gliks, 1992), is the method implemented in BUGS software as was 
pointed out by Patz and Junker (1999)). In order to verified this procediment, we consider also the Hamiltonian Monte Carlo using the no-U-turn sampler as implemented in (Stan Development Team , 2015) obtaining similar results. In addition, simulations in section 4, were conducted to evaluate its parameter recovery of the LPET model using our code. In summary, the parameter recovery of the LPET model was satisfactory. The code is available upon request.

In order to use MCMC, to LPE model we simulated two independent chains with 20000 iterations, considering 5000 as the burn-in, and to avoid autocorrelation, we considered a thin of 5 . To complex models as LPET and LT, is suggested consider a number higher of iterations (Sinharay , 2004), then we consider two independent chains with 40000 iterations, considering 10000 as the burn-in, and thin of 10. Convergence criteria given by Geweke (1992) indicated that the MCMC chains converged to all the models under analysis.

\subsection{Model comparison criteria using MCMC outputs}

There are several criteria suitable for model comparison under the Bayesian paradigm. One of the most used criterion is the deviance information criterion (DIC) proposed by Spiegelhalter et al. (2002). This criterion is based on the posterior mean of the deviance: $E[D(\boldsymbol{a}, \boldsymbol{b}, \boldsymbol{d}, \boldsymbol{\theta}, \boldsymbol{\gamma})]$, where

$$
D(\boldsymbol{a}, \boldsymbol{b}, \boldsymbol{d}, \boldsymbol{\theta}, \boldsymbol{\gamma})=-2 \ln (p(\boldsymbol{y} \mid \boldsymbol{a}, \boldsymbol{b}, \boldsymbol{d}, \boldsymbol{\theta}, \boldsymbol{\gamma}))=-2 \sum_{i=1}^{n} \ln P\left(Y_{i j}=y_{i j} \mid \boldsymbol{a}, \boldsymbol{b}, \boldsymbol{d}, \boldsymbol{\theta}, \boldsymbol{\gamma}\right),
$$

which is also a measure of fit that can be approximated by using the MCMC output, by considering

$$
\operatorname{Dbar}=\frac{1}{G} \sum_{g=1}^{G} D\left(\boldsymbol{a}^{g}, \boldsymbol{b}^{g}, \boldsymbol{d}^{g}, \boldsymbol{\theta}^{g}, \boldsymbol{\gamma}^{g}\right)
$$

where the index $g$ represents the $g$-th realization of a total of $G$ MCMC realizations.

The $D I C$ can be estimated using the MCMC output by considering

$$
\widehat{D I C}=D b a r+\widehat{\rho_{D}}=2 \text { Dbar }- \text { Dhat }
$$

$\rho_{D}$, the effective number of parameters, is defined as

$$
\left.\rho_{D}=E[D(\boldsymbol{a}, \boldsymbol{b}, \boldsymbol{d}, \boldsymbol{\theta}, \boldsymbol{\gamma}))\right]-D[E(\boldsymbol{a}), E(\boldsymbol{b}), E(\boldsymbol{d}), E(\boldsymbol{\theta}), E(\boldsymbol{\gamma})]
$$

where $D[E(\boldsymbol{a}), E(\boldsymbol{b}), E(\boldsymbol{d}), E(\boldsymbol{\theta}), E(\boldsymbol{\gamma}))]$ is the deviance of posterior mean obtained when considering the mean values of the generated posterior means of the model parameters, which is estimated by

$$
\text { Dhat }=D\left(\frac{1}{G} \sum_{i=1}^{G} \boldsymbol{a}^{g}, \sum_{i=1}^{G} \boldsymbol{b}^{g}, \frac{1}{G} \sum_{i=1}^{G} \boldsymbol{d}^{g}, \frac{1}{G} \sum_{i=1}^{G} \boldsymbol{\theta}^{g}, \frac{1}{G} \sum_{i=1}^{G} \boldsymbol{\gamma}^{g}\right)
$$

The model that best fits a data set is that one which presents the smallest value of the posterior mean of the deviance (Dbar) and DIC. 


\section{Studying the robust of LPE model to testlet effects}

\subsection{Sensitivity of LPE model}

Since the LPE model have not been studied in detail in the literature, we have developed a sensitivity analysis to explore the use of following three different priors for $d$ parameter in the LPE model:

- Prior1: $d=\exp (u)$ with $u \sim N\left(\mu_{d}=0, \sigma_{d}^{2}=0.5\right)$

- Prior2: $d=(1+u) /(1-u)$ with $u \sim U\left(\mathrm{a}_{d}=-0.9, \mathrm{~b}_{d}=0.6\right)$

- Prior3: $d \sim \operatorname{gamma}(s=0.25, r=0.25)$

The first prior corresponds to a lognormal distribution. The second is a transformation of the uniform distribution, and the third prior is the gamma distribution, proposed in Bolfarine and Bazán (2010).

We considered a situation where $n=(200,500)$ individuals answered a test with $k=20$ items. It was thought to have a support for the prior selection next of the number of items in the application. The true values of the item parameters were simulated from some specific distributions, i. e., for $a$ and $b$ were used the prior distributions given in Bazán et al. (2006), that is $a \sim N\left(\mu=1, \sigma_{d}^{2}=0.5^{2}\right) I(0, \infty)$ and $b \sim N\left(\mu=0, \sigma^{2}=1\right)$. For $d$ parameters, they were generate from $L N(0,0.5)$. We opt for choose $L N(0,0.5)$ to generate positive values around the number one, more values generated are fewer than one. The latent traits $(\boldsymbol{\theta})$, were generated from a $N\left(\mu=0, \sigma^{2}=1^{2}\right)$ distribution. A total of $\mathrm{R}=50$ replications, i. e., answers of the individuals to the items, were simulated from the LPE model and for each replica, all parameters were estimated using the MCMC algorithm. In order to measure the accuracy of the estimates was considered the following statistic: $M S E(\boldsymbol{\kappa})=\sum_{r=1}^{R} \frac{\left(\hat{\boldsymbol{\kappa}}_{r}-\boldsymbol{\kappa}\right)^{2}}{R}$, where $\hat{\boldsymbol{\kappa}_{r}}$ is the estimate of the correspondent parameter in $\boldsymbol{\kappa}: \boldsymbol{a}, \boldsymbol{b}, \boldsymbol{d}, \boldsymbol{\theta}$.

As summary, we report in Table 1 the mean and standard error (S.E.) of the MSE's of the parameters for each set of parameters, also DIC and time spent for running the MCMC algorithms are showed.

According to the results presented in in Table 1, we can conclude that all priors produce fairly accurate results (verify that larger sample sizes lead to increased precision of the estimates of the parameters). Consequently, we can conclude that the LPE model is not sensitive to the prior specifications for the item parameter $d$. However, we chose the first prior since it produced the smallest spent time and the values of MSE and DIC were quite similar to that ones obtained from the other priors.

\subsection{Absence of robustness of the LPE model under testlets structure}

We have investigated the robustness of the LPE model when testlets effect is considered. To accomplish that, we simulate $R=50$ replicas considering $n=500$ individuals answering a test with $k=20$ items under the LPET model, that is assuming the presence of testlet effect. The selection for $n$ was to have a similar quantity of data that we have in the application. The true values of the item parameters 
Table 1: Results of sensitivity analysis in the LPE model considering different choice of priors to $d$ parameter. Mean squared error (MSE), Deviance Information Criteria (DIC) and time of execution (seconds) are shown to the same simulation conditions

\begin{tabular}{ll|rrrrrr}
\hline & Prior1 & & Prior2 & Prior3 \\
& Mean & S.E. & Mean & S.E. & Mean & S.E. \\
\hline MSE $a$ & 0.083 & 0.014 & 0.088 & 0.015 & 0.091 & 0.017 \\
MSE $b$ & 0.426 & 0.195 & 0.388 & 0.130 & 0.444 & 0.125 \\
$n=200$ & MSE $d$ & 0.263 & 0.105 & 0.279 & 0.100 & 0.720 & 0.257 \\
& MSE $\theta$ & 0.212 & 0.008 & 0.209 & 0.008 & 0.211 & 0.008 \\
DIC & 4235.7 & 14.9 & 4239.7 & 15.0 & 4225.4 & 14.8 \\
& Time spent & 1209.44 & 0.88 & 1780.35 & 1.82 & 1523.61 & 20.76 \\
\hline MSE $a$ & 0.057 & 0.060 & 0.070 & 0.071 & 0.077 & 0.078 \\
MSE $b$ & 0.240 & 0.348 & 0.440 & 0.707 & 0.606 & 0.880 \\
MSE $d$ & 0.230 & 0.301 & 0.323 & 0.425 & 0.508 & 0.763 \\
MSE $\theta$ & 0.213 & 0.081 & 0.214 & 0.080 & 0.214 & 0.081 \\
DIC & 10205.6 & 77.8 & 10214.7 & 77.5 & 10198.4 & 77.0 \\
Time spent & 3959.98 & 536.69 & 5818.17 & 313.01 & 4701.04 & 124.76 \\
\hline
\end{tabular}

and latent traits were again simulated as in the preview subsection, i. e., for $a \sim N\left(\mu=1, \sigma^{2}=\right.$ $\left.0.5^{2}\right) I(0, \infty)$ as in Bazán et al. (2006), $b \sim N\left(\mu=0, \sigma^{2}=1\right)$. and $d \sim L N(0,0.5)$ considering the prior specification choose in Section 4.1. The latent traits $(\boldsymbol{\theta})$, were generated from a $N\left(\mu=0, \sigma^{2}=1\right)$ distribution. In addition, the simulated reading test was fixed to $t=4$ testlets with $\sigma_{\gamma}^{2}=\sqrt{0.4}^{2}$. The test structure was the following: testlet 1 : items 23 , and 4; testlet 2: items 56 , and 7; testlet 3 : items 89, 10 and 11; testlet 4: items 1213,14 and 15 with the items 1, 16171819 and 20 being independent items.

Then we have adjusted the LPE model, without testlet effect, the LT model, without penalty parameters and LPET considering both effects for each replica.

To evaluate the results, we calculated the posterior coverage probability $(\mathrm{PCP})$, that is, the proportion of the times that the posterior credible interval contains the true value for each set of parameters $\boldsymbol{\kappa}=(\boldsymbol{a}, \boldsymbol{b}, \boldsymbol{d}, \boldsymbol{\theta})$ along the replications. As summary, we report in Table 2 the mean and standard error (S.E.) of the CP's of the parameters for each set of parameters. In addition, we calculated the mean and S.E of DIC over the replicas, for each fitted model.

By inspecting Table 2 we can conclude that the parameter recovery in the LPE model in less accurate than in the LPET model to the parameters $a, b, \theta$ and similar in to $d$ parameters indicating that the LPE is slightly sensitivity to the presence of a testlet structure and consequently when data present testlets effect the LPE is not robust. In addition, we found that the mean of DIC in the LPET model was 11295.3 and the mean of DIC in the LPE model was 11460.6 indicating, as expected, that the LPET model is the adequated model under the presence of a testlet structure. Also, since that DIC 
was calculate for both models, we found that in all cases the best model was the LPET by considering the DIC value. Also, using information in Table 2 we can conclude that the parameter recovery in the LT model in less accurate than in the LPET model to the parameters $a, b$ and $x x x$ and similar in to $\theta$ parameters indicating that the LT is slightly sensitivity to the presence of a penalty item and consequently when data present penalization the LT is not robust. Note as the PCP is inadequatly recovery to the $b$ parameter. Also we found that the mean of DIC in the LPET model was 11295.3 and the mean of DIC in the LT model was 11265.5 indicating, that this criteria is not adequate to choose of correct model to this data. Also, since that DIC was calculate for both models, we found that in all cases the best model was the LPET by considering the DIC value.

Therefore, we can rely on the DIC criteria, for model selection within the LPET model framework. Thus, simulation studies show that when a set of responses are in testlets structure and present penalty in some items, parameters of the model are better estimated by using the corresponding LPE testlet model and DIC is a adequate model comparison criteria to choose this model as the best model to the data under analyze.

Table 2: Posterior coverage probability (PCP) for true parameters and Deviance Information Criteria (DIC) for LPET and LPE models considering 50 replicates of test following the LPET model

\begin{tabular}{lrrrrrr}
\hline & \multicolumn{2}{c}{ LPET } & \multicolumn{2}{c}{ LPE } & \multicolumn{2}{c}{ LT } \\
& Mean & S.E. & Mean & S.E. & Mean & S.E. \\
\hline $\mathrm{CP} a$ & 0.874 & 0.063 & 0.842 & 0.068 & 0.747 & 0.075 \\
$\mathrm{CP} b$ & 0.966 & 0.028 & 0.963 & 0.031 & 0.173 & 0.067 \\
$\mathrm{CP} d$ & 0.938 & 0.048 & 0.939 & 0.049 & & \\
$\mathrm{CP} \theta$ & 0.948 & 0.003 & 0.924 & 0.004 & 0.947 & 0.003 \\
$\mathrm{CP} \sigma^{2}$ & 0.950 & 0.024 & & & 0.950 & 0.030 \\
DIC & 11295.3 & 13.8 & 11460.6 & 13.0 & 11265.5 & 13.6 \\
Number of times as best model & 0 & & 0 & 0 & 50 & \\
AIC & 11454.0 & 17.1 & 12114.6 & 13.4 & 11469.8 & 17.1 \\
Number of times as best model & 50 & & 0 & & 0 & \\
BIC & 15491.8 & 17.1 & 16152.4 & 13.4 & 15507.6 & 17.1 \\
Number of times as best model & 50 & & 0 & & 0 & \\
\hline
\end{tabular}

\section{Application}

In this section we present an application of all IRT models earlier discussed (L, LT, LPE, LPET models) in a real data set analysis. The main goal of this study is to compare the performance of these four models in terms of parameter estimation and quality of goodness of fit. Specifically, we have interest in known if there is a testlet effect or using of a penalty parameter different of one, or both aspect are observed in a data set.

We consider an analysis on the response pattern obtained by the application of a text comprehen- 
sion test presented to second grade students in Peruvian elementary schools, conduced by the Ministry of Education of the country, which is part of the Census Evaluation Test (ECE in the Spanish initials), as presented in Minedu (2009).

The ECE Spanish explores the processes used by students to interpret a text in common communication situations. The ability assessed in the ECE correspond to those that is considered most relevant for other learning, and is evaluated on a large scale. For this study we consider the form 1 of the Test consisting of 23 items applied in 2010 to a control sample. This test is made up of five testlets. The test structure was the following: testlet 1 : items $3,4,5$, and 6 ; testlet 2 : items $7,8,9$ and 10; testlet 3: items 12 and 13; testlet 4: items 14,15,16,17 and 18; testlet 5: items 19,20,21,22, and 23 with the items 1,2 and 11 being independent items.

In order to illustrate the developed methodology, we considered the item response vectors of 730 students from Lima district, recorded as binary responses (correct or incorrect). For this data set, the test presents a high reliability index, given by a Cronbach's alpha of 0.80 . See by example Henson (2001). The data set is available from the authors upon request.

The Bayesian approach, described in Section 3.2, was considered for fit the L, LT, LPE and LPET models including the priors described in this section and prior to $d$ parameter used in section 4.1. Also, as indicated above, two chains each one with 20000 iterations, discarding 5000 of them as burn-in, and to avoid correlation problems we considered a spacing of size or thinness equal to 5 . Efficiency by using effective sample sizes above of 0.9 were obtained. In addition, convergence criteria given by Geweke (1992), as implemented in CODA, were achieved.

Considering the results presented in Table 3, using DIC and Dbar criteria, we found that the models LPE, LT and LPET, present better fit to the ECE Spanish than the traditional L model. Also, we found that testlet models (LT and LPET) were selected as best models that models without testlets ( $\mathrm{L}$ and LPE) confirming the presence of the teslet effect in the data set. In addition, we have found that LPET model presents a similar fit to the LT model (Dbar statistics selected the LPET model whereas DIC selected the LT model).

Table 3: Model comparison criteria for testlet LPE model and alternative models

\begin{tabular}{c|rrrr}
\hline Model & Dbar & Dhat & DIC & $\mathrm{pD}$ \\
\hline L & 13796.2 & 13207.1 & 14385.2 & 589.1 \\
LPE & 13773.1 & 13160.0 & 14386.2 & 613.1 \\
LT & 13132.3 & 12088.7 & 14175.8 & 1043.5 \\
LPET & 13128.9 & 12056.3 & 14201.3 & 1072.5 \\
\hline
\end{tabular}

In order to compare the LT and LPET models to analyze the data set, we consider a more detailed study considering the behavior of the items. To the ECE test considering LPET we give the value of penalty parameter including HPD interval to four items with evidence about of existence of a penality parameter different of one. See also the Figure 2. Thus, testlet 1: item 5: $d=0.49(0.12-0.94)$, testlet 2: item 7: $d=0.39(0.13-0.82)$, testlet 3 : item $12: d=0.47(0.15-0.95)$ and item 1 : $d=0.35(0.04-0.78)$ being independent and consequently the ICC follows the principle of penalizing failure in solving an easier item when $0<d<1$ (also it is considered that these items are less complex). 
Thus, considering this results we prefer the LPET model to ECE data.

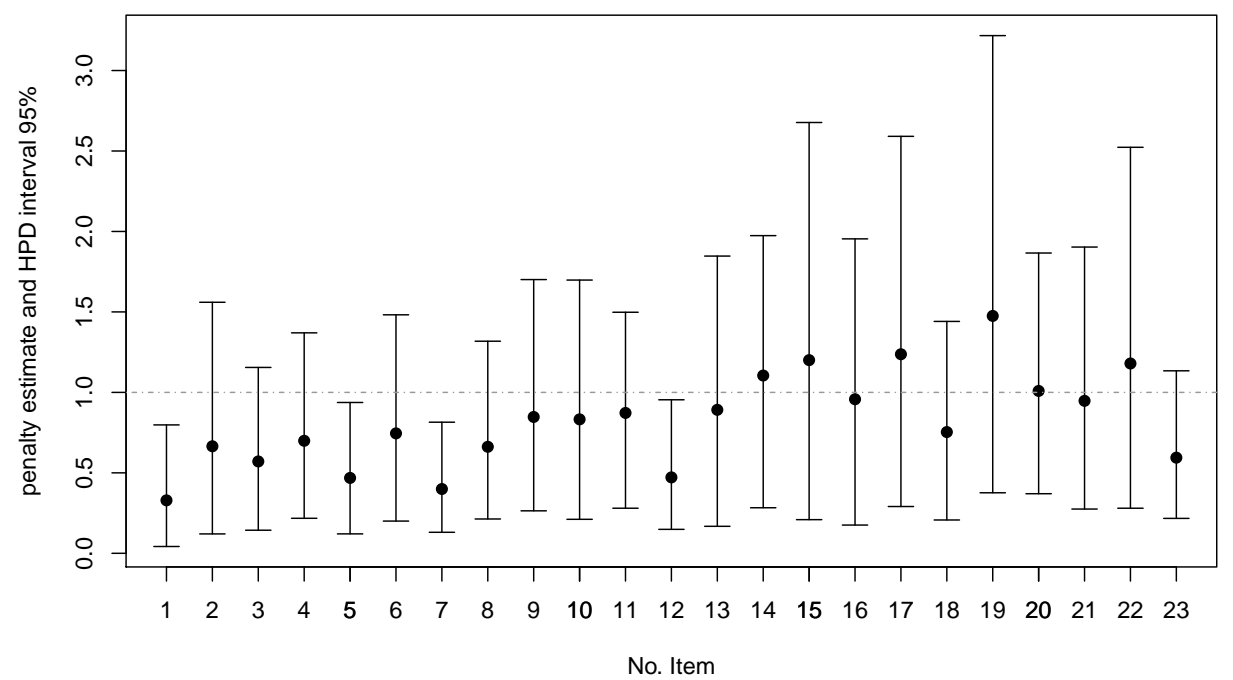

Figure 2: Box-plots for Bayesian estimates of penalty parameter obtained through the LPET models for ECE data

Additionally choose two of the items with evidence of a penalty parameter different of one, they are the item 12 and 7, then choose two items without evidence of a penalty parameter different of one, they are items 16 and 2. Then, we compare the Bayesian posterior expectations for these item parameters obtained through both models in Table 4.

Table 4: Posterior mean of item parameters to some items in ECE test under LT and LPET models

\begin{tabular}{cccccc}
\hline $\begin{array}{c}\text { Penalty } \\
\text { evidence }\end{array}$ & Item & Model & $\begin{array}{c}\text { Discrimination } \\
a\end{array}$ & $\begin{array}{c}\text { Difficulty } \\
b\end{array}$ & $\begin{array}{c}\text { Penalty } \\
d\end{array}$ \\
\hline Not & 16 & LT & $0.672(0.48,0.82)$ & $0.466(0.18,0.73)$ & 1 \\
& & LPET & $0.671(0.47,0.92)$ & $0.277(-1.34,1.70)$ & $0.946(0.18,1.95)$ \\
Not & 2 & LT & $1.571(1.08,2.07)$ & $-1.038(-1.50,-0.64)$ & 1 \\
& & LPET & $1.457(1.02,1.96)$ & $-1.184(-1.97,-0.34)$ & $0.696(0.12,1.56)$ \\
Yes & 12 & LT & $0.601(0.44,0.78)$ & $-0.957(-1.56,-0.43)$ & 1 \\
& & LPET & $0.581(0.36,0.81)$ & $0.040(-1.57,1.52)$ & $0.466(0.15,0.95)$ \\
Yes & 7 & LT & $0.657(0.48,0.84)$ & $-1.285(-1.95,-0.68)$ & 1 \\
& & LPET & $0.609(0.39,0.83)$ & $-0.188(-1.67,1.13)$ & $0.386(0.13,0.82)$ \\
\hline
\end{tabular}

We found that the estimates of discrimination and difficulty parameters are rather similar in both models when there is not penalty evidence, and are different when there is penalty evidence. For example, item 12 under the LPET model can be considered as an item with an averaged difficulty 
and low penalty but under the LT model, it can be considered as an easy item without penalty. This result, is coherent with the find of Bofarine and Bazán (2010) to item with penalty evidence (see item 2 in these work). In this case, althought penalization and difficulty parameter are related, they are differents. Penalization is associates with item complexity and when it is identified, it is separated of the difficulty, then an iten initially considered easy under LT model is now considered not easy because it is complex under LPET model. In this case results on Table 4 shows that for data with testlet stucture one could arrive to a wrong interpretation of the difficulty parameter when penalization parameter is not considered.

On the other hand, in Figure 3 it is shown the scatter plots between the Bayesian posterior expectations of the ability estimated or trait latent obtained through the L and LPET models. The $(0,1)$ line is added as reference. When we compared both cases, we found many points above $(0,1)$ line (59.7\% of the cases) and consequently more overestimation in the abilities. That is the overestimation of the abilities when considered an L model in relation to LPET model. Note also, that this is more evident for lower abilities on the left of the figure. This fact suggest that the overestimation effect for abilities when the existence of testlets is ignored is also detected when the LPET model is assumed to the ECE test.

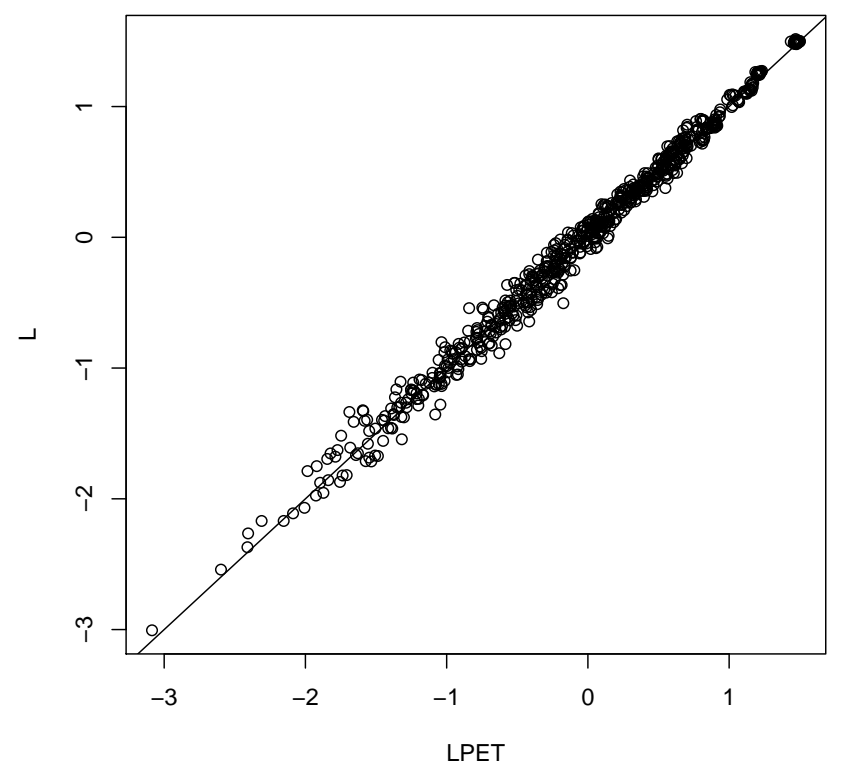

Figure 3: Scatter plots for Bayesian estimates of trait obtained through the L vs. LPET models for ECE data

Bayesian posterior expectations of the testlet variances including HPD interval under LPET are testlet 1: $\sigma_{\gamma_{1}}^{2}=0.15,(0.02,0.34)$; testlet $2: \sigma_{\gamma_{2}}^{2}=0.12,(0.03,0.26)$; testlet $3: \sigma_{\gamma_{3}}^{2}=0.30,(0.05,0.71)$; testlet $4: \sigma_{\gamma_{4}}^{2}=0.48,(0.26,0.76)$ and testlet $5: \sigma_{\gamma_{5}}^{2}=0.38$, HPD interval $=(0.19,0.58)$; indicating a 
effect of testlet specially in testlet 4 . The interpretation of the size of the testlet effects is aided by remembering that they are on the same scale as examine proficiency as indicated by Wang et al. (2002). Thus a testlet effect equal to one means that the variance associated with local dependence is of the same order of magnitude as the variance of abilities of the individuals. In this case the results indicate that variances of testlet effects range from 0.12 to 0.48 . The variance of the testlet effect for testlet 3 is 0.30 , where was identified one item (12) with penalty significant.

\section{Concluding remarks}

This article introduces a new testlet model, which extends the work of Bradlow et al. (1999) for asymmetrical IRT models with the inclusion of an additional random effect for the dependence between items within the same testlet. The full Bayesian specification by considering the hierarchical structure can be easily implemented using the MCMC method in WinBUGS or SAS. And also could be implemented in $\mathrm{R}$ and others packages.

For the reading comprehension data set, we showed that the testlet version of the LPE, which combines both the estimation of the penalty parameter as well as the random effects associated with the testlet, can be a useful alternative model. Also, a logistic two parameter considering testlet effect can be other alternative if penalty in some item can be thoughtless.

It would be interesting to study versions of this model which consider Rasch type models or guessing parameters with and without testlet effect. Also, extensions for polytomous and multidimensional item response models can be considered in future studies.

Additionally we suggest posterior studies evaluating other model comparison criteria to alternative IRT model incuding an analysis of item fit.

\section{References}

Albert, J. and Ghosh, M. (1999). Item response modeling. In D. Dey, S. GHOSH \& Mallick, (Eds.) Generalized Linear Models: A Bayesian Perspective, (pp. 173-193) Marcel-Dekker, New York.

Albert, J. H. (1992). Bayesian estimation of normal ogive item response curves using gibbs sampling. Journal of Educational Statistics, 17,3, 251-269.

Azevedo, C. L. N., Bolfarine, H. and Andrade, D. F. (2011). Bayesian inference for a skew-normal IRT model under the centred parameterization. Computational Statistics $\&$ Data Analysis, 55, 1, 353-365.

Azevedo, C. L. N., Andrade, D. F. and Fox, J.-P. (2012). A Bayesian generalized multiple group IRT model with model-fit assessment tools. Computational Statistics \& Data Analysis, 56, 12, 4399-4412.

Bazán, J, Bolfarine, H. and Branco, M. D. (2006). A skew item response model. Bayesian analysis, 4, 861-892.

Baker, D. R. and Kim, Seock-Ho. (2004). Item Response Theory: Parameter Estimation Techniques, Second Edition, Marcel Dekker, New York, NY. 
Bock, D. and Aitkin, M. (1981). Marginal maximum likelihood estimation of item parameters: Application of an em algorithm. Psychometrika, 46, 4, 443-459.

Bolfarine, H. and Bazán, J. (2010). Bayesian estimation of the logistic positive exponent irt model. Journal of Educational and Behavioral Statistics, 35, 6, 693-713.

Bradlow, E., Wainer, H. and Wang, X. (1999). A bayesian random ffects model for testlets. Psychometrika, 64,2, 153-168.

Bradlow, E., Wang, X. and Wainer, H. (2002). A general bayesian model for testlets: Theory and applications. GRE Board Report No. 98-01P.

Fox, J. and Glas, C. (2001). Bayesian estimation of a multilevel irt model using gibbs sampling. Psychometrika, 66, 2, 271-288.

Fox, J.-P. (2010). Bayesian Item Response Modeling Theory and Applications, Springer-Verlag New York, LLC.

Geweke, J. (1992). Evaluating the accuracy of sampling-based approaches to the calculation of posterior moments. In J. M. Bernardo, J. O. Berger, A. P. Dawid, A. F. M. Smith (Eds.) Bayesian Statistics,4 (pp. 169-193).

Henson, R.K. (2001) Understanding Internal Consistency Reliability Estimates: A Conceptual Primer on Coefficient Alpha. Measurement and Evaluation in Counseling and Development, 34. 177-188.

Kim, S., Cohen, A., Baker, F., Subkoviak, M. and Leonard, T. (1994). An investigation of hierarchical bayes procedures in item response theory. Psychometrika, 59, 3, 405-421.

Minedu (2009). Marco de trabajo evaluacion censal de estudiantes. Personal communication available at http://www2.minedu.gob.pe/umc/ece/Marco $e_{T}$ rabajo $o_{E}$ CE.pdf.

Patz, R. J. and Junker, B. W. (1999). A straightforward approach to markov chain monte carlo methods for item response models. Journal of Educactional and Behavioral Statistics, 24,2, 146178.

Rupp, A., Dey, D. K. and Zumbo, B. (2004). To bayes or not to bayes, from whether to when: applications of bayesian methodology to item response modeling. Structural Equations Modeling, $11,2,424-451$.

Sinharay, S. and Johnson, M. S. (2003). Simulation studies applying posterior predictive model checking for assessing fit of the common item response theory models. (ETS RR-03-26). Princenton, NJ: Educational Testing Service.

Sahu, S. K. (2002). Bayesian estimation and model choice in item response models. Journal of Statistical Computation and Simulation, 72, 3, 217-232.

Samejima, F. (1997). Departure from normal assumptions: a promise for future psychometrics with substantive mathematical modeling. Psychometrika, 62, 4, 471-493. 
Samejima, F. (1999). Usefulness of the logistic positive exponent family of models in educational measurement. Paper presented at the Annual Meeting of the American Educational Research Association (Montreal, Quebec, Canada, April 19-23).

Samejima, F. (2000). Logistic positive exponent family of models: virtue of asymmetric item characteristics curves. Psychometrika, 65, 3, 319-335.

Sinharay, S. (2004). Experiences with Markov chain montecarlo convergence assesment in two psychometric examples. Journal of Educational and Behavioral Statistics, 29, 4, 461-488.

Spiegelhalter, D. J., Best, N. G., Carlin, B. P. and van der Linde, A. (2002). Bayesian measures of model complexity and fit. Journal Royal Statistical Society, Series B, 64, 3, 583-639.

Spiegelhalter, D., Thomas, A., Best, N. and Gilks, W. (1996). BUGS 0.5 Examples Volumen 1 (version i).MRC Biosttistics Unit, Institute of Public Health, Robinson Way, Cambridge CB2 $2 S R$.

Swaminathan, H. and Gilford, J. (1985). Bayesian estimation in the two-parameter logistic model. Psychometrika, 50, 3, 349-364.

Swaminathan, H., Hambleton, R., Sireci, S., Xing, D. and Rivazi, S. (2003). Small sample estimation in dichotomous item response models: Effect of priors based on judgmental information on the accuracy of item parameter estimates. Applied Psychological Measurement, 27, 1, 27-51.

Stan Development Team (2015). Stan modeling language: Userś guide and reference manual. http: //mc-stan.org/documentation/.

Tuerlinckx, F. and De Boeck, P. (2001). The effects of ignoring item interactions on the estimated discrimination parameters in item response theory. Psychological Methods, 6, 2, 181-195.

Wainer, H., Bradlow, E. and Wang, X. (2007). Testlet Response Theory and Its Applications, Cambridge University Press.

Wainer, H. and Kiely, G. L. (1987). Item clusters and computarized adaptative testing: A case for testlets. Journal of Educational Measurement, 24, 3, 185-201.

Wainer, H. and Wang, X. (2000). Using a new statistical model for testlets to score toefl. Journal of Educational Measurement, 37, 3, 203-220.

Wang, W.-C. and Wilson, M. (2005). The Rasch testlet model. Applied Psychological Measurement, 29, 2, 126-149.

Wang, X., Bradlow, E.T., and Wainer, H. (2002). A general Bayesian model for testlets: theory and application. Applied Psychological Measurement, 26, 1, 109-128.

Wang, X., Baldwin, S.,Wainer, H., Bradlow, E. T., Reeve, B. B., Smith, A. W., Bellizzi, K. M. and Baumgartner, K. B. (2010). Using testlet response theory to analyze data from a survey of attitude change among breast cancer survivors. Statistics in Medicine, 29, 19, 2028-2044. 